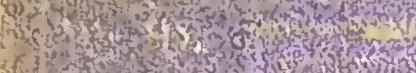

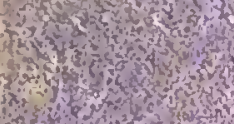

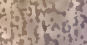

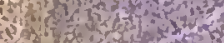

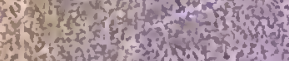

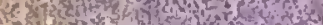

al

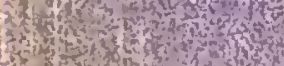

icte

int of

sid 610

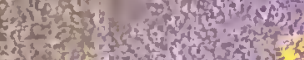

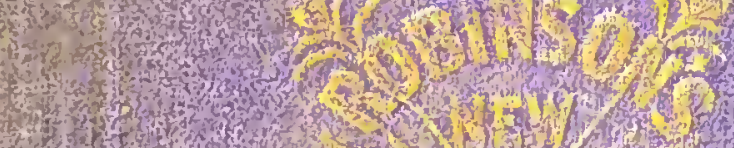

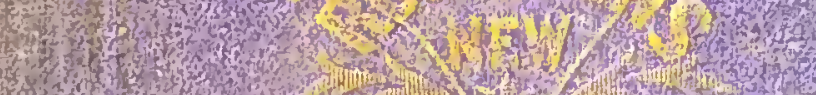

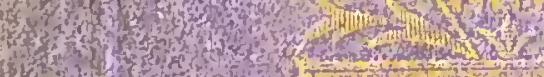

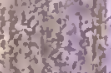

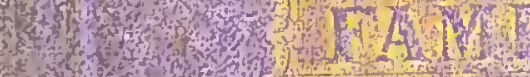

int

and

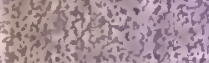

Bits

H.

act $15=$

? 31

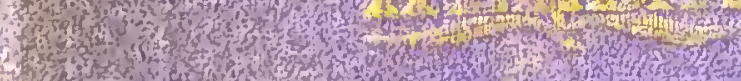

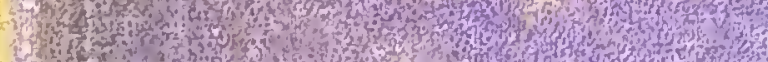

Fin

s.tint

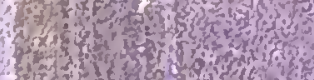

Pnt

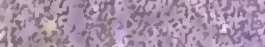

7i.

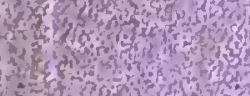

of

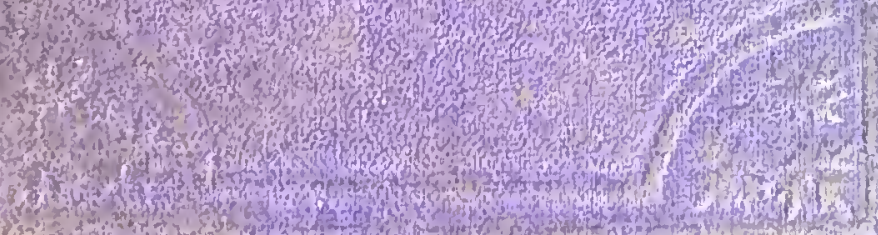




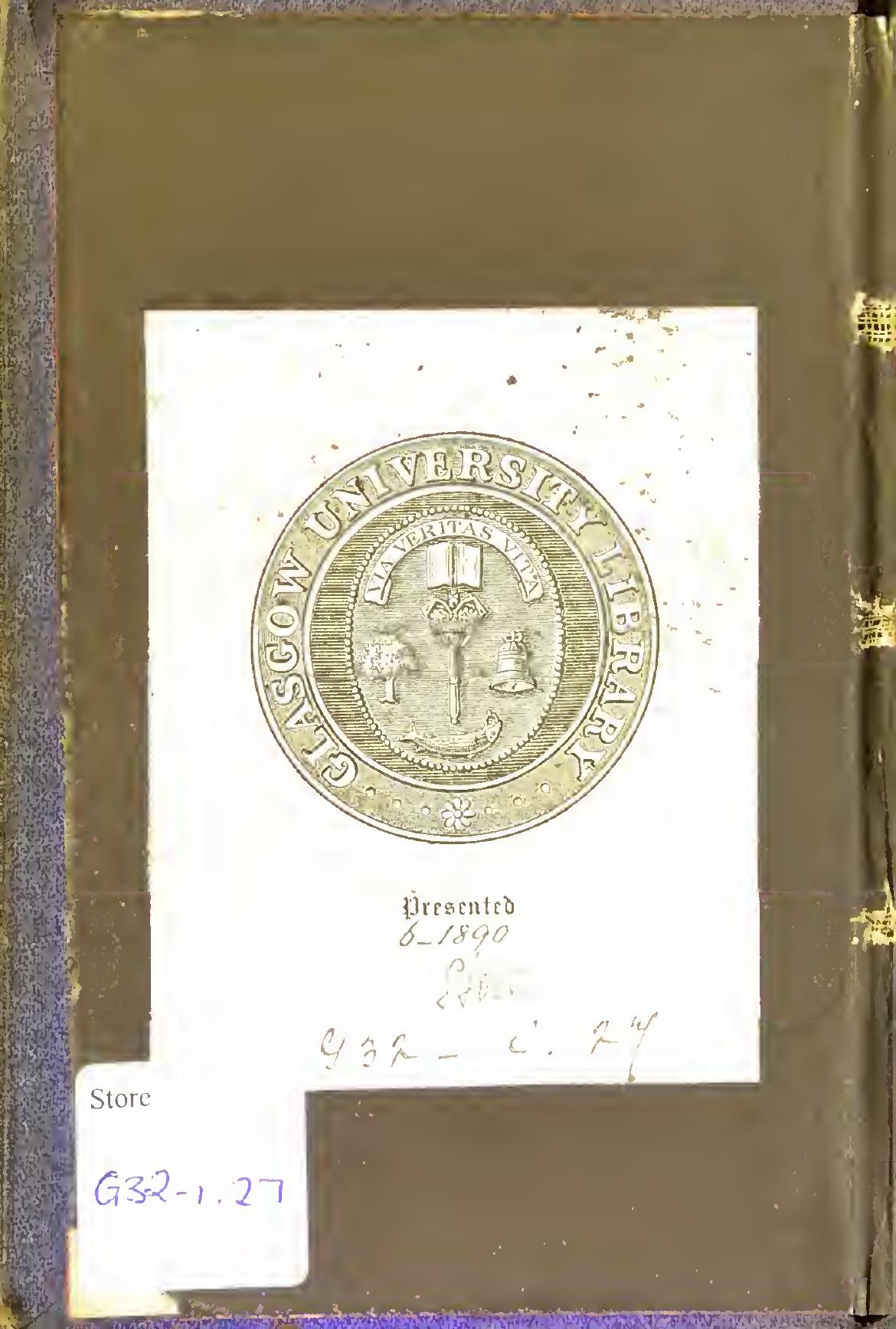



[ENTERED AT STATIONERS' HALL.] 



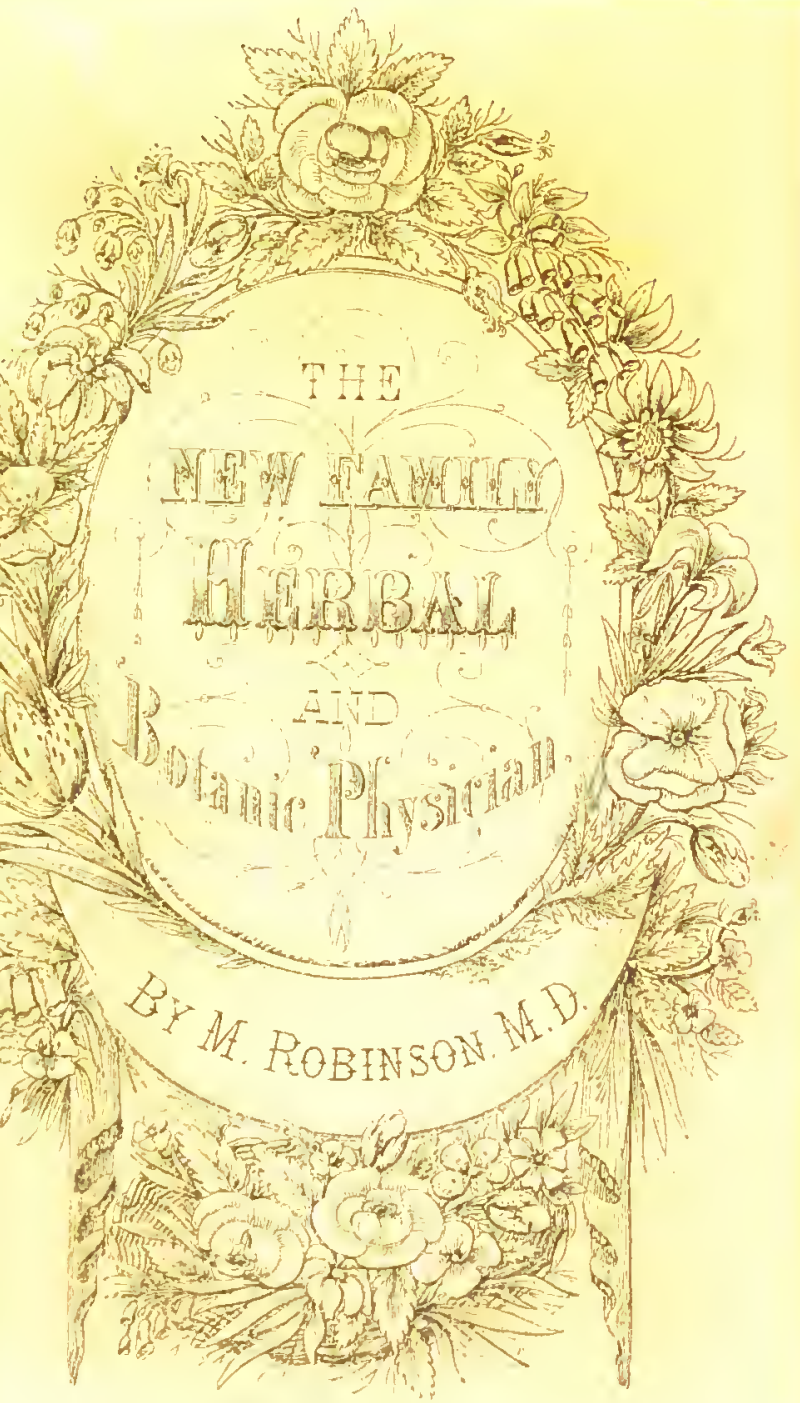

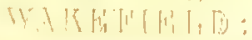




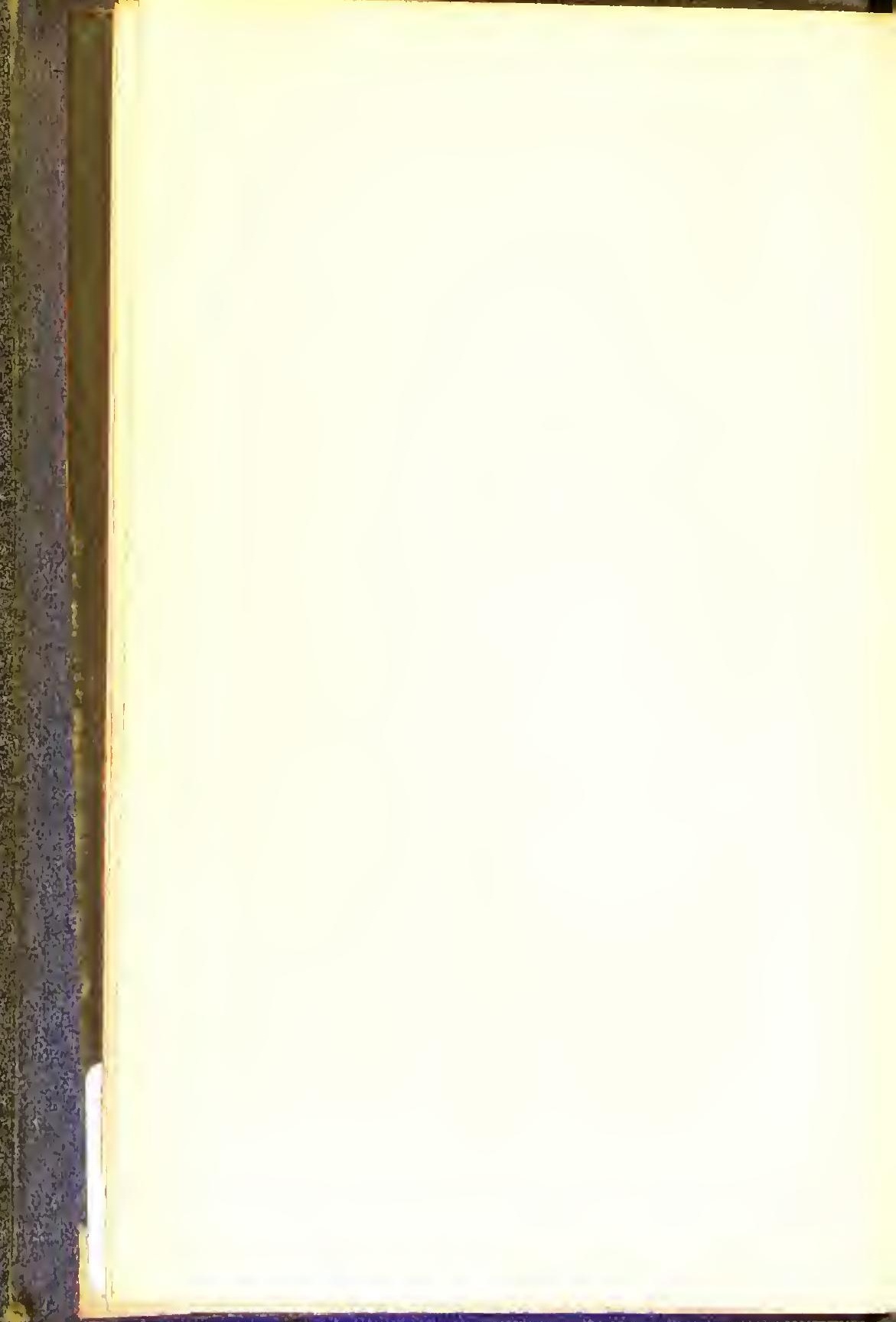




\title{
THE NEW
}

\section{FA MILY HERBAL:}

COMPRISING

A DESCRIPTION, AND THE MEDICAL VIRTUES

$\mathrm{OF}$

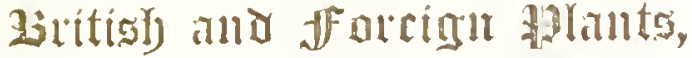

\author{
FOUNDED ON THE
}

WORTS OF EIINENT MIODERN ENGLISH AND

AIERICAN WRITERS

ON THE MEDICAL PROPLRTLES OF HERBS:

TO WIICH IS ADDED,

\section{THE BOTANIC FAMILY PHYSICIAN;}

VALUABLE MEDICAL RECEIPTS;

\section{$\triangle N D$}

IMPORTANT DIKEGTIONS REGARDING DIET, CLOTHING, BATHING, AIR, EXERCISE, \&c., \&c.

BY MIATTHEIV ROBINSON.

\section{WATEFIELD :}

WTLLIAM NIOIOLLUY AND SONS.

J.NNDON: 8. D. WWINS JR. AND CO., 22, IMTHRNOSTER ROW.

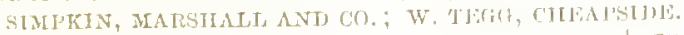

MANCHESTLR: JOLN ILEYWOOD, AND A HEXWOUD $A$ SUN.

1872. 


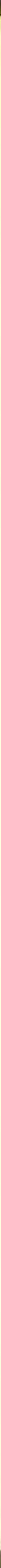




\section{PREFACE.}

Socn works as Culpeper's Irerbal, and those beforc his time, have becn in great repute till of late; and they contrin some really valuable information. But a great portion of their works is entircly uscless.

The government of Herls by the sun, moon, and planets, has been exploded by modem seience; and is now regarded by persons of ordinary capacity to be absurd in the extreme. He who would now conncet $\Lambda$ strology with Botany would stultify himself, and hold himself up to public contempt. Botanical knowledgc has been greatly augmented of late years, and some Medical men and Herbalists have very ably written upon it. The properties of Herbs, by scientific study, and by Mcdieal experience, are now bettcr unclerstoot than they were in the days of Culpeper, and others. While, thereforc, the Botanic System of Medicine is making rapid progress, it wonld be the greatest folly to perpetuate the ignorance and absurdities of arcient IIcrhalists.

Finally, whatever is valtulble in former Ilerbals, I have adopted. But the Astrological govermment I have rejecter witl discrust, and also their lauglable and ignorant descriptions of some Herbs-take Culpeper's description of Irormaond as a specimen. I have consulted the works of IIill, Woodville, Don, Thornton, and morlcru writers, and particularly some of the great American IIerbulists.

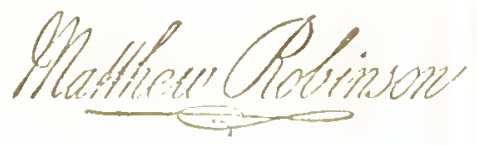




\section{AN EXPLANATION}

OF TIIE

\section{TEMPERAMENTS OF THE IIERBS.}

I. ALt medicines simply eonsidered in themselves are either lot, eold, moist, dry or temperate.

The qualities of medieines are eonsidered in respeet of man, not of themselves; for those simples are called hot, which hent our bodies; those eold, whieh eool them; and those temperate, which work no ehange at all in them, in respeet to either heat, eold, dryness, or moistnre. And these may be temperate, as being neither hot nor eold; yet may be moist or dry : or being neither moist nor dry, yet may be hot or eold ; or lastly, being neither hot, eokl, moist nor dry.

II. In temperature there is no degree or differenee, the differenees of the other qualities are divided into fonr degrees, begimning at temperatule; so that a medicine may be said to be hot, eold, moist or dry, in the first, seeond, third or fourth degree.

The use of temperate medieines is in those enses where there is no apparent exeess of the first qualities to prescrve the body temperate, to eonserve strength, and to repair dreaycd nature. And observe, that those medieines whieh we enll colcl, are $\mathrm{n}$ t so ealled beenuse that they are really cold in themkelves, but beemse the degree of their heat fills bulow the heat of onr bodies, and so only in respeet of om tempremture are said to be eold, while they are in themselves really hot; for withont there eould be no vegetation, nor life.

III. Such as are lot in the first denore, are of equal heat witl our bodies, and they only ald a natural licat to them, if it be cooled by uature or by accident thereby eherishing the natural heat when weak, and restoring it when it is wanting. 
Their use is, I. To make the offending humours thin, that they may be expelled by sweat or perspiration. 2. By ontward application to abate inflammations and fevers by opening the pores of the skin. 3. To help concoction, and kecp the blool in its just temperatmre.

IV. Such as are hot in thic second degree, as much exeeed the first, as our matmral heat execels a temperature.

Their use is, to open the pores, and take away obstructions, by relaxing tough humours and by their essential force and strength, when nature cannot clo it.

V. Such as are hot in the third degree, are more powerful in heating, because they tend to inflane and causc ferers.

Their use is to promote perspiration extremely, and soften tough humours; and therefore all of them resist poison.

VI. Such as are hot in the fourth degree, burn the body, if outwardly applicel.

Their use is to eause inflummation, raise blisters, and corrule the skin.

VII. Such as are eold in the first degree, fall as much on the one side of temperature as hot doth on the other.

Their use is, 1. To qualify the heat of the stomach and cause digestion. 2. 'To abate the heat in fevers; and 3. To refresh the spirits being almost suflocated.

VIJI. Such as are cold in the third degree, are, such as have a repercussive force.

And their nl:c is, l. to drive back the matter, and stop defluctions; 2. to make the hunnours thick; anel 3. to limit the violenec of choler, repress perspiration, and kecp the spirits from filinting.

IX. Such as are cold in the fourth degree, arc such as stupify the senses.

They are used, 1. In violent pains ; and 2. in cxtreme watchings, and the like cares, where life is despanired of.

X. Drying merliciness consume the humours, stop fluxes, stifien the parts and strengthen nature. 
But if the humidity be exhausted already, then those consume the matural strength.

XII. Such as are dry in the first degree strengtlien; in the second degrec bind; in the third, stop fluxes, but spoil the nomrishment, and bring consmmption; in the fourth, dry up the ralical moisture, which being exhansted, the body must needs perish.

XIII. Moist medicines are opposed to drying; they are lenitive, and make slipjery.

These cannot excecl the thitel degree; for all things are cither hot or cold. Now heat dries up, and cold congcals; loth which destroy moisture.

XIV. Such as are moist in the first degree, ease conghs and help the roughness of the windpipe; in the second, loosen the belly; in the third, make the whole habit of body watery and nhlogmatic; filling it with drojsies, lethargies, and such like discases.

XV. Thus medicines alter accorcling to their temperature, whose aetive qualitics are heat and cold, and whose passive are dryness and moisture.

XVI, The aetive qualities eradieate discases, the passive are subservient to nature.

So hot medicines may enre the dropsy, hy opening obstructions: and the same may also cure the jellow jauntice, by its attractive quality in sympathising with the humour albounding ; and contrarywise cold medicines may compress or alate a fever by condensing the hot vipours, and the same maty stop any defluxion or looseness. 


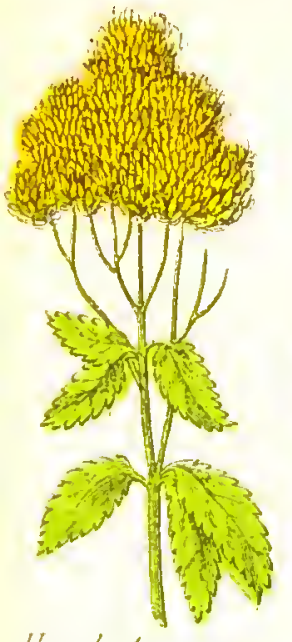

Item/L. Agrmmumel
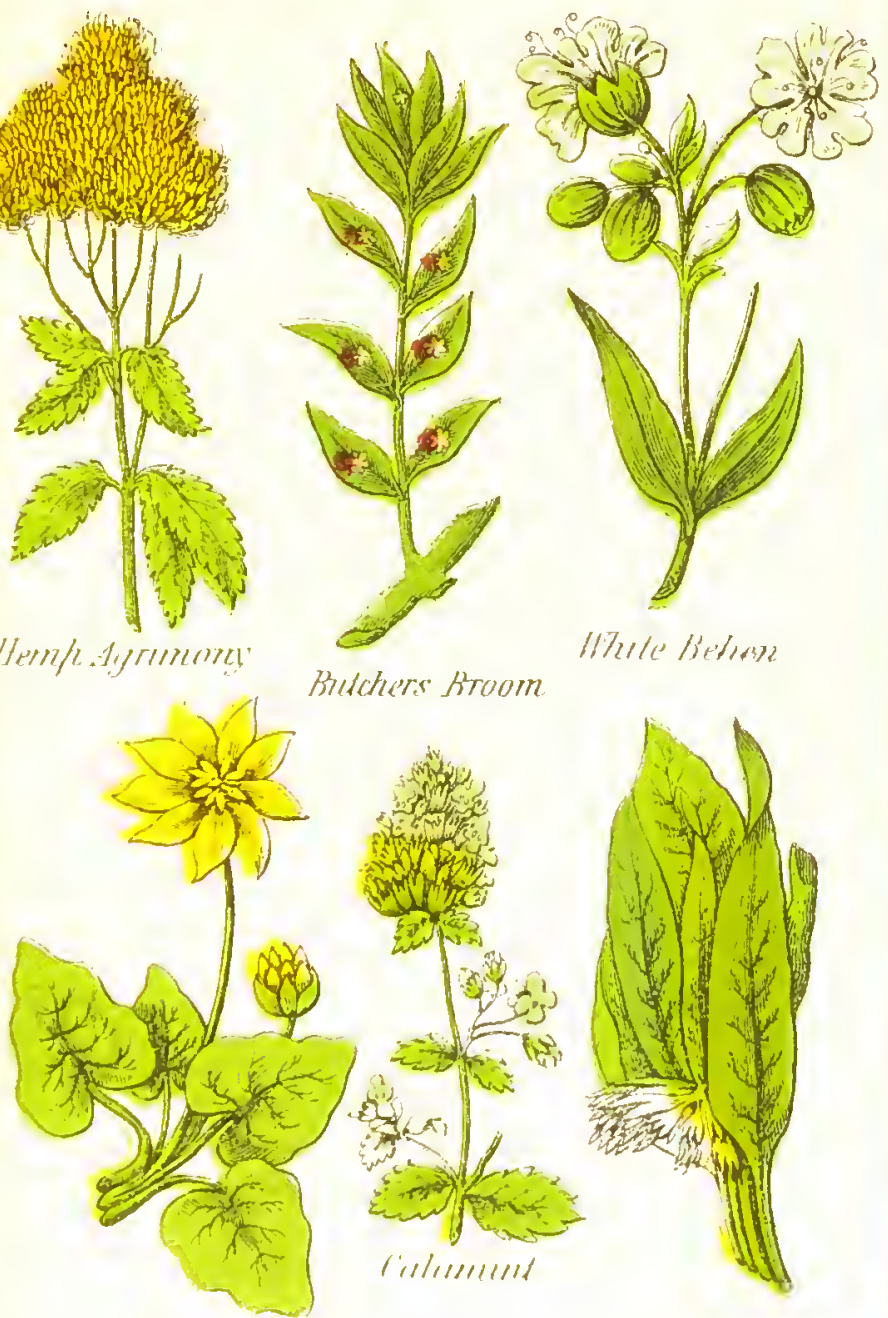

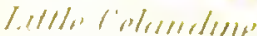




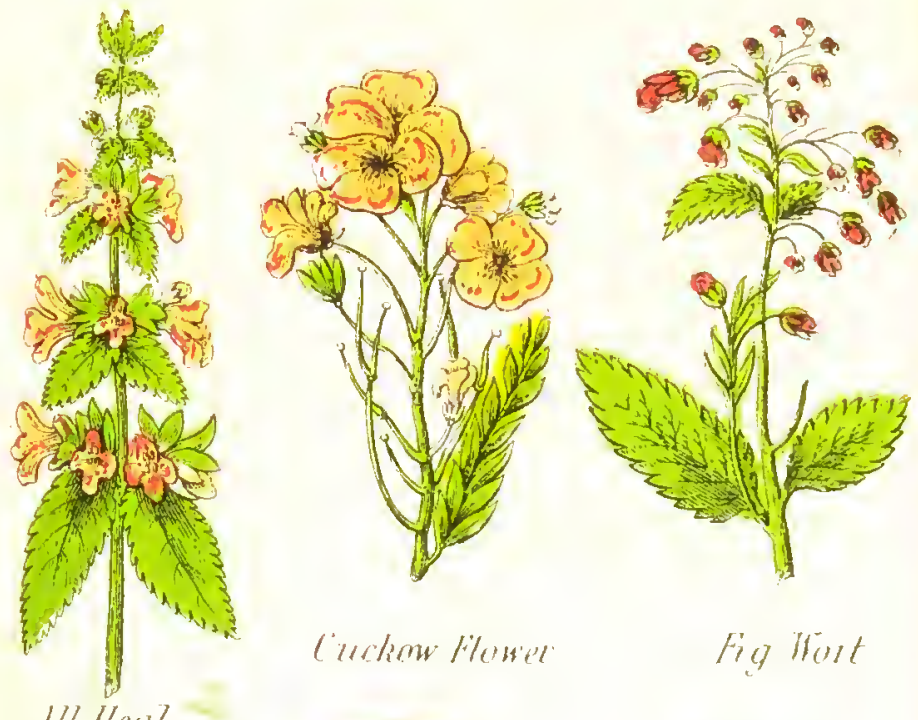

Fig thent

$111.1 / \mathrm{ell}$
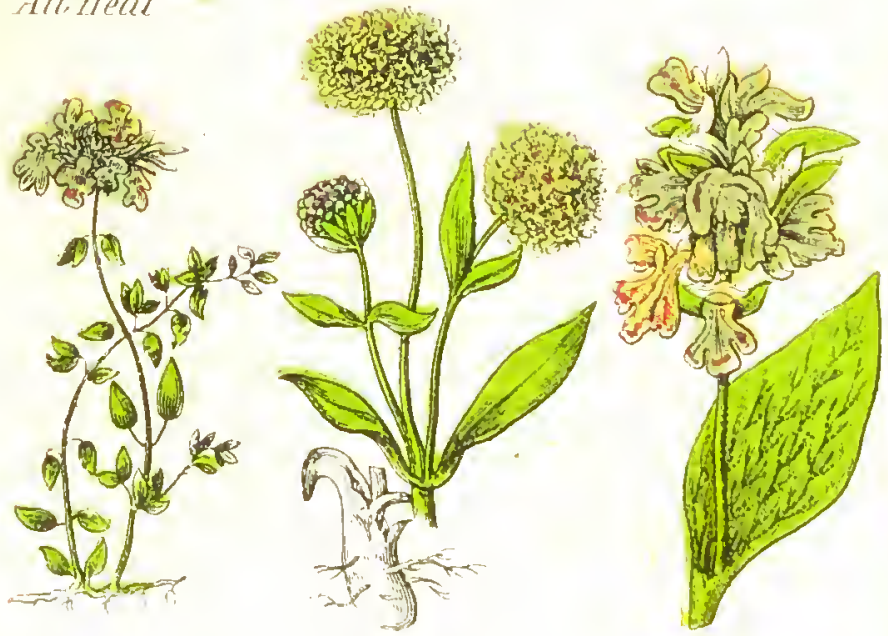

15.16, 1171,1111

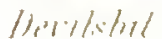

(1), /11: 


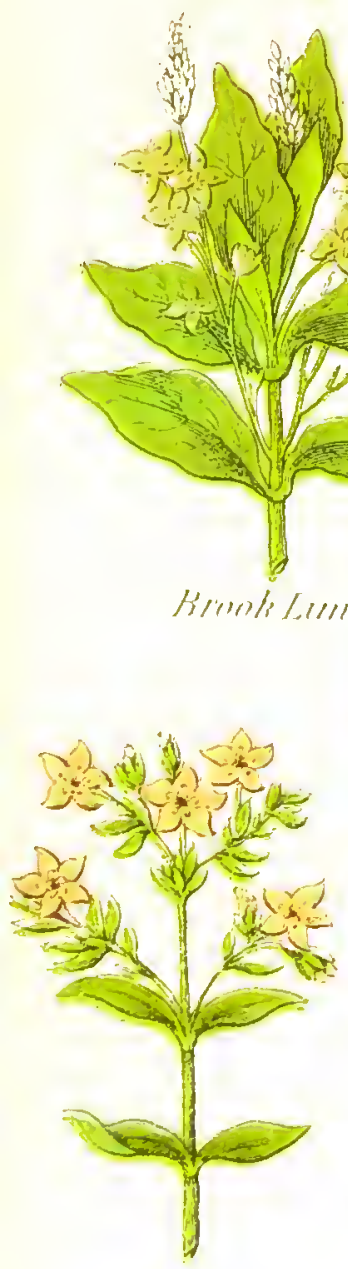

$131 / 1 / 1) l^{\circ}$

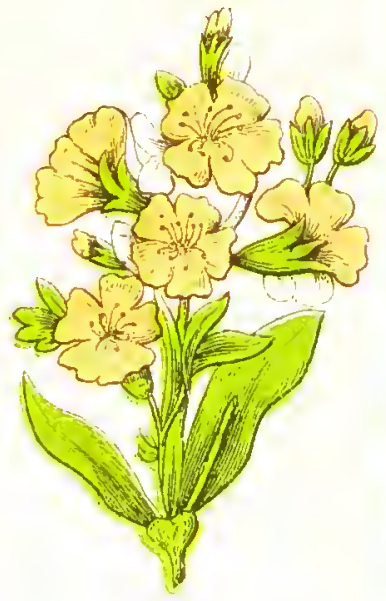

inseletherl 



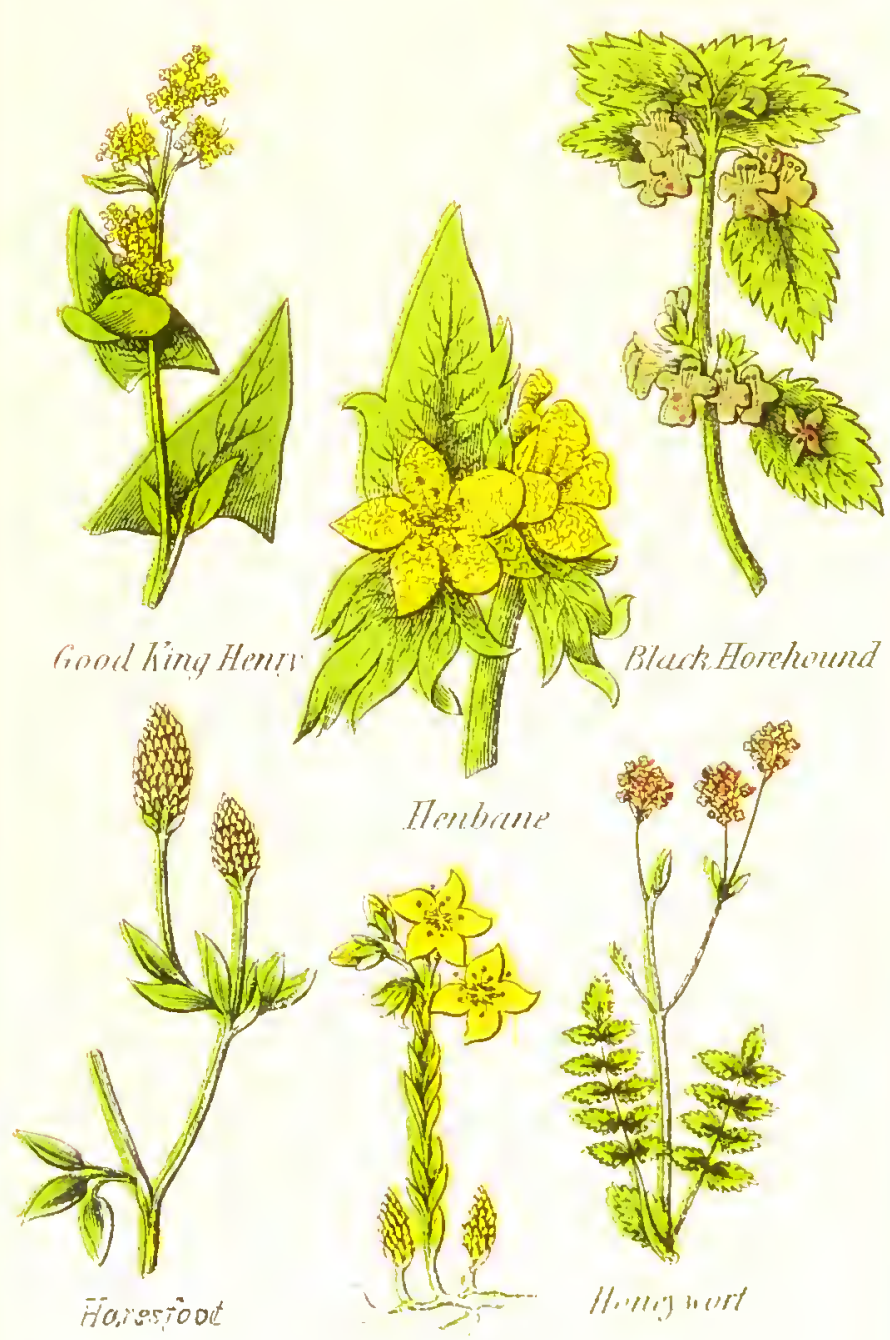

Least Moursaices 


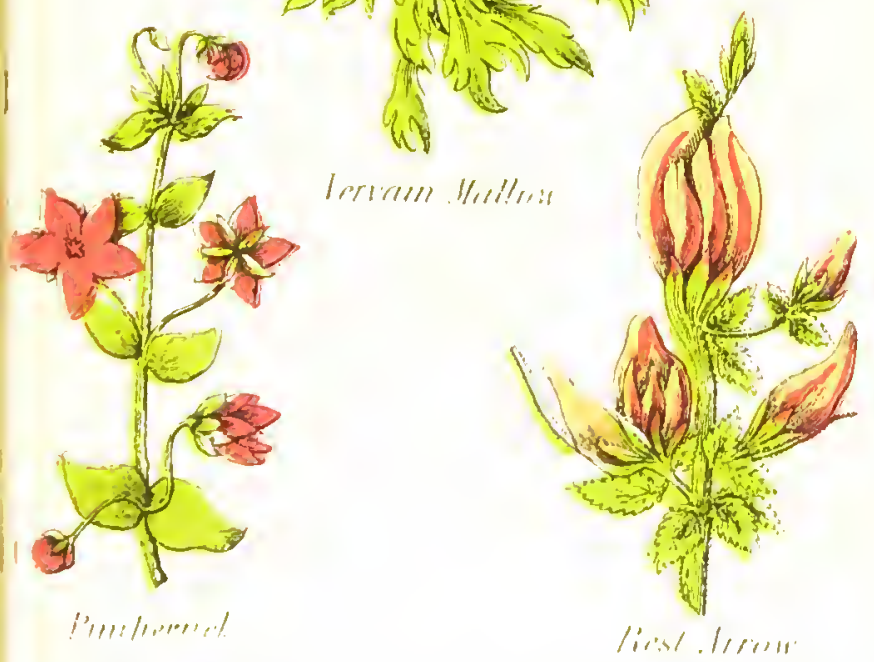





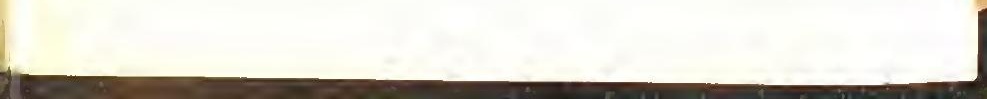




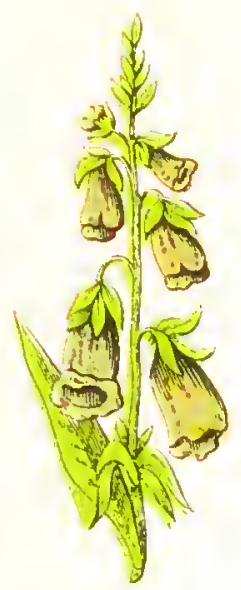

Fontilere

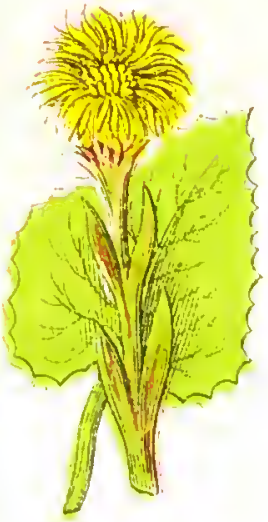

$\left({ }^{\prime}, 1 / .91, \ldots\right)$
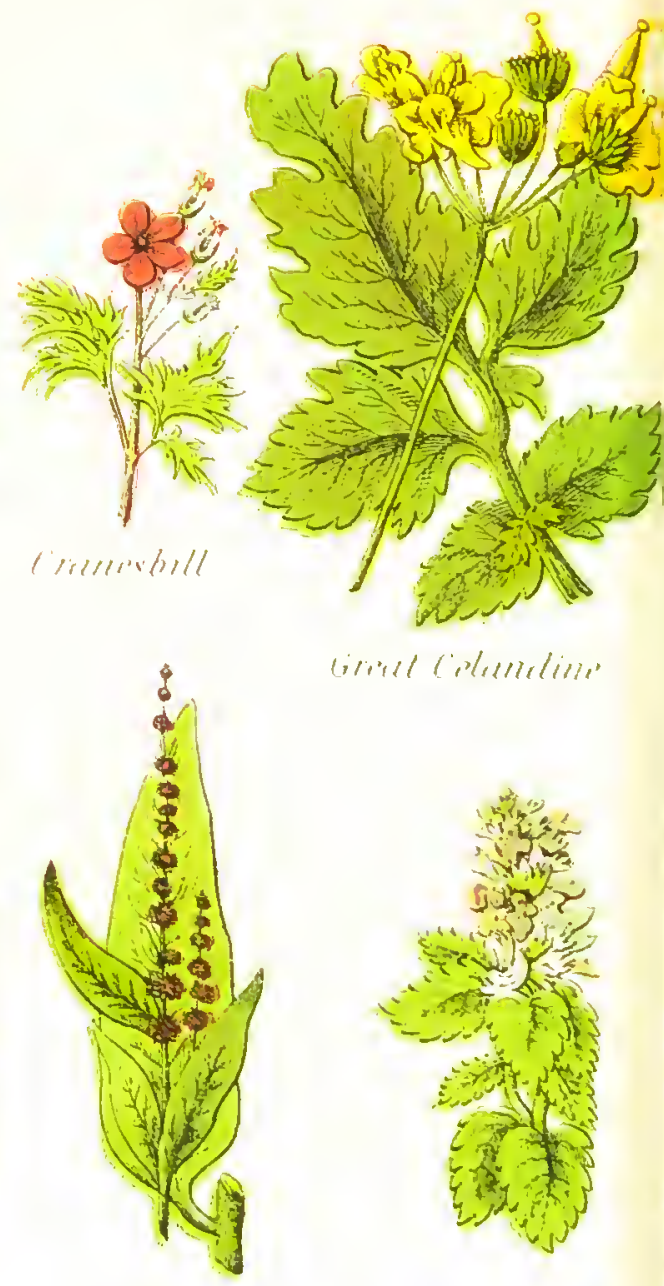

liverel Cielestelines

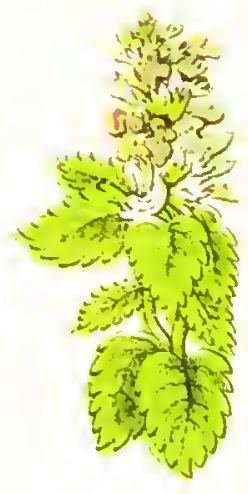

forndal Dente

(ill 1/111) 


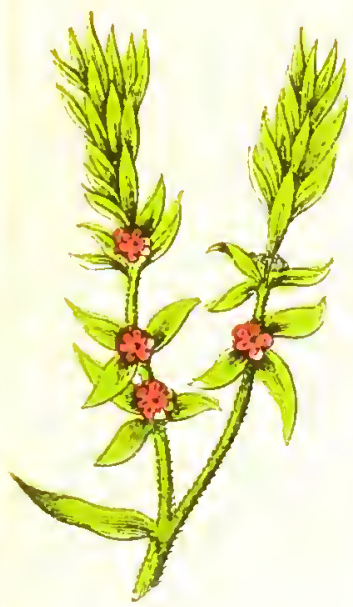

lilosiswort

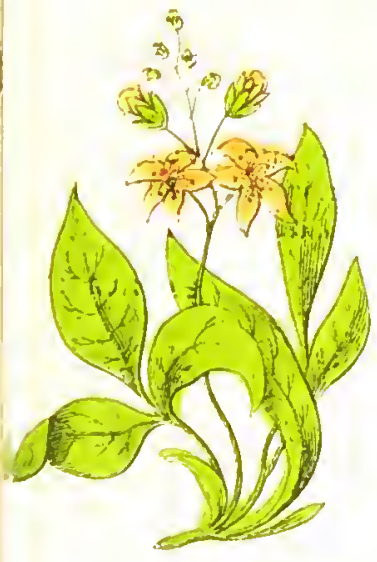

lindtherst
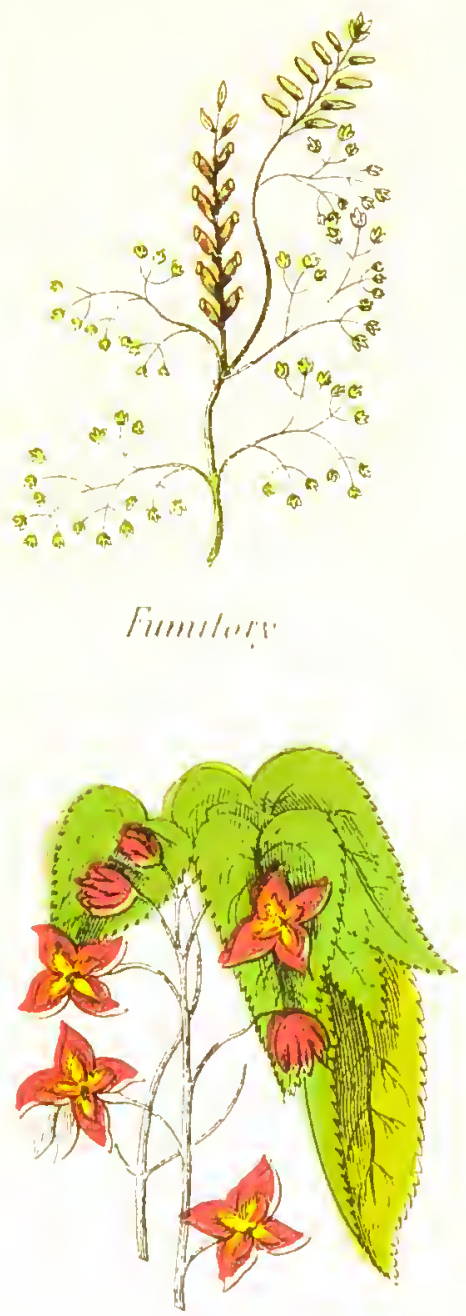

lintrent livel 



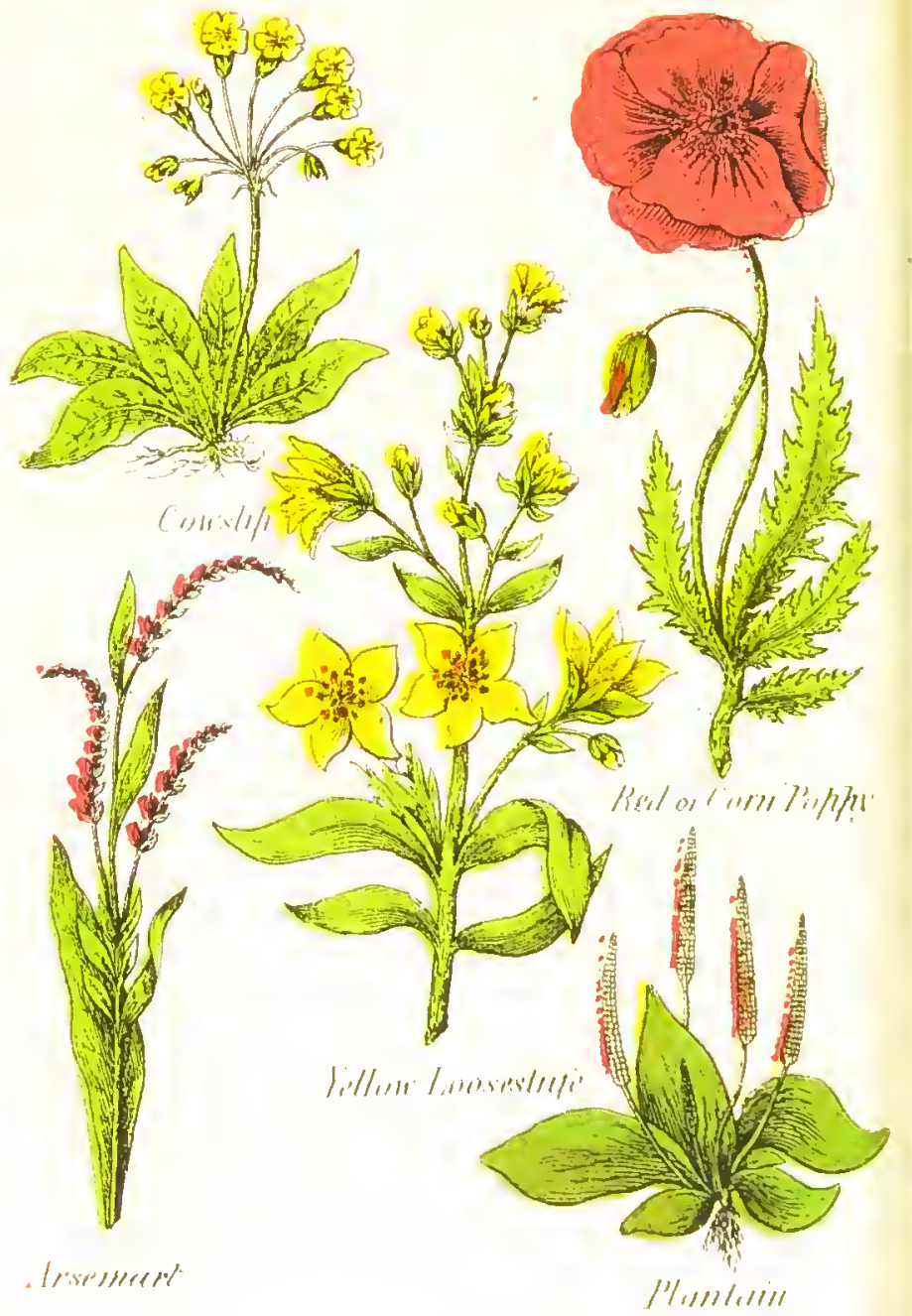




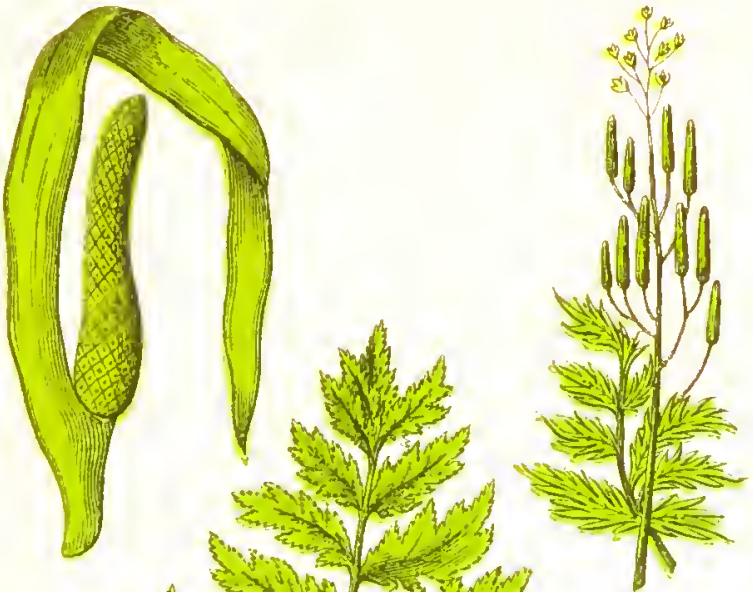

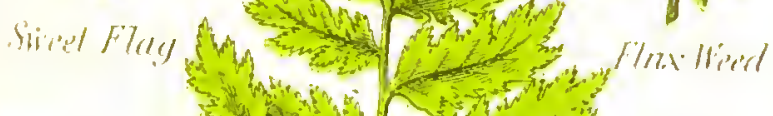

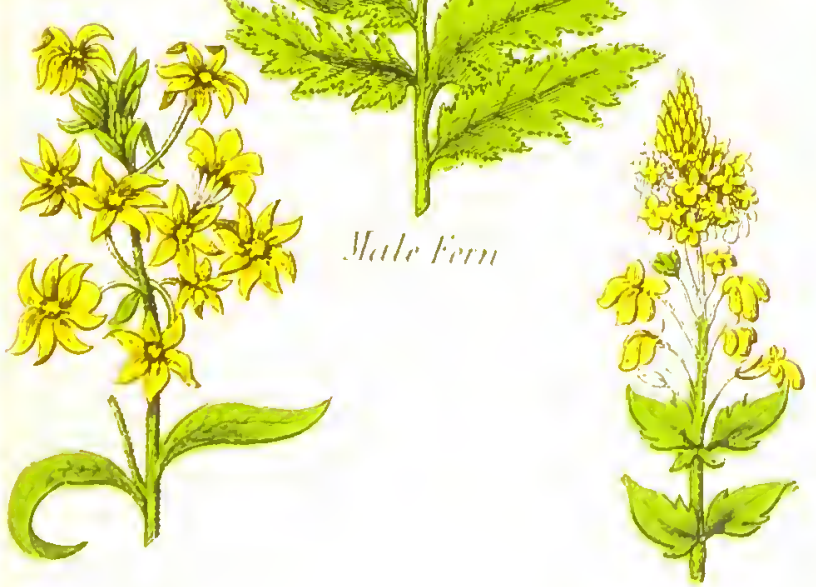

linlel,nlin,l

$1,1111,181,196$ 


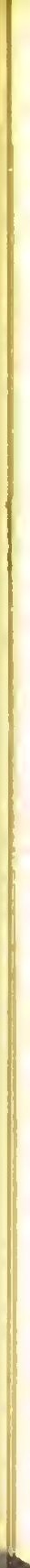




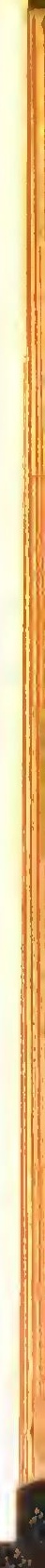




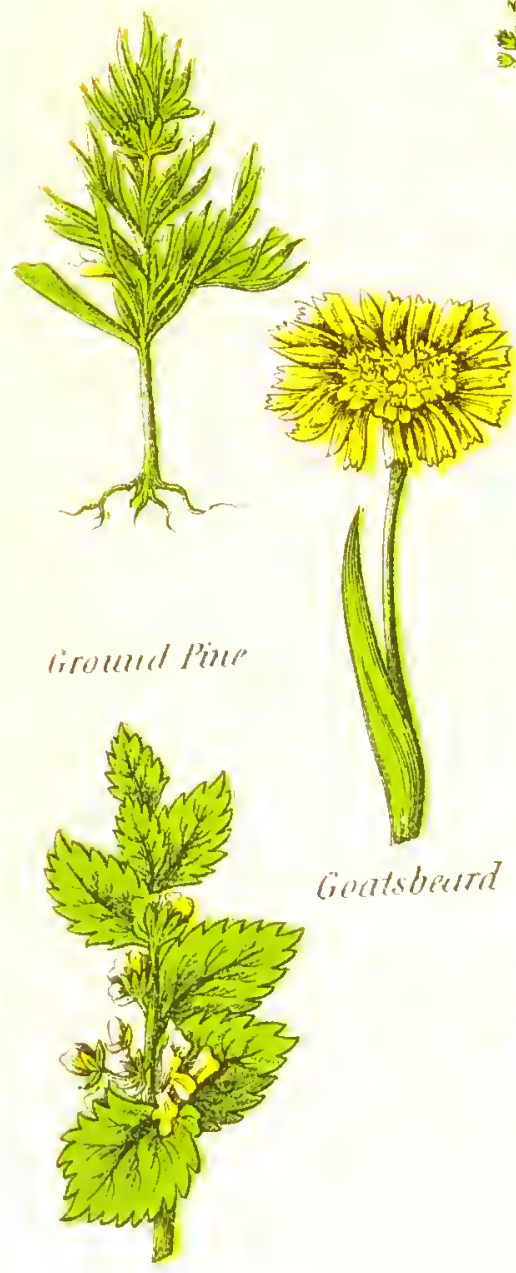

Hhle'Horrhemml

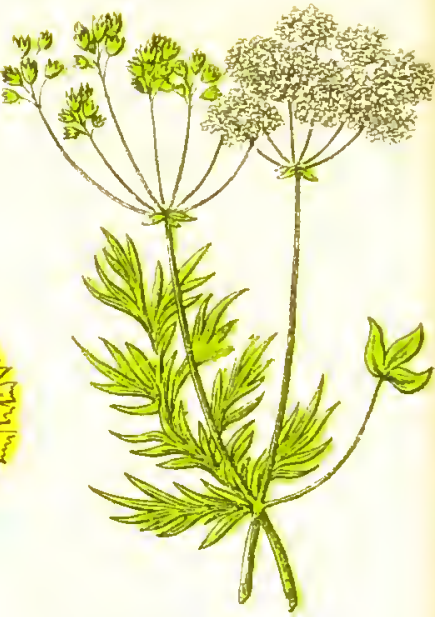

Burmed savifrage

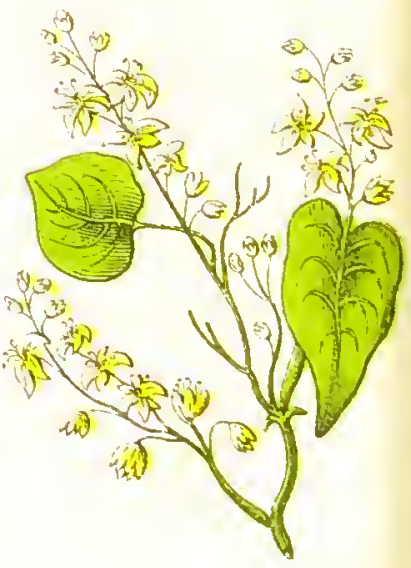

Briom 


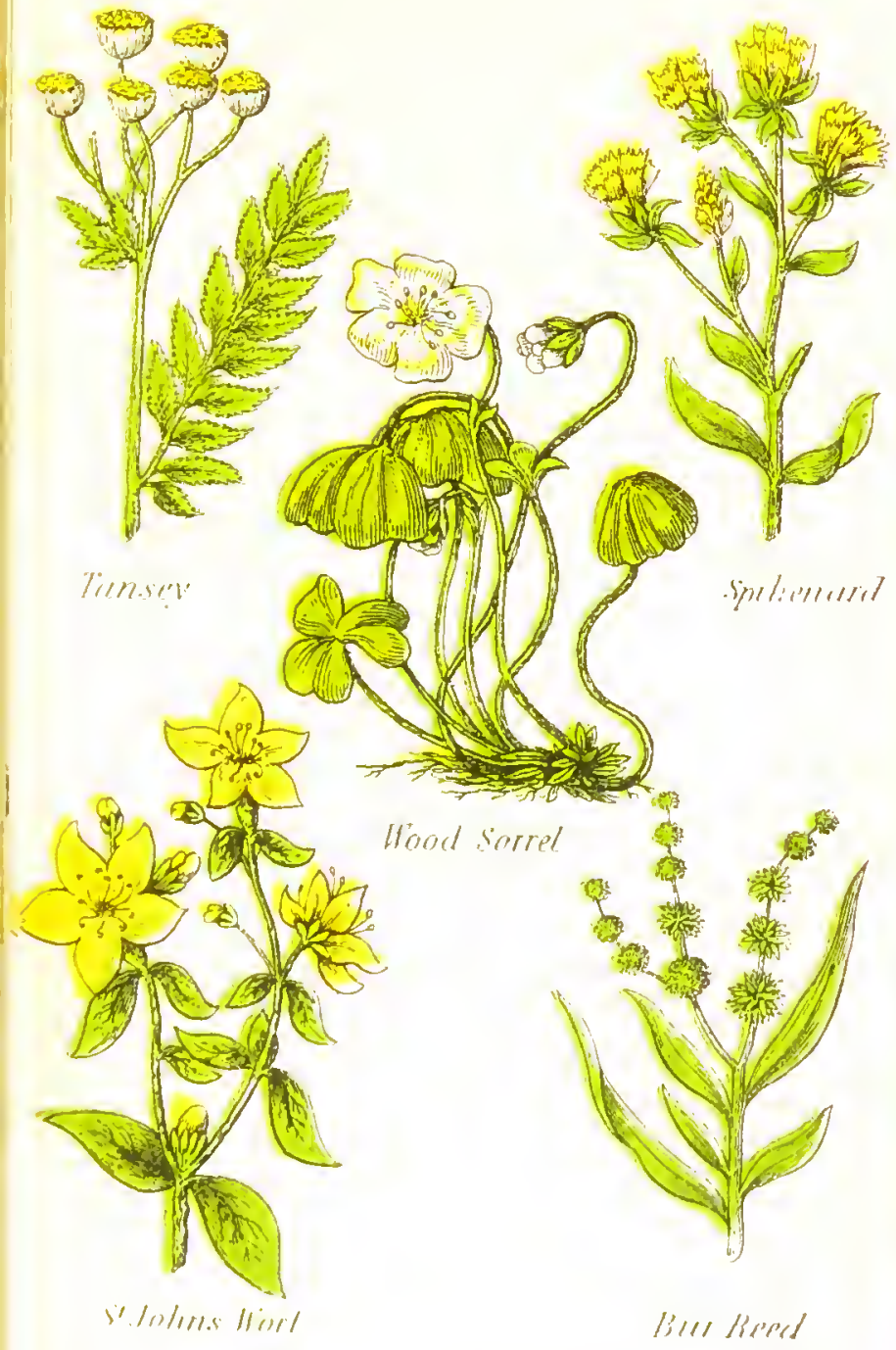





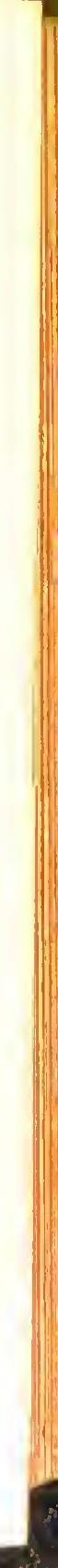



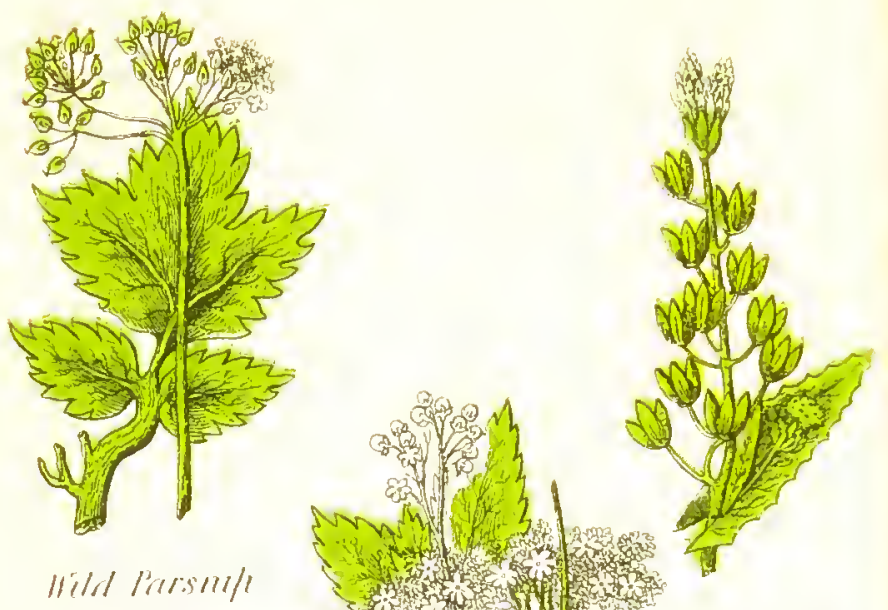

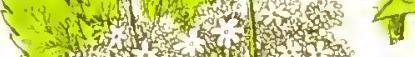

II Itesleret
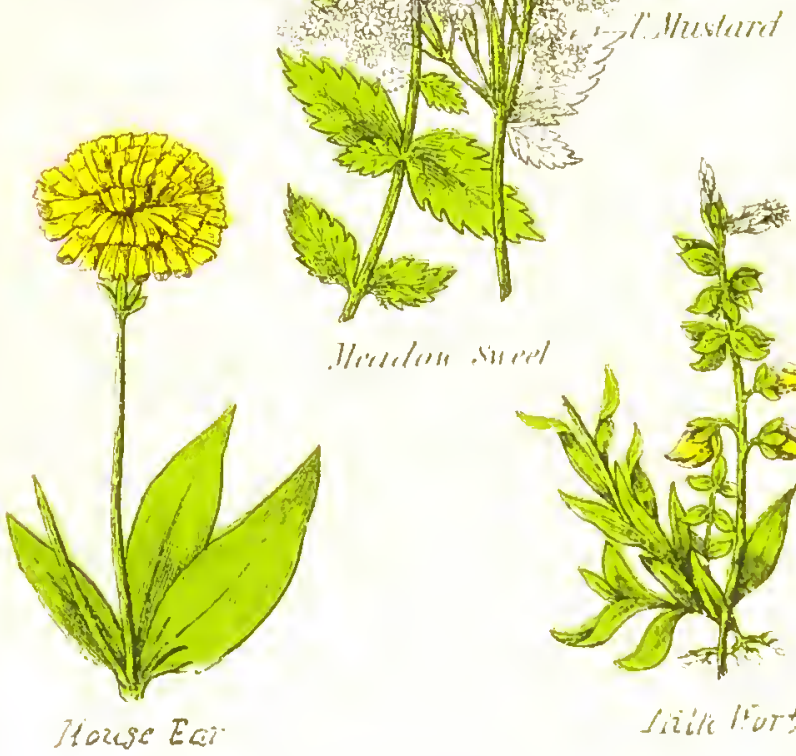

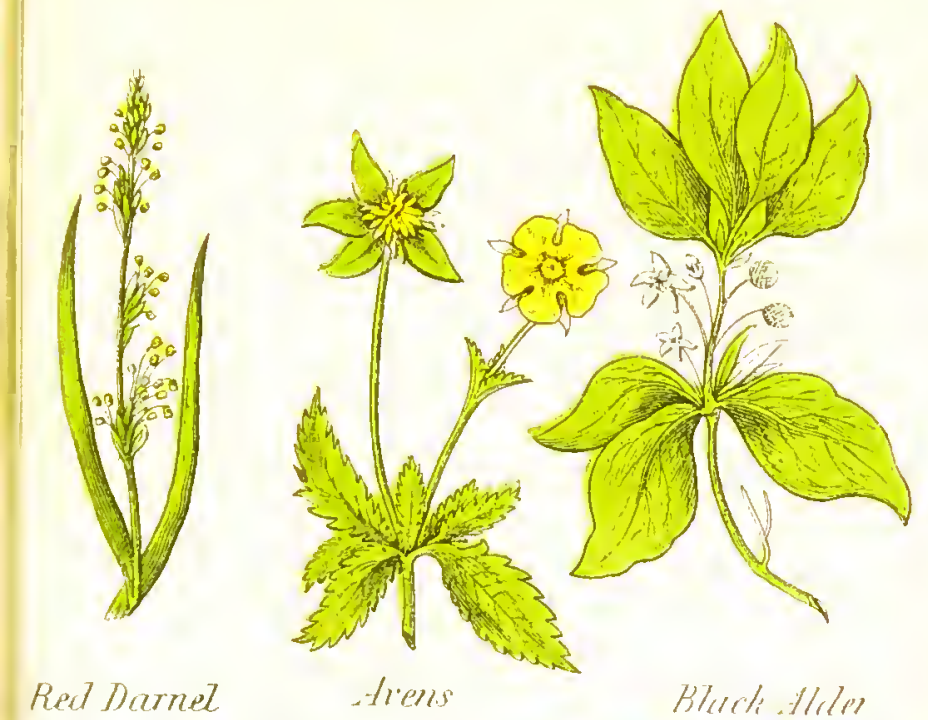

Red Darnel

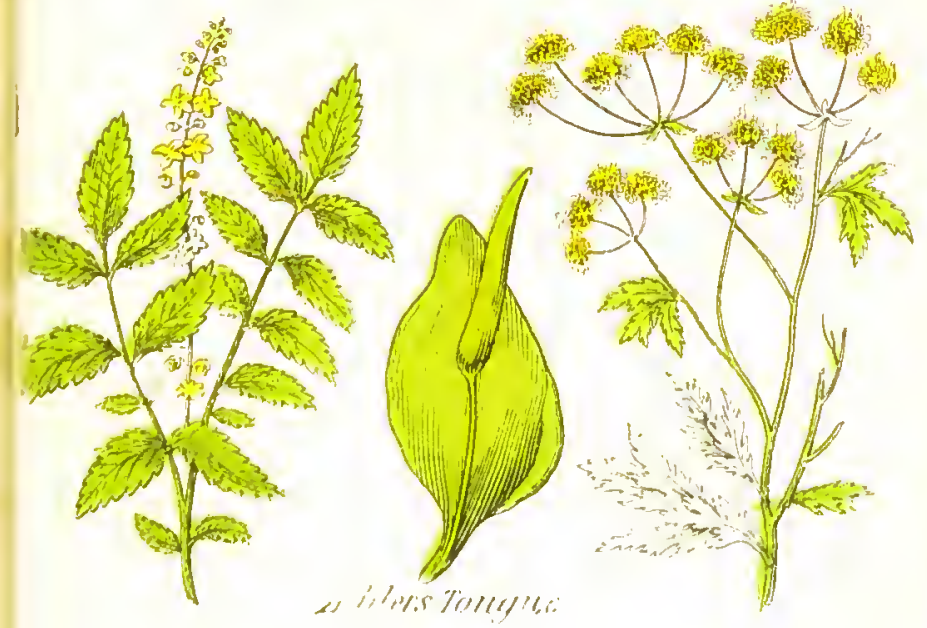

Afrimory

Amuritill 



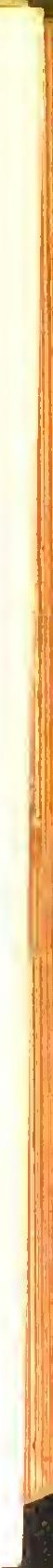



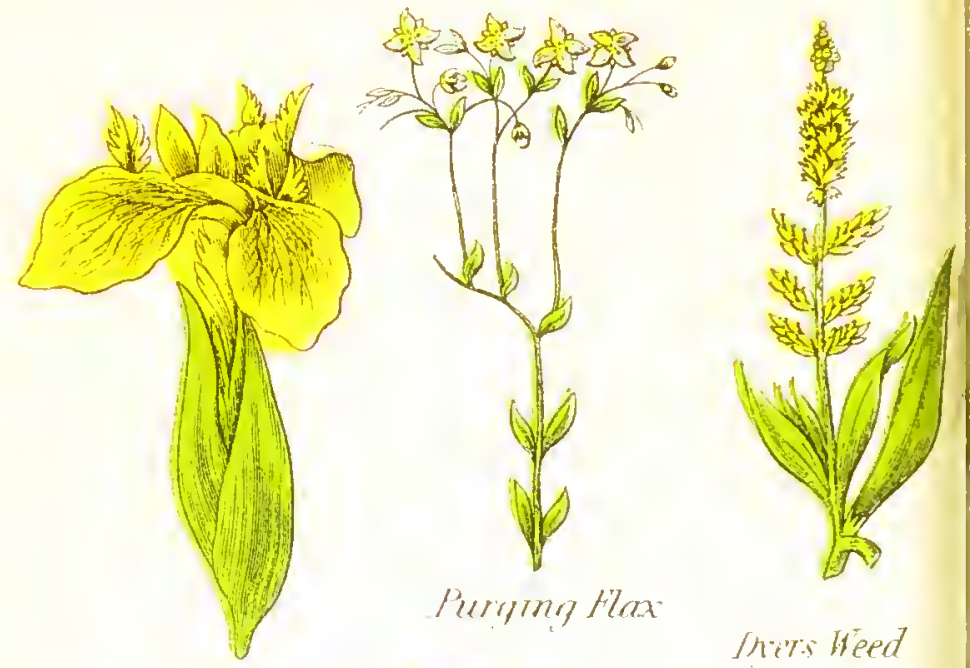

Sollow tiles,

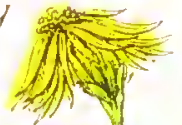

Jhits heed
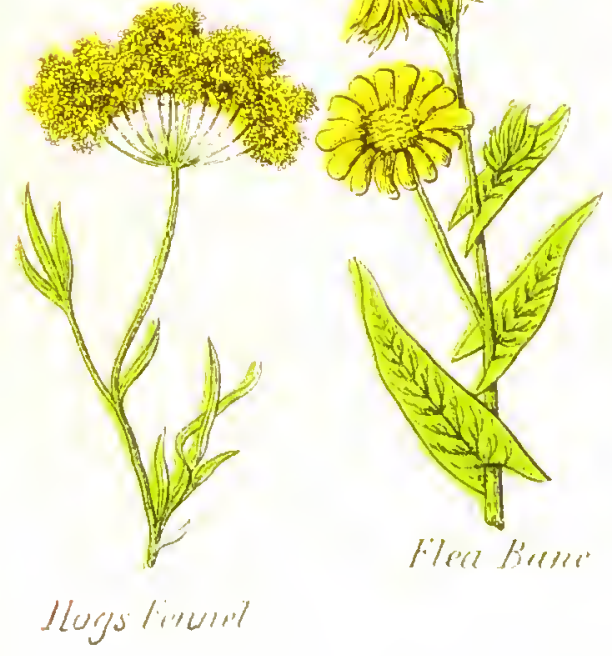

Fled binder

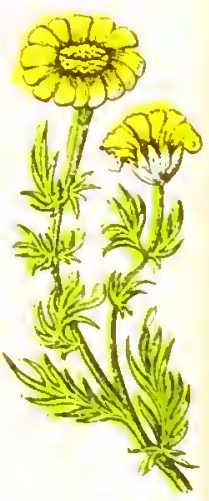

Cirtisesncile 


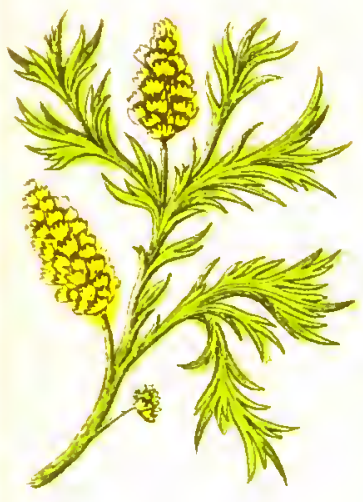

Hiart Ciess

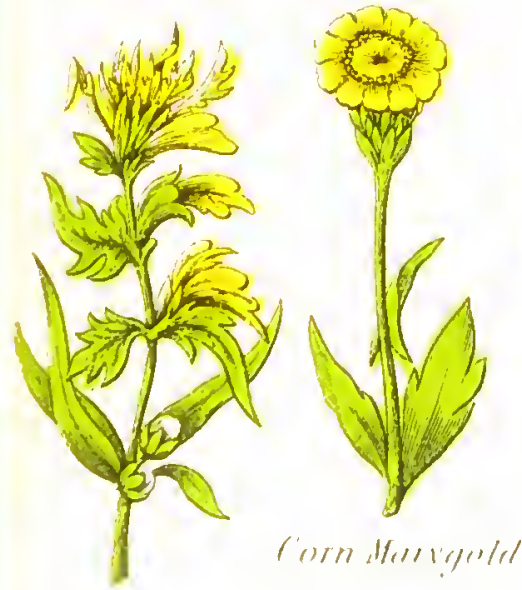

fiow $11 \%$ mel

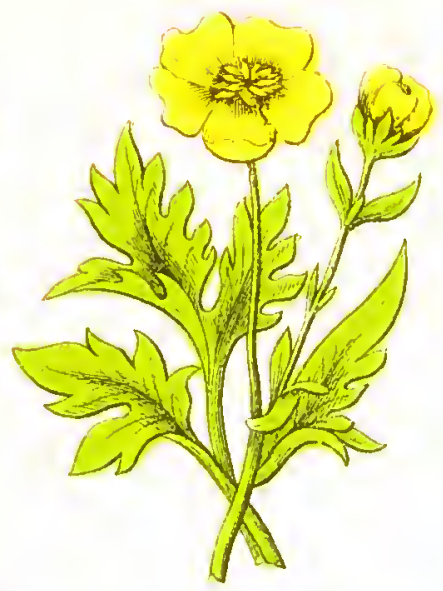

rinfont

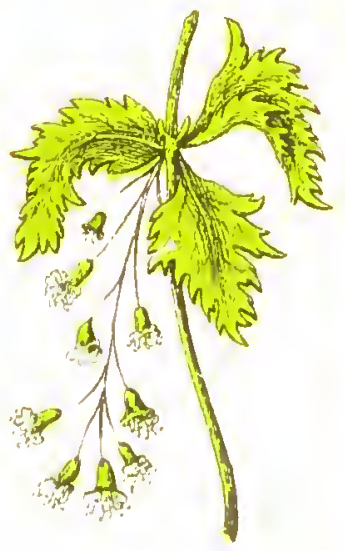

lineli rinferre 

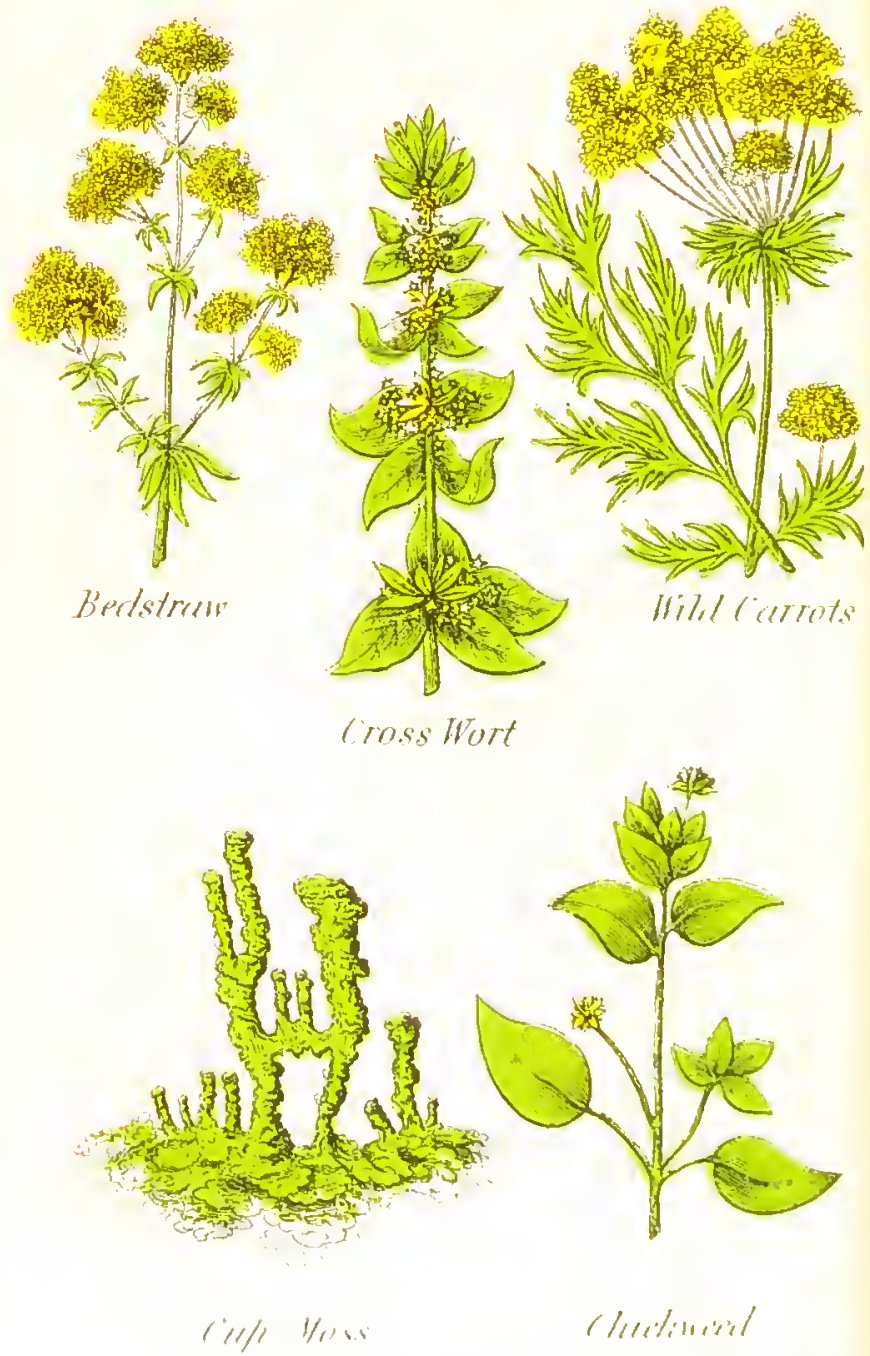


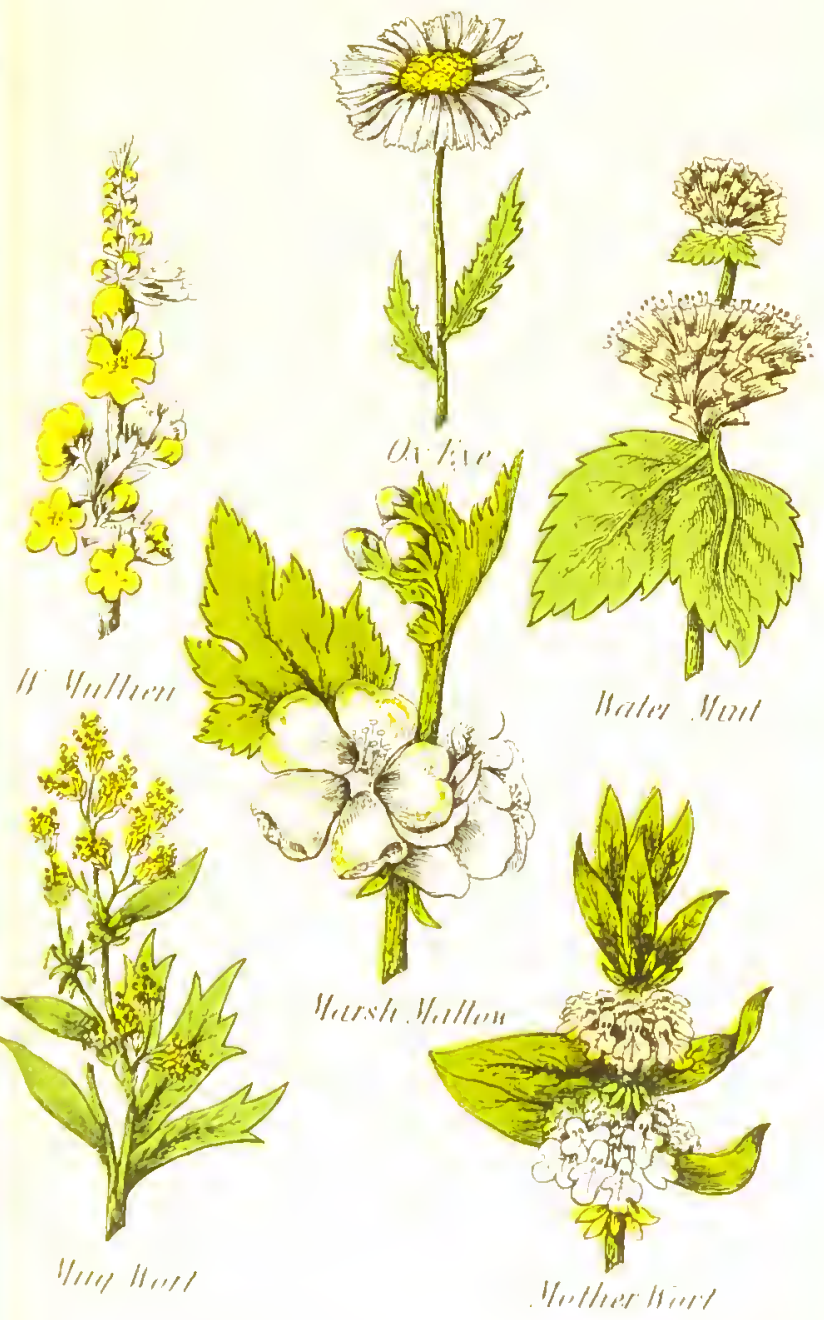




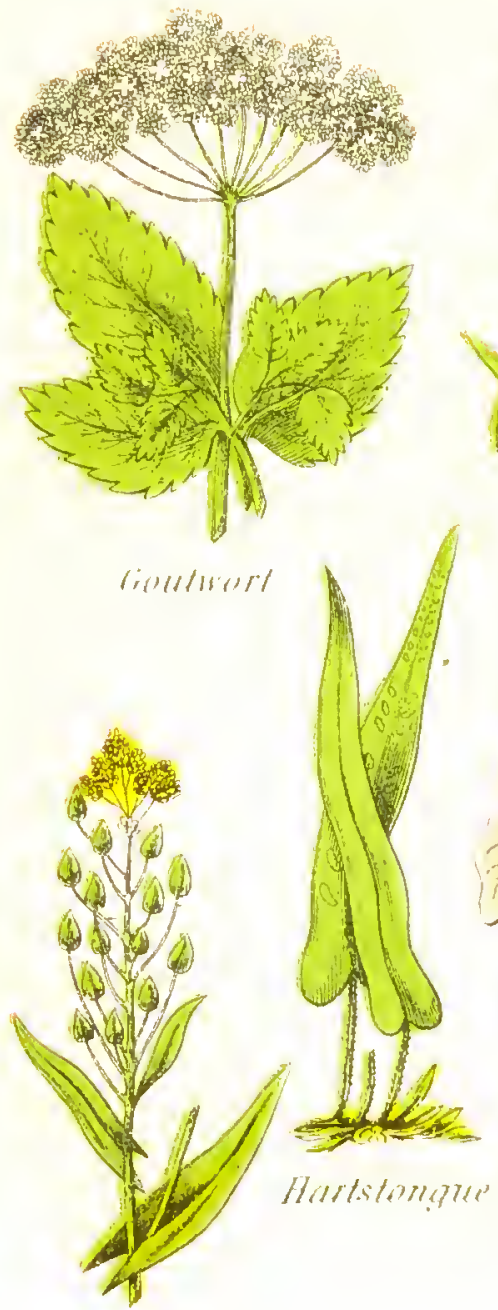

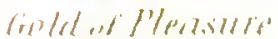

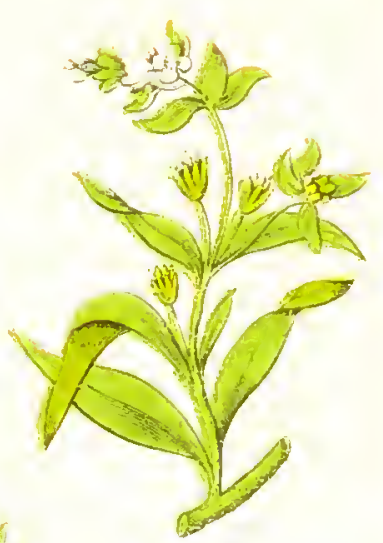

(i)

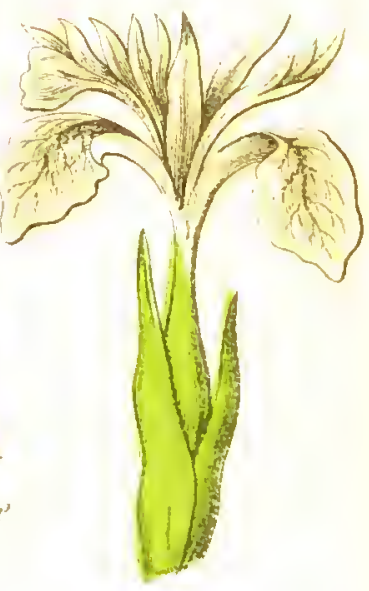

Gilolutel 

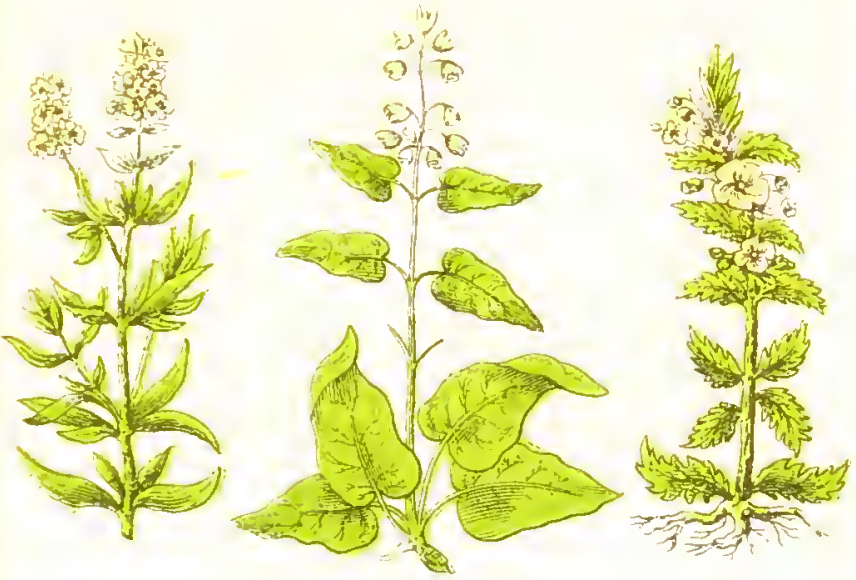

Ml:xiys

lipterepl.

sin/l / Ind
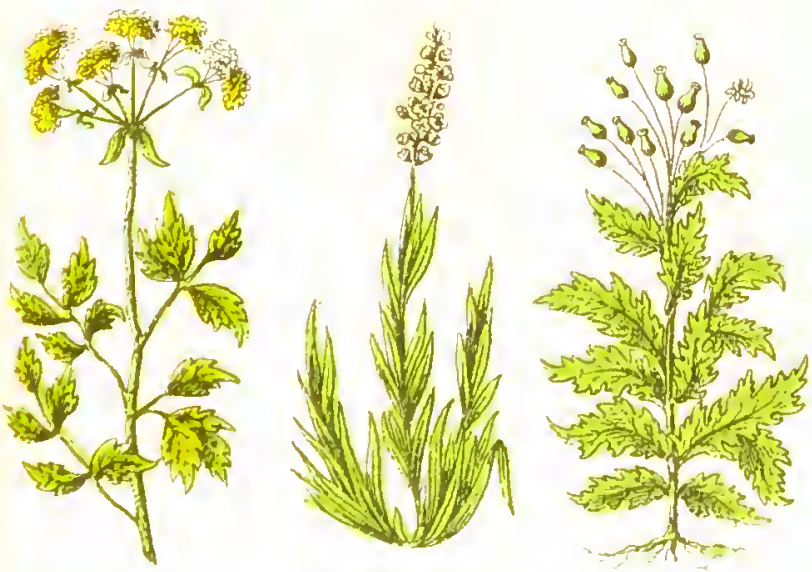

1,11111,

l.11811, 10

$11 / 111 / 1 / 6+21 /$ 



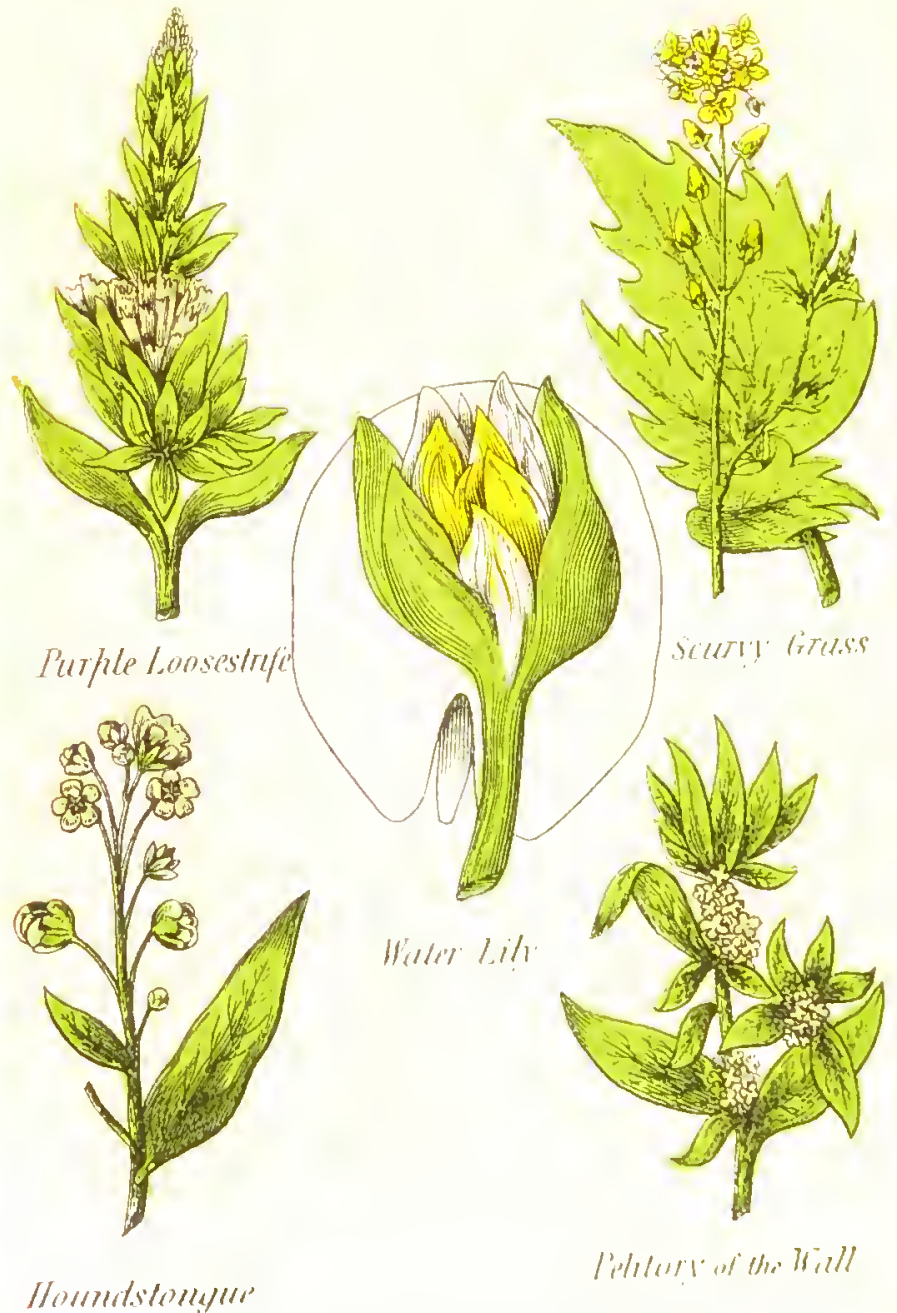




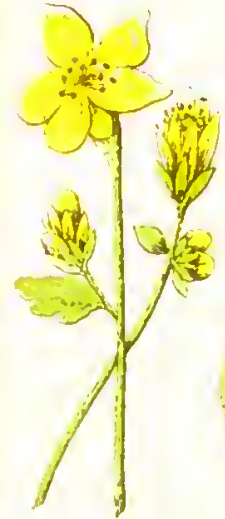

11 S11.1/finll/
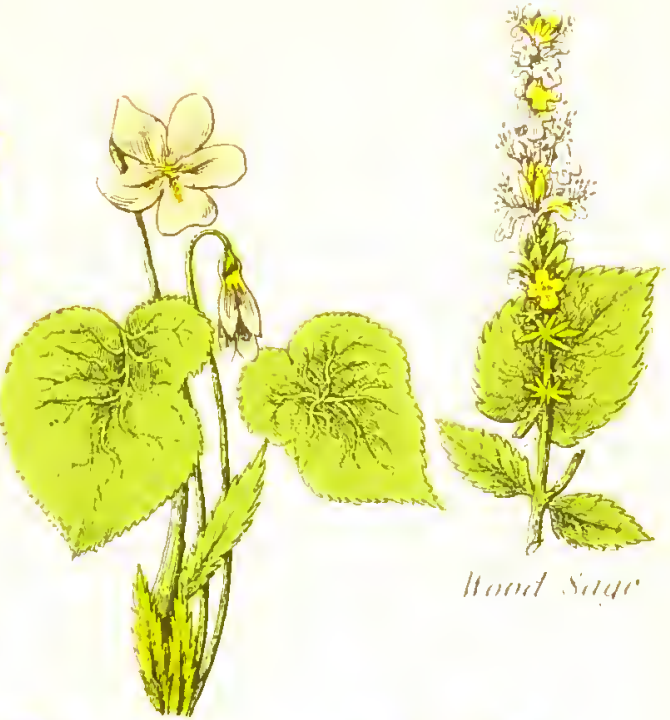

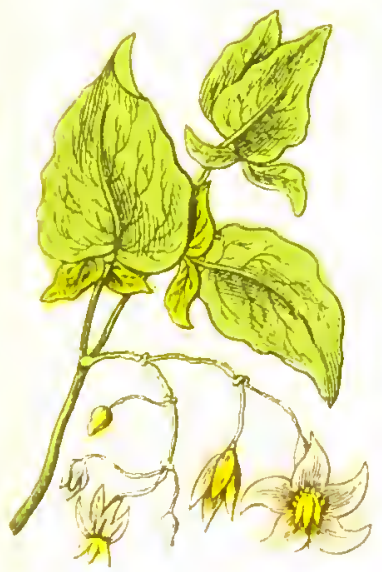

Billen Siness

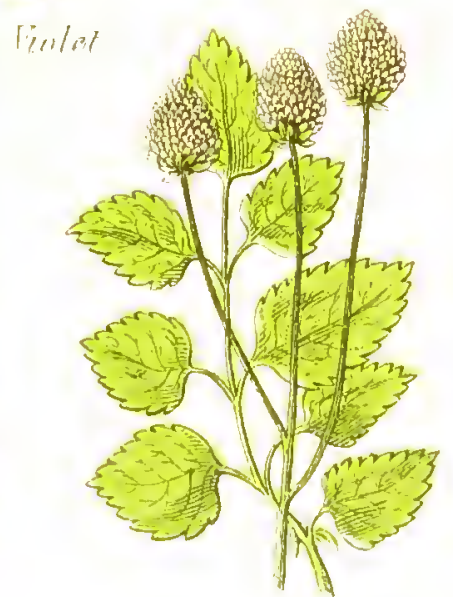

limillel 


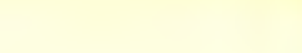




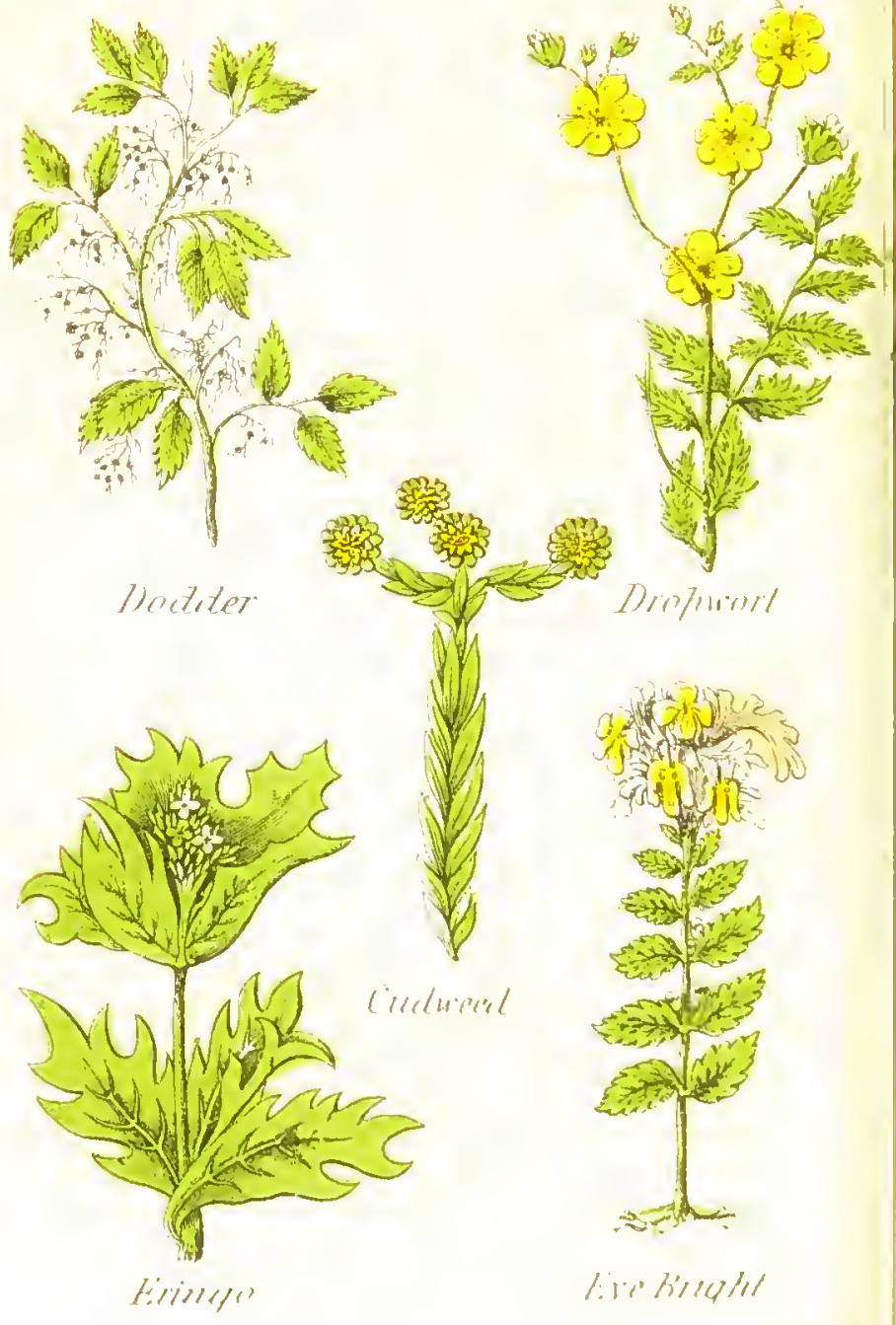




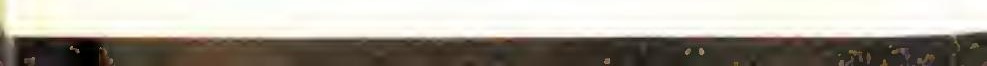



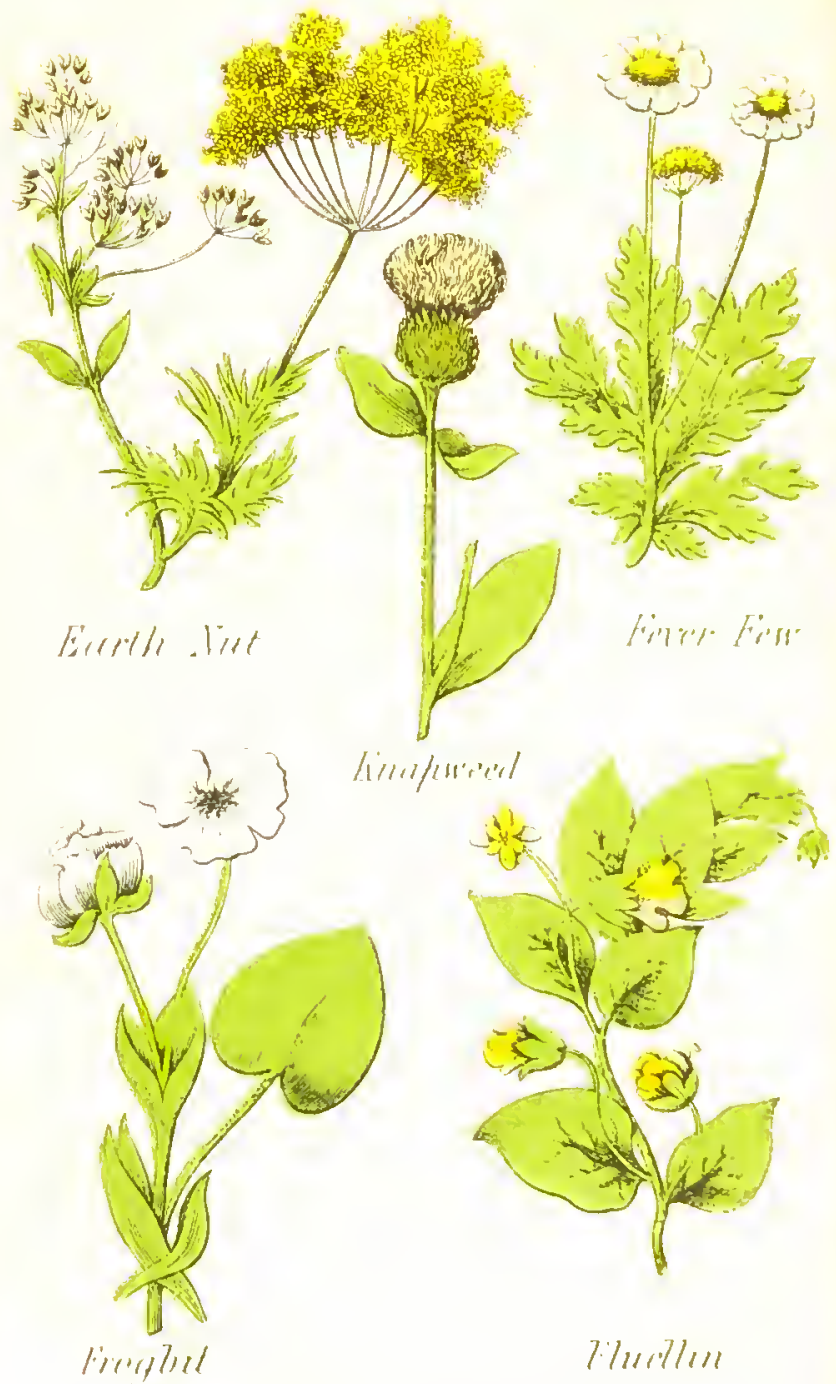


\section{THE DOCTORS WITHOUT A SYSTEM.}

THAT the doctors have no system, is a faet pretty genernlly acknowledged by themselves : or at least they have none that has been fixed upon as a general rule for their practice. Almost every great man among them has had a system of his own, which has been followed by their adherents, till some other one is brought forth more fashionable. This is mucloubtedly a great evil, for it malies every thing uncertain; where it is constantly changing, there can be no dependanee on any thing, and the practice must always be experimental; no useful knowledge can be obtained by the young praetitionel's, as they will be constantly seeking after new theories. What should we say of a carpenter who should undertake to repair a building without having any rule to work by, and shonld, for the want of one, destroy the half of all he undertook to ropair. The employers would soon lose all confidence in lim, and dismiss him as an ignorant blockhead. And is it not of infinitely more importance for those who undcrtake to repail the liuman body, to have some correct rule to work by. Their praetiee is founded on visionary theories, which are so uncertain and eontradietory that it is impossible to form any correct general rule as a guide to be depended upon. Tn order to show the opinions of others, as well as my own, I shall malie a few extracts from late writer's on the subject, - Speaking of the revolutions of medicines, one says :-

"We have now noticed the principle revolutions of medicine : and wo plainly perceive that the theory of medicinc, not only has been, but is yet in an unsettled state; that its practical application is wavering, fallacious and extromely pernicious: and taking a survey of the various fortunes of the art, we may well say with B.icon, that medicine is a seience that hath been more professed than laboured, and yet more labrured than advaneed; the labour having been in a cirele, but not in progression." 
"Theories are but the butterflies of the day-they buz for a while and tben expire. We can trace, for many centurics past, one theory overturning another, yet each, in its succession, promising itself immortality.

"The application of the rules which the practitioner lays down to himself, is direct, and in thcir choice, no one can crr with impnnity. The least erroneous view leads to some consequence. We must remember the lives of our fellorr-creatures wre at stake. For, how many crucl and premature deaths, how many impaired and debilitated constitutions have paid for the folly of theories? Follies which have proved almost always fascinating. The study of a system is more easy than an investigation of nature; and, in practice, it seems to smooth every difficulty."

"In my lectures on the art of physic, (says Dr. Ring,) both thcoretical and practical, I have fully proved that there is no necessity for tbat bane of the profession, conjecture or hypothcsis; and if I were asked whether, if I mysclf were dangerously ill, I would suffer any hypothetical, however plansible, physician, to prescribe for my malady, my answer would be No, assmicdly no, unless I wished to risk the loss of my life. I conld give a remarkable instance of this."

"Speculation and hypothesis are always at variance with sound expericnce and successful practice."

The above extracts crince the pernicious effects of false theory and hypothesis, which, at the present day, constitute nearly the whole art of physic.

The following just remarks are copied from the writings of the Rev. Jorrn Wescey:

As theorics increascd, simple medicines wcre more and moic disicgarded and disused, till in $n$ course of years, tbe greater part of them were forgotten, at least in tho more polite untions. In the room of these, new ones werc introduced, by reasoning, spcculative men, and those more and most difficnlt to be applied, as bcing more remote from common observation. Hcnce, rules for the application of these, and medical books wcre immcuscly multiplicd, till at length plyysic became an abstruce science, quitc out of tho reach of ortinary men. 
Physicians now bcgan to be held in admiration, as persons who were something more than hnman, and profit attended their employ, as well as honour, so that they had now two weighty reasous for kecping the bulk of mankind at a distance, that they might not pry into the mysteries of their profession. To this end they increased those dificultics by design, which were, in a manuer, by accilent. Thcy filled their writings with abundance of techuical terms, utterly unintclligible to plain men.

"Those who understood only how to restore the sicls to health, they branded with the name Empirics. They introduced into practice abundance of compound medicines, consisting of so many ingredients, that it was scarce possible for common people to know which it was that wrought the cure-abundance of exotics, neitber the nature nor names of which their own countrymen understood."

"The history of the art of medicine, in all agcs, (says Dr. BuANe,) so teems with the fanciful influences of supcrstitions observances, the imaginary virtucs of medicines, with ungatory, delusive, inefficicnt, and capricious practices, fallacious and sophistical reasonings, as to render it little more than a chaos of error, a tissue of deccit, unwortby of admission among the useful arts and liberal pursuits of man."

\section{GENERAL REMARKS ON BRITISH IIERBS,}

FOR DISEASES OF STOMACII AND BOWELS, AND ABSISTING DIGESTION.

CAmome agrimony, hetony, thistle (blcsscd,) caraway seeds, sweet tlag, femnel, garlic, horehound, hyssop, lavender, masterwort (the root,) mint, mustard sced, pennyroyal, horse radish, rue, wormwood.

Decoctions of the above are made by pouring boiling water on them. A little slowld be taken in the morning fasting.

For merging the Jowels.-Class 1. The powerful are tho folluwing: common dock, lelleborc (whitc,) in doses not 
exceeding four grains; black helcbore, from two to five grains; marsh-mallow leaf decoction, and mountain flax.

Class 2. more moderate; buckthorn berry, broom, and dandclion.

For Worms.-Bear's-foot, cowhage, camomile, garlic, fern root, savin, and wormwood.

Astringents, which serve to correct excessive discharges, $\log$ wood, red roses, sagc, and tormentil root.

Carminatives, or those herbs which allay pain, or dispel wind from the stomach; aniseed, caraway seed, peppermint, spearmint, ginger, and dill root.

Demulcents, or those which are useful in diarrhoea, dysentery, gravel, gonorrhcea, \&c.; colt's-foot, liverwort, mallows, liquorice root, wheat, sc.

Diaphoretics, or those which promote perspiration; burdock, centaury, bay tree, betony, balm, germander, lovage, and rue.

Tonics, or those which give strength and vigour to the body; bistort, balm, bog-bean, camomile, centaury (lesser,) logwood, gentian, southernwood, tansy, tormentil, valerian, and wormwood.

To heal Ulcers.-Adder's tongue, agrimony, archangel, arse-smart, cuclrow-point, bluc bottle, burdock, bryony, soapwort, celandine, centaury, chickweed, cinquefoil, comfrey root, mngwort, cudweed, dog grass, watcr dock, figwort, tlaxweed, foxglove, glass wort, ground ivy, ground pine, tormentil, tansy, bugle, scurvy grass, and nightsharle.

Either made into ointments, with hog's-lard, or washes made of them, and daily applied to the parts.

To purify the Blood.-Agrimony, borige, burdock (sea,) chicliwecd, chervil, fennel, fir tree, fumitory, gardcn cresses, wild water cresses, ground pinc, hops, maiden hair, sorrel, and tansy.

Made into decoctions with hot watcr, and talien erery morning. 


\section{NEW BRITISH HERBAL。}

\section{ACACIA TREE.}

Foreign. Grows in Egypt. We have from it two drugs; the Acacia juice, like liquorice juice, hard and black. Also the Gum Arabie; both astringent, useful in stranguries, and in coughs, hoarseness, \&e, Given in solution. An ounee boiled in a quart of barley water, or in powder as an electnary. In diseases of the lungs, kidneys, or intestines, on aecount of its demulcent properties, it neutralises irritation. Gum Alabie powdered, or in thick solution, is a good applieation for burns and execriations, forming a erist over, and protecting the parts from the atmosphere. Combined with powdered resin, it is a good styptie. As diet it is nutricious. The wandering Arabs, sometimes subsist wholly upon it.

\section{ACANTHUS.}

It is also ealled Brank Ursine and Bear's Breech. Acanthus, Greek, a thorn; and Latin, mollis, soft.

Description. This thistle has many large thiek, green leaves upon the ground, with a thick and juicy middle rib. The leaves are parter with deep gashes on the edges; and remain a long time before a stalk ajpears, three or four feet high, bearing white flowers hooded and gaping, and standing with brownish husks, and a small long nurlivided leaf' under each leaf, It has many thick roots, blackish without, and whitish within, and full of elammy sap. It is a Garden Plant, and flowers in June and July; and it ought to be in every garden.

Mremicisar, Virturs. - The lesves boiled, and the lirpuor userl as a clyster, bencfieially eleanse the bowcls, and strengthen the rectum. 'The deeoction is gronl for' the bloorly flux. 'The leaves boiled and applied as at poultiec serve to unite broken 
bones, and strengthen joints that have been dislocated! $\Lambda$ s a deeotion, or as a ponltiee, the leaves or roots are benefieial in scrofula or king's evil, when the sore is broken. It is a firstrate remely for burns, drawing ont the fire, and heals it withont a sear. It is a raluable remedy in licetie fevers, as it restores ladical moisture to the eonsmimptive. It has been mueh used as a dimretic. It is excellent in discases of the minary organs, given in the form of powder-that is, from the leavesfrom 12 to 40 grains three or oul times a day. It is a powerful dissolvent of stones in the kidneys.

\section{$\triangle \mathrm{CONITE}$.}

Description. - Aconitum Napellus. - There are many poisonous Aeonites not used. It is also ealled W"ult's Bane, or Monk's Hood. The Purple Monk's hood, formerly ealled the Purple Helmet-flower, is the most eommon. It is well known by its purple flowers resembling a Monk's hood. Children and delieate persons should not appronch too near it, as even inhaling the scent has sometimes jroduced sickness and fainting.

Medicinal Virtues.-The leaves and roots are medieinal. In proper doses they are anodyne, sellative, dinretic, and diaphoretic ; and very useful in dropsy, eonsumption, and enlargement of the heart. The Tineture of $\Lambda$ conite may be procured at the shops, and is a valuable external application for Rheumatism, Lumbago, Neuralgia, \&c. Liniment as follows ; Extract of Aconite, I scruple; Soap Liniment, and Compotnd Camphor Liniment, of each 1 ounce, rubbed into the affected part night and morning, or oftener.

(fexto No one should take it inwardly except under the direction of a skilful physician.

\section{ADDER'S TONGUE.}

Ophiglossum Vulgatum. It is also ealled Serpent's Tongne.

Description.-It is a smill plant, common in moist neadows, buried among the grass. It has but one leaf, oval, on a stalk a finger's length abour the gromml, flat, and of a fiesh green colour; broad like Water Plintine, but less, withont 14 
any rib in it. The stalk rises from a root composed of small fibres, about four or five inches high. The spike rises to the same lieight above it, and the touguc, or seed vessel is notelied on each side. The root is pereninial. It is to be found only in April or May.

Medicinal Vintues. - The juice of the leaves drank with distilled water of Horse-tail is good for wounds, and for vomiting, or bleeding at the moutls or nose. It is good for sore eyes. The lcaves make an excellent balsam for green and fresh wounds, for old and inveterate ulcers, and for inflammations. It is a fine cooling herb, which gives it rare adaptation as a curative of wounds, Sce. Make the ointment as follows; T'wo pounds of leaves ehopped vely fine, put into half a pint of oil and one and a half pound of suit melted together. Boil the whole, (but do not burn it) till the herb is rather erisp; straic off from the leaves, and the liquid will be, when cool, a bcautiful and efficacious Ointment. Some Surgeons add a little fine elear turpentine.

\section{AGRIIONY.}

Agrimonia Eupatoria.-A plant of the natural order rosacea, common over all England in the hedge-rows, pastures, and woolsides.

Description.-It has long leaves, dented at edges, green ahore, and grayish underneath, and a little hairy. The stalk which is strong, round, hairy, and brown, is two or three feet high, with smaller leaves upon it. At the top grow small yellow flowers, one above another, in long spilies, after which eone rough heads of seeds, pendant, and whieh adhere to garments, like burs. The root is blaek, long, and perennial. It flowers in July and August.

Medicinal Virtaes. - This herh ought to have high reputation on account of its great medicinal qualities. The leaves may be used fresh or dried. It is a fanous vilnerary herb. The leaves are astringent and aromatic, and thecefore very useful in jaundice, diabetes, and incontinence in urine. It is given for a lax tone of the bowels, on account of its astringency, and combined with raspbery leaves, would arrest diarlice. 
Few herbs have been so efficaerous in spitting of blood, bloody urine, and disorders of the liver:

The best method of using it is by infusion, swectened with a little sugar. It should be taken in the morning fasting, and repeated two or thrce times during the day. It bas been found uscful in colic, and in coughs. It cleanses the chest and the lungs. In Ague, the decoction of it taken hot bcfore the fit in time cures the disense. The leaves and sceds infused in wine cure the bloody flux. Made into an ointment, (with Hog's Lard) it cures wounds, sores, ulcers, \&c. In liver affections it is very serviceablc. By it some very obstinate cases have been cured. It is a most effcctual cleanser of the skin, and purificr of the blood, and it is an excellent gargle for sore throats. For diabetes and ineontinence of urine, boil in milk. Agrimony tea. with alum and honey is a remedy for tape worms.

Take equal quantitics of Agrimony, St. John's Wort, and Camomile flowers, and Wormwood, make into a decoction, and you have a good fomentation, for violent pains, cramps, \&c. The plawt should be gathered when in bloom, and carefully dried, and hung up in a warm place. How few know the value of this plant!

\section{AGRIMONY.-WATER AGRIMIONY.}

Eupatorium Canabinum. In some countries it is called Water Hemp, Bastard Hemp, and Bastard Agrimony.

Description.-The stalks grow several feet high, of a dark purple colour; the branches are numerous, growing distant from one another. The leares are winged, and indented. The flower's grow at the top of the branches, of a brown yellow colour, black spotted, having a centre like a daisy. The sceds are long, and adhere to any woollen substance. It is principally found in the north of England, in cold grounds, by ponds and ditches, by running watcrs, sometimes in the midst of waters. It flowers in July and August, and the seed is soon ripe.

Medicinal Virtues. - It heals and cleanses cancer, and relieves tough humours of the breast, taken as a decoetion. It
relieves the dropsy and yellow jaundice, and removes obstruc16 


\section{ALDER TREE-COMION. ALDER TREE-BL.ICK.}

tions of the liver, and applied outwardly, mollifies the hardness of the spleen. It is a good remedy for the ague, provolies urine and the terms. As a purge it operates powerfully, yet safely, and dropsies are said to have been cured by it. It strengthens the lungs, and is an excellent vermifuge. Farmors give it to cattle troubled with cough, or broken winded.

\section{ALDER TREE;-COMNON}

Descriptron, - Almus Glutinosa Trulgatus. The common Alder-tree is well known. Its stem is tree-lilie and full of branches ; the bark is rough, of a dark brown colour, and irregularly i,lotched with white, having large romml leaves irregularly notehed on the edges and clammy to the touch, especially while young. Its flowers are white, and the berries are black. It grows in hedges, moist woods, and watery places. It flowers in April or Miny and the seed is ripe in September.

Medicinal Virtues.-The decoction, or distilled water of the leaves, is good for burns and inflanmations. And especially for inflammation in the breast. An infusion of the inner green bark of the trunk in wine, or of the expressed juice of the berries in the dose of half an ounce, is said to purge moderately, and in small doses prove an eficicious deobstruent, promoting all the fluid secretions. The decoction, as thiek as treacle nearly, makes a gond pill for indigestion, impetigo, or pustular eruption. A strong decoction is recommended. The fresh leaves laid upon swellings clissolve them, and stay the inflammation. The leaves put wndler the bare fcet galled with travelling, greatly refresh them. The leaves with morning dew on them, and brought into a chamber tronbled with fleas, will gather them, which being suddenly east out, will rid the chamber of them.

\section{ALDER TREE; - BEACK.}

Alnus Gilutinose. Tt is also caller the herry-boaring Alder.

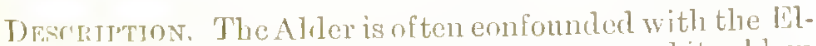
der. The Alroris more like a shrub than a tree, and it sehum grows to a great size. The branches are smooth, slender, 
numerous, of a dark brown or purple colour. The inner nark next the wood is yellow, which when infused, produces a saffion colour. The leaves resemble those of the ordinary Alder-trce, or the Femalc Cornet, or Dog-berry-tree. The flowers are white, with leaves at the joints, which produce small round berries, first green, and blackish when ripe. It grows plentifully in some woods. It flowers in May, and the firuit is ripe in September.

Medicinal Virtues.-The inner yellow batk decoeted is usetul in billious affections, and the dropsy. The bark boiled with Agrimony, Wormwood, and Fenmel, and taken every morning, is very effectual against jaundice and dropsy, a decoetion of the dried bark removes obstruction of the liver and splcen, and removes the hardness of the former. The outward bark is astringent, and is useful in Eluxes. The outward bark boiled in vincgar lills lice, cures the iteh, and removes scabs. It is a good wash for the teeth, easing tooth-ache and fastening loose teeth. As a deeoction it is an exeellent drink in the beginning of spring. On account of its purifying and exbilarating qualities, it onght to be esteemed as a jewel.

\section{ALTANET.}

Anchusa Officinalis. It is al:o called Orehanet, and Spanish Bugloss.

Description, - It has a large thick root, of a reddish eolour, long, natrow, hairy leaves, green like the leaves of Bugloss, which lie very thick upon the ground. The stalls are thick with leaves. The flowers are small, hollow, and of a redelish colour. The plant grows in Kient, Devonshire and Cormwall.

Medoinal Virtues. - It is serviccable in olil ulcers, inflammutions, bums, and St. Antlony's fire. 'The losst wity is to make it into an ointment; or make a vinegar of it, as ron nuke a vinegar of loses. It is useful in the yellow jamtice, splect, and gratrel. Dioscoriules saitl, it enres venomous bites, vhether it be taken inwardly, or applien to the wommd. It stays tlic flux, and kills worns. Its decoction mule in wine, strengthens the bate, and remores its pains. It is grood for 
biuises and falls, and to drive out the small por ami mensles. Ninte into an ointment, it is excellent for green wonnds, punetures, Ee.

\section{ALI-IIEAL,}

It is also called Wound Wort, Panty, Opopane Wort, Latin, Stachys Sylvatica.

Descriptiox. - It grous in wet grounds, has long hairy leaves, eneh leaf has five or six pairs of winged leaves, almost like ash-trec leaves set one against the other upon foot stalks, hroml at the base, and narrow at the end. The leares have a stron! smell and a bitterish taste. The flowers, which are yellowi, stand in clusters round the stalks at the joints, all they beal light yellow flat secels, hitter in taste. The root is peremnial, long, thick, of a hot biting taste. It flowers in Autumn, and soon sheds its secels.

Medicisal Virtues. - As its name imports, it is a good wond herb; the leaves being bruised and applied to a uew wound; they stop the bleeding and cure the wound. . It relieves gout, cramp, and pains in the joints, vertigo, filling sickness. Madc into an ointn ent it eures the itch.

\section{ALMIONDS.}

Fureign. - The Essential Oil of Bitter Almonds is used for flatrouring Custards; but on account of its poisonous uature great care ought to be cxereised. Sreet Alumends are cuullient and demuleent. and an enulsion of them is usedinl in brunchial cliscases, in tickling coughs, hoareness, dysentery, and allections of the urinary organs, often decreasing the acrimony of the secretions in a remartiable nimner.

\section{ALOE.}

Formign.-The juice which resolves itself into a very lilter rein is userl in merlicine as a stimulant cathatic, as ling clicefly on the lower lowels ; it is a tonie when falien in smatl dones. -There are three kimls of $A$ loes, Socotrine, or Cafe, Linliadoes, ankl II (opatic. 'The fom.er is the best, being the millkst 
in its effects. For indigestion, lowness of spirits, and jaundiee, aloes are servieeable, as they stimulate aetion on the rectum; and also on the uterus ; therefore must not be prescribed in piles, nor in pregnaney. Pills are the best form for taking it. It is best to eombine them with other purgatires to prevent after eonstipation. As they aet on the eolon and reetum, they expel ascarides, or seat worms. Dose from 3 to 10 grains, if taken alone.

\section{AMARANTHUS.}

Amaranthus Blitum. It is also ealled Flower Gentle, Flower Velure, Floramor and Velvet Flower.

Description.-It is a garden flower, well known. It grows from one to two feet ligh, streaked, and red towards the root, but very smooth, divided towards the top with small branehes, among whieh stand long broad leaves of a recldish green eolour, slippery ; the flowers are not properly flowers, but tufts, very beautiful, but of no sinell, of a reddish eolour ; if bruised they yield juice of the same eolom ; being gathered they keep their beanty a long time; the seed is of a shining blaek colour. They flower from August till the frost nips them.

Medicinal Virtues.-There are several kinds of the Amaranthus; but that nsed in medieine is the large one with the drooping purple spike. The flowers dried and powdered are used as a styptie, arresting the profusion of Menses, diarhoen, bleeding at the nose. \&e. One speeies bears a white flower, which stops the whites and eleanses and strengthens the kidneys.

\section{ANEIIONE.}

Caller also Wind Flower, becanse, they say the flowers never open but when the wind blowetl. The seed also flies away with the wincl.

Description. - It has a peremnial thiek root, full of knobs, very aterid to the taste. Its leaves are supported on long leaf staiks, which are divicled into three parts, each of which support a number of pointed and jarged segments, having a 
round slender and purple stem, six or eight inches high, with three leaves surrounding it near the top. The flowers are large and white, with more or less of a purple tinge, which stand on tender foot stalks, which rise from the centre of the leaves, surrounding the stem. It is found in woods, and by hedges; but it is mostly eultivated in cardens where its eolours are more beatilinl and valious. It flowers carly in the spring.

Medicinal Virtues.-The lcaves provolie the terms, when taken as a decoction. Bathing the body with it eures leprosy. The leaves being stamped, and the juice sunffed up the nose, purge the head. Being mide into an ointment, and the eyelids anointed with it, it is good for intlammations of the cyes, and other discases peculiar to them. amaurosis, cataract, and opacity of the cornea.

\section{ANGELIC $\Lambda$.}

Description.-Angelica Archangelica, a plant of the natural order Umbellifere or Apiacera. It is a large beautilul plant eultivated in gardens, and it grows wild in some parts. It grows eight feet high, the stalks are strong, and divided into branches. The leares are large, each of which is conposed of many smaller, set upon a divided pedicle. They are notehed at the elges, and of a bright green. The flower's are smill and white, but in large tufts of a globose form. Two scels follow each flower, which seeds are flat on one side, on the other convex, and marked with three furrows. It flowers in July, and the seerls are ripe in September.

Medicinal Virtues.-The stalks, leaves, and seeds possess stimulant, carminative, and tonic properties, which are strongest in the latter. It has a pungent taste, and an agreeable aromatic odour. The whole plant has the same virtues. It is eordial and sudorific, and lias always been reckoned good against pestilential and contngious discases. The root is valuable; but the best roots come from Spain. Water distilled from the root removes flatulent pains, and pains arising liom cold. This water with solue of the powdered root is goorl in the plemisy, disenses of the luners and breast, as eoughis, shortness of lureath, and a sylup of the stalks has the sime effects. It is grool in 
the colic, stranguary, ant stoplyage of mine, and removes obstruetions of the liver and splecre. 'L'le juice dropped into the eycs remores dimness of sight; and into the ears, deafices. Also some have found relicf in tooth-ache by applyiner the juice. The juice or the root powdered, cleanses sores and ulcers, and the distilled water eases gout, sciatica, themmatim.

Dosc, of the poudered root from 10 to 20 grains. - Distill d unter, I ounce.-Extract from 5 to 15 grains.-Infusion, a tablespoonfil or morc.-Tincture, a drachm.-Spirits, fiom nille a drachm to 3 drichms.

Angelica Cordial. - A small handful of the Angelica stems, from which strip the leaves, and pick ont the threads; then cut theu into little pices. To a jound put 12 pints of branty, or more, two diachims of cinmamon, and one of mace, with i. cloves; dissolve 4 pounds of stigne in 6 pints of water, and mix the whole in a jar that must be well corticel, to stand for about 6 wecks ; then filter it, and bottle for use. It is most serviceable in windy complinints.

\section{$\triangle N I S E E D S$.}

Foreign. - Anisceds are prorluced by a small plant growing on the island of Malta and elsewhere. They possess stimulant and carminative properties, useful in indigestion, flatulency, and colic. Dose of bruised or powdered seeds 10 to 30 gramin, intired in distilled water, a wine-glisstul;-compound spinit 1 to 4 drachms, essential oil 4 to 20 drops, on sugar.

\section{ARCHANGEL, RED, WHITE, AND YELLOW.}

Description. Lamium, Album, Flavus, Rubeus. Called also Dead Nettle, and Bee Netrie. It grows ahout hetleres, about a foot high, and its leares are shajed like those of the nettle, but they do not sting. The stalk is square, and the leaves are hairy. In the White Arcliangel, the flowers are white and large; they stand at the juints, where the leares issuc and are very pretty. The leares are in pairs. The herl Archangel has, of contre. fluwers of a diale redilish colour, The Xellow plant is like the others in the stullis and leaves; 


\section{ARCHANGTI, RRD, ere. ARRACII WILD, \&c.}

except the stalks are rather more straight nud ereet, and the joints with leaves are farther asmoler ant the flowers a little larcer, of a good yellow colonr in some, and rather paler in others. They flower from the beginning of the spring and throughout the summer.

Medicinal Virtues. - The Arehangels are used with great sneess in removing the hardness of the spleen or milt, which is supposed to be the seat of melancholy, \&e. A deeoetion is to be made witl wine, and the herb applied hot to the region of the splecn, as a plaster; or foment with the deeoetion. "The flowers of the White Arehangel are preserved or eonserverl, and used to stay the whites, and the decoetion is good for floodings, bleeding at the nose, and spitting of blood, or any kind of hemorrhage. It is an exhilarnting herb, driving away melancholy, and it makes the heart merry. Bruised and mixed with salt, vinegar, and lard, and applied to hard tumoms, swellings, or king's evil, it is of great service, it also gires ease to the gout, sciatiea, and other pains of the joiuts and sinews. It is very effcetral in the healing of green wounds, bruises and burns. The Yellow Arehangel is the most effectual for old sores and nleers, though they have beeome hollow; and to dissolve tumours.

\section{ARRACH, WILD AND STINIKTNG.}

Called also Dorg's Arrael, Goat's Arrnel, and stinking Motherwort.

Description.-It has small and roundish lenves, of a dusky mealy colont, grovring on slender stalks that spread on the ground, with small flowers in elusters set with the lenres, which leave small seeds. It is au anmual, and smells like rotten fish, or something worse. It usually grows upon dunglills, and flowers in June and July, and the sced is soon ripe afterwards.

Mrdicinat Viatues. - Stinkiug Arraeh is a valuahle medieine for diseatses of the womb, especially those whieh produce hard labour in child-birth ; for it cleanses and strengthens the womb, and cures barremess. It promotes aul moderates the mentes. In these respects it is very valuable. The best way of using it is to make it into a symul, by sugrar or honcy. 


\section{ARRACH, GARDEN.}

It is also ealled Orach and Arage, and it is enltivated for domestie use.

Description. - It is well known to every houscrvife. It is an ammul, and is grown in the ganden as a vegetable. It flowers from Junc till August.

Medicinal Visitues. Eaten as a vegetalle, it is laxative and healing to the bowels. If bruised, and applicd to the throat, is good for swellings in the throat. The best way is to boil it to drink the decoction and then apply the herb outwardly. It is also excellent for the jaundice.

\section{ARSESMART.}

Description.-Polygonum Hydropiper. -The hot Arsesmart is also ealled "Water-pepper, or" Culrage. The mild Arsesmant is ealled dead $A$ rsesmart, Persicaria, or Pench-mont, because the learcs are like the lcaves of a Pench-trce; it is also called Plumbago.

It has broad lcaves set at the great red joint of the stalks, with semi-eireular blackish marks on them, eitler. bluish or whitish, with such like secd following. The root is long, with many strings. It has no sharp taste (as another solt hath, whieh is quick and biting) but rather sour like sorrel, or elsc a little drying, or withont taste. It groweth in watery places, ditelies, and the like, which are for the most part dry in Stmpmer. It flowereth in June, and the sced is ripe in $\dot{\Lambda}$ ugust.

Medicinal Virtues. - It possesses great virtues. It is of a eooling nature, and effectually cures putrified ulcers, kills worms, and clennses putrificd places. The juice is good for cold swellings, and it softens and removes congenled blood of Intuises, by strokes, falls, \&c. $\Lambda$ picce of the root, or some of the seeds brnised, and held to an aching tooth, takes away the pain. 'I'he leaves bruised cure the felon. It destroys worms in the ears. If the hot Arwesmart be strewed in a chamber, it will soon lill all the flens; and the herb or juice of the cold Arsesmart, put to the sores of cattle, will drive away the fly in 24 
the hottest time of Summer. The mild Arsesmart is good agrinst all imposthmones and inflammations at the beginnimg, and to heal green wounds.

The hot Arsesmart grows not so high or tall as the mild, but has many leaves like peaeh leaves, seldom spotted; in other partieulars it is like the former, but may easily be known from it by breaking a leaf of it aeross your tongue, for the hot will make your tongue smart, but the cold will not. If you sce them both together you may casily distinguish them, beeanse the mild hath broader leares. It effeetually cures obstruetions of urine, in crravel and stone, and in the jaundice and dropsy it has wrought great eures. Dr. Elyerle consirlers this plant one of the best pronioter of menses we have. Use the eold watery infusion. Never boil or seald it.

\section{ARTICHOLE.}

This requires no deseription.-Cynaria. It has good medicinal qualities. The leaves yield a bitter juiee, which is diuretic, and useful in dropsy. The fresh root slicer and boiled in water, six ounces to a quart of water, makes a deeoction, has been known to cure the jaundice. The following decoction whieh was long kept a seeret by a person at Andover, is said to have carried off the water from several persons in the dropsy. Take off Artiehoke leaves and stalks, three handfulls, bruised juniper berries, one quart, a handful of scraped IIorse-rudish, bruised white mustard-secds two tahle-spoonfuls; boil the whole in two gallons of water to one and strain the liquor through a cloth. Half a pint for an adult, morning and evening. Add sugar if required.

\section{ASARABACCA.}

Description-Asarum, Europaum. It is an evergreen, putting forth new leaves in spring. It is will in many parts

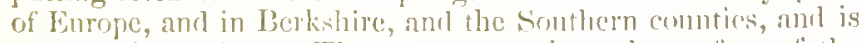
crommon in grardens. Thie roots crecp albont the surfice of the gromm, the leaves grow singly fiom them, withont stem or stalk; the leaves are errissy encen and kibuey-shtiped; tho lolossom grecuish, with purplc-brown streaks on a short stem; 
these flowers are near the gromnd. The roots are sllill and whitish; sweet in their snell, but more so when they are diy, and of a sharp, but not unpleasant taste.

Menicinal Virtues.-It is acrid, emetie, purgative, and sterrutatory, or provoeative of sneezing. The powdered root in the form of snuff is an effectual remerly for removing oustructions in the liead, removing headaches, girldiness, drowsiness, and colds in the head. It has been usetinl in deafiness arising from entarths. Two or three grains snuffed up the nose going to bed, will enuse a copions discharge of offensive mucous from the hend the following morning, and be of service all the day following. A decoction of it proves an emetie, and it purges downwards, and by urine also, and removes phlegm, and relieves colic. As a fomentation it relieves pains. Boiled in whey it removes obstruetion of the liver and spleen, and is therefore good for dropsy and jandice. Steeped in wine and drank, it is good for the ague. The oil of it with a little laudanum, promotes perspiration, the ridge of the back being anointed therewith. The roots have the same effect, but not so forcibly. Let it be used with eaution ; for I am opposed to much vomiting and purging medicines; they werken nature. $A$ physician shoulr strengthen as much as he can, and debilitate or weaken as little as possible. To make the smufi-take three parts of Asurabacea, one part of Marjorm, and one part of Laventer flowers. Reduce to a powder, and eork in botiles.

The Cephalic and Eye snuff's are composed of $\Lambda$ sarabaeen, root of White Hellebore, Lily of the Valley, and Betony.

\section{ASH.}

Description. - Fraximus Excelsior. It is a tree eommon in hedges and woorls. The bark of the brauches is gray, and the leaves are wingerl. 'The flowers are of a whitish gieen, and come hefore the lenves. More deseription is useless, as the tree is so well known.

Medicinal Vimtues. - The distilled water taken erery monning is very grout tor \{he dhopsy ant obesity. The decortion in white vine halps to rissolve the stone and expel, ant io cule the dropsy. 'The ashes ol the batk maxle into ley to wims 26 


\section{ASII.}

with, cure scahly and leprons hear?s. The hark, as a decoction removes ohstructions of the liver and spleen. The hark of the conmon Asl has been used as a substitute for Cinchona in larex doses. By some merlical men the leaves have been recommencled as a substitute for Scuna, having a less griping effect, and they answce well. They ate useful in rhemmatic atiections. They should be gathered in June, well dried, powdered, ancl kept in well eorlied bottles. For use, iufuse I drictum in a pint of boiling water nutil cold, then strain. Take a teacuptil twice a day. As a purgative, half an ounee of the Powder is required.

From the Fraxims On nus, or flowering Ash, is derived the conerete juice, called Manna, a very useful purgative for childreu and weakly persons. It is a pleasant and mild laxative.

\section{ASPARAGUS.}

Description.-Asparagus Officinalis. This vegetable requires but little deseription, as it is well known, and often scen in markets, ticd in bundles of a hundred for sale. It is cultivated in gardens; but in the south of England, near tlie sca coasts, it grows wild; and the roots of the wild are medicinally better than those in gardens.

Medicinal Virtues.-The roots generally used, whieh are very diuretic, aperient, and alterative, or deobstruent; thcir retion being causerl by the presence of an alkaloid, called Asparagin, given chicfly for dropsy, consumption, and undue action of the heart. It has becn known singly to cure the jamdice and dropsy. It is best given in deeoction. The dose is a teacupful threc times a day. Of the extract from 20 to 60 grains. Of the Syrup from 1 to 4 ounecs a day. The latter is most useful in Phthisis. The roots decocted in white wine, is a good extcrnal remedy for pains in the kidncys, bladder, cramp, and benumbed limbs!

This is the French methor of making Asparagin, which is so cffectual :- Wrap the stallis of $\Lambda$ slaragus in moistened linen for a few clays in a warm place, till decomposed, which mity he known by their unplensant smell. Beat in a mortar with water suficicit to dilute the visejd juice, press the juice strongy- 
ly through a eloth, and heat in order to eoagulate the allumen and ehlorophylle. Then filter, and concentrate in a marime bath; do it a seeond time, and then boil down to the eonsistenee of syrup, and put it in a eool plaee. The vessel eontaining the liquid will be lined with erystals of asparagine, eorerch with extractive matter: purify thein by washing in eold water, or diluted spirit.

\section{$\triangle S S A F Q E T I D A$.}

This stinking drug is the eonerete juiee of the Ferula Assafotida. It is antispasmodic, expeetorant, stimulant and gently aperient. It is a valuable remedy for all nervous disorders; for spasmodie eough, asthma, and other disorders of the ehest. The pills may be made thus:-Assafoetida, galbanum, myrrh, each 1 ounee; reetified oil of amber, half a draehm; beat them into a mass with simple syrup The dose is tell grains twiee a day in hysteria and asthma.

\section{AVENS}

Description.-It is also ealled Colewort, and Herb Bennet. It is a wild plant, and grows about hedges, rising nbout fourteen inehes high; the stalk is firm and slender, and divided into several branehes. It has long, rongh, dark green winged leaves; the stalks are hairy. The leaves growing up from the root are winged; they eonsist of three pair of small ones, and one inueh laiger at the end. Those on the stalk are smaller, and have fewer parts, otherwise they are the same. On the tops of the branehes stand small yellow flowers, eonsisting of five leaves, in the middle of whieh stands a small green head, whieh, when the flower is fallen beeomes ronnd, eonsisting of many long greenish purple seeds, whieh will atlhere to elothes. The roots eonsist of many brownish strings or fibıes, smelling like eloves.

Medicinal Virtues.-This plant is invalnable, and is much superior to most of the drugs kept in the shops. It possesses astringent, antiseptie, and tonie properties. The root powdered is equal to the Cinehona, or Peruvian Bark, in agnes, a draehm of the powder being given every two homs. "Fur" 


\section{AVENS.}

diarhoens, dysenterics, and the latter stages of contimed fevers, a wine gliss full of the infusion may be taken two or three times a day with good effeet. It is made by pouring a pint of boiling waiter on a half ounee of the root. It is good for disease's of the ehest or breast, for pains or stitches in the side. It expels erude humours from the bowels and stomaeh and revives the system by its warning qualities. It dissolves inwalrd congealed blood, caused by falls \&e., and spitting of blood, if the roots be boiled in wine and drank. In spring it is excellent, taken as a decoetion, as a purifier; it removes obstructions of the liver. It remores the windy eolie, and relieves those who suffer from rupture. It promotes digestion. As a wash, it removes spots or eruptions from the face.

A little of the root of Avens put in Ale gives it a fine flarour and makes it very wholesome. Henee the Angsburgh Ale whieh is so mueh prized on the Continent is said to owe its peculiar exeellenee to the eustcm which prevails of putting a small bag of Avens into eaeh Cask.

\section{Conpound Tincture of Avens.}

Avens Root bruised, 2 ounees

'Tormentil Root, brinised, $\frac{1}{2}$ ounee

Angeliea Root, bruised, $\frac{1}{2}$ ounec

Raisins, Museatel, 2, or 3 ounces

Freneh Brandy, l quart

Malecrate for a month, in a warm plaee, then filter.-Dose, half an ounce.

\section{BALM.}

Melissa Officinalis. This plant is so well known, that it neerls no deseribing.

Medictinat Virtues. - In some form or other this valuahle merlicine should always he liept in the honse. It is a plant of halsamic odour, the leaves of which are used as a dihent in fever. It possesses high stimulant and carminative propertics, which renter it valuable as a remerlial argent. Balm is a good tonie, whieh strengthens the stomach, braces the nerves and clevates the mind by its exlrilaratiug virtues. It is really ex- 


\section{BALA.}

cellent in colits, ntended with ferer, ns it is sure to promote a copious perspiration, alter repeated dranghts of the ten or decoction. It makes a good wash for aching tecth, and a suitable drink for those who have the bloody flux, or dysentery. The leares with a little nitre, decocted, will relieve yrijug pains, artl shortucss of breath. It is gond for inflamed liver. Used witl salt, it removes wens, kernels, or hard swellings in the fic: h or throat.

Dr. Copeland recommenils Balm to be infused with Liquorice-root, Anise sceils, Fenncl seents, and Coriander sireils ; $2 \frac{\pi}{2}$ drichuns each of the Bulm of Liquorice, and $\frac{1}{2}$ drachm cach of the secds to two pints of water. Duse from 1 to 2 ounces.

\section{Compound Splitit of Balar.}

Fiesh laves of Balm, 8 onnces;

Lemon Peel bruised, 4 ounces ;

Nintnegs and Carlaway seeds, cach 2 omnees;

Auise secds, 1 vunce;

Cloves, Cinnanon, Angelica root, of each l ounce.

Intuse for 3 wceks in a quart or more of Brandy, and well cork in luttles.

Sunc make tea of it combined with Iyscop, and Plackberryleatcs, which very much resembles that from Chiua.

\section{BARBERRY.}

Descriptron.-Berberis Thulyaris, natural older, Berberidacea. It is a well-known plant, the berries having eome much into use lately for making tarts and pies. 'They are a pleasant acidulous firuit, and may be caten with safety. The Barbery is fonnd wild in hederes in some parts of England; but it is common everywhere in gardens; it errows eight or tell fect high. 'The bark is whitish, wih abmalane of prickles abont the branches. 'Ilic leares are oral, indruted about the hedeses, ant of strong green colour. The flowers are small, of a pale jellow colom; - the stamens have a remallibile semsibility, when touched by anything, towirds the pistillum. The leaves are tender, and very sulject to the rubign, which will infest the corn in its neighbourhook. The berries are oblong, rect, and aciel in taste.

su 


\section{BAIBERLYY.}

Brentcinal Verreses. - The inner rind of the Barberty tree brited in white wine cleanses the body from choleric li:mours, from seabs, iteh, ringworms, inflammation of the liver, and dy-cutery, The hark of the stem infused in becr, laas the reputition of curing the jaundice, for it is tonie, and deohstruent. The dose of the infision is from 1 to 2 ounces twice a bily. The herrics are cooling, antiscorlutic, and deolstrment, containing malic and citric acid. They are very nsefnl in all infirmmitory fevers, especially typhus fever, and bilius disorfincs, and scurry. The fruit in the form of jam is very refteshiny in acute discases. The active principle of the bark, called himerine, is tonic, and in large loses, laxative. It is an exceflent remerly for dyspepsia, with functional derangement of the liver. 'The dose is from + to 10 grains; if more is given, it acts as a purgative. It is an excellent ganergle for sore month frum any cause. The bark dyes a beatutiful ycllow.

\section{BARIE,-PLRUVIAN.}

Foreinn.-The Barli most generally used is the Pernvinn, or Jesuits' Bark, Cinchona. It is a powerful tonic, felriftige, and antiseptic, very uschil in intermittent ferers and in general and urrous dubility, typhns fever especially when teuding to grangrene. In coufluent snzall-pox, it promotes languid erryution, and suppuration, diminisles the ferer, and prevents putresence antl gangrene; the same in gangrenons sore tluroats. In contruious ilysentery after due evacuation, it has becn used, tilken internally and by injection, with and withont opium.

Mrany cmincent physicians lanve great confiffence in it, joined with snfphuric arid, and the tincture of eayenue pepeler, in cartes

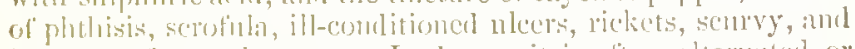
in state's of convalesecence. In dropsey it is uften alternated or

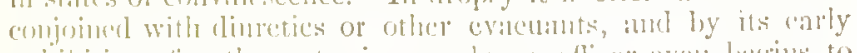

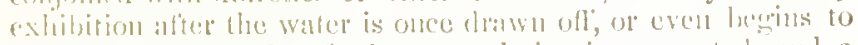

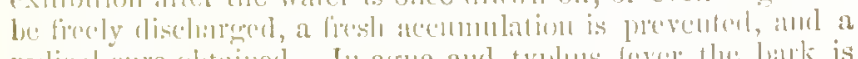
radis:al cure ohtalinel. In agne and typluns lever the bark is ole of the mest valuable peinerlies. The prowiter is more powcrfinl when taken as an influsiron in Port Wine, or mixed with

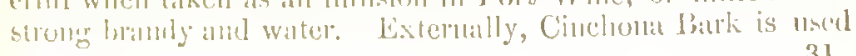


as an application to bad crrious, or gangrenons ulcers. The powder is an excellent dentrifice for spongy and blceding gums and the decoction is an excellent gargle ol 'wash.

It is given in the form of powder, infusion, decoction, or tincturc. Dosc of powder, 10 grains to 2 drachms. In agues, begin with 15 grains, and repeat in 3 or 4 hours.

Huxhan's Componnd Tincture of Burk-Peruvian Bark in powder 2 ounees; exterior peel of Seville oranges, dried $1 \frac{1}{2}$ ounce. Virginia Suakc-root, bruised, 3 drachms; saftion, 1 drachm ; cochincal powder, 2 scruples; proof spirit, 20 ounces ; digest for 14 days and strain. In taking, bcgin with 2 or 3 drachms. See Quinino.

\section{BARLEY.}

Hordeum Pretense, or Districhum, or Perlatum. It is so well known as a cereal, or in its prepared state, Pearl Barley, as to require no description. Barley in all its compositions (cxcept malt) is more cooling than wheat, and a littlc clcansing. Barlcy-watcr, and all other preparations of Barley, give nourishment in fevers, agues, and lients in the stomach. A poultice made of barlcy-meal or flour boilcd in vincgar and honey, and a few dry figs put in them, dissolves hard imposthumes, and reduces infiammations. Combincd with mellilot, camomileflowers, linsecd, fenugreck, and rue in powder, and applied warm it cases pains in the side and stomach, and fatulcnec. The incal of barley and fleaworts boiled in water, and made a poultice with honey and oil of lilies, applied warm, cures swellings under the ears, throat, neck, Sce, and a plaister made thercof with tar, wax, and oil, is good for the ling's cril; boiled with vinegar and quinee, it remores the pains of gout; barley flour, salt, honcy, and vinegar mingled together, eure the itch. The watce distilled from the green barley in the end of May, is very good for lunnours in the eyes, and dropped into them allays pain. To malke Darley Water:-Take 2 or 3 oumees of Pearl, or French liarley, wish it first in cold water, then in hot water; then hoil in 2 quarts of water till reduced to 1 quart, and strain. It is an cxecllent dilucut drink in $\mathrm{fe}$ vers; it is very soothing for infamed mueons surfaces, especially those of the minary organs; it mily be improved by a 32 
few slices of lemon. It may be malc into n laxative by arding choplyed figs and stoned raisins and lingurice-root. The denum cent properties may be increased by the addition of an onnee of Gum Arabic.

\section{BARRENIVORT.}

Description. - Epimedium Alpinum.-It is a curious, but very pretty plant. It is not so common in England. It is a wood plant, with beautiful purple and yellow flowers. It grows a foot high. The leaves are oval and formed like a heart, indented at the erlges, and of a dnsky green. The Hower stallis are weak, brittle, and often croolied; the flowers stand in a very loose spike, ten, or more, on the top; they are purple on the back with a red elge. It is called Barrenwort becanse it only flower's in the shade, and not in the sun.

Medicinal Virtues.-The roots boiled in milk are given by some to domestic female animals to arrest the matural enotions for the males. It has been suceersfully adninistered to females subject to lyysteries. It must not be given in litrge doses. as it might producc stupor.

\section{BAY TREE.}

This Plant is the laurel of antignity, and the Lamme nobilis of Linnasus. It needs no descrijtion ; it is so well known.

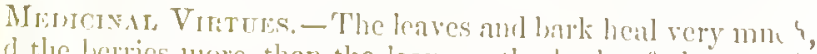
and the lerrics luore thin the leaves; the lark of the root ty less slarp and hot, hut more bitter, and astringent and cflecetual in dissolving stone, and remeving olstructions of the liver, spleen, and other inward parts, which brine the jaundiec, rlropsey, \&e. 'The berries are very effectmal argainst the sting of wasks and bees; and agrainst infections discases. They anc goorl for cold and rlenmatic distillations from the brain to the eyes,

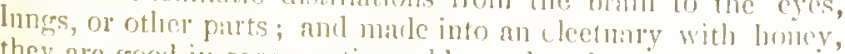

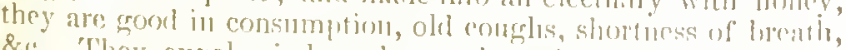
\&e. They expel winrl, mul provoke urine, and kill worluse,

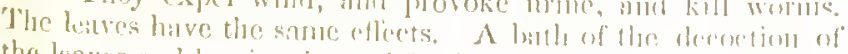

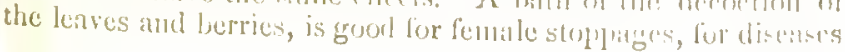


of the bladder, pains in the bowels by wind and stopping of urime. A decoction of equal parts of Bay berries, cummin seed, hyssop, with honey, and the head bathed therewith removes distillations and rheums. The oil made of the berries is useful in affeetions of the joints, nerres, arteries, stomach, belly, or womb, palsies, eonvulsions, eramp, and trembliugs, by anointing the affected parts. It is exeellent for the earehe being dropped into the enrs. 'The oil also removes marlis on the skin, eaused by bruises, falls, \&c.

\section{BAZIL,-Gafden or SweET Bazil.}

Description.-Clinopodion hortus, The greater or ordinary Bazil is cnltivated in gartens, on aceount of its fractant scent. It rises up with one upright stalk, brumeling forth on all sides, with two lcaves at every joint, broal and round, yet pointed, of a pale green eolour, a little snipped about the edges, and of a strong liealthy seent. The florrers are small and white, of the same shape as those of the dead nettle; they stand on the upper parts of the brinches in loose spikes. The IFild Bazil is similar, but not so fine as that which is eultivated.

Medicinal Virtues.-This plant is but little nsed, but it deserves to be. A decoetion of the leaves is a guod remedy for all obstruetions. No plant has such cticuey in grently pronoting menses, and the disurders eaused by thcir obstriction. It may be used in infiusion. It arrests romitiun, and allays numsea. The infusion of the seed is a remcdy in gonorrlica and nephritie affections.

\section{BEANS.}

Faba. Both the garten and field Boans are well-known.

Medichal Virtues. - The distilled water of the fluwer of Garden 13eans, is good to elcar the fuce and slin fiom spots nud wrinkles. 'The water distilled from the green husks, is

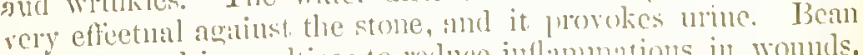
flower is rsoed in poultices to reduce inflammations in wounds,

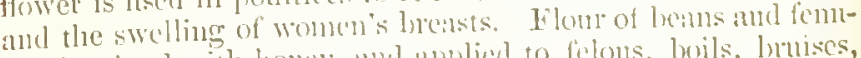
greek mixed with honcy, and applied to felons, bobls, lnuises, or blue matis by lolows, or the inprostlumes in the liencls of 


\section{BEANS-FrENCH.}

\section{BEECH TREE.}

the cars, is an excellent remedy, and with rose leaves, frankincense, and the white of an exwe, it may be bencficially applied to eyes that are swollen or water, or have receivel any blow upon them. Bean flomer boiled to a poultice with wine and vinegar, and a little oil, is good for swelled testicles.

\section{BEANS,-FRENCH.}

Phaseolus. Called also Kielner Beans, and it is cultivated for domestic use. It needs no deserijution.

Medicix.l Virtues. - The ordinary French Beans are of easy digestion, and make an exeellent vegctable for the tible. Dried and powdered they greatly strengthen the kidneys. A dram taken in wine oceasionally, prevents stone, and removes olstructions in the kirlneys and blatder. Shortuess of breath is much relieved by their use.

\section{TIF. BEECII TREE.}

Fagus. It is neerlless to describe it, it is so well linown. It grows in woods, and forests, and in other plicess. It blooms in the beginning of May, and the fruit is ripe in September.

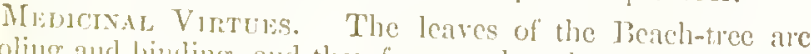
cooling and binuling, and therefore grool to be applied to hot swellings. $A$ diceoction of the bark is used in dialuetes. A tccoction of the leaves is excellent for obstinate nlcers, varions cutaneons rliscrses, and dyspejtie affections, accompruied with great weakness, licadache, and lowness of sjirits. The mits contain inuch mutriment for some aninals, as decr, piess \&e. The water that is fomd in the liollow places of decinying lieeches will cure hotl man and beast of any semer, scal, or rmunimer tetters, if they be wisled therewitls ; yom may boil the leaves intor a [roultice, or make an vintment of then when the time of year serves.

The Becen-Tree is sairl to be a non-enturtor of lightuing. Dr. Ficcton, of $\Lambda$ merica, says that the Bacch-thee is never known to be struck by atmosplucric elecericity, whilst others ane often sliattered into splinters. 


\section{BEETS}

Description-Beta Vulgaris. There are two sorts, the white and red Bects. The common white Beet has many leares next the ground, sumewhat large, and of a whitish green eolour. The stalk is yreat, strong, and ribbed, bearing many leares, almost to the very top of it. The flowers grow in very long tufts, small at the end, and turning down their heads, which are small greenish yellow buds, giving cornered prickly secels. The root is great, long and hard. The common red Beet diffirs not from the white, only it is less. The leaves are differently red, some only with red stalks or veins; some of a fiesh red, and others of a dauk red. 'The root is a decp red, spongy, and eaten when boiled either alune or mixed with sallad.

Mlencinat Vintues. - The juice of the root is a remedy for the liendache, and toothaclic, when the jaw is affected, snuffed up the nose to prontote sneezing. The white Beet opens and elcanses the bowels, and promotes digestion, and it is a good diuretie. The juice removes olsstructions of the liver and splecn, and is good for affections of the brain. Being applied to the temples, it stops inflammations in the eyes. MIixcd with oil and a little alum, it is good for burns, and St. Antlony's fire. It is good for all weals, blisters, and blains in the skin; and made into a poultiec, it is grood for chilblains. 'The decoction with sume vincharr, lieals the itels, if bathed therewith, and eleanscth the lacad from dandriff, scturf, and dry scabs, and is excellent for ruming sores, ulcers, and rankers in the heal, lears, or other parts, anil for haldness.

The red Beet root stays the hloody fux, women's courses, and the whites, and is a temedy for the yellow janndice.

\section{WATER BETOAY.}

Discriptron.-Fefonica Aquatica.--It is also called Brown-

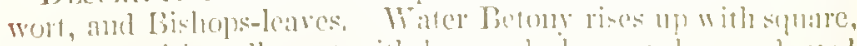

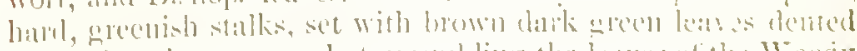

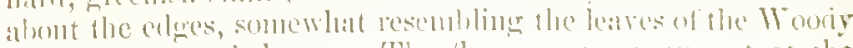
butong, but much larger. The flowers are many, set at the 36 
tops of the stalks and branches, being round ; opener at the brims, and clivided into two parts, the taplel one is like a loosl, and the lower like a lip hanging down, of a dark red colour, and suceceled by small round pointed heads, wherein lie small brownish seeds. The root is a thiek bush of strings and shreels growing from the head. It grows by the diteh-side, brooks, and other water-eonses, and is seldom found far firom the water-sicle. It fowereth about July, and the seck is ripe in August.

Medicinat Virtues. - It is appropriated more to wommls and laurts in the breasts than Wood Betony; it is a good remedy for sick hogs, it is of a cleansing quality. "The leaves bruised and applied are effectual for old filthy ulcers; and uspecially if the juice of the leaves be boiled with a little honey, and the sores dressed therewith; as also for bruises or hurts, inward or outwald. The distilled water of the leaves is uned for the same purpose, as also to bathe the fuce and hands sjotted or blemished, or disculoured by sun burning.

\section{WOOD BETONY}

Description. - Retonica Offanalis. - This is one of the herbs that ouglit to be kept in every fannily.

It has many leaves rising from the root, which are rather broarl and round at the end, roundly dented about the edires, standing upon long foot stalks, from which lise up small, Equare, slender, upright hairy stalks, with some leaves tliclcon to a piee at the joints, smaller than the lower, whereon alle set eeveral spiken licals ol flowers like laventer, and of a purple colour, the seeds are in the husks that holel the flowers, anel are blackish, The roots are many white threaly strings; the slalli perisheth, but the roots, with some leaves thereon, abile all the Winter. It srowes in woods, and in shady places. It flowers in July, after which the seed is quickly ripe, yet it is in its prime in May.

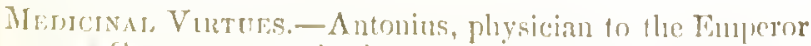

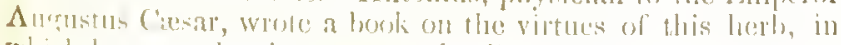
which he salys, that it jueserves the liver, and the luoty lrom 


\section{BETONY,-WOOD.}

epridemical diseases, and promotes digestion, eures belching of the stomach. It is good for disorders of the head, and for all nervous complaints. The herb or root, or the flowers in broth, drunk, or made into conscrve, syrup, water, clectuary or powder, is a good remedy for the jaundice, falling-sickness, the palsy, convulsions, ol shrinking of the sinews, the gout, and for dropsy, and continual pains in the head. The powder with honey, is most excellent fol all coughs or colds, shortness of breath, distillations of thin rhemm npon the lnngs, whieh cause consumptions. The decoetion made with mead, and penny royal, is good for putrid agnes, and to draw down and evaenate the blood and humours, that by falling into the eyes, hinder the sight. The decoction thereof made in wine, and taken, destroys worms, and removes obstructions of the spleen and liver. It cures stitches, pains in the baek or sides, and griping pains of the bowels, and the flatulent colic. Mixed with honey it purges. It is of great service in the falling down of the womb, obstruction of the menses, and stone in the bladder. The decoction with wine gargled in the mouth, easeth the tooth-ache. $\Lambda$ dram of the powder of Betony, taken with a little honey in some vinchar, is very refreshing for those that are wenried by trarel. It stays bleeding at the month or mose, and helps those that spit blood, or make bloody urine, and is good for those that have a rupture and are bruised. The green herb bruised, or the juice applied to any outward green wound in the head or body, will quickly heal it, and any veins or sinews that are eut. it is a curative of old sores and ulecrs, though they be fistulous and hollow. The fume of the decoetion while it is warm, received by a fumcl into the enrs, cases pain, destroys rorms, and cures the running sores in them. The juice dropled into them does the same. On the whole, Woot lietony is one of the most valuable herbs we have in Great Britain.

Betony must be gathered when ahout to flower. Some persons mix it with tobaceo and smoke it. With the Eye-bright, and Coltsfoot, it has been marde into tolmeco, and it relieves dilicult breathing. For a suntt, tulie Betony, Manjanoun, a

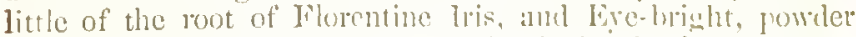
when dry, ant you have al rencely for the heide-ache, scre eyes, and obstructions in the heile. 


\section{BENZOIN.}

Foreign.-Styrax Benzoin.-Commonly ealled Gum Bentjamin. It is a good stimulant and expectorant. When burned, its rapour is dcodorant and antiseptic, and therefore nsclin for sick rooms. Benzoin mixed with ointment prevents it from bccoming rancil ; its rapour is sulpposed to be good for hooping cougr. In Cosmetic washes it is an ingredient, and also in Friar's Balsam, a most useful Styptic and healing application, as well as an inward Medicine.

Friar's Balsam to be made thus:-Gum Benzoin, $3 \frac{1}{2}$ onnees ;

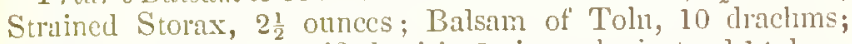
Aloes, 5 drachms ; rectificd spirit, 2 pints ; let it stand 14 days, shaking frecunently, and before use. This preparation is stimnlant, cxpectorant, and antispasmodic, and is beneficial in old Asthmatic cascs, chronic eatarth, and phthisis with a feeble circulation. The dose is about $\frac{1}{2}$ a draclim in mucilage, or dropped upon Lump Sugar. Applied to wounds it stimulates gently, and protects from the action of the air. A piece of lint, or soft rag dipped into it, and wrapped round a cut finger, will produce cmarting at first, yct it will commonly stay hxmorrhage, and effect a cure without the necessity for another dressing, untess the wound be extremely scvere. Probably Friar's Lilsam was used by the monks of old time to dress the womnls of travellers, and others, who called and rested in their convents.

\section{BILBFRRIES,}

CAILED BY SOME WORTS, THE WORTLE-TERRIES.

Vaccinium. Myntillus. Two sorts are common in England, viz, the black and red berries. And first of tle black.

1) Lscruption. The smatl hush lies unou the gromend, nearly

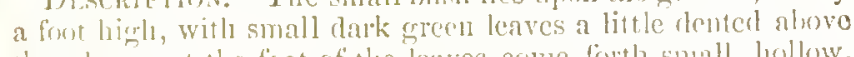
the erges; at the foot of the lentes conne forth smatl, loullow, bhish colonered flowers, the brims endling with five points, with

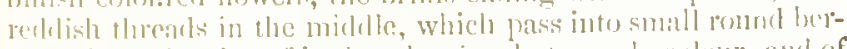

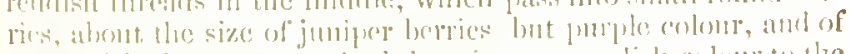

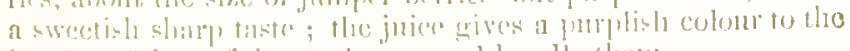

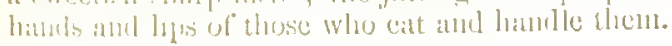


The Red Bilberry or Wortle-bush, rises up like the former, having sundry hald leaves, like the Box-tree leares, green and round pointed, standing on the several branches, at the top of which, and not from the sides as in the former, come forth round, roddish, sappy berries, when they are ripe, of a sharp taste.

The first grows in forests, on moors. and in roods. They flower in Miarch and $\Lambda$ pril, and the fruit of the black is ripe in Jily and Angust.

Medicinal Virtues.-It is a pity they are used no more in physie than they are. 'The Black Bilberries are good in hot agnes, and to eool the heat of the liver and stomach; they are astringent, and stay purgings, vomitings, and loathings. The juice of the berries made into syrup, or the pulp made into a conserve with sugar, is good for the pmposes aforesnid, as also for an old congh, or for an ulcer, or other diseases in the lungs. The red Worts are more bincling, and stop women's courses, spitting of blood, or any other flux of blood or humours, being used as well outwardly as inwardly.

\section{BILEOIL, or TWABI,ADE.}

Description - Listera Ovata. From a root somewhat sweet, shooting downwards many long strings, rises np a romed preen stalk, hare or naked, next the gronnd for an inch, two or three in the midlle thercof, as it is in age or growth ; as also from the middle upward to the flowers, havilue only two broad plaintain-like leaves (but whiter) set at the midelle of the stalk, one against motlier, compassing it round at the bottom of them, It is an inhabitunt of wouds, copses, and many other places.

$\Lambda$ nother sort grows in wet gronnds and marshes. It is a smaller plant, and greener, having sometimes three leaves ; the spike of the flowers is less than the tormer, and the roots of this, rm or ereep in the gromed.

They are often med by many to good purpose for womluls,

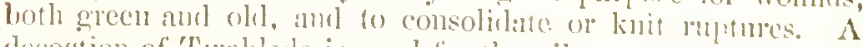
deroction of 'Twablade in grond for the piles, and also the external alpplication of its fiesli juice. 


\section{BIND TEED.}

Drscruprion. - Convolwulus Seprum. - A common will plant climbing about hedges, and bear's large white fiuwers, the form of the Garden Convolvulus. It is well known.

Medicinal Virtues. The root is used as a purge, boiled in ale. It answer's well, though on account of the namsea whieh it tends to produce, it is not fit for the delieate. Fur people of a strung constitution, there is not a better purge.

\section{TIIE BIRCH TREE}

Description.-Betula Albr.-Its appearance in summer is elcgant, and in winter the ballk is fiequently variegalted with red and white streal:s.

It is a tall straight tree, with many bonghs, and slender branches bending downward; the old being covered with a discoloured ehapped bark, ant the yonnger being mueh browner. The leaves are dented about the edges. It bears small sliort eatskins, somewhat like those of the hazlenut-tree, which growing ripe, fall on the ground, and their seed with them. It ustually grows in woods.

Medicinal Virtues.--The juice of the leaves, while young, or the distilled water of them, or the juice from the tree bored with an angur, and distilled afterwarls, any of these being drunk for some days together, tends to break the stone in the kidneys and bladkler, and is good also to wash sore mouths. The leaves have been used in the iteh, dropsy, \&c., either cxternally applied, or taken in decoction. Bircli-wine made firon the jnice of the tree, is an excellent remedy for eonsumptions, and senrvy; and the fungus which grows on the trec, is a good styptie.

\section{BIRD'S FOOT.}

DFscription. - Avis Prs. - This herl, groweth not alove a

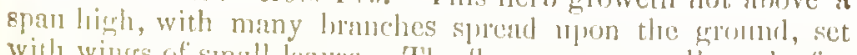
with wings of small larves. 'The flowers atre sulall, and of a pale yellow colour, being set a head tugether, which turnesh 
into small jointed eods, resembling the elaws of small birds, whenee its name.

There is another sort of Bird's foot like the former, but a little larger; the flower of a pale whitish red colour, and the eods distinet by joints like the other, but a little more erooked. They grow on heaths, and in open untilled places. They flower and seed in the end of Summer.

Medicinal Virtues.-They are of a drying, binding quality, and very good to be used in wound drinks; as also to apply outwardly for the same purpose. Bnt the latter Bird's-foot is found by experienee to break the stone, and drive them fortll, if the decoetion be talien; and it is very serviecable in ruptures, taken inwardly, and ontwardly applied to the place.

\section{BISTORT, OR SNAKEWEED.}

Description.-Polygimum Bistorta, natural order, Polygnnacer. It is also ealled Sapentary Drigonwort, Osterick, and Passions. It is a beautiful wild plant, growing in shadowy moist woods, at the foot of hills, and in some mealows. It flowers about the end of May, and the seed is ripe in July. It grows abont a foot and a half highl. The leaves are brond and pretty, and long like a dock leaf, a little pointer at the ends, of a bluish green colour on the upper sicle, of an ash-eolonred grey, and rather purplish moderneatli. The flowers grow in a thick spike or ear, at the top of the stalks, and are of a bright red colour. 'The stalls on which the flowers stand have a rim of the leaf running down them; the stallis are romul, firm, and ereet, of a pale green, almost witlout leaves, or with rery few and narrow, placed at distinces. The spike of the flowers is as long and as thick as a man's thumb. It has a thick short knobbed root, erooked, with black threats, and it lass an astringent taste. Manch is the Lest time for gahlering it, when the leaves begin to shoot.

Medicinar. Virtuls. - Both the leares and the ronts liave a powerfinl ficulty to resist prison. 'The root is one of the best

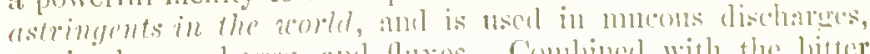
passive hamorriages, and fluxes. Combined with the bitter 42 
Flngroot (Calamus) it has heen effectual in the enre of intermittent fever and ague. Its active principles are Trennin end Ginllic Acid. The powder or decoetion of the roots is a most effectual remedy for profuse menstruation, and also for diabetes, and for fluor albus. The decoction is an excellent gargle for seurvy in the gums, and ulcerated sore throat, and for washing. The leaves kill the worms in children. $A$ dram of the powilev of the root taken in water, in which red lot iron has becn quenched, is a powerful remely. The dlose of the powdered root is from 1 seruple to a drachm; of the decoction, from 1 to 2 onnees. It makes also an excellent injection when nul ilstringent is required. The lierb is invaluable; therefure no family should be without it.

\section{BISHOP'S WEED.}

Description.-Episenpi IIerba ignobilis.-Some persons call it Ethiopian Cummin-secel, and others Commin royal, as also IIerl-W William and Bull-wort.

Common Bishop's weel rises up with a round straight stalk, usually three or four feet high, beset witl small, long, and broall leaves, ent in some places, and dented at the edges, growing one actainst another, of a dark green colour, having various branches, and at the top small mmlels of white flower's which tum into small round seerls, like parsley seeds, of a rutick hot scent and taste. It grows wild in many places in England and Wales, as lyetween Greenlithe and Gravesend.

Miderivar, Virtues.- It is hot and diry in the third degree, of a sharp bitter taste. It dispels humonrs, provoles nuine and women's courses, dispels wind, and taken in wine it cases pain and griping in the lowcls. It is used witl good eflect in needicines eriven to conmteract the poisonons operation of Cintharides upon the passage of the mine. Mixerl witl Itency, and applied to blark and blue marks, produced by bluws or bruiscs, it talies them away.

\section{BLITES.}

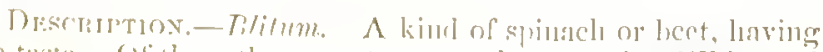
no taste. Of these there are ho sorts hisom, vi\%, White and 
Red. The White has leaves like beets, but smaller, rounder, and of a whitish green eolonr, eneh standing upon a small longr foot-stalk; the stalk rises up two or three feet liggl, the flowers grow at the top in long round elusters, eontaining small round seeds; the root is very full of threads or strings.

The Red Blite is like the white, exeept its leaves and tufted heads are very red at first, and afterwards turn purplish.

They grow in gardens, and wild in many plaees. They seed in August and Scptember.

Medicrand Vantules. They are eooling, astringent, and useful in fluxes of hlood, especinlly the red; which restrain the overflowing of the eourses, as the white Blites stay the whites. It is an exeellent seeret, you eamnot well fail in the use.

\section{BLOOD WORT.}

Description.-Lapathum Sanguineum.-A benutiful kind of doek kept in gardens, and wild in sume plaees. It grows to four feet high; the stalks are firm, stiff, upright, branched, and striated. The leaves are very long and narrow, broadest at the base, and smaller all the way to the end. They are not at all indented at the edges, aud they stand upon long foot-stallss: their eolour is a deep green, but they are in different degrees stained with a beantiful blood red; sometimes the ribs only are reel, sometimes there are long veins of red irregularly spreth over the whole lenf; sonetines they are very brondl, and in some plants the whole lenves and the stalks also are of a blood colour; the flowers are very numerons and little. 'They in all respeets resemble those of the eommon wild docks. T'ic root is long and thiek, and of a deep blood red colonr.

Medicinal Vintues.-The roots nre used: they are best dry, and they may be given in deeoetion, or in powder. 'They are a powerful astringent: they stop bloody fluxes, slitting of bloot, and the overflowings of the menses. It is also good against violent purgings and agrainst the whites.

\section{BLUE BOTTLE}

Discuiptron.-Centamea Cyamus. It is called Cymus from the eolour of it; Inut-sickle, beciuse it tums the cilge of 44 
the sickles that reap the corn; Bhe-blow, Corn-flower, and Bluc-bottle.

Its narrow leaves spread on the gromnd, being of a whitish green colour, amongst which rises a stalk diviled into diver's branches, with long leaves of a greenish colour, al little indented; the flowers are of a blue colour, consisting of many small flowers set in a sealy head, like those of knapweed. The seed is smooth, bright and shining, wrapped up in a woolly mantle.

They grow in corn-ficlds gencrally; towards the full of the moon, they will grow more clonble than they are, and many timics change colonr. They flower from the beginning of May to the end of harvest.

MIIDicinal VirTeEs. - The powder or dried leaves of the Bhe-bottle are given with good sucecss to those that are brised by a fall, or have broken a vein inwardly, and void much blood at the mouth. The herb is a valuable styptic, and cxcecrls all other things, and may save a life when surgieal ail is not available. The leares fresh grathered and bruised will stop the bleeding of a fresh wound, even if a large vessel be eut. An infusion of them works gently by urine. The leaves or secd taken in wine, is very good agninst all infections diseases, and pestilential ferers. Tlie juice put into fresh or grecn wounds, rapidly heals them, ancl it is very effectual to lreal alt ulecers amo sores in tho mouth, the juice dropperl into the eyes talies away muftummation, and the distilled water of this herb has the same virtues.

\section{BORAGE AND BUGLOSS.}

Description.-Borago Oficinalis, et. Sycopsis. These are ronerh plants, common in garlens, with great leaves and heautiful hilue flowers. They are so well known, as to need little deseription. There is a third kincl called Languee de beruf. 'Ille leaves are smaller than those of bugloss, but nutch rougli-

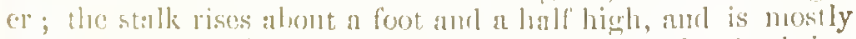
of it rerl colour ; the flowers stand in acaly romerl lreads, being

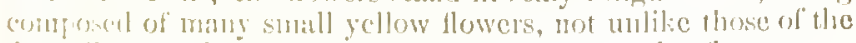

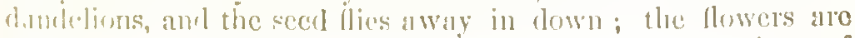
very bitter. 'The virtucs of this plant ate the same as these of 
Borage and Bugloss. They flower in June and July, and the secl is ripe shortly after.

Medicinal Virtues. $-\Lambda$ ll three are great cordials, and strengtheners of niture. The leaves and roots are very useful in putrid fevers, to defend the hent, and to expel the ronom of othel creatures. The seed and leares are good to inerease milk in women's breasts, and to drive away melaneholy; to elarify the blood, and mitigate heat in fevers. The juice made into a syrup has the same effect, and is a valuable remedy for the yellow jam dice, the itch, ringworm, \&c. The flowers candieil or macle into a conserve, are useful for persons weakened by long sickness, and for those who are subjeet to swoonings. The distilled water is as effectual, and cures inflammation of the eyes. The roots of Bugloss male into an electuary, promote expectoration, and remove a cough. They are exeellent for aflicetions of the lungs. $\Lambda$ gond way of taking it is to infuse it in wine, which partly neutralizes its mauseousmess.

\section{BOX TREE。}

Busus.-It is well known.

Menicinal, Virtues.-The wood and the root make a gond purifier of the blood. It has greater virtues than the Guiscum. Leprosics have been cured by a decoction of the wood ank root. 'llie decoction of the batk, or powdered, suceesslully cures intermittent ferers, and is a good tonie for debility, for billions disorders, jaundice, and low spirits.

\section{THE BRAMBLE, OR BLACK-BERTY BUSII.}

Rubus Fruticosus.-This needs no deseription.

Medicinal Vartues. - The buts and leaves while they are green, are of good use in ulcers and putril soles of the month and throat, and in quinsy, and to heal fresh wonnds and sores; but the flowers and unripe linit are very binting, and very useful for the bloody llux, and for spitumer of blood. "The ilecoction of poweler of the root heiner taken, is good to breali grancl and the stone. The leaves and hrmubles, erreen and liy, make agood lotion for soles in the montl, or scret parts. It is a 46 


\section{BROOK LIME. BROOM, AND BROOM-RAPE.}

powerful astringent, and restrains laxity of the bowels, and the undue flow of the menses. The decoction is goot for the piles, fevers, and the distilled water of the branches, leaves, and flowers, or of the firut, is effectual in ferers, and hot clistemuer's of the boly, liead, eyes, and other parts. The leaves boiled in ley, and the head washed therewith, heal the itch, and tend to tuin the hair black.

\section{BROOK LTIE, or WATER PIMTERNEL.}

Descripton. - Teronica Tecubmiga. This is one of those newlected vegctables which might occisionally be used for culinary purposes, particularly as a sallad.

It has a erecping white root, shooting forth strings at every joint, as it luns, dirers and sundiy green stakls, round and sapfy, with some branches on then, somewhat broud, roumel, decu green and thick leaves, set by couples the1eon; from the bottom whereof shoot forth long foot-tallis, with small heautifil slip-blue flowers on them, consisting of fire small round printerl leaves a-picce.

It grows in small standing waters, and usually neal water cresses. It flowers in June aud July.

Medicase Virtus. It is a hotaud hiting plant. Brook-lime and water cresucs are grenelinlly used together in dict-drink, with othere things serving to purere the bloou aml berly from all humonrs destructive to health, and ane eroud for discases of the bladiler, and help to brak the stone, and puss it away. 'The plant is nseful in removine fomale obstructions. It is of itself a crout scorbutic medicine. Dioscolinles states that its leaves

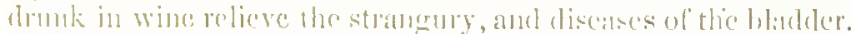
It operates gently hy urine, and is a grent purifier of the blood.

\section{BROOH, $\triangle$ ND BROON-TAPL}

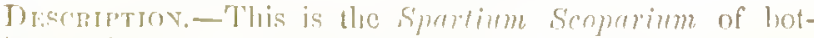

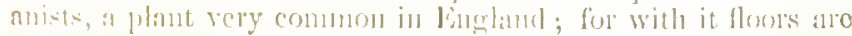
swept it therefore necels no rleserifution.

"Jlar IBnomerape springs my on many plares from the roots of the brvom. 'The stalk is allout the size of a fimger or thomb, 
ahove two feet high, having a show of leaves on them, and many flowers at the top, of a bcautiful bright yellow. It grows on waste grounds. It flowers in the Summer months, and sceds before winter. The flowers are shaped like a pea blossom, and are of a bright yellow.

Medicinal Virtues. - The tops of the Broom have a bitter disagreeable taste. The plant possesses eathartic and diuretic properties, which render it very useful in some eases of dropsy. The tops and seeds are the parts used, chicfly the former in the form of decoetion - one onnce to a quart of water. Boil down to a pint, and take half a wine-glassful, or a wine-glassful two or three times a day. Dr. Cullen says, "It seldom fails to operate both by stool and urine, and by repeating every day, or every seeond day, some dropsies have been cfeetually eured.", The green stalks infused in ale or beer opernte by urine, and remove obstruetions of the liver and other parts, they are very useful in jaundice. Some of the old physieians burned the tops to ashes, and infused them in wine; thus the salt was extracted and the wine turned into a ley. It works powerfully by urine; but the abore-mentioned deeoetion is the best.Bruised Broom-seed, infused in reetificd spirit-let it infuse for two weeks. Strain. A table-spoonful in a glass of peppermint water to be taken daily. $-\Lambda$ strong decoetion has been recommended in eases of lyydrophobia. The dose of the powder either of tops or seeds is from 1 seruple to 1 drachm. In liver complaints, the above decoction, with that of Dandelion, is very eflicaeious. Also in the aguc, producing profuse perspiration, taken before the fit, the person lying in bed.

The decoetion of Broom-rape has the same effect as the Bloom.

\section{BRIONY.}

Descristion.-There are two kinds of Bryony ; the White Bryonia Alba; (called by some persons the Ricel Bryonia Lioica; ) and the Black, Bryonia Nigra, wel Tamus Communis.

The WIITE BRYONIA is a tall, climhing will flant, growing in hederes. 'The leares are somewhint like those of the vine; the flowers are white, but ineonsiderable, the berries are 


\section{BRYONY,}

\section{BLACK BRYONY.}

red, and are very showy. The root is very large, rough, and whitish; the stalks are tougl, ten or twelve fect long; but weak and unable to support themselves; by tenclrils at the joints they fix themselves to bushes. The leaves are broal and divided deeply at the edge, of a hoary green eolour. T'le whitish flowers are on a long tuft, consisting of five small leaves eaeh open like a star. The berries hang like a eluster of grapes, very red when ripe, having a loathsome taste, producing nausen.

Medicinal Virtues.-The root powdered, or decoeted, is a very strong purgative, even if a small dose be talien. Great caution ought therefore to be excreised in taking it. It is a capital remedy for dropsies, hysteries, given in minute doses. For dropsies, two drachms of the root to six ounces of water, swcetened to the taste-take a spoonful every two hours. Mimy cases of dropsies it las eured. Very weak people should bectin with a less dose. The same will apply to hysteric eomplaints. Dr. Sydenham reeommended for maniacal disorders-a dritum of the powder in a gill of milk-or an infusion of the leaves, say about half an ounee in a gill of white wine; begin with a tea-spoonful at a time. The infusion is milder than the root in substanee; and Dr. Lcwis says, that an extract prepared by water acts more mildly, and with greater safety, than the rest itself ; given from haif a drachm to a draclm, it proves a sentle purgative; it operates powerfully by urine. It is grood for diseases of the heal by drawing away rhematic humours. In electuary made of the loot witl honey lroves a powerfinl cxperetorant. The root, leaves, and firut loilded, ale cood to cleim:o old sores, cankers, and gangrene; and the dccoction frees the faec from freckles, black and blue splots, \&ce.

The BLACK BRYONY, Bryonia Nigra, wel Temes Communis. The plant climbs upon bushes and hodges like tho former; but this by twisting its stalk alout the branches of trees and shmbs, for it las no tendrils. It runs to fifteres fort in height; thestalk is tough ant angular; the leares are hroul, and of a leart-like shape, perfectly smooth amil shinings, and if

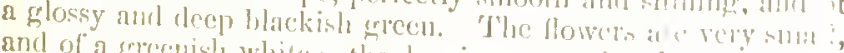
and of a greenisly white; the levries are rerl; the rout black without, white within, and full of a sliny juice. 


\section{BLACK BRYONY.}

\section{BUCKBEAN.}

Medicinal Virtues.-This herb onght not to be neglected, as its medieinal qualities are great, equal to any, and surpassing most herls. It is very effieneious in epilepsy, and rhematism. Dr. Thornton has witnessed its effieacy in cases of gout, rheumatisn, and paralytie affections. The root is Eeraped with a knite, and the scrapings whiel feel like soap, are to be rubbed over the affeeterl parts onee a day. Immediately a momentary sense of tingling is felt, like that produed by nettles; and this mild rubelicient he has found also to do good in eases of Asthma, when rubbed over the elsest.

The root of Black Bryony is one of the best diuretics known in medicine. It is a good remedy for grnvel, obstruetion of urine, and other disurders of the kidneys. The root has been thought to be the celeurated mandrake, and I belicre that in some parts they call it by that name; but Mindrake is a different plant, thongh it possesses some of its properties.

Dr. Tissot says, a ponltice made of the leaves of Bryony is an excellent remedy for painful tumours, rheumatism, and limbago. The juice of Biyony, turpentine, and a small portion of wax, is a grand remedy' for old sores, serofulas, strellings, \&e.

\section{BUCIBEAN, OR WATER TREFOIL.}

Descriptiox. - Meyanthes Trifoliata. - This perennial plant is very comnon in marslyy places, and is one of the must beautiful of our native flowers. It grows a foot high, the laves stand three upon each stalk, and these stallis rise immediately from the roots. They are thick, romd, smooth, and fleshy; and the leares thenselves are large, ollong, and have some resemblance to those of garelen beins. The flowers stand npon maked stalks, which are also thick, round, fleslyy, and whitish: they are small, but they wrow together in a kind of thiek short sjiks, so that in the chlister" they make a conspicuons apleatrance; they are white with a very finint linge of pmople, and are hitiry within; the root is whitish, long, and thick.

The leares of buck-bean are to he enathered before the stalks niplear for flowering, athd net to be dried. 


\section{BUCKBEAN.}

\section{BUCK'SHORN PLAINTAIN.}

Medicinal Virtues.-It is very tonic and astringent; in large doses purgative. Very nsefil in scurvy, serofila, gouty affections, and fevers. $A$ drachm of the leaves in poweler, purteres and romits. In infusion, or extract, they are useful in intermittents, in several enchectie and cntaneons discases. The dose of the extract is from ten to twenty glains.

It is surely Providential that this plant grows in places where agues prevail most. The remedy is near at hand. Bocrhave says, "It overeomes the tertian and quartan ague." IInIler says "that intermittents yield to it ;" and the German soldiers made us of it in one of the wars, with almost unraried success, They used it instead of bark. In eacheetic disease, that is, discase and cmaciation, and debility of the prime vite, it is known to be of great service. It is applienble to arrest consumption in its incipient stages, especially if combined with a little Cayenne Pepper, to produee heat, and a decoetion of Logwood, which is a most powerful antiecptic, or arrester of decay.

In scorbntic affections, and scrofula, it has often proved bencficial. Inveternte entancons discases have been removed by an infusion of the leaves drunk frecly every day for some weeks. Dr. Lewis says, "The leaves of the buck-bean have a bitter penctrating taste, which they impart both to watery and spirituous menstrua. They have come into use lately as an alterative and aperient, in impmitics of the humours, and in dropsical and rheumatic eases. They are usually taken in the form of infusion, with the addition of some acrid anti-scorbntie herbs, which, in most cases, improre their virtue; also add oraugepecl, or some other grateful aromatic, to alleviate their ill taste. The leaves have locen used in brewing ale. One onnec, it is said, will go as far as half a pound of hops. Boerhave was himself enred of gont hy taking it mixed with whey. IIe recommends it also as an external application for dissolving ghandular swejlings. Its scerls are sairl to be good for congris of lung standing, and lor disenses of the chest.

\section{BUCR'SIIOIN PIANTAIN.}

DEscripronos-Plantagn Coronopus.-It is a very pretty plant, which grows in our sandy fund batren places, will tho 


\section{BUCK'S HORN, CALLED BUCKTHORN.}

leaves spread out in manner of a star, all the way ronnd from the root; and in the heads like other" plantains, although so very unlike them in its leaves. The root is long and slender" the leaves which lie thus fiat upon the ground are narrow and long, very beautifully notched, and divided so as to resemble a buck's horn, whenee the nime, and of a pale whitish green, and a little hairy. The stalks are slender, six inehes long, but seldom quite erect: they are round, hairy, and whitish, and have at the top a spike of flowers of an inch or two in length, altogether like that of the other plantains, only more slender.

This plant has obtained the name of star of the carth, from the way of the leaves spreading themselves. These leaves bruised, and applied to a fresh wound, stop the bleeding, and effect a eure. It is said also to be a remedy against the bite of a mad dog; but this is idle and groundless.

It is a good remedy for stone, and inflammation of the kidneys, as it cools and strengthens the parts affected. 'The herb boiled in ate or wine, and taken night and morning for some time is serviceable in inflammation of the eyes.

\section{BUCK'S HORN, CALLED BUCKTHORN.}

Description. Rhammus Catharticus.-A Prickly shrub, common in our hedges, with pale green leaves, and black berries. It grows to eight or ten feet high. The bark is dark colomred and glossy, and the twigs are tough. The leaves are oval, of a very regular and pretty figure, and elesantly dented round the edges. The flowers are little and inconsiderable; they are of a greenish yellow, and grow in little elusters. The berries, which are ripe in September, are round, rrlossy, black, as big as the largest pepper-eorns, and eontain each three or four seeds.

Menicinal Virtues.-Some persons call it the purging Buckthorn, on acconnt of the cathaltie propertics of its berries, which nust be used fiesh or mirle into al syup. It has been found nseful in dropsies, rhemmatisuss and the gout. It has bcen found eflicacions in the expulsion of worms, makle into a symp--begin with a table-spoonlul. Of the fresh berres 20 numy lie takeu, or from 1 to 2 drachms of the dried ones. It is a rough purge, but a very good one. 


\section{BUCKTHORN.}

Syrup of Buckthorn.- Take the juico of the berrics fiesh gotten, one quart; bruised ginger two draclums; pimento powdered, half an ounce; refined sugar, two pounds. Set aside the juice for three days, that the fxces may sulsside, and then strain. Macerate the ginger and pimento in half a pint of the strained juice for four hours, and filter. Boil the rest of the juice to one pint; then add that part of the jnice in which the ginger and pimento have been macerated, and form a syrup of it with the sugar.

Three or four spoonfuls of this Syrup acts as a brisk purge; but it is a very useful one.

\section{BUGLE.}

It is also called Middle Confound, and Middle Comfrey, Brown Bugle, sicklewort, and Herb-Carpenter:

Description.-Bugula Reptans. -The flowcr-stalks grow eight or ten inches high, square, of a pale green, sometimes purplish, and have two leaves at every joint, the joints being a little distant. 'Ihese leaves are similar in form as those which rise immediately, oblong, broad, blunt at the point. and of a deep green eolour, slightly indented at the edgres. The flowers are small, of a pretty blue colour, which produce small, round blackish seerls.

The white-flowered Bugle differs not in form or size from the former, saving that the leaves and stalks are always green, and never brown, like the other, and the flowers thereof are whitc.

They grow in woods, copses, and ficlds, throughout Fngland, but the white-flowered Bugle is ratlier scarce. 'They flower from May until July.

Medicinal Virtues.-The deenction of the leaves and flowers mate in wine, dissolves eongealed bluot in thuse that arc lmiserl inwardly by a fill, and is very ceffertual for any iuward wonnds, thrusts or stats in the lorly or lowerls; and for olstructions in the liver. It eures nlecers amm sores, mamerenes and fistulas, if the leaves be luruined and alphlied, or their juices be used to wash and bathe the place. By infusion, it is very 
useful in eonghs, spitting of blood, and in ineipient consumption. In its action it rather resembles digitalis, lowering the pulse, and lessening its frequency ; it allays irritation, congh, and equalises the cireulation, and is eonsidered by Rafinesque, "as one of the millest and best nareoties in the world." A lotion made of it and some honey eures sores in the mouth and gums, and other parts of the body. $\Lambda n$ ointment made with the leaves of Bugle, Scabions, and Sanicle bruised and boiled in log's grease, until the herbs be dry, and then strained into a pot, is very good for all sorts of hurts in the body. It is good for the bad cffects of cxcessive drinking, as sickness, headache, delirium tremens, \&c.

\section{BURDOCK.}

Description. - Aretium Lappa, or Bardanus.-It is so well known, even by little boys. who pull off the bur to throw and stick upon one another that it needs no deseription. They grow plentitully by ditehes, watersides, highways, and ou waste grounds.

Medicinat Virtuls. - It is a most execllent herb. It lias been suceessfully used in many chronie discases, as seurvy, rhenmatism, gout, lues venerea, and affections of the lungs. It is a powerful dimetic, and it has been known to sueceed in dropsieal eases where other powerful medicines had been incfleetually used. $\Lambda$ s it neither exeites nausea, nor inereases imitation, it is worthy of a trial where more active remedies are improper. The seeds also possess a dimetie quality, and are very adrantageons in stone or gravel, and in the form of an cmilsion for eoughs. $\Lambda$ decoction may be made by boiling two onnees of the fresh root in two pints of wnter. This is exeellent for proroking urine. It slonhl be taken in one or two days. The leares bruised and mixel with the white of an egrg, is excellent for burns, scalls, \&e. The decoction applied io sores stops gangrene; lut the ointment of Burdock must also be applied. Powder the root and mix with hogr's lard, and a littlo vinegar. In short, it is aperient, diuretic, and sulorifie. It loas enred 1)opsies alone, and has ancested the progress of ferers. In finct it is a most valnable herl, ; lut its commonness is against it. femember, that l'oridence has male. some of the most useful 
plints the most common. Tho leaves bruised and noistened with Spirits of Hartshorn and Laudannm, form an excellent applieation for spruins, bruises, and other external injuries, it is good for old ulcers and sores.

\section{BURNET.}

Descriptiox.-Pimpinella Sanguisorba.-Tho great wild Burnet hath wingerl leares rising from the roots like the garden Burnet, but not so many; yet they are twice as large, and notched in the same manner about the edges, of a grevish colour on the under side; the stalks are greater, and rise highter, witl similar leaves, and greater heads at the top, of a brownish colour, and out of them come small dark purplo flowers like the former, but larger. 'The root is black and long like the other. It has very little scent or taste.

The first grows in gardens. The wild grows by waysides, and in dry pliaces. Tliey flower in Junc and July.

Medicisal Virtees. It is a most precions herb, little inferior to Betony. The continual use of it preserves lise hody in health, anrl the mind in vigonl. It is a friend to the lienrt, liver, and other mineipal parts of a man's borly. Two or three of the stalks, with leaves put into a cup of wine, especially clallet, are known to funicken the spirits, and drive away nnclancholy. It is a special lierly agranst infection, the juice being taken in some dlink, and the prarty lair] to sweat. It las also an astringent quality, and will stop fluxes of blood or lummours, staninch blcerlings inward or ontwarl, women's too-abundant cont'ses, tho whites, and the cholerie lochchings of the stomach. It is a goosl herb for all sorts of wommds, both of the liead and boly, cillier inwarel or outward, 11 serl eitlier in juice or decoction, or by powder of the rout, or distillecl, or made into an ointment.

\section{BUT-REET}

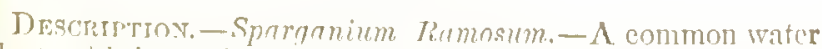
plant, with leaves like flager, and rongle lowals of sents: it is two or three feet lighh. 'The stalks are rominl, green, thick, slnd

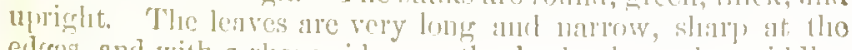
edges, and with a slintp ridge on tho back alony the middle; 
they are of a pale green, and look fresh and beautiful. The flowers are inconsiderable and yellowish: they stand in a kind of cireular tufts about the upper parts of the stalk: lower down stand the rough firuts ealled burs, from whenee the plant obtained its name; they are of the size of a large nutmeg, grecn and rough. The loot is composed of a quantity of white fibres.

Medcinal VirTues. - The unripe fruit is used: they are astringent, and good against fluxes of the belly, and blecdings of all kinds: the best way of giving them is infused in a rough red wine, with a little cinnamon. They $115 \mathrm{se}$ them in some parts of England exterually for wounds. A strong decoction of them is male to wash old nleces, and the juice is applied to fresh liurts, and they say with great suecess.

\section{BUTCHER'S BROOMI.}

Description.-Ruscus Aculeatus. It is sometimes called Knecholm, Kuceholy, and Pettigree.

The stalks are thick, whitish, and short, somewhat like those of Asparagus, but a foot and a lialf high, spread into divers branches, green, ronnd, tough, flexible and crossed, having broad and almost round hard leares and prickly, pointed at the end, of a dank green colour, two at a place elose together. The flowcrs are small, and whitish green, and grow in a singular mannel upon the baeks of the leaves; they are sueceded by a small ronnd berry, red when it is ripe, about the size of a pea. The root is thick, white, and great. It grows in copses, and upon heatlis and waste grounds, and under or near the holly bushes. It sloots forth its buds in the Spring, and the berries are ripe in September, the leaves are green all the wiuter.

Medicival Virtuls. - The root is the part used, and it is an execllent deolstincut. It works powerfully by minc, and is good in the jaundice, in gravel, and female obstructions. As such it was reconmended by Dioscorides and other aneicnt physicians. In serofulous tumours, great advantage lias been realized by administering tle root in doses of a drachm, every morning. 'The decoction swectence with honey, elears the chest of flitegm, and relieves diflienlt bresthing. $\Lambda$ conserve made of the berrics is a renedy fur gonorrhcar and scalding urine. 56 


\section{BUTTER-BUR.}

Description.-Tussilago Petasites. - Some Herhals denominate this herb Colt's Foot. But it is a very different plant. It springs up in February, with a thick stalk a foot high. The flowers appear before the leaves. The stalks are round thick and spongy, of a whiteish colour, and have a few imperfect leaves upon them. On the top of cach is a spike of flowers, of a pale reddish colour, and before it has been a month above ground, it withers, and the leaves begin to spring, which being full grown, are very large and broad, being rather thin and almost round, whose thick red sour-stalks above a foot long, stand towards the middle of the leaves; the lower part being divided into two round parts, close almost one to another, and are of a pale green colonr, and hairy underneatl. They grow in low and wet grounds by rivers and water-sides ; their flowers rising and decaying in February and March, before the leaves which appear in April.

Medicinal Virtues. It is a great strengthener of the heart, and ehecrer of the vital spirits. The roots are, by long experience, found to he very good against pestilential fevers, by provoking sweat, to be taken in wine. The decoction of the root in wine, is good for those that wheeze much, or are short winded. It provokes urine and is grood for gravel, and kills flat and broad worms. The powder of the root is a remedy for sores hard to be curcd, and it takes away spots and blemishes of the skin.

\section{CABBAGES AND COLEWORTS.}

Description is useless here. They belong to the genus Brrassicae. As an article of diet they are wholesome and nutritious; but not very suitable for persons who have weak rligestion.

Medicinal Virtues - Cabbages or Coleworts boiled in broth open the borly. 'The juice ninixed with honcy is grnorl for hoarseness, or loss of the voice, and for those troubled with Asthina. The often eating of them well boiled is groor for those that are entering into a consumptivil. 'T'he juice boiled with honey, and dropued into the corners of the eyes, elcurs the sight, by consuming any film beriuning to thin it 'The 
deeoetion of Coleworts allays the Ewellings of sore and gouty legs and linees, wherein many gross and watery humoms are fallen, the place being batlied therewith wam. Colewort stalks mixed witl old how's erense, are vely cffictual to anoint the sides of those who have had pains long therein. Cabbarges are very wintly: but Colewort flowers are more tolerable, and the more wholesome foort of the two. A red Catbage leaf placed on the side is eficetual in removing pains, stitches, \&c.

\section{CAL $\triangle M I N T$.}

Description.-Thymum Calmmintha.-It is also enlled Mountain-mint, it is a useful berb, but requires caution in some eases.

It seldom rises above a foot high, with square hairy, and woody stalks, and two small hoary leaves set at a joint, about the size of marjoram, a little dented abont the eilges, and of a very strong seent. The flowers stand at several spaces of the stalks, from the midlle almost upwards, which are small and gaping like those of Mints, and of a pale bluish colom"; after which follow small, romed blackisl sect. 'The root is small and woody, with fibres spreading the ground. It grows on heaths, and uplands, and dey gromels. It flowers in July, and tho seed is ripe soon after.

Medicinal Vintues. $-\Lambda$ s a decoction, it is rery neful in affections of the brain; for erantps, shortness of breatly, colic paius in the stomach, yellow j:undiee; and taken in wine, it anrests romiting. T'lic juice dropped into the cars relicres deafness. It is good for sciatical, $A$ decoction of the leares and wine, promotes persiniration, and remores obstructions of the liver imel splecen. It regrubates the flow of the gall, and is serviecable in old coughs.

\section{WATER CALTROPS.}

Descrinrion. Tribulus dquaticus, Tribulus Marinus. Called Water Nuts, and Water Clisuuts.

There are two Caltrops ; the first has a crecping and jointed ront, sendling forth tults at caich joint, fiom which joints ariso 58 
long, fiat, slender-knotted stalks, to the top of the water, divided into many branches, each having two leaves on botly sides, two inches long, and half an inch broul, almost transparent, they look as if they were torn; the flowers are lome, thick and whitish, set like a bunch of iriapes, sueceeded for the most purt by sharp-pointed grains altogether, contuining a small white kernel in then.

The second differs little exeept it delights in elearer water. Its stalks are round; its leaves are more pointed. They grow in the water, as their nane implies.

Menicinal Virtues. Made into a ponltice, they are good for inflammations, swellings, eankers, sore months and throats, being washed with the decoction. They eleanse and strengthen the neck and throat, and rednee the swellings of the same. It is a good remeriy for the king's evil ; for the stone and gravel, especially the nuts, being dried.

\section{CAMOMILE.}

Anthemis Nobilis. It is too well known to need description.

$\Lambda$ decoction made of Camomile, remores pains and stitehes in the side.

Medicinal Vitatuts. - The dried flowers have stomachie and tonic properties, which renders them very useful in dyspepsia and general debility. The flowers are an excellent remedy in spasmodic diseases, flatulent colics, in suppression of the menstrual rlischarge, in the vomiting of puerperal women, in the after pains, in agrnes, and in typhus fever. No bitter is so common as the Camonile. Light watery infusions of the flowers are numely used to promote, and to assist the operation of otluer ensefice, and strong infusions of it in small thoses, from two to fontr ounces, twice or three times in the day, have leen found, when used moderatcly to be good stomachies, and to assist, ligestion; and

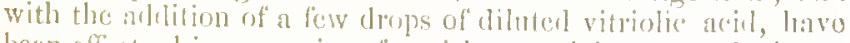
been effectnal in removing fererish complaints, and in intermittent fevers. Dr. Nortem silss that he has conred infermit-

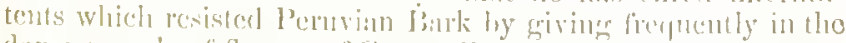

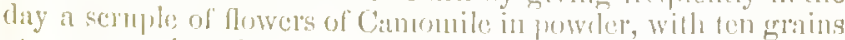
of wornivourl, and as mucle diaphloretic antimony. It is good 
for Liver eomplaints. The flowers steeped in boiling water make an exeellent fomentation for abscesses and inflamed parts, to promote suppuration and relieve pain. Flanncls dipped in the hot decoetion do as well.

Of the powdered fluwers, 5 to 10 grains may be taken; of the Infusion from 1 to 3 ounces; of the Extract, from 5 to 20 grains; distilled water, 1 to 8 drachms; volatile oil, 1 to 4 drops. Syrup made of the junce of Camomile, with the flowers in white wine, is a remedy against the janndice and dropsy.

\section{CAMPHOR.}

Foreign.-Arabie, Camfur.-The eonerete juice of the Camphora Officinarum. As a medicine, it is diaphoretic, antiseptic, stimulant, antispasmodie, narcotic, and externally, anodyne. It is good in typhus, conflucut small-pox, and all fevers and eruptions, of the typhoid class; also in measles, febrile delirium, hiccup, astlma, liysteria, epilepsy, gont, mclancholy, and acute rheumatism. But it must never be taken in large doses. It exhilarates and raises the pulse with prodncing fever, it promotes perspiration, and promotes slecp, even where opium has failed. It corrects the effects of strong purges, diureties, and narcotics. Dose, from 5 to 20 grains, in jills, powder, or emnlsions. Camphor Mixture, dose from 1 to 2 ounces, made by simply putting a lump of the grm in cold water, and let it stand for a few hours; or previously dissolve the camphor in spirits of wine.

Camphor, Tincture of-Camphor $\frac{1}{2}$ onnce, or 1 ounce; spirits of wine, half-pint, nix till the Camphor is dissolved. $\Lambda \mathrm{n}$ external application of great value in rhemmatism, paraly tie numbness, inflammations, for dispersing tumonrs, preventing or restraining gangrenes. - Not to be taken internally. - The Camphor may also be dissolved in a little spirit of wine, and then mixed with oil-this is called, Camphorated Oil.

\section{CAMIPION IVILD.}

Description.-Lychnis flure albo. There are forty-five kinds of Campion: 


\section{CAMPION WILD.}

\section{CAPSICUMS.}

The common English Campion is the only kind used in medieine. The Wild White Campion has many long and rather broad dark green leaves lying upon the ground, somewhat like plaintain, and hairy ; broader, and not so long; the hairy stalks rise up in the middle two or three fect high, with great white joints, all which bear on several footstalks white flowers at the top, eonsisting of five broad-pointed leaves, each cut in on the end unto the midile, making them seem to be two a-piece, and each of them standing in a large green striped hairy bush, large and round below next the stalk. The seed is small and greyish in the hard heads that eome up afterwards.

The Red Wild Campion differs in its leaves which are notso plainly ribbed, but shorter, rounder, and more woolly in handling. 'The flowers are of the same form and size, in some of a pale, in others of a bright red colour. They flower in summer, some earlier than others.

Mebcival Virtues. The deeotion of the herb, either in white or red wine stops inward bleedincss; applied outwardly, it has the same effect. It is an execllent dimretic, removing stone, and obstructions in the kidneys. 'T'wo drachms of the seed drunk in wine, purges the bouly of eoleric humomrs. It is good for old sores, ulecrs, fistulas, to cleanse and heal them, and preventing putreliaction.

\section{CAPSICUMS.}

Forpign.- The pungent berriss of the Capsicum fustigratum. They are very stimulanf, msefinl in debilitutert stomachs, (lyspepsia, or indigestion. Used with vergetalıles to renler them nonflatulent. Tlucy make an excellont inulge in maliguant sore throats, and relaxed statc of the uvulat; and other oligans of that part, as well as eluronic hourseness. Cayenne Pepper, which is Capsicum powelered, is taken from 2 to 8 enrins. Taken molerately it is a superior medicine, Two palls Cary-

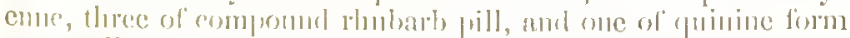
an execllent clinucr pill. - Seo C'ayenne L'yner at the cul of the book. 


\section{CARATAY.}

Description.-Camm Cami.-The Caraway is propogated chicfly for the sceds. It bears divers stalks of fine ent leaves a little like the leares of carrots, from among which risc a square stalk, at whose joints are set lcaves a little like those of the carrot, but smiller, and at the top snuall muljels of white flowers, whieh turn into small blackish secd, whieh are well known. The root is whitish, small and long, like a parsnip, but with more wrinkled bark, and much less. It is usually sown in gardens. It flowers in July and seeds quiekly after.

Medicinal Virtuls, It is a good remedy for expelling wiul, and for eotic. 'The young root is better food than parsnips; it is eomfortable to the stomach, and promotes digestion. The powrler of the sced male into a poultice, takes away black and blie spots produced by blows and bruises. The herb itself, or with some of the seed bruised, liat hot in a bag or double eloth to the lower part of the belly, removes wind and eolie. Conthined with semna, these seeds eorrect its griping effects. The oil of Caraway, given in six or cight drops on a lump of sugar, is good for jains of the stomach, heart-burn, \&e.

\section{CANDAMOM.}

Description.- Elettaria Cartamomum, a plant of tho natural order Zingiberacen. - This is an Intian plant, lather resembling our recus. It produces a triamgulitr frut, about the size of a horsebean. These fruits or pots ane an clegant aud useful aronitic, of a gratefil smell and flarour, very wam, yet not ficry like pepjer. They strengthen the stomach and promote digestion. 'They are roorl for the hendialse, arising from a billious aflection, and they also relieve the colic. Sinne dyspeptics regularly clew them, and they are not disagrecalte. The latrge Cardamom, or Gran of l'andise is an exedlent tonic.

Tincture of Cardamom.-Threc onmees of the seeds, proof spirit, two piuts. Bruise the seedk, and digest for s days.

Componme Tineture of Curdumoms.-Lesser Cardinnom Eectis powdered, Caraway sceds powdered, Cochinesl powdered, twi) dratchns of eacli, Cinnanon bruised, hall an onnce; rili62 
sins stoned, fonr otuces, proof spirit, two pints. Digest for 14 days, and strain. Dose of the I'ineture, two to three drachuns, and of the Compound Tinchure from three drachms to half an ounce. In dyspeptic labits, half a glass taken before dinner serves to rouse the nerves of the stomach, and to aid digestion.

\section{WILD CARROTS.}

Description.-Duncus Sylvestus.-Garden Carrots need no deseription; but in medicine they are not so eflicacious as tho wile.

The Wild Carrot grows altogether like the garden but the leaves and stalks are whiter ind rougher. The stalks bear linge tufts of white flowers, with a lecp purile spot in the middle, which are eontracter together when the seed begins to ripen, and the middle part being hollow and the ontward stalk rising high, make the whole nmbel appenr like a hird's nest. The roots small, long, and hard, and unfit for meat, being sharp and strong.

The wilt kind grows by the fich silcs, and untilled plaees. They flower and secel in the ent of Snmmer.

Memenal Virturs. Wild Carrots cxpel wind, and remove stitches in the sirles, promote nrine and women's conrses, anul expel the stone. 'The seed also has the same cellect, and is

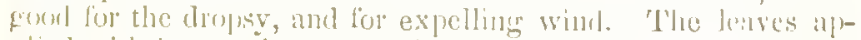

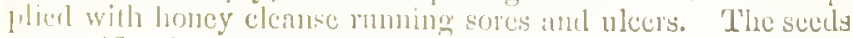
are antifatulent, and su excellent dinretic.

\section{CASTOR OIL.}

Foreign.-This valuahle oil is obtunen from the secds of a

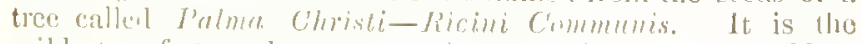
millem, safest, and nust ecrtain pursative known, sclidem

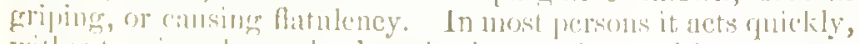

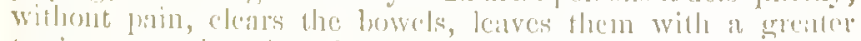

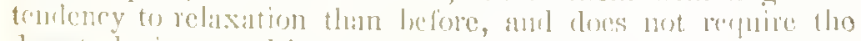

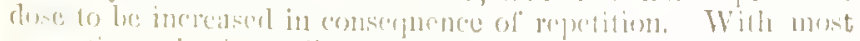

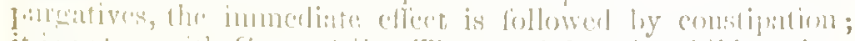

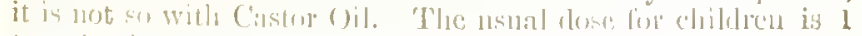

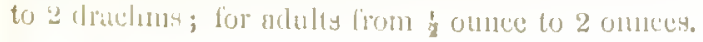


The great objeetion to Castor Oil, its siekly nauseousness has produced many modes of taking it :- floated in brandy and water, barley-water, \&e. \&e. But perhajs tle simplest way is to take it in a small quantity of Oat-meal and water-the meal neutralizes the taste.

\section{CATECIIU.}

Foreign. A substanee obtained from the wood of the Acacia Catechu. As a tonic it is most valuable in diarrhon, ehronie dysentery ; it makes an excellent gargle for sore throats, or elongated uvula. It is good for sponginess of the gums, being allowed to dissolve in the mouth ; it makes an exeellent dentrifiee. It is serviceable in gleet, Cucorrhœa, in passive hæmorrhages, especially those of the bowels and uterus, and for uleerated mouth, ehapjed nipples, used as a tineture.

\section{CATMINT.}

Description.-Nepeta Cataria.-It grows a yard high, and has broad whitish leaves, and white flowers like mint. The stalks are square, whitish, hairy, and erect; the leaves stand two at a joint; they are broadest at the base, and terminate in an obtuse end; they are a little indented at the edges, and of a whitish green on the mpper side, and very white underneath. The flowers are small and white; and they grow in spiked cluster's, sulrounding the stalks at certain distances. Tho plant has a strong and not very pleasant smell.

Medicinal Virturs.-Its virtues are eonsiderable. It is a good female medicine; an infusion of it prevents lysterie eomplaints, vapours, and fits; it is also good to promote the evacuations after ehild delivery. It is good for pains in the head produeed by eolds, catarils, \&c. $\Lambda$ decoction sweetened with sugar, or honey relieves an olstinate congh. The green leaves brinised, and applicd to the ants, relieves the piles; the juiee made into an ointment lias the same efleet. The deeoetion is good for elcansing the head.

64 


\section{CELANDINE,--LITTLE.}

The greater and the Lesser Celandine are two different plants. They agree in nothing, exerpt they have yellow flowers. The Great Celandine is much like the Poppy; and the Incs:er Colandine resembles the Crow-foot. Their virtnes also rliffer. It is surprising the old Herbalists did not make a distinction.

Description.-Cheliclonium Blinus. It is also known by the name of Pilewort and Foywort. Celandine, or Pilewort spreads many round pale green leaves, set on weak and triniliner branches, which lic upon the ground, and are fat, smooth and somewhat shining, and in some places minked with black spots, each standing on a long footstalk. The flowers, which are yellow, rise singly fiom the root, on long, slender, and nakerl stalks, eonsisting of nine or ten small narlow leaves, very like Crowsfoot. The seed also is not unlike, being many smail kernels like a grain of com, of a whitish colonr, with fibres at the and of them. It grows mostly in moist corners of ficlds, ant near water sides; yet it will grow in driel grouncl if it is a little sharly. It flowers abont Mareh or $A$ pril, is quite gone by May.

Medicinal Virtues.-If you dig up the root of it. you will perceive the prefeet image of the disease commonly ealled the piles. Experience proves that the elecoetion of the lenes and roots is a wonderfinl remerly for the piles numl hemorrhoids, the king's evil, or any othel harel wens or tumours.

Pilewort marle into an oil, ointment or plaister, has the same affect in euring the piles, or hemorthrirls, and the kinge's evil. The herb bone abont one's borly next the skin, helps in stril liseases, though it never touches the allecterl place. With his I curerl my own dauchter of the king's evil, broke the sorer, lrew ont a quarter of a pint of colruption, and cured willout uy scar at all in one weuk's tine.

\section{CETANDINE,-GREAT.}

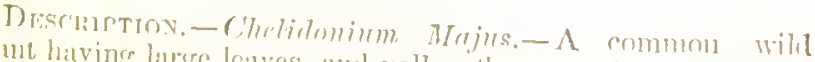

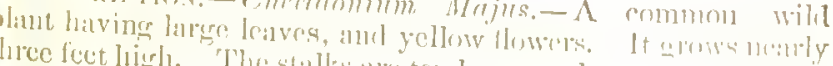

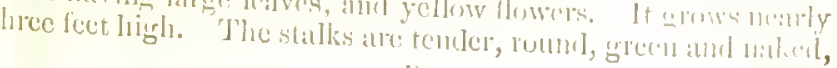


with thick joints. This plant, when broken in nny part, emits a ycllow juice, bitter in taste, and strong in scent. The leares stand two at cach joint; they are large, long, and decply divided at the edges, and are of a ycllowish green. The flowers proluee small long pods, with blackish secd.

They grow by old walls, hedges and way-sides, in untilled places, and in gardens. They flower all the Summer.

Mindcinal Virtues. It is a most valiable remedy for diseases of the eye, used as a deenction, or made into an ointment. The juice is the best way of adminstering it, it is an cflicacions remedy for the jaundiec, scurvy, and all obstructions of the liver and other viscern. The addition of a few aniseeds in makincr a deeoction of it with wine, increases its effiency in removing obstructions of the liver and gall. The juice applied to warts soon removes them, also ring-worms. Tlic juice mixed with sulphur is a remedy for the itch. It has becn goiven with great effect in serofila. An ointment made of the roots and hogslard is a good remedy tor the piles. Boil them together.

\section{LITTLE CENTAURY.}

Description. - Centantium MIinus. - There are two kinds of this plant, one bearing pale red flowers, the other white; but their rirtues are the same. It usually grows with one round and somewhat erusted stalk, about a foot high or better, bumching forth at the top into many sprigs, and some also from the joints of the stalks below; the flowers stand at the tops in one eluster: They are of a pale red, tending to carnation eolour, consisting of five or six small leaves, rery like those of St. John's wort. 'The root is sullall and harel, perishing every year. The plant is rery bitter in taste.

It grows in ficlds, pustures, and wools. It flowers in July, and sceds a montl atfer.

Mandunat, Vumpes. Centaury is justly estecmed as oue of the most efticacions hitlers in this islimel. It is often sulutituted for Gentian, which it much resembles. It is mikler than Wormwonl, or lloly 'l'histle. It is an excellent stomachic, both 66 
in substanec and iufusion ard eclebrated for the enre of intermittent ferers. It is a good remedy for worms; and like camomile, is made into tea for assisting the operation of emcties. As a bitter it is often taken to ereate an appetite. It removes obstruetions of the liver and spleen; and is most useful in the jaundice, dropsy, green sickness, colie. It is very serviceable in olstrueted menstruation, in eounection with some mild purgative. The green herb bruised is very good for trounds, soles, Ee. An onnce of Centanly, with two drachms each of Arens, and Angreliea, infused in one quat of boiling water, and then ald two ounees of Cardamons-these makc an exeellent stomachic. Take a wine-glassfil two or three times a day. Remember that the long continued use of any bitter impairs the coats of the stomach, and produces an ineurable debility of that oryan.

There is, besides these, anofher small Centunly, which ben's a yellow flower, like the former, save that the leares we larger, and of a darker green. In discases of the blood, use the red Centanly ; if of choler, use the yellow; but if phlecrm or water, you will find the white best.

\section{CIIERY-TREE.}

Drscriptios.-Ceresum Durasinum.-This tree is well known.

Mromcinal Vintrea.-Clerries, as they are of different tostes, so they are of clifferent qualities; the sweet digest more specdily, lust lave litte momishment. The acid are more pleasing to a hot stomach, jroence appetite to incat, and help to ('ut tongh phlegnı, and gross humonrs; but when they are dried they are more eonsipinting than when they anc fiesh, heing zooling in lost diseases, and grateful to the stomach, they pruroke urine. The gum of the Cherly-trec, dissolved in wite, is good for a colrl, congh, and lualkeness of the throat; it improves the eomplexion, and the cye-siglit. Cherries inprose he appetite, lolace Cherries boniscel with the stones, and disolved, the watce thereof is used to exich wind and the gravel. 


\section{CIIERRIES, - WTNTER.}

Descriptron.-Allekengi. A very singular and pretty plant eultivated in gardens.

The Winter Cherry has a running root in the rround, shooting forth at several joints in several places. The stalk rises about a yard high, whereon are set many broat and long cricen leaves, somewhat like Night shade, but larger: at the joints eome forth whitish flowers, composed of five leaves cach, which produce green berries inclosed with thin skins, which are reddish when ripe, and as large as a cherry. The pulp encloses flat yellowish secds, which being gathered and strung up, are kept all the year for use.

They flower in July; and the fruit is ripe about Angust, or the beginning of September.

Medicinal Virtues. The leares heing cooling, may be used in inflammations, but they are not so purgative as the berries and fruit. They promote a copious and an casy discharge of urine, and are cxcellent for the rravel. The berrics and leares distilled, or made into a decuetion, with milk and a little sugar, must be drumk morning and erening. Or, take threc or four good handfuls of the berrics, either ereen or dricd, and having bruised them, punt them in so many wallons of beer or ale when it is new and tumned up. This drink, taken daily, has been very useful in urinary discases, Sc. It prevents the accumulation of stonc. The decoction of the herrics in wine and water is the most usual way, but the powder of them taken in drink is nore eflictual.

\section{CITRVIL, Suct, or SHEET CICELY.}

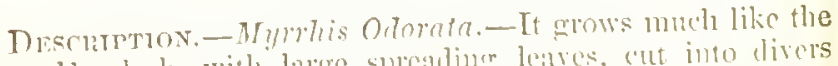
great bemlock, with larege spresuling leaves, cut into divers parts, yet of a fresher green than the llemlock. 'The siallis grow a yard high, are creased hollow, and havimg :maller lenves at the joints. 'The stalks are erowned with ints of white flowers, which pronesec long black shining seeds, pointed at 68 
cach end, of a sharp, sweet, and pleasant taste. The root is large and white, deep in the ground, and its smell is stronger than that of the plant.

Medicisil Virfues. - The plant is a wholesome addition to salad. 'The root boiled, and eaten with vinegar, warms and stimulates cold stomaclss; it is beneficial in complaints of the chest and lnngs. It relieves flatmleney, and promotes appetite, and remores female obstructions. The juice is good to heal old ulecrs. - It is so harmless that it eamnot do any harm.-Pulverize the root, and take half a spoouful in brandy for flatulency, colie, Se.

\section{CHERVIL.}

Description.-Senadix Odornta.-As a salad herb it is cultivated in gardens. It is like Parsley in its manner of growth; but after it is grown, the leares rather resemble those of Hemlock, hairy, and sometimes rather red. The stalks are round, striated, hollow, and of a light green; they divide into several branches, and they grow two feet high. They bear white flowers in large tufts, which produee blackish seerls, of a sweet taste. It sonietimes grows wild, two or three feet high, in meadows, by the hedge sides, and on heaths. It flower's and sects carly.

Medicinat Virtues. - As a garden vegetable, it onght to be generally eultivated. The roots deeoeted work moderately by arine. As a vegetable they warm the stomaeh, and prrify the bloorl. The leaves, combined with a few Hemloek leaves, made into a poultice, relieve the sore breasts of women giving suck; by removing the knotty pants, it causes the milk to flow freely. It should be applied warm. $\Lambda$ pplied to the belly it gives relicf in gravel. It is an expectorant, and relieves Asthma, if brilerl in whev. Bruiser and applied, it removes swellings, and marks oceasioned by blows or bruises.

\section{CIIESTNUT TREF.}

Alsculns IVippoenstamum. - It is needless to deseribe a treo so commonly known. 


\section{CHestnuts.-Earti Cirestints. Chickived.}

Medicinar. Virtues.-It is a powerful astringent, and it has been used as a substitute for Cinchona, in cases of Arne, intermittent fevers, \&e. The inner skin of the nut is so binting, that a seruple taken by a man, or ten grains by a child, instantly stops fluxes. The dried nut powdered, and a drachm taken is good for the overflowing of the menses. The powder made into an electuary relieves eoughs and spitting of blood.

\section{CHESTNUTS.-EAR'TH CHESTNUTS.}

Description - Bunium Fexuosum.-They are ealled Earth Nuts, Earth Chestnuts, Ground Nuts, Pig Nuts. The root is the size of a Chestnut, brown ontside, and white within, and sweet in taste. The plant grows a foot high; the leares are divided into fine and numerous partitions; the stalk is firm, upright, round, and green; the flowers are small, white, and grow in tults.

Medicinal Virices. They are rather hot and diy in quality; the seed is good to provoke mine; and also the root, but it is not so efficacions as the seed. The root dried and beaten into a powder, and made into an electrary, is a singular remedy for spitting of blood, and for bloudy urine.

\section{CHICKTEEED.}

Alsine Media. It is well known. It is very common in gardens.

Medicinal Virtues.-The plant chopled and hoiled in Ind malses a fine green cooling ointment, and is good for piles, ulcers, sores, Se. The juice taken inwards, is groor for seury. A cloth saturisted with the juice, and applied to opposite the liver, reclues inflammation; the juice is goul for inflimmmations of the eyes, when alopped into them. 'The leaves boilcel witl Marshmallows, and nute into in ponltice with tenungeck and linsed, applied to swellings and imposthmmes, breat them, reduce the swrelling, and ease the pain. A poultice mate of the leswes is al great eooler for inflamnations. 


\section{CHICK PEAS.}

"Some German plysicions affirm that this plant, combined with Elecompane, is is specifie in Ilyctrophobia, I achninistered it in a case, and the patient recorered."-Dr. BEach, dmerica.

\section{CHICI PEAS, or CICERS.}

The garden sorts, whether rel, black, or white, are so well known as to require no description.

Medicisal Virtues. - They are less windy than beans, but nourish more; they provoke urine, liave a clensing faculty, and break the stone in the kidneys. To driuk the cream of them, being boiled in water is the best way. It purges, and promotes menstruation. One ounce of Ciccrs, two ounces of French barley, and a small handful of marsh-mallow roots, washed and cut, and boiled with a chicken, and four ounces taken in the monning, and fisting two hours after, is a good medicine for pains in the side. The white Ciecrs are used more for meat than medicine, yet have the same effects. The wild Cicers are much more powerfil than the graden kind.

\section{CHOCOLATE AND COCOA.}

Foreign.-Both are prepared from the seeds of the Thealroma Cacao, a tree growing in the West Indies, and other places. Cocoa when grenuinc and properly prepared, is whole. some and nutritious, containing a large yuantity of oily or fintty matter, starch, \&c. Cocon does not allect the nervous system in the same manner as tca aull coffec, and therclone it may be used where they are not proper. Cocon can sektom be obtained in a perfectly pure state; the only way is to purchase the nibs and erush and boil them.

Chocolate is of the same nature, bnt very liable to be artulteraterl. That of French make is generally to be prelerred. Chocolate when pure is exceedingly nutritions.

\section{CINOUEFOIs.}

Discruptons. - Pentaphyllon. - In sone combrics it is calleci live-lingereel grass. It spreats and creeps firr upon the 
ground, with long slender strings like strawberies, whieh tnke root agrin, and shoot fortl many leaves made of five parts, and sometimes of seven, dented about the edges and somewhint hard. The stalks are slender, leaning downwards, and bear many small beautiful yellow flowers, with yellow threads in the middle. The root is of a blackish brown eolour, growing long, with small strings, by whieh it soon spreads over the ground. It grows by wood sides, hedge sides, the pathway in ficlds, and in the borders and eorners of them.

Medicinal Virtues. - The root is to be used, which must be dng up in $A$ pril, and the outer bark taken off and dried; the rest is not used. Few diugs have power equal to this root for all kinds of fluxes. As an astringent, it stops purgings, and profuse menstruation. A seruple of the powder in wine will etre the agne. It may be repeated onee or twice when the eomplaint is obstinate. It stops bleeding of the lungs, or hronchial tubes, blecding at the nose, and is useful in conghs, jaundice, and ulcers in the kidneys. By washing the eyes in a deeoetion of the root inflammations are remored. The juice of the root is very eflicalcious. The juiee and whent bread boiled first is a good styptie. For the decoetion, boil $1 \frac{1}{2}$ onnce of the root in a qualt of water down to a pint. The juice nuised with huney, relieres eonerhs, and hoarseness.

\section{GARDEN CLARY}

Description.-Salvia Verbeneca.-Some know it by the name of Clenr-eye. Garden Clary has four square stalks, with broad, rongh, wrinkled, whitish, or hairy green leares, evenly indented on the edges, and of a strong sweet scent. The flowers grow at certain distances, witle two small leaves at the joints nunder them, somewliat like the flowers of sage, but smaller sund of a whitisly blne colour. 'The sect is lrownish, sud somewhal halt. It is propatgated by sced ammually.

Mroncisat, Vuntus.-The whole of this herly is used fresh or lly. It is corlial and rather astringent. It strengthens the stomach, relioves hestaches, and cures the whites. A decoction is gool for inflamed eyes. The mucilitye of the seed ri- 
luted with water, and applied to tumonrs, or swellings, 1nkes them away; the leaves used witl vinegar, or with a little honey, cures boils, felons, and inflammations caused by the same. The powder of the dricd root provokes sneezing, and purges the head of much rheum. It is of much use both for men and women who have weak backs; and it strengthens the reins.

WILD ClARY grows on the banks of ditches, and in dry ground. It is less than Garten Clary. Its moclicinal virtucs are rather more powerful. It is a capital remedy for dimness of sight. The plan is to put the seed into the cyes. They inmelliatcly eollect a eoat of mucilage about them, and this catches hold of any little thing it meets with in the eye-the sceds drop out of themselies, and cause little pain.

\section{CLEAVERS.}

Descriptros. - Aparme - It is also called Goose-share, and Goose-grass. The eommon eleavers has diver's very rough squaro stalks, rising two or three yards sometimes, if it meets with any tall bushes or trees, whercon it climbs without claspers, or it creeps on the ground, full of joints, cach of which shoots out a branch, and leares usually six, set in a round compass, like a star, or rowcl of a spur: From between the leaves or the joints at tho top of the hranehes come forth very sinall white flowers. 'The secds grow two together; they are rough. The stalks, leaves, and especially the sectls are so rough that they will stiek to any' thing they touch.

It grows in herlges, and by ditch-sides, and it is injurions to whatever grows near it. It flowers in June or July, and the seed is ripie in $\Lambda$ ungust.

Mlibrinat Vilturs. - The juice of the herb is a goorl styptic forl hleceling wounds. It is taken in brotls, to kecp those lean who are apt to shrow fat. The distillem water drank

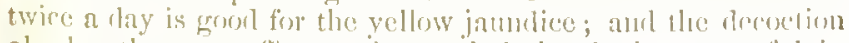

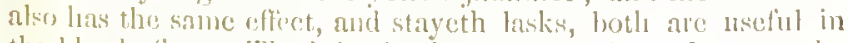
the bowely flux. Tho juice is also very goot to close up the lips of errecon wonnds, and the powter of the dried herts cures

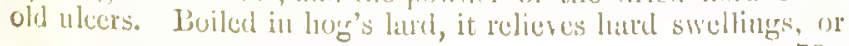


kiemets in the throat. The juice is good for ear-ache. It is a renowned diuretic, most appropriate to remove specdily suppression of urine, gravelly eomplaints, remoring slimy matter and obstruetions from the kidneys and bladker. It has been fonnd usetul in the ene of senry. The infision should always be made in cold water ; say 4 ounces to 2 pints.

\section{CLOVE.-SPICE.}

Foreign.-Cloves are exeellent agninst disorders of the head, and the stomach; they are warm, eordial and strengthening; they expel wind, and are a good remedy for the eolie. Dose of Powder 2 to 3 grains. Infusion, 1 to 2 onnees. Tineture 20 to 30 minims. 'The oil of Cloves is exeellent for' the toothache, and better still combined with Cajeput oil, opium, and Camphor.

\section{CLOWN'S WOUND WORT.}

Description-Rusticum Vulna Horba. It grows usually abont two feet high, with square, green, rough stalks, but slenter, joined far asunder, and two of them are rely long, narrow dark green leaves, blun ry dented at the edges, ending in a long point. The flowers stand towards the tops, compassing the stalks at the joints with the leares, and end in a spiked top, having long and and gaping hoorts of a purplish red colour, with whitish spots in them, and standing in somewhat round husks. 'The root is eomposert of many long filres, with tuberous long knolss of a pale yellowish or whitish colour. The plant has a strong smell.

It grows frequently by patli-siles in fielis, and in or noar ditches. It flower's in June or July, and the seed is ripe soon after.

Medicinal Vilzedes. It is very eflectual in fresh and erreen wounds, and therefore beareth not its lanue fir nonght. And it is very available in stannching of blook, and to itry up the Inmour's in old uleers, cankers, sce. that linder the healing of them.

$\Lambda$ syrup made of the juice of it is inferior to none for inwarl 
wounds, ruptures of veins, bloorly fnx, vescels broken, spitting, or romiting blood. Riuptures are wonderfully cured by taking now and then a little of the syrup, and applying an ointment or plaistel of this herb to the place. Also, if any vein, or muscle be swelled, apply a plaister of this herb to it-the addition of a little Comfrey to it, renders it more effectual. This Herb is very valuable, and should not be overlooked.

\section{COCI'S HEAD.}

Description._Galli Caput.-It is also ealled Red Fitehing, and Medce Fiteh. It has various weak, rough stalks, drooping, set winged leaves, longer and more pointed than those of lintels, and whitish underneath; from the tops of these stalks arise other slender stalks 11aked unto the tops, where there grow many small flowers like a spike, of a pale reddish eolour, with some blucness among them; after which rise up in their places, round, and somewhat flat heads. It grows under hedges, and in the open ficlels.

Mreicinal Virtues.-It has power to rarify and digest ; and therefore the green leaves bruised and used as a plaister, disperse knots, or kernels in the flesh; and if when dry it be taken in wine, it relieves the stranguary; and being anointed with oil, it provoketh sweat. It is a singular food for eattle, to canse them to give much mills, and boilcd in ordinary drink it must be useful for nurses!

\section{COFFEE.}

Foreign. - The herries of the Coffer Arabieus. It is a tnnie and stimulant, and possesses exlilarnt and autionorific properties, It is soorl in eases of poisoniner by opinn and laudanum. It is georl for hoopiner-coneh and asthulis. It is not suitable where there is a profise secretion of lite, as it stinulates the system too much. It is far more nutritions than tea. Coffee shoulth be used frealuly ground, infuser in looiling, and never briled. It assists digrestion, expels wind, and enently promotes urine. It suspends the inelination to slecep, especinlly 
when taken at night. It is a first-rnte disinfectant. Even the cmell of musk and eastor, whieh cannot be overpowered by any other substance, is completely dispelled by the fumes of Coflee - the same remark applies to the odour of asafouticla.

\section{CASCARILL $\Lambda$.}

Croton Eleuteria - The Bark is imported from the Baliama islands, in curled picees. It has a light agreeable smell, and a moderately bitter taste with some aromatie warmth. When burning, it has a very fragrant smell, like that of musk. It produces a sense of heat, and excites the action of the stomach. It may be advantageonsly employed in flatulent colies, internal hæmorrhages, dysenteries, diarrhoa, \&e. It is mueh used among the Germans, as a febrifuge, for stopping agues. In the year 1719 , it was of great scrviee in an epiclemie dyssentery which raged at Paris, and had not yiclded to ipeenenanha. Dr. Lewes, in his New Dispensatory, says that it deserves to be more regarded than it is at present._-Dose, from ten grains to half a drachm, or more._-Tincture:-Four ounces of the bark powdercl; two pints proof spirits; digest with gentle heat seven days, and strain. It is a fine stimulating medieine, and excellent in the gout, or after that disease, to give to the stomach tone and system. Dose, two drachms four times a day in eimmanon water.

\section{COLEWORTS.-SEA.}

Description.- - Soldanella.-This has rather long and broat, large, and thiek wrinkled leaves, a little crmmpled abont the enges, and growing upon a thick footstalk, very brittle, of a greyish green colonr, fiom which rises up a strong thick stalk, two feet high, with leaves thereon to the top, where it hranches forth mueh; and on every branch standetl a large bush of pale whitish flowers, consisting of four lenves a picese. Some of these plants lave red llowers, shaped like a bell. 'They grow oll the sca-consts.

Mruicinal Vintues.-The whole plant is to be gathered 76 
fresh when about flowering, and boiled in ale with nntmeg and cloves, and taken according to a person's strengtl. It is strongly purgative and sometimes promotes nine rery beneficially. The brulised seel decoeted, kills worms, and is very cftectual in clap or gonoryha.

\section{COLOCYNTIT.}

Foreign.-Bitter Apple, a plant of the natural order, Cucurbitacece. It is the firuit of a erecping plant, growing on the shores of the Meclitcriancan. An extract from the dried pulp is used in molicine. It is rery useful in habitual constipation, in affections of the brain, as a revulsire. In small doses it is cxpectorant, diuretic, and alterative. Dose;-powder 2 to 8 grains; Extract, from 4 to 10 grains. It is best to take it with some aromatic, to neutralise its griping tendeney. For Pills, combine with rhubarb, ginger, and extract of gentian. It is a most valuable aperient, tending to discharge watery humours.

\section{COLT'S FOOT.}

Descrimtioy. - Tussilngo, Farfura. Called also Conglwort, Foal's-toot, IIorse-hoof, and Bull's foot. It shoots "lp a slentler stalk, with small yellowish flowers as large as those of the Dandelion; these come hefore the leares; they fall away quickly, and then come round leaves, sometimes dented about the erlges, with a little down or firicze over the green leaf on the upper side, which may be rubberl away, and whitish or meally underneatl. 'The rout is small and white, spreading much under ground.

It grows in wet grounds and also in diry plaecs. It flowers in Felsuary.

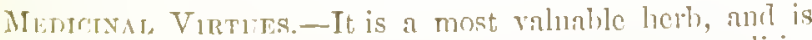

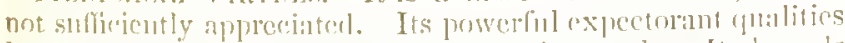

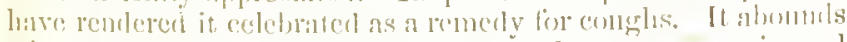
with mucilages; it is slightly bitter ; and possesses tomic anul

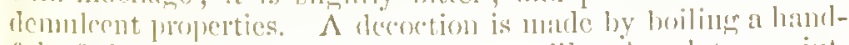
ful of the leares in a clinart of water sill reduced to a lint, 
swcetened with Sugnr Candy, and acilulated. with a slice of I.mon. A wine-grissful may be taken three or fonr times a day. This is very usctul in coughs and in all discases of the lungs, shortuess of breath, wheezing, \&c. It thickens the expectoration when thin, and of course must allay inflammation. The Syrup of Colt's foot is muel reeommended by Frencl plysicians for chronic bronchitis. Boiled in milk it is exeellent for eonsumptive patients with distressing conghlus.

Dr. Cullen found this plant of gient service in scrofulous discases. He gave a decoction of the dried leares, and found it suceeed where other remedies had firiled. Fuller relates that a girl] with twelve serofulous sores was eured by drinking rlaily as much as she could of a strong decoction. Dr. Percival found it useful in heetie diarhnens. A decoction with wormwood has done wonders in caleulous eomplaints. Sweetencd with honey, it is gool for colds and asthma.

The laves are the basis of the British Incrb Tobaceo-to them are added the leaves of Eye-lright, Buckhean, Betony, Rosemary, Thyme, Lavender, and Camomile Flowers. This 'Tubneco is firstate for Asthmin. Let the Colt's foot preponderate.

\section{COLUMIBINES.}

Aquilegin Vulgaris.-These are wall known, grrowing almost in every garden.

Mentanal Virtors.- The leaves of Colmubines are commonly used in lotions with good success for sore months and throats. Tragus says, that a drachm of the serel laken in wine, with a little saffron, onens obstunetions of the lirer, and is good for the yellow faundice, if the party alter taking it, sweat well in bed. The Spaniands llsed to cat the root in a molning fasting, many days together, to enre grarel, and other disenses of the lidlueys.

\section{COMHLET.}

Description. - Symphytum. Ofjeinal.-The common great 78 
Comfrey has linge hairy green leates lying on the ground, so hairy or prickly that if tliey tonch any part of the body, they will carre it to iteh. The sțalls rises two or three fect highl, hollow and cornered, and is very thairy. It has many sneh leaves as grow below, but decreasing in size to the top. At the joints of the stalks it is divider into many branches, with some leares thereon, and at the ends stand many fluwers in orler one abare another, which. are long and hollow like the finger of a glove, of a pale whitish colour, after which come small black sceds. The roots are large and lorrg, surciding lare thick branches under ground, black on the ontside, ancl whitish within.

There is another sort like this, but rather less, and whieh bearetl flowers of a pale purple colour. They grow by ditches and water-sides, and in inoist ficlls. They flower in June or July, and gire their secel in $\Lambda$ ugust.

Medicisal Virtues. What was spoken of Clown's Wommwort, may be said of this. The Great Comfrey relieves spitting of bloor, and bloody urine. The root boiled in water or wine, relicres inward hurts, bruises, womnds, and nlecrs of the lungse, and loosens tough phlegm. It relicres those eolds in the hend which deposit rhenm in the lungs; enres bloody flux, inmortcrate courses, the whites, and discases of the kidneys. $\Lambda$ syrup made thercof is effectual for all inward hurts, and for outward wounds and sores in the fechy or sinewy part of the body. 'T'le roots are more elfectual than the leaves. "They are good for fres ls wounds or ents when bruserl and latd thereon, and also for ruptures, and very powerful in lintting lnoken bones. It is an cxcellent remedy for sore nipples. The roots leaten small, and spread mpori leatlecr, and laid upon any place alfected with the gont, immerliately relieres the pains; also painerl joints, and is very nscfil in moist ulecrs, gangrencs, and mortifications.

\section{COPAIBA, OR COPAIVA.}

Foreign.-A resinous juice procuret fiom the lark of tho Copmifres Mulymga. It is very dimetic, and timulates the

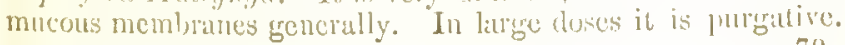


It is very useful in diseases of the urinary organs, especially gonorhoea; in ehronic affections of the chest, and piles, and cxternally for chilblains and indolent ulecrs. Take 10 to 40 minims or drops in plain or aromatie water. Of oil of Copaiba, take 10 to 20 minims, or drops.

\section{CORALIWORT.}

Description.-Comeallim Herbo. It is also called Toothwort, Tooth Violet, Dog Tecth Violet, and Dentaria. This plant shoots forth one or two winged lcarcs, upon long brownish footstalks, whieh are doubled down at thcir first coming ont of the ground; when they are fully opened, they eonsist of seren leavcs, of a sad green eolour, dented abont the edgres, sct on both sides the middle rib one against another, as the leares of the ash-tree; the stalk has no lcares on the lower laalf, the upper half bears three or four, each consisting of fire leaves, sometimes of three; on the top stand four or five flowers upon short stalks, with long hnsks; the flowers are rery like the flowers of stoek-gilliflowers, of a pale purplish colour, consisting of four leares a picce. The root is smooth, white and shining, ereeping, and has various small round knobs sct together.

Medicinal Virtues. It clcanses the bladter, and provolics urine, expels gravel and the stone; it cases pains in the sides and bowels, and is very good for inward rombs, especially such as are made in the breast or lnugs. $A$ drachm of the root powdered must be taken every monning in wine. An ointment made of it is good for wound's and uleers.

\section{CORIANDER.}

Forcign.-The scels produced by the Corinndmem Sativum.

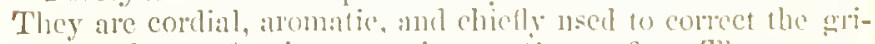
ping tendency of act ive purgatises, as Senna, \&u'. They are cxcollent to expel wind, wintm, and strengthen the stomads, ant sill digestion, ane good for pains in the licakl, and amest pumoingers.

80 


\section{CORN COCKLE。}

Description. -Agreste Gith. $-\Lambda$ tall and beantiful plant, wild in eorn-fields, with red flowers. It grows two feet hight the stalk is single, slender, round, hairy, firm, and very ereet. The leares stand two at a joint, not numerous; they are long, narrow, hairy, and of a bright green colour, the flowers stand singty, one at the top of each branch,- large, and of a beautiful red. They have a beautiful eup, composecl of tive narrow hairy leares much longer than the fluwer.

Medicinal Virtees. - The seeds are neel; they promote urine, the menses, and all obstructions, and are good in dropsy and jaundice. The best way is to give them in powder, made into an electuary, to be taken for sone tine; for the medieines, whose virtues are against chronie disease, do not talie effect at onee.

\section{COSTMARY or ALCOST, nI BALSAM IIERB.}

This is known to be an inhabitant in almost every garden, so that it is needless to deseribe.

Medicinas Virtues. - Costmary gently purres eholer and phlegm, extenuating that which is gruss, and cutting that which is tongh and glutinous, and hinders putrefaction and corruption. It is astringent to the stomach, and strengthens the liver, and the other inwarl parts; and taken in whey, it is more effectual. Taken fasting in the morning it relieves chronie pains in the head, and drics up, and consumesall thin rhemms or rlistillations from the head into the stomach. It is very profitable for tlose that are fallen inte a eontinual evil disprisilion of the looly, ealled Cachexy, but esperially in the heginning of the discase.

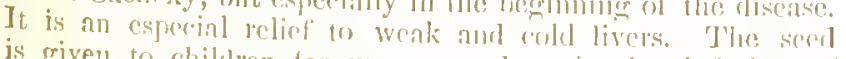
js given to chilelren tor worms, aurl so is the inftision of flowers in white wine, nlont two omuress at a time. It nllikess

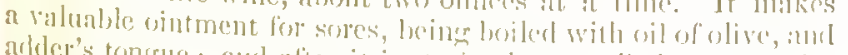
srider's tringne; and after it is strainesl, put an little wax, resin, and tenpentine. to loring it to al consenicut body. 


\section{COWHAGE.}

Foreign.-The stiff hairs which eover the pods, or seed vessels, are used. This hair or pile seraped off, and mixer in some viseid vehiele, is the part to be taken to dislodge intestinal worms, espeeially the lumbriei, resembling carth worms. It is a most effectual remedy. The dose is from 3 to 10 grains, or more, on going to bed, in treaele, honcy, or syrup; repeated for 3 or 4 days, and then administer a brisk purgative, as infusion of Senna. Cowhage is quite harmless, in a vehiele as above.

\section{COWSLIPS, OR PEAGLES.}

Primula Veris. The wild and garden Cowslips, are so well known, that they need no deseription. They flower in April and May.

Medicinal Virtues. The flowers are held to be more effeetual than the lcaves. An ointment being made with them, taketh away spots and wrinkles of the skin, sun-burning and freekles, and increases personal beauty; they remedy discases of the head arising from heat and wind, as vertigo, phrenzies, falling sickness, palsies, eonvulsions, eramp, and pains in the nerves. The roots allay pains in the back and bladder, and are a good diurctie. The lcaves are good in wounds, and the flowers take away trenbling.

Because they strengthen the brain and nerves, and remedy palsies, the Greels gave them the name Paralysis. 'The flowcrs preserved or eonserved, and the size of a nutmeg taken cvery morning, is a sufficient dose for inward discases. The ointment is made of the leaves and hog's lard.

The flowers of the Cowslip make an exeellent wine of a rather sedative nature, easing pain, and disposing to slecp. It may be made as follows:-

Allow 4 pounds of sngwe to a gallon of water, and boil and slin it till it be quite clent. Ald a gallon of the flowers, picked from the stalls, and the riml of a lemon; and let them boil thee minntes. Put info a vessel to cool, and then into the cark; add the juiee of the lenron, and a littlo brandy. 


\section{CRANESBILL.}

Description.-Geranium.-It is sometimes ealled Storkbill, Dove's-toot. There are many kinds of it. It is more generally known by its Botanical name than otherwise, Geranium. While some are tender and eultivated in the Greenhouse, others grow wild in many places by the path-sides. That known as Dove's-foot has small, round, pale-green leaves indented at the edges, rescmbling mallows, standing upon long hairy stallis, lying in a round compass upon the ground, from which rise two or more reddish jointed, slender, hairy stalks, having similar leares, upon which grow many small bright red flowers, of five leares each.

Medicinal Virtues. - It is good for the eolie, and for the gravel. The decoction in wine curcs inward wounds, hurts, or brinises, arrests the bleeding, and expels the congealed bloor. The decoction is a good fomentation for gout, joint-aclies, or pain of the sinews. The root is very astringent, subtonic, and antiseptic. It is one of the most pleasant and valuable astringents known. It gives tone to the stomacli and bowels, restrains all immoderate discharges, and prevents inward mortifieation. It is excellent for all bowel complaints. The best is a decnetion by boiling the root in milk. An infusion of the rout immediately suppresses blecling at the lungs. - The dose of the root from 12 to 25 grains.

\section{CRANESBILL.-STINIING.}

Description.-Geranium Robertianmm.-It is often ealled Herb lobbert. It very much resembles tle Cranesbill previonsly deseribed, except the five leaves at the top of the stallis are much larger, and of a redder colour. The flowers alle morleratcly large, and of a briglit red, conspicuons and pretty; the fruit that follows is loner and slender, resembling the long beak of a birkt lience the natume.

Megrexul Vhatris.-It is in great repute among farmers, being a cure for black water, bloody thux, griven in ilecostion, and repeatel. "The whole pliant is io be gathered, even to tho root, and dried for use. It is a rare astringent, scareely any 
plant ean equal it. It may be giren dried and powelered, or in decoction. It restrains frofuse menstruation, dysentery, and all other bleclings. The decoction grives great relief in stone or gravel. It is a first-rate vnlnerary, or wound herb. An ointment made of the green leares and lark reduces scrofulous and cancerons swellings, and heals sore nipples. Herb Rubert, and Tutsan, or St. John's Wort, are two of the best remedics for outward and inward blectings.

\section{CRESS,-GARDTN.}

Nasturtium Hortense.-Every one knows this plant. It warms and strengthens the stomach. It is good for the scurry, being a great puritier of the bluod. The seeds open obstruetions.

\section{CRESS,-DLACK.}

Description. - Nasturtium Niner. - It has lone leares, decply eut and jagged on both sides, not much unlike wild mostard; the stallis small, very linber, thongh very tongh; you may twist them round as you may a willow he fore they break. The flowers are very small and ycllow, atter which come small pods, containing the sect.

It usually grows by the way sides, and sometimes upon mud walls, but inost anong stoncs and rubbish.

Medicinal Vintues. It is a plant of a lot and hiting nature. The secd of Black Cress strengthens lic brain, and in that lespect is little inferior to mustart-secul. It is good to stay rhenms, which fall fiom the load mpon the lungs. Beat the seed into powder, and make it into an electu:ny with honey; and you will have an excellent lemely for coungs, yellow janndice, and sciatica. The herb hoiled into a punleice, is an excellent remedy for inflanmations, both in women's breasts and men's testiciles.

\section{CRTSS, - SCIATICA CRESS.}

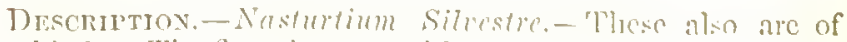
two linkls. The first rises up with a round stalli, about two 84 
feet high, spread into several branehes, whose lower leaves are larger than the upper, yet all indented on the edges, lilie garden cress, but smaller; the flowers are small and white, at the tops of branches, which produce small brownish sceds, very sharp in taste, more so than garden cress; the root is long, white, and woody.

The other hath the lower leaves whole, rather long and broad, deeply dented about the edges towards the ends; but those that grow up higher are less. The flowers and seeds are like the former, and so is the root, and both root and seed are as sharp as it.

They grow by the waysides in untilled places, and by the sides of old walls. They flower in the end of June, and their seed is ripe in $\mathrm{July}$.

Medicinal Virtues. - The leaves, but espeeially the root taken fresh in Summer-time, and made into a poultice or salve with lard, and applied to the plaees pained with the sciatica, for four or five hours, the place afterwards to be bathed with wine and oil mixed, and then wrapped with wool or skins after they have sweat a little, will assuredly eure not only the same disease in the hips, or other joints, as gout in the hands or feet, but all other old diseases of the head, (as inveterate rhemms,) and other parts of the body that are cliffieult to be eured. Repeat in five or six days. It is also effectual in discases of the spleen; applied to the skin, it taketh away blemishes, whether they be sears, leprosy, or scabs. It may ulecrate the part, yet that is to be healed with a salve made of vil and wax.

THE CANDY-TUET, Iberis Amara, is of the same nature. Flowers, different colours. 'Tlic leaves are uscol, and give relicf in sciatica, or hij-erout. "The best way is to beat then witl a litile lard. It is a groul remedy, and ought to be more in use.

\section{CRESS, -W WTRR CRESS.}

Nrsturtium Aqualicum.-This is well-known.

Mismernat Virtuks. 'They are more powerful against the scurry, and to cleanse the blood and humours, than litooklime, 
(which sce.) It removes the stone, and is very diuretic. It removes female obstruetions. The deeoction eleanseth ulecrs, by washing them therewith. The leaves bruised, or the juice, is good to be applied to the face, or other parts tronbled with freekles, pimples, spots, or the filse, at night, and washed away in the morning. The juice mixed with vinegar, and the fore part of the head bathed therewith, is very good for those that are dull and drowsy, or have the lethargy.

\section{CROSSWORT.}

Description.-Cruciata.- It is so enlled from the situation of its leaves.

Common Crosswort has square hairy brown stalks, a little above a foot high, having four small broad and pointed, hairy, green leaves growing at every joint, each against other erossway. Towards the tops of the stalks at the joints, with the leaves in three or four rows downwards, stand small, pale, yellow flowers. The root is very small and full of fibres. It grows in moist grounds, and meadows. It flowers from May all the Summer long.

Medicinal Virtues. - This is a very good wound herb, and is used inwardly, not only to stay bleeding of wounds, but to eonsolidate them, as it ontwardly does any green wound, which it quiekly healeth. The deeoetion of the herb in wine, raises phlegm from the ehest, and is good for obstructions in the breast, stomach, or bowels, and it reetifies a decayed appetite. It is also good to wash any wound or sore with, to eleanse and heal it. The herb bruised and boiled, applied outwardly, and renewing it often; and in the mean time the deeoction of the herb in wine taken inwardly every day, certainly eures rupture, if it be not too inveterate; hut rery speedily if it be fiesh and of late occurence. It is a good remedy for fever, rhemmatism nud dropsy.

\section{CROTON OIL.}

Foreign. $-\Lambda \mathrm{n}$ oil extracted from the seeds of the Croton Tiglii. It is the most powerful of all knowu purgatives. No 86 
one ought to venture on more than a drop at first. In obstinate costiveness, in dropsy, in apoplexy, and paralysis, this oil is generally used. In lock-jaw, and mania, it is of great advantage, a drop or two placed on the tongue will be sufficient. Externally applied it is a valuable counter-irritant; soon producing eruption, and therefore is a special remedy for inflammation of the chest.

\section{CROWFOOT.}

Description.-Ranunculus Acris.-It is also called Frogsfoot, Crowfoot, Gold Cups, King's Kinob, Poults, Butter-flowers, and Butter-cups.

The most eommon Crowfoot hath many dark green leaves, cut into divers parts, in taste biting and sharp, biting and blistering the tongue; it bears many flowers, and those of a bright resplendent yellow colour. They grow very common every where, especially in fields.

Medicinal Virtues.-This fiery and hot-spirited herb is not fit to be given invardly; but an ointment of the leaves or flowers will raise a blister, and may be applied to the nape of the neck to draw rheum from the eyes. The herb being bruised and mixed with a little nustard, raises a blister as perfectly as Cantharides, and with far less danger.

\section{CUCKOW-POINT.}

Description.-Arum Maculatum.-By some it is called Aron, Arum, Ramp, Starehwort, Cuckow-pint and WakcRobin.

It sends forth three, four, or five leaves from one root, each large and long, broad at the bottom next the stalk, forked, ending in a point, of a full green colour, each standing upon a thick round stalk, 4 to 6 inches long, among which, after two or three months that they begin to wither, rises up a bare, round whitish green stalk, spotterl and streakerl with purple, higher than the leaves : at the top of which are long hollow husks elose at the bottom. but open from the middle upwards, ending in a 
point; in the middle whercof stand the small long pestle or clapper, of a dark purple colour, as the husk is on the inside, though green without, which, after eontinning for some time, the liusk with the elapper deeays, and the foot thereof groweth to be a small long buneh of berries, green at first, and of a red coloul when ripe, of the size of a hazel-nut kermel. They look very tempting, but are highly poisonous, as indeed the whole plant is. The root is round and long, of the size and shape of a walnut, extemally brown, and white internally, and of a shap acrid taste, and so is the whole plant. The root was aneiently used instead of stmell.

There is another sort of Cuckow-point, with lesser leaves tlian the former, and sometimes harder, having blickish spots upon them, which for the most part abide longer green in Summer than the former, and both leaves and roots are mole sharp and fieree than it: in all things else it is like the former.

These two sorts grow under onr hedges.

Medicinal Vimedes. The root is the part nsed. It is a good medieine in palsies. Half of one of the roots, fresh gathered and bruised, will sometimes restore the speeeh at onee; if not, repeat the merlicine. It is also gool in seotbutic ciases, and in all inward obstructions. Half a pound of the roots, $1 \frac{1}{2}$ lb. of Sugrer, beaten together in a mortar, is the best way of taking it. 'Take a drachm at a time. This is good for the above diseases, for gout, and serere rheumatism. An elcetuary made of the root and sugar is good for difhcult breathing, conghs, and affeetions of the chest. "The juiee of the leaves is good for Polypus in the nose. The water, in whieh the root hus been boiked, dropped into the eyes, fiees them from fim or mist which hindel the sight, and also cnles the eyes when inflamed. The root mixed with bean-1lower, and app]icel to the throat or jaws that are inflamed, cures them. The juice of the lentics difuted with a little water, and dropled intu the ealls, caseth pains in thems.

\section{CUCUMBER.}

MEDicinat Virtues.-The best of Galenists hold them to be eold and moist in the sceond degree, and then not so hot as 88 
either lettuces or purstain; they are good for a hot stomach, and hot liver ; the immolerate use of them fills the boly full of raw humours, "The face being washed with their" juice cleanses the skin, and is good tor hot rhemms in the eyes; the seed is good to provoke urine, and to elcanse the mrinary passages when they are stopped. There is not a better remerly for ulcers in the bladder. The usunl course is, to talie the Cueumbers, bruise them well, and distil the water from them, and let such as are troubled with ulcers in the blarliler drink no other drink. The face heing washed with the same water, cures redness of the fiuce; it is also good for sum-burns and freckles.

\section{CUDWEED, OR COTTONWEED.}

Descriptrox.-Gnaphaliun.-It is also ealled Chaffweed, Dwarf Cotton, and Petty Cotton. The eommon Culweed rises up with one stalk, and sometimes with two or three, thick set on all silles with small, long, whitish, and woody leaves, from the midrlle of the stalk almost to the top; with each leaf is a small flewer of a lorownish rellow coloul ; alter the flowers are lisllen, eome sinall seed wrapped up, with the down therein, which is earried away with the wind; the root is small and thready.

There are smaller kinds of this plant, the flowers paler, and more oper.

They crrow in dry, barren, sandy, and gravelly grounds. They flower about July, and their seed is ripe in Aurust.

Medictan Virtuls. - Tlie plants are all asuringent, binding or clrying, and therefore profitalife for defluxions of ${ }^{\circ}$ lemm from the hearl, and to stay the lluxes of blout. The decortion being marle in red wine, or the porroler may be taken. It is very useful in elysentery, and for the immorlente entress

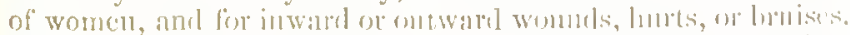

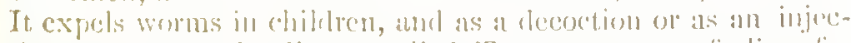

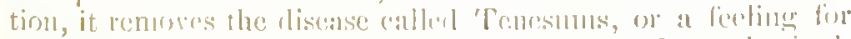

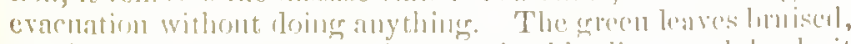

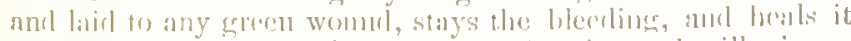

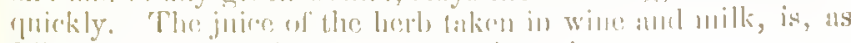
P’liny salys, a surereign remedy for the quinsy. 


\section{CUMMIN.}

DAFFODIL.

\section{CUMMIN.}

Foreign.-Cummin seeds are in tolerable repute; they are the produce of the Cuminum Cyminum. It is extensively eultivated in the East. The seeds are of a disagreeable flavour; but of exeellent virtues. They remove flatuleney, are good for the eolie, and strengthen the stomaeh. The oil applied outwardly, in the form of plaster, will often remove local pains, espeeially those of the side.

\section{CURRANTS,-RED AND BLACK.}

These require no deseription. The former Ribes Nigrum, Black Currant, has a more astringent taste than the red or white, and is somewhat aromatic. The fruit in the form of preserve or jam, is very useful in eolds, fevers, and eoughs. The fruit is an expeetorant, or having a tendeney to loosen phlegm, and allay irritation in the mueous membrane. It is also useful in sore throats, and it gently aets upon the bowels. Black Currant leaves are used in infusion, as a domestie diuretie.-Boiling water is poured upon a quantity of the preserve, as a remedy for fevers, eoughs, \&e., forming one of the pleasantest and most useful of our fever beverages.

The Red Currant, Ribes Alpinum; its fiuit is very wholesome, disagrees with few, and is partieularly well adapted, either fresh or eooked, to form part of the eooling diet requisite for health in very hot weather. The meehanical aetion of its seed has a most beneficial effeet in exeiting the bowels. Some bilious persons say they find benefit from eating a few ripe red currants a short time before bieakfast, and that the practiee tends to prevent bilious attaeks during the hot weatler, when currants are in season.

\section{DAFFODIL.}

Pseudo Nareissus. - This is known by all. It grows in woods, and donble in gardens 90

Medicinal Virtulis.- The fresh root is to be used, which 
has great virtues. It aets as a gentle emetie, and purgative. It is the best to give in the juice with . $^{\circ}$ ine ; but its principal uses are external, The firesh root, bruised and applied to wounds, soon heals them. It takes away the swelling and pain of sprains and bruises.

\section{DAISY.}

Bellis Perenis.-It needs no description.

Medicinat Virtues. - It is guod for wonnds in the breast, and very fitting to be kept both in oils, ointments, and plaisters, as also in syrup. The greater wild Daisy, is a very good wound herb. The juice of the small Daisy reduees inflammation of the liver, and the other inward parts. A decoetion cures ulcers and pustules in the mouth or tongue, or in the seeret parts. The leaves bruised and applied, reduee swellings. $A$ decoction made of Daisies, and Wallwort, and Agrimony, and places fomented therewith warm, gives ease to the palsy, sciatiea, or gout. An ointment made thereof relieves inflimed wounds.

\section{DANDELION.}

Taraxacum dens Leonis. - No plant is better known than this. From its effeets it has been called by country people, Piss-a-bed.

Meincinal Virtues, - The leaves and root are bitter, and contain a bitter milky juice. It is of an opening and cleansing quality, and therefore very effectual for obstruetions of the liver, gall and spleen, and the tliseases that arise from them, as the jaundice and hypoehondriasis; it opens the passages of the urine both in young and old; powerfitly elcanses imposthumes and inward ulecrs in the urinary passage, aud by its drying and temperate quality heals them; for which purpose the decoction of the roots or leaves in white wine, is very effectual. In progressinur consumption, or in an exil disposition of the whole borly, called Cachexy, hy the use of Dotudelion great relicf will be olutained. It promotes rest and sleep to bodies distempered by the heat of arge fits or otherwise. 
The Dandelion therefore is a most useful herb, and ought to be more extensively known, on aecount of its tonie, alterativc, diaphoretic, and dimretic properties. It is as valuable as Sarsaparilla, and is often given in dyspepsia, dropsy, eutaneous eruptions, and ehacheetie disorders generally. A deeoetion is made of the fresh root slieed, 1 ounee to a pint of water, boil down to half a pint, and strain, adding 2 draclums of Cream of Tartar, and take a wine glassful twice or thrice a day. Physieinns generally order the extrat prepared thus:- obtain the juiee from the root by pressure, and then evaporate till it is a little thicker than treacle - the dose is from 10 grains to lialf a drachın. 'The French use the leaves in Sallad, and the Germans roast the root for Coffee.

\section{DARNEL.}

Description.-Lotium Rubrum.-It is ealled Jum and Wray in Sussex, and some call it Crop; it is an encmy among
eorn.

All the Winter it has long, flat, and rongh lenves, whieh when the stalk rises, which is slender and jointerl, are narrower, but rongh still; on the top' grows a long spikic, composed of many heads set one above another, contnining two or three hnsks, with sharp short beards of awns at the end ; the seed is easily shaken out of the ear, the husk itself being somewhat rough.

Medicinat Virtues. - It has many virties. The meal of Darnel is very good to stay gangrenes and other eating cankers and putrid sores; it also eleanses the skin from ringworms nut the like, if it be used with salt and Radish roots. And being insed with brimstone and vinegar, it dissolves knots and kernels, and cspeeially if boiled in wine with linsed. A decoction male with water and honcy, and the plaees bathed therewith is goon for sciatica. Darnel meal aplulied in a ponlice draws forth splinters and broken bones in the flesh. The red Damel boiled in red wine, restrains all fluxes, and the immoderate discharge of urine. 


\section{DEVIL'S BIT.}

Description. - Succisa Scabiosa. - A wild plant in on meadorrs, with slender stalks, and globous flowers. It grows two feet high. The stalks are round, firm, ancl upright, and clivided into several branches; they have two little leares at cach joint. The flowers are as big as a small wahnut, and composed of many little ones; their eolour is very strong and beautiful. The leares which grow from the root are four inches long, an inch broad, obtuse, of a dark green, andl a little hairy, not at all divided, or so much as iudented, at the edges. The roots arc white, and composed of a thick head, which terminates abruptly, as if it had been bitten or broken off, and of a multitude of fibres. The Devil, as old women say, bit it away, envying mankind its virtues.

Medictral Virtues. The plant is venereal, pleasing, and harmless. The lerb or the root, boiled in wine, is very powerful against fevers, poisons, and bites of venomous creatures: it relieves those inwarelly bruised by any easualty, or outwardly by any falls and blows, dissolving the clotted blood; and the herb or root beaten and ontwardly applied, takes awny black and bluc marks in the skin. The decoction of the herb, with honey of roses put therein, is very cficctual in inveterate tumours and swellings of the throat, by oftem gargling the throat therewith: it is an expellant of wind. The prwiter of the root taken in drink expels worms. The juice of the lierl, is effectral for green wombls or old sores, and cleanseth the borly inwarlly, and ontwarlly from sores, itch, fimples, and freckles, cspocially if a little vitrol be dissolred therein.

\section{DJLL.}

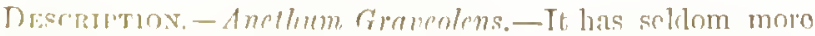

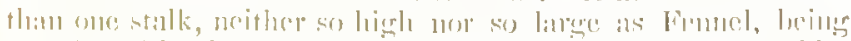

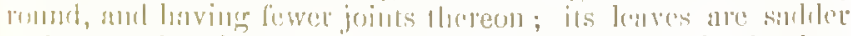

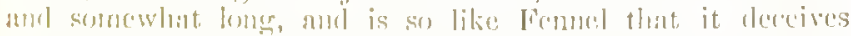

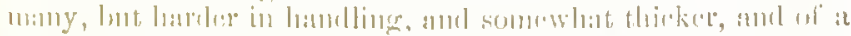

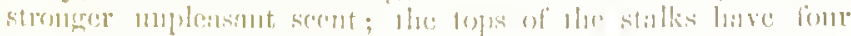
branclies, and snatler mubels of yellow flowers, which torn into 
small seed somewhat flatter than Fennel-seed. The root is long. It usually grows in gardcus and grounds for the purpose, and is also found wild in some plaees.

Medicinal Virtues.-It is stimulant and Carminative, and much used in flatuleney. The dccoetion of Dill is good to ease swellings and pains. The seed is of more use than the leaves, and more effectual to digest vicious humours, and is used in medieincs that serve to expel wind, and the pains proeeding therefrom. An oil made of Dill is effcetural to warm or dissolve humours and imposthumes, to ease pains and procure rest. The decoetion of Dill, herb or seed, in white wine is a powerful expeller of wind. The Dill WVater of tle shops is made by rubbing down the oil of Dill with sugar or Magnesia, addling water ; and straining-about one drop of oil to one ounee of water. Dose from half an onnce to two ounees for adults, aud one or two tea-spoonituls for children.

\section{DOCK.}

Lapathum.-This nceds no description. All know it.

Medicinal Virtues. The red Dock is eommonly called Bloodwort; it eleanses the blood, and strengthens the liver; but the yellow Dock root is best to be takicn when either the blood or liver is affeeted by eholer. It lias a cooling drying quality. The seeds stay fluxes of all sorts, the lonthing of the stomach through bilc, and is good for those that spit blood. The roots boiled in vinegar remove itch, seabs, breaking out of the skin, if it be bathed thercwith. The distilled water of the herb and roots have the same virtne. Blood-wort is very strengthening to the liver, and proemres good blood, being as wholesome a potherb as any that gruws in a garden.

\section{DOCK.-GREAT WATER.}

Description.-IIydrolapathum maximum.-This is the largest of all Docks. It is much like the sharp-pointed Dock, but much langer. It grows abont watcrs, five or six feet high,
In all respece, it is the sante as the forner, except its great size.

Mtedicinal Virtues. - Like the rest it is remumed for tho
94 
cure of seurvy. So it was with the ancients; and it possesses great astringent qualities, and is good therefore for diarthoes. In skin disorders it is a good remedy. In powder it is healing to old sores, ulcers, eleansing and healing them. The powdered root is a capital dentrifiee for the teeth ; removing seurvy from the gums As a tonie, to strengthen the stomach, ten or twelve grains will be suffieient. A decoetion of it may be used for the same purpose. Take two ounces of the root sliced, to three pints of water, with a little einnamon, or liquorice in powder, and boil down to a quart. A wine-glassful two or three times a day.

\section{DOCK.-SHARP POINTED.}

Description.-Lapathum folio acuto. - A common plant, like the ordinary Dock, but handsomer, and distinguished by its sharp-pointed leaves, being narrower and longer. It grows three teet high. The stalks are ereet, round, striated, green and branched. The leaves are of a fine green, sniooth, with large ribs. Flowers, small, at first greenish, and when ripe, brown.

Medicinal VirTues. - The root is the part to be used. It is excellent for scurvy, and is one of the best herhs for sweeteniug or purifying the blood. It is best given in diet-drinks, and rlecoctions. Used externally, it is good for cutaneons eruptions, and for this pupose it should be bcaten up with latel.

\section{DODDER.}

OEsCrIPTION. - Epythymon. - Dodder of Thyme, and other Dorlder's.

The first from sced gives roots in the ground whiel shoot forth threads of a jurplish colour, gmesser or finer according to the profrerty of the plant hesicles which it grows, creeping and spregrling on that plant wherens it fastenctll, le it high or low.

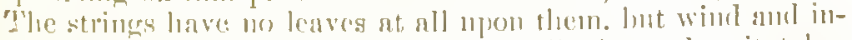
terlace themselves so thick ly non a small plant, that it takes away all comfort of the sun from it : and is ready to stranglo 
it. After these strings are risen up to that height, that they may draw nourishment from the plant, they scen to be broken off from the ground, cither by the strength of their rising or withered by the heat of the sun. Upon these strings are found small heads or husks, out of whieh shoot forth whitish flowers, which give small pale coloured seed, somewhat flat, and twiee as lig as Poppy-scel. It gencrally participates in the nature of the plant upon which it elimbs. The Dodder of Thyme is accounted the lest, and is the only true Epithymum.

Medicisal Virtues. Thyme is the hottest herb it usually grows upon: and therefore that which grows upon Thyme is hotter than that which grows unon colder herbs; for it draws nourishment from what it grows upon, as well as from the earth where its root is. It is accomted cffeetual for melaneholy diseases, and to purge bad bile, which is the enuse of many diseases of the head and brain, as also for trembling of the heart, faintings, swoonings; and all discases of the spleen, that arise from the windiness of the hypochondria; it purges kidneys by urine; it opens olstruetions of the gall, and relieves those who have the jaundiee.

\section{DOG'S GRASS, or COUCII GRASS.}

\section{Description.-Canis Gramen.-This is called Dog's} Grass from its effency in relieving dogs when sick.

It is well known, that the grass crecpeth firr alrout under the ground, with long white jointed roots, and small filores almost at erery joint, rery swect in thete, as the rest of the licrb is, and interlacing one another, from whence sloot many fair grassy leaves, small at the culs, anrl sharp on the edtres." The stalks are jointel like corn, witl similar lonwes, ancl a spikerl

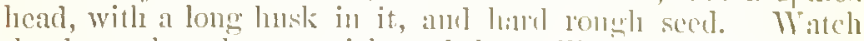
the dogs when they are sick, and theyo will liad you to it. It grows almost excrywlice.

Mrncinal Vintues. It is the most modicinahle of all the Quickgranses. As a lecoction it opens olstruetions of the liver, gall, and mrine; and cases the gripling prains of the belly, and iuflummation; and firets away stone in the bladder, and 
ulecrs. The roots bruised and applied heal wounds. The sced is the most powerful. The distilled water with a little wormseed, kills worms in ehildren.

The way is to bruise the roots, and having well boiled them, drink the decoction ; it is opening, but not purging, very safe; a remedy against all diseases arising from obstructions; and fully one half of diseases spring from this eause; therefore this herb is invaluable.

\section{DRAGONS.}

They are well known to those who plant them in their gardens; at the lower end of the stalks they look like a snake.

Medicinal Virtees.-In all lierbs of this quality, the safest way is either to distil the herb in an alembick, or what rehicle you please, or clse to press ont the juice, and distil that in a glass still, in sand. It scoureth and elcanseth the internal parts of the body greatly, and externally applied, it removes fieckles, iteh, and sun-burning. The best way to use it externally is to mix it with vinegar; an ointment of it is good in wounds and ulecrs; it consumes cankers, and Polypus in the nose. The distilled water dropped into the cyes, takes away spots, and l'emoves dimness of sight.

\section{DRAGON'S BLOOD.}

Foreign.-Sanguis Draconis Arbor. $-\mathrm{A}$ benutiful tree of the Palm kind, native of the Canaries, \&ec. Drangon's Blood is kept by the Druggists; it is a redl fivible resin. It is oltanerl by entting the trunk of the tree in the grent heats. It is a very good astringent; and very usefinl in purgings, profise menstruattion, spitting of blood, \&c. It may be given in powder.

\section{DROPWORT.}

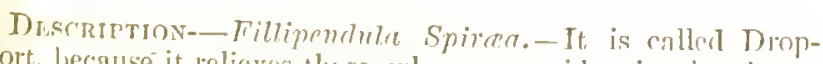
wort, hecause it relicves these who may voris mine lyy drops. It has many leaves, different si\%cs, dented at the enliges, a litilo 


\section{DUCK WEED}

like Wild Tansy, or Agrimony. From them one or two stems arise two or three feet high, with leaves growing thereon, sometimes branching out and spreading at the top into white swectsmelling flowers, having five leaves each, with threads in the middle of them standing together, in an umbcl. The seeds are flattish, and grow several together. The root is eomposed of a great number of black tubers, united by filaments. It grows in the eomers of dry fields, and hedge sides. It flowers at the end of June.

Miedicinal Virtues. - The root is the part most nsed. It relicres fits of the gravel, for it is a powerful cliurctic. For this purpose the juice mist be given, or a strong decoction of the fresh root. It is a gentle and safe astringent, and is cxeellent for the whites or for purgings. All pains of the bladider and kidneys will be reliered by it. The root powdered, and made into an electury with honey, reduces fulness of the stomach, arising flom flatuleney. It is bencfieial in disenses of the lungs, shortness of breath, wheezing, hoarseness, and coughs. It is a eapital expectorant.

\section{DUCK WEED.}

Lemna Trisulca.-This is so well known to swim on the top of standing water, as ponds, pools, Ee., that it is needless to describe it.

Mroicinat Vintues. It rednecs inflammations, and $\mathrm{St}$. Anthony's fire, and the gont, either applicel by itself, or in a ponltice with barley meal. The distilled water by some is highly esteemed against all inward inflammations and pestilent fevers; inflammation of the eres and swellings of the private parts, and of the breasts. The fresh herb applied to the forehead, relieves head-ache arising from heat. It is a good remedy for the jaundice. Many have been enred by it alone. The juice is to be taken, and to be repeated for severnl days.

\section{ELDER TRFE.}

Sambuens Nigra.-It is so common in liedges as to require no description.

98 
Medicisal Viritess.-An infusion of the inner green bark in wine, or the expressed juice of the berries in the close of half an ounec or an ounee, purges moderately, and in small doses it proves an effiencious deobstruent, promoting all the fluid secretions. The juice boiled in sugar till it is stiff; is a nseful opening medicine; it promotes the natural evacuations; and, if continted for a sufficient length of time, is of considerable use in varions chronical disorders. The young leaf-buds are strongly purgative, and require eantion. The flowers are different in quality; have an agreeable aromatie flavour. They are made into an ointment, by boiling them in lard till they are almost crisp, and then pouring it off: this is very cooling. The juice of the berries boiled down with a little sugar to the consistenee of honey is good for eolds and sore throats. A decoction of the bark or berries, is successfully given in dropsy. A recoetion of the midille or inward bark is mure powerful. The juiee of the leaves is good for inflammation of the cyes.

Elder Wine is an excellent bevcringe for sore thruats, colds, \&ec., as it is a powerful pronterer of perspiration.

\section{ELDER,-DWARE ELDER.}

Descritrtion, - Ebulus.-It is very much like the Elicetree; but growing lower, and lseing more of at lierbaceons natture. It is wilr in Emglanrl, but not so common.

Mendcinal Virtiles. - It is more powerfinl than the Common Elifer, as a purgative, an exjectorant, a tlinetic, an!l suldorific. Dr. Butler states it to loc an eflicancions remorly for dropsy-made into a decoction by water or wine. 'This iud the other Elder are said to tum the laair black.

\section{TILCAMPANE.}

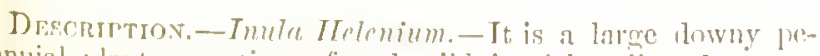

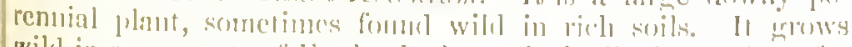
wild in some frats of lingland; but principally- in garelens fin 
the use of medicine; it grows five feet high, and the large flower is yellow. The stalk is romd, thick and reddish. The lcaves are long, lirge, rongh, and pointerl at the ends. The flowers grow at the top of the branches, and rescmble a double sun-flower. They are two inches wide and very beautiful.

Medicinal VIr'] de3.-The fresh roots of Eleeampane preserved with sugar, or made into a syrup or conserve, are very effectual to warm a cold windy stomach, or the pricking therein, and stitehes in the sides eaused by the spleen; and to relieve eough, shortness of breath, and wheezing in tho lungs. The dried root powdered and mixed with sugar, serves the samo purpose The root is esteemed a good pectoral, and, like Angeliea root, is candied, and sold as a sweetment. Dr. Ilill says, he lias found an infusion of the fresh root, sweetened with honey, to be rery successful for the hooping-eough. It operates by urine powerfully, and by sweat; the juice will euro the iteh, applied externally. The decoction of the root in wine, or the juice taken therein, expels worms; and gargled in the mouth, or the root elrewed, fastens loose teeth, and kceps them from putrefartion. The decoction, or the juice in honey, is good for" those who spit blood. 'The root boiled well in vinegar, beatell, and made into an ointment with hogr's lard, is an cxccllent remedy for seabs or itch. In the roots of this herb lies the chief effeet.

\section{ELMI.}

Ulmus Campestris. - It requires no deseription.

Medicinal. Virturs. - The leares bruiscl and applied, heal green wounds. 'The leares or' the hark nect witl viucgarar, eure scurvy. The deeotion of the lenres, bark, or root, as a wash, leals broken bones. The water that is foml in tho blactder on the lenres, while it is fresh, is very clfectual to elcanse the skin, and make it fail ; and if cloths be often wet thercin, ind applicul to the ruptures of children, it henls them, if they be well bound "up with a truss. "The teenction of the bark of the root as a foncutation, soltcus hard tmonours, and the shrinking of the sinews. The roots of the Elm boiled for a long time in water, and the fat scummed oft the top, and ap100 
plied to the head is a cure for baldness. The sad bark ground with brine and pickle, until it comes to the form of a poultice, and laid on the place pained with the gout, gives great calse. The decoction of the bark in water is excellent to bathe such places as have been burnt with firc. It is one of the best galgles for a sorc throat : it slould be the imuer bark, and it should be sweetened witl honcy.

\section{ENDIVI.}

Chicorium Endiva. Endive is well known by gardencrs and salad caters.

Medicinal Virtues.-It is a fine cooling and cleansing plant. The decoction of the lcaves, or the juice, abate inflammation of the liver, and the heat of the stomach; and it operates powerfully by urine. The sceds have the same property, or are rather more powerful, and arc available for faintings and passions of the heart. Outwardly applied, they temper the sharp humours of fretting ulcers, hot tumours, swellings, and remove inflammations of the cycs, and climness of sight. They allay gonty pains. $\Lambda$ syrup made of it is a fine cooling medicine for fevers. Used constantly for some time it cures scurvy, and jaundice.

\section{ERYNGO, OR SEA-IIOLLY.}

Description.-Eryngion Compestre.-A wild plant, growing by the sen-side, and in gartens, for its medicinal uses. It is prickly, like a thistle, and the plant is whitish. 'Tlic stalk is firm, woody, round, strintel and thick, branched and sprend irregrilarly aleut. 'The leaves are small, of a pale, bluish green; broal, ollong, jaggered and prickly. The flowers grow in little hearls at thic tops of the stalks, with a circle of small leaves under them. They are of a pale grecnish white. 'The root is long and slender, sometines liom five feet long; its taste is plensant.

Memcinat, Vuernes. The plant is venereal, and lereds seed exceculingly, and strengthens the spirit procreative. 'The 
decoction of the root in wine, opens obstructions of the spleen and liver, and is good for yellow jaudice, dropsy, pains of the loins, and for eolic. The candied roots are most excellent for conghs, and general dehility. They possess rare virtucs as a diurctie, and are a good remedy for jaundice. They are balsamic as well as diurctie. The roots bruised and applied ontwardly, are good for King's evil. The roots bruised and boiled in log"s lard, and applied to broken bones, thorns, \&c. remaining in the flesh, they do not only draw them forth, but heal up the plaeo again, gathering new flesh where it was cousumed.

\section{EYE-BRIGHT.}

Description. - Euprhasia Oficinalis. - So ealled from the very bright eye of its flower, and from its eflieacy in clcaring the cye-sight.

Common Eye-bright is a small low herb, rising up usually with one blackish green stall, six or cight inches ligh, spread from the bottom into several branches, whercon are small, almost round, pointed, dark green leaves, finely snipped abont the edges, two ahways set together, and very thick. At the joints with the leaves, are small white flowers streaked witl purple and yellow spots or stripes. i'he root is long, small, and thready at the end. It grows in meadows, and grassy places.

Medicinal Virtues. If the herb was but as much nsed as it is neglected, it would half spoil the specticle-makcr's trade. The juiec of Eycbriglit dropped into the eycs, for sercral dlays together, relieves infirmities of the cyes that canse dinness of siglit. Some make conserve of the flowers to the sanc eflect. Being used any of the ways, it strengthens a weak brain or memory, Tunned with strong beer, and fermented together; or the powder of the dried herb mixal with sugar, a little Mace, and Fenurel-sed ; or the puweler mado into an clectuary will sugnt, lans the same powertul effect to restore sight decnged throngh age; and Arnoletus de Villa Nowal sary, it lias restorel sight to them who lave been blind a long time.

102 


\section{FENNEL.}

Foniculum.-It is grown ncurly in cvery garden and therefore requires no description.

Medichal Virtues.-One good old custom is not yet left off, viz. to boil Fennel with fish, for it consumes that phlersmatic humour, which fish copiously produces, though few know why they use it. Fennel is an cxpellant of wind. It is a good diuretic, and remedy for gravel and urinary diseases. The leaves or seeds boiled in barley water and drunk, are good for nnrses, to increase their milk, and make it more wholesome for the child. The leaves or sceds boiled in water, stay hiccongh, and remove nausea and heat of the stomach. The seed boiled in wine is good for those who have caten poisonous herbs, or mishrooms. The seeds and the roots open obstructions of the liver, spleen and gatl, and are good in the yellow jaunclice. The seed is good in medicines for slortness of breath, and wheczing. It promotes the fluw of the menses. The whole plant is a remedy for obesity, or over-fatness. The juice dropped into the eyes, eleanses them from mists and filns that hinder the sight. The Sweet Fennel is much wealice in physical uses than the Common Fennel. The Wild Femnel is stronger and hotter than the Tame, and therefore most powerful ngainst the stone, but not so effectual to inerease milk, bccause of its dryness.

\section{FENNEL,-HOG'S FENNEL.}

Description. - II ippomarathrum.-The common Sow-Fennel has several lyanclied stalks of thick and long leares, alunt three joined at a place, anong which arises a crested straight stalk, less than fennel, with some joints and leaves thereoul, and towarls the tops some branclies. On the tops of the stalks ancl branches, are large clusters of yellow flowers; the secel is oblong and flat. At the top of the root is a tult of liairy miltere,

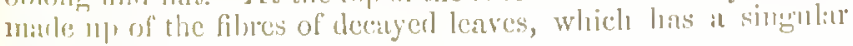
תplesirimace.

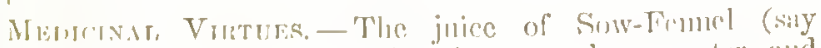
Diuscorides and Girlen) used with vinergat and rose-water, and 
put to the nose, benefits persons troubled with letliargy, giddiness of the head, the falling sickness, inveteratc head-ache, sciatica, and eramp, and all disenses of the sinews, used with oil and vinegar. The juice mixed with wine, or egg, is good for a eough, shortness of breath, and flatuleney. It purges gently. A little of the juiee dissolved in wine, and dropped in to the enrs, or put into a hollow tootll, removes the pain. It removes the hardness of the splcen. The powdered root mixed with lard is a good salve for green wounds.

\section{FERN,-MALE.}

Descriptron.-Aspidium Filix MAas.--Most British Ferns are much alike, and therefore they require some discrimination. It grows at the roots of trees, in dry ditehes, on henths, border's of woods, and in rocky plaees, and sometimes contiguous to old walls. It has no flower-stalk; but several lcaves risc from the root, each a distinet plant. It is two feet high, (the female Ferul is much higher, ) and nearly a foot broad. The stalk is nakcd for 6 or 8 inches, above which it has a row of ribs or smaller stalks, eneh carrying a double row of smaller leaves, with an odd one at the cud, the whole forming one great leaf. Round elusters of seeds grow on the back of the smaller leares.

Medicinal Virtues.-The root, which is eliefly used, should be collected fiom July to September, washed and cleared of all decayed parts; diy well quickly and in the open air ; powder those parts which are grecnish internally, and kecp in wellstopped bottles, in a diy place. It is a nowerful remedy for roms, and its powder has been sold nuder a fictitious hame as an infillible specific for worms, cspecially taple-worms. It is sul ancient rencely, recommended by Diuscorides, Frangns, and Spigclins. The ne of it has been rey" wisely revived, for it is the best anthelnintic, perhapss superior to the colebrated liousso.

For Tape-rorm, of powder, from 1 to 3 drachms, taken on su empty stomiale, and followed in 3 or thours, hy an apericul, as Castor Uil. $\Lambda$ decoction of the fresh root or buds is 104 
effectual ; dose abont 3 ounces. The roots bruised, and boiled in oil, or lard, form a good ointment for healing wounds. The powdered root is also said to enre rickets in elildreu.

\section{FERN,-FEMALE FERN.}

Description.-Felix Femina. It grows on heaths, \&c. It grows four feet high, and is called by country people, brakcs. The stalks are round, green, and smooth. It is more branching than the Male Fern. The whole plant is often two or three feet broad. On the edges of the little leares stand the seeds in small clusters, though not so numerous as in the male.

Medicival Virtues. - The roots have similar virtues to the malc. Fresh gathered, and decoeted, they expel long and flat worms fron the bowels. No medieine destroys them so cffectually. The male Fern is the more powerful.

\section{FERN,-WATER.}

Description.-Osmunda regalis.-In winter the leaves perish, and in spring it sends fortly scveral rongh hard stalks, half round and yellowish, or flat on the other side, two feet high, having sereral branches of winged yellowish green leaves on all sides, set one against another, longer, narrower, and not nicked on the elges as the former. From the top of some of these stalks grow a long bush of small and more yellow, green, sealy aglets, set in the same manner on the stalks as the leaves are, which are acconnted the flower and seeds. 'The root is rough, thick, and scalsby, with a white pith in the middle, ealled the heart. It grows on moors, bogs, and watery places.

Mrimcinat, Virtues. It has all the virtnes of the former Ferns, is more effectual than they, botlu for inward and ontwarl ailunents, and is goorl in wounds and brusises. 'J'le decoction to be drank; or the root may le male into an ointment for lruises and bones breken, or out of joint, and for ruptures. The decoction of the root in white wine, provokes nine exceedinirly, and clemses the bladder aud urinary jassarges. 


\section{FEVERFEW, OR FEATHEREEIV.}

Descriptron.-Pyretherum Parthenium.--It grows wild about farmers' yards, and is cultivated in gardens, and ought to be more so, on account of its medicinal uses. It has divided leaves, and many flowers like daisics. The stalk is round, hollow, upright, branched, two feet high. The flowers stand alont the tops of the stalks, white round the edges and yellow in the middle. The root is small, but has strong fibres.

Misdicinal Virtees. - The whole plant is to be used. It is to be given in decoction, or infusion. It is very appropriate to female complaints. The infusion is excellent for profuse menstruation. Combined with wormwood and cammomile flowcrs, it greatly assists in child-birth. Add also St. John's Wort, and you have a capital fomentation for sevcre after-pains, flatulency, and colic. It is beneficial in inflammation and hardness of the womb. With hot water it makes a very good sitz-bath in cases of difficult trivail. A decoction with sugar or honey, is good for coughs, wheczing, and diflicult breathing. The powder in wine with oxymel of equills, remores phlegm, and oppression of the chest. The herls bruised and applici to the crown of the hend, relieves hcallaches, and swimming in the head.

The decoction drank warm, and the herb brnised with a little bay-salt, and applied to the wrist, previons to the Anne-fits coming on, wards them oft: The herl, bruised and henterl, or fried with a little wine and oil, is a wim external application for wint and colic. It is a good remedy for orer-eluses of Mercury.

\section{FIG TRLE.}

DEscRurTon. Fichs. $-\Lambda$ slumb grown in some grulens, especially in the south of lingertutl.

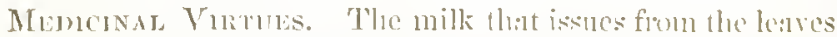

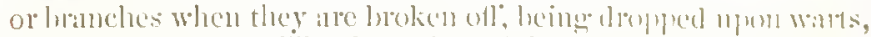

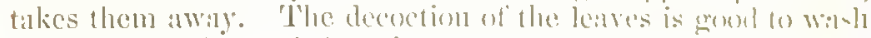
sore leads witl; and there is searedy a better renerly for the 106 
leprosy. It clears the faec from seurvy, and the body from senrf, scabs, and running sores. A decoction of the learcs, or a syrup made of them, dissolves congenled blood, cansed by bruises or fills, and it allays bloody flux. A syrup mate of the leares, or green fruit, is good for eorrghs, lioarseness, shortness of breatlu, and all diseases of the lungs; also dropsy, and falling sicliness.

The DRIED FIGS of the groeers are the finit of the same tree in Spain and Portugal, but they grow larger there, and ripen better. The pulp is wholesome, and rather aperient; but the tough skin shonld not be eaten by the dyspeptic. Green figs grown in this country are more laxative than the preserved ones from abroad, but they have an unpleasant flarour. The fincst come from Turkey. Fing are sometimes u*ed externally, boiled in milk, or roasted. They are applied to boils, or small absecsses, to promote suppuration; - they are very ajpropriate to grum-boils. They makc a good demulceut gargle for sore thrnats, thus ; - Mallow Roots. 1 onnec; or if they camnot be obtainel, Linseed, 1 ounec, 3 figs, split open; water 2 jints; boil to a pint, and strain.

\section{FIG WORT.}

Description.-Scrophularia.-It is sometimes enlled ThroatWrort. - Fig-wort has several strong, harl, squitre browit stalks, three or fonl feet high, on which grow dark green leaves, two at a joint, harder and larger than nettle leaves, but not stinging; ; at the tops of the stalks stand many purple flower's set in luskis, which are sometines gaping and open, sometwhat like those of

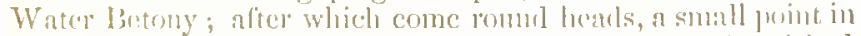
the mirklle, contatining small bownish sect. It is distingentishod from Water fartomy by not laving the romed indentinges of the

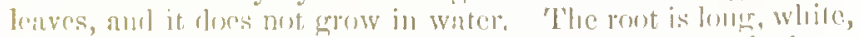

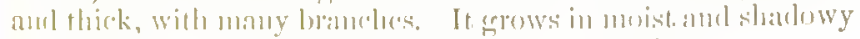
woreds, and in the bower parts of lickls and meatows.

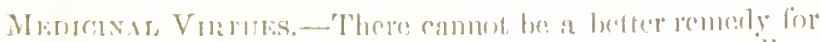

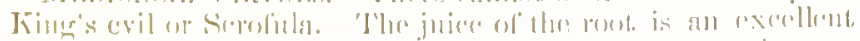

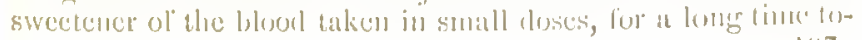


gether. The fresh roots bruised and applicd as a ponltice, give ease in the piles. A decoetion of the leaves talien inmardly, and the herb bruised applicd outwardly, removes congcaled blood, within the body, arising from wounds, bruises, or falls. An ointment made of the green leaves is used for the same purposes, and drys up the virulent moisture of hollow and corroding uleers; it takcs away all redness, spots, and freekles in the face, and the seurf.

\section{FLAG,-YELLOW WATER.}

Description.-Iris Luteus Aquatieus, or Flower-de-Luce. This plant shonld not be allowed to grow where eattlc feed. It grows like the blue Flower-de-lnee, but has longer and narrower green leaves, jointed together. The stalk often grows as high, bearing small yellow flowers, shaped like the Flower-deluee, with three falling leaves, and other three arched, which eover their bottoms ; but instead of the three npright leaves, as the Flower-de-lnce has, this has only three short picces standing in their places, after which sueced three-square heads, eontaining large flat sccl. The root is long and slender, of a pale brownish colour, very harsh in taste. It ustally grows in wintery ditehes, ponds, lakes, \&e.

Medicinal Virtues. The root of the Water Flag is rery astringent, eooling, and drying, and is good for fluxcs, as blceding at the mouth, nose, or other parts, bloody flux, and the immoderate flux of women's eourscs. The distilled water of the whole herb, flowers and roots, is a sovercigu remedy for watcry eyes, to be dropped into them, or to have cloths or sponges wetted therein, and applied to the forchead. The sald witcer fomented on swellings, and inflammations of femile hreasts, upon cankers also, and sprealing ulecrs. It cures foul ulcers in the privities; lut an ointment made of the flowers is better for those external applications.

\section{FLAX,-COMMON.}

Description. - Limm Usitatissimmm. - This valuahle annual platit originally cane from those parts of ligyt orertlowed 108 
by the Nilc. It is now extensively cultivated in this country. The seed is what is called Linsecd. Linseed contains about one-fifth of mucilage, and one-sixth of fixed oil. The eake which remains after the expression of the oil, contains the farinaceous and mueilaginous part of the sect, and is used in fattening cattle.

Medicival Virtues.-Linsed is emollient and demulcent. The entire secds, or the sceds ground into meal, called Linsecd Meal, make very useful cataplasms, or ponltices. In ulecrated and inflamed parts, it allays irritation and pain, and pronotes suppuration. It is commonly used for abscesses, and other loeal affections, which require to be brought to a crisis as soon as possible. The intusion of the secd is mucly employed as a pectoral drink, in scalding urine, nephritic pains, \&c.

Linseer Oil mixed with an equal quantity of lime-water is an excellent application for burns.

As a domestic remedy for colls, coughs, and irritation of the urinary organs, Linseed Tea is most valuablic. Take of Linsed 6 drachms, Liquorice root, 2 drachms; bruise or slice the latter, and pour on both a pint of boiling water ; in a covered vessel, let it stand four hours near a firc ; strain; when cold it is fit for usc. $\Lambda$ little honey, and a table-spoonfinl of lemon juice, make it very agreeable, and more cfficacious- - Linsecd Oil is sometimes given internally as a laxative, (in milk) from 4 drachms to 1 ounee. It is given in pleurisy and peripneumony with great stccess; and it is exeellent in the gravel and stone.

\section{FL $\Lambda$ X,-MIOUNTAIN OR PURGING.}

Descricrons. - Limum Catharlicum: or Purging Elax.$\Lambda$ pretty little licrb which grows profisely in lilly pastures, in patks, and watrens, about eight, inches lights. The stalk is round, firm, and at the top divided into small branclies. 'The lewes are little, oblomer and obluse, two at eatch joint. 'l'he flowers are small and white, and the plant much resembles chickweerl; lant the seesl vessel, on reanmination, imlicates it to be of the flix kind. 'The root is small and threarly. 
Medicinat Virtues. - It makes a strong but safe purge; owing its activity to a peculiar dlastie principle, called Linin, and which is afforded by the plant after the flower has fallen. The eomntry people boil it in becr, and take it as a remedy for rheumatie pains, for eatarlhal affections, as conghs, \&e. and dropsy. It has also yielded great relief in biliary disorders. It is useful in all enses where a brisk purgative is required. Extract, from 4 to 8 grains two or three times a day; - the dried herb, 2 drachms or more, has been found very useful in obstinate rheumatism.

\section{FLAX-WEED, or TOAD-FLAX.}

Descreptron.-Antirhhinon Linarium. - This weed is reckoned by some to be poisonous; yet it is very useful. Common Flax-weed has various stalks, abounding with long and narrow ash-eoloured leares, and fiom the miklle of them almost upward, stored with a number of pale yellow flowers, of a strong umpleasant scent, with decper yellow months, and blackish ffit seed in round heads. The root is a little woody, and white, espeeially the main down right one, with many fibres, abiding many years, shooting forth roots every way round about, and new branches every yeal. It grows on diy banks, by the waysides, in meatows, by ledge-sides, and upon borders of ficlds. It flowers in Summer.

Mejicinal Vintues. - The tops me used fresh gathered, or the whole herb dried. An infusion is rery good anginst jaundice, and to remove by urine, those watery humours which eause dropsy. $\Lambda$ decoction of both leaves and flowrers, is rather purgative, and tends to the removal of ohstructions of the liver. The herb distilled answers the same purpose. It is very effectual if a little l'eruvian Bark, or Sohution of Quinine, and a little Cimmonon, he combined with it. 'The juice of the lierb, or the distilled water, is a grout remerly for inflammation of the eyss. $A$ fine cooling ointment is male by hoiling the firch plant chopped in lard, till it he crisp-strain, and you will havo a fine green ointment good for sores, ulcers, cancers, Se. 


\section{FLEABANE.}

Descriptros.-Conyza, or Erigeron Canadensis, belonging to the natural order of Compositce. - It is a pretty wild plant, with whitish leaves, bearing large yellow flowers in Autumn. The stalk is round, erect, strong, and of a reddish colour. It has many leaves which stand irregularly, about an inch long, moderately broad, and of a rongh surfice. The flowers stand at the top of the branches; they are bronder than a shilling, yellow, having many yellow petals. The whole plant has an unpleasant smell. It is found plentifully in the southern countics of England.

Medicisal Virtuls.--It possesses dimetie, tonie, and astringent properties, which render it very useful in dropsical complaints, and in diarthen. The juiec of the plant eures the itch, and the very smell of the herb is suid to destroy fleas, For dropsy, or diarthon, the dose is, of the flowers in powder, from 30 to 40 grains; of the infusion, from 2 to 4 ounees; of the extract from 5 to 10 grains. For dysentery or bloody flux, infuse the herb in hot water, and give a cupfinl every lionr or two, until a eure is effceted. In colic, it affords immerliate relief; alministering a cupful of the infusion or decoetion every half hour. When the case is obstinate, give also an injection of strong infusion. The rlose of the powtler is tron 15 granis to a drachm. The oil is a sure remedy in hemorrlage-fire to ten drops.

\section{FLEA-IVORT.}

Descrimtins, - Payllizm.-There are two kinds of Flenwort, cliffering very little, only the leaves of one kind abide the winter, but the others rlo not. Orlinary Flea-wort rises np with a stalk two fect high, full of joints aml branches on every sille to the top, and at cvery jobit two small, long, and natrow whitish green leaves, somewhat latiry. $\Lambda \mathrm{t}$ the (o) of every brancl stand several small, short, scaly, or clunfy licals, from shlicl como forth small whitish yellow threals, like those of the plaintain, whieh are the bloomings of flowers. 'The seded 


\section{FLEA-WORT.}

enclosed in these heads is small and shining, like fleas, both for colonr and size, whence its name. The root is not long, but white, hard, and woody, perishing every year. The whole plant is whitish and hairy, smelling like resin. It is a native of France; and is cultivated in gardens in England. It flowers in July.

Medicinal Virtues. The seeds fried and eaten, are good in fluxes, and in over-purging cansed by mercurinl doses. The mueilage of the seed made with rose-water, and a little sugarcandy, is very good in agues and burning ficvers, and other inflammations, to eool the thirst, and to remove dryness and roughuess of the tongue and throat, hoarseness of the voice, and diseases of the breast and lungs, and the pleurisy. The mucilage of the seed made with plaintain water and the yolk of an egg, is a sure remedy for piles. It relieves inflammations in any part of the bolly, the headache, and all hot imposthumes, swellings, or eruptions of the skin. It relieves the gout, and sciatica, and the swelling of the navel, applied with oil of roses and vinegar. It is good to heal the nipples and sore breasts of women. The juice of the herb with a little honey put into the ears, cures the ruming of them, and the worms brceling in them. The juice mixed with lard, is excellent for sores.

\section{FLOWER DE LUCE.}

Descriprion.-Iris.-A common flower growing in our gardens. The plant grows three feet high. The lcarcs are a foot and a half long, narrow, flat, and in all respects like the leaves of flags, and of a blnish green. The stalks are romm, or a little flatted ; thick, firm, npright, and of a greencr colour. The flowers are larger, and of a deep blue. The roots sprearl about the surface, and is thick and of a brownish colour, and marked with rings.

Mencuxd Vmates. - The juice of the fresl roots of this plant bruised with white wine is a strong punge; it will sometimes also vomit; but that is not hurtful; it is a cure for etropsies. Gorton, an oly physie writcr, says if a dropsy can be cured by the hand of man, this root will effect it. I lave found it true in practice.

112 


\section{FLUX-WEED.}

Description.-Sisymbrium Sophia.-There are two kinds ; one has broader leaves than the other; the smell is disagreeable. It rises up with a round, hard, erect stalk, four or five feet high, spread into many branches, whereon grow many greyish green leaves, fincly cut and serered into a number of short and almost round parts. The flowers are very small and yellow, growing spike fashion, after which come long pods, with small yellowish seed in them. They grow wild in fields, by hedge-sides and highways, among rubbish and in other places. They flower and seed quickly in Junc and July.

Medicinat Virtues. The lierb and seed of Flux-weed are excellent to stay the flux and diarthor. Put the seed and plant into water in which heated stecl or iron lins been repentedly quenched. It is effectual to restrain any other flux of blood in man or woman. The juice drank in wine, or a dceoction of the herb, kills worms, made into a salve, it quickly heals all old sores, however foul and malignant they may be. The distilled water has the same effects, yet rather weaker. It is called Flux-weed hecause it eures the flux, and because it unites broken bones, \&c. Paracelsus highly extols it.

\section{FOX GLOVE.}

Description.-Digitalis Purpurea, of the natural order of Scrnphuleriacece. Its stalk is erect, tapering, rising four or five fect. The leaves are large, oval, wrinkled, veined, on short wing footstalks, and are downy underneatli. The flowers liang down; they are a reddish purple, bell-shaped, marked internally witl little dark-coloured spots placed in whitish rings, and loner hairs defend the entrance of the tube ; so that no insects can enter. The flower-stalks vary in length; at first they depend like the flowers, alterwarels thicy become erect, when they elevate a two-celled capsile containing blaekish sects. This most elegrnt, but very poisonoms plant, muless skillinlly and carclully actministered, is very common in Britain, in dry sancly soils, by hedge-sides. It llowers in July, and seedls in $\Lambda$ ugust. 


\section{FOX GLOVE.}

Medrcinal Virtues.-Its properties are narcoctic, diuretie, and sedative. Useful in inflammatory diseases. 'The pulse is sometimes remarkably diminished by its use, and sometimes as remarkably resists the powers of this remedy, Dr. Thornton says, "We have seen the pulse sink down, in a patient at Guy's Hospital, to 13 beats a minute, and in other instauces, as much as 3 ounces of the tineture have been taken without any alteration in the pulse.

In severe eolds, and inflammations of the lnngs, the digitalis has been administered instead of bleeding; and also in mcasles. "Considering that searlet fever is a mixture of high inflammation and putrid diathesis, confluent, or the one lunning into the other, this remedy was tried by us in large doses, as 20 drops of the Tineture of Digitalis with ten drops of antimonial wine, in ehildren of twelve years of age and under; and in a large experienee in the St. James's Charity School, and in private practiee, we have had abuntant reason to approve of this cliscoverv, whereby even in the most desperate eases none have died."

In aetive hremorrhages, and in phthis, the foxglore has a beneficial effect; it lowers the pulse without at the same time diminishing the strength, and it should be in tineture, beginning with two or three drops at first twiec or thrice a day, gradually increasing to twenty or thirty drops. It is also need with great advantage in all kinds of dropsieal swellings. Dr. Withering says, "If dropsy ean be enred at all, it ean be cured by foxglove : for if this firils, there is little chance of any other suececding." "In dropsy of the chest," say's Dr. Grahim, "It is considered by some able physicians to be superior to cvery other remedy. It is of great service in other kinds of dropsy, especially in the clropsy smervening searlet ferer; and its benefieinl eflicets are more certainly obtained in those constitutions, in which there is laxity of fibre, ple complexion, fechle internitting pulse, cold skin, an! where the swelling casily pits. It has been found of preat value, when conjoined with uitrie aeid, in the dropsy which occur's in lroken-domn constitutions that lave been long harassed by meremy."

It lus also lieen used succestinly in mania, ntising from an

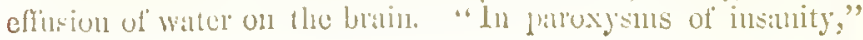
114 


\section{FOX GLOVE.}

says Dr. Grahnam," it will act as a raluable narcoctic ant sectative, provided the infammatory symptoms be first controlled by the usual means, and licnee also it appears fitted rather for the advanced that the cirly. stages of consmuption."

It was in scrofulous tumours that foxglove first acquired its reputation. Haller reports that a scorbutic leprosy was cured by a long use of this plant; and that Zerter, by bruising its fiowers, along with lard, cured glandnlar tumours, and that a deplorable case of Evil yiclded to this remedy. The expressed juice mixed with linsced meal has been foumd a snecesstul topical application in several cases when the medicine was also used intermally.

In spasmodic asthma, the greatest advantage has been realizerl, probably by producing absorption, and strengthening the liabit, for foxglove acts as a tonic. The ancient opinion of epilepsy olten yieldingr to the use of foxglove is confirmed by modern expericnec. Where this disorder has been inducer by a rletermination of blood to the liead, modern practitioner's hare sueceded in removing this aftictive disorder.

The herb is much used by the Italians to heal any fresh and green wound; they bruise the leares, and bind them on the wounrl. In the form of ointment (made of the juice and larl) foxglove is applied to scrofnlons sores with good elfect; and this oiutunent is one of the lest remedies for seabbel head.

For Pills, cach shonld contain a grain of powdered lenvesone to be taken twice a day, and wradually increased till its chiets are aprarent eilloc on the kidneys, the stomach, the fulse, or the loowels; then discontinne.-In dropsy it miny be repeaterl after in interval, il all the water las not left.Infusion:- maccrate in a pint of boiling waler 2 drichims of the dried leaves, adding 1 ommee of spirit of Cimmamom;-dose from two to six drachus twice or thriec a day. - Tinchere; -

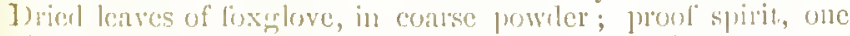
Jint, rligrest for 7 to 20 chass, and filtere; dose, fom 6 to 15

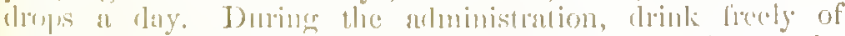
diluting doinks. A little sweet nitle witl the jullusion or de-

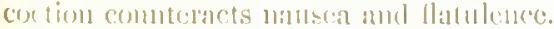

The T'incture, with Soalp Ininincut, nay lue rubbed into tho 
elest, or other parts to relieve pain; and a strong infusion of the leaves may be applicd warm to the albdomen to produce dimesis in dropsy.

To counteract the deleterions effeets of an orel dose, use landanum in brandy and water, or ammonia, small doses of opium, or a strong iufusion of green tea.

\section{FLUELTEN.}

Description-Antirhinon Elatine. There are two kinds of Fluellen. The first sends forth many long branches, partly lying upon the ground, and partly standing npright with almost red leaves, a little pointed, and sometimes more long and romd, without order, hairy, and greenish white at the joints of the stalks, and with the leaves come forth small flowers, one at a place, upon a very short foot stalk, somewhat like snapdragons, or rather like toad-flax, with the upper jaw of a yellow and the lower of a purplish colonr with a small heel or spme behind ; after which come forth small brown heads, containing small black seed. The root is small and thready, dying every year.

The other sort lias longer branches, wholly trailing n] on the ground, two or three feet long, and thimner, set with leares upon small foot-stalks. The leares are a little larger and rounder, and eornered sometimes on the edges; but the lower part of them being the broalest, lias on each sitle a small point, like ears, sometimes hairy, but not hoary, and a better green colonr than the former. "The flowers cone forth like the former, but the colonrs therein are more white than yellow, aud the purple not so fair.

They grow in corn-ficlds, and in horders ahont them, and in other fertile grounds chielly in the sonth of Fingland.

Menicinal Vertuls. - The leaves hmised amk applien with borley meal to watering eyes hot aml inflaned lyg tefluxions from the liean, very much reliere them, as also the bloodyflux, women's comses, and blecelinge at the mose, month, se. cansed by any bronise or lunt, or lmrstinge a rein ; it is very effectual both to heal and elose green womnds, to clense and 
heal all foul ulccrs, sores, cankers, \&c. Made into an ointment with nou's lard, and spermaeeti, it is a good remedy for sores, cuts, bruises, \&c.

\section{FROG-BIT.}

Description.-Hydrocaris Morcus Rane.-A kind of water-lily; not uncommon on watcrs; its lcaves arc round; but it is different from the ordinary water-lily. The lenves are of a roundish figure, and of a dusky grecn colour ; better than an inch broad, and they rise many together in tufts from the same stalk. This stalk runs along a little distanee under the surfaee of the water, and from it desecnd the roots, loose like the fibres of duckwecd. The flowers stand singly upon slender footstalks; they are bluish whitc, and eomposed of thice leaves a-picce, whiel give them a singular appearanec.

Medicinal Virtues. - The fresh leaves bruiscd arc uscl in external applieations, as they are very eooling. 'The juice mixcl with latd makes an cxccllent ointinent for sores, \&c.

\section{FUMTTORY.}

Description.-Immaria Officinalis.-It is a beantiful little wecrl. It shoots forth from one squarc, slencler weak stalk, and leaning downwards on all sides, many branehes two or three feet long, with fincly eut and jagged leaves of whitish, or rather bluish sea green eolour; at the tops of the branches stamd mumy small flowers, in a long spike one above another, mate like little birls of a reddish purple eolour, with whitish lonllies, after which eome small romul liusks contaning small black secels. 'Tle root is yellow, small, anel not very lome. It oretsyrreads the Gugrlish eom-ficlis; and it flowers in May.

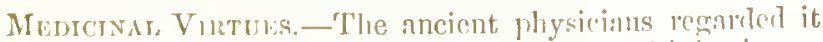

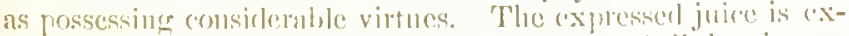
eclent agrinst scoury. It opeus olstructions of all the viserea,

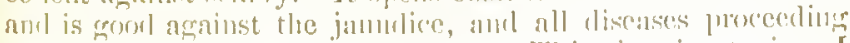
from obtsmetions. Dr. C'ullen salys, "'llats plant is at tonic. I 
have formd it useful in many enses in whieh bitters are prescribed; but its remarkable virtucs are those of clearing the skin of many disorders. I liave scen its good effects in many instanecs of cutancous affections of the worst charaeter, which I deemed to be lepra. I have commonly given the expressed juice, tro ounces twice a day; but the virtues remain in the dried plant ; so that they may be cxtracted by infusion or decoction in water. It is best to combine it with other aperient herbs, for it is not strong enough of itself, and either in syrup, or decoction, it will improve the liver, remove jaundiec, and clear the blood, and strengthen all the inwarel parts. The secd is stronger than the leares. The juice dropped into the eyes, clears the sight, remores infammation, and redness, thongh it is rather painful at the first. The juice of Fumitory and Docks, mixed with vincgar, makes an exeellent wash for the cure of scalus, pinples, blutches, \&c. on the skiu.

\section{FURZE, or WHIN.}

Drscription. - Ulex Europeus. It is one of the niost common of all plants on heaths, and moors. The flowers are rery leantiful. Limneus almost ilolized the flower. Sume call it Fure, others Gorse, and Whin. It is well known.

Mudicinal Virtues. - The virtues are the same as those of the Broom, but in a less decrec. A decoction male with the fowers las been tound eflechul atainst the jamulice, and to gromote arine, and cleanse the kidncys firom gravel or stune.

\section{GALIS.}

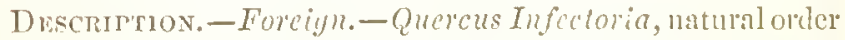
Corylacer.

Medornat, Virtere.-Galls possess peculial astringent qualities on account of the lare quantity of tammin which they contain. 'They are chiclly nacd in garerles, lotions, injections,

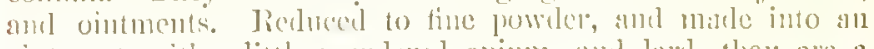
cintusent, with a litte powdered opium, am lard, they are a 
raluable remedy for the piles. The tineture of Galls in mneilage is sometimes given with gool effect in cases of cliarihuea; the dose of this preparation is from 1 to 2 drachms. $\Lambda$ diachm of powdered galls, with a seruple of Sulphate of copper, and 1 ounce of lard, makes a good ointment for ringworms. They form a trseful injection in whites and glect, and are of much nse as an astringent in prolapsus of the anus and womb. In bleeding from the bladder, Gallic acid is the best remedy -5 grains in solution of Gum Arabic, repeat as required.

\section{GARLIC.}

Allium Sativum. It needs no cleseription; it is so well known.

Medicrisal Virtedes. - Applied extcrinally it aets as a stimulant, rubefacient, and blister. Intermally, it is often useful in discases of langujd cirenlation, and intervented secretion. In cold leuco-phlegmatic habits it is a powerful expectorant, diuretic, and if the patient be kept warm, sudorific. It is thought to be an emenarogue. But in eases where irritability prevails, lavge doses may be injurious. $\Lambda$ s a condiment, taken in moteration, it promotes digestion; taken in excess, it produces hearlaclie, flatil lence, thirst, \&e. In fevers of the typhoid kind its virtues have had a good effect. It has sueceeded in euring obstinate quartanagues. In entarthal disorders of the breast, spasmoilic and pituitons asthma, flatulent colics, hysterical and oflice dliseases, proceerling lrom laxity of the solids, it has gool effects. Sydenliam says that he has known the dropsy curcel by the use of Girlic alone.

Cotton satmiter with the juice, and put into the cal is good for deafness. Renew it several times a diny. $\Lambda$ ]plied as a ponltice to the puhis, it has promoted the flow of urine. Syclenliam resarderl Garlic as a powerful means of causing a derivation or revulsion from the loat, spplied fo $\$ 10$ soles of the fect. For this he nsed it in the conlluent smatlpos, about the seventl or eierht day, after the litec berrint to swell. The root eut sunall, and tiol in a linen cloth, was ay-

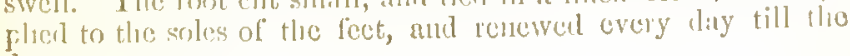
danger was oyer. 
A dose or two of the juice of Garlic may be taken in the morning for worms. An infusion of Garlic, made of half a pound of the bruised roots to a pint of boiling water, two spoonfuls before and after every meal, for epilepsy. Of the syrup of Garlie, made of one ounee of the cxpressed juice, to $1 \frac{1}{2}$ onnee of lump sngar, a tea-spoonful taken oecasionly by ehildren, for conglts, without inflammation. Of the milk of Garlic, 2 draehms, of the bruised bulbs boiled in 6 or 8 ounees of milk, nseful as a clyster for thread-worms in ehildren. Wine of Garlic, three or four bulbs bruised and macerated in a quart of proof spirits, is a good stimulant lotion for baldness of the head.

If you are tronbled with asthma, take a number of bulbs, and boil till they are soft; then dry them well. Put an equal quantity of good vinegne to the water in which the bulbs of Garlie have been boiled, add sugar, and boil into a syrup. Pomr the sylup over the dried bulbs, and seeure in a jar for nse. Take a bulb or two in a morning lasting, with a little of the syrmp, and yon will find relief. We are informed that Dr. Bowles sceured a large fortune by this remedy.

\section{GENTIAN,-BRITISH.}

Descriptron.-Gentiana.-Sometimes ealled Felwort, or Baldmony. Thongh the foreign Gentian is prineipally used, yet there are two kinds in this eonntry, whieh equal that imported. The greater of the two has many small long roots deep in the ground, and abiding all the Winter. The stalls are of a brownish green colonr, two feet high if the gromul be fruitfnl, liaring many long, narrow, dark green leaves, in comples up to the top; the flowers are long and hollow, purple, ending in fue corners. The smaller sort grows with several stalks, not a foot high, parted in several small branelies, wherem grow simall leaves together, very like those of the lesser centualy, of a whitish green eolour; on the tops of these stalks grow hlue flowers, standing in long husks, hut not so linge as the other; the root is very small, and full of threats.

Botly grow in several plises loth of the Fast and West comtries, near Graresend, in Lunt, and in Bedfordshire. They flower in August. 
Medicixal Virtues.-They resist putrefuctions, poison, and a surec remedy cannot be found to prerent the epirlemic diseases; ikstrengthens the stomach execedingly, helps digestion, comforts the heart, and preserves it acrainst faintings. The powder of the dry roots opens obstrnetions of the liver, and restores the loss of appetite. The herb stecped in wine, and drank, refresh such as be overwerly with travel, and lame in their joints. It relieves stitches, and griping pains in the sides; it is an execllent remedy for such as are brtised by falls; it provokes urine and the terms ; but should not be given in pregnancy. A decoction of it is very useful in cramps, convulsions; in stone, rupture, and in cold diseases, and to such as are troubled with tough phlegm, scabs, itcli, or sores and ulcers. It is an admirable remedy to kill the worms, by taking half a drachm of the powder in a morning in any convenient liquor; taken inwardly it is good for the king's evil. It relieves agues, and the yellow jaunrlice, as also the bots in eattle: when kine are bitten on the udder by any venemous boast, only stroke the place witl the decoction of any of these, and it will instantly heal them.

\section{GENTIAN,-TOREIGN.}

It is obtained from the Gentiana Lutea, or yelluw Gentian. It is a native of the Alps, Pyrenees, \&re. The root is uscel. It is one of the most usefill of our bitter vegetable tronics. It is especially useful in states of exhaustion, from clironic discase, and all cases of debility, uneonnected with excessive irritability of the stomach. It possesses fehrific, anthelnintic, and antiseptic propertics, and as a warms stomachic tonic, it is murivallen. It is an excellent tonic to commline

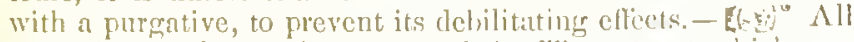
puregatives ought so to be componmled. The extrac/, which mily

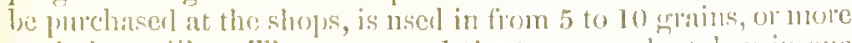

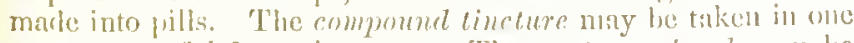
or two spormelul deses, in water. The root ponodered may he taken ; dose, fom 10 to 20 grains - this is somelimes spritikled

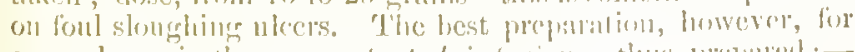
general use, is the concentrated infusion,-this peprated :- 
To every ounce of sliced Gentan root, and a quarter of an ounce of dived orange pecl, and infuse these-not boil, with suecessive quantities of boiling water poured over them, until their strength is exhansted. Strain the liquor from the root, and concentrate by boiling in a well-tinned or porcelain-lined sauecpan, milil the quantity is so fin recluced, that there is left half a pint of the conecntrated infusion for every ounce of Gentian used. Then to each half pint, half an ounce of alcohol is to be added. The effect of the alcohol is to congulate it from a quantity of jelly-looking snbstanec, which must uc separated by straining. This infusion will kecp a long time the dose being one ter-spoonful in an ounce of water. This is one of the best strengtheners of the human system.

\section{GERIIANDER.}

Description, - Teucrion, vel, Chamnedrys.-This celcbrated plant is cultivated chicfly for medicul purposes. It has several stalks with small round leares dented at tho cilges. The flowers stand at the tops, of a deep purple colour. It is cultivated in gardens. It flowers in June and July.

Medicival Viridues. - It strengethens the brain and apprehension execedingly when weak, and relieves them when drooping. Taken with honey (says Dioserides) it is a renenly for conghs, hardness of the spleen, and diflienlty of urine, and gives relief to dropsey, especially at the begiming of the discase, a deeoction being made of the green herb. Tsed with honey it cleanses old ulecrs; and made into an vil, ancl the eres monited therewith, it removes dimness and moisture. It is likerise goot for pains in the sides and for cramps. The decoetion taken for four days together, cures both tertian and quantmu atrues. It is also good aganist all diseascs of the brain, as continual headache, filling-sickness, melancholy, dromsiness, bowness of syirits, convulsions, and palsies. A ilrmbm of the seed taken in powder, is good agninst llo yellow jammelice as it promotes mine. The juice of the leares dropperl into the cars, litls worms in them. The tops when in flower, steceded twentyfonl livm's in white wine, destroy worms. 


\section{GERMINDER,-WATER.}

Description.-Tencrium Scordium.-It is an insignificant looking plant, growing wild, and cultivated in garlens for its merlicinal uses. The stalks are squarc, hairy, of a dirty green, and very weak. The leaves are short, brond, indented at the edges, woolly and soft. The flowers are small and red, stancling in little. parecls on the upper joints of the stalks. The smell of the platt is umpleasant.

Medicisal Virtues. - Used as a decoction, it is sudorific. It is good against fevers. The Tincture, in small doses, is a good remedy for exhilarating and rousing torpid ficultics.

\section{GINGER.-FOREIGN.}

Amomum Zingiber. It is a perennial plant, indigenous in the East and West Indics, having stimulent, calminative, and tonic propertics, which render it extremely valuable. It is very uscful in cold flatulent colics, and in laxity and debility of the intestiues, not heating so much as the peppers, and itsefrects are more durable. Persons suljeet to indigestion, flatulency, and gont, have been known to receive great benefit fiom the use of Ginger tea. Many gouty patients have for years been in the habit of taking a tea-spoonfiul of powdered Ginger, mixed in any liguirl, an houl before diuner, with considernble atrantnge. When employed with foorl, it is called a condiment, and by stimnlating the stomach and bowels, it may be considered as one of the most nseful. Combined witl purgatives, it corrects their griping tendency, and it acts exterlisily, like mustarl, as a rubelacient, eren laising a blister.

As Ginger promotes the circulation throngh tlic extremo ressels, it is to be arlvised in torpiel and plesmaric habits where the stomach is subject to be londed with sline, and the bowels distencled witl flitulency.

\section{GILLIFLOWTRS,-CTOVI\%.}

It is in vain to deserilye a pliunt so well known. It i:3 sonetistes called Gilliver. 
Medicinal Virtues. They are gallant, fine, temperate flowers, yea, so tenperate, that no exeess, neither in heat, cold, dryness, nor moisture, ean be pereeived in them; they are great strengtheners both of the brain and heart, and will therefore serve either for eordials or eephalies, as your ocension will serve. There is both a syrup and a conserve made of them. To take now and then a little of either, strengthens nature mueh in sueh as are in eonsumptions. They are good in hot pestilential ferers, and expel poison. One onnee of the flowers, in one pint of boiling water eonstitutes the infusion. For the Syrup, flowers, 1 onnee, boiling water, 4 onnees, refined sugar, half a ponnd. Let the flowers infuse half-a-day; then very gently boil down to one-fonlth the quantity. The vinegar of eloves is a eephalie, the smell removing headnehe, siekness, \&e. It is an exeellent deodoriser for siek rooms. It is made by merely steeping one ounee of petals in a pint of best vinegar for 14 days.

\section{GLADWIN,-STINKING.}

Description.-Iris Folidissima.-It is a wild plant of the Iris kind. Its leaves are very like a Flower-de-luee but sharpedged on both sides, and thieker in the middle, of a decper green colour, sharper pointed, and have a strong ill seent, if bruised. In the middle rises up a strong stalk, a yard high, bearing three or fom flowers at the top, like the flower-de-lince, with three upright petals, of a clearl purplisls ash colour, with some veins diseolonred in them; the other three do not fall down, nor are the three other small ones so arelied, nor eorer the lower leaves like the flower-de-luee, but stand loose from them. The root is like that of the flower-de-luee, but reddish on the ontside, and whitish within, very hot in the taste, of a bad seent.

It grows in ligh lands, in moist plaees, woods, and shadowy places, and by the sen-side, and is enltivated in gamrdens. It flowers in July, and the seed is ripe in August.

Memoinal Vintues. It is used hy eontry people to purge eormpt pll legm and choler, by drinking the deeoetion of the roots; or by infusing the sliced roots in ale; and some use the lenves. 124 
The juice snuffed up the nose, eauses sneezing, and drinws from the licad much corruption; the powdel has the sane cftect. 'The powder drank in wine, relieves cramps and convulsions, the gout and sciatica, and griping pains. It is given witl much profit in fluxes which it stops, having first cleansed and purged them by its astringent qualities. IIalf a drachm of the seed beaten to powder, and taken in wine, promotes a flow of nuine. Taken with vinegar, it removes the hardness of the spleen. The root is effectual in all wounds especially of the head; and to draw forth splinters, thorns, or broken bones, or any thing sticking in the flesh, without eausing pains, being used with a little verdigrease and honey, and the great Centaury root. Boiled in vinegar, and laid upon any tumour or swelling, it removes them. It is a fine remedy for the king's evil. The juice of the lenves or loots heals the itch. and all running sores, blemishes, or sears in the slin.

\section{GOLDEN ROD.}

Description.-Solida Virga-Aurea.-By some it is enlled Woundwort. It has small round stalks, two fect high, having many narrow and long dark green leaves, undenterl about the edres, and without stalks or white spots therein, yet they are sometimes rliviled at the tops into many small branches, with small yellow flowers on every one of them, which are all turned one way. The seeds are downy. The root consists of many small fibres. It grows in the open places of woods and eopses, on heaths, and it is enltivated in gardens.

Mentcinst Virtues. - Arnolins de Villa Nova commends it much agrainst stone, and to provoke urine in aburulance, by which gravel and stone may be voiderl. 'The decoction of the lierb, stecen or diey, or the distillexl water, is very eflectual for inwarl bruises; outwarlly applierl. it arrests bleeting in any part of the bo :y, ame of womble; also the fluxes of humours,

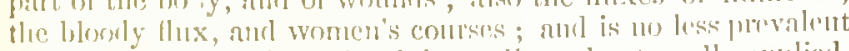

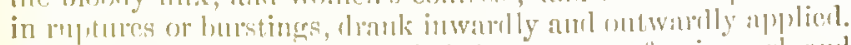

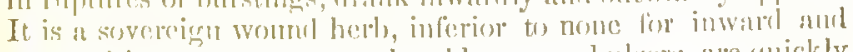
outwatrd liurts; green wounds, old sores auml ulcers, are quirkly 
enued with it. It makes an excellent lotion fol sores or ulcers in the month, throat, or privy parts in man or woman. The deeoction tends to fisten loose tecth.

\section{GOLD OF PLEASURE.}

Description.-Camelina Sativa. It is a pretty plant growing in some parts of England, and easily known by its numerons seed vessels. It grrows two fect high ; the stalk is round, thick, ercet, having many erect branches at the top. The leaves are long, not very brond, of a pale green, few and irregular, indented, and encirele the stalk at the base. The flowers are small and white. The seed vessels, short and roundish, and they appear in great quantitics, resembling a spilie to the very top of the branches.

Medicinal Virtues.--The fresh tops of the plant should be nised before the flowers are gone. The flowers make an execllent poultiec for influmed parts. An infusion of the fiesh tops swectened with honey, is excellent for sore throats, and ulecration of the mouth. From the seed a great quantity of oil may be cxpressed; and probably the plant would pay for eultivation, on neeount of its great yield of oil. The oil is pleasant, well-tasted; and it makes an excellent rubcfieient.

\section{GOOSEBERRY-BUSII.}

Description.-Ribes Gros-suluria.- $\mathrm{Yt}$ is well known.

Medicinat Virtues. - The fruit is most wholesome. The berries are aperient, and the seeds add to this property, by their mechanical aetion upon the bowels. The green berrics being sealded, or baked, are good to stir up a finting or decinged appetite, espeeially in persons afllicted by eloleric humonts. The deeoction of the keares eool hot swellings and inflammations, and St. Anthony's fire. The ripe grooselerities ane an exeellent remedy to allay the violent heat of the stomach amd liver. The yonmg tender leates expel the gratel both from the kidneys and blitlder. 


\section{GOU'TWORT.}

Description. - Podogravia. - It is also ealled Gont-weed, Horh-gerrard, Ash-weed, and Ground-ash. It is a low lerb, seleten rising half a yatd high, having many leaves standing on brownish green stalks by three, suipped about, and of a st:ong and unpleasant savoul' ; the nmbels of the flowers are white, and the secd blackish, the root rumeth in the gromnd, taking a great deal of room. It grows by liedge and wall-sides, and in the border and corners of fields, and in gardens also.

Medicrisal Virtues.-Goutwort has not its name for notling for it heals the gont and sciatica ; as also joint-aches, and other pains. The root and leaves boiled tugether, and anplied to the hip, and oecasionally renewed, has a wonderful effect. The plant makes au cxechlent fomentation for pained and iı@lamed parts.

\section{GRATSS OF PARADISE.}

The seeds of the Amomm Gramum Paralise, belonging to a genus of plants, all of which bear aromatic seeds. Thiese grains are stimnlant, aromatic, and tonic, and lave been given in large floses with goonl eflect in agues, and palrilysis. They are also used to give strengeth to beer, wine, \&e. In morlerintien, they certainly improse those beverages, int act as it tunic. In veterinary practice, they are very serviceable in the discases of animals, ats a ficrmatuent stimnlaut.

\section{GROMIVELL.}

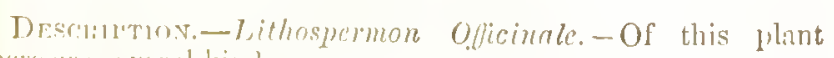
there ance acveral kints:--

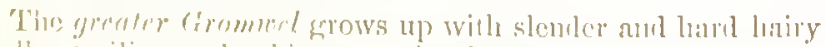

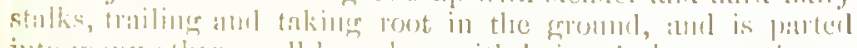

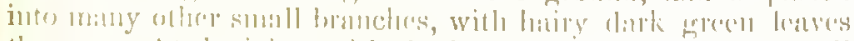

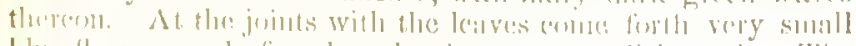

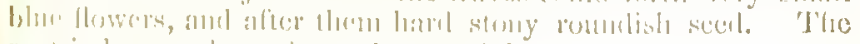
roos is long and wouly, and purcunial. 


\section{GROMWELL.}

\section{GROUND PINE.}

The smaller wild Gromwel has several npuight hard branched stalks, two or threc feet high, fiul of joints, at every one of which grow small, long, hard, and rongh leaves like the former, but less; with small white flowers, and after them greyish round seed like the former, the root is not large, but has many fibres.

The garden Gromwel hath various mpright, slender, woody hairy stalks, blown and eressed, very littlc branched, with lcaves like the former, and whitc flowers; after which in rongh brown husks, is contained a white hard round scerl, shining like penll, larger thau both the former; the root is like the first.

The great and the small Gromwell grow wild in harren or milled plaees, and by the way-sides. The last is cultirated in gardens.

Medicinal Virtues. - The seed powdered and taken in barley water, is excellent to dissolve the stone, and to remove gravel from the kidncys. It mist therefore be very diuretic, powerfully promoting urine. The herb itself (when the sced is not to be had) either hoiled, or the juice thereol" drank, is effeetual, but not so powerful as the secd.

\section{GROUND PINE.}

Descriptron.-Ajuga Chamapitys.-A small wild mossy plant, of a resinons smcll. It grows fonl inches ligh. The stalks are hairy, the leares close set ; the young shoots obsenre the stalk, in the form of a thick lound tuft. The leaves are slort, narrow, and divided into three parts at the curl, rough and hairy. The flowers are small and yollow, standing at the joints.

Mentchal Virtues. - The whole plant is to be powdered for infusion. It is a powerfinl diuretic, pronoting nurne, and removing obstmetions of the liver and spleen ; therefore valnuble in janndiec, rhemmatism, antel most of the chronic clisenses. 'Jake, for a dose, a smatl teaspomblin of the powder. $\Lambda$ decoetion of this plant, Dandelion, and $\Lambda$ grimony, is a great remely for liver conplutints, and obstruetions.

128 


\section{GROUNDSEL.}

Description.-Senecio Vulgaris.-This plant is well known; and it grows everywhere.

Medicinal Virtues. - Groundsel is now ehiefly used as food for birds. It was formerly much used for ponltices; and it was reckoned as good for sickness of the stomach. A weak infusion of the plant is now somctimes givelu as a purgative, and a strong infusion as an emetic, as it eauses no irritation and pain. As a weak decoction it is safe and firendly to the body of man. It is a great cooler. It relicves pain at the - stomach arising from choler or bile. The juice taken in weuk wine has the same effcet.

\section{GROUND-IVY.}

Glechoma Hederacea. - It is also called Cat's-foot, Alchoof, Gill-go-by-ground, and Gill-ereep-by ground, Turnhoof, Haymaids, and Jack-by-the-Heclge.

Description. - It creeps upon the ground, sends forth the roots at the corners of tender jointed stalks, and has two round leaves at every joint, crinmpled, and dented about the elgcs. The stalks arc hollow and square, a foot or more in length. It has liollow long flowers of a blueish purple colonr, with small - white spots upon the lips which hang down. Tle root is small and fibrous. It is found under hedges, and on the sides of ditches, in sharly lanes, and waste grounds. The plant has a peculiar smell; it flowers early, and it should be gatlıcred when in lower.

Medicinat, Virtues. - It is known to be gently stimulant, and tonic, aperient, diuretic, and corrobarant, with a particulat action on the lungs and kidneys, and it lias long been a pojpllar remely for coughs, pulmonary complaints, and mintry affections. A conserve of it may be made in spring, ancl it may be male into tea. The expresserl juice sunfled un the nose is curative of hearlache, when all other medieines lave litiled. It maly also be taken with great liencfit, conjoined with Elecam- 
pane leaves, Liquorice root, equal quantities, infused in boiling water. It is a very good remedy for inward wounds, for colic, griping pains, and the yellow jaundice, by removing obstructions of the gall and liver; it removes melaneholy by opening the spleen. A decoction of it in wine is good for sciatica, or hip-gout, and for gout in the hands, fect, and other joints. If some honey, and a little burnt alum be added to the decoetion, it is useful as a gargle for a sore mouth or throat. The juice boiled with honey and a little verdigrease, eleanses fistulas, and ulcers. The juice of Celandine, of Ficld Dinsies, and of Ground Ivy elarified with a little suga dissolved therein, and dropped into the cyes, is a sovereign remedy for inflammation, watery humours; and dropped into the car, it is good for deafness.

In short, this is a valuable herb, and ought to be gathered in the season by crery family for use. Such a step would never be regretted.

\section{GUIACUM.}

Foreign; Guiacum Officinalis.-Lignum Vito is a West Indian tree. The wood and gum are botle used for the eure of chronic cutaneous and syphilitic diseases, for gout and rheumatism. From the rasped wood is prepared a decoetion, to bo taken from 2 to 4 ounces at a time. It is also one of the ingredients of the Compound decoction of Sarsaparillin, and other diet driuks for prurifying the blood. Guibum is often extremely useful in rheumatisur.

Dr. Graham thus deseribes a compound by which Lord Amherst was cured of rhenmatism. Guiacum, I drachun; powdered rhubarb, 2 drachms; erean of tartar, l onnce; flowers of snlphur, 2 ounces; one nutmeg fincly powdered, male into an electuiny with 1 pound of honey. "Two large spoonfuls to be taken night and morning. The best form of administration is the 'lincture, which may he given in one or two teasploonful doses at licl-time. Milk is the lest velicle for its atministration. The tincture is execllent for painful menstruation. 


\section{' HART'S TONGUE.}

Description.-Scolopendrium Vulgaris.-It is always green, thongh it has fiesh leaves in Spring. It has screral leaves arising from the root, which fold themselves in their first springing and spreading: when full grown they are about a foot long, smooth and green above, but hard, with little sap, and streaked on the back, thwirt on the sides of the midelle rib with small autl rather long brownislu marks; the bottons of the leaves are a little bowed on each sirle of the micldle rib, rather narrow and small at the end. The root has many black threads interlaeed together. It is green all the Winter; but new leaves spring every year.

Medichin Virtuls. - It is an excellent purifier and strengthener of the liver, and it onght to be more extensively known.

\section{HAWI-WEED.}

Descriptron. Of this plant there are several kinds, as Molse-ear IhawiweEd, Hierracium Dubium; and LungWORT HAWIE-W LIDD, Hieracium Pulmonarium, but their virtnes are the same. It has many large leares lying upon the ground, much rent and torn on the sides into grashes like Dandelion, but with greater parts, more like the smooth Sow Thistle, from among which rises a hollow rough stalk, two or three feet high, branched from the middle upward, whereon are set at every joint longer lenves, little or nothingr rent or eut, bearing on their top beautiftul pale yellow flowers, consisting of many small, narrow leaves, lroarl pointed and nickerl at the enrls, set in a double row or more, the ontermost lecing larger than the inner, which torn into down, and witl the small brownish seerl is blown away with the wind. 'The root is long, and ratlier large, with many small fibres thereat. The whole plant is full of bitter nilk. It grows in many places about the fickle-sides, and the pratli-wany's in dry grounds. It is now cultivated in cratrilens.

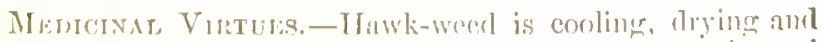
binding, and therefore good for the lecit of the stontiach, and 
gnawings therein; for inflammations, and the hot fits of agnes. The jutice in wine, promotes digestion, expels wind, and neutralizes acidity in the stomach. A scruple of the dried root given in wine and vinegar, is good for the dropsy. The decoetion taken with honey, and with hyssop, promotes expector:ation and allays eough. The decoction with a little wild sueeoury, made with wine, relieves colie, and hardness of the splecn: it procmes rest and slecp, purges the stomach, inereases and pnrifies the blood. It is also good for bleeding piles, and the leaves boiled in milk may be applied outwardly. In many parts of Europe it is a constant medicine in diseases of the lungs, asthma, and incipicnt cousumption. The juice mixed with milk is good for inflamed cyes. The green leaves bruised and mixed with salt make a good oiutment for bums, erysipelas, and inflamed parts.

\section{HAZEL-NUT.}

Corylus Avellana. - Hazle Nits are so well known mat they need no deseription.

Medicinal Vintues.-The parted kemels made into an electuary, or the milk drawn from them, with honey water, relieves an old eough. The dried lnisks and red skin of the kernels to the weight of two draclins, taken in red wine, restrain frofuse menstruation. Nuts do not canse shormess of breath. For how enn that whieh strengtheus the lungs canso shortness of breath ? If any thing of the Inazcl-nut be stopping, it is the husks and shells, and nobody is so mat as to calt them, unless medicinally; and the red skin which eovers the kernel, you may easily pull off.

\section{IIEART'S EASE。}

Description.-Viola Tricolor.-It is also called Pansy. Some of them grow wild in fields, and they ate extensircly cultivated in gardens.

Medicinal Vintues. - It is anti-rencrenl, made into a de132 
coetion. The spirit of it is good for eonvulsions in elihtren, for falling-sickness, and for inflammation of the lungs and breast, pleurisy, scabs, itch, \&ce.

\section{HEDGE HYSSOP.}

Description,-Gratiola Officinalis,-There are several kinds of this plant; the first is Italian, and cultivated in gardens. Two or three sorts grow wild. The first is a smooth, low plant, not a foot high, very bitter in taste, with many square stalks, diversly branehed from the bottom to the top, with several-joints, and two small leares at each joint, broader at the bottom than they are at the end, and full of veins. The flowers stand at the joints, of a frir purple colonr, with white spots, like those of dead nettles. The seed is small and yellow, and the roots spread much under ground.

The sceond seldom grows half a foot high, sending up many small branches, whereon grow many small leaves, set one against the other, somewhat broad, but very short. The flowers are like the flowers of the other in fashion, but of a pale reddish colour. The seeds are small and yellowish. They grow in wet low grounds, and by the water sides. They flower in June and July.

Menictinal Virtues. - They are violent purgatives especially of choler and phlegm. They assist in the eure of dropsy, gout, and sciatica, outwardly used in ointments; they kill worms, and are goorl to eleanse old uleers. The best mode to use them is:-put 2 drachms of the fresh leaves, into 6 ounees of boiling water, and let it stand 12 lour's, and then add 6 blinches almonds, and 1 ounee of syrup of violets. $\Lambda$ tablespoonful to be taken every hour, until it vounits or purges.

\section{IIELLEBORE,-DLACK.}

Descriptions.-Helcborws Niger.--It is also called Setterwort, Setter grass, Bear's-foot Christmals-hurb, and ChristmasIive.

It has fair green leaveg rising from the root, encl of them 133 
standing about a handbread th high from the earth; each leat is divided into eight or nine parts, dented from the middle of the leaf to the point on both sides, abiding green all the wintel" ; about Christmas, if the weather be temperate, the flowers appear upon footstalks, eonsisting of five large, lound, white leaves a-piece, sometimes purple at the edges, with many pale yellow threads in the middle; the seeds are divided into sevcral eells, like those of Columbines, but are larger, they are black, long, and round. The root eonsists of numberless blackish strings, all united into one liend. They are found in some woods.

Medicinal Virtues.-It is an imitant poison, although sometimes given medicinally. In large doses both black and white Hellebore are drastic purgatives; in smaller doses, they are diuretic and emmenagorrue. They are prineipally used as purgatives in ease of mania, melancholy, coma, dropsy, worms, and emmenagogue. It onght not to be given except nnder skilful dircetion. The Helleborus Foetidus, Stinking Hellebore is given to expel worms; the dose of the Powdered Leaves being for a clild 4 to 20 grains, or a fluid onnee of the deeoction. The Helleborus Viridens, Green Hellebore, has been employed in America as a remedy for typlus ferer, and for some convulsive diseases of elildien. But its admiuistration requites both skill and great care.

\section{HEMLOCK.}

Description.-Conium Maculatum.-The common great spotted Hemloek has a green stalk, four or fire feet high. or more, sometimes full of red spots, and at the joints very large winged leaves which are divided into many other winged leaves, one set agrainst the other, dented at the edges, of a sal green colour, brimched towards the top, where it is full of umbels or white flowers which prodnce whitish flat scel; the root is long, white, erooked, and hollow witlin. It liss a very disagrecalle suncll. It grows thronghout the limel, by walls and hedge sides, in waste grounds amd untilled pliees.

Medicinal Virtues. Henlock is rery cold, and very dangerous, especially to be taken inwardly. It may safely be 134 
applicd to inflammations, tumours and swellings in any part of the boly, (save the private parts) as also to St. Anthony's fire, uleers that arise from hot lumours, by eooling and repelling the heat; the leares bruised and laid to the brow or forehead are good for eyes red and swollen; and to take away films, specks, ste. in the cye; this is a tricd medieine.

The ancients regarded it as a good diseutient and anodyne external applieation, and used it both for fomentations and ponltiees, The dried leaves mixed with a carrot, or other poultice, and applied twice a day, eorreet the fotor of a caneerous diseharge in a very short time, and alter the discharge into a salntary pus. The decoction is good for swelled testicle. This is also a valuable remedy for ulcers, and glandular tumours. It allays pain and irritation in palsy and rlıcumatism. The powdered leaves and the extract are the forms in which it is given. The dose of the powder is three grains twiee or thrice a day. It las been regarded as valuable in serofula, in the latter stage of hooping cough, and in pulmonary consumption. The extract of Hemloek and Henbare in mucilage, subdues cough and pulmonary irritation, or they may be made into pills. Dose of extract, 2 to 3 grains once $n$ day ; (increase if neccssary, ) of the Compound Pill from 3 to 5 grains.

For poisoning by Ilemloek, the antidute is vinegar, taking previonsly as an cmetic 20 grains of Sulphate of Zine.

\section{HEMP.}

Cannabis Sativa,-It is too well known to require deseription.

Medicinal Virtues. - It has nareotic propertics. The Hindoos prepare from it an intoxicating liquor called Bangi, and so do the 'Turks, Arabians, and ofluers. These prejerties are not (quite so strong in the European ilemp. 'The seed builex in milk, relieves a hot dry contrb ; strain and driuk. 'Tho Dutch nake an emnlsion of the seed, and give it with grool success in jamudice, for it opens obstructions of the gall and

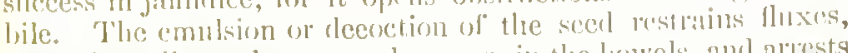
enses the colic, sunl renoves lammours in the lowels, and alrests bleceling at the month, nose, and other plisers. It is grond to kill worns, and the juice droprucd into the ears, kills the worns 
and other inseets which may have entered. The dccoction of the root eases gouty pains, the hard humours of knots in the joints, the pains and shrinking of the sinews, and the pains of the hips. The fiesh juiee mixed with a little oil and butter is good for burns.

\section{HENBANE.}

Description--Iyoscyamus.-Henbane has very large, thick, soft, woolly leaves, lying on the gound, indented or torn on the edges, of a dark, ill greyish green colour, among which rise up several thick and short stalks, two or three feet high, spread into several small branches, with smallcr lcaves on them, and many hollow flowcrs, scarcely appcaring above the husk, and torn on one sidc, encling in five round points of a dead yellowish colour, paler towards the edgres, with purplish veins; and a dark yellowish purple in the bottom of the flower, with a small point of the same colour in the middle, each of them standing in a hard elose husk, which after the flowers are past, grows very like the husk of $\Lambda$ sarabacca, and somewhat sharp at the top points, having mucl small sced, like Poppy secd, of a greyish colour. The root is grent, white and thick, so like a Parsnip root (but not so white) that it has deceived othcrs. It eommonly grows by the way-sides, under hedges and walls, and on ditch banks.

Medicinal Virtues, - It is a strong narcotic poison; the leaves and sceds being chicfly used in medicinc. It is found to allay pain, and subduc nervons excitement without confining the bowels, and acting otherwise prejudicial, as opium often does. In irritalle affections of the lungs, bowels, and otlicl organs, its scrative jropertics make it very valuablc. Like Ilemlock, it farours the natural action of ilic bowcls. It is useful in red grarcl and stone, as it allays irritation and pain. It is a valualle arldition to purgatives which alre apt to gripe. It may be giren in the form of extract or tineture. Extract, from 4 to 20 grains male into jills, wice or thrice in 24 hours. Tincture fion half a drachm to 1 or 2 drachlons. The dose of the poudered leaves is fiom hislf a drachm to 2 draehms - of the fresh juice from half a drachn to 1 drachn. 136 
In his Elements of Materia MTelica, Dr. Thompson says, "In my own practice, I have seen more good derived (in mania) from 8 or 10 grains, combined with 10 grains of camphor, and given at bed-time, than from the repetition of smaller closes." It forms a valuable ingredient in Cough Pills. The seeds sometimes relieve toothache:- Heat a small picee of metal nearly red-hot; and place the secd upon it; inhale the vaponr, but not too much. The remedy for an overdose, is vinegar, as prescribed under Hemlock.

\section{HOLLYHOCK.}

Althece Rosea. It is wcll known as a benutiful garden plant.

Medicinal Vintels. - The root is white, long, and thick, and of a slimy nature. This is the part to be used. A decoction of it operates by urine; it is execllent for gravel. It has nearly the same virtues as the Mallow, and Murshinallow. The flowers are rather astringeut.

\section{IIOLLY.}

Description,-1lex Aquifolium. Belonging to the natural orter Aquifolincea the only British menber of the genus Ilex. It is well known. It is sometimes eallerl IIolm, or Hulm, or II ulver Bush. ILolly is probably a corruption of Holy.

Midreisat VirTues. - The leaves are bitter, mucous and astringent, having an austere taste. The berries expef wind, and therefore goorl for the colic, They are very purgative, 10 or 12 being generally snfficient to act on the bowels. Used when rife, they are efficacions in eleansing from morbid matter. They also act as an cmotic ant diuretie. The explressed juico is sail to be benefietial in janndice. $\Lambda$ decoction of the bants anel leaves makes an excellent fomentation for broken bones, \&ece. The berries drierl, and powelered, are astringerat and stay fluxes. The leaves were formerly useel as an linphrotic, and an infusion of them was given in catallth, grout, plentisy, and 
small-pox. In France, a few years ago, some phrsicians prononneed it to be a very superior febrifuge, being equal, if not superior to Peruvian bark, their virtues being dependant on a better principle called Tlicin. Pliny absurdly says the branches of the tree defend houses from lightning, and persons from witcheraft! From the inner bark bird-lime is prepared; it is steeped in cold water for a few hours, and then beaten in a mortar, washed in cold water, left to settle a day or two, the scum taken off, and the bird-lime is ready for use.

\section{HONEYSUCKLE.}

Periclymenos.-It is so well known as to forbid description. It is known also by the names of Woodbine, Meadow Trefoil.

Medicinal Virtues.-A decoetion of the lenves removes obstructions of the liver and spleen; and is a good garcle for sore thronts. It promotes urine. The secd and flowers boiled in water, made into a poultice, with a little oil, and applicr, cures hard swellings and imposthumes. The juice dropped into the eyes, is a familiar medicine, to take away specks, \&.

\section{HONEWORT.}

Descriptron.-Sison Segctum.-A common plant in colnficlds and dry places. It has pretty leares, and little umbels of white flowers. From the root arise six or more leaves, which are beautifully spread on the ground. The stalks do not appear till the end of summer, and by that time the leaves deciy, so that they are not known to belong to it. These leares are cight inches long, and nearly two inches broad. Ench is composed of a double row of smaller leaves, on a common rib with an odd leaf at the culd; they are niecly indented, and of a fresle green colour. The stalk is two tect high, npright, romb, hollow, not very firm, and lirmelied at the top.

Menicinal Vikturs.-- Its mame is derived from its rirtues. In some parts parintul swellings are called hones, and the herb fiom its eflicacy in enring them, has sereived the name of honeherl, or honewort. 'The leares are to be nsed, fresh gathered, 
and redueed in a mortar to a kind of paste. Applied to red and painful swellings, it is effeetual in dispersing them. Some say it is good for scrofula.

\section{HOP.}

Humulus Lupulus.-This plant is well known, and requires no deseription. It is cultivated, and also grows wild.

Medicival Virtues.-Hops are used to impart a bitter farvour to ale and beer. The bitter principle is tonic, the aromatic warm and stimnlating; they are also astringent and slightly anodyne. A pillow stuffed with hops has been found to promote sleep, and a fomentation to allay the pain and irritation of angry tumours. A teaspoontul of the Tincture of Hops will often induce sleep when opium las failed, and without the injurious effects of the drug. Heropliilus Lobbuis says that by a decoction of Hops he has softened the hardest urinary calenli ; and Darelius says that half a pint, or more, of the decoetion, taken in the molning, expels worms. Dr. Thornton says, the IIop merits regard in consumption, disorder's arising from weakness of the prime vix, gont, and especially calculous complaints. They are good to remove obstructions of the liver and spleen, and to cleanse the blood. In cleansing the blood they help to eure scabs, itch, ring-worms, and spreading sores. A brearl poultice well saturated with strong Hop decoction, is a powerful remedy for bad ulcers. IIalf a diachm of the seer in powcler taken in dink, destroys worms. $\boldsymbol{\Lambda}$ syrup marle of the juice and sugnr, cures the ycllow jaundice, and tempers the hent of the liver and stomach. IJops heated in a flannel hag, are a common remety for toothache, and neuralgic pains. 'The Tineture is mirlc by macerating for cight or nine rlays six or seven onnees of ILous in two piuts of proof spirit. Bugin with half a draclum.

\section{IIOREIOUND.}

Warrubium Vulgare.-There aro two kinds of TTosehomal, white and bitek the latter is also caller ILen-bit; but tho white is the one liere recommended. 
Common Horchound has square hairy stalks, half a yard or two feet high, set at the joints with two round crumpled rough leaves, of a sullen hoary green colour, of a moderate seent, but a very bitter taste. The flowers are small, white and gaping, set in a rough, hard prickly husk round the joints, with the leaves in the middle of the stalk upwarls, after which follow sinall round black seed. The plant is well kuown.

Medicinal Virtues. - $A$ decoction of the dried herb, with the seed, or the juice of the green herb taken with honey, is a remedy for difficult breathing, congh, and consumption, through thin distillations of rheum upou the lungs. It promotes cxpectoration of tough phlegm, taken with the roots of Iris or Orris. As a decoction, it is useful in female weakness, removing obstruetions, \&c. The dose is an ounce or two of the expressed juice, or the infusion of half a handful of the fresh leaves in a sufficient quantity of boiliug water. Sweetened with sugar or honey, and a little ginger, it becomes more efficacious. The best part of the plant for medicinal use.is the-tops of the young shoots. It is an exccllent drink in winter for honrseness, coughs, \&c. A handful of the leaves of White Horehound, one of Black and one of Betony in 5 or 6 pints of boiling water is a serviceable drink for gouty and rheumatic subjects. Symup of Horehound is made by boiling a pound of Lump Sugar with the same quantity of a strong deeoction of the leaves, until it assumes the proper consistency, Candied IIorehound is made by evaporating the Syrup until it becomes thick enough, ou cooling, to eat as a lozenge. Galcn says, it opeus obstructions of the liver and spleen. The powder, or the decoction, destroys worms. The green leaves bruised, and boiled in lard, and made into an ointment, is good for wounds. There is a syrup made of Horehound to be had at the apotheearies, very good for old eoughs.

\section{HORSE RADDISII.}

Cochlearia Amoracea. - It is well knowu. It belongs to the Scurvy-grass tribe of plants.

Medicinal Virtuls.-It is a powerful stimulant, whether taken inwardly, or applied outwardly. $\Lambda$ poultiee of the 
scraped root scrves instcad of a Mustard plaister. Its therapeutic cticets arc, diuretic, cmetic, sudorific, and stimulant. It is chiefly administered in paralytic affections, and chronic rheumatism, and in scurvy. As it operates powerfully by urine it is good for the jaundice and dropsy. The decoction is a great purifier of the blood. It destroys worms in children \&c. The root bruised and applied to any part affected with sciatica, joint-ache, \&c. or to hard liver and splcen, gives great relief.

Dr. Cullen says, "I have found that one drachm of the root fiesh scraped down was sufficient for four ounces of water, to be infused two hours in a close ressel, and made into syrup with double its wcight in sugar. A tcaspoonful or two, occasionally repeated, and swallowed leisurcly, is very effectual in hoarseness. As a condiment, it stimulates the stomach, and promotes digcstion. I have known a strong decoction of this root drunk as an emetic, which has relicved pituitous asthma more than by any other means. It should be much used in clict by persons of phlegmatic habits, espccially if afflicted with dropsy.

\section{HORSET $A I L$.}

Description.-Hippurus.-There are many kinds of this plant. As it riscs up, it has heads like those of asparagus, which grow to be hard, rough, hollow stalks jointed at various plnecs up to the top, a foot high, as if the lower parts were put into the upper, where grow on each side a bush of small long rusl-like hard lcaves, cach part resembling a horsc-tail, from whenec it is so called. At the tops of the stalks come forth small catkins, like those of trees. The root ereepeth. It grows in wet grounds. They spring up in $A$ pril, and produce catkins in July.

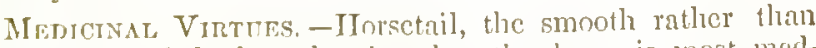
the rough, autl the leavel rather than the liare, is most modicinal. The juice or decoction is very powerlin to stauch blecting cither inward or outwarl, or the juice or distilled water applierl ontwardly. It is astringent, and restrains blooly flux, and hloody wrine; and it heals inward and ontward ulcers, excoriation of the entrails, bladeler, Ec. and soun closes and 
heals green wounds. The deeoction in wine is dinretie and relieves the stonc and stranguary. $A$ small quantity of the distilled water drunk two or three times a day, eases and strengthens the intestines. A drachm of the dried leaves powdered taken three or four times a day, is very effeetual in spitting of blood.

\section{HOUND'S TONGUE.}

Description. - Cynoglossus Vulgaris. - The grent Found's tongue, or Dog's Tongue, has a disagreeablc seent, resembling

The great ordinary Hound's Tongue has many long, and narrow, soft, hairy, darkish green leaves lying on the ground, resembling Bugloss leaves, from which rises a rough hairy stalk, two feet high, with sinaller leaves thereon, and branched at the tops into several parts, with a small leaf at the foot of every branch, somewhat long, with many flowers set along the same; they are small, and of a deep purple. It has sometimes a white flower. The seeds are rough, flat, with a small point in the micldle, easily elcaving to any garment. The root is black, thick, and long, hard to break, and full of clammy juice. It grows in moist plaees, in waste gromnds, and untilled plaees, by highway-sides, lancs, and hedge-sides. It flowers a bout Miay or June.

Medicinal Virtues. The root is principally used, and is rery cffectual in pills, as well as the decoction, to stay all sharp and thin humours from the head into the eycs or nose, or upon the stomach or lungs, and for eonghs, and shortness of breath. The leaves boiled in wine are gond for purgings, retchings, and violent pains in the stomnch and intestines. The decoction reheves the piles, and stops their blecding. The lenes bruised, or the juice boiled in litril, and applied, stops falling away of the hair. The root baket under the culbers, wrapped in a wet double cloth, and applied to the functiment, effectually relieves piles. An ointment made of the leaves with honey and turpentine, makes an excellent ointment for clrcssing old ulcers, sores, \&c. Let the dccoction be drank freely at the same time. I cured the biting of a mad dogr with this only medicine. 


\section{HOUSELEEK, OR SENGREEN.}

Sedum, xel Sempervivum Lectorum.-No description is needed. It grows on the tops of walls and liouses.

Medicinal Virtues. - It eontains malic acid, in combination with lime, and is cooling, astringent, and diuretic. Its thick succulcnt leaves are somctincs applied to burns with success, stings of insects, ulccrs, and inflammatory swellings, and to corns and bumons with good effect. A posset made with the juice of Houscleck is good in hot agues, for it eools the blood and spirits, and quenches thirst; it is good to stay hot and salt rheums in the eyes, the juicc being dropped into them. It is good in Erysipclas, called St. Anthony's fire, and enses the pain of the gout. The jujce takes away warts and corns, the skin and leares being laid on them afterwards; applied to the temples and forchead, it enses the headache, and heat of the brain in ficnzies, or through want of sleep.

\section{HY ACINTH,-WILD.}

IIyraintlus. - The common Wool Ilyacinth is a native of Persia, ant of many parts of Europe. In the spring it is rely common in our woorls, hedges, Se. It is familiarly called, Blue-bells, and the Hattcbell:-

\section{"In the lone copse, or sharlowy rlell,}

Wild cluster'd knots of harebells blow."

Mrnictal Virtules. - It abounds with a slimy juice. But. it is to be carrefinly dricel. The decoction of the roots is diuretic, promoting tle fluw of mrine. The powder is bilsamic, and rither styptic: $A$ more prowerful remedy for the whites caln scarcely be found. It ought to be better kuown.

\section{IIYSSOP.}

IIyssopus O.ficimalis. $-\Lambda$ very pretty garten plint requiring no description.

Medicinal Vimpues.-It shonld be gathered when just 
beginning to flower, dlied, and plaeed in bngs. An infusion of Hyssop sweetened with honey is good for lroarseness, and obstruetions in the breast. Made into a Syrup with honey, it has the same effeet. Some persons add a little Oil of Almonds. It makes a wholesome teal combined with Balm as the prineipal, and a very small quantity of Mint. Hyssop is a vermifuge cxpelling worms from children. $\Lambda$ handful of dried Hyssop in a linen eloth immersed in boiling water, is the best application to a black or blood-shot eye. Boiled with Rue and honey, it relieves eough, wheezing, shortness of brenth. WVith brnised figs it is an easy purgative. It improves the natural colour, spoiled by the yellow jaundiee; and taken with figs and nitre, relieves dropsy and spleen. Boiled with wine it is good to wash inflammations. It takes away black and blue spots eaused by strokes, bruises or falls, applied with walm water. It is execllent for the quinsy, to wash and gargle the throat, being boiled with figs. The hot vapours of the decoetion forced by a funnel in at the ears, ease inflammations and singing noises. It assists to expeetorate tough phlegm, and is effeetual in all diseases of the ehests or lungs. The green herb bruised, and a little sugar, quiekly heals cuts or green wounds.

\section{ICELAND MOSS.}

Cretaria, or Lichen Islandiea.-It belongs to the elass of Lichens. It is a parasite, growing upon the trunks and branches of trees. It is found abundantly in Ieeland, and also in Northern Europe, and amil the higher mountains of North Britain. It is generally sold by Druggists in a dried state. The taste is bitter and unpleasant. The Icelanders use it as an article of food, and denominate it "the grit of a bountiful providenee, alfording them bread out of the very stones." Its preparation is by repeated steepings in cold water, drying, and powdering, after whieh it. is male into cakes, or boiled in milk. Washing, of eourse, leteriorates its tonie properties, though it may retain a part, and all its demulcent and nutritive properties.

Its medieinal virtues in eonsumption have been highly eommended, perhaps too much so ; yet it is unquestionably of much 
Ecrvice in catarrhal consumption, which has its seat in the windpipe and its terminations. It allays the tickling congl, relieves the oppressed breathing, arrests the liective fever, strengthens the digestive organs, it has a soothing influence on the bronchi, and helps to sustain the system by the nutrition which it contains. It may be administered by decoction, by 1 or 2 ounces in a quart of water till it becomes a jelly, adding sugar, and straining. $\Lambda$ wineglassful may be taken twice or thrice a day either alone or mixed with milk. Olasson asscrts that a soup made with the meal or powder is twice as nutritions as that prepared with flour.

\section{IPECACUANHA.}

Cephaelis Ipceacuanha.-It is a Brazilian plant of the order Chinchonacece. The root is nsed, of which there are three kinds, the brown, the grcy, and the white. The brown is the best. $\Lambda$ s an emetic Ipecacuanha is the most ccrtain, safest, and the hest that we have. It is also a valuable expectornnt and diaphoretic remedy, and greatly aids the action of aperients. It has a specific action on the Bronchial mucous membrane, so as to excite its sceretion when too dry ; it relieves the system, and causes perspiration. $\Lambda$ s an emetic it does not nauscatc, and reduce the system so much as Tartar Emetic, nor is its action so irritating as Sulphate of Zinc. $\Lambda \mathrm{n}$ cmetic given at the commenecment of fevers will arrest their course ; and if it fail, it is sure to give to the elisease a mikler form; say from 10 to 20 grains of Ipecacusnha powiler. Dr. Graham Eays, "In closes of two or three grains, repeated every 3 or 4 hours, till it operates by vomiting, sweating, or purging, it is found of grent utility in dysentery and chronic looseness: indecrl its effects in these severe complaints are often invaluable, and it is perhaps the most beneficial aperient in clysentery; for when we can luring it to act in this way, it produces a stearly determination of the peristaltic motion of the bowels durve warls, at the same tine that it strengthens their interial surface, mul reluxes the skin."

Whicre it is necessary to excite namsen and vomiting in children and delicate persons, I]ecencuanha is the best; its expece- 
torant property renders it very useful In ontarrhal affeetions, when it is frequently eombined with squills. In looping cough and in asthma, it relieres spasmodie restrietion, and to clear the ehest of phlegm by vomiting. In spitting of blood it is invaluable, arresting its progress, and preventing its return. In dyspepsia, or indigestion, bilious, and liver eomplaints, it has great effieney.-Dose; of powder, as an expeetorant, from 1 to 2 grains; as a diaphoretic, from 2 to 4 grains; as an emetic, from 10 to 20 grams, aeeording to the age and strength of the patient. The vomiting is promoted and faeilitated by drinking eopiously of warm watery fluids. The Ipeeacuanha Lozenges are useful in eough, and may be taken also to the extent of an emetie, even one or two sometimes being suffieient for that purpose.

The compound ponver, or the eelebrated Dover's Sndorific Powder. I I ecencuanha, in powder, and purified opinm, of each one part; sulphate of potass, eight parts, triturate them together into a fine powder. This powder is one of the most certain sudorifies, reeommended by Dr. Dover as an effeetual remedy in rheumatism; it is useful also in dropsy, and several other diseases, where it is diffienlt, by other means, to prodnee a copions sweat. The dose is from 2 to 5 grains repeated as the paticnt's stomach and strength ean bear it. Aroid much drinking immediately after it, to avoid vomiting before the other effeets are produeed.- "It is a valuable anodyne, sudorific, and alterative, of great serviee in acutc and chronic rhenmatism, and in other eomplaints; it relieves pain, proemes sleep, and relaxes the skin."-It is the best to buy the root, whieh is soon powdered. The wine may be made hy stecping well lualf an ounec of the root, bruised in half a pint of sherry for two or three wecks, and then filtering. Dose; expectorant, 10 to 20 drops; as an emetic, 2 to 4 drehens; for a ehild from 10 arops.

\section{IVY.}

Hedera Helie.-Iry is known by all.

Midicinal Virtues. $\Lambda$ drachm of the fowers decocted in wine, restrains dysentery, or bloody flux. The yellow ber146 
ries are good against the jaundiee; and for those who spit blood, and the white berries being taken inwardly, or applied outwardly, destroy worms. Taken in wine, they help to break the stone, provoke urine, and women's courses. The fresh leaves of Ivy boiled in vinegar, and applied warm to the sides of those who ale troubled with the spleen, ache, or stiteh in the sides, give much ease. The same applied with Rose-water, and oil of Roses, to the temples and forehead, eases the headache. The leaves boiled in weak wine form an exeellent wash for uleers, sores, burns, sealds, \&e. The juiee of the berries or leares snuffed up into the nose, purges the head and brain of rheum, which eauses defluxions into the eyes and nose; the same dropped into the cars, cures sores therein. The fresh leaves applied to corms and bunions effectually eure them. Intoxication by wine, the effeets are removed by a handful of leaves bruised, and gently boiled in wine, and the liquor drank.

\section{JALAP.}

Convolvulus Jalapa.-It is a plant of Mexieo and Vera Cruz. The root is used. Half a drachm of Jalap proves an effectual, and in gencral, a safe purgative, operating mildly. But in hypochondriacal disorders, and in hot bilious temperaments, it gripes violently, if the jalap be good, and rarely takes due effect as a purge. The best form for its administration is the compounrl powder, composed of jalap in powder, 3 ounces, eream of tartal, 6 ounees, and ginger, 2 drachms, well rubbed up together; - dose, half a drachm to a drachm.

Jalap accelcrates the action of rhubarb, and in this form it expels worms. Some, for that pmpose, add a little calomel; but powdered Wormwood would be better. In rleumatism jalap is an excellent purge. When triturated with sugar, in small rloses, it is a safe purge for children; they will receive it in this way, the jalap having but little taste.

\section{JUNIPER BUSII.}

Trriperis Communis.-It is needless to give a deseription of a bush so eommonly known. 


\section{JUNIPER BUSH.}

It grows plentifully in several woods in Kent; Warney Common, near Brentford, in Essex; 11pon Finchley Common, Newfund wells, near Dulwich, upon a common between Mitcham and Croydon; and other places. The berries, however, are ehiefly brought from Holland.

The berries continue green two Summers and one Winter before they are ripe, at which time they are of a purplish black colour, and therefore you will always find upon the bush green berries.

Menicinal ViRTues. - The berries have a strong aromatie odonr peculiar to themselves, and a flavour much like that of turpentine. They are aromatic, stimulating, diurctic, and diaphoretic, and are ehicfly cmployed as a combination witk other remedies, and to increase the diseharge of urinc in dropsy. The oil of juniper is an effertive expellant of wind, and it quiekly relieres eolie. It is a good stomachie. An infusion of the berries will have a similar effeet; say a pint of boiling water poured on 2 or 3 ounces of the berries, taking a eupful every three hours. From 6 to 12 berries eaten will have a similar effect. They are very good for a eough, shortness of breath, and pains in the belly. They are good in all kinds of agues, are good for gout, seiatiea, and they give strength to the limbs. The ashes of the wood make an excellent dentrifiee for scurvy in the gums. They are useful in dysentery, stone, and diseases of the kidneys.

The essential oil of Juniper is a prime ingredient in Genera or Hollands Gin, and upon which its flavour and diurctie properties depend. English Gin, however, has more of turpentinc than of this oil in it. - The dose of the oil is from 3 to 6 drops.

\section{KIDNEYIVORT.}

Descriptron.-Cotylentom Umbilicus. - It is also eailed Nisel Wort, Wall P'eningreyal, and Wall Pemport. It has many thick, flat, and roind leaves growing fron the root, each having a long footstalk, fastened underneath, about the middle 148 
of it, and a little uncvenly wcaved sometimes about the edges, of a pale green colour, and rather yellow on the upper side like a sauccr; from which arise onc or more smooth, hollow stalks, half a foot high, with two or thrce small leaves thercon, rather long, and divided at the elges; the tops are divicled into long branches, bearing a number of flowers, round a long spike one above another, which are hollow like a little bell, of a whitish green colour, aftcr which come small heads, containing small brownish seed. The root is round and smootl, greyish without, and white within. It grows upon stonc or mud walls, upon rocks, and in stony places upon the ground, at the bottom of old trecs, and on those that are dccayed. It fiowcrs in May.

Medicinal Virtues.-The juice and the extract are reputed for the cure of Epilcpsy. The juice allays inflammations and heat of the liver, stomach, and strengthens the bowcls. The juice of the herb outwardly applied restrains St. Anthony's fire. or erysipelas. It heals pimples, sorcs, \&c; and taken inwardly it relicves inflamed kidneys, and is good in all gravelly complaints. Made into an ointment, it is good for the piles, for gouty pains, sciatica, and swcllcd testicles; the ointment, or the juice alonc is good for scrofula sores, clilblains. It stops the bleeding of green wounds.

\section{KINO.}

This is an extract obtainerl from several trecs of the genus Pterocarpus. It has becn regarded as the most powerfit of all the regretable astringents, contrining $70 \mathrm{per}$ ecnt of tanuic acirl. Hence it has becn found eminently useful in diarrhoa, dysentery, gonorrhoca, leucorrhoca, internal blecdings, and discharges fencrally. Externally, it is a good application to loul ulecrs. It makes an execllent garorlc for sore throats, and discascl uvula. It is usefinl as a styptic. The lose ol the powder is fiom 12 grains to 1 drachin; of the tineture froul one to two rlasclıms. 'llie compound powele contaius one sranin of opium to 20 grains of Kino; - take from 10 to 20 grains.- 


\section{KNAPWEED.}

Description.--Centaurea Jacca.-It has many long and rather broad dark green leaves, dented about the edges, sometimes a little torn on both sides, and rather hairy; amongst which arises a long round stalk, four or five feet high, divided into many branches, at the tops stand great scaly green heads, enclosing a number of dark purplish red thrums or threads; which after they are withered, come blaek sceds wrapped in down, resembling thistle-seed, but smaller. The root is white, hard, and woody. The flowers appear in Jume and July. It is found in fields and mcadows, and on the road sides.

Medicinal Virtues, - It stays dysentery, or bloody flux, blecding at the nose, and inward blecdings. It is good in catarthal affections, restraining distillations of thin and sharp humours from the head upon the stomach and lungs. It is strongly recommended for cuts and bruises, and running sores, as it dries them up, and heals them gently. It may be taken in decoetion, or be made into an ointment for outward application.

\section{KNOTGRASS.}

Description.-Polygonon.-A vely common wild plant growing in fields, pathways, and hedges. The stalks of finotgrass are ten inches long, round, jointed, and of a dusky green. The leaves are oval, of a bluish green, not indented. The stalks lie upon the ground, and only one of these grows at cach joint. The flowers are snall and white, with a slight red tinge.

Medicinal Vintues. - $\mathrm{It}$ is an excellent astringent. Tho juice is effectual to stay bleeding of the month, drunk in stecled or red wine; and blecding at the nose, to be applicel to the forehead or temples, or to be squirted up into the nostrils. It cools the blood, and the stomach. It restrains bloody flux, profuso menstruation, and ruming of the reins. It is useful in that distressing complaint strangury, proroking urinc, and easing pains in the bladder, and it is :me cxpellant of stone, ste. Take a drachm of the herb powdered in wine, twice a day. Tho decoction destroys worms. A decoction of the roots, stalks, 150 
and leaves, is a first-rate astringent, applicable to all bleedings, and especially to the blecding piles; and the juiee made into an ointment, it is a sovcreign remedy for inflammations, breakings out, hot swellings and im posthumes, gangrene, canker, and green wounds. The juice is good for sores in the ears.

\section{KOUSSO.}

The dried flowers and unripe seeds of the Brayera Authelmintica, obtained from Abyssinia. It is a most effieient cure for the tapeworm. Dr. S. Thompson says, "In two cases which had resisted all previous treatment, I found the Kousso perfectly suceessful." It should be taken in the morning fasting; no solid food to be taken for 24 hour's before taking it, and a doso of eastor oil administered the previous evening. Half an ounco of the powder must be taken, which must be infused in warm water, and taken unstrained; it will be more palatable with honey and lemon juice; and if it does not operate in 10 or 12 hours follow with a dose of eastor oil. It is very seldom that a seeond dose is required; if it is, repeat in a day or two after the first, taking only very simplo food.

\section{LADIES' BED STRAW.}

Description.-Galium Verum. - It is also called Cheese Rennet, because it performs the samo offee as Rennet; Maid Hair, and Wild Rosemary. Galium Verten. It grows in meadows and pastures, and by hedges. It riscs up with small, sometimes it branches forth into divers parts, full of joints, with several very small leaves at evcry one of them. $\Lambda$ t the tops of the branches grow very thickly many yellow flowers from the sevcral joints, which eonsist of four leaves cach, which smell strong, but not unplcasant. The seed rescmbles poppy branches bend to the tround, having many small fibres. Tho which it is increased. 
There is another kind whieh bears white flowers; but the branehes of this are so weak, that, unless supported by the hedge, \&re, it lies on the ground. The leaves are larger than the former, but the flowers are not so numerons.

Medicinal Virtues. - This herb possesses very great virtues. It is a popular remedy for hysterieal eomplaints and epilepsy, and has been given in inflammations of the brain, as an infusion, made by pouring $1 \frac{1}{2}$ pints of boiling water on 2 drnehms of the herb, taking a wineglassful several times a day. The deeoetion is good to dissolve stone, to provoke urine, to stop inward bleeding and bleeding at the nose, and to heal inward wounds. The herb and its flowers made into an ointment, by boiling with sallad oil, and adding a little wax, then straining, is a remedy for burns and sealds, and espeeially for serofinlons sores. The deeoetion of the herb and flowers refreshes the feet after long walking. The ointment removes the dry seab and iteh.

\section{LADIES-MANTLE.}

Description.-Alchemilla Vulgaris.-It is a beantiful plant, eommon in gravelly fields, and by road sides. It has many beautiful broad romdish leaves, divided into eight parts, eneh prettily indented at the edges. They are of a yellowish green eolour, nearly as broad as the palm of the hand. They look plaited at first, and then a little erumpled, a little hairy, as is the stalk also. The stalks are round, eight inehes long, or more, not very upright, and of a pale green eolour. The flowers stand abundantly at the top, and they are white, proeeeding fiom small yellowish green hends. The root is long, thiek, and dark eoloured. It flowers in Mray and June.

Menicinal Vintoes.-Ladies-Mantle is very proper for inflamed wounds, and is very effectnal to stay hleeding, romitings, fluxes of all sorts, bruises, and it relieves ruptures. Some females apply the lenves to cnlarged breasts, in order to remee them, and give them their proper form. As a decoetion it is useful in eoneeption, ly its retentive influence. It is a most valuable wound herb; highly prized by the Germans, who nse 152 
it in all inward and ontward wounds. They drink the decoetion, and wash the wounds with it, and it effectually heals them. The herb and the root powdered, is good for violent purgings.

\section{LADIES' SMOCK.}

Description.-Carlamine Pratensis. It is also ealled Cuckoo-flower. It is a beautiful wild plant, fiecuent in meadows in Spring. The root is eomposed of many small white threads, from whenee spring long stalks of winged leaves eonsisting of round, tender, dark green leaves, set one against another upon a middle rib, the greatest being at the end, amongst whieh rise up weak, round, green stalks, streakerl, with longer and smaller leaves upon them; on the tops of which stand flowers almost like the Stock Gilliflowers, but rounder, and not so long, of a blushing white colour; the seed is reddish, and of a sharp biting taste, and so also the herb.

Mraicival Virtues. - The plant has the same virtues as Water-Cresses, and is good for the senrvy. It provokes urine and breaks the stone, and warms a cold and weak stomaeh, restoring lost appetite, and promotes digestion. It is very useful in jaundice, and green siekness.

\section{LAVENDER.}

Description. - Lavendula Tera.-- It is a wgll-known, small, shrubby, perennial plant, a native of the South of Euope, and eultivated in our gardens for the sake of its perfume.

Mencinal Virtues. - Its flowers contain a volatile oil, obtaincl by distilling. It is warm, aromatic, and earuinitive. It is used as a stimulant in dobility, lowness of spinits, and other nervons affections. It invigemales the stomach, and removes obstructions from the liver am spleen. The oil is good for toothache. The distilled water removes houpseness, liss of voiee, faintiugs, tremblime, \&e. Jt removes ulstruct ion of urine, and tatuleney. The Oil and also the Compound 'Tincture may 
be obtained at the shops; the latter preparation is known by the name of "Lavender Drops," which are very useful in languors and faintings. It is a useful addition to stomachic infusions, as infusion of gentian, cascarilla, \&e. The oil of Lavender, with equal quantities of Lard and Butter of Cocoa, makes a good application to stimulate the growth of the hair.

\section{LEADWORT.}

Description. - Plumbago Europon-This is a small garden plant, growing two feet high. The stalks are slender, tough, yet weak, not able to support themselves. The leaves are a pale bluish grcen colour, oblong, but not brond, growing round the base of the stalk. The flowers are red, very small, in thick oblong elusters, standing on the tops of the stalks.

Medicinal Virtues. - Every part of this plant is acid, particularly the root; which when chewed excites a flow of saliva, and it has been recommended for toothache. Slightly boiled in Olive oil it is a suecessful application for the itcl, old uleers, and cven cancers. It is excellent for headache. It is more aerid and fiery than even Pclitory of Spain. It makes a first rate rubefacient for pained limbs.

\section{LEMON.}

Citrus Communis.-It is eultivated chiefy in Frnee, Spain, Italy, Sicily \&e. It is common in the green-houses of this country. The aeidity in the juice is owing to the presence of Citric $A$ cid, the most agreenble acid for eftervescing dranghts. Lcmon juice is a powerful and pleasant antiseptic. Dr. Wright says, its powers are much increased by saturating it with Muriate of Soda. This mixtme he recommended as very efficacious in dysentery, remittent fever, bellyache, putrid sore throat, and as being perfectly specific in diabetes.

Citrie $A$ cid is often suceesfully used for allitying romiting ; it is mixed with carbonate of potish, from which it expels the carbonate aeid with eflervesecnce. It should be drank as soon 
as it is male; if not it wonld do harm instead of good. The doses are about a seruple of the earbonate dissolved in eight or ten draehms of water, and an ounee of lemon juice, or an eqnivalent quantity of Citrie Aeid. It is one of the greatest sick-room luxuries that we know; it is of great use in allaying febrilt heat, and thirst.

The ehief medieal use of Lemon-juice has hitherto been in seurvy, in whieh it is a eurative medieine, and a preventive; and therefore it is most useful in long sea-voyages. The best way to preserve it for keeping, is to add to it about one-tenth of Spirits of Wine, whieh eoagulates the gummy matter, whieh would be likely to eause fermentation; and it should therefore be seperated from the elear juiee by straining. A little of it should be taken every day when at sea, when fresh vegetables eannot be obtained, during the use of salt provisions. Limejuiee is sometimes used as a substitute, but with less effeet.

Latterly, Lemon-juiee has been employed for the eure of gout and rhenmatism with great sueeess. The author has reason, from his own experienee, to speak favourably of its remedial power in rhenmatie fever. The dose is half an ounee every half hour, or hour on an empty stomaeh. Besides being antiseorbutie and antiseptie, it is tonic and diaphoretic. As a tonic, it forms with Orange peel an ingredient in the Compound Infusion of Gentian.

Lemon-juiee also eounteraets the effeets of Opium.

"Srlts of Lemon," sold for removing the stains of ink or iron from linen, is wrongly named; for it is a salt of Oxalie Aeid, and a rank poison.

\section{LENTIL.}

Ervum Leme. - Ientils belong to the Pea tribe, and are used as foorl all over the sonth of Europe, in the East, anrl in Firyut. The flour is very wholesome ancl mutritious, and I) r. Playfair found that it eontained more nutritious matter tlusn any other Pea or Bcan meal. In ardition to their rice the IImulnos take Lentils when engraged in hard lalsoul. The Egyptian Lentil meai known as Picvalenta and Ervalenta Arabica is very 
nutritious, easy of digestion, and possesses aperient propertics, and thereforc very suitable for the diet of invalids, especially for the dyspeptic.

\section{LETTUCE,-GARDEN.}

Lactuca Sativa.-As an article of diet, Lettuce is extensively cultivated in the kitchen garden. The botanical name, Lactuca, from Lac, milk, is given on account of the milky juice which exudes from the plant when cut, this milky juice turns brown, and dries on exposture to the air, and is then called Lactucarium, or Lettuce-opium. It is marcotic, but less powerfully so than opium, and it does not confine the bowels as that gum is apt to do. It is recommended in phthisis and eatarrh. It is given to ease eoughs, and to proeure sleep; the dose is from 1 to 6 grains.

The juice mixed with oil of roses promotes sleep, and relieves headache. It is gently aperient, and aids digestion. It is also a good applieation for inflamed parts.

\section{LE'TTUCE,-WILD.}

Lactuca Virum. - It is found in many parts of Britain, in hedges. It resembles the Garden Lettuce in its flowers, though not in the manuer of its growth. It rises four or fre feet, and has three different kinds of leaves. They are very large, a foot long, and five inches broad, of a pale green colour. Those procceding from the root are slightly toothed; those from the stcm are cut into pinnated lobes; and those attached to the flower-stalks are arrow-shaped, pointed entire, and minute. The flowers are pale yellow.

Medicinal Virtules. - An extract prepared from the expressed juice of the leaves; gathered when in flower, in small doses is good in dropsy ; two gruins at hist, twice a day, and gradually increased till two scruples, or more, are given laily. In dropsies of long stauding, proceding from viscerinl obstructions, it has been given to the extent of lalf an ounce a day. A syrup made from a strong infusion of it, is a good anolyne; 156 
it cascs the most violent pain in eolics, and other disorders, and gently disposes to slecp. It is said to agree with the stomach, to quench thirst, to be gently apericnt, very diuretic, and rather diaphorctic. Plentiful dilution must be allowed during its operation. Dr. Cullen, of Vicnna, asscrts that out of 24 dropsieal patients, all but onc werc cured by this medicine.

\section{LILY OF THE VALLEY.}

Descriptrox.-Lilizm Convallium.-It is also called Male Lily, and Lily Confaney. The root is small, and erceps far in the ground, as grass roots do. The leaves are large, long, and broad, of a dark green colonr and fill of very thiek ribs and veins, from which rises a stalk half a foot high, with many white flowers, like little bells with turned cdges, of a strong, thongh pleasing smell; the berries are red, not much unlike those of $A$ sparagus.

Menicinat Virtues. A deeoction of the flowers is said to be usefu! in removing obstructions in the urinary canal. Powdercd, thcy are serviccable in headachc, earaehe, and apoplexy. But they must not be used when there is a tendency to inflammation of the brain. Mixed with lard it strengthens the spinc. Equal quantities of the leaves, and of the lcaves of marjoram, and 12 drops of the essential oil of marjoram, form an excellent cephalie snuff. The distilled water dropped into the cyes, helps inflammations there, as also that infirmity which they eall pin and web. The spirit of the flowers distilled in winc, restores lost speceh, helps the palsy, and is excceding good in the apoplexy, it eomforts the hcart and vital spirits. Gerrard 8nys, that the flowers being close stopped up in a glass, put into an ant-liill, and taken away again a month after, you shall find a liquor in the glass, whieh bcing outwardly applied, helps the gout.

\section{III,Y, - W ATER.}

nf these there are two kinds, viz. the White and the
Yellow 
Description.-Nymphoea Alba.-The White Lily has very large and thick dark green leaves lying on the water, sustained by long, and thick foot-stalks, arising from a great, round, and long tuberous black root, spongy or loose, and internally white; from which rise other similar thick green stalks, sustaining one large flower, green on the ontside, but as white as snow within, consisting of several rows of long, thick and narrow leaves, encompassing a head with many yellow threads in the middle. The seed vessel is large and roundish, abounding with sceds.

The Yellow kind is little different from the former, save only that it has fewer leaves on the flowers, greater and "more shining secd, and a whitish root both within and without. They grow in pools and standing waters, and in slow rumning rivers, and ditches of water.

Medicinal Virtues. The fresh root is the part chiefly used, given in a strong decoction. The leares and flowers are cold and moist, but the roots and sceds are cold and dry. The lcares cool inflammations, and the heat of agues; and so do the flowers, either in syrup or conserve. The secd is effectual to stay fluxes of blood or humours of wounds, and severe purgings. But the roots are more effectunl to restrain all fluxes in men and women. Its frequent use extinguishes venerous actions. The root is likewise rery good for those whose urine is hot and sharp, to be bolled in wine and water, and the decoetion drank. The distilled water of the flowers has the same cffect taken inwardly, or applicd outwardly ; and it is said to take away freckles, spots, sunburn, and morphew from the face, and other parts of the body. The oil made of the flowers, as Oil of Roses is made, is profitably used to cool hot tumours, and to ease painful sores.

\section{LILY,-WHITE.}

Lilium Album IIortense.-This is a well known garden flower, needing no description.

Mledicinal Virtues. - This plant is good in pestilential fevers, the roots being bruised and boiled in wine, and the decuetion 158 
drank; for it expels the venon to the exterior parts of the body. The juice being mixed witl barley-meal, baked, and caten for ordiuary bread, is an excellent curc for diopsy. An ointment made of the root and lard is good for seald heals, and for elcansing ulecrs. The root roasted, and mixed with a little lard makes a gallant poultiee to ripen and break plagne-sores. The ointment will curc burnings and scaldings without a sear and trimly dock a blank plaee with hair.

\section{LIME TREE.}

Tilia Europora. The Linden or Tcil tree, common in parks and in some gardens. Tlie trunk is thick, the branclies pretty regular, the leaves short, broar, nearly round in figure, pointed, and serrated at the elges. The flowers are yellowish white, of a sweet sincll, and delicate.

The flowers are useful in Epilepsy and nervous fevers, made into a decoction or infusion; they are uscful in asthma and irritable coughs. The tree, and especially the inner bark abounds with a soft mucilage, which is very uscful in burns, scalds, and gouty swellings. The leaves powdered, and half a drachm taken in treaclo, or in tea, subdues urinary lieat and inflimnmation.

\section{LIQUORICE.}

The root of the Glycyrrhiza Glabra.-It grows wild in many countries, and is eultivated in some parts of England, as Pontefract, \&e. Its virtucs are very great. It is tlic principal constituent part in Spanish Juice, or Spanish Liquorice. Its demuleent properties render it very usefinl in coughs and bronchial irritation, and in some stomacl complaints, arising from a deficiency of the natural nucus which slond defend the stomacl against the acrinony of the fored, and the fluids secreted in it. It is also wsed in learlourn, and may le taken in cont-

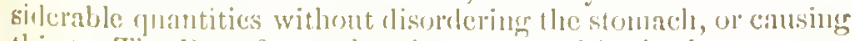
thirst. Tlic I'ontefract cakes, lozenges, and liatl-p)ipe, are very useful in coughs, chortness of breatli, and hombenetss. Liquorice 


\section{LIVERWORT. LIVERWORT,-Ash ColOURED.}

nIso works gently by urine, and is very soothing to uleerated kidneys or urinary passages. The extraet is employed to eover the taste of nauscous drings, as aloes, \&e. The powdered root is mueh used.

\section{LIVERWORT.}

Description. - Lichen Vulgavis.-Botnnists reekon on upwards of 300 spceies of Liverwort.

Common Liverwort grows elose, and spreads mueh upon the ground in moist and shady plaees, witl many small green leaves, or rathel stieking flat to one another, very unevenly cut in on the elges, and errmpled; from among which arise small stender stalks an inch or two high at most, bearing small star-like flowers at the top; the roots are very fine and small.

Medicinal Virtues.-It is a singular good herb for all disenses of the liver. It is to be given in strong decoetion, and is very effeetual in yellow jamndice. Bruised and boiled in small beer, it has the same effeet. It is a good remedy for diseased kidneys, the whites, and very nppropriate in the first stages of eonsumption. It is good to stay the spreading of ringworms, and other ruming sores and scabs, and is an exeellent remedy for those whose livers are eorrupted by surfeits, which canses their bodies to break out, for it fortifies the liver, and makes it impregnable. It grows on old walls, in wells and other damp plaees.

\section{LIVERWORT,-ASH COLOURED.}

Lichen Canimus. - It spreads on the ground, eonsisting of a leather-like substance, asli-coloured, and appears as if eovered with farina, divided into lobes, woolly underneath, and reined. It is found in dry pastures, woods, and on lienths.

It has heen user for the bite of a mad dog, enting in hydrophobia. It was eombined with black pepper, one prot of the latter to two of the former. By the antlority of Sir Hans Sloane, it was pulylished in the l'hilusopluical 'T'amsactions, and afterwards, at the regutest of Dr. Mend, it was adopted in tho London Plarmacopocia. 


\section{LOBELIA.}

Lobelia Infuta.-It is a native of Ameriea; where it is much nsed as medicine, its nse having heen derived fiom the Indians. It is recomnended for spasmodie Asthma. In small doses it is a gnod diaphoretie, and ex]ectorant ; in large doses, it is antispasmolic, sedative, and emetic. Sometimes it is of extraordinary efiricacy in $\Lambda$ sthma, and if other preseriptions have failed, this has been found effiencious. The tinetnre is the form in whieh it is nsed, which is made by digesting for a few hours two ounces of the dried plant in a pint of diluted spirits of wine. A tea-spoonful taken in water, to be repeated three times a day; or the powder from + to 10 grains, beginning with the smallest, and gradually increasing, in plenty of warm watel:- 1 Always eomnence with small doses.

\section{LOGWOOD.}

Homatorylon Campechinnum, or Logwood, is used medieinally in the form of iccoction, and Extract, for diarlloea, or looseness, and dyssentery, or bloody flux. It atets as an astringent, without irritating the conts of the stomach. For extreme diarthoa, Logwood decoction, a tew raspberry leaves, and a few drops of Laudanum, will effeet a eure.

For the ordinary decoetion, Buchan says, "Boil three ounees of the shavings or ehips of Logwoorl, in four pints of water, to one half; two or three onnees of Cinnamon water may be alded. In fluxes of the belly, where the stronger astringents are improper, a tea-cupful of this recoction may be taken with great advantage three or four times a day.

\section{JOOSESTRTEE,-PURPLE.}

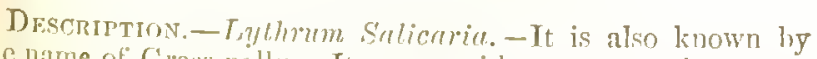
the name of Grimss-polly. It grows witl many wortly anturare stalks finll of joints, three fect lighl, on each stind fwo longs leaves, shorter, natrower, and a greener colonl than the former. The stalks branch into long stersis of spilied flowers half a lout 
long, growing in bundles, one ahovo another, out of small husks, like the spilicd learls of livender, ench of which flowers hate five round pointed leaves of a purple violet colonr. The secols ate small and brow. 'The root ereeps like the yellow, but it is larger. It grows by rivers, and diteln-sides, in wet grounds. It flowers in June and July.

Minicinal Vintues. - For prescrving the sight, and for the cure of sore eyes, this herb is fully, if not styerine to Eychright. This I have found by experience. The distilled water is a present remedy for hurts and blows on the eyes, and for blindness, provided the erystalline humour be not injured or destroyed. This was experienced by an intelligent man, whokept it long as a great secret. It clears the eyes of clust, or any thing got into them, and preserses the sight." It is also very arililale against wounds, made into an ointment. To erery onnce of water, and two drachms of May lontter without salt, sngar and wax of cach as much, boil them gently together" after it is eohl, apply it on cloths to the wonnels. It cleanses and benis ulcers ancl sores, and strys infanmations, by washing them with the water, and laring on them a greenl leaf or two in summer, or dry leaves in Winter. The water sarghled warm in the mouth, and clrank, emres the cininsy, or serofula in the throat.

The Irssop-Lasaven Purl'ue Loosfotrife, is much like the former, and its virtues are about the sane.

\section{I,OOSESTIRIFE OR WIHLOWIIERB.}

Descmintion - There are three kinds of Loosestrife; the yellow, the Ilyssop-leaved, and the purple speel:led. 'llhe common yellow Loosestrite, Lysimaclial l'utgeris, grows about five feet high, with great romml stalks, a little crested, diwersely branclied fiom the mindalle of them to the tops into greit anc long branches, on which, at the joints. wrow longer ant ninrow

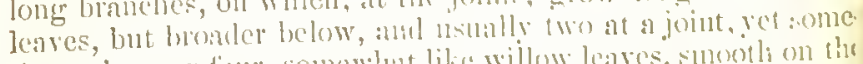
times three or fonr, somewh hat like willow leares, smoctlo on the

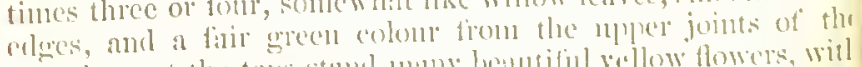
hranches, at the tops stanl many hemutiful yellow flowers, witl yollow thremts in the middle, which turn into small romul honds

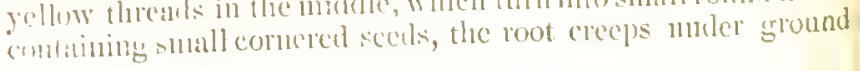




\section{LOOSESTRTE OR WILLOWHERB. LOVAGE.}

nlmost like eonch-grass. It grows in moist mendows, and by water-sides. It flower's from June to Angust.

Medichan Virtes. - This herb enres blecding at the moutl, nose, or "wounts, alid the bloodly flux, given either to drink, or talicu by clusters; it restrains profinse menstruntion, and is a very good wound-herb; the young leaves bruiserl ans bound about a fresh wound, stay the bleeding, and quickly close together the lips of the wound. It has demuleent and astringent virtues, which render it useful in invetcrate diarrhea.-Dose of the powdered herb, I drachin three times al day ; of the decoction 1 ounce of the herb boiled in a pint of water; take 2 ounces at a time. It is often used in garghing for sore moutlis, 'The smoke of the herb bumed, drives away flies and gonats, which in the night-time molest people dwelling near marshes, and in fenny countries.

\section{LOV $\triangle \mathrm{GE}$.}

Descruptiox. - Ligusticum Oficinalo.-It is a salad plant, having a strongr and peculiar odour, 'The stalk is roumd, llick, and loollow, indel aleoply striated or ehanneller. The leares are very large, caclu lecing composed of a mumber of smatler; these are set on a dividerl stalk, and are slort, broand and indented at the edges. The flowers are small and yellew; the seeds are flat anrl lrown. 'The root is thick, lange and brown, laving
many fibres.

Mlideinat. Viritriss. - The roots and fruit are aromatie, stimulaut, and elialduretie, ansl may be used as remedies for

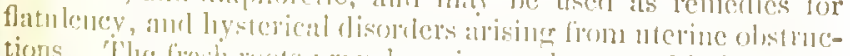
timss. Whe forth rests provole urine, ancl are goesl in jannlice. As they are surforific, they are goorl in ferers. Hall a clatclun at a tine of the dried root in pownter taken in wine, wonderfully wantss at eold stomach, and promotes dighestion. It relieves inwarel gripinge and pains. The decoction of the herb is good for the angue, ant to case pains in the luwels cansed by cold. The secerl is still more eflectual. 'Jle rlistilled water or

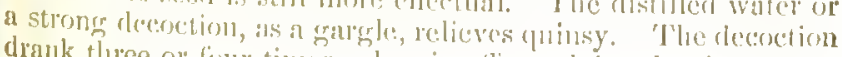
drank three or four times a day is eflectual in pleurisy. 'T'lo 
juice applicd to the eyes takes away inflammation. The leaves bruised, and fried with a little hog's liard, and laid hot to any blotch or boil, will quickly break it.

\section{LUNGWORT.}

Description.-Pulmonaria officinalis. - It is fomd in gardens. The stalk is alout a foot ligh. The fowers lranch out at the tops of the stalk; they are generally red before they expand ; afterwards they are of a blue colour.

Medicinal Virtues.-It deriyes its name from its supposed efficaly in discases of the lungs. It is mucilaginous and rather astringent, and is regrarded as cmolient and pectoral. It is good therefore for coughs, wheczing, and shortuess of breath. Haller says that its viscous juice, possessing some acidity, is very usefill for dryness of the throat, for congh accompanicd with spitting of blood. An infusion is the best way of taking it.

\section{MADDER.}

Descrtption. - Rubia Silvestris. It has many long weak four-square, recidish stalks, trailing on the ground, rongh and hairy, and full of joints: at every one of these joints conve forth diver's long and narow leaves, standing like a star abont the stalks, rough and hairy, at the tops come forth many small pale yellow flowers and then small romd heads. green at first and reddish, but black when they are ripe, wherein is contained the seed. The root is long, and decp in the gronnd, red and very clen" while fresh. It grows in confields, and flowers at the end of summel.

Mendcinal Vhitues. It has an onening quality, and afterwards binds and strengthens. It is a sure remeily for the yellow fanndice, by removing olstruetions of the liver and galt, and eleansing those parts; and also olsitructions of the splecn. It is good for palsy and sciatica, and for inwallel and ontwatd bruises, and is much wed in vilucrity drinks. The root may be boiled in wine or water, as the camse requires, and sono loncy and sugar added. The seel taken in vinegar and 164 


\section{MAIDEN HAIR,--Golden, AND White.}

honey, reduecs the swelling and hardness of the splecn. The leaves and roots beaten and applied to any part that is discolonted with freckles, or auy such deformity of the skin, takes them away.

THE DYE MADDER, Rubia Tinctora, is chicfly ralued for the excellent dye which it furnishes. This plant has been said to possess the same properties, to be diuretic and an cmmenagoguc, and was formerly much used in dropsy, jaundice, and female complaints.

\section{MAIDEN HAIR,-GOLDEN.}

Description.-Adiantum Aureum.-It has many small, brownish, red hairs to make up the form of leaves growing about the ground from the root; and in the middle of them, in Summer, rise small stalks of the same colour, set with very fine yellowish green hairs on them, and bearing a small gold, ycllow head, less than a wheat coln, stancling in a large husk. The root is rery small and thready. It grows in bogs and on moors, and in dry shady places.

Its Medicinal Virtucs are much the same as those of the Whitc Maiden Hair. It makes an execllent wash for the hair, cleansing it, and promoting the growth.

There is also a Black Maiden IInir, Adiantum Nigrum. It is like the Common Fern of the divided kind, only very small. It grows nearly ten inches high. The stalks are thick and glossy, and black. The leaves are beautifully divided into mary parts, of a short bright green, and notched at the edrges. The seeds lie on the elges of the under part of the leaves in form of a brown clust.

Its Medicinal Virtues are similar to the other Maiden IIairs. A decoetion of it works powerfilly by urine. It relicves a troublesume coughls.

\section{MAIDEN IIAIR,-WIITTE.}

Description.-Adiantum Album.-It is slso called Wall Rue. It is gatliered by clitelien nnder the name of Linlios' 
Hair. It has very finc, pale green stalks, almost as fine as hairs, set confusedly with sereral pale green leaves on rery short foot-stallss, somewhat in form, bnt more diversely ent in on the edges, and thieker, smooth on the upper part, and spotted finely underneath. It grows on old walls, near ruins, and dry places. It is green in winter as well as in summer.

Medicinal Virturs.-A decoction of the herb is a good remedy for coughs, difliculty of breathing, yellow jaundice, and obstruetions of the spleen, and mine. It is rery effectual in removing stones fiom the kilneys, and in obstricted menses. It restrains internal bleedings and fluxes. A decoution of the green leaves is aperient, removing barl bile, and tough phlegm, from the lungs and the liver. It purifies the blood, so as to give to the body a good eolour. The herb boiled in oil of cammonile, removes knots, swellings, and dries np moist ulcers. A ley made thereof eleanses the head from eculf, and from dry and ruming sores; it prevents the hail from filling off, and causes it to grow. For this purpose some boil it in wine, adeling a little Snallage, and a little wine.

\section{MALLOW, - COMMON.}

Dracinption. - Malva Sylvestris. $\Lambda$ wild plant growing ahout hedges, in fiekls, and gartens. It grows thece ol four feet high. The stalk is romul, thick, and strong. The leares are roundish, indented, and divided, at the edges. The fowers are numerous, round, and red. The root is long aud white, tomgh and fim.

Medrelnat Virturs.-The root has most virtue. Tho laves are used in deeotion for elysters. The decoction mate stromy is excellent to promote nine, and to cure str:mermy and gravel, and tor remoring shatp humoms from the bowels.

'The VERV AIN MALLOUV is commom in pastmes. It grows two feet high; the stallis are romm, thel, erect, amd a littlo havy. The luwer leares ane rommlet and sli-htly divided at the certys; those on the stalks ale beantilully cut into very stall palls. The flowers alle of a very brithe led, thee times the size of the Common Mallow. The root is white. The

\section{6}


root is usel. It has the same virtmes as the Common Mallow, thotgh not quite as strong. The leaves lave the same ellect.

\section{MANDRAKE.}

Description. - Atropa Mandugora.-It is an exotic; bue began to be enltivater in England, 1560. Superstition has said much about it. Its root sometimes dividing into two below and shooting on each side, give a rescmblance to a man, and aided by art, this rescmblanec became so complete as to deceive the multitude. It was sairl to be death to dig up the root; that sercans were beard when these became wounded; and that they were to be drawn ont by a dog, which perisled; ant in this way only could they be extracted. $-\Lambda$ s an amulet, it was onee placed on Miantel-pieces to avert misfortunc, and to bring prosperity and happiness.

The Mandrake has no stalk; the large leaves rise immediatcly from the root, a foot long, fonl inchies broad, of a dusky green colour, and disagrecable smell. The flowers stand upw foot-stalks four inches high, slender and hairy, and rise inmediately from the root; these flower's atre linge, of a dingy pulpish colour, and of a bad smell. The fruit is of the size of a small apple, like a small pear, ycllow when ripe. The root has been described. By designingr people the roots are taken up, sliaped like a man, and then put back to grow, and thus people are deccived.

Mejicinal Virtues.-It is narcotic, and soporific. Some say that even the smell of the plant prorluees slecp. It was employed by the ancients in maniacal eases, and Panlins mentions its frequent tose in Arealful chronic disorrlers which require alleviation by some powerfinl druer. In serofinlens or glandular aftections, the leaves boiled with milk are reporterl by Bocrhave as bencficial. The root finely ser:aped into a pulp, and mixed with brandy, has leen fonnd efficicions in chronie rhenuatism. 'The luerrics eaten, above two or three, are dangentous; five lave been known to produce syneope, and othei clingerous symptoms. 


\section{MANNA.}

Manna a conerete juiee, is the prodnction of the flowering Ash, Ornus, vel Fruximus. Sometimes the juice flows spontaneonsly, or is obtained by tapping the tree. It has a swcet and slightitly bitter taste, and is a gentle purgative, so mild in its operation that it may be given with safety to ehildren, persons of rery wak habits, and in pregnaney. In some eonstitutions, however, it produces flatnlency, and therefore requires the addition of a suitable aromatic, especially when given to an adult. As it is a very mild purgative, it may be eombined with a decoetion of senut, or rhubarb, and an aromatie, say, a small portion of Cayenne pepper.

\section{MARIGOLDS.}

Calendula Officinalis.-They need no deseription, they are so eommon, nearly in every garden.

Medicinal Virtues. - They strengthen the henrt exceedingly, and are very expulsive and little less effectual in bringing ont the small-pox and measles than saffion. The juice of Marigold leaves mixed with rinegar, and any hot swelling bathed with it, instantly gives cise. The flowers, either green or dried, are munch used in posscts, brotlis, and drink, as a comforter of the heart and spirits. A plaister made with the dry fluwers in powcler, larcl, turpentine, and rosin, applied to the breast strengthens and sueeours the heart in fevers.

\section{MARJORAM SWEET.}

Description.-Amaracus.-Swect Marioram is so well lnown, as an inhahitant in every garden, tlitt it is needless to write any deseription of it, nor of the Winter Swect Marjoram or Pot Minlyorann.

Mrnicinal Vuitmis. - Sweet Minjoram is nomatie, and

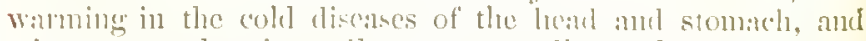
other parts, taken imwarlly, or ontwandly applierl. The deeoction is good for diseases of the eliest which obstruct brea168 
thing, and it remores obstruetions of the liver and spleen. It neutralizes cold grief's of the womb, and the windiness thereof. The decoetion thereof male with some pellitory of Spain, and long pepler, is grood for the first stages of dropsy, for those that eannot make witer, and against pains in the lielly. The powder mixed with honey, it olliterntes the black marks of bluws and bruises; it is good for inflammation and watering of the cycs, mised with fine flour, and laid upon them. The juice dropjed into the cars, eases pains and a singing noise. It is profitilly put into ointments and salves that are warm, and comfort the outward paits, as the joints and sinews; and for swellings. The powder snnfled provokes sneczing, and purges the brain, and chewed in the month, it promotes expjectoration of phlegm. The oil is very warm and comfortable to stiff joints, to mollify and supple them. It is the principal compound of the various rubbing boltles, sold for out ward application, "I have known," says Dr. Roberts, " the dried lierb put into a bag and inmersed in laot water, prove a capital fomentation for tumours and swellings. A strongr infusion for a foot-bath is very effectual in relicving violent pains.

\section{MARJORAM,-WILD.}

Description.-Origamum Vulgare.-Called also Origanum, Eastrard, Marjoram, and Grore Marjoran. Will ol Fielil Marjoram root which ereeps inuch under gromind, and eontinues a long time sending up sundry brownish, hard sefuare stalls, witl small dark green leaves, very like tlose of Sweet Marjoram, but hardor, and broader; at the top of the stallis stanl tulis of flowers, of a deep pumplish red colour. J'le sced is small and blarker than that of Siweet Majoram. It grows abundantly in the borders of eorn-fichls, anrl in some eopses.

Medrolnat. VirTues. - Tt strenerthens the stomach and head much, there beine searerly a hetter lemerly growing for sucli as are troubled with acillity of the stomsels; it is a stumblice,

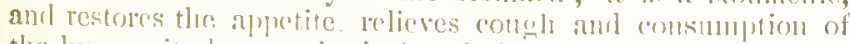

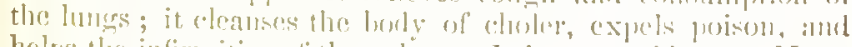

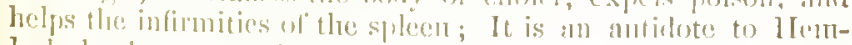
lock, heubane, or opium. It provoles minc, and the terms in 
momen, relieves dropsy and seurvy, seabs, itch, and yellow jamlice. The juice being dropper in to the curs, relieves deafness, pain and noise in the ears. It is generally taken as an infusion, which is rery serviccalhle to nervous hahits. The volatile Oil, enlled Originum, hus been highly extolled as a cure for toothache.

\section{MARSHMALLOWS.}

Description. - Althea Offeinalis. $-\Lambda$ plant of the natural order Halvacece. Mirshinallows have solt hairy white stalks, risiug three or four fect high, with many branches, the leares are hairy, less than the other Mallow leaves, but longer poinced, eut into some few divisions, but deep. The flowers are many, but smaller than the other Irallows, and white, sonctimes with a reddish taint; alter which conse long rouncl cases and seeds, as in the other Mnllows. The roots aic inamy and long, shooting from one head, of the size of a thmull or finger, very pliant, tough, and like liquoriee, of a whitish yellow colour on the ontside, and whiter within.

Medicinal Vintues. - The root is most insed. It his emollient and demulcent properties, which rende: it nsofis in inflammations and irritations of the alimentary eanal, and of the urinary and respiratory organs. The dry roots hoiled in water give out hall their weight of a grmm matter like sturch. Deeoctions of this plant have been very nseful where the natural muens has been abruded from the conts of the intestines; in eatarrhs from a thin rhemm; in nephritic and ealeulons disorders; in cases where the loehia have heen too thin and sharp atier child-birth. The decoction onght not to be made too thick and viseid. It is excellent to promote urine, and bring away gravel and smiall stones. It enres stiangury, and is grood in coughs. It is a gentle apericut, ensing pains in the borrels. Boiled in wine or milk it relieves disealses of the chest and lungs, if taken frepuently. Pliny salys that whosoever shinll take a spoonful of the juice shath that diay he free from all clis-

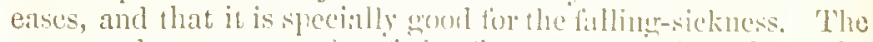

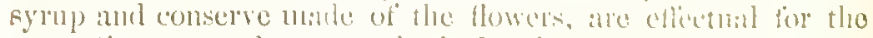
Eame diseases, and to olsen the budy when cuslive. 'J'he leares 170 


\section{MARSHMILLOWS.}

bruised, and laid to the eyes with a little honey, tnke away imposthumes, and to persons stung witl bees, wasps, \&e., it fresently takes away pains, redness, and swellings caused by them. A poultice made of the leares, boiled and bruised, with some bean or barley flour, and oil of roses, is a special remedy against hard tumours, iuflammations, imposthumes, of swelliurs of the privates and other parts, and arainst hardness of thic liver or spleen, being applied to the pluees. 'The juice of the Mallows boiled in oil takes away seurf, roughness of the skin, dandriff, or dry seabs in the head, if they be anointed with it, or washed with the deeoction; it preserves the hair from falling off. It is also effectual against sealdings, burnings, St. Anthony's fire, and other hot and painful swellings. The flowers boiled in oil or water, with a little honey and alum, is an excellent gargle to elcanse, or heal a sore month or throat. The gieen leares, (suys Pliny) beaten with nitre, and applicd, draw out thorns or prickles in the flesh. The deevetion is first rate for clysters to case all pains of the boly, opening the uriuary pussages, making them slippery that the stone maly descend casily, and without pain, out of the kidneys ant blatder, and to casc the torturing pains. But the roots are the most porverful for conchs, shortness of breath, hoarseness. The roots and seeds boiled in wine and water, are sueeessfilly used by those who have inflammation of the intestines, or the bloody-flux. Boiled in wine, it is a good wasls lor serolitlous sores, impostlumes of the throat ; the dried roots boiled in milk, is good for the Ilooping-eotgh. IIippocrilles grave the decoction of the roots or the juice to those who were wounderl, and faint through loss of lifoot, and he applied tho same, nixect with loney and rosin to tle wounds. It is healines to brenises, fills or bluws, or boues out of joint, or suly swelling, pin, or ande in the muscles, sil:cws or arteriss. The

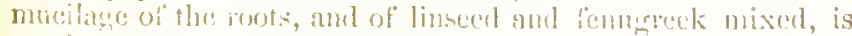

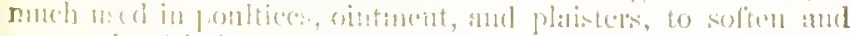
remose laud inflamed swellings, and to case paipls ill any part of the borly.

My som lont the blooty-flux with great exeoriation of the

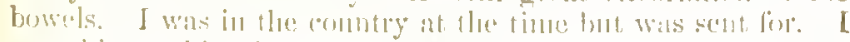
gave him nothing but bruised Mallows and in two days le was cured. 
About 4 or 5 ounees of the dried root, 2 ounces of raisons, frecd from their seeds, put into 5 pints of water, and boiled lown to 3 pints, and then strained, is a good form of administration. Half' a wine-glass to be taken frequently to allnv cough and irritation. The addition of liquonice, coltsfoot, and holchound, would make it still more pectoral.

The syrup of Marshmallows is made by boiling 8 ounces of the fresh root sliced, in 4 pints of water ; adding $2 \frac{1}{2}$ lbs. of lump sugar'; dose half an onnce to 1 ounce. 'The ointment of Marshmallows is a very healing application. The lozenges are also very useful in hoarseness, coughs, \&c. They may be made of the syrup by adding a little more Sugar, and IIucilage of Gum 'Tragacanth.

\section{MASTERWORT.}

Description. - It grows two fect high, the stalks are round, striated, hollowed, erect, not very strong. The leaves are composed of three smaller oncs; they are of a dark green colour, blunt at the points, and edges indented. The flowers are small and white, standing in little umbels at the tops of the brancles. 'The roots are long, brown, divided, of a strong smell, and a sluarp aromatic taste.

Medicinal Virtues.-The root greatly promotes perspiration, it warms a cold stomach. Haller says, that it is bencfieial in diseases of the chest, arising from a load of mucus, and in the pituitous asthma, and in those diseases arising from defective circulation, ns chlorosis and dropsy, and it has sueceded in a quartan ague even after cinchona had failed, Emplored as a clyster it facilitates parturition; and the same when taken inwardly. It expels worms. It is good in gravel, promoting urine, and expelling stonc. It is good for dropsy and cramps. The juice dropled on lint. and ilphlied to ereen wounds or ulecrs, cures them. $-\Lambda$ dratelum of the root in substance, and a drachm in infusion to be taken four times a dialy. 


\section{MATICO.}

Arbanthe Elongata.-It is a native of Sonth Ameriea, and belongs to the Pepper tribe. It is now used in British Medieal practice as an astringent styptie. It is used in ehronie bloody Hux, or dysentery, and diarrhoca, given as an infusion. The undersides of the leaves, or 1 owdered, will, when applied, arrest the flow of blood from euts, bruises, or obstinate lecehbites. The Tineture mixed with water, is a good astringent lotion for the month. Dose of the Powder, from 10 to 30 grains. The infusion, made by pouring two pints of water on two ounees of leaves; it may be taken in agreeable doses 3 or 4 times a day. The Tineture is made thus. Leaves, 2 ounees; Proof Spirit, I pint. Take from I to 2 drachins.

\section{MEADOW SAFFRON.}

Description.-Colchicum Aunemnale- - It is a perennial bulbons-rooted plant which grows in wet meadows. It flowers in September. They rise with long slender tubes about four inches high. The green leaves appear in Mareh, about four to a full-grown root. It is a native of most parts of Europe, and it grows in many parts of this land. It is poisonous to animals of all classes; but their instinet, implanted in them by the All-wise and Benefieent Creator, leads them to avoid the foliage in the field.

Medicinal Virtues. Stoerek, Collin, and Pleuk have praised its virtucs as a diuretic in hydrothorax, and other dropsies. Some nse the juice to destroy vermin in the hair. In Germany and France it is very popnlat amongst practitioners, who employed oxymel colchici in the afore-nentioned complaints very effectually. In England, of late years, Colehicum, ne Meadow Saffion, has hec'n extensively nised in the form of Tincture, and powrter, for the cure of gout and rhenmatisn ; in botls of which it is a specific. It lias been recommended in gonorrloxte with 'Tineture of Opisun, tow diet, ant warm baths. On the continent it is used for liuneral astlima.

Dr. Graham says, "it operates chicfly on the duodenum, or 


\section{MEADOW SAFFRON.}

first intestine; and its action is that of a purgative, diurctic, and nareotic. It stimulates the exeretory duets of the liver and francreats, and the mucons nembrane of the intestines, producing copjous bilious stools, and diminishing febrile action. It is sometimes of gleat service in discases of the heart, erunt, yeumatism, and inflammatory complaints; but in order to its being of mueh permanent beriefit in these maladies, it requires to lye administered with cantion and judgment; otherwise it may prove detrimental, instead of being uscful."

When it is properly prepared, it is a safe and powerful meclicine. In gonty and rhemmatic affections, it allays the pains of those eruel disorder's sooner and more completely than any olliel remedy. Its principal forms of administration are T'inegur of Colchicum, which is male by merely stecping the bulb in vinegar for two or three diys, dose, from 25 to 90 drops: Oxymel and $\left.S_{y} r u p\right) 1$ to 2 diachins; Extract, $\frac{1}{2}$ a myain to 2 grains; Tinetrue $\frac{1}{2}$ a drachm to 1 drachm. The Tineture is malde by putting 2 ounces of Colchicum seeds, 1 pint of proof spirit, and macerate for twelve days.

\section{MEADOW STEET.}

Descriptron.-Spivea Ulmaria. - A wild plant mrowing by river sides. It has divided leaves, and beautiful tults of white flowers. The stalk is round, striated, erect, firm, pale green, sometimes purjele. The leaves are each composer of illout three pairs of smaller, set on a thick rib, with an odd le: af alt the end; of a fine green on the upper side, whitish molencuteli.

The flowers are sumill and white, but they stant so cluse that the whole elueter looks like one large flower. 'llie secds are set in a twisted order.

Menicinal Virtues. - An infusion of the fresh tope prodnees perspiration. It is ratlice astringent. The root has lieen a specifie remedy in fevers. Decoct the root in white wine, and take one or two table-spoontirls at a time. An infision of the flowers, drank as a common bevelane, is gronil for collaneous eruptions, greatly inproving the skin, and tending to re174 
move serolulons affurion. Lot the boly be bat?ed and wellrahbe:l at the sitme time, and the system will be greatly invigurated.

\section{THE MEDLAR.}

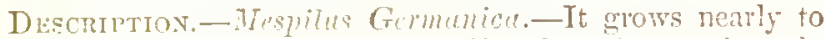
the size of the Quince Tree, sinending branches muleraty latge, with longer and namower leaves than either the alyple or quince, not dented at the enlyes. At the end of the sprigs stant? the flowers, mate of five white, broad pointerl leares, nicherl in the middle with some white threals also; the truit is of a brown green colour, bearing a wown on the top, which, laxjuter fallen away, the head is hollow. Tle finit is vely hatrs before it is mellowed. It is culivaterl in gardens.

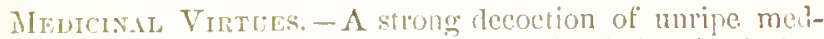
lars arrests dianphua. A plaster milite of the fruit dricel before they are rotten, ansl other conbenient things, and applied to the kirlineys prevents abortion. 'Tley are prowerful to stay flazes of bloor or humours; the leaves have the sane quality. 'Tlue fruit prevents unnatural longings in females. The decoution is rood to grargle anrl wash the mouth, throat and teeth, whin affecter with fains and swellings. It is a good bath to sit oser for the blexting piles. If a poultiec or plastrer be mate with dried Merlats, with the juire of rerl roses, and a little clove anul nutmegr, and applied to an unsettlod and fonl stoma:al, it grives relief. The dried leaves in powler strewed on fresle lulectibirs

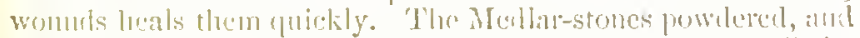
pu. into wine in which parsley ronts have been boiled a little, is effectual in removing stones from the kiclueys.

\section{METIIISOT.}

Descriptros.-Melitotus Offrimstis. - It grows wild in the

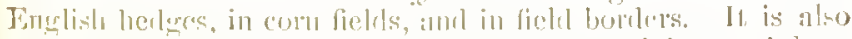

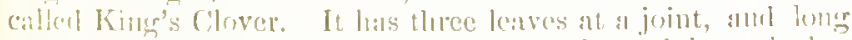

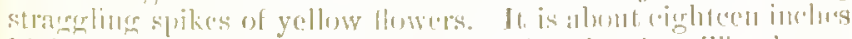

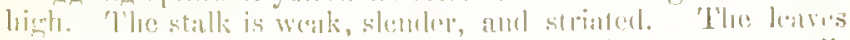

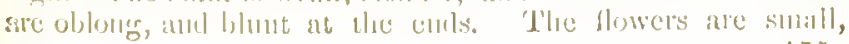


shaped like those of tares by a rough roundish green pod. The plant has a singular, but not unpleasant smell. The plant is prolific of honey, and makes excellent pasturage for bees; hence the Latin name is derived from Nel.

Medrcinal Virtues.-Mellilot boiled in wine, and applied, softens hatel tumours, and inflammation of the ryes, fundament, or privitics; sometimes the yolk of a roasted cgrg, or fine flour, or poppy-sced, is added. A ley made of it is a good wash for ulcers in the head, especially if affected by mania. It relieves pains of the stomach, applied fiesll, or boiled with any of the afor-named things; also pains in the ears, being dropiped into them; and stecped in vinegar, or rose-water, it eases the henlache. The flowers of Mcllilot and Camomile form a good clyster to expel wind and case pains; and poultices for the same purpose, and to assuage swelling tumours in any part of the body. The juice dropped into the eyes, is a singular good medieine to take away the film which dims tle sight. Boiled with lard, it makes an exeellent ointment for sores, and for dressing blisters.

\section{MERCURY,-DOG.}

Description.-This is also of two kinds, male and female, having many stalks, slender and lower than Freneh Heremy, without any branches, the root is set with two leaves at crery joint, langer than the female, but more pointed and fill of seins, and harder in handling ; of a dark green colour, and less dented at the edges. At the joints come forth longer stillis tlian the former, with two hairy ronnd secds upon them, twice as large as those of the former Mereury; the sinell is strong and virulent. The female has harder leaves upon longer foot-stalks, nud the stalks are longer; from the joints enne forth spikes of flowers like the Firench Fente Mereury, The roots are finll of small fibres, which rum mulcer gromud, and nult rery much, abiding the Winter, and shooting forth new brancless every yeatr.

EFe This is a highly poisonous plant, and must be granded against. There is not a more firterl plant than this, and it has 


\section{MERCURY,-Englisir.}

been described morc to prevent misehicf. Its medical properties have not becn accuratcly made known. The qualitics attributed to it by Culpeper are absurd in the cxtrene, quoted from some of the. old astrological botanical writers. The virtucs given to it by Culpoper must apply to some other plant; for those of Dog Mereury have not yet been discovered, except the poisonous.

\section{MERCURY.-ENGLISH.}

Description.-Chenopodium.-Called also Good King Henry-and English Mercury, to distinguish it fiom French Mcremry. It grows a foot high ; stalk round, thick, ectlom crect; is grochish and purplish, and is covered with a kind of grey powder unctuous to the tonch. Leaves large, broad, the shape of an arrow-head, stand on long stalks, palo green above, greenish underneath, covered with a grey powder. Flowers small, grecnish ycllow, in longr spikes at the tops of the branches. The plant is eommon in fimm-yards.

The young shoots are catcn as slinach. The jnice of tho whole plant works gently and well by urine; and the dried herb is used in decoctions for clysters.

\section{MERCURY,-FRENCII.}

Description. - Miereurialis mas et fomina.-It grows ten inches high. The stalks arc angular, green, thick, but not firm, and rather erect. 'The leaves are ollong, broudest in the middle, sharip-pointed, serrated at the edeges, and of a deep green colour. The female plonts produce two sects growing torether at the top of a little spike. 'Flac male plants probuec only ono spike of dusty flowers, withont any secels. l'cople mistake, calling the fentale the mate.

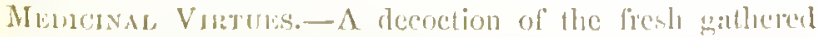
plant is gently aperient, and dintetic, pronotiny strine; it is coslingr, and ingoed for hot constitutions and orer-finluess. 'I the dried lierb is uscel in decoetion for elysulers. 


\section{MEZEREON.}

Descremption.-Daphne Mezereum.-This shrub is a kind of Spurge Laurel. It is cultivated in gardens on acconnt of the beautiful early flowers, in February and March. The flowers come before the leaves. It grows four feet high, and sends off several branches. The leaves are few, tender, and lanceshaped. The flowers are in thick clusters, each conposed of a single petal, eut into four oval segments, of a bright red colour, They produce numerous red berries, which are black when ripe. They are very inviting, but poisonous, and they should be kept beyoud the reach of children.

Medicinal Virtues.-It has been used with success in syphylis. Dr. Home not only found the decoction to cure seirhous tumours, which remain after lues venerea, and after the use of mereury; but it healed also some scirrhous tumours from other causes; he found it useful in cntaneous eruptions. In diffieult swallowing caused by paralytic affections, Dr Withering tested its eflicacy. The patient was directed to eherv a thin slice of the root as often as she conld bear it, and in about a month she recovered the power to swallow. For three years she had been able to swallow liquids and solids only very imperfectly.

The Russian peasantry take 30 or 40 of the blossoms as a purgative, and give them as an emetic to children with hooping congh ; in this country 8 or 10 of them will cause purging. The bark, both of the root and the stem, is nsed medicinally: Internally taken, it is stimulant, having a tendency towards tho side and lidneys. It is of considerable efficacy in chronie rheumatism, and scrofula; and slso in syphilis, combined with Sarsaparilla, as a decoction. Boil 2 drachms of the bark, and half an omce of liquorice root in three pints of watcr down to two. The dose is 3 to 6 ounces, two or three times a day.

It has been nsed instead of a perpetual blister with much less pain and inconrenience. A stume pice of the hank, an inch long, anul an inch liroad, macerated in a little vinegatr. is applied to the skin, oree which is bouml a leaf of Iry or 1"lantilin; renewed till it canterizes the part, and brings on a serions dischatrge. $\Lambda$ s a plaster it mily be applied behind the ears to 178 
relieve the eycs. An ointment of the juice of the leaves, flowers, and bark, is valuable for dressing issues, \&c. ; it is superior to Savine or any other ointment for this purpose.

\section{MINT,-HORSE.}

Monarda Punctata. - This plant is much used in American practice. Like all the Mints it is aromatic and carminative, and yiclds a volatile oil, very stimulaut, and having a powerful odour. It grows besides ditches, and in America it is cultivated.

"I have known," says an Ameriean Doctor, "its efficacy in remoring flatuleney, colic, and difficult breathing. It is a great purifier of the breath.-It is execllent for earache, and snuffed up the nose, for headache. The oil is given as a carminative in doses of two or three drops, on a lump of sugar. Outwardly, it is a good lubefaciont. The lenves and twigs are male into an infusion, which is excellent in flatulent colic. This plant is also an cmmenagoguc.

\section{MINT,-PEPPERMINT.}

Descrirtion.-Mentha Piperata.-It is a garden plant, much like the Wild Mint. It grows two fect and a half himl, The stalk is square, firm, and upright, of a pale green. The leaves stand two at each joint; broad, not very long, dark green, deeply serrated at the edses. The flowers grow in thick spikes, not long, yet large ankl pale red. The smell is fragrant and agrecable, the taste hot, like pepper.

Medicinal, Virtues.-The whole plant is used fresh or dried; lut the distilled water is the hest. It enres the colic, often almost instantaneously, and is goorl against the gratrol. Pelpermint Water shombl he distiller from the forst plamt.

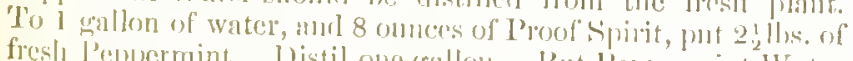
fresly P'elpermint. Distil one gallon. Jut l'eplermint Water is now gecincrally made by mobing down the oil with a litlle

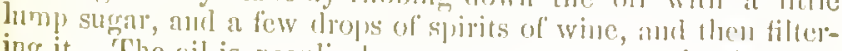
ing it. The oil is peculiarly pungent, very camminative and 
MLNT,-Peprermint.

stimulant, whieh render it very useful in indigestion, flatulenee, and diarrhoa. The dose of this oil is from I to 3 or 4 drops. It may be taken in water or any other vehiclc. It has the same virtues as the other Mints, but more powerful. The infusion of the leaves is very uscful in bowel eomplaints, as laxity espeeially, and flatuleney.

\section{MINT,-SPEARMINT.}

Description.-Mentha Viriclis.- -Spenr Mint has several round stalks, and long narrowish leaves set thereon, of a dark green eolour. The flowers stand in spiked hends at the tops of the branehes, being of a pale blue eolour. The plant has a fragrant smell, and a pleasant aromatie taste. It is eultivated in gardens. Its roots are abunclant.

Medicinal Virtues.- It is valuable for its earminative and aromatic properties which reside in its volatile oil, of a pungent and peeuliar odour. Dioseorides says it has a heating, binding and drying quality, and therefore the juice taken in vinegar, stays bleediug. It dissolves imposthumes being applied with barley-meal. The application of the juiee mixed with honey relieves pains in the ears, and roughness of the tongue. Applied to the forehear and temples, it relieves pains in the head, and the heads of children, agrinst brcalings-out, sores or seabs. The whole plant is used fresh or dried, and is exccllent for flatuleney, sickness, voniting and wealness of the stomach. It generilly stops vomiting and ereates an appetite. Some apply the fresh herb bruised to the stomaeh for the remoral of its complaints. Bruised and mixed with salt it is said to eure the bite of a mad dog. Given as an infusion it has relived diarrhoa. The deeoelion gargled in the month, cures sore gums and mouth. I have frequently cured young ladies of rclaxed and eonsumptive habits by ordering them to go with the maid a milling for in few mornings, and take with them a new hid egs beaten up with a tahlc-spoonful of Rum, and a little Spear-Mint ent small, to which add a tea-cup full of new milk from the eow. This dranls in the ficld, and the morning air have done wonders.

180 


\section{MINT, - WATER MTNT.}

Description.-Mentha Aquatica. - It grows wild by ditch sides. It grows a foot and a lialf high. The stalks are square, erect, firm, and strong, generally of a brown colour; leaves broal and short, they stanel two at a joint, and are of a brownish or dark green colonr, rather hairy, and scrrated abont the elges. The flowers are larger than those of eommon mint, and are of a pale red colour; they stand in round thick clus. ters, at the tops of the stalks and round the upjer joints, The smell is rather agrecable, mixed as if Mint and Pemlyroyal.

Menictara Virtees. The distilled water is a remedy for colic, pains in the stoniach and bowcls, and it promotes inenstruation. A single dose frequently eures the colic. Its virtucs are great, and it ought to be better known, and more used. It may be given in infusion. It removes obstructions, and strengthens the system.

\section{MISTETOE.}

Description, - Viscum Album. - This parasite rises up from the branch of the tree, on which it grows, with a woorly stem, putting itself into sundry branches, ancl again divided into many other smalter twigse, interlacing themsclves, and eovered with a greyish green hark, having two leaves set at every joint, and at the cnel likewise, which ale somewhat longr art narrow, small at the hottom, but bronder towards the enc. At the joints of the hranches grow small yellow flowers, which ron into sinall, white, transparent berrics, threc or four together, full of a glutinous juice, with a blackisls seed in each of them, which was never known to spring, when put into the gruunel. It grows on various trees ill woods and groves, and sometines on firut trees.

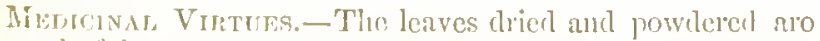
a womelerful remerly lo, the filling sickness. They are woot

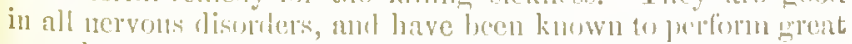
cures by persevelance in laking an infisson. Instances of tho efricacy of Mistletoe, alte to be fuund in the writings of P'ints- 
celsus, Pliny, \&c. The late Drs. Fothergill. Willan, Gilbert, Thompson, and Fraser, employed this medicine with great success for the cure of epilepsy. The juice, or bird-lime, softens imposthumes, ripens and heals them. Mixed with rosin and wax, it cures ulcers and sores.

\section{MONEYTORT.}

Descriptron.-Lysimachia Nummaria.-It is called also Herb Twopence. From a small thready root, come forth several long, weak, and slender brauches, running on the gronnd two or three feet long, set with leaves two at a joint one against another at equal distances, which are almost ronnd, but pointed at the ends, smooth, and of a good green colonr. At the joints with the leaves from the mildle forward come forth at every point sometimes one yellow flower, sometimes, two, stauding on a small foot-stalk, consisting of five leaves, narrowpointed at the end, with yellow threads in the middle. It grows plentifully in moist grounds by hedge-sides and in grassficlds.

Medicrnal Vintues.-The juiee is a well-known remedy for profuse menstruation. The leaves powdered are excellent against scurvy, loss of blood, fluxes, weakness of the stomach, and romiting. Take 8 or 10 grains at a time, as the disense may demand. It is good for ulcernted lungs. Matde into an ointment with lard, it is healing to wounds, either fresh or old. The deeoction is a good wash for inveterate sores, \&c.

\section{MOONWORT.}

Descriptron.-Lunaria. - It lises up with one dak green, thick, and flat leaf, upon a short foot-stalk; when it flowers it bears a small slender stalk about four inclies high, having but one leaf, much divided on both sides, into five or seven parts on a side, ench of which is small like the middle rib, but broad forwalds, pointed and round, resembling a half moon, the nppermost parts being larger than the lowest. The stalks riso above this leaf two or three inehes, bearing many branehes of 
small long tongucs, each like the spiky hear of the adder's tongue, of a brownish colour, which at list lesolve into a mealy dust. The root is small and fibrous. It grows on hills and heaths, where there is much grass. It is to be found only in April and May.

Medicinal Virtues. Moonwort is cold and diying more than adder's tongue, and therefore more available for all wounds both inward and outward. The leaves boiled in red wine, stay profuse menstruation and the whites, also blecding, vomiting and other fluxes. It heals blows and bruises, and is good for ruptures; but it is chicfly used with other herbs to make oils or balsams to heal fresh or green wounds, inward or outward.

\section{MOSSES.}

I shall speak only of two kinds, viz. Gronnd Moss and Tree Moss, both of which are very well khown.

The Ground Moss MIuscus Clavatum, grows in moist woods, and in the bottom of hills in boggy grounds, and in shadowy ditches. The Tree MLoss grows only on trees.

Medictinat, Virtues. The Ground Moss is said to be good to break the stone, and to expel it by urine, boiled in wine and drank. The herb being bruised, boiled in water and applied, eases inflammations and pains arising fiom a loot causc, as the pains of the gout.

The Tree Mosses, Lichen Plicatus, are cooling and linding, and have a digesting and mollifying quality. But eaeh Mriss partakes of the nature of the tree from whence it it is taken ; therefore that of the oak is more binding, and is of good eflect to stay fluxes, vomiting, or bleceling, the powder being taken in wine. 'The powder takien in clrink for some time is good against the dropsy. The oil that has harl fresh Moss stecped therein for a time, and then boiled and applied to the temples and forehead, eases the headache coniug of a liot cause. 'The powter of this Moss is a good astringent. It is good against the whites, and spitting of blyorl. It deserves to be much more regarded. Tlie dose is half a drachm. 


\section{MOTIIER OF THYME.}

Descriptron. - Serpyllum. - A common wild plant, very pretty and fiagrant. It grows in little tults by waysides, and on dry hilloeks; the stalks are round, slender, reddish, six or eight inches long. Leaves, very small, of an oval figure ; they grow two at eacli joint, are smooth, and of a bright grcen. The flowers are of a pale red, in little tults at the top of the stalks; the plant has a fragrant smell, and an aromatie and agrecable taste.

Medicinal Virtues. - In nervous cases, it is a better medicine than most that are used. An infusion of the fresh plant may be used ; the taste is agreeable, and if there be persereranee in the use, nervous disorders will be enred. The infusion drank before going to bed will effeetually prevent nightmare.

\section{MOTHEIWORT.}

Description,-Cardiaca.-A tall and pretty plant. It grows wild in firm-yards, and dry places. It is a yard high ; the stalk is square, tinick, and erect. 'The leares stand on long foot-stalks, two at each joint. 'They are divifed into threo parts, and are much indented at the eilges; colonlr, thark creen, stnell, bad; flowers, pale red; they grow in a kind of prickly eups.

Medicinat, Vilitues.- There is no better herb for strengthening and graddening the heart; therefore it is called Cardial'it ly the Latins. It is exhitamatis in travail, and therefore cablal Motherwort. It maly be made into a syrnl', which, when talken, will allay inward tremors, faluting, Se. It is good against lysterie complinits, and especially for enring palpitation of the heart, arising from liysteric catses.

\section{MOUST-EAR.}

Description, - Pilosella.-This is a small herb possessing great virtlles.

Mouse-Lar is a low herb ereping upon the ground by small 184 
strings, like the Strawberty plant, by which it shoots forth small roots, and many short leaves, set in a romnd form together, very hairy, which being broken, give a whitish milk: from among these leaves spring up two or three small hoary stalks about a span ligh, with a few smaller leaves thereon; at the tops but one flower appears, consisting of many pale yellow leaves, broad at the point, and a little dented in three or four rows, very like a dandelion flower, and redish underneath the edges. The secels are winged with down. It grows on diteh banks, and in dry ditches, and in santy grounds. It flowers abont June or July, and is green all Winter.

Menichal Virtues.-The juice taken in wine, or the decoction clrank, is good in jaundice, cren of a chronic eharacter, to be taken in the morning and erening, and abstain from other drink three hours after. It is a special remedy against the stone, and the tormenting pains thereof, and griping paius of the bowcls. The decoetion with succory and centaury is very effectual in dropsy, and the diseases of the spleen. It restrains fluxes of blood, either at the mouth or nose, and inward blectinerseo. It is a sperific for wombls linth inward and outward. There is a syrup made of the juice and sugar by the apothecarics of Italy, and otlıce plares, which they decm a lemety for cough and consumption. The green herb bruised, and brand on a cut or wound, quickly henls it. The distilled water is a good wash for wounds and sores.

\section{MUGiVuRT.}

Diecretion.-Artemisin. Tulgaris.-It has various ?ngves lying upon the gromul, unch divilerl, or eut clecerly in alvent the brius, like wormworkl, hat larger, of a dants green collour

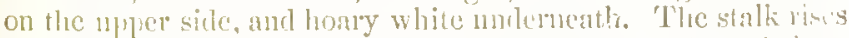
four or five fect high, having on it such leases as those below, but lother smilles, hromehiner forth towards the top, on which small pale yellowish flowels, like buttons atplene in tudts. 'The root is long and hard, with many small filses. It grows plentifilly by water sirles, and by snisll water-tomlecs.

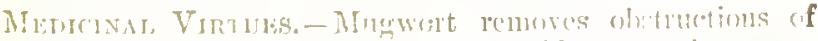
wrine caused by stone. $\Lambda$ decoction is satel to cure the mene. 
The Chinese use it to heal wonnds, applying the fresh plant bruised. A draelm of the leaves powdered was given four times a day, by Dr. Home to a woman who had been affeeted with hysterie fits for many years. The fits eeased in a fow days. All other medicines had failed. Being made up with lard into an ointment, it takes away wens and kernels that grow about the neek and throat; it is more effectual by adding a few field daisies. Three drachms of the powder of the dried leares taken in wine, is a speedy and eertain remedy for seiatiea. A deeoction of it with eamomile and agrimony, and the plaee bathed, while it is warm, takes awny the pains of the sinews, and the cramp.

\section{MULBERRY TREE.}

Mones Nigra. This is so well lnown where it grows that it needs no deseription.

Medicinal Virtecs.-The Mulberry is of clifierent parts ; the ripe berries, by reason of their sweetness and sliplyery moisture, open the body, and the unripe bind it especially when they are driet; they are good to stiy fluxes, and proftuse menstruation. The bark of the root kills worms ealled tania or tape-worm. A syrup made of the juiee of the berries, eures inflammations or sores in the month, throat, and palate of the month when it is fallen down. The leares beaten with vinegar are good for burns. A dceoetion made of the bark and leaves is good to wash the month and teetl when they ache. The leaves of Mulberries applied are said to stay blecding at the month or nose, or the blecting of the piles, or of a wound. The Syrup ma be made by boiling the juice of the ripe fruit with tivice the quantity of sngar.

\section{MULLEIN.}

Description. - Terbascum Album.-This from the textrme of the lenves, is also ealled Poor Man's Flannel. Common White Mullein has many fair, large, woolly white leaves, lying next the ground, longer than broad, pointed at the end, and 186 
dented about the edges. The stalk rises four or five fect high, covered ovel with similar leaves, but less; so that no stalk can be seen for the multitude of leaves. The lluwers come forth on all siles of the stalk in great numbers upon a long spike, of a yellow colour, consisting of fire round pointerl leares. The root is long, white, and woody. It grows by way-sicles, lanes, and on ditch banlis.

Medicryat Virtues. - Catarlis and diarlioens are said to be arrested by this plant. Dr. Home tried it in these diseascs, but allows its virtue only in the lattel disortler. He relates four cases in which it was given; and he says, "that it is uscful in diminishing or stopping diarrhoeas of an old standing, and in ensing pains in the bowels. 'This arises from the cmolient and gently astringent qualitics of the plant. The decoction is made by boiling two ounecs of the lenves in a quart of water for twenty minutes-two or three ounces to be given every three hours. A strong decoction eases the toothache, A decoction of the leaves, and of sage, marjoram, and eammomile flowers, and the plaees hathed therewith, eases cramp in the sinews, and joints. Three oumees of the distilled water of the flowers, drank morning and evening for some days together, is an excellent remedy for the gout. The juice of the leaves and flowers laid upon rough warts, or the powder of the dried roots rubbed on takes them away. The decoetion is of great effect to dissolve the tumours, swellings, or inflammations of the throat. The leaves brused and wrapped in domble papers, and covered with hot asties to bake a while, and then taken and lair warm on any blotch or boil liaplenening in the groin or share, soon heals them.

\section{MUSTARD.}

Sinapis Nigra.-This requires no description. The sects are used ; gronmil, the powilel called musturel is used as a condiment. 'J'hey contain an acrisl principle, and a fixcol oil, which give them a pungent smell and taste. and stimulant, diuretic, and aperient properifes. They are also anti-flatulent.

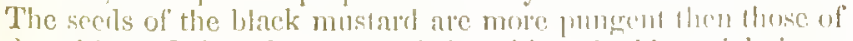
the white. It is to be regretted that this valuable article is so 


\section{MUSTARD.}

frequently adulterated. Mustard secils excite tle stomach, and stimulate the nervous encrgy, and ant as a laxitive. In costiveness and indigestion they are rcally useful. They aet very mildly, yet effeetually as an apericut.

Dr. Graham says, "they" cxert a considcrable alterative effect on the constitition when perserved in, owing to thcir eontaining sulphur, and also to their regular lnxative operation. For whatever substance acts regularly and mildly as an aperient, is at the same time altcrative; a fact which demands attention. This depends no doubt, on the marked influenee whieh a regritar healthy action of the bowels has on the whole system." Dose, a table-spoonful, or less, twice a day. Thicy liave also been given with advantage in dropsy, and torpid state of the howels which aecompanies palsy, for weakness of stomacl, and impurity of blood. The seeds are good for all eold disenscs.

Mu tard is frequently used externally, and is generally beneficial when applied orer the sent of inward infammation, as the elest, belly, or throat. A Mustard Cataplasm, or poultice, is made by mixing good fresh mustard with water, (some nse with it flour or linsced-incal, to moderate it,) as for the table, and sprearling it thickly on a picec of linch or ealico; put a thin piece of muslin over it, and then apply it to the part affected for 15 to 20 minutes so that it may reden the slin, without prodneing a blister; if it should bum much rlacn takcu off; sprinkle the part with flomp. Shonlel a mustarl plaster be applicel to one in a state of inscusibility, it stonla not remain above laalf an hour; otherwise, it might produce nleeration. Never apply a mustard-plaster where you are assured a hot bran, or a hot ont-meal poultice wonld be more soothing and useful.

Mustard is a safe and cfictual emetic, in doses of one, two, or three ten-spoonfuls in water. It is thus nsed in paralytie eases; and it is often efiectnal when other cmetice fail. Mínstard lotions and ointments are sonetimes nsed for local friction in homoptysis, or spitting of hlool, applied to the elicst or extremities, as the legs, \&e.-and for chillilins and other indolent swellings. In cases of poisoning, forper, or palalysis, a Mustard foot-batl maly be employed to rouse the systemi. 188 


\section{MUSTARD,-TRE $A C L E$.}

Description. - Theriaca Sinapis. - It is known also by the name of Treacle MIustard. It has a hard round stalk a foot high, parted into branclies, having soft green leaves, long and narrow, and waved, but not indented. 'The flowers which grow at the tops of the branelies, are white, in spikes one above another; cach flower produces a blackish brown seed on each side of a pouch parted in the middle. The roots are small and threaly.

\section{MUSTARD.-MITIIRID ATE.}

Descriptron.-Sinapis Mithridaticum.-It grows higher than Treacle Mustard, having more and larger branelies; its leaves are smaller and narrower, unevenly indented at the celges. The flowers are small and white, growing on long branches; the seeds are formed in the same way, ret smaller, and sharper in taste. 'Tluey grow under walls and hedges.

Medicisal Vintues. - Both these Mustarls are purgative, cleansing the horly both mpwards and downwards. 'They promote menstruation, luteak inward impostlumes, taken inwardly and used as clysters, and outwardly applied they are grond for eciatica. Thie seed is very effectual. They are tonic and antiseptic.

\section{MUSTARD,-IIFDGE MUSTARD.}

Descriprion. - Sepes Simapis. - It is a different plant from the garlen Mnstarl. It has one l, lackislo green stalle, slender, but tough, luanched into several parts, and sometimes with several stalks, full of breutches, on which grow lengr, riegred leaves, mucla cut on the ectges in nany parts, some larger and

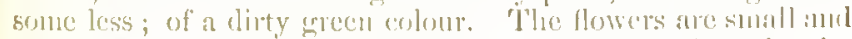
yollow, at the tepes of the branchess in loner spike's, thewering by

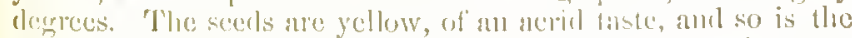
brib). It grows hy the waty and herlge-silles, and in the open fickefs. It flowers in July. 
Medicinal Virtues. - It is good in all the discases of the chest and lungs, hoarseness, for loss of voice, and lowness of spirits. The juice made into syrup, with honcy or sugar, is no less cflectual for the same purpose, and for' all coughs, wheczing, and shortness of breath. It is a remedy for the jaundice, plemrisy, pains in the ljack and loins, and for colic, being also used in elysters. The seed is a special remedy for sciatica, joint-aches, ulcers and cankers in the month; throat, or belind the cars, and for hardness and swelling of the testicles, or women's breasts.

\section{MYRRI.}

Description. - This is a resinous gum which cxudes from a small trec belonging to the natural oriler Terebinthacece. Its clissical name is Bulsamodendron Ny/yrhe. Though mentioned in Seripture, Gen. xxxvii. 25, so carly, yet very little is yet known of the production. At that carly period it was probably known as an antiseptic, and was used in cnbalming. The tree from which it is thonght to cxudc is a native of Liabia, Abyssinia, and the countries on the shores of the Red Sca.

Medicinal Virtues. - It is antiscptic, and possesses tonic, antispasmodic, and stimulant, and expectorant propertics. It acts upon the mucous membranc as a balsamic, checking excessive sceretions. It is advantageously administered in indiycstion, old coughs, in green sicliness, chronic asthma, and tho latter stages of consumption; and it should be giren in small doses in the incipient stages. The gum, with a small quantity of aloes, and a mimute portion of singer, slould be mitle into pills, and taken ocensionally. Where the bowels are relaxed, the aloes and ginger must be omitted. It his been found very beneficial for conghs peculiur to pregnaney, or contwls after abortion, and in bronchitis. On account of its antiseptic propertics, it is excellent for nlecrated lunges; dose, firm ciglit to fifteen grains twice or thrice a tlay. If hectic fever prevals,

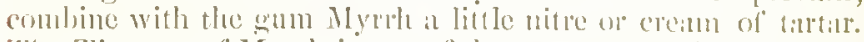
'Tlue Tincture of Myrth is me of the most angreable washes in aliections of the moutl. In:If au onnce of Thineture to half a jinit of water, and a few drops upon the tootli-brusl, is a most 190 
exeellent mode of eleansing the teeth, especially if the gums are weak or spongy. It is still more efficacions if combined with Tincture of Ciltechu; this is also a first-rate gargle for sore throat and elongated uvula, or soft part of the palate. The Tineture of Myrh, Tineture of Citcelut, to which is adderl, Caleined Alum, is a eure and a preventive of toothate. It maly be diluted with water.

\section{NAILWORT, OR WHITLOWGRASS.}

Descriptron.-Paromychia Rutula Foliosa.--It derives its name froul its virtues. This small and eommon licrb has no roots, but a few strings; it grows about four inehes high, leaves very small, rather long, not unlike those of ehickweed, among which rise up several slender stalks, benring many very small white flowers one above another, after which cone small flat ponches containing very small sced, of a sharp taste. It grows upon old stone and brick walls, and in dry gravelly grounds, if there be grass or moss to protect it. It flowers in Febrinary; for before the end of $A$ pril it is not to be found.

Mempinat. Virtues. It is helel to be execeding good for those imposthumes in the joints, and unler the mails, which they call whitlows, felons, and nail-wheals.

\section{NETTLE.}

Urtice Dioica.-It is eommon everywhere. Every ono knows it.

Madicinat Virtues.-This is a valualle plant. Tho youngr shoots in spring, form a whlolesome vegetilule, boiled, like other greens. Nettle lroth is goorl araitust the semrvy. It is a ereat purifier of the blood, and removes the plulemmatic

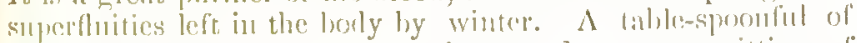
the expressed juice given four times a day stops splitliug of

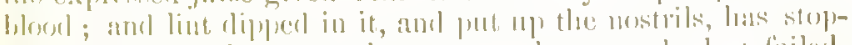
peil bleerling at the nose, when every ofluer remerly hat failonl. Cancers have becn said to yick to the juice of nettles, rubbing 
with the juiee mixed with oil and laudanum, and thejuiceta. Een inwardly very freely. Paralytie parts, being stuug with zettles have regained their vigour, and the use of limbs, lost by rheumatism, has been restored. Exeessive eorpuleney may be redueed by taking a few of the seeds only. Fourteen or fifteen of these seeds powdered, and taken uight and morning, will eure goitre, or enlargement of the thoroid gland, eausing frightful swelling of the throat, withont injuring the stomael or the health. It is a good gargle for it, and a poultiee of the leaves should be applied. Nettle is autiasthmatie; the juiee of the roots or leaves made into an eleetuary with honey and sngar opens the bronehial tubes of the lungs, the stoppage of whieh eauses wheezing, shortlless of breath, \&e. It stiunlates expeetoration of phlegm very freely. It is a good deobstruent for suppressed menstruation, used as a deeoetion, and for the reteution of uriue, for the gravel and stone. For this purpose the flowers aud seed should be made into a conserve. The deeoetion kills worms in children.

Some say that a leaf put upou the tongue, and pressed against the roof of the month, will restrain bleediug of the nose. "The fresh juiee of the Nettle has been highly reeommended," says Dr. Speneer "Thompson, "in eases of internal homorrhage, partienlarly from the lungs and wounb. Dose one tea-spoonful three times a lay. Nettle is now eoming into use as a material for the uninfacture of paper. The sceds serve to fatten fowls, and are sild to intuse life and spirit iuto horses.

\section{NIGHTSHADE,-DEADLY.}

Descrmpton-- Atropa Belladoma. - A wild plant of a gloomy aspeet. It glows five fect ligh ; stillis ingulated, dark green; leaves large, broal, and llint, of a lull dear green. The bell-shaped llower's stant lhickly on long foot-stalls, rising from the bosom of the leares; they aro large, hollow, amd lung down. Extemally the eolour is dusky between brown and green; and within of a leep purple. They are sueeeded by beries abunt the size of clicrivics, violet hiack, glossy, sweet, anl pleasant to the taste; hence they hivo

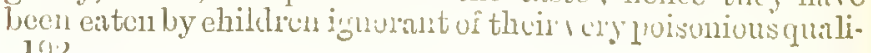
192 
ties, with fatal results. In 1793, some orphans, at the ILspice de la Pete, at Paris, were employed in wecling a botanical garden. They were attrated by the tempting looking finit of a Belladoma plant, of which they ate a large quantity. Fonrtecn of them died a few hours afterwards in consequence. This lamentable eatrstrophe justifies the generie name $A$ tropa, from one of the fates, who was supposed to ent the thread of life. Belladonna, signifies beautiful lady, beeanse the Italian ladies used the distilled water of this plant as a cosmetic.

Medicinal Virtues. - It is a valuable medieine in proper hands. The leares were first used externally to discnss scrofulons and cancerous tumours, and as an application to ill-conditioned ulecrs. Some plyysicians began to employ them internally for the same disorders, on account of their external efficacy. This plant alloviates pain, nervons exeitement, and spasm; it is uscul in nouralgia, convulsive aftections and rheumatism. The vapour of the decoetion is sometimes inhaled to relicre asthma.

Belladonna is said to be efficacious in protecting against the infection of searlet fever, when given in repeated small doses, during the prevalenee of the disease, to thuse who atre exposerl to it. Eight grrains of the extract are to be rublyed up with 1 fluid ounce of water, and frum 5 to 20 drops, alccording to agge, given twice a day. After all, its use ought to be iu skilful hands.

\section{NIGIITSII $\Lambda$ DE, - WOODY.}

Its Latin name is Duleanara (dulcis, sweet; amarus, bitler.) In varions conntries it has different nanes; as, Murtal, Bitter Sweet, and Felon Wort.

I) Escuespros. - It is a climling plant, and is common in moist herleres; its sterrs often reach to the heirlut of live (r) vix fect. The branch las a whitish hark, and a pith in the minlillo of it. Thar matio stem divides into many small ones witl claspers, laying loold on what is next for themen. It lowals many leaves, rather lonir and broatl, and pointed at the ends; some of them laave one ol two little leaves growing at the end of their 
footstalks. The colour of the leaves is pale green; the flowers are purple with a ycllow centre, and they stand together in linots. The berries, when ripe, are red, approaching to scarlet, and they stand together in linots. They taste sweet at first, and then bitter. This plant is nearly allied to the potato, which it very elosely resembles in the odour of its root. The berries are poisonous, but not so much so as the twigs of the plant which are very acrid and narcotic. This plant flowers in July, and the seeds are ripe at the end of July.

Medicinal Virtues.--To make the decoction, the twigs slould be gathered carly in spring; as thick as a goose-quill. One ounce of them to be chopped up, and boiled in a pint and a lialf of water, till reduced to half the quantity. It has been regarded as a powcrful medicine, increasing all the sceretions and excretions, to excite the henlt and arteries; and in lurge doses to produce nausea, voniting, and convulsions. The plant may be regarded as alterative, diuretic, sudorific, and mildly narcotic. It has been recommended in eutancons affections, in thenmatic and cathartic swellings, in bad ulcers, sclofula, jaundice, obstructed menstruation, and syphillis. The dose of the powder is from 1 to 3 seruples; of the lecoetion about a wineglassful ; of the Extract, firom 5 to 10 grains; of the Syrup, hilf an ounce to an ounce. The berries both purge and romit, and are extrenely dangerous for chiklren. Take a pound of the wood and leares bruised, and infuse in three pints of white wine over a grentle fire about 4 or 5 hours; and strain. This renoves obstructions of the liver and spleen, and relieves difficulty of breatling. It forms a gentle purgative.

\section{NIGHTSIIADE,-COMLON.}

Description. - Solemm Vulgare.-This is a different plint from the Deally Nightshale, which is so poisonons. It lias an erect, round, wreen hollow stalk, two feet ligh, having many branches, will many leaves, rather broul, amil pointed, soft alud full of juice, and merenly inkented at the edges. 'Ille flowers entrow in litfle chusters, from six to a dozen in a bun b; they ane white, whith a yelowish centre, and streceded ly roum black berries. It grows wikl tunder walls, anong 131 
rubbish, the sirtes of elges ant ficles, and in gardens, which it Eoon orer" luns, if not stopperl.

Mediciral Viltels.-The common Nightshade is wholly used to cool inflammations outrindly. It must be used carcfully, as most of the Nightshazles atre dinnerous. The juice mingled with vinegar, is good to wish an influmed mouth and throat. The juice, as an ontward application is good for riugworms, and foul nlecrs. The bruised leaves applied to inflammations, scalls, burms, and cruputions on skin, are rery grood. A cloth saturated with the juice is a good application for trout, inflamed privities. The juice dropjed into the cars, relieves pains.

\section{NU'TMEG 'IREE.}

Descriptuns.-Nux moschata. $-\mathbf{A}$ tall, sprending trec, native only of the warm elimates; the trunk is large, and the branches are unmerous and irregular; the bark is of a greyish colontr, and the wood light and soft. 'The leaves are large, long, and somewhat broad : they are not unlike those of the bay trec, but larger and are of a beintiful green on the upper sirle, and whitish underneath. They stand irregularly, but often so nearly opposite, that they seem in pairs, as we sec in the leares of some of our willows. "The blossom is of the shape and size of our cherry trec, but its colour is yellow. The fruit which succeeds this, is of the size of a small peach, and not unlike it in the general form; when cut open there appears first the fleshy coat, which is a finger tlick, and of a rough taste, then the mace spread over a woorly shell, in which is the nutmeg. We often hare the whole fruit sent over preserved.

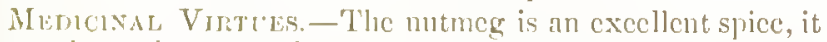
strenertlicus thic stomach, ancl alssists digestion. It will stop vomitinge, and is grourl arginist the eholic. When ronsted before the fire, and nixed with a small quantity of rhubarb, it is the best of all rennedies against pungings.

\section{OAK.}

Quercus Robur.-This nolle tree, the king of the forest, nerils ur dereriplion.

Mrincina, Vhaturs. - The burk is a powerfinl astringent. The decostion is very useful in blowly flux, and splitling of blond. It is diuretic, causing the flow of mrinc. It lats heen 
given with advantage in intermittent fevers. Boil 10 drachms of the bruised bark in two pints of water until redueed to one jint ; it may be nsed also as an injection, gargle, or lotion. This is very useful in chronie sore throat, with relaxed uvula. Galen applied the bruised leaves to heal wounds. It remores obstructions of the liver, and is nsefnl in gravel. The water fomd in the hollow places in old Oaks, is cffectual in curing scabs, itch, \&c. 'The distilled water of the leaves is a sovereign remedy for the whites. 'The decoction makes a firstrate wash for a rupture, if used early.

\section{OATS.}

Menicinal Virtues.-As an article of diet, when ground into meal, it is excellent. A notion prevails that it is dict fit only for the inferior animals, but it is a very erroneons one. Since Oatmeal fell into disuetude, people have degenerated in muscular strength and form. 'The Scottish Highlanders and the Lowland peasantry live almost entirely on oatmeal, proving its nutrition by their well-knit, muscular and bony fiames, and their clear and vigrorous intellects. Oats fried with bay-salt, and applied to the sides, removes pains, stitehes, and winel. A poultice male of oatmenl and oil of bays, cures the itch and leprosy, fistula, and dissolves hard imposthumes. Oatmeal jonltices are more stimulating, and draw more mpidly than those made of Linsecd Meal.

\section{ONE BLADE.}

DEscription, - Unicaulis.-So ealled becanse it nerer bears more than one leaf; though sometimes it has a stalk, and in that case it lias two leaves; bit this selelom oecurs. 'T'he leaf is of a bluish green colonr, pointed with many ribs or veins, like plantain. At the top of the stalk srow many small whito fluwers, star-fashion, smellingr rather sweet; affer which come sumall red becries. The root is sumll, erepping muler the erust of the carth. It grows on moist, shirlimy amd glissy places of woods. It fluwers about Maly, and the berries are ripe in Junc,

196 
Men!ctnat Vertues. It is a precions herb. IIalf a drachm, or a drachm in powder of the roots taken in wine and vinegar, of each cqual purts, and the person lajel to sweat therempon, is held to be a sovereign remedy for those who have a sore unon then, by expelling the poison and infection. It is a rery good wound herb, and is used in many compound balms for curing wounds, whether fresh or green.

\section{ONIONS.}

Medicinal Virtues.-Allium Cepa.-They are more an article of diet. As to medical properties, they are the same as garlie, yet mueh milder. They act as a stimulant, promoting njpetite, easing the bowels, and disposing to sleep. A roasted onion eut in two, is a domestic remedy for boils, as it hastens their breaking. They kill worms in ehildren, if they drink the water fasting in which they have been steeped all night. Roasted and eaten with honey, or sugar and oil, they relicve an inveterate cough, and expectorate tough phlegrm. The juice snuffed up the nostrils purges the head, and renroves lethargy. It has been regarded as a preservative against infection, to eat onions fasting with bread and salt. An onion made hollow, filled with treacle, and then roasted, and beaten torether, is a sovereign salve for sores, or a putrifying ulcer. 'The juice of onions is good for scalds and burns, and used with vinegatl, tukes away blemishes, spots, and manks in the slin. Figs and onions leaten togrether, ripen and break imposthumes and other sores.

\section{OPIUM.}

Papnerer Somnifrem, of the natuml order Pepaveracere. Opium is the dried juice of white or Eatem l'oplyy. Perlays it is the most useful tomg in the entire list of nuedical agents usad by man, aml has probably yichled more rolict to hmman sulfering than any other physical monss. Applied externilly, it alets as al serative, casing pain; given interually, in moleraso doses, its first effect is that of anl cxoitant; it quickens the fulse, and increases the lieat of the skin, aul indices a ton- 


\section{OPIUM.}

deney to sleep; proin is aluated or remored, irritation sublumb; and the muscular system relixed; the secretion of the howels is lessened by it, but that of the skin is increnserl, and thus it acts as a sudorific. If small doses are continnaly taken, it intoxicates; if over-rloses, it is a narcotic proison ; cansing intense slecp, with contraction of the pupil of the eye, whieh results in eoma and death.

Opium should never be given to a person in a state of high fever, or inftanmation; a parehed tongue and a dry skin should gencrally forbid its use. But if the fever is only moterate, and the skin moist, with no cercbral disorder, it may safely be given to alleviate pain and subduc intitation. It is given with effect in Bronchitis combined with Camphor and Ipecacuanha; in canecr, dclirimm tremens, and all neuralgric disorders; in convulsive disorders it is giren as a mutispatsmorlic; in some cases as a diaphoretic; and in dysentery and diarrhoa alone, or combined with astringents, there is no medjeine so good as this. It is given advantagcously also in typhus feret and gangtene, as it then supports the action of the srstem, also in rheumatism, and small-pox, and for the relief of eonghs. In typhns, it should be combined with a tonic and wine; but, as aforesairl, it shonld not he giren where the fever is high, the skin dry, \&c. It is injurions where there is a dipposition to local inflimmation, cspecially of the chest, and where there is much determination of blood to the heal. Combined with bark it has often eured the ague. It is of the grentcst use in tetanns, St. Vitus's dance, hysterics, and cholerar morbus.

A pplicd ontwardly opium sublucs pain and spasmodic action.

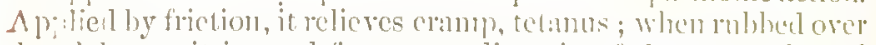

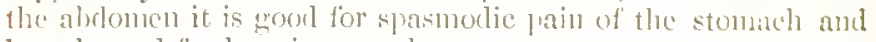
bowels, and for hooping-cough.

The dowe of opinm for an arlult is from ? a a grain to 3 grains; it is not safe to give it to childrem, excepte hy shilful hrands: Ex-

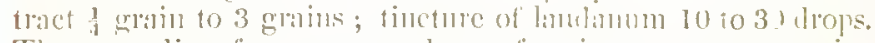
The remedies for an over-done of (n) firm the stomach. Acid of kemoms talken innerdiately

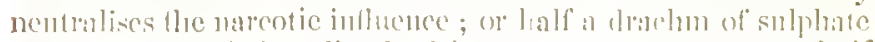
of zine (white vitriol) dissolved in willer, or mustarl, or salt, if 
nothing clsc be at hand, and even very strong enflee, mustart plasters between the shuulders, and the person constantly roused from lethargy.

\section{OR 1 NGE.}

Citrus Aurantium.- The orange tree belongs to the natural order Aurantacee. It is a beantiful plant which gives a refreshing shade in hot elimates, and perfin mes the air for miles. It is extensively enltivated in every place where there is sullicient heat to bring it to perfection. The supply to this country eomes prineipally from Spain, Portugal, the Azores, and the islands of the Mediterranean. There are several valietics of this species; but they all may be refered to the bitter or Serille Orange. 'The St. Michael's perhaps, is the most delicions, and this variety is grown largely in Milta and Provenee. The juice of the sweet Orange, which consists principally of mucilage, sugar, and eitric aeid, is one of the most wholesome veretable juices known. It is very grateful to invalids, especially when fever and thirst prevail. The flowers of the Orangetree are highly odoriferous, and have been long in great esteem as it perfume. They yield their flavour by infusion to rectificd sprits, and in distillation both to spirit and water: the bitter matter is dissolved by water, and on evaporating, the decoetion remains entire in the extract. On the eontinent the distilled watel is used as an antispasmodic and anotyne; it is extremely useful in hysteria, in doses of one or two onuces.

The ehef direet melicinal use of the Orange is derived from the rind, and the hest for the purpose is the Seville Oranre, which yiclis an agreeatle aromatic, stimulant, astringent, and toni: bitter. The rind of the sweet orange may be used, but it is less bitter. A confection, infusion, syrup, ambl a tincture of ornure prel, are all used. It is very of ten preseribed in comblination with stronere bitters, such as Grontian and Quinime, aum it forms a grood velicle for disigreenble and nauscous purgatives.

$A$ very goom infusisu may be male thus : 1 onnec of the

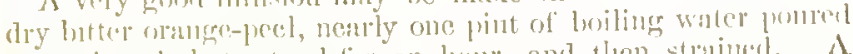

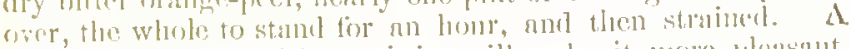
little lump sugal and lemon juice will make it nore pleasint. 


\section{ORCIIS.}

\section{ORPINE}

It is a stomachie; dose, a wineglass full twice a day. Orange Marmalade upon bread is a good breakfast diet for dyspeptie patients. Syrup of Orange is made by infusing $2 \frac{1}{2}$ oinces of the dried peel in a pint of boiling water for 20 minutes, strain, ancl add 2 poumls of l1mpl sugn" ; boil for 10 miuntes. This mixed with water, and a little lemon juice, forms Orangeade. It is niee also to mix with puuch.

\section{ORCHIS.}

Description.-Orchis Masculata.-It is ealled dog-stones, goat-stones, foul-stomes, fox-stones, satiricon, eulbeans, together with many other too tedious to rehearse. It is a beautiful plant, found in moist pastures in June, with a stem like that of the tulip, erowned at the top with a spike of beautiful purple flowers, eurious in shape. The corolla is formed of three petals, and terminating behind in a spur. The leaves are long, pointed, and grow from the root. The root is a double tuber.

Minicinal Virtues.-From the root the Salep of commere is olstaned, a mutritious and wholesome furina. When carefilly prepared, it is one of the best articles of diet for a weakly jerson, and for invalids. They are only to be washet in hot water, the brown skin scraped off with a eorse eluth, and then pliced in a hot oven for abont 10 minutes, and then dried tor use as a poweler. It is rery valuable.

\section{OTPTNE.}

Description.-Sedum Telephimm. Common Orpine has sereral romul brittle stalks, thick set wilh flat ambl flesly leaves without any orler, and little slented ahont the ediges, of a groen colour. The flowers are white and hemulifil, wowing in tufis, alter which come small chally husks, with scerls like dust in them. 'l'he roots are thick, romb, white inlwoms elogs. It grows in hedger, and in woods. It flowers in , hlly.

Mizncinat, Viktulis. - Trngus sarse, tlat the distilled water is profitable for groawings in the stomale and buwcls, or for 200 
nleers in the lunge, liver, and the matrix, heing drank as a decoetion for dlays together. It stays the blooty flux, ant other fluxes in the ljody, or in wonnds. The root has the like effect. It is usel ontwardly to cool inflamed wounds, and to case the pain. The jnice of the leares mixed with oil is good for burns and scalks. The leaf bruised and laid to any green wound, heals it quickly; and being hound to the throat relieves the quinsy; the juice made into syrup is gooul for sore throat and quinsy.

\section{PARSLEY.}

Medicinal Virtues, - Apizm Petroselinon.-The roots are the part generally used in medieine. A strong decoction of them is good against jaundice. It operates powerfully ly urine, and it expels wind. It gently opens the borly, and remores obstructions of the liver and spleen. Galen recommended it in falling sickness, and in obstructed menstruation. The secels are also powerful. The distilled water of Parsley is a good merlicine to give children tronbled with wind in the stomach or bowels. The leares of Parsley mixed with meal and applied to inflamed eyes greatly relieves them, and fried with butter and applierl to hard breasts, greatly relieres and mollifies them. Tragus gives the following medicine for jaundiec, falling sickness, chropsy, and stone in the kidneys; seed of Parsley, Fennel Amnise, and Carraways, of cach an ounce; roots of Parsley, Burnet, Saxifrage and Carraways, of cach an ounce and a halli ; bruise the seeds, wash the roots and eut small; all nighlit steep in a bottle of white wine, and in the morning boil in a close cartluen vessel, until at thirel part be wasted; which being straincel, trlie font onnces morning and crening, abstaining from driuk after it for three hourts.

\section{PARSLEY P'IERT'}

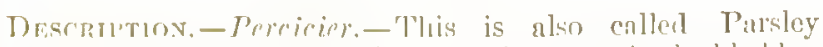

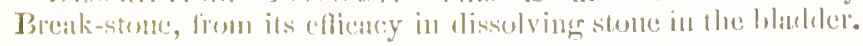

The root, thongh it is very small and threaly, comtines many yeurs, from whence arise many leaves lying on tho 
ground, ench standing upon a lonrs small foot-stalk, the leaves are as broal as a man's nail, much indented at the exlyes, like a parsley leat, but of a very dusky green colum, The sialks are very weak and slender, three or four fingers in length, set so full of leaves that they can harrlly he seen, eilluer luving no foot-stalk at all, or but very short ones. The flowes are very small. The seud is small and romd. It grows anong com, and in barten sandy, moist places.

Medicinal Virtues. - The whole plant is used. An infusion of it is very powerful agninst the rrivel. It operates violently, but safely, by urine, and it removes oustructions of the liver, and is therefore nceful in jamdice. Some suppose that it has the power of dissolving stone in the bladder. 'I'he powder should be taken in wine.

\section{PARSLEY, -MACEDONIAN.}

Description.-Petroselinon Macedonicum. It is also called Alisander, Horse Parslcy, and Black Pot Herb. It grows wild on the eliff's of the sea-const, and is cultivated in gardens. It is two feet high. The stalk is slender, branehed, and hairy. The leaves are composed of many parts, smali, and rounder; those on the npper prart of the stalk ane more finely divided. The flowers are suall and white, like Connmon Parsley, and stand in clusters at the top of the stalks. The seeds are small, rather hairy, and of a dusky colour.

Mromeinal Virtues. - The seed is used; it is given in powder. It operates porverfully by urine, and relieves enlie and gravel arising from obstructions. It is also good ngainst the dropsy and jammdice. It has almost the same virtics as the common Pitrsley.

\section{PARSNIP, - WHAD.}

Discription. - Pastamea Setiva.- It is a wild plant. common on our road-sides, and iu marsley places. Thle wild l'ar-

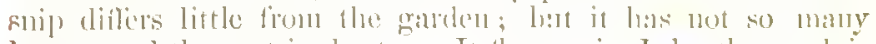
leaves, ant the root is shorter. It fluwers in July, the seed is ripe eatly in Arigust.

\section{2}




\section{PARSNIP. - IVILD.}

Mredicinal Virtues.-The garden Parsnip is good and wholesome, but it has a tendency to prodnce flatulency. It is a very nutritions and wholesome fond, easy of digerion, and as a veyctable, it onght to be more firequently eiten. It removes obstructions of the uline. The wild P'atrinip lials a cotting, attemating, eleansing, and opening quality therein. It relieves pains and stitclies in the sides, and thissolves wind, both in the stomach and bowels, which is the eolie, nnil provokes urine. The root is often used, but the seed mucli more.

\section{PARSNIP,-COW.}

Description. - Facere Pestanaca.-It is a very different plant from the former. It grows with three or four lal'ge spreal-winged, rongh leaves, lying often on the gromul, or raised a little from it, with long, round hairy foot-stalks mnter them, in five dlivisions, the two eouple standing each against the other; and one at the end, and each being almost round, y et much indented at the erlges in some leaves, but not so rleep in others, of a whitish green colour, smelling strongly ; from which springs a rouml, erusted, hairy stalk, two or three fect higrh, with a few juints and leaves thereon, and branched at the top, where stand large umbels of white, sometimes redilish flowers, and after them whitish wingecl seeds, two always juined together. The ront is long and white, with two or thece Iongrg strings growing down into the gromed, smolling unpleasint. It grows ill mojist mealows, near ditedes, and fichl cormers.

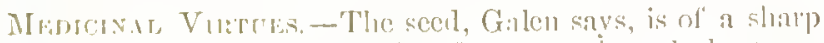

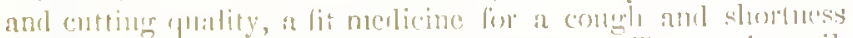

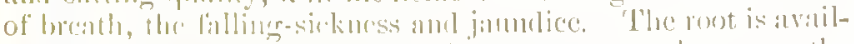

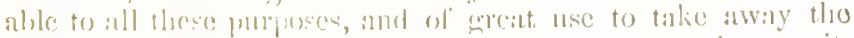

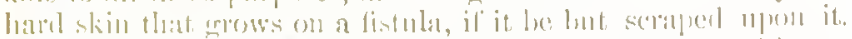

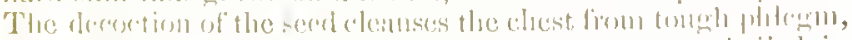

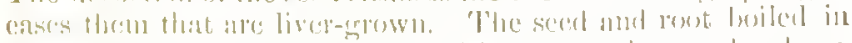

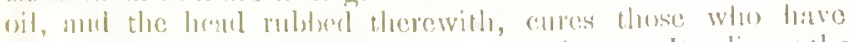

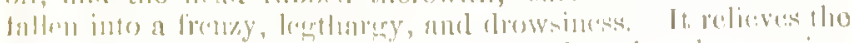

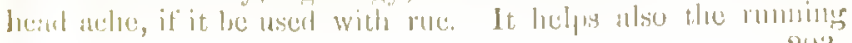


seab and the shingles. The juice of the flowers dropped into the cars that run and are full of matter, clcalses and lieals
them.

\section{PEACH TREF.}

Descriptron.-Persica mabus vel Amygdalis. It is very nearly allicd to the Almond, and gencrally included in the same family. They are nursed in gardens and orchards, and need no further description.

Medicinal Virtues. The flowers are to be made into a sylup by pouring a pint of boiling water on a pound of peach blossoms, to stand 24 hours, and then strained, and dissolve in it 2 pounds of sugar over the fire. It is a good syrup for children, and adults who have become debilitated. It is good against the jaundice, and worms. It is mildly apcrient, and taken largely, it is a safe emetic. The powder strewed on fresh wounds arrests bleeding, and closes them up. The flowers made into a conserve, have the same effect. The liquor that drops fiom the trce, being wonnded, is given in the decoction of Coltsfoot, for cough or shortuess of breath, adding some sweet wine and saffion. It is good for hoarseness and loss of voice; it clears and strengthens the lungs, and relieves those who vonit and spit blood. The liernels of the stoncs cflectually relieve both colic and the stone. Take fifty kemels of pench stones, and one hundred of the kcrnels of cherry stones, a handful of elder flowers, and thrce pints of museadel ; infuse for six days near the fire, after which distil, and take a wineglassful occasionally. The oil drawn from the kerncls, applicd to the temples, procures slecp for the sick. The oil applied to the belly renores pains cansed by colic. An infusion of the dried laves of peach has been uscd for the cxpulsion of worms.

\section{PEAR-TREE.}

Medicinat Virtues.-Pymus Communis. $-A$ H the sweet and luscions sorts are gently aperient, and cooling. Pestrs boiled with a little honcy, relicre an oppressed stomach. The 204 
pulp is execllent to bind on green womds, to eool and stay the fllood, and lieal the wound without inflimmation ; Galen sitys, he fouml it so by cxpericnce. The wild Puars souner close the lips of grecn wounds than others.

\section{PELLITORY OF THE WALL.}

Description. - Parieturia Oficinalis.-This plant is generally known where there are any old walls or ancient ruins. It rises with brownish, tender, weak, and almost transparent stalks, two feet high, upon which grow at the joints two leaves rather broad and long, of a dark green colour, rough and hairy, as the stalks are also. At the joints from the middle of the stalk upwards, where it spreads into branches, stand many sinall, pale purplish flowers, in hairy rough hoals, after which come small, black, rough secd, which will stiek to any gotalment that shall touch it. 'The root is rather long, with small fibres of a dark reddish colour.

Menicisar, Virtues. - The dried heib Pellitory made into an clectuary with liency, or the juice of the herb, or a decoetion made with sugar or honey, is a singular remedy for an old or dry eonch, shortness of breath, and wheczing. Threc ounces of the juice taken at a time promotes urine, and cures gravelly affections. It is combined with other herbs used in elysters to mitigate pains in the back, sides, or bowcls, produeed by wind. If the bruserl herb, sprinkled with some museadel, be licated, and applicd to the belly, it has the same eflect. A decoction with a little lioney, is good to gargle a sore throat. The juice helel a while in the mouth, cures the toothiche. The juice dropperl into the car's takcs away pricking and shooting pains. The distillerl water rerluces hot and swelling imposthumes, burns anr scalds; being bathert often with cloth dipped thereiı. 'The powlered herb mixed with lant, and applied to the findanent, is a remeily for the piles. 'Tle juice is very ellece-

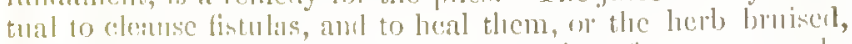
and applien witlo a little salt. It is curative of green womuls,

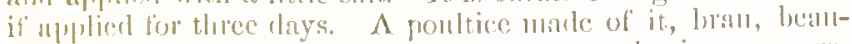

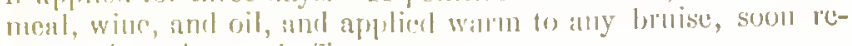
mores the pains, antel eflects a cure. 


\section{PELLITORY OF SPAIN.}

The juice of Pellitory of the Wall boiled to syrup with honey, תnd a s joonful of it drank every moming ; and continuing to clo so for a week, is a sufe and certain cure for drojsy.

\section{PELLITORY OF SPAIN.}

Description. - The root of the Anacyclus Pyrethrum,- It is a forcign plint, lunt it is grown in sone gardens in England. It requires care and attention. The root gocs down into the gronnd, bearing leares, similar to, but larger than the leares of eamomile. At the top it bears one single lange flower at a place, haring a border of many leaves, white on the npper side, and reiddish underneath, with a yellow thrumb in the mictdle, not standing so close as that of camonile.

The common Pellitory which grows here, has a root of a biting taste, searecly dimernible by the taste from that just des-

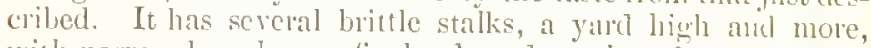
with narrow long leares finely dented at the colsces, standing one above another up to the tops. The flowers are many and white, in tults like those of yarrow, with a small ycliowisl thrm in the middle. The sceil is very smanll. The list glows in fields, under hedges, and other places. It flowers in June and July.

Medicinal Virtues.-I am persuaded it is one of the best purgers of the brain that grows. An onnce of the juice takcn in a dranght of light wine an hour before the fit of ague conse, it will drive it away at the sccond or third time taking. Either the herb or root dricel and elsewed in the montly, jumpes the hearl of phlegmatic humon's, by which headicle will be removed, and conghs, falling sickness, and lethangy relicved. The powder of the herb or root smutter up the nostrils. canses succzing, and eases lead-anche; being milte into an ointment with lard, it talics awny black and hine spots oceasioned ly

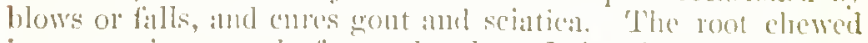
is a sovereign rencely for touth-ande. It is sold lye the Drug-

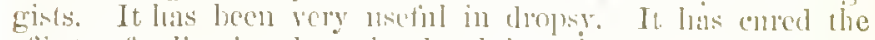
eflects of sallivation, hans stimulanter the pral liy tongroe and throat, and given relief to diseased nvula.

2016 


\section{PENNYROYAL.}

Pennyroyal, or Fleamint, the Mentha Puleginm of lotanists, of the order Labiate, is perennial. It flowers in September. It is a well-known plant. There is a larger kind than the ordinary sort found wild with us, now eultirated in gardens, and differs from it in the largeness of the leaves and stalks, in rising higher, ani not ereening upon the grominl so much. The fluvers are purple, growing in rundles about the stalks like the other. The wild species grows in marsly places.

Medicinal Virtees.-Dioscorides says, that Pennyroyal makes tough phlegm thin, warms the coldness of any part to which it is applicel, anl digests raw or corrupt matter. The herb is warm, pungent, and aromatic; somewhat similar to spearmint, but less agrceable. It is used as a popular remedy with much confidenee in obstructions of the courses, especially if attended with pain and hysteria. The oil is pungent and peculiar, differing from the other mints, which it resembles in its properties. A strong decoction of the whole lierb is a goon application for the gront, the pliee being rubbed with it till it is red, nurl if some salt be added, it is a rubefneient for the sicle in liver eomplaints, and for the itell. It is very warming and strengthening to stiff and coll joints, and removes cramps. The green herb bruised and put into vinegrar, clcanses foul uleers, and takes away marks, bruises, or blows about thie eyes. The oil is a remedy lor tooth-iehe. Pliny says that Pennyroyal and Xrint together, help faintings, being put into vinegar, anrl smelterl, or put in to the nostrils or month. It eases heatache, pains of the breast and belly, and gnawing of the stomach. Boiled in milk and rlank, it is ellectunl tor eoughs, and for nlecrs and sores in the mouth. Matthiolus says the rlecoction cures the jamblice and dropsy, all pains of the licill and sincws that conce of a cold catuse, and it clears the eycsigritst.

\section{PEONY.}

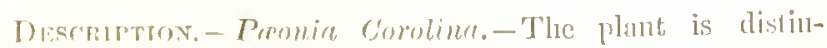
genisiber by Mate andel liemate.

Male leouy rises up with brownish slalks, whercon grow 


\section{PEONY.}

green and reddish leaves, upon a stalk without any particular division in the leaf. The flowers stand at the top of the stalks, consisting of five or six lnoul leaves, of a purplish red colonr, with many yellow threads in the mildle standing about the head, which become seed vesscls, divirled into three, or four crooked pods like horms, which eontain round, black, shining seeds, with crimson grinins, intermixed with blaek. The plant is beantiful. The roots are thick and long.

The ordinary Female Peony has many stalks, and more leaves than the male; the leares are not so large, but of a dead green, smaller, and of a more purple colour thin the Male, with yellow thrums at the head. The seed ressels are like those of the Male. They are culivated in gardens.

Medicinal Virtues. Male Peony roots are the best; the roots have more virtue than the seed; next the flowers, and then the leaves. The roots fresh patherecl, emre the falling sickness. The roots powdered is excellent for hysterical and nervous complaints. The root chopled small and inlused in white wine 24 honrs, and strained, is excellent tor nervons complaints, taking a wine-ylassful occasionally. A deeoction of Betony shonld be drank between. $\Lambda$ decoction of the root is very cleansing immediately after chikl-birth, and so is the black sect infused in wine; it also drives away melaneholy and nightmare. The Fentale is often used for the purposes aforesaid, beeause the Male is searee.

\section{PEPPER.}

Bhek and White Pepper are the fruit of the Piper Nigrum, belonging to the natural oriler Piperaces. It is a shmbry creeping plant, growing will in the East Indies, but chichly in

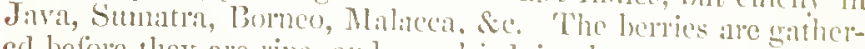
ed before they are ripe, and ane drical in the sun; their taste is hot and fiery, and theil sulell is slighlly aronatic. White I'eper is the fint of the salne plant, suthered after it is fully ripe, and fieed of its external cout by natceration in water. It is snnooth on the surfiec, and less pmingent than the Black I'eprer:

208 
Pepper is mostly used as a eorreetive of the eoldhess and flutulence of a vegetable dict, and is much adipted for warron climites, where the food is maturally atpeous, ant of a cold nature. Hence we use it with most regretables, especially eueunbers and peas, anul as a condiment to fish.

Medicinally, it is aromatie, enrmiuative, and stimulaut. It assists digestion, and gives tone to the stomach, if taken moderately. In gout, dropsy, rheumatism, cold pllegrmatie habits, the use of Pepper is advisable, and taken in a large dose, it is said to eure intermittents. In ineipient quinsies, before the tumour has broken, a basin of gruel well-seasoned with Pepper, taken at bed-time, will resolve it. Ward's Paste, so eelebrated for the cure of chrouie piles, is ehiefly eomposed of Pepper, whieh has been given in gonno:hoca, and applied as ointment to ringworms. As an antiflatulent it is mixed with other medieines, Mixed with breat, as a poultiee, it has proved benefieial in tic doloreux, and other neturalgie pains. It is mueh reeommended in palsy.

Ward's Paste for Pilrs.-1 ounee of Blaek Pepper, finely powtered, 1 ounee of Elecunpane Root, 3 ounces of Fennel Seed, well mixed. Melt togrether 2 ounces of Sngar, and 2 ounces of clarificd Honey, for a Syrup, which add to the mixed powiler, triturate them well. Talse the size of a nutmegr twico a dlay; wash well down with a glass of eold water or white wine.

\section{PEPPERWORT, OR DITTANDFR.}

Description. - Lepirlinm Campestre.-It derives its namo from the biting taste of its leaves and root. Pepluerwort puts forth somewlat long and broad leaves, of a light l, hish grecuish colom, finely denterl alyot the edges, and printerl at the ends,

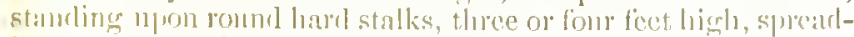
ing many batuches on all silles, and having matuy sulill whito flowers at the tors of them, after which follow suntll secels in

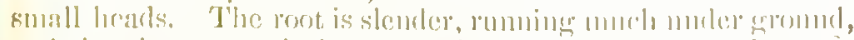

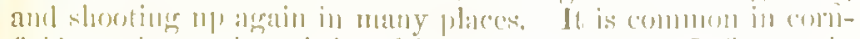

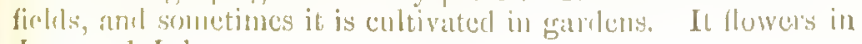
June aurd July. 


\section{PERIWINKLE.}

\section{ST. PETER'S WORT.}

Medicinal Virtues. - Pliny and Paulus Agineta say, that Pepperwort is very slleeessful for seiatiea, for gout or pain in the joints; the leaves to be bruised, and mixed with lard and applied to the place for four hours in men, and two hours in wonlen, the plaee being afterwards bathed with wine and oil mixed together, and then wrapped up with wool or skins, after they have sweat a little. It also mends the deformities or diseolumings of the skin. The seeds are very effeetual in warming eold plilegmatie eonstitutions.

\section{PERIWINILLE.}

Description. - Vinca Minor.-There are two kinds, the Garden and the eommon. The eommon has many branehes rumning upon the ground, shooting out small fibres at the joints as it runs, rooting thereby in the ground. At the joints of these branches stand two small dark green shining leares, somewhat like bay leaves but smaller, and with them eome forth the flowers, (one at a joint) standing upon a tender footstalk, somewhat long and hollow, parted at the brims, into four or five leaves. The eommon sorts are of a pale blue eolour : some are pure white, and some of a dark reddish purple eolonr. The root ereeps, and spreads rapidly. Those with pale blue, and those with wlite flowers, grow in woods and orchards, hy the hedge-sides, but the purple-llowered in gardens only. They flower in Mareli and April.

Medicinal Virtules - The Periwinlile is a great binder, stays bleeding at the month and nose, if some of the lenves be eliewed. 'The French nse it to stay wonen's con'ses. Dioscoriles, Galen and Asyineta eommend it agrainst fluxes, to be drank in wine. It is a remedy for hreding piles, the leares bruisct and made into an oindnent, with lavd.

\section{ST. PETERS WMTT}

1) Escompron. Petre Iterbu. - It rises up with square

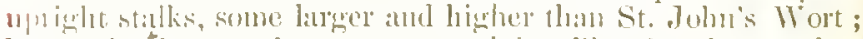
bunn, laving two leates at crely joint, like, but linger thon 210 
St. John's Wort, a little round pointed, witl few or no holes in the leaves, and having some smallcr leaves rising from the bosom of the greater, and a little hairy. At the tops of two stalks stand many star-like flowers, with yellow threads in the midlle, very like those of St. John's Wort, differing only in size and height. The secel is the same in both. It grows in many small low woorls, and near water-conrses. It flowers in Junc and July, and the seed is ripe in August.

Medicinal Virturs. They are nearly the same as those of St. John's Wort, yet rather weakcr. Two drachms of the seeds taken at a time in honey-water, purges cholerie humours, (as say Dioseorieles, Pliny and Galen) and therefore it relieves the sciatica. The leares are used as St. Johu's Wort, to euro burns and scalds.

\section{PIMPERNEL.}

Descriptiov. - Anagallis Arvensis. - This is a pretty ornament to meadows and corri-ficlds. Common Pimperinel has scveral weak square stalks lying on the ground, linving two small and almost round leaves at every joint, one against another, very like Chickweed, but witliont foot-stalls; for the leaves compass the stalk. The flowers stand singly on tender font-stalks; they consist of five small round-pointed leaves, of a searlet colour, with threarls in the midulle. It grows almost every where, and flowers firom MLay until Angnst.

Pimpernel is known as the Punr Butun's Weather Glesse, the flowers openinger at alout 7 in the morniner, and closing alount 2 in the afternoon; and also the Shepherd's Barometer clusing on the approncle of rain.

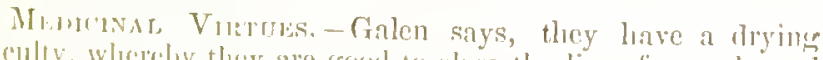

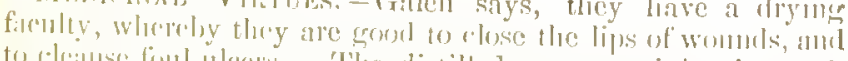

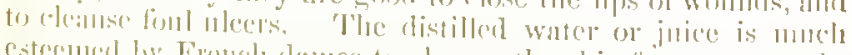

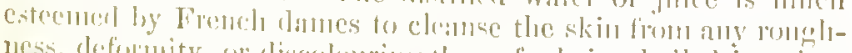
ness, elefolmity, or discolouring thereof; lecing lwalerl in wine, and given to drink. It is a gond remedly nerainst pestilemtial fevers, if the party after taking it be wallon in bed, and sweat for two hours after, and use the sime twice at least. It conres 
stings and bites of bees, wasps, and even mad dogs, used inwardly and applied outwardly. It removes obstructions of the liver and kidneys, prorokes urine and cxpels gravel, and relieves inward pains and ulcers. The decoction or distillal water is effectual to be applicd to all fresh wouncis and to old ulcers. A little honey mixed with the juice, and dropped into the cyes, remores clourly mists, or thick films which grow over them. Ray states that the distilled water is effectual in consumption, bcing mixed with milk.

\section{PAREIRA BRAVA.}

The root of the Cissampelos Paveira, a plant growing in the West Indies, and in South Amerien. It has a bitterish sweet taste, and is tonic, dimetic, and aperient. It is highly valued by the inhabitants of Biazil, \&c. They use a decoction of it for pains and weakness of the stomach arising from general debility. It is of great service in urinary disordcrs, on account of its tonic influence upon the bladder. It has been found very serviceable in uleeration of the kidneys and bladder. Dr. Graham in his "Domestic Medicinc," says, "One of the most prominent symptoms of chronic inflammation of the bladder is an abundant diseliange of a ropy adhesive alkaline mucus, and we have Sil B. Brodie's testimony to the fact that the use of the decoetion of the loot of the Pareira Brava is here frequently productive of execllent efticts."

"The decoction is prepared by simmering 4 ounces of the root in 3 pints of water, until it is reduced to 2 pints, and then strain. The dose is a small tea-eupful, (abont 4 ounces) twico or thrice a day. A little tincture of Heubune may sometimes be advantageously eombined with it."

\section{PINK,_INDIAN.}

Spigelia Marilandica-This grows in North America. It is :uthelnintic, and noted for its expulsion of lumbrici worns fiom the alimentary camal. Some order it in doses of $1000^{\circ} 1.5$ grains, others in drachun doses, alleging that the nervons atliec212 
tions it sometimes produces, more readily happen from small doses; while the larger doses purge or vomit. Some grive an infusion of Indian Pink and Scnna for worms of all kinds. Infirsel in wine, it has been fond nseful in intermittent fevers. T)1. Barton recommenils it in the insirlious remittent fever of children, which often lays the foundation of water in the head.

\section{PLANTAIN.}

Plantago Major.-It grows in meadows and ficlds, and hy pathsides. It is also called Way-bread, and Waty Broud Leaf.

Medicival Virtees.-The leaves are bittcr and astringent, and have been long held in popular esteem as a wound herb. They are used as an external application to ulecrs, and indolent scrofulons tumours. The root has been found useful in intermittents. A mucilage prepared from the sceds has been found bencficial in the catarthal and mild inflammatory form of diarrhœa. The juice is exccllent for pains in the bowcls; it restrains fluxes, spitting of blood, bloody urine, proceeding from an ulcerated bladder, and bleeding wonnds. $A$ decoction of the roots sweetened with honey or sugar is excellent in consumption, allaying cough, \&ce. It is also good in ague. Tho herb (but especially the seed) is effectual against dropss, falling sickness, yellow jaundice, and obstructions of the liver and reins. The roots of P'latintain and P'ellitory of Spain, beaten into powder and pat into the hollow teeth, take awily pain. 'The clarified juice, or distilled water, clropped into the cyes, cools inflammation, and elcars the sight, and dropeped into the ears, cases min and removes the heat. The lyruised leaves form a good application for burns and sealels. The juice mixel with lart is a good application for the piles. 'Tle juice mixed with oil of roses, nnd the temples and forchend battled with it, cases pains of the licad arising from licat, and is very applical,le to lunatic an.l frantic persons; to hot gonts in the feet or hankls, esjecially in the begriming. It is goost to tio applied where lone is ont of joint, to linder inllimmations, swelliness, and pains. 'The powrler ol the drierl leaves talkin in drink destroys worms Une part of plaintain in deroctisn, 


\section{PLANTAIN.}

\section{POLYPODY OF THE OAK.}

and two parts of the brine of beef, boiled together and clarified, is a sure remedy to heal spreading seabs, or iteh in the heal and borly, also lingworms, the slingles, \&e. It is remarkable that it is the chief remedy for the cure of the rattesnake, for which discovery an Indian reecived a great reward from the assembly of Soutli Carolina.

There is another speeies of Plantain, ealled HoArr PlaxTar, Plantago Media. The leaves are small, and less blunt than in the last, hoary, lying elose to the ground. Its Medicinal Vivtues are much the same. The seeds boiled in milk are laxative and demuleent. Boyle recommends an eleetuary, marle of fiesl comfiey roots, juice of Plantain, and sugar, as rery cfficacious in spitting of blood. Plantain juice mixed with lenon juice, is an excellent diuetie.

\section{POLYPODY OF TIIE OAK.}

Descriftion. - Polypodium Vulgare.-This is a perennial herb of the fern tribe. It is a small herb eonkisting of nothing but roots and leaves, bearing neither stalk, flower, nor seed. It has three or four leares rising from the root, each one single by itself, of about a hand lengtl, are winged, consisting of many small narrow leares, ent into the middle rib, standing on each side of the stalk large below and smaller up to the top, not dented at the edgres is the male fern is, of a sad green colour, and smooth on the upper side, but on the other side rongh, by reason of some yellowish spots set theteon. The root is smaller than one's little finger, creching under the upper ermst of the earth, of a sweetish harsh taste, set with rough knigs on each side, having mucl mossiness or yellow hairiness upon it and some fibres undementh. It grows also upon old rotten stumps, or trunks of trece, as oik, heech, hazel, willow, or any other, als in the woods under them, and upon old mud walls, and in mossy, stony, and gravelly jlaces nean unto wook. That which grows upon onk is aceounted the best.

Medicinal Virtues. - The fresh root is used; it is a safe and gentle purge, used ans a decoction it promotes the flow of urine. It is eflicacions in jandice, drepsy, and senryy. It is 214 
an expectorant removing phlegm copiously. Combined with mallows it drives away melancholy, removes hardness of the spleen, stitehes in the sides, and colic. Combined with a littlo ginger it is a safe and gentle medicine, fit for all persons. A drachm or two of dried loots powdered, taken fasting in a cup of honey water, works gently, and for the purposes a foresaid. The distilled water both of roots and leaves, is much eommended for the quartan ague, to be taken for days together, and with some sugrar-eandy dissolved therein, is good against cough, shortness of breath, wheezings, and those distillations of thin rheum upon the lungs, which causc consumption. The fiesh roots beaten small, or the powder of the dried roots mixed with-honey, and applicd to the nose, cures the discase called Polypus, which is a picce of flesh growing therein, which in time obstruets the passage of breathing through the nostrils.

\section{POMEGRANATE.}

Punica Granatum.-It belongs to the natural order of Byrtacee. This tree grows in $\Lambda$ sia and $\Delta$ frica, and in warm countries generally. It yiclds a pleasantly acid and sweetish fruit, which is used for the same purpose is the orange. The flowers, the rind of the fruit, and the bark of the root, have been used in medicine, as astringents. The bark is powerfilly astringent, and is employed, in decoction, as a gargle for sore throats. It is also given in diarhoea, and as an injection in leucorrhcea, and the powder in intermittent fever; dose 20 grains. The natives of India grive it as a vermifinge. The bark of the root is reckoned a powerful remedy for tapeworm. Dr. Cluristian says, "It seems searccly $\mathrm{cvel}^{\circ}$ to fail, if properly nserl."-Steep 2 onnees of the fresh liats in 2 pints of water for 12 lonrs; then boil down to 1 pint, strain, and give a wine-grlassful every two hours till the whole is tirken. Stometimes joints of the worm come in less than :Hn lionl after the last rlose; but often the droses innst lee repeated several successive molnings lefole the effect is complete; and it is right to repeat occasionslly for $40 \mathrm{Ol}^{\circ} 5$ days after junds late curacel to come away. Laxatives should be admiutstered from tiule to time. 


\section{PONDWEED.}

Description. - Potamogiton Natans. Called also Crab's Claw, Water IIouscleck, Se. It grows plentifully in the Lincolnshire fens. It has long narrow leaves, with sharp prickles on the erlges. The stalks have a forlied head, like a clab's claw, ont of which comes a white flower of three leares with jellowish hairy threads in the midelle. It roots in the mud in the bottom of the wiater.

Minicinil. ViRTues. - It is a great strengthener of the lindneys; it is bereficial in Erysipelas, and rodues swellinge, inflammations, \&e. An ointment male of the leaves wirb Hog"s Larl is very hoaling. It is one of the most valuable remedies for discased kidneys.

\section{POPLAR TREE.}

Description. - Popalus Nigra.-There are two kinds of Poplars, viz. Black and White. The White Poplar groms large and high, covered with thick, smooth, white bark, cspecially the branches, having long leaves eut into divisions almost like a vine leat; they are a glossy shining green. The eatkins which come before the leaves, are long and of a reddich colonr; which fall away, seldom bearing good seed with them.

The Black Poplar grows hicher and straighter that the White, with a greyish bark, bearing hoal greenl leaves. somewhat like ivy leaves, not indented on the edives like the irhite, cucling in a point, and not white nulerieatli, hanging ly slender long foot-stalks, which contimally Alake like the aspen leares. The catkins liereof ate reatel than those of the White, composed of many romul green breries, in a long clus-

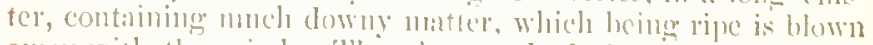
nway with the wind. The dimmy holls loctere they spread

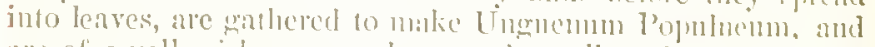
ane of a yellowish green colonr, and sulall. lather sweet, but stroner. (bu both these treece grows a sweet kind of musk, which formerly was therl to put into swent ointments. 216 
Medicirar Virtres. - White Poplar, says Galen, is of a cleansing property: one ounee in powder of the luats being drank, says Dioscorides, is a remerly for those that are tronbled with the seiatica, or the straugury. 'l'le juice of the leaves dropped warm into the cars, eases pains in them. The young elammy buds, or eyes before they break out into leaves, bruised and $\mathrm{n}$ little honey put to them, is a good medicine for a dull sight. The Black Poplar is held to le more cooling than the White, and theretore the leaves bruised with vincarar, and applied relicre the gont. The seed drank in vinegal is held good against falling sickncss. The water that drops from the hollow places of this tree, takes away warts, wheals, and other like breakings out of the borly. The youmg lilitck Poplar buds, says Mattliolus, are much used by women to beautify their hair, bruising them with fresh butter, straining them after they have been kept for some time in the sun. The ointment ealled Populneum, which is male of this Poplat, is good for all inflammations in any part of the body, and tempers the heat of wounds. It is much used to dry up the milk of women's breasts, when they have weaned their child.

\section{POPPY}

Description.-Papnver Album, has three kinds, viz. the White, Black, and the Red Poppy.

The White Polpy has at first four or five whitish green leaves lying upon the grounil, whole rise with the stalk, "(umpassing it at the bottom, are rery lange, mucl cout on the edgers, and rlented; the stalk which is fom or fire fied ligh, sumbtimes no branches at the top, msually but two or thre :if mas, each bealinger one hearl wriplecel down before it blows, ant then rising, the flower bonalis ant,

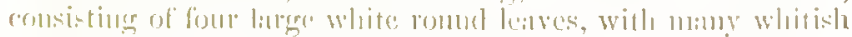

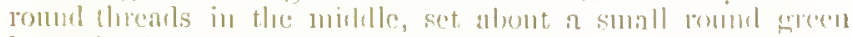
hearl, haviug a comm or stall-like covel at the end therent,

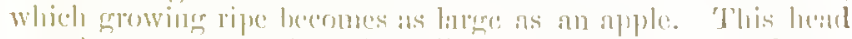

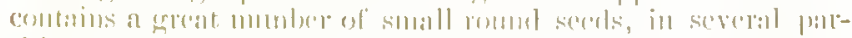

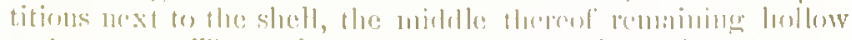

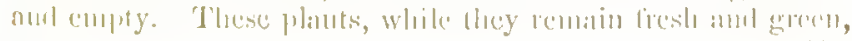




\section{POPPY.}

yield a milk when they are broken, of an unpleasant bitter taste, and of a strong smell, whieh being condensed is called
Opium.

The Black Poppy, Papaver Nigrum, little differs from the former; but the flower, whieh is somewhat less, and of at black purplish eolour, but without any purple spots in the bottom of the leaf. The head of the sced is much less than the former, and opens itself a little round about the top, under the erown. The seed is black.

The wild Red Poppy, or Corn Rose, Papaver Erraticum, has long and narrow leaves, very much eut in on the erlges into many divisions, of a light green eolour, sometimes hairy ; the stalk is blackish and haily also, but not so tall as the garden kind, having sinilar Jeares thereon to grow below, parted into three or four branches, on wich grow small hairy heads, on which is the flower, of a yellowish red, crimson, or scarlet coloul, withont any spot in the bottom of the leaves, Inaving many black threads at the middle, eompassing a small green head, which eontain much black seed, smaller by half than that of the garden. The former two are cultivated in gardens, the Iatter grows in eorn-ficlds, on ditch banks, ste.

Medicinal Virtues.-It is a valuable plant, for all its parts, and especinlly the eapsule, or sced-vesscl, rield a white opaque nareotic juice, called Opiun. Syrup of Poply is mado fiom the eapsule. But it should be given by the skilliul hand, for it is dangerous otherwise. It is taken to proeure ense, rest, and sleep for invalids; and also to ense coughs, hoarseness, and loss of roice. The Puppy heads nsed for fomentation, are mostly of home growth; their anodyne properties render them valuable to soothe infammations and pain. They should bo broken up, and boiled, the licuor only to be nsed. $\Lambda$ fannel dipperl into it, wrumg ont, and alpliecl to the palrt alfected, and renewed as it begins to cool. The decoction also taken in moderation, relieves prain, and promotes sleep.

The Extract of Poppies is not so strong as opinm, and may be given in doses from 2 to 10 grains. Mrade thus:-Brnised Polyy heads 15 onnces; boil in 1 gallon of water down to 4 pints ; strain, and evapurate to a proper consisteuce.

218 
The Wild Poppy, or Corn Rose, is gnod to prevent the falling sickness. 'The Syrup made with the leaves and flower, is cffectual in plenrisy, and St. Antlony's fire, or Erysipelas. The dried leaves decoetel have the sanne efliect

\section{PRIMIROSES.}

Primula Veris.-The root is used. The juice snuffed np the nose canses sneczing, and is a good remedy against headache. The dried root powdered has the same effect.

\section{PRIVET.}

Description, - Ligustrum T'ulgare. $-\Lambda$ little wild shnub in hedges. It grows four feet high. The flowers are small and white. The fruit is a black berry. But it is well knowu as it fiequently forms a beantiful hedge.

Medictinal Virtees. - The tops are nsed; and they are best when the flowers are in bud. Mattluiolus says, that the oil made of the flowers of Privet infused, and set in the sum, is good for inflammations of wounds and healache coming of a hot eause. There is a sweet water also distilled from the flowers, that is good for all those diseases that need cooling or drying. A strong infusion of the tops in water, with the addition of a little honey and wine, make an excellent wash for the mouth, and throat when there are little sores in them, and when the gums are apt to bled. It is a good wash for all sores.

\section{PRUNES.}

The rlier fruit of the Plum, or Prunus Domeslien, of tho natural orler finserece. I'runes possess much mucilagrinons and sacclarine matter. They alsate lest, aucl gently open the bowels, which they perform loy lubrisating the pilssiges and softening the excrement. They are of great service in costiveness, acerm janied with hent and irritation, which the more activo catliarties wouk tend to argratrate. Whate furmes are not 
suffieiently purgative of themselves, their action is promoted by eombining with them a little rhubarb, or by putting them in an infusion of Senna, adding a little ginger to prevent flatuleney. They form a part of the Lenitive Fleetuary; and even taken alone, gently, in some eonstitutions, open the body. The Freneh Prunes are the best.

\section{PURSLANE.}

Description.-Portulaca Sativa.-Garden Purslane, as a salad herb is so well known as to require no deseription.

Medicinal Virtues. - It is good to eool heat in the liver, blook, reins, and stomaeh, and in hot agnes nothing better. It restrains hot and eholerie fluxes, the whites and gonorrher, distillation from the head, and pains therein proeeeding from heat, want of sleep, or the frenzy. The seed is more effeetual than the herb to eool the heat and sharpness of uriue. The seed bruised and boiled in wine, and given to ehildren, destroys worms. The juiee of the lierb is effeetual to stay vomitings, and taken with some sugar or honey, it relieves an old dry eough, shortness of breath, and immoderate thirst. The juiee also is singularly good in the inflammations and uleers of the privities and bowels. The herb bruised and applied to the forehead and temples, allays exeessive heat, and applied to the eres, it removes inflammation and St. Anthony's fire. If a little vinegar be put to it, and laid to the neek, with as mueh of galls and linseerl together, it takes away pain. The juice is used with oil of loses for the same purposes; applied to the navels of ehildren that projeet, it rednees them; it is also goorl for sore months and gums that are swollen, and to fisten loose teeth. Camerarius says, that the clistillerl water took away pain in the teeth, when all other remedies failed, and the thiekened juice made into pills with the powder of grum tragneanth and arabie, being taken, is a remedy for blookly urine, and applied to gonty limbs, it eases pain.

\section{QUASSIA.}

Qnassia Chips eome from Jamaica and the Caribhean Islands. It was ealled after Quassi, a negro of Surinan, who first dis$2: 0$ 
eovered its tonic and fehrifuge properties, which he employed with great success in the cure of malignant fevers. It is a very powerful tonic, invigorating the digestive oroans and the intestinal canal, with little excitement of the circulation, or increase of animal heat. Its taste is intensely bitter. It is excellent for nervous irritability, intemittent, and bilious remittent fevers, looseness, and gout. It is good for female complitints, as hysteries, the effect of debility. An infission may be male hy pouring a pint of boiling water on a drachm of the ehips, as a tonic and antiseptic, in bilions fevers, mited with Alkaline Salts. Dose from 1 to 2 ounces, repeated twice or thrice a day; in gout, with aromaties and ginger; in lysteria, with Cimphor and Tincture of Valerian.

\section{QULNCE TREE.}

Cydonin Tulgaris. - It is now cultivated in gardens, especially in the south of England. It yichls a fruit which is used for imparibur a pleasant Havour to tarts and pies. Quinces are also marle into marmalade; and the syrup made from them is n pleasant addition to hererages during siekness. The juice of the ripe Quine mate into a syrup with surall is exeellent to stop voiniting, and to strengthen the stoniach. 'The green finit is astringent, and restrains Alux, and diarhocis. The syrup made ol the juice is still more so. The mueilnge is used extermally as an enollicut and sheathing application to eracked lips and nipples. Lantoline, nsed by hairdressers as a eement for dressing the hair in hrairls, is merely this mucilage evalpolatcit. It apppears to have nareotic properties, for a strong deepetion sweetened with honcy, destroys flics. If a little vinewar be added, it pronotes appetite. Some spices beingr alded, it revives f.inting spirits, and removes obstructions from the liver. If you would lave them purging, put. honey to them insteal of sugrar; sull il nore laxative, llumbab; but if note

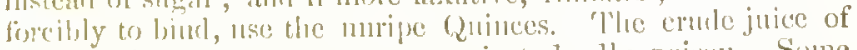

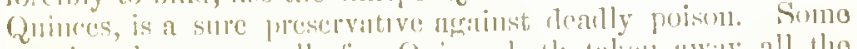

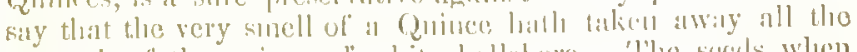

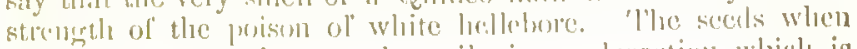
boiled in water make a goorl mucilaginoms decoction which is 


\section{QUININE。}

\section{RADISH}

useful in thrnsh, and other irritable conditions of the mucous membrane:-Quince seed 2 drachms in 2 pints of water, boil $10 \mathrm{or}^{\circ} 15$ minutes, and strain. Sweeten with sugar or honcy.

\section{QUININE.}

Quinine is a chemical preparation from the Yellow Peruvian Bark, by means of Sulphuric Acid. It appears as a pure white powder, partly soluble in hot water, and wholly so in diluted Sulphuric Acid, and also in Spirits of Wine. For internal administration, it has almost superseded the bark on account of the minute dose required. Eight grains are equal to about one onnce of the bark. There is scarcely any drug so valuable as Quinine.

In cases of violent periodic headache, it is most nseful. It is also a powerful tonic. In agues and intermittent ferers of all kinds, it is found to be indispensable. In neuralgic affections, and those caused by debility, its cficacy is marked and decided. It is adopted in cases of typhoid ferer, and in the sinking stage, combined with Port Wine, it is very heneficial; and in recovering fiom low fever, and other severe diseases, very debilitating, the Quinine is of ten prescribed with great advantage. The simplest mode of administration, in drspepsia, and as stomachic, is, Quinine, 1 grain; Elixir of Vitriol 5 drops; Watcr, l ounce; Syrup of Orange Pecl, 1 drachm. Mix, and take ocensionally. Combined with Valerian, it is highly recommended as a nervine and autispasmodic.

\section{RADISII.}

Raphamus Satimus. - The garden Riddish is so wejl known that it needs no deseription.

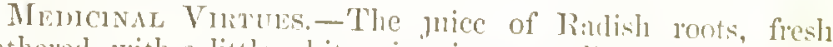
gathered, with a little white wine, is mexcellent ronedy in the gravel. Scarcely any thing operates more spedily by ninc, or brings away little stones more sncecsifully. 'The liadish is fit only for those who have a good digestion, not for the dysjeptic. 


\section{RAGWORT.}

Description.-Senecio Jacobea.-It is also called St. James's Wort, and Stagger-Wort, and Stammer-Wort, Segrum, and Rilgrweed.

The greater eommon Ragwort has many large, long dark green leaves lying on the ground; it has very ragged leares, fiom which rise sometimes one, and sometimes two or three square blackish purple stalks, three or four feet high, sountimes brinehed, benring such like leaves upon them, unto the top, whrre it branches into many stalks bearing yellow flowers, consisting of various leaves, set as a pale or border, with a rank yellow thrum in the middle. The root is very fibrous, anct the seel is downy.

'There is another sort that rises not so high, the leaves are not so tinely jagged, nor of so dark a green colour, but rather whitish, soft and woorly, and the flowers paler. Both grow wild in pastures, and untilled grounds, and oftentimes both in one field.

Medicinal Virtues. - The deeoction of the herb is good to wash the mouth or throat affecterl with uleers or sores, and for swellings, harchess, or imposthumes, for it thoroughly cleanses and heals them; also the quinsy, and the king's evil. It is useful in eatarths, thin rhems, and defluerions fiom the head into the eyes, nose, or lungs. The juice is grood to heal green wounds, and to cleanse and heal obl ulcers, inward wounds and ulecrs, rmnning cankers, anil hollow fistulas. It gives relicf to aches aurl pains either in the fleshy part, or in the nerves and sinews; as also the sciatica, or pain of lie hips or huckle-lone, by fomentiug with a deeoction of the herb, or anointing them with an ointment mate of the berb, bruised, ancl boiled in hoges land, with some matstie atud olibanum in puwrler arkled moto it alter it is stminerl.

\section{IRSNUNCUIUS.}

The various speeies of Ramunculus, or Pullereup, so common in this commtry, ate chicily rematiable for their acrility, moved 


\section{RASPBERRY.}

\section{RATILE GRASS.}

by chewing a small portion of thcir leaves. Their aetion is emetic, and when bruised and applied to the skin, irritating, ncting like a mustard-plaister, or blister. Sce Crowfoot. 'Tlecil acriclity arises from in rolatile prineiple, whicl is destroyed by boiling, or even ly drying. It is not fit to be taken inwardly, on aecount of its poisonous influence. "The juice of nust members of this genus of plants when applicd to the skin acts as a rubefacient; in come cascs it acts as a blister. The knowledge of this might prove very useful.

\section{RASPBERRY.}

This well-known plant is the Rubus Idcus of botanists. In some parts it grows wild, but is usunlly enltivated in gardens. Its funt is fragrant, sub-aeid, and cooling. It is very wholesome, and allays heat and thirst better than any other kind of fruit, except strawbery, which it equals. Both of then are not liable to acetous fermentation in the stomat. Raspberry Jam is one of the most pleasint and wholesome of confections. In fever and feverish discases generally, when the acid is not an objection, the well-known hespberry linegar is an agreeable and salntary beverage. It is an cxcellent gargle for sore throats. When the acid is not proper, a pleasant bererage is made by mixing the preserve or jam, witl water. An infusion or decoction of Rasplierry leaves is a sure remedy for great laxity of the bowels. I have lnown this prove eftectual in the sererest cases.

\section{RATTLE GRASS.}

Descinition.-Quassatio Gramen.-Oof this there are two kinds, vir. the red and yellow. The common hed latile las reddislı lollow stalks, and sonetimes green, mostly lying on

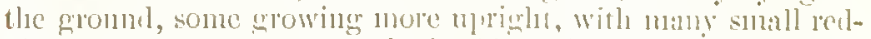

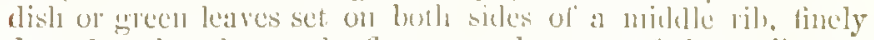
dented at the elges; the flowers at the topls of the stallis are ol'a purplish red colour, like smatl ganping looks, after which 


\section{RATTLE GRASS.}

\section{REST HARROW.}

eome blackish seed in small luuks, which being loose, rattle with shaking. The root is fibrous.

The conmon Yellow Rattle has only one rond great stalk, about lalf a yard or two feet high, with few lranches, having two long and rather broad leaves set at a joint, indented on the edges, like the comb of a cock, broadest next to the stalk, and smaller at the end. The flowers grow at the tops of the stalks, with shorter leares, hooded like the former, but of a fin yellow colour, or in some paler, and in some whiter. The seed and root are the same as the former. They grow in mealows and woods, and flower from Midsummer until Argust.

Medicinal Virtues. - The Red Rattle is good to heal fistulas and hollow ulcers, and to stay the flux or humours in them, and profuse menstruation, or any other flux of bluot, being boiled in red wine and drank.

The Yellow Rattle, or Cock's-Comb, is said to be good for eough, or dimmess of sight, if the herb, being boiled witl some holley, be drank, or dropped into the eyes.

\section{REST HARROW.}

Description. - Ononis Avveusis. - A little tolngh and almost shruldhy plant, common in dry fields, and by roar sides. Some call it Cammoek. It is one or two feet high. The stalks are round, rerldish, tongh, nearly woorly. It has numerous leares, three stanrling on each foot-stalk, elose to the stalk. 'Tliere are several sliort and sharp prickles about the stallss, prineipally at the insertions of the leaves. The flowers are small, purple, anrl stand among the leaves towards the tops of the stalks, sliajed like pea-lolossoms, but fatter, ench is followed by a small porl. The root is white within, long, tough, and woorly.

Mancinal Virtues.-It removes olstuctions in the lirlneys. The bark of the root powelered is a goorl reucily for tle stone. It should lue taken in wine. Matthiolus sayys that it rules the eliserase ealled IIeruia Carnosa, the fleshy rupture, by talking the poweler for some monthe constantly, and that it luas cureal some which seened incuable loy ary oblice meuns than by eut- 
ting or burning. The decoetion is an excellent diuretic ; atu. it is very powerful to open obstructions of the liver and spleen. It is celcbrated as a remedy for rhcumatism, especially the ehronic, Though it may not be successful in every ease, it can do no harm. It has been known to cure many cases that had long resisted other means. The powder of the root made into an electuary, or lozenges, with sugar, also the bark of the fresh roots boiled tender and afterwards beaten to a conserve with sugar, has the like effect.

\section{RHATANY ROOT,}

This is the root of the Irameria Triandria, a native of Peru, where it is called Ratanhia. It is a powerful astringent, and tonic, and is very efficacious in debility and relaxation, in chronic diarhoen, and passive hamorrhages, or dysentery. It is much used in the manufacture of Port Wine, and in some cases with Logwood, to which it gives its rich red colour, and astringency. It may be administered in infusion; half an ounce of the root bruised to six ounces of boiling water; and by decoction, by boiling two ounces of the bruised root in a pint of distilled water; Dose of each from one to two ounces. The tincture is very useful. Take a ten-spoonful or two in water, two or three times a day.

\section{RHODODENDRON.}

This is a well-known beantiful garden shrub. It belongs to the natural order Ericac. 'Thicy all possess medicinal properties. The juice is acrid, and to some extent, nareotic. Hence the ancients said, that the loncy obtained by the bees from the species, Azalsa Pontica, male those nnad who ate it. In Siberia, the Rhododemtron. Chrysanthemum is used as a remcly in rheumatism; an infusion of the leaves is talich, which camses a crecping or pricking sensation, which gralually subsires, and with it the rhemmatic pains. It is good in palsy and syllilis, Those grown in om gardens have the same effect. $\because \div 6$ 
But skill, and caution are requisite in the use of their narcotic properties. Beantiful ornaments of gardens and shrubberries, they are redolent with poison.

\section{RHUBARB,-BASTARD.}

It is also called the Great Round Leaved Doek. It is the Garden Rhubarb, which every borly knows. And what is said of the virtues of the Forcign Rhubarb, may be said of this in degree. Culpeper bas written many absurd things about Rlubarb. I will not disfigurc this book with them; but cxtract the hest. The juice of the leaves or roots or the dccoction of them in vincgar, heals scabs and ruming sores. A decoction of the seed cascs pains in the stomach, and strengthens it, by incrcasing the appetite. The root strongly decocted is a good wash for scrofulous sores, \&c. And taken inwardly, it removes obstructions of the liver, and cools the blood. In short Garden Rhubarb differs not fiom the Foreign, exeept the latter is more powerful.

Garden Rhubarb, nsed as food, has a slight aperient aetion upon the bowcls. In some cascs, this may be bencficial ; but those who have tender bowcls had bettcr abstain from it. Some mix with it a little ground Gingcr in puddings, pies, \&c., which counteracts that tendency. It is a very wholesome and cooling dict. Its agrecable acid depends on the presence of the oxalie (slightly) and malic aeids, which it abundantly eontains. Persons subject to urinary iritation slould take it very spar-
ingly, or not at all.

\section{RIIUAARB,-FOREIGN.}

This is sold by Drugrgists in the root, or the root powrlered. It is one of the most usefinl dirugrs. The species of Rherem which produre it are thought to be Rherme Pulmatum, Undulabum, Raponiticum, and Austrele. It principally grows in Chinese Tartary, and is gatloered in summer from plants six years old. A partion of this Rerubarb grocs to China, the remainder passes through Lussia, and is known in this eoutury 


\section{RHUUARB,-FOREIGN.}

as Runsinn or Turkey Rhubarb. This is the lacst. It is in roundish piees, of a yellow reddish colour on the outsinte, soft and ensily reducible, having many streaks of a benutiful bright red eolour. It has gencrally a hole in the middle, as it is the custom to string them when newly gotten, in order to dry the pices. It is also enltivated in Oxfordshire; and that is the kind sold by men dressed up as Turks as the gennine Rlunbarb. Sume of this is very good; yet so powerful and unrealsonable is prejucliee, that very little of it ean be sold.

Few medicines are more valuable or safer. It is a mild and effeetual aperient, the aetion depending upon the amonnt of the close. It rarely gripes; it has a benefieial tonie netion upon the stomaeh. It is astringent, and therefore has a little tenleney to eonstipate after its purgative effeet is orer. Dr. Griham says, "In the dose of one, two, or three grains, twice or thrice a day, it aets as a raluable stomachie, stimulating the stomaeh, inereasing the appetite, and promoting a healthy flow of bile, and is of mueh serviee in indigestion, low spirits, jammice, and a weakened relaxed state of the bowels. It aets clicfly on the stomaeh and first intestines, and in these eomplaints may be advantageously combined with soap, dried subearbonate of soda, ipecaeumnlia, or extraet of gentian. A pili of two grains of rhubarb, one of ipeencuanha powder, and one of soip, repented thrce or four times a-day, is sometimes of snperior bencfit in indigestion, and bilions eomplaints, especially of elderly persons.

Rhubarb may be taken alone as an aperient, in doses from ten to thirty grains, mingled with water, or made into pills. Some persons earry the root with them, and chew it occasionally, and this is a good way of taling it. Where the bowels are sluggish, it makes an excellent dinner pill, combined with ginger and a tittle Castile soap. Rihnbanb is very useful in a lix state of the bowels, as it expels any acrid matter that may be oflending the bowels, before it acts as an astringent. It strengthens the intestinal enual, and therefore it is a safe and valuable purgative for elildren, "in whom," as Dr. Graham says, " that cunal generally possesses a great degree of relaxation, and morbid inritability." "When it is intended to act on the bowels, it should be given in conjunetion with about fifteen 
grains of super-snlphate of potash, which covels its taste, and causes it to aet morc readily and with grcater ccrtainty."

Gregory's Pouder is valuable, as a stomachic, and mild apericnt, very advantageous to both adults and children. Composed thus:-Rhubarb, 2 parts, Calciucl Magnesia, 4 parts, Ginger, 1 part. It may be taken in simple water, or 11 watcr and a few dropss of sal-rolatile, which will increase its stimulant and tonic propertics. It slonkld not be takcu regullarly, as the quantity of magnesia might irritate the coats of the stomach, and bring on diarrhœa.

The Compound Rhubarb Pill, is a safe and valuable apelient. Rhubarb, 4 drachuns; Alocs in powder 3 dracims; Myrhl in powdcr, 2 drachms; Hard soap, scraped, $\frac{1}{2}$ a draclim; Oil of carraway, $\frac{1}{2}$ a drachm. Malic up with trcacle or mucilare.

The Tincture of Rhubarb is one of the best stomachies known. Made thus:- $-\frac{1}{2}$ ounces slieed rlubarb; suffron, 3 drachms ; liquoriee, brnised, 6 drachms; proof spirit, two jints ; macerate for a week, and strain.

Extract of Rhubarb, dose, 10 to 20 grains. The Infusion is made by maecrating 3 drachms of the sliced roots in 1 jint of boiling water for 2 hours. Dose, a wineglassfull. It will nut keep.

Syrup of Rhubarb is madc with Sugar, \&c. It is exccllent for young children. Dose 1 to 2 drachms-All may be obtained at the Drugrerists.

The powrler of linubarh sprinkled on foul indolent nlcers excites them to a healthy action.

\section{RIIUBARB,--MONK's.}

Descrempton. - Tupathum sntivum, vel mationtin. - It is also called Garilen Paticnce. It leas's the name of Rhuharlin on account of its aperient properties. It luas larepe tall stalks, set witl loroal and lone fiul gereen leaves, mot denterl. The tops

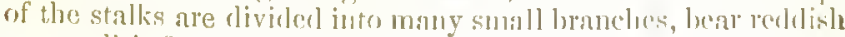
or purjulislo flowers, and seerl, like dock sced. T'lue root is lomer, 
great and yellow, like the wild dorks, and if it be a little dried, showeth less store of discoloured veins than the Bastard Rhubarls when it is dry. Its virtues also are not so strong.

\section{RICE.}

Oryza Sativa.-This is a tropical plant, and it is well-known. As an article of food, Rice is very nutritions, ensily digested, and therefore suitable for deliente stomachs. As it lias no laxative effeet, it is very suitable for those persons who have tender bowels. Rice water is good for those whose stomach and bowels are subject to irritation. It should be made in the same way as Barley-water; a little sngar and lemon-peel may be added to improve the flavour, and a little isingliss to render it more astringent. When intended to correct relaxed bowels, it should be used ground. It is not so nutritious as whent, Ste., yet it affords sustennnce to about three-fourths of the inhabitants of the globe. It should always be well-eooked, otherwise it will not be so digestible. The property of Rice, intending to confine the bowels, renders it a valuable food for siek persons so requiring it. For yomg persons and invalids, nothing is so good as pudlings made of Rice. Softened, and then boiled in milk, and sweetened, it is very agrecable.

\section{ROCK CRESS.}

Description. - Arabis Hirsuta.- It is also called Swine's Cress. It is a small wild plant, growing in fielels and gardens. The stalks are five inches long, firm and thick, reposing on the gronnd, much branched, and fill of lenves. The leaves diret from the root are long, and deeply divided; those on the stalks are smaller. The flowers are smill and white, standing smong the leaves, at the tops of the brancles.

Mentcinal Vuzwols. $-\Lambda$ decoction of the plant is a good diuretie, powerfinl, hut very safe. "Ille juice 1nay be explessed and taken as a renedy for the scurvy, the faundice, and all inwiml olstructions. It is a good sil linl herb, and some persons cultivate it in the grueden for that puryose.

230 


\section{ROCKET.}

Description. - Reseda Sativa:-The Garden-Rocket being rather used as a salad herb than for any medicinal purpose, I shall speak of the common wild Rocket only. The common wild Rocket has longer and narrower leaves, more divided into slender ents and jags on both sides the middle rib thim the garden kinds have; of a sad green colour, from which rise divers stalks two or three feet high, sometimes set with the like leares, bnt smaller upwards, branched from the middle into several stiff stalks, bearing yellow flowers, of four leaves each, as the others are, which afterwards yield small reddish seed, in small long pods, of a more bitter and hot biting taste than the garden kinds, as the leaves are also.

Medicinal Vintues. - The Garden rocket works by urine, and is good against the seurvy. The wild Rockets should not be used alone. A decoetion swectened promotes digestion, and relicves conghl, and destroys worms in children. An infusion of the leaves made into a syrup causes expeetoration, and relicves cough and difficult breathing, The seed mixed with honey, and used on the face, cleanses the skin from morphew, and nsed with vinegar, takcs away freckles and redness in the face, or other parts.

\section{WINTER ROCKET, OR CRESSES.}

DEscription, - Reseda Lutcola.-The winter rocket is a different plant from the former. It has rather large sall green leaves lying upon the ground, torn or ent in various parts, like Juscket or turnip leaves, with smaller picees next the botum, and broad at the ends, which abide all Winter, from which rise up several sniall round stalks, full of lnanches, benring many small gellow flower's of four leaves a-pisece, alfer which conte stliall prols, with redelish seed in them. The tont is rillher stringy. It grows in gardens and fielels, and loy the waly-sirles.

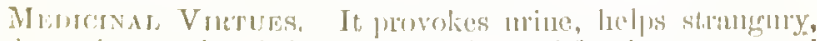

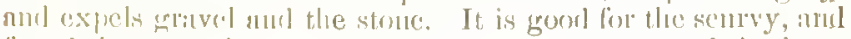
fonmel by experience to be a singulatr good wound herb to 
cleanse inward wounds; the juice or deeoetion being drank, or ontwardy applied to wash them, will prevent dead flesh from growing, and heal them by astringeney.

\section{ROSA SOLIS, OR SUN-DEW.}

Description. - Drosera Anglica. - It is also ealled Red-rot, and Youth wort. It has various small, round, hollow leares, rather greenish, but full of eertain red hairs, whieh make them scem red, eall standing upon its own foot-stalls, reddish and hairy. The leaves are moist in the hottest day. Among these lenves rise up slender stalks, reddish also, three or four fingers high, bearing small white knobs or flowers one above another, after which in the heads are contained small seeds. The loot is a few small hairs. It grows in bogs and wet places, and sometimes in moist woods.

Medicinal Vintues. Rosa Solis is good for those that have a salt rheum distilling on the lungs, whieh induees eonsumption, and therefore the distilled water in wine, is fit for such to drink. The same water is held to be good for' all diseases of the lungs, as phthisie, wheezings, shortness of breath, or eongh; and also to heal uleers in the lungs; and it is good for nervous fainting spirits. The leaves ontwardly applied to the skin, will raise blisters, whieh has eanserl some to think it daugerons to be taken inwardly; but many things will drow blisters, yet are not damgerous to be talien inwardy. It is reckoned a great eordial, good agiainst convulsions, lysteric disorders, and trembling of the limbs.

\section{ROSEMARY.}

Description, - Rosmarinus. - It is too well known to need descrijution.

Menichal Virturs.-The forrers and tops are need medichally. 'They eontain a liogrant volatile oil, which is

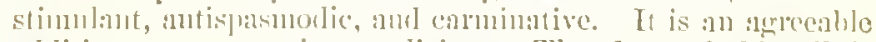
adulition to more retive molicincs. The dose of this oil is firm 2 to 3 drops as a emminutive. The oil mily be athed to 232 
liniments, as a fragrant stimulant. A spirit of Rosemary is male, which nray he nsed as an antispasmodie in closes of 30 drojs, in water, or on sugar. If the flowery tops of Rosemary are uscel as a toa, they are cxcellent against licalache, tremblings of the limbs, and all nervous disorders. A conserve marle of the same has similar power. Beat up the fresh gatherecl tops with three times their weight of sugar. A strong decoction applicel to the temples removes fainting, and taken inwardly, it cxpels wind, and strengthens the stomach. It tends to enliven the whole frame. It removes obstruetions of the livel, and promotes digestion. It is very good against the jaundice. The leaves and flowers burnt are a good disinfectant. Both the flowers and loaves are good against the whites, if they be daily taken. Smoking the dried leares shred, like tobaceo, is a remecly for cough, phthisie, or consumption, by warming and drying the thin distillations which enuse those discases. The lcaves make a good fomentation, made into ointment, or oil, for cold benumbel joints, sinews, or members, which are much relieved thercby.

\section{ROSES.}

The Rose is estemert the Qryecn of flowers. Its botanieal name is Rosa, of the matural orter Rosucece. The varieties of tris ylant are very numerous. Three kiuds are used medicinally, as follows:-

The I)or Rose, Rosn. Canina. It grows wild in hedges, and is well known as tlic Wild Rose. 'The fruit is cliefly used. 'Tle Mips are mate into a confection, which is uncel as a vehicle for other remedies. It is pleasant and acidulons, and alliys thrirst caused by fever. 'The confection is thus made, 'The julp is sejarated from the skins and seeds, and beat up into a conserve with surgart. Thub them well together. It is

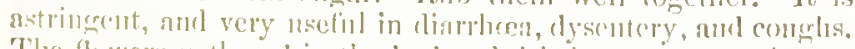

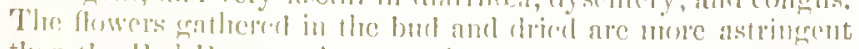

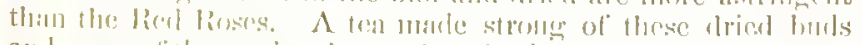

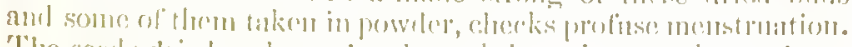
The secels dried and pwowleresl, work by urine gently, amb uro gowl sugailst gravel. 
The Cambage, or Hundred-leaved Rose, Rosa Centifolia. Of this species Rose Water is made by distilling the lenres, or by mixing with water the volatile oil. It is a nseful rehiele, a good cyc-water, and much used in lotions. The petals make an cxeellent laxative Syrup.

The Damascus Rose, Rosa Damuscena. The flowers are nscd. From them is obtained the delicious perfume Otto, or Attar of Roses, of great eelebrity throughont Europe, and Eastern lands especially. The Syrup is an exeellent purge for ehildren. There is not a better purgative for adults than this Syrup. Rose Water is also distilled from this kind.

The Red or Frenci Rose, Rosa Gallica. The flowers are used. Gather them when in bud; cut from the hnsks, without the white bottoms, and dry. The conserve of Red Roses is made of these buds; they are beater up with three times their weight of sugrar. The infusion is made thus:Dried Rose leaves, 3 drachms, on which pour boiling water, 1 pint; then add dilute Sulphnric Acid, or Elixor of Vitriol $1 \frac{1}{2}$ drachms; macerate for 40 minutes in a corered vesscl, strain, and add 6 drachms of lump sugar. Thoronghly mix.-The infusion is a useful beverage in ferers. It is an excellent gargle, and vehicle for many active remedies, It is given with altrantage in Consumptive sweats, and fever ; and with additional acid, and nitrate of Potass, in uterine and pulmonary homorrhages, or spitting of blood. The lnfusion also strengthens the stomach, prevents vomitings, and restrains dysentery.

Some affirm that the White Roses possess equal virtures, and are rather more astringent. The leaves ground, and made into an ointment with lard, and a minute portion of Landimnm, are enrative of the piles, and otler inflamed parts. Rose leaves and Mint, heated and applicd to the stomach, stay vomisings and strengthens a weak stonlach. They form a good cooiling fomentiation for inflaned and pained piats.

\section{RUE,-GAIRINA.}

Ruta Graventens. - It is so common in garrelens, that it requires no description. It was anciently ralued for its unedicidal virtues; but lats of late becu litile estecmed. 'This is a 


\section{RUE,-Garden,}

mistake; for if valnahle at one time, why not now? Strange if lierlss are to be silljected to "the filshions." It acts as a stimnlant, and antispasmodic; but in large doses it is nareotic. It is very uscful in lysteria, and in flatulent colic. It hils been found useful in infantile convulsions, and as a distroyer of worms, especially the thread-worms, nsed as an injuetion. In aceumulations of flatulenee in the bowels, tympanitis, a strong infusion of Rue given as an injection, is of great nse. In suppressed menstruation, when stimulants are required, the Rue clyster is of great nse. Bochlanve says that mixed with wine and salt, it stops gangrene, restores vitality to the part, prevents suppuration and lieals the wound. Nedieal men sadly neglect Ruc, as a medicinal agent. Wly go to foreign lands whell we have remedies at our doors? I decoction of it relieves the colic, and all inward pains. The leaves bruised and well rubhed on the parts, relieves pain, seiatica, inflammation of the chest. Some of the ancients believed that it arrested generation. They regarderl it too as anti-pestilential, and the juclyes lial their noses regaled with this foetid plant; they believed that Mithridrate, in which Rue has a principal share, repelled all loisons. Rue, and honey, and the gall of a coek, they said, eured rlimness of sight. An ointment, made of the juice with lard, oil of roses, and a little vinegar, enres erysipelas, ranning sores in the hear, and ulcers. The antidote used by Mithridates, every moming fisting, to secure limself from any poison or infection was this: take twenty leaves of Rue, a little salt, two wahunts and two figs, heaten into a mess, with twenty junifrer licries, the fllimitity appointed for every day. Suother clecturary is made thus: take of nitre, pepject, min commini-

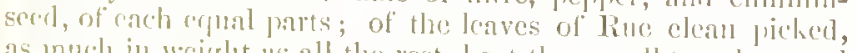

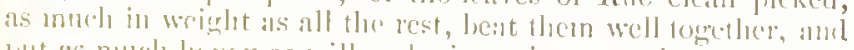

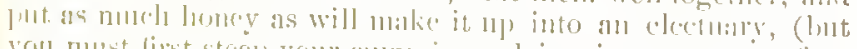

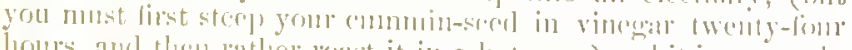

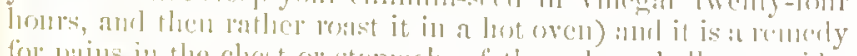

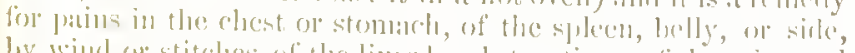

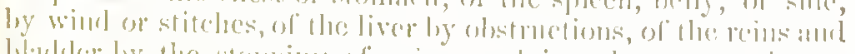

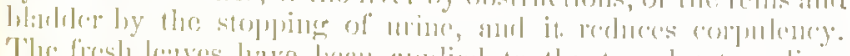

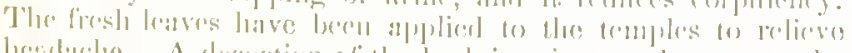

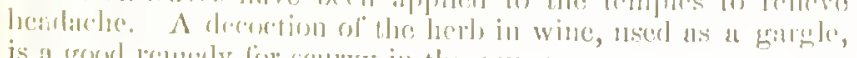
is a goosl remedy lion scurvy in the gums. 


\section{RUE,-MEADOW.}

Description.-Ruta Pratense.-It is also ealled Spurious Rhubarb, or Rue-Weed. Meadow Rue rises from a yellow stringy root, mncli spreading in the ground, shooting new spronts round about, with many green stalks, two feet high, crested all the length of them, set with joints, with many large leaves on them, above as well as below, divided into smaller leaves, dented in the forepart of them, of a red greeu eolour on the upper side, and pale grecn underneath; at the top of the stalk the branehes have two, three, or four small heads or bittons, which eventually shoot forth a tuft of pale greenish yellow threads, which falling awny, small three-cornered pods suceed, containing small, long and round seed. The plant has a strong umpleasant seent. It grows in the borders of moist meadows, and diteh-sides, and flowers in July and Augnst.

Medicinal Virtues.-Dioseorides snys, that this herb bruised and applied, perfeetly heals old sores, and so does distilled water of the herb and flowers. It is used by some among other pot herbs to open the body ; but the roots washed clean, and boiled in ale and drank, purge more than the leaves, yet very gently. The root boiled in water, and the parts of the body troubled with vermin and lice, washed therewith while it is warm, destroys them utterly.

\section{RUPTURE WORT.}

Description. - Herniaria Glabra.-It spreads many threndy branches upon the ground, abont a span long, divided into many smaller parts, full of small joints, very thiek together ; the stalks lying on the ground form a kind of eircular firnte. The leaves are very small, nearly oval, of a pale green; they stand two at each joint, and are also of a pale green, tinged yellow. The flowers are rery small, and yellow, scarcely diseemible from the stalks and leaves. The root is very long and small, and deep in the ground. It grows in dry, sandy, and roeky places, and is enltivated in gardens.

Medicinal Virtuls. - It has not its name in vain ; for it is found by experience to eure the rupture, not only in ehild236 
ren, but also in adults, if the disease be not too inveterate, by talking a drachin of the powder of the dlied herb every day in witu, or a decoction for some days together. The juice or distilled water of the green herb, relic ves fluxes, vomiting and gonolrhoea. It relicres those who have the strangury, or the sione or gravel in tbe bladder. It removes stitehes in the sides, griping pains, obstructions of the liver. It crues yellow jaundice, and kills worms in ehildren. The bruised herb bound on wounds, heals them. It is a very goud remedy for all wounds and sores.

\section{RYE.}

Rye is one of the cereals whose cultivation has been a great blessing to man. Its botanical name is Secale Cereale. It produces a nutritious flour having less bran and more farina than wheat has though darker in colour. It is not so mutritions as wheat, but it is casicr to digest, and it slightly promotes the action of the bowels. It makes excellent poultices fol imposthumes, boils, and other swellings. Rye-meal moistened with vinegar, placed between a cloth, and well heated in an oven, and applick to the head, very much relieves its pains. Ergot of Kye, or the Spured Rye, is a discased production whieh grows on the ear of Rye. It is of a poisonous nature. This substanco has however been employed as a cliild-bed remedy. Its great influcnce over the uterine system is undoubted. It is the only medicine now employed as an excitent of the womb, or to rouse the energies of that organ in cases of lingering labour. Dose from five to twenty-five grains in powder. It is good also for Leneorrhrea. Matthiolus says that the ashes of Rye straw stecped in water twonty-four liours, will enre chapped liands.

\section{SAFFRON.}

It is prodineed from the Crocus Sativa, or the hlue antumn fluwering cocus, cultivated in this comntry, ank on the conti-

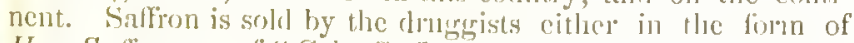
Hay Safron, or of "Cake Sallion." 'The former is composed 
of the loose dried stigmata. It is used as medicine, and as colouring matter. It was at one time a farourite stimulant and antispasmodic. It is now given when scarlatina, or the measles are suspected, as an exjulsive, to hasten the eruption. It is gool in asthma, congh, and difficulty of breathing, and is a good remedy for the jaundice. It must be used as a decoction.

\section{SAGE.}

Salvia Officinalis.-The common garden Sage has tonic properties, as its aronatic odonr and bitter taste indicate. It is often made into tea, and is tonie, astringent, and carminative; as a gargle with vinegar, or honey and almm, it is good for inflamed throats, or relaxed uvula. It removes obstructions of the kidncys, and of the menstrual flux. Orpheus says, three spoonfuls of the juice of Sage, taken fasting with a little honey, arrests spitting or vomiting of blood. These pills are much commended : take of spikenarl, ginger, of each two drachms, of the seed of Sage, cight drachms, of long pepper, twelve drachms, all being powdered, add as much juice of Sage as may make them into pills, taking a drachm every moming fasting, and at night, drinking water after them. 'Mathiolus says, it is very good tor pains in the head, coming of cold and rheumatic humours; for all pains in the joints, and for the falling sickness, lethargy, palsy, and is of much nse for diseases of the ehest or breast. The leares of Sage and nettles bruised together, and laid upon imposthumes belniud the cars, eures them.

The juice of Sage taken in warm water relicres hoaresness and congh. Sage taken will wormwood is goon for the bloodyflux. Ant with other hot herbs, Suge is looiled to bathe tho borly and legs in the snmmer time, especially to warm cold joints or sincws, troubled with elanup, and to strengthen the parts. The rolatile oil is sonnetimes preseribed in toses of 1 or 2 drops. It is a nseful indreclient in cunlurocations for rheumatisn. An infusion is rery cooling in fevers, a little lemon-juice being added. It eleninses and purifies the blood. 238 


\section{SAGE,-WOOD.}

Description.-Salvia dgrestis.-It is also ealled Wood Germander. It lises up with square loary stalks, two feet high, with two leaves at every joint, like other sage leaves, but smaller, softer, whiter and rounder, and a little dented about the edges, and smelling rather stronger. $\Lambda$ t the tops of the stalks and bramehes stand the flowers, on a slenler large spike, turning all one way when they blow, and are of a lale and whitish colour, smaller than Sige, but hooded and golying like them. The secd is blackish and round; the root is lone and stringy. It grows in. woods and by wood sides, and in lyye lanes.

Menicisal Virtues. - The decoction of Wood Sage promotes the flow of tuine, and perspiration, and reduces swellings in the flesh. The decoction of the green herb, made with wine, is a safe and sure remely for those who by falls, bruises, or lilows, suspeet some vein to be inwardly broken, to disperse and vrirl the congealed blood, and consolidnte the veins. The juice of the herb, or the powder dried, is good for moist ulcers and sorcs, to dly them and cause them to lieal more specedily. It is no less effectual in green wounds.

\section{$\mathrm{S} A \mathrm{GO}$.}

Sngro is prepared from the pith of several species of Palm, especially those of the genus Sragus Lovis. The granular form is given to it by passinger it when half alry througl a couse sieve. The process of ledining it, and griving it a pearly lustre, is sttrituterl to the Chinese. Thus preprued, it is ealled Pearl Srugo; this is reckonorl the hest, yet many aver that the hrownec and coarser kimkls prssess the mont nutriment. Sapo is learly lume starel, and closely resembles $\Lambda$ rrow-lont, for which it is

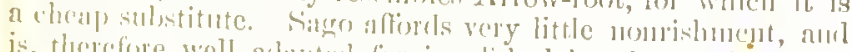

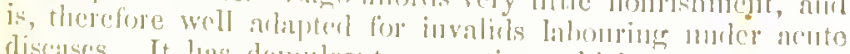

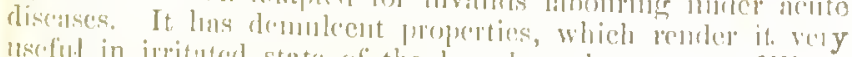

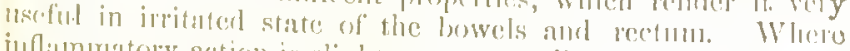
inflammatrory action is slight, a very small prortion of whesten flest may be adcier for the sake of intriancut. 
Sago is made into puddings, boiled in milk and cooked a valicty of ways. Sago Possct is an exeellent cordial, where acute discases have left the body debilitated. Madc thus:Put 2 ounces of Sago to 1 quart of water, and boil until a mueilage is formed; then rub half an ounec of lump suerar on the rind of a lemon, and put it, and a tea-spoonful of tincture of ginger into half a pint of Sherry IVine; add this mixture to the Sago mueilage, and boil the whole five minutes. A wineglassful may be taken every four or five hours. But during sickness Sago Gruel must be made of Sago and watel only, exeept a little sugar and lemon juiee to render it morc palatable.

\section{SAMPHIRE.}

Description. - Crithmum Maritimum.-A plant common about sea consts, very mueh like femmel, but not so tall; it luas bcen ealled sca-fennel. It grows on roeks that are often saturated with sen-water. It his a tender green stalk about two feet high, branching forth almost from the bottom, and stored with thick and almost round leaves, of a decp green colour, sometimes more on a stalk, and silppy, and of a pleasant, hot, and spicy taste. At the top of the stalls and branches stand umbels of white flowers, which produce secd like femncl-seed, but larger. The root is large, white, and long, aud of a hot, spicy taste.

Medicinal Virtules.--The lenves are used fresh, but those nearest the root are the best. It is diuretic, and tunic. The juiec of the fresh leaves operate very powerfully by mine, and is good against the gravel and stone, menstrual suppression, and the jaundice. It is excellent for promoting digestion. It makes a fine pickle, which was formerly highly estecmed. The sale of it has been almost stopped by adulteratiou.

\section{SANICLT.}

Description.-Sanicula Europea.-A pretty wild plant growing in woods and under shady hedges. It has many large round leaves standing mpon long brownish stalks, every one 240 
dceply eut, or divided into five or six parts, and some of these also eut like the leaf' of erow's-foot, or dove's-foot, and finely dented at the edges, smooth, and of a dark shining colour, and redilish abont the brinl ; fiom which rise np small, round, green stalks, withont any joint or leaf, except at the top, where it branches into flowers, having a leaf divided into three or four parts at that joint with the flowers, which are small and white, starting out of small round grecuish yellow healds, in a tuft, in which afterwards are the seeds, which are small round bur's, almost like the leaves of clevers, and stiek in the sane mumer upon any thing they touch. The rout is fibrous.

Medicisal Virtues. It heals green wounds speedily, or any ulccrs, imposthumes, or inward bleeding, and it is gooil for tumonrs; for the deeoction or powder taken in beer, and the juice applied ontwardly, dissipates the humonrs; and there is not found any herb that can give such instant help, when tho clisease falls upon the lungs or throat. It is good for healing malignant ulecrs in the mouth and throat, by gargling with the decoction of the leaves and roots made in water, and a little honey. It has been celebrated for the cure of ulcers, and ruptures,

There is another SANicte, ealled Yorlshire Senicle, or Butterwort or MIarsh Vinlet; and there are four varicties of it. It grows will on wet bogs on the moors in the north of England and Scotland, on the mountainous parts. This and its fellow the Bladderwort, are, o: alccount of their bealty, cultivated in some garlens. The Butterwort is ensily knowil by its violeteolonred flowers, and its thick plaintain-shilped leatves growing at the root. The remanksible greasy fect of the leatres, hase

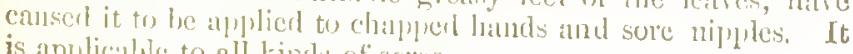
is applicaldic to all kinisls of sores.

\section{SARACEN'S CONFOUND}

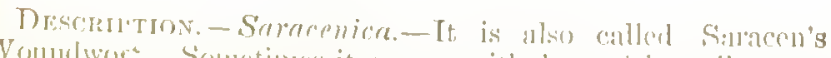

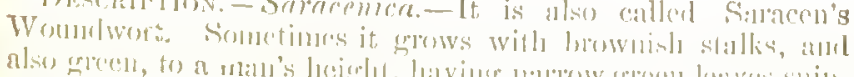

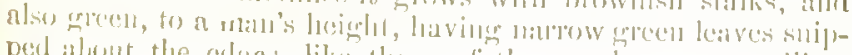

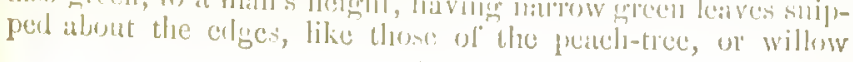


leaves. The tops of thé stalks have many yellow star-like fluwers, standing in green heads. The seed is rather long and brown, downy when rije, and is blown away. The root is fihrous. The taste is strong and unpleasant, and so is t? smell. It grows in moist and wet grounds, by wood-sid, and in the moist places of shadowy groves and by the watcr side.

Medicinal Virtues. - Among the Germans this wound herb is preferred betore all others of the same quality. Being boiled in wine and drank, it rednees inflammation of the liver, and frees the gall from obstruetions; and therefore it is good for yellow jaundice, dropsy, inward ulcers of the reins, mouth, or throat, and inward wounds and bruises. Steeped in wine, and then distilled, it is good to ense gnawing in the stomach, or other pains of the body. A decoetion in water is good for the ague; and it is very effectual to heal any green wound, or sore or ulcer. Briefly, the medicinal virtues of Butglo or Sanicle belongr also to Siuncen's Contonind.

\section{SARSAPARILLA.}

Smilax Sarsaparilla.-The Sarsiparilla plant is n native of the West Indies, Mexico, and Soutl Americil. It has a mil.? bitterish and glufinous taste, not disagrecable. The root is used. It consists of one head, from which nulny fibres, or small roots proceed about the thickness of a grouse quill. These are the parts producing Sarsajarilla.

This drug is known to possess tonie, demulcent, and alterative properties; and sometimes diuretic and diaphoretic. It possesses the power of improving the general state ol the system, and acstoring the vigune of the constitution when broken dewn by long protracted disease. That these heneficial effects result frum the rtse of Sartapartilia, Dr. A. Thompon says lis experience has fully demonstrated. It is necessang to give it in lingo deses-from half a pint to a pint, for insime of the decoction

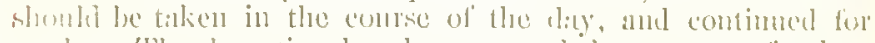

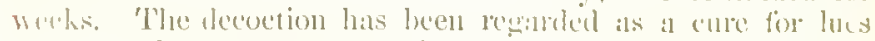

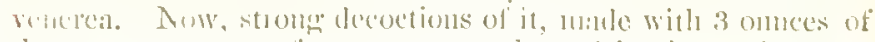

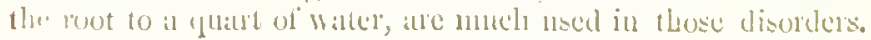
$2+2$ 
A small quantity of antimonial wine, (from 30 to 60 drops to the quart,) to these decoctions, which much increases their effieaey. These decoctions are found to be of creat nse in purifring the blood, and resolving obstructions in seorbutic and scrofulous eases, and in cutmeons elnptions, and miny other discases. "I lave knuwn," silys Dr. Thornton, " two obstinate swellings that had resisted the effects of other remedies for twelve months, enred by drinking a quart of this decoction daily
for some weels.

Dr. Graham says, "It is given with advantage in various obstinate internal chronic diseuses, and in sivellings, ulcerations, and other local maladies, depending upon constitutional indisposition. I have fonnd it of inestimable value in eases of extreme irritation and debility of the mueus membrane of the digestive orgars. In nocturnal pains in the limbs, painfial enlargements of the knee and elbow-joints, nodes, and cutaneous ulcerations, arising from a syphilitic taint, it is superior to any other remedy," 'The Doctor instanees two cases in which Sallsaparilla was the means of saving life.

The powter of Sarsiparilla, is an invaluable alterative, more efficicious than the dccoction. From one to two drachms mily be takcu in witter, twice or thriee a day. The Liquid extract, which contains a portion of spirit, wilt lieep any length of time; dose firm half a draehm to 2 drachms in water. The Compound becoction is made thus: -5 ounces of Sarsaparilla clipis in 4 pints of water ; let it gently simmer for 2 honrs; tislise out the clipe, hritise and replace them in the water ; boil down to two pints. While briling arld Sassafine, sliced ; Guiaemn wood, rasped; ant Liquorice-root, bruised, of cach 10 drachms; Mracreon roots 3 drachins, hoil for 10 or 15 minutes, then strain. The: Concentrated Essence is the most convenient and 16rlstle form lour its administration, antel, from the nicety anul

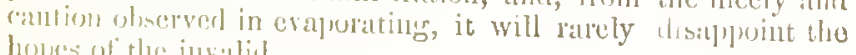
hopes of the invalial.

\section{SASSATRAS.}

$A$ beautiful tree, native of Ancrien, the word of which is

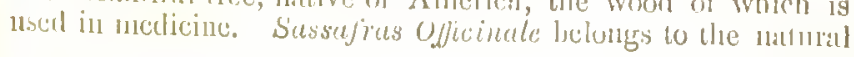


order Lauracea. It has a sweet aromatie taste, and an odonr like that of fennel, owing to the presenee of a volatile oil, in which its virtues ehiefly reside, though it eontains fisty matter, resin, gum, albumen, wax, \&e.

It is best taken in infusion, or tea ; it is a very pleasant beverage; it promotes sweat; and is a remedy for seurvy, and foulness of the blood, of whieh it is a great purifier. It has been found to reeruit exhausted strength more rapidly than either eoeoa, ehocolate, or any farinaeeous snbstances, and to sit lighter on the stomach, than either animal or vegetable jellies. It is a most nutritions beverage ; "but the seandal of its being good in Venereul cases, is a great detriment to its credit, whieh prevents good being done by it; for it is a firstrate sweetener of the blood."

\section{SAUCE ALONE.}

Description. - Erysimum Alliaria. - It is also ealled Jaek by the Hedge. The lower leaves are rounder thon those towards the tops of the stalks, and are set singly on the joints, being round and broad, pointed at the ends, dented at the edges a little like nettle leaves, but of a fresher green eolour, hot rongli or prieking: the flowers are white, growing at the tops of the stalks oure above another. The seeds are in pods, round and blaekish. The root is stringy and thready. The plant being bruised, smells of garlie, and tustes hot and sharp, like rocket. It grows under walls, by hedye-sides, and pathways in tields.

Medrcinal Virtues. - This is eaten by many eomntry people as sanee to their silt fish, and wonderfully wams the stomaeh, and promotes digestion. 'Tle juice boiled with honey is as good as hedge musturl for congl, to cut and expeetoratio tough phlegm. The seed lorisised and hoiled in wine, is a good renedy for colie, or stone, leing llank warm. The lenves also or the seerl boiled, is grood to be used in eljsters to ease "the pains of the stone. 


\section{SAVINE.}

Description.-Tuniperus Sabina.-It rises two or three feet high. Its leaves are numerons, and firmly pointerl. The flowers are very small, of a yellowish colom, producing a blackish purple berry. It is a native of the south of Europe, and of the Levant; but grows in English gardens.

Medicixal Virtues. - It has powerful cathartie, emmenagogue, and stimulant propertics, reting especially on the uterus of the female. Those who take it for the purpose of abortion greatly endanger their lives; in many eases it lias ruined the constitution, and in some produced instant denth ; for taking large doses for that purpose, it is an irritant poison, proving fatal. The herb powdered, and mixed with honey, makes a good dressing for all kinds of sores, earbuncles, ringworms, Eerofulons runnings at the ears, neck, \&e. Dr. Cullen observes, "Savine is a very aerid substance, and I have often, on that account, not employed it in the quantity to render it cmmenagogrue. Yet it indicates a more powerfirl determination to the uterus than any other plant I have cmployed. But it requires a great deal of caution. Dr. Home had grent suecess with it; for in five eases of amenorrhoen at Erlinburgh Royal Infirmary, four were cured by Savine, which he gave in powder fiom a seruple to a drachm twice a day. He says it is well suited to the weak, but improper in plethoric habits. It mokes an exeellent drawing ointment for issues, as under:- Freslı Savine leaves separated fiom the stalks, and bruised, quartel of a pound; hogr's larr, 1 pound; yellow wax, quarter ol a pound. Boil the leaves in the lard until they beeome crisp, then filter, with expression; add the wax, and melt thom together.

\section{SAVORY.}

Saluria Inortensis.-There are two kinds, Winter and Summer Suvory. It is well known as a kitchen gardsu phunt.

Mlinginal Vuaturs. - It is a soverign remerly fir tlie colic, nnt the Iline Passion; keep it hy you all the year, keep it dry, make conserves and syrups of it for your use, antel take notico 
that fle Srmmer kind is the hest. They are both of them hot and dry, especially the Summer kind, whieh is sharp in taste, expllingr wind fiom the stomach and bowels. It is very bencficial to take during pregnancy. It is a good expectorant, removing tough phlcom from the clicst, and improving the breathing. The juice dropped into the eyes, remores dimness of sight, if it procecd from thin cold humours distilled from the brain. The juiee lucated with oil of Roses, and dropped into the ears, removes noise and singing, and deafness. Ontwardly applied with whent flour, like a poultice, it gives ense to them. It also takes away the pain that comes by stinging of bees, whers \&e.

\section{SAXIFRAGE,-BURNET.}

Description.- Mimpinella Sarifraga. It grows with long stalks of winged leaves, set dircetly opposite one to another on both sides, eneh being rnther brond, and a little dented at the edges, of a sad green eolour. At the top of the stalks stand umbels of white snowy flowers, after which eome small blackish seed. The root is long and whitish. The lesser Burnet Saxifiage has mueh finer leaves than the former, and rery small, set one against another, deeply jagged about the edges, and of the same colonr as the fomcr. The umbels of the flowers are white, and the secd and root very small. The taste is very hot. These grow in moist meadoirs, hid mong the grenss. 'i'hey flowcr in July.

Medicinal Virtules.They are hot as pepper. They have the sante properties as Pallsley; but in proroking nitie, ensing the pains thercot, and of wind and colic, are morc effictual, the roots or secel being used cither in powder, or in decoction. They are diuretic, and good anginst gravel and stone. They assist to expectorate. It lias bicen nsed for the remoral of tumonts and obstmetions of the glands, and in scorbutic and cutancons diseases. The juice of the herb dropped into the most grievous wounds of the liend, drics up fheir moisture, and henls them quickly. Some women use the distilled water to talie awaly freckles or spots on the skin or fiee. 


\section{SAXIFRAGE-W -WIITE.}

Description.-Saxifraga Alba.-The common white Saxifrage has a few small reddish kernels of roots corered with skin, lying among small blackish fibres, which send forth round, yellow green leaves, greyish underneath, lying alsore the ground, unevenly dented about the edges, and hairy, each upon a little footstalk, from whence rise brownish, hairy, green stalks, two ol three feet high, with round leares, rather branched at the top, on which stand pretty large white flowers, of five leares apieec, with ycllow threads in the middle, standing in a brownish green lusk. After the flowers comes a round hard hend, forked at the top, containing small black sceds. The grains of the root are usually ealled the White Suritinge-secd, and so used. It grows in the dry comers of meadows, and grassy sandy places. It usually flowers in May.

Medicinal Virtues.-It is sail to expel stone and gravel from the bladter, to relieve strangury. The rlecoction of the herb or roots in wine, or the powder of the small kernal root in wine. The distilled water of the whole herb, root and flowers, is most familiar to lee taken. It eleanses the stomach and luness from thick tough phleorm. There are not many better metisines to break the stune than this.

\section{SCABIOUS.}

Description. - Scellinsa Surcise.--There are several kinds of Scabions, but these here described are the most limiliar.

Common fich Scabious grows up witl inany hairy, soft, whitish ereen leares, some of which are very smiall, a little jarged on the cheres, others moch rent and torn on the sirles, and hitye

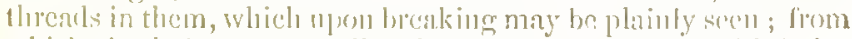
whirh rise latiry green stalks, three or four fret high, with hairy green leaves decely and fincly dividerl snd hanched a little; they are makerl anil bare of teaves for a goot space, but on the tops

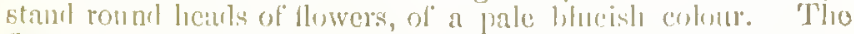
flowers are the size of a small walnut, and compresed of many little ones. The romt is large, white, and thick, growing deep into the ground, aut abilles many yours. 
There is another solt of FrTLD SCARIOus different in nothing from the former, but in being smaller.

The Corn Scmmors diflers little fiom the first, but it is larger in all respects, and the flowers more inclining to purple, and the root ereepss under the elust of the earth.

The first grows usually in meadows, 'The second in dry fields, but not so plentifully as the former. The third in standing com, or fallow fielus. They flower in July, and August.

Medicinat. Virtues.-Scabious is very cffectual in the cure of conghs, shortness of breath, and all other disenses of the breast and lungs, digcsting and cxpectorating cold phlegm. Etmuller" extols it for" "Astlima and Pleurisy, and inward abscesses, ulcers, and impostlumes. The decoction purifies the blood, and taken inwardly, and nsed as a wash externally, it is a first-rate remedy for cutancous eruptions. Some make the decoction in wine. Tho green herb bruised and applied to any earbuncle or sore, is found by certain experience to dissolve and break it in three homs. The decoction remores pains and stitches in the side. The juice or decoction drank, takes away scabs and breakings out of the itch. The juice madc into an ointment is cflectual for the same purpose. The dried root given in powder, promotes swcat, and is beneficial in fevers. By its astringency it tends to heal all inward wounds. A syup made of the juice and sugar, or honey has the same effect. The decoetion of the herb and roots outwardly applied, reduces hard or cold swcllings, and relieves shrunk sinews or reius, and it heals green wounds and sorcs. The juice of Scabious, with the powder of Borax and Samphire, cleanses the skin of the face, or other parts of the body, fiom fieckles, pimples, morphew and leprosy. The licad washed with the warm decoction, cleanses it from scurf, sores, dandriñ, and itch.

\section{SCAMMONY.}

This purgative substance is the concrete $\mathrm{gum}$ of the Convolvulus Scammonium. It is importel from smyrma. It is a powerful drastie purge. closely allied, in its operition, to jalop, but morc aetive and irritating, yet not so naluscous. 248 
It is used as a smart purge for children, especially for those who have worms, on account of the smallness of the dlose necessary to produce its cffect, the slight tastc, and the cnergy of its operation. It is useful as a hydragogne in dropsies. As a vermifinge it might be combined with powdered Wormwool, or Tansy, \&re. It is inarmissible, howcrer, in inflammatory conditions of the alimentary canal. - The dose of the powder for adults is, fiom 5 to 10 grains; for children, from 2 to 5 grains. It should always be combined with an aromatic to prevent griping. The Compound Seammony Powder of the shops is the best; dose of it, for an adult, from 10 to 20 grains; and for children fiom six to twelve ycars old, half that quantity.

\section{SCURVYGRASS.}

Description.-Cochlearia Oficinalis.-English Semryygrass has many thick flat oblong leaves, smootl on the edges, and sometimes a little warcl; sometimes plain, smooth and pointed, of a sad green, and sometimes a bluish colour, each standing by itsclf upon a long foot-stalk, brownish or greenish also, from which arise many slender stalks, bearing few leaves but longer and less than those near the root. The flowers stand at the tops of the stalks in little clusters; they are wlite, small, and bright. They are succecder by short roundisll, seed vessels. The root is white and fibrons. It grows wild on the sea coast, and also in grardens. It flower's in April and May.

Menicivar Virturs. - The plant possesses antiscorbutic and diuretic propertics. It has wonderful efficacy to clcanse the bloorl, liver, anrl splecn. The juice, for this purpose, faken in Spring, every morning fasting, will answer this purpose. The decoction has the sano cflect ; it opens olstructions, cvacuates coll, clammy and plilcgmatic humours from the liver and splecen, ancl restorcs the borly to a more lively colour. Senrvygrass is consirlererl a goosl wash for the moutle and gums in scurvy. It nay le mixed with Seville Otange juice to make it more argicenble. 


\section{SELF-IIEAL.}

Description. - Prumella Tulgaris. - It is also ealled Carpenter"s IIerb, Iook-heal, and sickle-rort.

Self-heal is a small, low ereeping herb, having many small, romdish-pointed leares, like leaves of wild mints, of a dark grcen eolour, without dents on the edges; from which rise square hairy stalks, a foot high, whieh spread into branches with small leaves set thereon, up to the tops. The flowers are small, and of a bluish priple; they stand in a kind of short spikes, or heads; the enps of then are often purplish. The roots eonsist of many fibres downwril, and speading strings. The small stalks, with the leaves ereeping on the ground, slioot forth fibres taling hold on the gromnd, whereby it is made a great tuft in a short time. It is found in woods and fields. It flowers in May.

Medicinal Virtues, - This herb is a enrative of inward and outward wounds. As a deeotion, or sylup, inwardly, and the juiee of the roots and leares alone, or inade into an ointment, for external application for bruises and sores. $\Lambda$ s Selfheal is like Bugle in form, so also in its medicinal virtues. If it be aecompanied with Bugle, Saniele, and other wounl-herbs, it will be more effectul to wish or injeet into ulcers oncwardly. Where it is necessary to repress the lioat and sliarmess of hilmours flowing to any soles, intlumnations, or swellings, or to stanch the fluw of bloorl in any womm, this is used with good sueeess. It is a inceial rencely for all green wounls, to close and heal them. 'The juice need with oil of roses to anoint the temples and forehead, cures the heal-aehe, and the same ninixed with honey of roses, enres ulcess in the month and throat. Am the proverb of the Germans, Frenclu, and uthers, is verified in this, that he needs noither plusician nor surgeon who has Self-lieal and sanielo to eure himselt.

\section{SENNA.}

The lenves of rifferent species of Cassia. It is a rery old merliciuc, havilug lecu used by the Alabians. The plant is a
250 
native of Upper Forpt. It is also cultivated in India. Alcxandrian Senna is most lighly estecmed.

Senna Leaves are a very 11 seful purgative, operating millly, and yet eftectually. The only ineonrenience complained of in thisclrug is its tendeney to grije, and its sickly nauseons flarour. This may be obviated by the addition of an aromatic, as ginger, cinnamon, \&c. ; and its operation may be facilitated by drinking copionsly of any warm mild diluent. The best folm of alministering it is that of watery infusion, two drachms being infused in 4 or 5 onnecs of tepicl or warm water, (it should never be boilcal) to which add 3 or 4 drachms of compound tincture of carlamoms, or some aromatic, as stated before, to prevent griping. Sugar or manna, eorcrs its taste, and makes it more agrecable to children. Dose from one to three ounces. It is often given in combination with Epsom Salt, Glauber's Salt, or Soluble Tiutar. It sl.ould not be arministered when irritation and fever are plesent, nur during pregnamey.

Buack Draught ;-Epsom Salt, $\frac{1}{2}$ onnec, infusion of Senna, $1 \frac{1}{2}$ ounce, 'Tinctule of Senna, 1 drachm, Syrup of Ginger, 1 drachm, Spirit of Salvolatile, $\frac{1}{2}$ a drachm. Mix. Take accolding to age and constitution.-

An Infusion of Senna may be taken as under:-One ouneo of Senna leares iufused in a pint, or more, of tepill water ; strain, and ack to it one ounce of Cumplior mixtmre, which will nentralise its griping tendency. Fonr talle-sponutuls of this iufision, with a tea-spoonful, or lather more of lisum Sialt, is a grood purgative.

Erectuary of Senta.-Senna leaves, in finc powder, 4

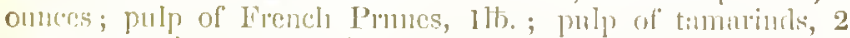
ounces. - molasses, $1 \frac{1}{2}$ pint; essential oil of Cimamay, 2 thachims; boil the pulps in the Syrup to the thickness of honey; then adil the poweler; and when the mixture cools the oil; lastiy, mix the whole iutinately.

\section{SERPEN'T $\Lambda R I \Lambda, O R$ SN $\Lambda$ KE TOO'T.}

Ariatolorhir Serpentreria. It is a native of $\Lambda$ merien. $\quad W$ owe the kuowlerge of this nedicine to the Anerican Indians, 


\section{SERVICE TREE.}

who give it as a remedy for the poisonous bite of the Rattlesnake. It possesses great virtues. Dr. Tennant brought it into England, and it has been regarded as a powerfnl remedy in pleurisy, quinsy, and all other diseases where the blood is sizev. It was said to dissolve the daugerous texture better than all other known remedies. It is a warm eordial, aromatie, tonie, and aets as a diaphoretic. It is ealeulated to support ritality, and promote free perspiration in low and putrid fevers. The ague yields to Pertuvian bark mueh sooner when it is eombined with Serpentaria. It is also promotive of digestion; and wonderfully arrests gangrene or mortification, eombined with Opium and other eordials.

It may be given in infusion by pomring $1 \frac{1}{2}$ pint of water on 1 onnee of the bruised root. Strain after 12 hours. Two tablespoonfuls to be taken three or four times a day.

English Polygala, Snake-root, or the eommon blue, or whiteflowered Milkivort, has the same effeets. They have been given in pleurisies with great effeet.

\section{SERVICE TREE.}

Pyrus Domestica. - It is so well known in the place where it grows, that it needs no deseription.

Medicinal Virtues.-Serviees when they are mellow, stay fluxes, scouring, and ensting, yet less than medlars. It they be dried hefore they are mellow, and kept all the year, they may be used in deeotions for the said purpose, either to drink or to bathe the parts requiring it; and are nsed to stay the bleeding of wounds, of the mouth or nose, to be applied to the foreliend, and nape of the neek.

\section{SHEPHERD'S PURSE.}

Description. - Thluspi Bursa Pustoris.-It is also ealled Shepherd's Serip, Shepherl's Poneh, Toywort, Pickpurse, and Casewort. It is a very eommon plant, overruming gardenbeds, farm, and court yards. The leaves spread upon the 
ground, are long, rather broad, a little inclented at the edges. The stalks are rouncl, erect, 9 or 10 inches high, and have few leaves. The flowers stant at the tops in little clusters, they are small and white. The sced vessels are like a bag or pouch. The sects are small, yellowish, and the roots are white.

Medicinal Virtoes.-It is very astringent and glutinous. It is good for bleeding at the nose and spitting of blood, and in diarthoens, dysenteries, and bloody urine. It may be applied with great sucecss to cuts and fiesh wounds; and mate into a ponltice, and applied to the wrists, it enres the ague; apply it before the fit comes on. The same is beneficial also in Erysipelas. An ointment may be made of it for wounds.

\section{SLOE BUSH.}

\section{Prunus Sylvestris. - It requires no deseription.}

Medicinal Virues. - All the parts of Sloe are astringent, and effectual to stay bleeding at the nose and mouth ; or bloody flux, profuse menstruation; and it eases pains of the sides and bowels, produced by diarrhcea. The decoetion of the bark or fruit to be uscl. 'The conserve also is taken for the same purpose. The distilled water relieves pains in the stomach, sides, and bowels. The leaves make a good lotion to gargle and wash the month and throat in which are swellings, sores, or kernels; to cool inflammations of the eyes, and to case pains of the hearl, bathing the temples and forcheat. The distilled water of the flowers is very citicetual for the same purposes.

\section{SMALLAGE.}

Descriptron. - Apium Graveolens. $-\mathbf{A}$ eommon wilıl plant alrout ditch sirles, a kind of Parsley, but resembling Celery. Leaves many and larere; stallis two feet and a lialf' in height, round, smontl, striaterl, and branched ; leaves like those from the root, broal and indentexl, but smaller. The flowers stand in little nunbels at the division of the branches; they are smatl, of a ycllowish white. 
Medicinal Virtuls.-The roots are most used. Smallage is hotter, dricr, and much more medicinal than parsley. It is more cffectual in opening obstructions of the liver and spleen. It provoketh mine and is good against the yellow jaundiee, tertian and quattan agues, if the juice be taken, but especially if made into a syrup. The juice also put to honey of loses, and barley water, is very good to gargle the month and throat affecteil by sores and ulcers. The same lotion : lso heals uleers and cankers. The sects dried are good arganst the colie, worms, and they strengthen the stomach. The root is more powerful in operation than the herb, especially to ojen ohstructions, and Jemove agu', if the juice be taken in wine, or the deeoction in wine be used.

\section{SOLOMON'S SEAL.}

Description. - Polygonaton.-There are two kinds of this plant, the common and the sweet smelling. 'The common Solomon's Seal grows a foot and a half high. The stalk is round, striated, and of a pale green; naked half way up, and from thence to the top, it has litrge oval leaves of a jale green, blunt, smooth, ribbed, mindented at the edges. Small, hollow white flowers hang from the under part of the stalk; the firuit is a berry about the size of a pen, and when ripe, black. The root is white and knotted in some places, and creeps. It is a flat, round eircle, rejucsenting a seal, from which it derives its name. It grows wild in many places, and it grows in gardens.

Medicinat Virtues. - The root is the part nsed. It is a very good application tor cxtemul bruises, blows, \&e. It enres a black eye sooner than any thing ; first alphy the bruised root mixed witlo a little crean, and then the bruised leaves made into a stiff" ointment with lancl. It is good to close the lips of green wounds, and to hent all kinds of sores. The prowelered root is good agailst purgings attented with bloorly storls; and the fiesl root made into a consilve with sugar, stay's the whites. The decoction of the root in wine is a suitable beverage for persons with hoken-bones, ale it dicposes the hones to knit; also fin fluse who hathe ruptures. 'llhe decoction or the distilled 25. 
watel of the whole plint applied to the face, or other parts of the skin, cleanses it from fieckles, spots, or marks, leaving the plice fresh, fair, and lovely.

\section{SOPEIVORT.}

Description. - Saponaria oficinalis.-It is also ealled Bruisewort. The root ereeps under gromd. with many joints, of a brown eolour on the ontsikle, and yellow within, shooting forth weak and lound stalks, full of joints, each set with two leaves a-picee on the contrary side, which are ribbed like the herb Plantain, and formed like the common field White Campion leares, scliom having any branehes from the sites of the sialks, hot set with flowers at the top, standing in long husks like the IVild Campions, haring five leaves caeh, round at the ends and dented in the midlle, of a rose colonr, almost white, sometimes deeper, sometimes paler. It grows wild in low and wet gronurds, by brooks and by rumning waters. It flowers in July, August, and part of September.

Mreichal Virtuls. - It is an old faslioned remedy for gont and sl:in diseases. It possesses alterative, diaphoretie, and diuretic properties; it is very mueilaginous and will mako a latlicr like soap, insteat of which it is sometimes used. It may be used in infusion or decoetion. A lecoetion of the root removes olstruetions, and promotes the flow of urine, and perspiration. It is a great prufifier of the blood. It is of great serviee in Asthma, and in all disorders of the breast which require expeetoration. The conntry people in some plaees bruise the leaves of Sopewort, and lay them upon their fingers, hauds or leers, when they are ent, in orrler to lical them. It is very frowerfic to expel gravel and the stonc from the kidneys or b) luthler, and ato to expel or prevent the aceumulation of water

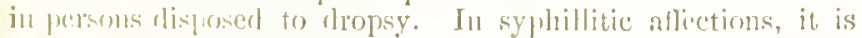

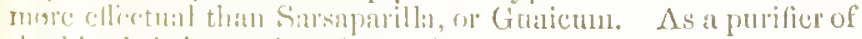
the blorol, it is worthy of attention.

$$
\text { Sótililit. }
$$

limmer Arefosa, - Sorrel grows in gadens, and wild in fields. It is well known. 
Medicrnal Virtues. - Sorrel is useful in all hot diseases to evol inflummation of blood in agues, or siekness and finting in fevers, and to proenre an appetite in fainting, or deeaying stomachs. It destroys worms, and is a cordial to the heart. The seed is most powerful and astringent, and rely useful in the bloody flux. 'The root in deeoetion, or in powder, is effectual for all these purposes. The decoetion of the roots is good against jaundiee, and the gravel and stone in the lidneys. The decoction of the flowers made with wine emes the black jaundice, and nleerated bowels. A syrup made with the juiee of Sorrel and Fumitory, is a sorereign remedy for the iteh. The juice with a little vinegar, is a eure for tetters, ling-worms, \&e. It removes kernels and soles in the throat; the juice being gargled in the month. The leaves wrapped in a cabbage-Icaf, lonsted, and applied to a hard imposthume, boil or plague sole, ripen and brutli it.

\section{SORREL, - WOOD.}

Description.-Oxalis Acetosella.-This is a different plant from the former. It grows upon the ground, having leaves coming fiom the root comprising three leares, like trefoil, broad at the cnds, and cut in the middle, of a yellowish green colonr, each standing on a long foot-stalk, whieh at first are folched together, to the stalk, till they expand; they have an aeid taste. The juice turns red when it is elarified and makes a fine clear syrup. Among these lcares rise up tender, wazk footstalks, with a flowcr at the top, eomprising five smill-pointed lcaves, star-fiashion, of a white colour, and in some with a small show of bluish, on the baek side only. After the flowers follow small round leads, containing small yellow sceds. 'J'he roots are yellowish, small, and fibrous. 'The herb grows in woods, and wood sides. It flowers in A pril and May.

Medrana, Vintues. - This is more eflefunt than the other Sorrels in preventing putrefiction of blood, snd nlects in the mouth and body, to enench thirst, to strenethen a woak stomach, plocme an alpletite, staly romitims, and to prevent comtanions sickucss or ferers. It operanes by mine, and removes chintruetions in the viscera. 'The sylup) inade of the juiec and 


\section{SOUTHERN WOOD.}

the distilled water of the herb are equally effectual. Sponges or linen cloths saturated with the juice, and applied to any hot swelling or infammation, tends to reduec them. The juice gargled in the month repeatedly, is a remerly for canker or nlecrs therein. It is very good to heal wounds, or to stay blcedings. Sults of Lemon is obtained from this plant, used to take ink-spots out of lincn, and Oxalic Acid also, both rank poisons.

\section{SOUTHERN WOOD.}

Abrotonum Mras.-Every one knaws this plant, especially by the name of Lad's-Love.

Medicinal Virtues. - The tops of the young hranches are used. A decoetion of then destroys worms. It is not very pleasant to take. They may be madc into a conserve by adding sugar, cinnamon in powder, cloves, or any thing aromatic, to render it agrceablc. It corrects a bad stomach, and strengthens it much. It restrains the Whites. It is a nervinc, and therefore good against nervons disorders, and all hysterical complaints. It is also anti-serofulous, and deobstrucnt, thercfore valuable in mrinary suppression. The oil applicd to the backbone, before fits of aguc, prevents them. Boiled with barlcymeal, it takes away pimples, \&c. The ashes mingled with old sallad oil, canses the hair to grow again. Darmters says that Southern Woorl oil, and a little White Hellcborc, is very effectual to kill lice in the head. The distilled witter of the lerts is said to remove the stone, and discases of the spleen and womb.

\section{SOW TIIISTLE.}

Sonchus Asper. Sow Thistles are so well known that they need no description.

Menternat Virituls. - Sow Thistles are cooling, limdiug, and rery fit to eckl a hot stomach, anul ealse its paims. 'The herb,

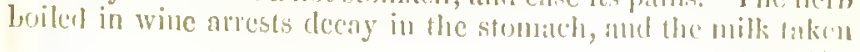


from the stalks given in drink relieves those that are short winded, and have a wheezing. Pliny says it has eansed the gravel and stone to be voided by urine, and the eating of it eures a foetid breath. The decoetion of the lenves and stalks eauses abundanee of milk in nurses, and their ehildren to be wellcoloured. The juice or distilled water is good for inflammations, eruptions, or heat in the skin, or itching of the hamorrhoids. The juiee thoroughly heated in a little oil of bitter almonds in the peel of a pomegranate, and dropped into the ears, is a sure remedy for dcafness, singing, \&e. Three spoonfuls of the juiee wamed in white wine, eauses women to have an easy and speedy delivery, so that they are able to walk presently after. It is good for women to wash their faees with, to elear the skin and give it lustre.

\section{SPEEDWELL.}

Veronica Officinalis.-This is one of the commonest and prettiest of the wild plants of Britain. It grows in dry pastrures and on heaths. Its stalks are about 6 or 8 inehes high. The leaves are short and oval. The stalks trail on the ground only rising at the upper parts. The leaves are of a pale green eolonr, a little hairy, and dented at the edges; the flowers are small and blue; they grow in slender spikes, arising from the bosoms of the leaves. The root is small and fibrous.

The whole herb is used, and it is best freslr. An infusion taken freely works by urine, and opens all obstruetions; it promotes the menses. It is good against obstruetion of the lungs, and is an excellent elennser of the blood. It removes blotehes, and eutaneous eruptions.

\section{SPIGNEL.}

Description.-Athamanticum Nrum.-The roots spread dcep in the ground, many fibres growing from one head, which is hairy at the top, of a blackish brown eolonr on the ontside, and white within, fragrant, and of an aromatie taste. from whienee arise long stalks of fine eut leaves, like hair, smaller 258 
than dill, set thick on both sides of the stalks, and of a good scent. From these leaves rise up round stiff stalks, with a few joints, and leaves, and at each top, an umbel of purc white flowers; the edges tinted with a reddish blue, espccially belose full blown. The secds are brown. It grows wild, and is plauted in gardens.

Medicinal Virtues. - Galen says the roots of Spignel proroke urine and women's courses; but if too mueh be taken, it causes headache. The root boiled in wine or water, curcs stoppage of urine, expels wind, allays swellings and pains in the stomach, and joint-aches. If the powder of the root be mixed with honey, it breaks tough phlegm, and dries up rheum that falls on the lungs. It strengthens the stomach, creates au appetite, and removes eolie.

\section{SPLEENWORT.}

Description.-Asplenium Trichomanes, vel Ceterarch, Scholendrii.-It is also called Hart's tongue by some. From a black thready, and bushy root, arise long single leaves, indented on each side irregularly, and covered on the under part with small secds. As they spring from the root, they are folded inward, so that the under part only appears; they appeur more like some insect than a leat. It grows on old walls, and is green all winter.

Mradclnat Vartues. - It is said to be binding and strengthening, and espeeially a cleanser of the spleen, removing strangury, stone in the bladder, the yellow jaundice, and the hiccup. Matthiolus says, that if a draehm of the dust that is on tho back of the leaves be mixed with half a drachn of amber in powder, and taken with the juice of purslain or plantsin, it restrains the running of reins and that the deeoction of the herb enres melaneholy diseases. Camerarius says that the distilled water drauk, is very effectual agrainst the stone.

\section{SQUIIL.}

This drug is the produce of the Scilla, or Squilla Naritima, the bulb being the part used. It is soll in the Shops. It is un 
expectorant medicine of great value. It also acts as a diuretic, and in large doses may cuuse sickness or punging. It is inadmissible when there is inflammatory action, or active irritation in the bronchi or air passares; in such eases, it aggravates cough instead of relieving it. $\Lambda$ s an expectorant, squill is nust serviceable in chronic bronchitis especially in the aget, but in all eases when the phlegm is tough, viseid, and diffieult to roid. It is most advantagreously combined with opiun, as it does not impail the expectorant property of the squill, but modifies its tendeney to imitate. From one to two drachms of paregoric, with 20 drops of 'Tincture of Squils in a wine-glassful of water, is a most excellent congh draught for uight to which, if there is much debility, one drachm of sal-volatile may be added.

As a diuretic, Squill is generally given in dropsies in from one to three grain doses. The root is used dried, or infused in vinerar, $2 \frac{1}{2}$ ounces in a pint of distilled vinegar for a week. After straining, $1 \frac{1}{2}$ ounce of proof spirit is alded to insure kecping, and then filtered. The Syrup of Squills is made by dissolving $3 \frac{1}{2}$ ths. of fine sngar in a pint of squill vinegar by the aid of gentle heat. The dose is from one to two drachms. In dropsy of the abdomen, a liniment, composed of two parts of Soap-liniment, and one part of Tincture of Squills rubbed well into the skin, frequently, is said to be very scrviceable. In asthma, the oxymel of Squill is very serviceable. The wine of Squills works by urine, and is good against the jatudice and dropsy.

\section{STAR TIISTLE.}

Descriptron, - Calcitrapa. - The Star Thistle has narrow leaves lying in a circular manner on the gromul, indented at the edges, soft, or a little woolly, green, from whichl rise weats stalls parted into many branclies, all lying to the ground, a pretty bush, set with divided leates to the top, where stant small whitish green licads, with shup white gricks (no part of the plant else being prickly) which are yellowish; out of which rise the flowers, composed of mamy sunli redelish purple theads; they resemble the flowers of thistle. The secks ale wintred with $\because 60$ 
rnwen. The root is oblong. It grows on heathe, and flowers in July.

Mencinal Virturs. - The sceds nude into powiler, and drank in wine, proroke mine, and break the stone. The root in powder, given in wine and drank in the moming fanting, helps to cure a fistula in any part of the body. It opjens obstruetions, and is good against gravel.

\section{STAVESACRE.}

This is a plant of the crow-foot tribe, botanically known as Delphimem Staphisagria. Its secds are violently emetic and cathartic. They are seldom given internally : though the powdered seeds have been given as a purge for dropsy, in very small quantitics at first and increased till the offeet is jurduceri. Dose at first shonld not exceel two or three grains. 'The serils are used as an external application to some entaneous eritptions, and to destroy liee in the hend. The deeoction applicd with a linen ragr is effectual in euring the iteh. The seeds ate merely boiled in water.

\section{ST. JOHN'S WORT,}

Description.-IIypericum, Perforatum.-It grows a font and a half' high. The stalks are round, thiek, firm, upriglit, and at the top divided into several branches. The lenves are a little like those of the lesser Centuary, but narrow, short, anul obtuse at the end, and if held up against the light, they appear full of small round holes. Large and bright yellow fluwers abumiantly grow at the tops of the branclies, full of yellow threarls, which, when rubbed upon the hand, stain it leed, like llood. The secr is black, and smells like rosin. It grows in mearlows, woorls, and copses.

Meinctinal Virtuse. A decnetion of the flowers is very flinertic, promoting the flow of urine, is goorl for gravel, and inflammation of the ureters. It lus been used as a vuluerary, Loth externally and internally, and luns been considered nselini 


\section{STONE-CROP.}

in hysteries, intermittent fevers, dysentery, hemorrhages, eliest complaints, worms, and janndiee. For womnds, the tops gathered fresh and bruised are used. Boiled in wine it is excellent for inward wounds and hnrts. It is a first-rate wonnd herb, made into an ointment; it soon closes ents, wonnds, \&e. The decoction of the plant and flowers, and especially of the seed, with the jujee of Knoturass, relieves vomiting, spitting of blood, and obstruetions of urine. Two drnehms of the powdered herb drank in a little broth, expels eholer and eongealed blood from the stomach. A warm deeoetion of the leaves and seeds taken before fits of ague, relieves, and, erentually, drives them away. The deeoction of the seed, frequently and continuously taken, will cure seiatiea, falling siekness, and palsy.

\section{STONE-CROP.}

Description.-Sedum Acre.- $\mathrm{It}$ is a kind of Honse-Lcek, growing npon stone walls, mud walls, the tiles of houses, and amongst rubbish, and gravelly plaees. It grows with trailing branelies upon the ground, set with many thick, flat, roundish, whitish green leares, pointed at the ends. The yellow flowers stand together, rather loosely. The roots are small, and ereep uncler the ground.

Mndicinal Virtues.-It is astringent, and good to stay defluxions, especially such as fall upon the eyes. It stops bleerling, both inward and outward, tends to enre eaneers, and fretting sores and uleers. It abates the heat of the bile, and prevents disenses arising from bilious humonrs. It expels poison, prevents fevers, and tertian agnes, the decoetion of it being nsed. It is so harmless an herb, you can scarcely use it amiss. The leaves bruised, and applied to scrofulous sores, and the piles, is an effeetual eure.

\section{STRA WBERRY.}

Fragaria Vesca.-This plant needs no deseription.

Memenal Virtues.-Dr. Thompson says, "The delieions Init nust be elassed with the most wholesomo of the vegetable 262 
kiugdom." It is said of Fontenelle that he attributed his longevity to them, in consequence of their having regnlarly cooled a ferer which he bad every spring; and that he nsed to say, "If I ean but reach the season of strawberries, I shall do well." Boerhave regarded their continual use as one of the prineipal remedies in cases of obstruction, and viseidity, and in putrid disorders. Hoffiman furnished instances of obstinate disorder's cured by them, cven consumption in its incipient sitges; and Linneus says, that by eating plentifully of them, he kept himself free from gout. They are grood even for the tectlı, and may also be used as a safe and effectual dentrifice.

They cool the stomach, the liver, and the spleen, quench thirst, and regulate the kidneys. The juice dropped into foul ulcers, tends to eure them. It is good to stay eatariths, or defluxions of rheum in the lungs. The juice is good for inflaned eyes, if dropped into them.

Strawberries make a good wash for inflamed parts, and take away redness of the lace, sprots, \&cc.

\section{SUCCORY, OR CIICORY.}

Description. - Chicorium.-This is a species of the endive and is commonly known by the name of Chicory.

The wild Suecory has long leaves, lying on the ground, vely mueh cut in or torn on the edges, on both sides, even to the middle rib, ending in a point; sometimes it has a rib down the middle of the leaves. From the leaves rise a hard, romm woorly stalk, sjreading into many branehes, set with suraller and less divided loaves on them up to the tops. where stand the flowers, which are like the garden kind, and the sect is also; the root is whiter but harder and more wooly than the garden kirrl. The whole plant is excecding bitter. It grows in wasto untilled barren fiekls.

Menicinae Virtues. - The plant has heen relehrated as a conler. It is of great service in fill ollstructions of the viscera, friticularly of the liver. It has been extulled in complatints procecting from at redumbant bile; it is therefore good agatiost jaundice, influmnation of the liver, and the gruscl, as it works 
powerfully by urine. The deeoction of the leaves has the same effeet, if marle strong ; and is good also for dropsy and ague ; for the latter a decoetion of the leaves and root in wine. The distilled water of the herb and flowers is speeially good for hot stomaehs, and in agrues; for swoonings and passions of the heart, for the heat and headache in children, and for the blood and liver. The bruised leaves applied allays swellings, inflammations. St. Anthony's fire, espeeially if used with a little vinegar.

\section{SWEET FLAG.}

Acorus Calamus.-A common wild plant that grows undistinguished amnoug the flags and rushes by ditch-sides. It grows three feet high, but consists only of leaves withont a stalk. They are long, narrow, and of a pale green eolour. Amongst these there are three or four like the rest, but they liave a clus-. ter of flowers at one side, five or six inehes from the top. It is long, brown, and thick, like the catkin of a filbert tree, but longer and thieker. The root is long, flattish, and ereeping; at first the smell is unpleasant, but becomes otherwise in drying, quite fraglant and aromatic.

It is an aromatie stimnlint, and never causes fercrish exeitement. It is a very powerful tonie, and very nseful in weakness of the digestive or gans, loss of appetite, and general wenkness. Combined with Pernvian Bark, or Quinine, it has becn of great service in the low stage of nalignant fevers. The roots powdered, and infused, or deeocted, has cured the colie, flatulence and ague. The dose of the root powdered is from 15 to 40 grains; of the Infusion from 1 to 2 ommees; of the tineture, from $\frac{1}{2}$ a drachm to 1 draehms. Outwardy, it is applied as a stimulating fomentation.

\section{TAMARIND.}

The tree is a native of the liast and IVcst Tulics, Tamarindus Indica. The frut is a flat pod. It contains a pulpes substance, and the secds a stringy matter with them. 'The pulp, strings, and seeds are imported, and the pulp is separated for 264 
use. It is of a pleasant acid taste, and is an excollent gentlo purge. It worls by urine. It is gond in the janndice. The julp is neful to cool the month, and to quench thirst in fevers. The efficacy of sweet purgatives is increased by this fruit, such as Cissia, MIanna, \&c. Preserved tamarinds, as an aperiunt are very suitable tor the sick in fevers, or feverish dicenses. It is used by infusion - in lot water, and allowed to cool.

\section{THE TAMARISK TREE.}

Tamarix Gallica. - A little tree whieh grows wild in France, and is kept in sume English gardens.

Medicrat Virtues. - The roots, leaves, or bark boiled in wine, stays the bleeding of the hæmorlhoidal veins, spitting of hlood, and profuse menstruation. This decoction is gool against the jaundice and eolic. A watery decoetion cxternally applied hot is powerful against hardness of the spleen, tooth-rehe, pains in the ears and inflamed eyes. The decoetion with honey, is a good application to stay gangrenes and fretting ulcers, and to destroy lice. Alpinus and Veslingius affirm that the Egyptians give it to those who hare the leprosy, serios, ulcers, or the like. Its ashes quiekly heal blisters raised by burnings or sealdings. It helps thic dropsy, arising from hardiess of the spleen. It is good in melancholy, and the black jaundice.

\section{TANSY,-GARDEN.}

It is a eommon plant, eultivated in gardens. It is the Trunacefum. Vulgare of botanists. It is so well knowll as to need no rleseription.

Mentrinat Viritues. - This herb bruised and applicd to the navel, prevents mis-carringe, at least ancient physicians reckoned so. It eonsumes the phlermatio humonls engenderes ly winter, and this cansed Tausy to be eaten in spring. The deenction of 'Tansy, or the juice drank in wine, promotes mine, eures strangury, and strengthens the kidlucys. It is very anti- 
flatulent. The decoetion is also good against worms. The seeds combined with Worm-seed, and made into an electuary, destroy worms effeetually.

\section{TANSY,-WHLD TANSY, OR SILVER IVEED.}

Descriptron.-Tanacetum Argentina. A common wild plant growing on way-sides. It rises to no height. The stalks creep upon the ground, and take root at the joints; but it is easily distinguished by its silvery leares, and yellow flowcrs. The stalks are round and reddish. The leaves rise from these, like the leaves of Tansy. It flowers in June or July.

Medicinal Virtues. Wild Tansy restrains fluxes of blood in men and women, also spitting or vomiting of blnod. The powder of the herb taken in some of the distilled water, arrests the terms, and the whites. It is also good for ehildren that have a rupture. Boiled in water and salt, it eases griping pains of the bowels, and is good for the sciatica and joint-aches, as an external application. Boiled in vinegar, honey, and alum, and gargled in the month, it relieves tooth-ache, heals sore gums and strengthens the palate of the mouth when lax. It is given with success in bleeding piles, and, as a gargle, for an ulcerated mouth. The juice of the leaves and root made into an ointment is good to heal green wounds, and rmnning sores in the legs. The distilled water frees the skin from sun burning, pimples, freekles, and the like. The juiee dropped into the eyes, or eloths wet therein and applied, takes away inflammations in them.

\section{TAPIOCA.}

Tapioea is the pith of the roots of Jatropa Manihot, a slumb growing in Brazil and the West. Inties, where it is ealled Cassava. It resembles Sago, but it is less coloured, and in larrger grains. The jniee of the root in its prinitive state is liphly poisonons, and with it the Indians poison their arrurs. This juice is thoronghly removed ly wisling, and the stamb or Talioea, dried in the form of gralls. Tapiocal is lised in siek-
266 
room cookery like Arrowroot and Sago. To make Tapioea into a proper mueilage for the sick, 1 ounce should be macerated in a pint of water, on or near a slow fire, or in a slow oven, for one hour, then boiled ten minutes, stirring well during the boiling. The mueilage may be sweetened with sugar, or flavoured with lemon-juiee. It is a nutritious farina; but by the addition of a little flour it is rendered more so. Dr. Christison says, "No amylacenus substance is so much relished by infants about the time of "caning; and in them it is less apt to turn sour during digestion than any other farinaceous food, even Arrow-root not excepted."

\section{TEA.}

The dried leaves which we infuse, and call Tea, are produeed by the Thea Viridis, of the natural order Theace. 'The teaplant is a native of China, Japan, Tonquin, and Assam, in India. The different varieties are eaused by different morles of eultivation, or of preparation of the same species. Tea has slightly stimulant and astringent properties, and besicles its daily use as a beverage, it is taken inedieinally.

Dr. Thompson says, "Tea possesses a natmral fragrance which requires no arldition. The Clinese say, that only eonmon tea requires seenting; nevertheless there are varions seented teas which are in high estimation even in China...... Tea is liable to immense adulteration-much after it reaches this eountry, but partly in China. The Chinese annully dry many million pounds of the leaves of different plants to ningle with the genuine; and the leaves of the following species love been deteeted from time to time in samples of tea of lirtivh fabrication;--beech, elm, horse-chestnut, plane, bastarl-plane, faney-oak, willow, poplar, hawthorn and sloe."

"One of the most frequent adulterations of tea is its admixture with exhansterl leaves which have been relried..... Catteehu is a frequent aldition to the exhausted aud otluer leares, to give tliem astringency. Sulpate of iron, rose-piuk, lewwonl, plumbago, indign, \&ce, are all used at times in the alulteration of tea...... Such arlditions are highly deleterious..... Groen 


\section{TE $\Lambda$.}

tea is so greatly adnlterated, that, althongh there is certainly a genuine preparation of this kind, it scems donbtful whether any is sold pure. From authentic examinations, it appcars that all the green teas imported into this conntry, are faced with a powder consisting either of Prussian blue, or sulpbate of lime, or gypsum, or of some other colouring matters.

Tea, especinlly the green, exerts a very powerful inflence upon the nervous system. "There are some persons uron whom grcen tea produccs nearly the same effect as digitalis, and it has been medicinally employed in the diseases for which that herb so decidedly obtained a high reputation. Where persons have any tendency to dyspeptic affections, they are very apt to be aggravated by the use of tea.

Dr. Graham says, "Tea appenrs to me to exert a very injurious influence on the stomach, bowels, and nerves-a very marked and irritating effect on the nervous system, and is drank in this country far too often and too strong. It forms a refiresling and anti-spasmorlie beverage, but should not be taken either strong or hot; the addition of milk renders it more wholcsomc, that of sugar less so. Individuals of a rigid and solid fibre are less injured by it than those of an opposite habit; but none should take more than two sinall tea-cupfuls morning and evening. I cannot think it equal to cocon or thin chocolate for eommon use; and it is probable that some of our indigenons plants would yield a more wholesome and equally as palatable an infusion as the tea-leaf of China. With some tea loes not agree; an infusion of Agrimony or some other native plant, should be used instead. I may state on very respectable anthority, that the first leaves of Wrortleberry, dried in the slade, eamnot be distinguished from real tea. Suge, (the Tomentosa, or Balsamic Sage) and Balm, are valuable substitutes for tea, particularly in the case of debility in the stomach and nervous system. John IIussey, of Sydenluam, in Iient, who lived to 116 , took nothing for his breakfust for fifty years, but Balm tea sweetened with honey."

Tea is occasionally of service in ardent and bilions fever, eramp of the stomacli, flatulency, and to relieve the sensations of oppressions acconpanying indigestion and bilious complaints.

268 


\section{TEAZLE,-OR FULLER'S THISTLE.}

Dipsacus Sylvestris.-It is well known, and necds no description.

The root is used; it is bitter, and given in infusion strengthens the stomach, and cleates an appetite. It removes olsstructions of the liver, and the jaundice. The juice diluted with water is said to take away freckles. The sane also, or the distilled water dropped into the eyes, remores inflimmation, aut improves the sight. The juice is said to take away warts and wens.

\section{THISTLE,-BLESSED.}

Description.-Carduus Benedictus.-This plant is a native of the warmer countries, and is raised with us in gardens. It is two feet high ; the stalk is reddish, slender, and wcak ; very much branched, and scarce able to keep upright under the weight of leaves and heads. The leaves arc long, narrow, cut in on both sides, and of an obscure green, The flowers are yellow; they stand in a kind of green leafy hends: the little leaves composing these heads are prickly ; and each ol the cups of the flowers ends in a long brown spine, dented on both sides.

Medicinal Vrrtues.-It is hitter and stomachic. An infusion of it taken in large quantities, will excite vomiting: in smaller draughts, it is good to create an appetite, and prevents sickness and reachings. The leares dred and powdered, are yoorl against worms. It was at one time supposed to possess very great virtucs against fevers of all kinds : but that is now disicgarticed.

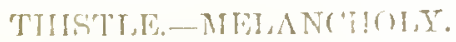

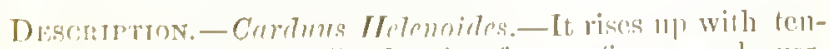
der vingle hrany green stalks, bearing four or live green leaves, dented at the celges; the points thereof ares a little prickly, and at the top it has but one hear, yet somctimes from the bosom 


\section{THISTLE,-MeLANCHOLY. THISTLE, -OdR Liad's.}

of the uppermost leares there is another small head, scaly, and prickly, with many reddish threads in the middle, which being gathered ficsh, will kecp its colons, and fade not for a long time, while it perfects the seed, which is downy. The root is stringy and black. It is easily known by its long straight stem, purple flowers, and linear leaves. They grow in moist meadows, and flower abont July or August.

Medicinal. Virtues. Its virtues ale not to be despised; for the decoction of the thistle in wine expels superfluous melancholy out of the body, and makes a man as merry as a cricket. Persons troubled with melancholy and depression of spirits may take a decoction of the root-a wine glassful two or three times a day, with the greatest advantage. Dioscorides asserts that it cures melancholy. Morlern writers langh at him. Let them laugh that win ; my opinion is, that it is a good remedy agraiust melancholy discases.

\section{THISTLE,-OUR LADY'S THISTLE.}

Description. - Carduns Marice. It has sercral large broad leaves lying on the ground, indented and crumpled, hairy on the edges, of a white green shining colour, with many lines and streaks of a milk-white colour rumning all over, and set with many hard prickles, among which rise one or more strong round, prickly stalks, full of similar leaves to the top, where at the end of every branch, comes forth a great prickly Thistlelike head, strongly armed with prickles, with bright purple thrums rising out of the middle. The sced grows in the heads in soft white down, which is dispersed by the wind. The taste of the plant is bitter. It grows on ditch-banks, and by roadsides. It flowers in June and July.

Medicinal Virtues. - The roots and seeds are used. An infusion of the fresh root works by urine, and removes olsetmetions of the liver and splecn, and is therefore good for jaundice, It hinders the ague, expels the stone, and relieves dropser. it relieves inward pains and gripings, pains in the sides, $\&$. It is often applied ontwanlly with cloths to the regrion of the liver, to cool the distemper thereof, and to the region of the heart,
270 


\section{THISTLE,-WOOLLEN.}

\section{THORN APPLE}

agninst swoonings. It cleanses the blood excecdingly; and in Spring, if yon boil the tender plant without the prickles, it will change youl blool as the season changes, and that is the way to be sate.

\section{THISTLE,-WOOLLEN THISTLE.}

Description. - Carlina Irulgaris.-It is also called Cotton Thistle. It has many large leaves lying upon the ground, indented and crumpled on the clges, of a green culour on the upper sicle, but eorered over with long hairy wool, or cotton down, set witl very sharp priekles : firom the middle of whose heads of flowers come many purplish erimson threads, and sometimes white, but seldom. The seed in these white downy heads, is large and round, resembling the seed of Lady's Thistle, but palcr. The root is large, thick, and spreading much. It grows on ditch-banks, and in corn-ficlds and highways.

Medicinal Virtors.-Dioscorides and Pliny write, that the leaves and roots taken in drink, eure stiff neck. Galen says that the roots and leaves are good for such persons that have their bodies clrawn together by spasm or convulsion, or other infirmities; as the rickets in children, a discase that hinders their growth, by binding their nerves, ligaments, \&c. It is good also in nervous complaints.

\section{THORN APPLE.}

Description. - Datura Stramonizm. - It is a native of Ameriea ; but is now eultivated in this country, ou account of its beanty. It grows three feet ligh. The leaves are muel toother, of a light green; the flowers are white and lrumpetshapert. The fruit is of the size of a wall-nut, covered will juickles or thoms, hence its name.

The loaves, stems, finit, and seeds sue cut up torether aur

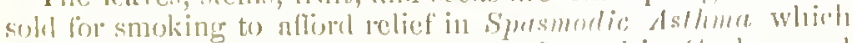
it certainly roes. For this purpose it is mserd in Coylon, annl the poorer 'T'urks use it insteml of Opium. J alets is in sedative upon the macus membranc, and promotes the secretion of the 
mueus; it allays the spasmodie symptoms attendant on the paroxysms of asthina and respiration proceeds in a calm and undisturbed manner. A little only slould be swoked at the first and gradually inereased.

Its internal use is very tlangerous; for it is very stimulant and nareotic, - a deadly poison, excreising much the same influenee as belladonna: It is given to quiet the mind during violent paroxysms of insanity: as a speeific in severe clnonie pain of the head. It is given in the form of Tineture or extraet; of the former from 5 drops twiee a day in water; the latter from $\frac{1}{4}$ of a grain. It ought to be administered by persons of medieal skill.

\section{THOROUGH WAX.}

Description. - Perfoliata. - It is sometimes ealled Through Leaf. It is a beantiful wild plant growing among corn, distinguished by the stalk growing throngh the leaves, three feet high. The stalk is round, firm, ereet, whitish, and brancling at the top. The leaves are broad and oval; the stem runs through them toward the bottom; for they have no footstalks, and they surround it in thcir largest part cuding in a blunt point ; of at bluish green eolour, unindented. Tlıe flower's are small and yellow, in elusters with a parecl of small leaves under tliem. The root is white, oblong, and slender. It flowers in July.

Medicinal Virtues.-Thorough-TWax is useful for bruises and wounds, either inward or ontward, if the decoction of the herb with water and wine be drank, and the place wasked with it, or the jnice of the green herb bruised, male into an ointment. The decoetion of the herb, or powder of the dried herb, taken inwardly, or the leaves bruised, and applied ontwardly, is good for all ruptures, especially in children. It the navels of children project, the juice nixed with \&lour, and a little wax, cures them.

\section{TIIYME.}

Thymus. $-\Lambda$ eommon plant in kitehen gardens, well known. Midicinal Vintuls.-It is a noble strengthener of the 272 
lungs. An infusion of the fresh tops is goor in asthmas, and stuffing of the lungs. It is excellent in nervous aficetions, and a special remedy for hooping cough. It expectorates phlegrm, and relieves shortness of breath. It kills worms, and provolses the terms. It is so harmless you need not fear the use of it. An ointment made of it removes hot swellings and warts, relicves seiatica, dulness of sight, and pains and hardness of the spleen, it is good against the gout, and swelled testicles, pains in the back and loins. The herb taken any way inwardly, comforts the stomach and expels wind.

The Wild Thyme, (See Mother of Thyme) is preferable. For obstructed menstruation, a bath for the feet and legs in a strong infusion, or deeoetion, gives relicf after the failure of all other remedies. $\Lambda \mathrm{n}$ oil is made from the Wild Thyme, a drop or two of which eures the tooth-ache; apply with a little lint.

$\Lambda$ writer in the "Lancet" says, "An infusion of Wild Thyme will, in many cases of Hooping Cough, and affeetions of the air passages, remove the complaint, when all other remedies fail."

\section{TOBACCO}

Tobaceo is manufacturcl from the dried leaves of the Nicotiana Tabacum, a native of the Sonthern states of Amcriea. It is a dearly narcotic, especially the oil, so much of which is absorbed by the pipe in smoking. Its cfiect on the system is that of a rareotic and sedative, prodncing sickness, and depressing tlue action of the heart; it is slightly dinteric, and antisliasmorlic; in over-doses it procluces convulsions, which aro likely to terminate in death.

Jike many other poisons, Tobaceo is used medicinally. Tho A merican Indians bind the leaves on the bite of the Risttle-snalio and cure it. $\Lambda$ nd the bite of a marl dog has heen cured by tho applieation of a thick ponttice of 'Tobacen. It has been givent

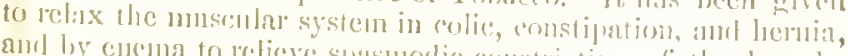

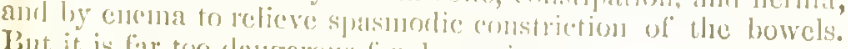
But it is far too dangrerous for clomestie: ase.

I lesitate not to say that 'Tolaneco has killed thousands. In $\mathbb{R}$ 27.3 
some it promotes rapid digestion, foreing the food down faster than it can be disposed of. In others causing "shameful spitting," gradually wasting the frame, or disposing it to those diseases which terminate in death. In some it affeets the brain, and renders the person liable to apoplexy. In short, its evil influences are many and great. In other's it produces disorder and extreme irritation of the digestive organs, of ten attended with extreme nervous irritability. The lips of smokers are rery liable to cancer, and its injury to the teeth is notorious. Smolers too are very liable to discases of the throat and air-passages, laryngeal phthisis and bronchitis.

Exes Snuff is even worse than Tobaceo; for it often is a eombination of the rankest poisons with the powdered leaves of 'Tobacco.

\section{TORMENTIL.}

Descriptron.-Tormentilla Erecta.-Also ealled Septfoil, or Steptfoil. It has reddish slender branches rising from the root, lying on the ground, not quite upright, with many short leaves closer to the stalks than Cinquefoil, (which this is very like) with the foot-stalk compassing the branches in several places, but those that grow to the ground are set upon long foot-stalks, which leaves are like those of Cinquefoil, but long and less, dented about the edges, some divided into five, and some into scren, on account of which it is called Scptfoil; yet many have six, and some cight, according to the fertility of the soil. The flowers are small, of a beautiful shining yellow; they grow on slender footstalks, in shape and colour like the crow-foot flowers, but more benutiful and less. The root is short and thick for the size of the plant, externally brown, and reddish within, of an austere tustc. It grows in woods, shady places, and in borders of ficles.

Medicinal Vilitues. - Tormentil is most exeellent to stay all kind of thuxes of bloor. "The juice of the herb and root, or the decoction, taken in Venice treacle, and the person laid to sweat, exjocls venom, poison, ferer, or other contagions disenses, ns the pox, measles, \&e. The root taken inwardly is most effectual to relicve any flux of the belly, stomach, spleen, or 274 


\section{TORMENTIL.}

blood; and the juice wonderfully opens obstruetions of the liver and lungs, and thereby arrests the yellow-jaundice $A$ plaster made of the root and vincerar is good for those who caunot retain their urine. It should be externally applied to the back, against the kidneys. The powter of the root mixed with the juice of plantain is a remedy against worms. The root made up with Pellitory of Spain and alum, and put into a ho!low tooth, stops the pain. The juice or powder of the root combined with ointments and plasters, that are applied to wounds or sores, increases their power to heal. 'The juice of the leaves and the root bruised, and mixed with a little vinegrar, is a good application for seroffulous sores near the cars, on the neck, \&c. and for any sore or eruption on the head, or elsewhere, and for the piles. $\Lambda$ decoction strongly made is a good wash for the piles, and for inflamed eycs.

This plant is very astringent; so much so that it has been used in some places for tanning, and this astringency invests it with active remedial powers. If it were brought fiom a forcign country, it would be extensively used; growing in England, it is too cheup. The root is chiefly used. Powdered, it is given in from half a drachm to drachm doses. The decoction is made by boiling 2 ounees of the bruised root in 30 ounces of water, till it is relueed one third, and strained. Dose $1 \frac{1}{2}$ ounce. It may be used as an astringent gargle.

Dr. Graham says, "It is a mild yet powerful astringent, operates withont produeing any stimulant effect, ealenlated to rheck the diarrhoen of pulmonary consumption, and all diarrlowas, where the greneral excitement is considerable! For tlis purpose, its union with small doses of ijecacuartha powrer forms a very simple medicine, recommended by that distinguisherl physician, Dr. George Fordyce. It is also beneficial in olk ulecis, and in cases of weak bowels liable to fiequent relaxations, although they may be of short duration,"

Dr. Thorriton says, " $\Lambda$ pool" man, fond of botanical excursirns, knew the powers of this root, ard by makinge a strong decention of it, sweetened with honcy, he enred nentes which harl resisted the hark; loug-standing iliarrlusels, nfeers of the lecro turned out of hospitals as ineinable, the worst sembutie ulcers, fluxes, \&c. 'This excited the attention of Lord Willinm 
Russel, who allowed him a pieee of ground out of his park to eultivate Tormentil, whieh he kept as a secret. In fluxes of blood, I have found 1 drachm given four times a day, in an infusion of hops, do wonders.

\section{TREFOIL.}

Descriptron. $-\Lambda$ eommon wild plant in our meadows. It grows 8 inches high, stalk round, not very upright; the prineipal leaves rise immediately from the root, they stand three together on long fuot-stalks, and are of an oval figure, but pointed; of a pale green eolour, and a little hairy, having a white spot in the eentre of each. The leaves on the stalks have the same form, but are less. The flowers stand at the tops, in short thiek spikes; they are small and red, fullowed by little flitt pods.

Medicinal Virtues. - The fresh flowers are fresh used, and given in infusion. They are good against the blecding piles; and while they are balsamie and astringent in the bowels, they work benefieially by urine.

\section{TRUT-LOVE, OR ONE-BERRY.}

Description. - Verus-Amor.--It is also enlled Irerb-Paris, and Four-leared True-Love. It has a small creeping root, like eoneh-grass root, but not so white, shooting forth stalks with leaves, some bearing berries, and others not ; every stalk is smooth, without joints, and blackish green, rising halt a foot ligh, if it bears berrics, otherwise scldom so high, bcaring at the top four leaves one against another, like a eloss or ribbind tied (as in a true-lover's knot) which are each of them apirt like a night-shade leat", but rather broater, having threc, fire, or six leaves. In the midlle of the four leaves rises np a small slender stalk, an inch ligh, bearing at the top onc flower spurad like a star, eonsisting of font small and hong narrowpointed leaves of a yellowisl green colont, and four les. lying belween them; in the mithle of which stants il romed iark puplish button or head, comprissed abont with eight small 276 
yellow mealy threads with three eolours, making it the more eonspienous, and lovely to behold. This button or head in the midille, beeomes a blackish purple berry, full of juice, abont the size of a grape, having within it many white seeds. It grows in woods and eopses, and sometimes in the eorners or borter's of fields, and waste grounds. They spring up in April or Mlay and flower soon after. The berries are ripe in the end of May, or in the beginning of Jnne.

Medicinal Virtues.-The leaves or berries hereof are effeetual to expel poison, espeeially that of the aconite. The roots in powder taken in wine relieve the eolic. The leares are very effeetnal for green wonnds, and to eleanse and henl old sores and ulcers ; and to disperse old tumours and swellings in the private parts, the groin, and to allay inflammations. The juiee of the leaves eures felons, and heals imposthumes or sores about the nails of the hands or feet. Children should not be allowed to eat the berries.

\section{TURNSOLE, OR HELIOTROPIUM.}

Description. - Heliotropizm. $\mathrm{A}$ plant celeblated for its fragrance. The blossom is very small, of a pale blue, inelining to white, and sherdling an almond like-perfume. The name is derived from two Greek words, signifying the sun, and to turn; the leaves or flowers having been supposed to tum with the sun; henee it is ealled Turnsole, or Turn Sol. Hero it is eultivated in Greenlouses.

Medicinal Virtues. - It is a gool herb. Dioseorides says, that a good handful of this herh, boiled in water, purrges both choler and phlegm; and boiled with enmmin, removes stone in the kidneys, or blacller, provokes urine and menstruation. The leaves bruised and applied to places pained with the gout, or that have been ont of joint, and newly set, and finll of pain, give much ease; thic seed and juice of the leaves also being rubberl with a little salt upon warts or wens, anul other kerucls in the face, cye-lirls, or any other part of the borly, will by often using, tako them awny. 


\section{TURPENTINE}

Terebinthina.-It is an exudation from different speeies of Pines. It is a valuable remedy, either extemally or internally. Sprinkled on flannel dipped in hot water, wrung out, and then loeally applied, it is a powerful connter-irritant, aeting like mustard, and even blistering. It is useful for loeal pains, for lumbago, sciatien, and for inflammatory diseases in the abdomen. As an external application to burns, turpeutine has been mueh used.

Internally turpentine is anthelmintie, diaphoretic, dinretie, purgative and stimnlant. It is also given as an astringent. As a destroyer of worms, it should be given in comlination with Castor Oil, lest failing to purge it should over-stimulate the urinary organs. As a diuretie, it is prescribed in dropsy, and suppression of urine. As a purgative, it is nseful in enscs of tympanitie distension of the abdomen, and in acute stages of puerperal fever. As a stimulant to the nervous system, in neuralgia and epilepsy. Dose, as a stimulant and diuretie 6 to 30 drops-as a purgative and worm-expellant $\frac{1}{4}$ ounee to 2 ounces.

\section{TUTSAN, OR PARK LEAVES.}

Description.-Androsæmum.-It deserves sneeial notice, on aceount of its great virtues. It lias brownish shining round stalks. It grows two feet high. The stalks are firm, and smooth, tolerably upright, not branehed, exeept for some young shoots near the tops. The leaves stand two at each joint, opposite to one another, at no great distnnee, they are large, and wearly oval. 'Their eolour is a brownish green, they are smooth, and not serrated at the edges. The flowers are not large, but of a beautiful yellow, like those of St. John's Wort, full of yellow threads, which stain the hands red. The fruit is a kind of berry, when ripe blaek, eontaining many small seeds. The plant in antumn frequently appears of a blood red eolour, very singular and beautiful. "The root is small, reddish, and irregular; it ereeps under the surface. It grows in woods, groves, and woody grounds, parks, and forests. 


\section{TUTSAN.}

Medicinal Vintues. - The lcaves are an exccllent cure for fresh wounds. Scarcely any thing is cqual to them. The young and tender ones at the tops of the branchcs are to be used; they arc to be bound upon the wound, and they stop the bleeding, and effect a very specdy curc. There have been very singular instances of the cfficacy of this herb. Many other plants are celcbrated for their curative properties; but the efficacy of this is surprising. A decoction of the tops promotes urine. Tutsan purges choleric humours. Its virtues are very similar to those of St. John's Wort

\section{VALERIAN.}

Description. - Valeriara Oficinalis.-It has a thick, short, greyish root, partly lying above the ground, shooting forth all around small pieces of roots, which have many long grecu fibres under them in the ground. From the head of these roots spring up many green leaves, which at first arc broad and long, without any divisions or denting on the edges; but those that rise up after are more divided on each side, somc to the mild le rib, being winged, the leavcs on the stalk are morc divided, but smaller towards the top than below; the stalk grows a yard high, it is sometimes branched at the top. The flowers stand in largc tufts like umbels at the tops of the stalks, and are small and white, with a reddish blush. The root is of a whitish colour, composed of a great many fibres. The scent is strong and disagreeable. It is eultivated in gardens, and it also grows wild.

Medicinat Virtues.-Dioscoricles says that Garden Valerian has a warming faculty, and that being dried aud given to drink, it provokes urinc, and relicves strangury. The dceoction removes pains of the sides, provokes women's courscs. Pliny says, that the powder of the root given in drink, or the decoction removes all obstructions and pains in the body. Tho root of Valcrian boilct with liquorice, raisins, and anisecd, is goorl for those who are short-winded, and for those who aro troublerl with cough, causing casy expcctoration of phlcerm. The grecn herb with the root, bruised and applied to the head, takes away pain. The juice is good for the cycs, clcaring them 


\section{VANILLA.}

from inflammation, and dimness. It is an exeellent medieine in nervous disorders. The root is one of the most useful remedies in lyysteria and in spasuodic attaks gencrally. Its aetion is eliefly upon the nervous system, and is very useful for depression of mind, and for most affections of the nerves, melancholy. It may often be advantageously combined with bark. Dr. Cullen thought lighly of it as a remedy for nervous disorders, and he remarks that it shonld be given in large doses. It is best given in substance, with a little mace, or cinnamon to disguise the flavour. The Ammoniated Tincture is very valuable. It may be bought at the shops. Dose, one to three spoonfuls thriee a day in water.

\section{VANILLA.}

It is the fiuit of the Vanilla Aromatica, a ereeping shrub of the Orehis tribe, growing on the mountains of Mcxico and Peru, and Soutl Ameriea. This fruit has a strong, peeuliar, and agreeable odour, a wann aromatie, and sweetish taste; it appears to eontain benzoic aeid. As sold in the shops, Vauilla is a shrivelled pod of the kidney-bean shape, 6 inelies long, wrinkled, feels oily, and adhesive to the fingers, has a balsamio odour, a taste like prunes, with the faromr of buming pastiles. It is used by perfumers, confectioners, and distillers, and to sive a balsamie flavonr to confectionary; and it is employed in small quantities as an alljunct to ehocolate, to which it gives sweetness and a delieate flarour. It is valuable to the perfumer, the odour of the substance being one of the most exquisite imaginable. Medicinally it assists the digestion, and restores the impaired gastrie forees; it gives tone to the stomach, strengthens the intestines and heart, gives vigom and activity to the brain and the mental powers; therefore it is valuable to dyspeptie and
persons nervously low.

\section{VIRVAIN}

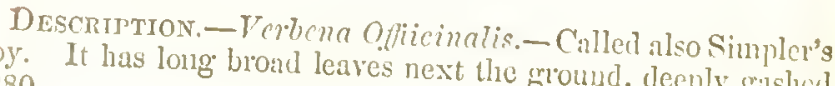
280 
ahout the erlges, and some decply dented, or ent all alike, of a dark green eolour on the upper side, grey underneath, The stalk is square, branehed into several parts, about two feet high, if you rcekon the long spike of flowers at the tops, which are set on all sides one above another, sometimes two or three together, small and gaping, of a blue eolour and white intermixed, after which eome small round sced, in small long heads : the root is small and long, but of no use. It giows by the hedges and way-sides, and other waste grounds.

MIedicnal Virtues.-It is slightly astringent. It removes obstruetions of the liver, and strengthens the nerves. It eurcs the yellow jaundiee, dropsy, and gout, and cxpels worms. It warms and strengthens the stomach, and eleanses, and strengthens the internal viseera. It is good in all minary affections. It is good for eoughs, asthma, and most affeetions of the lungs. It is a good wound herb, the leaves being ground, and made into an ointment with lard. It is good also for the piles. The jniee mixed with viuegar is a remedy for the headache. This has often been tried with suceess. As a eosmetie, it very mueh improves the skin, being mixed with a little vinegar.

\section{VINE.}

Vitis Viniforn.-The leaves of the English Vine being boiled, make a good lotion for sore mouths; boiled with barlcy meal into a poultiee, it eools inflammations of wounds. The ashes of the burnt branehes will make teeth blaek as a eoal, to be as whitc as snow, nsed every morning.

Grapes, the fruit of the Vine, are the most wholesome of fruits, containiug mueh sngar, vegetable jelly, aurl mueilage, the eharaeteristie tartarie acis in eombination with potassa, glutun. on whieh dcpends its property of ready fermentation.

\section{VIOLET.}

Vinla Odnrata.-It nects no deseription. They flower from March till the ent of . July.

Mrevicinal Vhimuls. - All violets are eold and moist whilo 281 
they are fresh and green, and are used to cool any heat of the body, either inwardly or ontwardly, as inflummations of the eyes, in the fundament, in imposthumes and hot swellings. A deeoction of the leaves and flowers should be made with water and wine. A poultiee made of the flowers and leaves, and locally applied, has the same effect. A drachm weight of the dried leaves or flower's of Violets, purge the body of eholerie humours, and heat, being taken in wine, or any other drink; the powder of the flowers dried, and drank in water is said to relieve the quinsy and the falling siekness in children. The flowers of the white violets ripen and dissolve swellings. The Violet-flower's are used medieinally on aecount of their demuleent and mildly laxative properties. They are good for eoughs and lung affeetions, and plemisy. The Syrup of Violets, to which has been added, a little lemon juiee, and a few drops of the oil of vitriol is very powerful to cool the heat and queneh the thirst. The green leaves are used with other herbs to make plasters and poultices for infammations and swellings, and to ease pains arising from heat, and for the piles. The Syrup of Violet may be bought at the Shops; or a combination of it and Almond Oil. It relieves eoughs and tightness of the ehest. Syrup of violets mixed with Almond Oil, and Syrup of Senna, makes an exeellent demulcent and aperient medieine. To make the Syrup, take a quantity of flowers, and boiling water sufficient to cover them; let it stand all night. Strain and add sugar, 2 pounds to each pint, and urclt over the fire. It is a good gentle purge for ehildren.

\section{VIPIR'S BUGLOSS.}

DESCRIPTION. - Echium Yulgare.-It has many long rongh leaves lying on the grount, from which rise up hard round stalks, very rongh, as if set with prickles or hairs, on which are set similar prickly green lenves, somewhat narrow: the middle rib beng white. The flowers stand at the top of the stalk, binnehed forth in many long spiked laves of flowcrs, turning like the turnsole. The flowers are large of a bantiful bhe with a red stamen in the midllc. After the flowers arc fullen, tho sceds when ripe aro blackish, shiped like the head of 282 
a viper. The root is large, blackish, and woody. It grows about pathways, on ditch-banks, and ahont old walls.

Medicinal Virtues. - The leaves are nsed; those growing from the root are the best. An infusion of them is cordial, and operates by sweat. It is good in fevers, eures the licadache, and all nerrous complaints. It relieves inflammatory paius, the secl being decocted in wine. This decoction comforts the heart, and drives away melancholy. It is a sweetener of the blood. It is said to be an expellant of poison, and renom, and to cure the bite of a viper; hence its name.

\section{WALLELOWER.}

Leucoion.-It needs no deseription.

Medicinal Virtues. - Galen says, that yellow Wall-Flower works more powerfully than any of the other kind. It cleanses the blood, and the liver and reins from obstructions, promotes menstruation, removes the hardness of the spleen, reduces inflammations and swellings, comforts and strengthens any weak part. It cleanses the eyes from mistiness and filns, and ulcers in the mouth, or any other part, and is a singular remedy for the gout, and aches and paius in the joints and sinews.

\section{WALNUT TREE.}

Juglans Regia.-It requires no deseription.

Menicinal Virtues. - The bark and leaves of the tree are very astringent. The husk and shell, and peal of the kernels, are sudorifie, especially if used while the walunts are green. It is sairl to expel the broal worms, or tape-worm. No insect eats the leaves of this trec. The leaves have the same property. The juice of the green husks, hoiled with lioncy, is an exeellent gargle for a sore month, and inflammation in the throst and stomach. The kemels when they grow old, are more oily, and therefore not fit to be eaten, but ane then nserl to buil wounds, gangrenes, and earbuneles. 'The kernels bumel are 
vely astringent, and will stay women's eonrses, being taken in red wine. The green husks have the same effeet. The kcrnels beaten with rue and wine, and applied, relieves the quinsy; and broised with some honey, and applied to the ears, eascs the pains and inflammation of them. The oil pressed out of the kernels, taken inwardly, is good for the colic, and to expel wind; half an oumee may be taken at any time. The young green nuts taken before they are half lipe, preserved with sugar, are good to strengthen weak stomaehs. The distilled water of the green husks, before half ripe, eools the heat of agues; dose an ounce or trvo at a time. It is a very cooling application to green wounds, quiekly healing them. The distilled water' of the green husks being ripe, is very good against the quinsy, gargling, and bathing tho throat with it.

\section{WATER PLANTAIN.}

Description. - Plantago Aquatica. - A very common tall plant in ditches, and having not the least resemblance of any kind of plantain, except in the leaves; from which, however, it has received its name. The root is eomposel of a great quantity of fibres. From this, there rise in spring a number of leaves, oblong, broad, smooth, and of a beantiful green colour, and having in shape, though not at all in colonr or consistence, some slight resemblance of plantain : they are perfectly smooth, of a glossy surface, and brittle. These stand for many months withont the stalk; and doubtless in this state it got the name. The stalk is two feet or more in height; ronnd, firm, and upright; and at the top it sents out a vast number of branehes, whieh send ont other" smaller; and even these last are agnin divided. On the tops of the last divisions stand the flowers with their buds, and the seed-resscls; so that the whole has the appearance of a cone. 'Tlie flowers are little and whitc, and eonsist of three leaves each ; they stand but a little time, and only a few are secn torether.

Medicinal Vintues. - The sced is the part nsed : the plant is to be suffered to stand, till this is thoroughly ripe, and then eut up gently, and laid to dry two or three dages upon a table: a smart stroke or two, will dislodge a great quantity of the 284 
sceds; they are very good against the overflowing of the menses, and all other blecdings; and are given in powder, in electuaries, small doses to be taken at a time and often repeated.

\section{WHEAT.}

Medicinal Virtuts.-Triticum.-Pliny says, that the cerns of Wheat roasted in an iron pan and eaten, are a speedy remedy for those who are ehilled with cold. The oil fressed frum wheat, licals tetters and ring-worms; and Galen says, he has known many eures performed by it. Matthiolus recommends the same to be put into hollow uleers to heal them. It is good for chilblains in the hands and feet, and to make the skin smooth. Slices of Wheat bread soaked in warm water, and applied to the eyes that are red and inflamed, or bloodshot, eures them. The flower of Wheat boiled in vinegrar eures the shrinking of the sinews, says Pliny; and mixed with vinegar, and boiled, it heals freckles, pimples, and spots on the face. Wheat floul mixed with the yolk of an egg, honey and turpentine, draws, elernses, and heals any boil, sore, or foul ulcer. The bran of Wheat meal stecped in vinegar and bound in a linen cloth and rubbed on the places that have seurf, scabs, \&c, it will take them away. Wheat bran boiled in good vinegar, and applied to swollen breasts, reduces them, and all inflammations. Boiled in water into a thick jelly, it checks spitting of bloor ; and boiled with mint and butter, it relieves the hourseness of the throat,

\section{WILLOW TREE.}

Minernat, Vintuss.-Salix.-Buth the lenres, bark, and the scerl, ate used to stannch blectiong ol wounts, syitting of

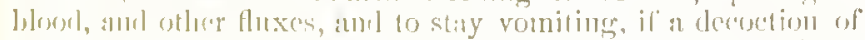
them in wine be drallik. It loclus slso to stily thith, salty rlistil-

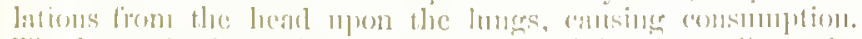

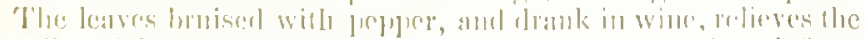

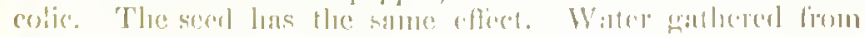
the Willow, whon it flowers, the lank being slit, is vely grool 
for redness of the eyes, and dimness of sight ; to provoke urine, if it be drank; to elear the faee and skin from spots and diseolourings. Galen says, the flower's have an admirable faculty iu drying up humours, as it is a medieine without any sharpness or eorrosion; you may boil them in white wine, and drink freely of the liquor. 'The bark has the same effect, if used in the same manner; the bumt ashes being mixed with vinegrar t.ll e atway warts, and eorns. The decoetion of the leaves or bark in wine, takes away seurf and dandriff by washing the place
with it.

\section{WINTER-GREEN.}

Description.-Ganetharia Procumbeus.-This plant is little known. It sends forth seven or eight leaves, from a small, brown, erecping root, npon a long foot-stalk. The leaves are hard, resembling the leaf of a Pearl-tree. From them arises a slender, erect stalk, bearing at the top many small white smelling flowers, spread open like n star, with yellowish threads in the middle surrounding a green head. The seed is as small as dust. It grows in fields and woods, espeeially in the north. It flowers in July.

Menicinal Virtues. - It is a good wound herb, the green leaves, or the juiee of them being applied. A salve inale of the green herb bruised, or the juice boiled with lard, or salad oil, and wax, with a little turpentine, is a sovereign salve. The Germans use it for all kinds of wonnds and sores. A decoetion of the herb relieves uleers in the kichneys, or neek of the bladder. As an astringent it arrests dysentery, immoderate conrses, and bleeding of wounds. It is good for diseases of the heart.

\section{WOAD.}

Descriptron.-Insatis Tinctoria. $-\mathbf{\Lambda}$ plant eultivated in fields, for the use of dyers.

Medicinal Virtues. - The herh is so astringent that it is not fit to be given inwardly. An ointment male there of

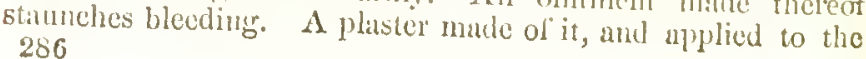


region of the spleen which lies on the left side, takes away its harlitess and pains. The ointment is good in such ulecrs as ahound with moisture, for it takes away corroding and fietting humours. It cools inflummations, quenches St. Anthony's fire, and stays defluction of the blood to any part of the body.

\section{WOLD, WELD, OR DYER'S WEED.}

Description.-Genista Luteola.- The common kind grows bushy with many leaves, long, narrow, and flat upon the ground; of a dark bluish green colour, a little like WVoad, but not so large, a little erumpled, and pointed, which so abide the first year; and the next ycar rise wp from their round stalks, two or thiee feet high, beset with many such like leaves, but smaller, and shooting forth small branches, which bear many small yellow flowers, in a long spike at the top of them. The secd is small and black. The root is loug, white, aud thick. It flowers in Junc.

Menicinal Virtues.-It is said io be a good expectorant of plulegm; and to be a deobstrucut in affections of the liver, \&c. The bruised leaves are a good application to cuts, bruises; and mised with lard to be a specific for serofulous sores.

\section{WORMSEED PLANT.}

Description.-Erysimum Cheroides.- $\Lambda$ kind of Wormwood, native of the Last, and not known so much as in our gardens. The plant is two feet high. The leaves are very fincly dividerl, like those of the true Roman Wormwood, and of a pale green on the upper side, and a silvery white below. The stalks are stiff, firm, woody, and branched; they are of a whitish colour, and have a loose downy skin upon them: the fluwers are snatl sind brownish; they resemble those of wormwoul, and stand in a kind of loose spikikes at the tops of the stalks.

Minucinal Virtuls. - Thic sceds are used: on dimggists k.ejo therr ; and very often the unrifue butls of the flowers in their place are mixed with them. 'l'hey are good against 
worms in ehildren; the good women give them mixed with treale: and few medicines for this purpose have better effect. For people of nieer palates, they may be powdered, and made

\section{WORMWOOD.}

Culpeper has written a great deal of trash about this Herb viz. the conferenee of Jupiter, Mars, Saturn, the Moon, se. about its virtues. To an intelligent mind, such trash is utterly disgusting. I verily believe that the vain old fellow was threefourths drunk when he wrote such rubbish ; and it is very strange that persons are still found to print, and eredit his astrologieal foolery. in use.

There are three kinds of wormwood. The common is mostly

\section{WORMWOOD,-COMMON.}

Description.-Artemisia Absinthium.-A wild plant growing by way-sides, and on ditch banks. It is a yard lighl. The stalks are round, striated, white, firm, and branehed. The leaves are large, but they are divided into a great number of small parts. They are of a pale whitish green, and stand irregularly on the stalks; many larger, but of the same kind rise from the root. The flowers stand in a kind of loose spikes at the tops of the stalks; they are small and brown. The whole plant is of a very bitter taste.

Medicinal Virtues. - Its smell is strong and disagreeable, taste intensely bitter, so as to beome the foundation of a prorerb. The tops of the plants are to be used fresh gratlered; a very slight infusion of them is cxeellent for all disorders of the stomneh, and will prevent sickness after meals, and create an appetite. Dr, Grallan says, "It is a litter touric of considerable serviee in indigestion, and low spirits, and it las also been used with great arlyntage in ague, gent, and semry. It has been reported to have been of great service in epilepsy. Its powers in expellingr worms are well ascerianed. It will fice288 
quently bring away the smaller sorts of worms in great quantities. The dose in powder is from one to two scruples twice or thrice a day. The Infusion is made by pouring a pint of boiling water on an ounce of the plant; of which fiom an ounce to an ounce and a half may be taken twice or thricc a day."

The juiee of the large leaves of wormwood, which grow from the root bcfore the stalk appcars, is good against the dropsy, and jaundice, for it removes obstructions, and works powerfnlly by urine. Another cminent physician says, "It is used in stomach complaints and is of great scrvice to pcrsons labouring under hypochondria. It is most usctul in intcrmittent fevers, (ague); I have frequently found it so, in cachectic and hydropie affections, and in janndice. The extract is a pure and simple bitter. The essential oil is of a dark green colour, and eontains the whole flavoul of the plant. It is stimulating, and a powerful antispasmodie, and anthelmintic. Wormwood was formerly much used for the preparation of medicated winc and ales. It forms purl when used with the last, which hard drinkers are in the habit of taking in the morning, to go through their hard day's labours." Haller says that Charles V. used this plant for the gout; and for the same purpose Dr. Tholnton cmployed a decoction of Wormwood with success upon himsclf, so that ho had no return for many years.

SALT OF WORMWOOD, fotmerly much used medicinally is pure Carbonate of Potass, obtained from the ashes of this and othcr plants. In small doses, say 8 or 10 grains, dissolved in a little rose-water, and taken twice or thrice a day, is very useful in indigestion and billious complaints, attendecl with acirlity in the stomall. It is rendered eftervescent by mixing witl a little lemon juice.

\section{WORMWOOD,-SE $\boldsymbol{\Lambda}$.}

Description. - Atsinthium Seriphium. - A plant eommon in our salt-marshes, and about ditches, where salt water comcs. It has somewhat the aspcet of wormwood, but the lanves are much narower in the divisions, and the whole plant is sunaller.

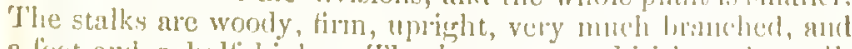
a loot and a lall ligh. 'fle leaves aro whilish and sumbl. 
The flowers stand in loose spikes at the tops of the stalks; they are little and brown; and they very mueh resemble those of the common wormwood, exeept for the size. The whole plant has a bitter taste, but not disigreeable, and it has a plensant aromatie smell.

Medicinal Virtues.-The tops fiesh gathered, and the whole plant dry, are used. They call it Roman wormwood at the markets and in the shops; and it is used for the other : it has the same general virtues. All the three kinds indeed possess them in common; but the common wornwood is the most disagrecable to the taste, and sits worst npon the stomach; this is better than that; but it is mueh more disagrecable than the true Roman wormwood. It is very strengthening to the stomaeh; it assists digestion, and prevents wind. It is commonly an ingredient in the bitter infusions, and tinetures of the shops, but it does very well alone; boiling water ponred upon it, and suffered to stand till it is cold, then straiued off, is an excellent modicine to cause an appetite. Put into white wine, it also gives a pleasant bitter flavour, with the same virtues.

\section{WORMWOOD,-ROMAN.}

Description.-Artemisia Romanum.-A delicate plant of tho Wormwood kind, kept in our gardens. It is two feet and a half high ; the stalk is round, smooth, hard, npright, of a brownish colour, and somewhat woody. 'The leares stand irregularly on it, and they are small and divided into very fine segments: they are more like the leaves of tho common southere wood in figure, than those of either of the other wormwoods. The flowers are little and brown, like those of eommon wormwood; but vastly smaller; they are very mumerous, and stancl at the tops of the stalks in a kind of long and thiek spikes. The root is crecping and spreading, and comprosed of fibres. The whole plant has a bitter taste, but not at all like that of wormwood, extremely aromatie and pleasing. The flowers are very bitter, and have little of an aromatic flavoms.

Medicinat Vintules. - The fresh tops are nsed, and the whole plant dried. It is excellent to strengthen the stomach; 290 
but that is not all its virtue. The julee of the fresh tops is good against obstructions of the liver aud spleen, and has been known singly to eure the jaundiee.

\section{YARROW.}

DESCRIPTION. - Millefolium. - It has many long leaves spread upon the ground, finely cut, and divided into many small parts ; its flowers are white, but not all of a whiteness, and stayed in knots upon divers green stallss which rise from among the leaves. It is frequent in pasturcs.

Medicinal Virtues. - The wbole plant is used fresh gathered; but the tops of the shoots are the best. These are to be boiled in water gently a short time, and the decoetion sweetened with fine sugar. It is good against the blecding piles, bloody flux, and profuse menstruation. An ointment made of it eures green wounds and other sores. It arests the falling off of the hair by washing the head with a decoetion of it. It eures diseases of the kidneys, and the whites, and relieves those who cannot retain thcir water. The lcavcs elhewed ease the tooth-aehe. Yarrow tea is a good remely for severe eolds. It is also a good substitute for Tobaeeo. For colds, the best way is to sweeten the tea with sugar, or honey, or treacle, adding a little Cayenne Pepper. 


\section{ADDITIONAL HERBS.}

\section{BEILN,-WHITE.}

Description.-Behen Album.-A eommon wild plant in our corn fields. It is two feet high; the stalks are weak and often erooked; but they are thick enough, round, and of a whitish green colour. The leaves are oblong, broad, and of a fine blue green eolour, not dented at all at the edges, and they grow two at every joint; the joints of the stalks where they grow are swelled and large, and the leaves have no stalks. The flowers are white, moderately large, and prickly. They stand upon a husk whieh seems blown up with wind.

Medicinal Virtues. - This is one of those plants of our own growth, that have more virtne than people imagine. The root, whieh is long, white, and woody, is to be gathered before the stalks rise, and dried. An infusion is one of the best remedies known for nervous eomplaints: it will not take effect agrinst a violent present disorder; but is an cxcellent preservative, taken eatiously.

\section{BEHEN,-RED.}

Description.-Limonium majus. $-\Lambda$ common wild plant about our sea-eoasts, and a very pretty one. It grows to a foot in height; the stalks are naked, and the flowers red; and in their disposition, they somewlat resemb!o lavender, wheneo the plant is also ealled by some Sen Lavender. About the bottoms of the stalks stand ehusters of large and brout leares, rounded at the ends, of a leep green colomr, and fittish substance; these rise immerliately from the root, and the stalks grow up among them. The stalks are very tough and strong. and branched, and of a puler green; the root is long and reddish. 
Medicinal Virtues. - The people in Essex eure themselves of purgings, and of overflowings of the menses, with an infusion of this root; and it is a very great medieine, though little known. It is to be gathered, as soon as the young leaves appear, cleaned and dried; it may be taken in powder, half a drachm for a dose. These are not the white and red Behen roots of the old writers on physie, but they are better.

\section{WART CRESSES, OR SWINE'S CRESSES.}

Description.-Coronopus Ruellii.-A little wild plant very eommon about our fields and gardens. It spreads upon the ground. The stalks are five or six inelies long; firm, and thiek, but usually flat on the earth; very mucth branehed, and full of leaves. The leaves that rise immediately from the root are long, and deeply divided : and those on the stalks resemble them, only they are smaller: they are of a deep glossy green eolour, and not at all hairy. The flowers are small and white; they stand at the tops of the branehes, and among the leaves; the seed-vessels are small and rough.

Medicinal Virtues. - This js an exeellent diuretie, safe and yet very powerful. It is an ingredient in Mrs. Stephens' medieine: the juice may be taken; and it is good for the jaundice, and against all inward ohstruetions, and against the scurvy; the leaves may also be eaten as sallad, or dried and given in decoction.

\section{CUP MOSS.}

Description.-Muscus Pyxidatus.-A eommon little plant on ditch banks, by woorl sirles, and in dry barren places. It ennsists of $\Omega$ thin eont of $\Omega$ leafy matter, spreal npon the surfice of the ground, and of a kind of litle eups rising from it. The lenfy part is dry and without juiec, divided into several portions, nnd these irregularly notcherl; it is grey or greenish on the upper sirle, and whitish mnderneath. TThe enps are laslf an ineh high. They have eneh a thick stem, and an open moutl, and rather resemble a elunisy drinking grass, than a 
cup. They are of a grey colour, often with some odd mixture of green, of a dusty surface; sometimes they grow one from the edge of another, up to the third or fonth stage: they have also many other aeeidental varieties; and sometimes they bear little brown lumps, whiel are supposed to contain the seeds.

Medicinal Virtues. - The whole plant is to be used; it is to be taken fresh from the gronnd, shook clean, and boiled in water, till the deeoetion be rery strong; then there is to be added as much milk as there is of the liquor, and it is to be sweetened witl honey. It is an excellent medicine for children's coughs: it is recommended particularly in that called the Hooping Congh.

\section{CYPERUS,-LONG.}

Description.-Cyperus Longus.-A wild plant in onr marshes, fens, and other damp places. It is a foot and a half ligh. The leaves are a foot long or more, narow, grassy, and of a bright green colonr, flat and sliarp at the ends. The stalk is triangular and green; there are no leaves on it, except two or three small ones at the top, from which rise a number of small tufts or spikes of flowers. These are brown, light, chaffy, and in all respects like those of the other water grasses.

Medicinal Virtues. - The root is nsed. It is long and brown, and, when dried, is of a pleasant sinell, and aromatic warm taste. It slould be taken 11 p in spring. It is good against pains in the head, and it promotes urine.

\section{GLASSWORT.}

Description. - Kali. $-\Lambda$ eommon wild plant on the sea coasts of many parts of Finrope, but not a native of our comntry. It is ealled coehleated kili, from the form of its seed-ressels, which are twisted in the manner of a suail's shell. It grows to a foot and a half in height. The stalk is ronnt, thick, Aleslyy, and brittle. The leaves are few, and they stand imegrlarly"; they are ullong, and blunted at the ends, and of a bluisl green colomr. The flowers are small, inconsiderable, and yellow. 
Miedicinal Virtues. - The juice of the fresh plant is sald to be an excellent diuretic; but we have no opportunitics of knowing its virtues here. Some say the seed vessels have the same virtue, and give them in infusion, but we have better remedies of the same kind, of our own growth. The whole plant is burnt for its fixed salt, which is used in making glass.

\section{HARTWORT.}

Description. - Seseli.-A tall, robust, and handsome plant, a native of the $\Lambda$ lps, but kept in our gardens. It grows five or six feet in height: the stalk is round, thiek, striated, and hollow, very firm and upright, and but little branehed. The lenves are very large, and they are divided in to a great number of parts, by fives and by threes; they are of a yellowish green. The flowcrs are small and white, but they stand in great tufts or umbels at the tops of the stalks : the seeds follow, two after each flower, and they are oblong, broad, and edged with a leafy border; they are of a dark colour, a strong smell, and acrid taste.

Medicinal Virtees.-The seeds are the only part used; they promote the menses, and the necessary discharges after delirery, and are an execllent warm and cordial medicine; they work also gently by urine, and eure colicy pains; they are to be given in powder or infusion.

\section{LEOP $\triangle R D$ 'S-B $\triangle N E$}

Its botanical name is Arnica NIontana; natural order, Asteracea. It is a very common perennial plant in the Alpine parts of Germany, in Sweden, Tapland, and Switzerland, where it has long been medicinally used. The flowers are yellow, compound, consisting entirely of tubular florets and are distinguisherl from other similar flowers, (with which they are often mixed, from ignoranee or fraud,) by the common ealyx, which is shorter than the florets, and consists entirely of lanectshaped scales, lying parallel and elose to ench other, of a green colour, with purple points. These flowurs have a slightly bitto taste, combined with a degree of acrimony, and when rub 


\section{LEOPARD'S BANE.}

bed with the fingers, hare a somewhat aromatie smell. They contain a great deal of resin, and a portion of essential oil.

As a medieine, it las not been mueh used in England, althongh it has been employed with the greatest adrantage in Germany. The plant possesses very great virtues. It is diuretie, diaphoretie, emmenagogue, and vulnerary. It is given in amaurosis, paralysis, and other nervous affeetions. It has been reeommended for hydroeephalous, and typhous fevers, espeeially in the latter stages. Dose of the powdered flower's, 4 to 15 grains; powdered root, 10 to 30 grains; infusion, half an ounee; extrat, 1 to 10 grains; tineture 20 or 30 drops; essential oil, 1 or 2 drops.

"The flowers," says an eminent physieian," are stimulating and diseutient. In small doses, and properly administered, they produce very benefieial effeets, in raising the pulse, in exciting the aetion of the whole sanguinerous sristem, in eheeking diarrhœas, in promoting expeetoration, and espeetally in removing paralytie affeetions of the voluntary museles; but they are frequently attended with no sensible operation, exeept that in some eases of paralysis, the eure is said to be preeeded by a peculiar priekling, and by shooting pains in the affected parts. When given improperly, or in over-closes, they exeite an insupportable degree of anxiety, shooting and burning pains, and even dangerous hamorrhages, vomiting, vertigo, and coma. For these dangerous symptoms, vinegar is said to bo the best remedy."

Haller says, "that even gutta serena, or loss of sight, has yielded to the powers of this medicine." It is also reeommended in ehronic rheumatism; in retention of the urine, from paralysis of the bladder ; in intermittent ferers, when eombincd with Peruvian bark, where it has been very eflicaeious; in putrid diseases; to promote the uterine discharge: and in interual pains and eongestions, from bruises.

"In the eountries where the plints are indigenous, the flowers have long been a popular remedy in these enses. Ther are best given in infinsion, one or two scruples may be infused with liall a pound of water, and drauk at proper intervals. Tho [lowers shonld be wropped up in a picee of linen, to prevent 293 


\section{LEOPARD'S BANE.}

the diffusion of the down in the liquid, whieh would canse violent irritation of the throat.

Dr. Speneer Thumpson says. "It is seldom preseribed internally in this comntry. But as an external application, it is much and beneficially used in the treatment of wounds and eontusions. From 1 to 2 drachms of the tincture in half a pint of water forms a convenicnt lotion. The lomosopatlic practitioners elaim Arnica, or Lcopard's Banc, as one of their own remedies, and chemists ask for their tincture an extravagant price. But the tincture may be procmed equally good, and much cheaper, at many respectable chemists. Like every thing elsc, there is mnch spurions tineture sold. When the pure tineture is dropped into water, it gives a milky or opaleseent apperranee."

The Homcopathists recommend it as possessing very great virtues, and that justly, in contusions, wounds, produced by falls, erushes, where the skin is lacerated and bruised ; for bedsores, when the skin is not much broken ; for pain in any part, produced by severe plysical excrtions, and in muscular wealsness, sore or blistered fect, and liands. The body to be sponged with the aforesaid lotion as stated by Dr. S. Thompson. "I have found it," says one, "of the greatest use in whitlows, or painful gatherings in the fingers, chilblains, where the skin is not broken, and black eycs, chapped hands and lips, in gonty pains. For this prrpose the Corate of Arnica is a good applieation. The lotion takes away the soreness and pain of any discased part, and it is remarkal,ly beneficial for sore gums, especinlly after the extraction of teeth, or the straining of any part by surgical operations. The Montly Homoopathic Review gives many instances of remarkable cures ly Arnica, as cataract of the eyes, inflammation of the eyes, chronic rhenmatism, fractures, and even hlinduess, \&e. The applieation of Arnica in some cases was alternated with deonite, an oldfashioner, but most valuable remerly. The lotion must be applied ley saturating a piece of linen or cotton with it, and covcring it with a hatulagre, reprating as the eloth dries. Some seres, or aching parts may he washed with the lotion. Slontre the skin be broken, the lotion should be reduced to half its strength. Shonlc a earcless administration produce eruption, 
it may be neutralized by diluted laudanum, say 30 or 40 drops to 4 ounces of water, frequently bathing the part. A weak solution of Coeulus Indieus is also reeommended.

\section{MARIGOLDS.}

See page 168. This plant, Calendula Officinalis, has been used in Franee as a vulnerary. The tineture is useful for enring warts. It may be used as a lotion, by adding 10 drops of the tineture, to 2 ounces of soft water. It is of special service in severe ents, and laeerations; they are speedily relieved by it, and pain and bleeding arrested by its external application. It heals wounds so completely, when properly applied, as to leave no eicatrix or scar ; if there should be any, it is searecly perceptible. It has a wonderful power to heal witbout produeing suppuration, or the formation of matter'; it contracts the mouth of the small arteries which may have been ent across longitudinally. Where the ent cannot be elosed, it may be washed with the lotion; it may be diluted as above, or be used in a pure state with perfeet safety. It may also be applied by eloths and bandages as in the ease of Leopard's-Bane.

\section{SPIKENARD,-INDIAN.}

Nardus Indica. - An East Indian plant, of the grass kind, with triangular stalks, and yellow flowers. It is like the yellow tufted grass, frequent in onr meadows in spring. Breynius ealls the Spikenard plant, a kind of Cyperns grass.

The tuft of fibres at the tops of the root, is what wo eall Indian Spikenard; they are brown, flattish, matted together, and of a pleasant fragrant smell; they are good in the disorder's of the nerves; but we lave better remedies. 


\section{I R E C T O N S}

\section{FOR GATHERING HERBS.}

\section{THE LEAVES OF HERBS OR TREES.}

Of leares, choose only such as arc green, and full of juice; piek them carefully, and reject decrying ones, for they will pntrify the rest, obscrve the places in which they grow best, and gather them there; for Betony in the shade is far better than that which grows in the sun, because it delights in the shade; also such herbs as grow well near water, should be gathered near it, though you may find some of them upon dry ground.

The leaves of such herbs as mn mp to sced, are not so good when in flower as before; (some few cxcepted,) if through negligence you have gathered them when in flower, talie the tops and the flowers, rather than the leaf.

Dry them well in the sun and not in the shade; for if tho sun draws away the virtues of the herb, it must do the liko by hay, which every farmer would regard as nonsense.

Frving well dried them, secure them in brown paper, and press them not too harel together and kecp them in a dry placo near the fire

\section{THE FLOWERS OF IIERBS.}

The flower, which is the beanty of the plant, and often medicinal, is to be gathered when it is in its prime.

$\Lambda s$ for the time of the day to gather them, let it be when tho sun shines upnn them so that they may be dry - for if you gather eitloce flowers or herbs when they are wet or dewy, they will not keep.

Dry them well in the sun, ant keep them in papers nest tho fire. So long as they retain the colour nut smell, they aro good; either being gone, su are their virtuey also. 


\section{SEEDS.}

The seed is that part of the plant whieh is endored with the vital faculty to bling forth its like, and it contains potentially the whole plant in it. Gather them in the place where they delight to grow. Let them be full ripe when they are gathered. Diry them a little, and bnt a little, in the sun before you lay them up. Ireep them in a dry place, they will keep many year's; yet they are best the first year' ; for they will grow soonest the first year after being gathered, if sown; therefore being in their prime, they must have more power.

\section{ROOTS.}

Do not ehoose such as are rotten or worm-eaten, but proper in their taste, eolour and smell, such as exeed neither in softness nor hardness.

The drier the time in which yon gather the roots, the better they are, having less tendeney to deeay. Dry soft roots in the sun, or near the fire. The hard roots you ean dry nnywhere. Large roots will keep longer than the small, yet all will keep a year.

\section{BARKS.}

The barks of frnit are to be taken when the fruit is full ripe, as Oranges, Lemons, \&e. The barks of trees are best gathered in the Spring, if of oaks, \&e. for then they come ensier off; but the best way is to gather barks only for present use.

$\Lambda$ s for the bark of roots, take the roots of such herbs as liavo a pith in them, as parsley, fennel, Se. slit them in the mildle, and when you have taken out the pith, that which remains is ealled the bark, and is only to be used.

\section{JUICES, SYRUPS, PRESERVES, \&o.}

\section{JUICES.}

Juices aro to be pressed ont of herbs when they arc young and tender, ont of stalks, and tender tops of lierbs and 
plants, and out of flowers. Brulse them well in a stone mortar with a wooklen pestle, put it into a canvass bag, press it hard in a press, then take the juice and clarify it thus:- Put it into a pipkin or skillet, and set it over the fire; take off the seum; lieep on the fire till no more seum arises.

When almost cold, put it into a glass, and put so much oil on it as will cover to the thickness of two fingers; the oil will swim-at the top, and so keep the air from putrifying it. When you intend to use it, pour it into a porringer, and if any oil come ont with it, you may easily seum it off with a spoon, and put the juice you use not, into the glass again, it will quickly sink under the oil. Or, when you have clarified it, boil it over the fire, till (ueing cold) it be of the thickness of honey: this is most commouly used for discases of the mouth.

\section{SYRUPS.}

Syrups made by infusion, are usually made of such flowers as soon lose their colour anil strength by boiling, as roses, violets, peach-flowers, \&ec. They are thus made :-IIaving pielied your flowers elcan, to erery pound of them add three pounds, or three pints of spriug water, boiling hot; first put your flowers into a pewter pot, with a cover, and pour the water on them; then shutting the pot, let it stand by the fire twelve hours and strain it out; (in such syrups as purcre, as damask rose, peach-flowers, se. the best way, is to repeat this infusion, adding fresh flowers to the same liquor, several times, that it may be the stronger) having strainer it, put the infusion into a pewter bason, or an enthen one well glazel, and to every pint add two pounds of sumri, which beiug melted over the fire, withont boiling, and seunmed, will produce the sylup.

Syrups marle by decoction are usually inate of componurs, yet may any simple herb lie thus couverterl into syrup: Talke the herb, root, or flowels, and bruise a little, then boil it in a convenient quantity of spring water; tloe more watter you hoil it ill, the veaker it will be : at handful of the herl or rnot is a convenient cunatity lor a pint of water; boil it till half" tho 
water be evaporated, then let it stand till almost cold, and strain it throngh woollen cloth, letting it run at leisure, withont pressing. To every pint of this decoetion add one pound of sugar, and boil it over the fire till it comes to a syrup, which yon may know, if you now and then cool a little of it with a spoon : scum it while it boils, and when it is sufficiently boilcd, whilst it is hot, strain it again through a woollen cloth, but press it not.

Syrups made of juice, are usually made of such herbs as are full of juice, and the juice makes the best syrup. Having beaten the herb in a stone mortal, with a wooden pestle, press out the juice and clarify it, as before; then let the juice boil away till about a quarter of it be consumed : to a pint of this add a pound of sugar, and boil it to a syrup, always scumming it, aud when it is boiled enough, strain it through a woollen cloth.

If you make a syrnp of roots that are hard, as Parslcy, Fennel, and Grass roots, \&c. When you have bruised them, lay them to stecp some time in that water in which you intend to boil them, hot, so will the virtue the better come out.

Keep your syrups cither in glasses or stone pots, and stop them not with cork or bladder, only bind paper about the moutl. All syrups, if well made, continuc good a year; yet such as are made by infusion, keep shortest.

\section{PRESERVES.}

Flowers are very scldom prescrved; I never saw but cowslip flowers. It is thus done: Take a flat glass, we call them jar-glasses ; put in a layer of func sugar, on that a layer of fune flowers, on that another layer of sugar, on that another layer of flowers, lill your glass be full : then tie it over with paper, this will make an excellent and pleasant conserve.

Fruits, as quinecs, and the like, are preserved two ways.

Boil them well in water, and then pulp then throngli a sicve; then with the like quantity of sugar, boil the water they nere boiled in into a syrup, viz. a pounl of sugar to a pint of liquor ; to every pound of this syrup add fom omees of the pulp ; then boil it with a very gentle fire to their right consistenee, which 302 
you may easily know, if you drop a littlo of it upon a plate; if enongh, it will not stick to your fingers when it is cold.

Another way to preserve fruits is this : pare off the rind ; then eut them in halves, and take out the corc, then boil them in water till they are soft; then boil the water with its liko weight of sugar into a syrup; put the syrup into a pot, and put the boiled finit, as whole as you left it when you eut it, into it, and let it remain till you use it.

Roots are thus preserved. First, scrape them very clean, and cleanse them from the pith, if they have any, for some roots have not, as Eringo and the like, boil them in water till they are soft; then boil the water in which you boiled the root into a syrup; then keep the roots whole in the syrup till you use them.

As for barks, few come to our hands which ean be done, oranges, lemons, citrons, and the outer barks of walnuts; if there be any more, put them into tle number. The way of preserving sueh as are bitter is to soak them in warm water, often changing it till their bitter taste be fled: but I like not this way, because when their bitterness is gone, so is their virttic also. It is best first to boil them whole till they are soft, then make a syrup with sugar and the liqnor in which you boiled them, and keep the barks in the syrup. They are kept in glasses, or in glazed pots. The preserved flowers will keep a year; the root and barks much longer.

Thus medicines are made pleasant for sick and deliente stomachs, which otherwiso would loath them.

\section{OILS.}

Olive Oil, eommonly known by the name of Sallad Oil, because it is usually eaten with sallads, if it be pressed ont of ripe olives, aceording to Galen, it is temperate, and execels in no one quality. Of oils, some are simple, and some are compound. Simple oils are such as are made of finits or seeds by expression, as oil of sweet and bitter alnonds, linsecel, and rape-seed oil.

Compound oils, are made of oil of olives, and other simples, 303 
as herbs, fowcrs, and rnots. They aro madc thus :- Having bruised the herbs or flowers, put them into an earthen pot, and to two or three handfuls of them pour a pint of oil, corer the pot with a paper, set in the sun about a fortnight, or so, according as the sull is in heat, then having wamed it rery well by the fire, press out the herb, \&c. very hard in a press, and add as many more herbs to the same oil ; bruise the herbs in like manner, and sct them in the sun as before; the oftencr you repeat this, the stronger the oil will be; at last when you think it strong cnough, boil both oil and herbs together, till the juice is consumed, which you may know by its ceasing to bubblc, and the hcrbs will be crisp; then strain it while it is hot, and kecp it in a stonc or glass ressel for your usc.

The gencral usc of these oils is for pains in the limbs, roughness of the skin, the iteh, \&e, as also for ointments and plasters. If you usc it for wounds and ulcers, in two ounces of oil, dissolve half an ounce of turpentine, the heat of the firc will quickly do it; for Oil itself is olfensive to wounds, but the turpentine qualifics it.

\section{ELECTUARIES.}

An Electuary is a preparation made up of powdered drugs made up with tracle, honey or syrup.

That you may makc Eleeturies when you need them, it is requisite that you always keep herbs, roots, florrers, sech, St. ready dricd in your house, to beat them into a powder when you need them. It is better to keep then whole than benten; for benten, they are nore subject to lose their strengtl ; as the air soon penetrates then. Having beaten then, sift them through a fine sieve, that no great picees may be fonmd in your Electnary. To onc ounec of your powder add three onnces of clarified honcy; If you would makic nore or less Elcctury, vary your proportions aecordingly. Mix them woll together in a mortar, you cannot mix them too much.

The way to clarify honey, is to set it over the fire in a convenient vessel, till the senn rise, and when the scmun is talken off', it is clavified. The ustual dose of cordial Electuaries, is fron 304 


\section{CONSERVTS.}

\section{OINTMENTS.}

half a drachm to two draehms; of pnrging Electuaries, from half an ounce to an ounce. Ficep them in a jar. The time for taking them, is cither in a morning fastiug, and fasting an lour after them; or at night going to bed, three or four hour's after supper.

\section{CONSERVES.}

The way of making conserves is twofold, one of herbs and flowers, and the otlee of fruits.

Conserves of herbs and flowcrs, are thus made; if you mako your conserve of herbs, as of sentry-grass, wormwood, rue, and the like, take only the leaves and tender tops; and having beaten them, weigh them, and to every pound add threc pounds of sugar, you cannot beat them too much.

Conserves of fiuits, as of barberties, slocs and the like, are thus made; first scald the fruit, then rub the pulp through a thick hair sieve callerl a pulping sieve; you may do it for a need with the back of a spoon; then take this pulp thens drawn, and add to it its weight of sugar, put it into a pewter vessel, and over a charcoal fire; stir it up and down till the sugar be melted, and your conserve is made. The way of keping them is in earthen pots. The dose is usually the yuantity of a nutmeg at a time morning and evening, or (unless tlicy are purging,) when you please. Some conserves will keep nany year's, as conserve of roses ; others but a year, as conscrve of horage, bughoss, cowslips, and the like. Look at them nnce a day, and stir them, lest they ferment; conserves of borige, bugloss, and wormwood, are very liable to ferment.

\section{OINTMENTS.}

Ointments are made thus: Bruise those herbs, flowcrs, or roots, you will make an ointment of, and to two lanulfuls of

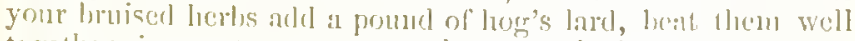
togetloer in a stone nortar, then put it into at stone pot,

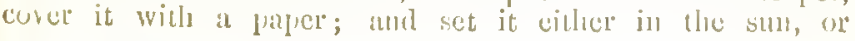


somo other warm plneo, three, fonr, or firo days, that it may melt; then talic it out and boil it a little, and while hot strain it out, pressing it very hard in a press ; to this composition add as many more herbs bruised as before, let them stand in like manner as long, then boil them as beforc. It the ointment is not strong enough you may do it the third and fourth time; for the fuller of juiee the herbs are, tho sooner will your ointment be strong : the last time you boil it, boil it so long till your herbs be erisp, and the juice consumed, then strain it, pressing it hard in a press, and to every pound of ointment add two omnees of turpentine, and as much wax, beeause groase is offensivo to wounds, as well as oil.

\section{POULTICES.}

Poultiees the Latins eall Cataplasmata; now sometimes called Cataplasms. They are made of herbs and roots, fitted for the disense to which you are liable; they are to be chopped small, and boiled in water almost to a jelly; then adding a little barley-meal, or oatmeal, aud a little oil, or rough sweet euct, spread upon a eloth and applied to the affeeted place.

Their use is to case pain, to break sores, to cool inflammations, to dissolve hardness, to ease the splecn, to concoet humours and dissipate swellings. Use no poultices that are of a healing nature, before you have first eleansed the body, becalse they are subject to draw the humours to them fiom every part of the body.

\section{TROCHES.}

Tho Latins eall them Pracentula, or littlo cakes, and tho Greeks Procnirois, Kutisior, and Arersen; they aro usially little round or oval flat calies, like the Pomfret Cakes, or Lozenges.

Their first invention was, that powders heing so kept, miwht resist the intermission of air, and so enelure pure the longer. They cau be better carricel iu the poeket of those who travel, Se. 306 
They are made thus : Tako two drachms of fine gum tragncanth ; put it into a gallipot, and put half a quartcr of a pint of any distilled water fitting for the purpose you wonld make your troches for, to eover it, let it remain ten hours, till it bccomes a mucilage. With this you may malic a powder into a paste, and that paste into a calke callcd troches. Dry them in the shade, and keop them in a pot for your use.

\section{PILLS.}

They are called PILULA, beeanso they resemble little balls. This way of making medicines was invented only to deccive the palate, that so by swallowing them down whole, the bitterness of them might not be perceived, or at lcast might not be insufferable; and indeed most pills are bittcr. But I think they wcre made in this form, that so they might be the longer digesting. The inveution of pills is to purge the head; such infurmitics as lie near the passage, are best removed by decoctions, becanse they pass to the grieved part soonest; so herc, if the infirmity lics in the head, or any other remotc part, the best way is to use pills, because they arc longer in digestion, and thereforc better able to call the offending humonr to them.

The way to make pills is very easy, for with the help of a pestle ancl mortar, you may make any dry powder into pills, either with syrup, or jelly.

\section{JULEPS.}

A term now not miteh uscrl in medicine; it formerly cxpressed what we now nnflerstand by mixtures. Thus Camphor Mixture was then called Camphor Julep.

Simple JuJeps are thus made: Take a pint of such distilled water, as conduces to the cure of your clisease, to which arld two onnecs of syrup; conducing to the sinne elfiect; mix them toretleer, ant clink of it at your plensure. II" you like tart things, atel tend thops of oil of vitriol to your pint, and slake it together, and it will have a fince grittefil tesstc. 


\section{DECOCTIONS.}

Decoetions do not keep long. They are made of those leaves, roots, flowers, sceds, fruits, or barks, eondueing to the cure of the disease for which you may make them, they are made in the same manner as Syrups. Deeotions made with wine last longer than such as are made with water ; and if you take a deeoetion to elcanse the passage of the urine, or open obstruetions, your best way is to make it with white wine instead of water, beenuse it is penetrating.

Deeoetions arc of most use in such diseases as lic in the stomach, bowels, lidncys, passages of the urine, and bladder, beeause deeoetions pass more quiekly to those plaees than any other form of Medieines. The deeoction may be sweetened with sugar or honcy. If in a deecetion you boil roots, herbs, flowers, and seed together, let the roots boil a good while first, heeause they retain their virtue longest; then the next in order by the same rule, viz. barks, herbs, seeds, flowers, spiees, if you put any in, beeause their virtues eome soonest out. Such things as by boiling eause sliminess to a decoetion, as figs, quinec-seed, linsecd, \&e. your best way is, after you have bruised them, to tie them up in a hnen-rag, and boil them. Keep all decoctions in a glass elose stopped, and the eooler place in which you keep them, the longer they will last before they turn sour.

The usual dose to be given at one time, is usually $2,3,4$ or 5 ounees, aeeording to the age and strength of the patient, the senson of the year, the strength of the medieine, and the quality of the disease. 


\section{TIE BOTANIC \\ FAMILY PHYSICIAN.}

I have bestowed considerable labour upon this department, availing myself of the experience of the most celebritted and learned Botanieal Doetur's of Great Britain, the continent of Europe and Ameriea:-

\section{ON STEAMING \\ FOR THE CURE OF DISEASES.}

Steaming is a very important branch of my system of practice, which would, in many eases withont it, be insufficient to effiet a cure. It is of great importunce in many eases cunsidered by the medical faculty as desperate; and they wonld be so under my mode of treatment, if it were not for the nianner of applying heat to the borly, for the purpose of re-animating the system, and aiding nature in restoring health. I had but little knowledge of medieine, when, throngh neecsity, I diseovered the nse ol steanning, to add heat or life to the decnying spark; and witl it I w:1s cnabled, by administering such vegetable preparations as I then had a knowleige of, to eflicet a cure in enses where the regular practitioners had given them over.

In all eases where the heat of the borly is so fur exhansted as not to be rekindled by using the medicine, and bcing shiclded from the surroundingr air by a blanket, or being in bed, and chills or stupor attend the patient, then heat applied by steinningr becomes indispensaluly nceessary; and heat earsed by stean in the manner I use it, is more natural in producing perspiration than any dry heat that ear be appliel to the borly in any other manner, which will only serve to dry the air and prevent perspiration in many cases of disense, where a stean by water or vinecrar would promote it, and adt a natmal wam to th the bouly, and therely increase the life and notion which has lain silunt in conserginence of the cold. 


\section{TIIE BOTANIC FAMILY PIISICIAN.}

Dr. Jennings has contrived a plan to apply heat to the bodf by dry vaponr, eaused by burning spirit, whieh he calls a vapor bath; the idca of whieh was, I have no doubt, taken from hearing of my steaming to laise the heat of the body. It may answer in some eases and stages of the disense; but in a settled terer, and other cases where there is dry inflammation on the surface of the body, it will not answer any good purpose, and I think would be dangerons, without the use of my medicine to first raise a free perspiration ; for when the sniface of the body is dry, the patient eannot bear it, as it will erowd the head and canse distress, the same as is produced by burning chal'coal, or from hot stoves in a tight room, and will bring on a difficulty in breathing, which is not the ense in steaning in my way. This machine ean only be used in bed, where the rapomr eannot be applied to the body cqually at the same time, therefore it is no better than a hot dry stone, put on eael side and to the feet of the patient, for he ean tur'n himself and get heat from them as well as to have all the trouble of burning spirit and turning to the rapour of it, to get warm by this dly heat. When the patient stands over a steam raised by putting a hot stone in water, which gives a more equal heat all over the body than can be done in any other manner, it ean he raised higher, and may be tempered at pleasure, by wctting the face and stomaeh with eold water, as occasion requires.

The method arlopted by me, and which has always answered the desired objeet, is as follows :-Take several stones of differ ent sizes, and put them in the fre till red hot, then take the smallest first, and put it into a pan or kettle of lot water, with the stone abont half immersed-the patient must be mndressed, and a blanket put around him so as to shichl his whole body from the air, and then place him over the stean. Change tho stones as often as they grow cool, so as to lieep 11 a lively stcam, and keep him orer it; if he is fint throw a little cold water on the face and stomaeh, which will let down the ontward licat and restore the strength: after he lias been orer the steam long cnough - which will generally be about fifteen or twenty ninutes - he must be washed all orer with cold water, and be put into bed, or may be dressed, as the ciremustances of the case shall permit.-Bcfore he is placed over tlic stenu, rive a dose of Nos. 2 am I 3, or complosition, to raise the inward heat. When tho 310 
patient is too weak to stand orer the steam, it may be done in bed, by heating thrco stones and putting them in water till done hissing, then wrap them in a number of thicknesses of cloth, wet with water, and put one on each side and one at the feet, oceasionally wetting the face and stomach with cold water, when faint.

Many other plans may be contrived in steaming, which would make less trouble, and be more agreeable to the patient, cspec ially where they are unable to stand over the steam. An open worked chair may be made, in which thcy might sit and be steamed very conveniently; or a settee might be made in the same manner, on which they might be laid and covered with blankets, so as to sbield tbem from the surrounding aur. Such contrivances as these would be very convenient, in cases whero the patient would have to be carried through a course of medicine and stcamed a number of times, as is frequently necessary, particularly in complaints that lave becn long standing.

As I have frequently mentioned a regular course of medicine, I will here state what is meant by it, and the most proper way in which it is performed. Firstly give Nos, 2 and 3, or composition, adding a tea spoonful of No, 6, then stcam, and when in bed repeat it, adding No. 1, which will cleanse the stomach and assist in kceping up a perspiration: when this lias dono opcrating, give an injection made with the same articles. Where there arc symptoms of ncrvous aflection, or spasms, put half a tea spoonful of the nerve powder into cach dose given, and into the injection. In violent cases, where immediate rolicf is nceded, Nos, 1, 2, 3, and 6, may be given together. Injections may be administcred at all times, and in ill cases of disease, to arlvantagc; it can never do liarm, and in many cascs thcy are indispensably ncecssary, especially whero thero is cancer and inflammation in the bowels, and tlicre is dangel of mortification; in which case add a tca spoonfirl of No. 6. In cases of this kind, the injection should be given first, or at the time of giving the composition, or No. 3.

The nse of stenming is good in proventing sickncss as well as curing it. When a person has heen exposed to the colrl, and 
is threatened with disease, it may be prevented, and long siekness and expense saved by a very little trouble, by standing over a steam and following the dircetions before given, till the cold is thoroughly thrown off and a lively perspiration takes plaee; then go to bed, taking the stone from the kettle, and wrap it in wet eloths and put it to the feet. This may be done without the medieine, when it eannot be had; but is much hetter to take something to raise the inward heat at the sme time. A tea made of may-weed, or summer savoury, or ginger and hot watel sweetened, may be given, or any thing that is warming. This advice is for the poor, and those who have not a knowledge of the medieine; and will many times save them mueh trouble and loug sickness.

Stenming is of the utmost importance in eases of suspended animation, such as a drowned person; in which ease place the body over a molerate steam, slielded by a blanket from the weight of the external air, aud rarifying the air immediately alound them with the stcam. Ponr into the moutl some of the tineture of Nos. 1, 2, and 6 ; and if there is any internal heat remaining, there will be musenlar motion about the eyes, and in the extremities. If this symptom appears, repeat the doso several times, and renew the hot stones, raising the heat by degrees; if the outward heat is l'aised too suddenly, so as to balanee the inward, you will fail of the desired objcet, even after life appears. This is the only danger of any diflieulty taking plaee-always bear in mind to keep the fountain above tho stream, or the inward heat above the outwad, and all will he Eafe. After life is restored, put them in bed and lieep the perspiration free for twelve hour's, by hot stones wrapped in elotlis wet with water, oecasionally giving the tinetule as before mentioned the coldness and obstrnctions will be thrown off, and tho patient restored to the enjoyment of his natural strength. Beware of lleeding, ol blowing in the mouth with a bellows, as either will generally prove futal.

In many eases of spotted fever, stcaming is as neecsary as in drowned persons; such as when they fill apparently dead; then the same treatment is necessary to lighten the smmonnding air, till you can raiso tho immard licat so as to get the chetcr312 
mining powers to the surface. Berin with a small stone, and as life gains, increase the steam as the patient can bear it; if the distress is great, give more hot medicine inside, and as soon as an cquilibrium takes place the pain will cease. In all cases of this kind, the difficulty cannot be removed withont applying heat to the body, and it is morc natural by steam than by any other menns that ean be made use of. In cases of long standing, where the patient has been run down with mereury, and left in a cold and obstmeted state, liable to rheumatism, and other similar complaints, they eannot be eured with medieine without heat applied by steam, as nothing will remove mereury but heat.

When a patient is earried throngh a course of my medicine, and steamed, who has been long under mereurial treatment, and while under the operation of the steam, when the heat is at the highest, the face will swell in eousequenee of the poisonous vapour being condensed by the air, the face being open to it. To relieve this, put him in bed, and take a hot stone wrapped in several thicknesses of eloth wet with water, ponring on a little vinegar, and making a lively steam; put it in bed and cover his bead with the elothes and let him breatle the steam as hot as ean be borne, until the sweat eovers the swelled part. This will, in about fifteen or twenty minutes, throw ont the poison, and the swelling will abate. This metlorl, also, is of great service in agnes, and teeth ache, caused by cold; and many other catses of obstructions from the same causc, cspecially young clitdren stuffed on the lungs.

To steam small childien, the best way is to let them sit in the lap of a person, covering both with a blanket, and sit over the stenm, ponring a little vinegar on the stone; or it nuay be done in bed, with a hot stone wrapped in cloths wet with water, putting on a little vinegar, and coveringr them with the bed cluthes lail lonsely over them-but in this way you cannot exercise so goor jurlement in tempering the stem, as when yon are steamed with them. If they appear languid and faint, the outwarl heat is high cnongh; punt a little cold water on the fisce or breast, which will restore the strength; then rub them with a cloth wet with vinerge, spirit, or collt water, pur on elean clothes and put them in bed, or let tlicm sit up, as their strength will 
permit. This is safe in all eases of eold and obstrueted perspuration. It ought always to be borne strongly in mind to give a child drink often, when under the operation of medieine, or while steaming; if this is not done they will sufler muel, as they eannot ask for it.

In all eases of falls or bruises, steaming is almost infallible; and is much better than bleeding, as is the eommon pratice, whieh only tends to destroy life, instend of promoting it. If the person is not able to stand over the steam, it must be done in bed, as has been lleseribed. Give the hottest medieine inside that you have, and keep the perspiration free, till the pain and soreness abates, and the strength will be soon restored.If the advantages of this mode of treatment were generally known, bleeding in suel eases, or any other to remove disease, would never be resorted to by the wise and prindent.

The use of steaming, is to apply heat to the body where it is defieient, and elear off the obstruetions eaused by eold, whieh the operation of the medicine will not raise heat enough to do: -for as the natural heat of the body becomes thereby lower than the natural state of health, it must by art be raised as mueh above it as it lias been below; and this must be repeated until the digestive powers are restored sufficient to hold the heat by digesting the food; then the health of the patient will be restored by eating and drinking sueh things as the appetite shall require. In this way the medicine remores disease, and food, by being properly digested, supports nature, and continues that heat on which life depends.

Some who practiee aecording to my system, boast of carrying their patients through in a shorter time, without the trouble of steaming; this is easily aceounted for ; steaming is the most laborious part of the practice for those who attend upon the siek, and the most useful to the patient; as one operation of stenning will be mole eftectual in removing disense, than four conrses withont it; and to omit it is throwing the labonr npon the patient, with the expense of three or fonr operations more of the medieine than wonkl be nected, did the person who attends do his duty faithinlly.

314 
I have adopted the plan of numbering the remedies, and describing them under their respeetire numbers. Nos. 1, 2, 3, are used to remove disease, and the other as restoratives.

\section{Number One.}

\section{EMETIC HERB,-LOBELIA INFLATA.}

\section{IT IS USED TO CLEANSE THE STOMACH, OVERPOWER THE COLD, AND PRONOTE A FRER PERSPIRATION.}

It is the most important article user in the Botanical system of medicine. It was first diseovered as a medicine by $\mathrm{Mr}_{1}$. $\mathrm{S}$. Thomson of Ancrica. The faculty, with few exceptions, have opposed this remedy; but many of them lave only expressed their ignoranee. Some, like Dr. Gralım, have stated its valne. See page 161. Yet most of them have acknowledged its great use in Asthma.

In America the loetors were astonished at its beneficial effects, and they coneluded that it must be poison. Such a conclusion is easily accounted for ; they know nothing in all their medical science capable of producing a powerful effect upon the body except what is poisonous, and therefore they form their opinions after this crroncous theory. Mr. S. Thomson says, "Forming an crroneous opinion of this lierb, they represented it as a deadly poison, and to destroy my practice, they falsely asgerted that I killed my patients by giving it to them. Some of them made oath that it was poison. But the faet is very well known that there is no death in it. On the contrary, there is no vegetable grown more harmless in its effects on the human system, and none more powerful in removing discase and promoting health,"

"While the faenlty thonght Tohelia to he poison they called it my medicine. But sinee they rliscovered its melicinalsle virtues to be so valuable, they are restless to loll me of the credit of making its value known. D)r. M. CMtle says, "If' the rpualtity bo a little increased, it operatues as an cmetic, and then as a 
cathartic; its effects being mueh the same as those of the eommon emeties and eatharties. In this he is mistaken, for it is entircly different from every other emetic. I never kuew it to act as a eathartie in all my practice for above twenty year's, having administered it in every form in which it can be given, and for every disease that has come within my knowledge. Dr. Cutler eured himself of Asthma with it. I introduced the use of Lobelia, tinetured in spirit, for the astluma, and other complaints of the lungs, and cured many people. I cured a woman at Newington, of astluma, who had not lain in bed for six months. After taking the tineture she lay in bed the first night after"; she recovered, has been in health twelve years, and has not beel obliged to sit up one night simee."

"Now the doetors have begun to say it is a good medieine in skilful hands. Dr. Thacher says that its fatal effects were owing to the quantity given, and eharges me with liaving given a tea-spnonful of the powder; and when he gives directions for using it, he says, that from 10 to 20 graius, may be given with safety. Just look! If a tea-s]joonful be given by an empirie, its effects are fatal; but if $i t$ be administered by a learned doetor, and called grains, it is a very usejul medicine!!"s

Mistakes have been made as to the real herb Lobelia. A poisonous root grows in the Southern States, called Lobelia and it has been used as a medicine; this may account for the true Lobelia having been called poison. This cmetic herb may be found in the first stages of its growth, through the Summer from the size of a sixpence to that of a half-crown, round, and lying flat on tle ground, (in America) pressed fiat on the ground by the snow in winter, like a rose pressed flat. In summer it lifts up its leaves, and slioots forth a stalk a foot high, with branches, earrying wp its leaves with its growtl. In July it bears small pointed blue blossoms, followed by small pods, containing numerous small seeds. The pod is just like the human stomach, having an inlet and ontlet ligher than the middle; from the inlet it receives nourishment, and by the outlet diseharges the seeds. It grows in highways and pastures, by waysides, and in stmbble land. It is abundant in Ameriea, and grows in other comntries, and in some garmlens.

This herb may be prepared for use in three different ways, $2 \lambda 6$ 
viz-the poudered leaves and pods - a tin :ture made from the green herb witb spirit-the sceds redueed to a fine powder and compounded with Nos. 2 and 6.

1. After the leaves and pods are separated from the stalks, pound or grind them in a mortar to a fine powder, sift through a fiue sieve, and preserve it from the air. It may be given by itself, or compounded with other articles. Dose, a tea-spoonful of this powder, some quantity of sugar, in a tea-eup half full of warm watel; or a tea-spoonful of No. 3, may be used insteal of the water; to be taken two or three times, at intervals of 10 or 15 minutes. 'The liquid must never' be more than bloodwarm; hot water destroys its efficaey.

2. The Tincture. Take the green herb, (if the small plants are used take roots and all) pound them fine in a mortar ; add a suffieient quantity of good spirit; when well ponnded together, strain it through a fine eloth, and preserve the liquor in elosely stopped bottles for use. It is an eficetual counter poison, either taken inwardly, or extermally applied. It is an effeetual remedy for the asthma and all complaints of the lungs, nearly every doeter now acknowledges it.-Dose, from half to a tea-spoonful. Its effect will be more certain if the same quantity of No. 2 be arded, and where there are nervous symptoms, add half a tea-spoonful of nerve powder, (nmbil) to the dose.

3. Rednee the seeds to a fine powder, and take half an ounee of it, or a large spoonful, with the same quantity of No. 2, marle fine and put them into a gill of No. 6 and a tea-spoonful of umbil. Bottle for use. It is intended for violent attreks of disense, such as loek jaw, hydrophobia, fits, spasms, drowning, and in all eases of suspended animation, where the vital spark is nearly extinet. It will go through the system like electricity, giving heat and life to every part. Lock-jaw is relieved by ponring some of this liquid between the ehcek and the teeth. As soon as it tonehes the glands at the roots of the tongue the spasms will relax, and the jaws be loosened, and the nouth bo opened ; then give a dose of it, repeating it as the spasms abate; afterwarls grive a tea of No. 3. "This coulse." says Mr. Thomson, I never knew fail of sriving relief. It is effectual in bringing ont measles, and small prex, and in the removil of warts, pimples, \&e. I have eured thite cases of eatuino 


\section{THE BOTANIC FAMILY PHYSICIAN.}

madness, by it ; it is a specifie for that disease. Dose,-a
tea-spoonful.

Lobelia is most powerful to remove diseases, but perfeetly innoeent in its effects. It has been given to ehildren of one day old and to persons 80 years old. There are two cases where this medieine will not operate, viz. - when the patient is dying, and where there is no disease. There can be no war where there is no enemy. When there is no cold in the body, there is nothing to contend against, and when there is no leat there is nothing to kindle; in both eases this medicine is silent and harmless. It is calculated to remove the eause, and no more. It elenrs all obstructions, until it produees an equilibrium throughout the system whieh is felt in the fingers aud toes, - a prickling sensation like that eaused by a blow on the elbow - an alarming symptom to those unaequainted with its operation; but it is always a eertain inclication of a turn of the disorder, and patients generally gain from that time.

The best way will be to give the smallest preseribed dose first, and repcat till it produces the desired operation. If the stomaeh is eold and foul, its operation will be expedited by giving No. 2. To patients in a deeline, or to those who have ehronic diseases, three to eight courses of tbe medieine are neeessary to produee the favourable erisis; and the lower they have been, the more alarming will be the symptoms to those unaequainted with its effects. "I have seen some," says Dr. Thomson, "lie and sob like a eliild, for two hours, unable to speak, or raise their hands; and the next day quite well. If mueh opium has been taken, Lobelia will, in its operations, produce the same symptoms produced by opinm, whieh, still lodging in the system, is ronsed into action by Lobelia, and the patient may be thrown into a scnseless state, or be agitated 60 as to require holding. Sometimes they grow cold as though dying, and remain so fiom two to cight hours, and then arako like one from sleep after a good nicht's rest, as if nothing had ailed them. It is the last struggle of the discase, and they generally begin to recover fiom that time._- By taking a dose when first attacked by a disease, Lobelin will throw it oft, and prevent long sickness. It repuires, Irowever, to be followed by sone other medicine to hold the vital hoat till natude is able to 318 
supnort itself by digresting the food ns No. 2, aud oceasionally No. 3 to remove canker, ${ }^{*}$ the great cause of discase, and then follow with No. $t$, and 5 , to correet the bile, restoro the digestion, strengthen the system, and effect a cure."

\section{Number Two. \\ CAYENNE-CAPSICUM.-SEE PAGE 61.}

\section{ITS USE IS TO RETAIN THE INTERNAL VITAL IEEAT OF} THE SYSTEM, AND CAUSE A FREE PERSIIRATION.

It is well known. It is desirable to have it pure, as it is frequeutly adulterated by red sand, red woods, and salt. It is best to buy it in pods, and grind it at home for use ; though it may be obtained ground, and pure, fiom tlose who vend botanieal medieines. It has been used prineipally for eulinary purposes and latterly for medieinal purposes. It is one of the safest and best artieles ever diseovered to renove disease. The Fdiuburgh Dispensatory says, "There ean be little doubt that it furnislies one of the purest and strongest stimulants that ean be introdueel into the stomach, while jt has nothing of the nateotie effeets of ardent spirits. It las been used with sueeess in somo discases that hat resisted all other remedies." Dr. "Thacher gives the same opinion.

Mr. S. Thomson says, In the fall of 1807, I was in Newburyport, and saw a bottle of pepper-sance. Peing the first I hat ever seen, I bonglit it, got some of the same linel of pepper that was flried, which I put into the bottle; this made it very hot. On my way home, I was telkcn unwell, ancl was quito cold. I took a swillow fiom the bottle, which cintsed violent pain for a few minutes, when it produeed perspirsulion, and I Eoon grew easy. I afterwarls tried it, and found that alter it harl expellerl the cold it would not cause prin. I'rom theso experintents I lecune convinect that this kind of perper was nulleh stcongel, and would be better fol medical use than tho

* The Anorican faculty frequelthy use the worl "C'anke" which menta a sourbitic state, or tendency to dssusc in uny loculity, tuterinl or exterunl. 
common red pepper. Soon after this, I was ragain at Newburyport, and made inquiry and found some Cayenne; but it was prepared with salt for table use, whieh injured it for medieal purposes. I beeame acquainted with a French gentleman who had a brother in Demerara, and made arangements with him to send to his brother and request him to proeure some, and liave it prepared without salt. He did so, and sent out a box containing about eighty pounds in a pure state. I sent also by many others that were going to the places where it grows, to proeure all they could; in consequence of which, large quantities vere imported into Portsmouth, much more than there was immediate demand for.

I was only able to purehase but a small part of what was brought, and it was bought up by others, on speculation, and sent to Boston; the consequence was, that the price was so much redueed, that it would not bring the first cost, which put a stop to its being imported, and it lias since been very searee. When I first began to use this article, it caused much talk among the people in Portsmouth and the adjoining towns. The doetor's tried to frighten them by saying that I made use of eayenne pepper as a medieine, and that it would burn up tho stomach and lungs as bad as vitriol. The people generally, however, became convineed by using it, that what the doctors said about it was false, and it only proved their ignorance of its medicinal virtues, and their malignity towards me. It soon came into general use, and the knowledge of its being useful in euring disease, was spread thronghont the eountry.

It bas effectually euled the spotted fever. In all kinds of diseases, it has been given to patients of all ages, and under every cireumstance almost. It is perfeetly harmless, as thoso who have administered it for year's can tostify that they lavo never known it to produce bad effeets. It is the most powerful stimulant, to laise and maintain that heat on which life depends. It is extremcly pungent, sctting the montl on fire, for a few minutes, but even this is beneficial; for its eftects on the glands, eauses the saliva to flow freely, and leare the mouth clean and moist.

It must be gromud to a fine powder. Dose, from a quarter to a tea-spoonfil in hot water, sweetened; or it may he mixed with cither of the other Numbers when taken. It will produes 320 
a free perspiration, to be maintained by repcating the dose, till the disease is removed. A spoonful of Cayenne, and one of salt, put into a gill of vinegri, makes a very good dinner sanee to assist the appetite, and strengthen digestion. A tea-spoonful of this preparation will remove faintings and flatulcney. A tea-spoonful of Cayenne in a tumbler of Cider is bctter than ardent spirit. It is good to be combined with most medieines.

\section{RED PEPPERS.}

These are abundant in America. The pods are nsed in pickling. This pepper is of the same nature as Cayenne, but not so strong, and the best substitute for it.

\section{GINGER.}

See page 123. It may be used when a milder remedy than Cayenne is required. It is best to obtain the roots and grind or pound them to a fine powder. It makes an excellent poultiee, mixed with pounded biscuit, or bread, or Slippery Elm Bark. To chew a little of the root constantly, and swallow the saliva, is good for a cough; and for those of a consumptive habit. It prevents the contagion attendant on sick rooms, \&e.

\section{BLACIK PEPPER.}

See page 208. This may also be used as a substitute for the preceding remedies, and administered in the same manner. These four maintain the heat of the body longer thin any otlier prescribed remedy.

\section{Number Three.}

To scour tius STOMACH AND BOWELS, AND RFMOVi CANKER.

I shall describe those remerlies which aro goorl to remove canker from the throat, stomach and bowels; caused by colld; 
for when eold obtains the power over the inward heat, the stomael and bowels beeome eoated with eauker, whieh prevents its numerous little ressels from performing their duty, Some remedies proposed for this disense are too binding, and eause obstruetions. The following is a good method to aseertain what is good for eanker :-Chew some of the proposed artiele, and if it eause the saliva to flow freely, and leaves the mouth elean and moist, it is good; but if it dries up the juices, and leaves the moutl rough and diy, it is bad.

(fer The following artieles may be purehased of the Medieal Botanists, nearly in every town.

\section{BAYBERRY, OR CANDLEBERRY.}

It is a speeies of Myrtle, eommon in Ameriea. It produces berries which eontain wax in abmndanee. The bark of the roots is used in medieine, in fiue powder. It is an excellent medieine alone, or eomponnded with other articles, and a real speeifie for eanker ; probably the best. It is highly stimulating, and very pungent, prieking the glands, and enting the saliva, and other juiees to flow fieely. It is a first rate tooth-powder, eleansing the teeth and gums, and removing senryy. As snuff it elears the head, and eures headache. It is good in relax, and all disorders of the bowels. When the stomach is very foul, it will often operate as an emetie.-Dose, a tea-spoonful in hot water sweetened.

\section{WHITE POND LILY.}

The roots are used. They are laree. They should be wollwashed, split into strips and dried; then pulverised, and mescrved for use. It is a good medicine for calnker, and all bowel eonplaints, given in tea alone, or mixed with other artielcs.

\section{HEMLOCK.}

The common IIemlock-tree grows in New England. The inner bith is uscel, an intusion of the bark in liot water is a $32: 2$ 
good mediciue for canker, and discases arising from it. Mr. $\mathrm{S}$. Thomson says, "I have constantly given it, and always found it a good medicine for complaints of the stomach and bowels. A tea made of this bark is very good, and may be used frecly; it is good to give the cmetic and No. 2 in, and may be used for drink in all cases of sickness, especially when going through a course of medicine and steaming. This, with bayber'y bark and lily root, forms No. 3, or what has been commonly called coffee, thongh many other things may be added, or either of them may be used to advantage alone. The boughs, madc into a tea, are very good for the gravel, or other obstructions of the urinary passages, and for rheumatism."

\section{MIARSH ROSEMARY.}

This is grood for eanker and sore mouth. It has been used with Bayberry bark for No. 3 with good success. It should not be used without a large proportion of Bayberry bark.

\section{SUMTACH.}

This is a new remedy. It has been found very cffectual in dysentery. The bark is used; also the leaves, and the berrics, when ripe; and when used as part of No. 3, slould be pounded; and the threc may be used separately, ol altogether. $\Lambda$ tca made of cither of these articles is very good, safe in almost all complaints, and put iuto injections. It will cleansc or scoul' the stonuch and bowels; is good for stranguary, relieves all obstruetions in the kirncys, and strengthens them. 'Tlue nse of this article witl, Bayberry bark and Jily root, equal parts, for No. 3, or coftce, hats been very useful.

\section{WITCII II $\triangle Z \mathrm{EL}$.}

$\Lambda$ tea made of the leaves may lee taken frecly with advantage. "It is the best thing for bleceling at the stomaclı," says Mi. Thomson," of any atisle I have ever foum, either by 
tca made of the dry leaves, or chewing them when green. I have eured several of blecding with it ; and also in eonplaints of the bowels I liave seen its efficacy. An injection of this ten, with a little of No. 2, is good for the piles, and many fema?e complaints. In bearing down pains it will afford immediate relief, if properly administered.

\section{RASPBERRY LEAVES.}

See page 224. They may be used green, or dried. They have performed wonderful eures in relax, and the nsual bowel complaints. An infinsion alone, or as a eomponent part of injeetions, nerer fails to give immediate relief. Its ntility in travail is surplising. Give a strong infusion of the leaves, with a little No. 2, sweetened, and it will regulate every thing as natnre requires. If the pains are untimely, it will make all quiet, if timely, and lingering, give more of No. 2, and Umbil in the infusion. When the ehild is borm, give it some of the tea with sugar and milk in it ; this prevents sore month; it is good to wash sore nipples with. A poultiee made of the infusion and bread, or slippery elm bark, is very good for burus and sealds; if the skin is off, this poultice, or washing with the infusion will allay pain, and promote healing.

\section{SQUAIV WEED.}

Indian name, Cocash. The roots and tops are nsed for medicine. Mr. 'Thomson says "It was given to me when I had the Canker-1'ash, and eflected a eme. I linve frequently used it for that eomplaint, and fombl it very good. Tink the grecu roots and leaves, bluise them, poul on hot watcl, ant give this tea sweetened. It may be kept by adding a little spirit, and is good for rlemmatisn, or for nerrous aflection. It is perfectly la:momless, and may be nsed fiecly. It makes a very grool bitter il linetured with hot water and s] irit, and when thus prepured, is grood for dizziness, eold hands anıl feet." 


\section{Number Four.}

\section{Bitters to correct tile Bret, and restore IMPAIRED DIGESTION.}

\section{BITTER HERB, OR BALMONY.}

It is rery good to eorreet the bile and ereate an appetite. The infusion of it may be used alone, or may be added to any of the other artieles adapted to restore the digestive powers.

\section{POPLAR BARK.}

The bark of the stinking Poplar is the best, as it is the most bitter. An infusion of the inner bark is one of the best articles to regulate the bile, and restore the digestive powers. To make bitters, No. 4 , it should be powdered very fine, and mixed with the other artieles, or used alone. To make an infusion, take a handful of the bark pounded, put it into a quart mug, and fill it with boiling water. This infusion will relieve a relax, headache, faintness, and other eomplaints caused by incigestion. Those who have affections of the kidneys, or are eonsumptive, will find great benefit from its use.

\section{BAYBERRY.}

See page 33. The bark of the root or top, is a good bitter, and useful to correct the hile, and assist digestion. It is aclministered by infusion, which may be freely used in all cascs of indigestion.

\section{BITTER ROOT.}

It is also called Wandering Mill: Treot. The root is very bitter, ancl a sovereign corrector of the bile. It removes constipation, ransing llo hovels to move in a matural way. $\boldsymbol{\Lambda}$ strong infusion, with hot water, if drank freely, will operale as 
a cathartic, sometimes as an emetic. It is sure to throw of fever in its first stages, and should be used in all cases of constipation.

\section{GOLD SEAL.}

Called also Kercuma. It is a pleasant bitter. The powdered root is used. In weakness of stomach, where food clistresses, a tca-spoonful of the powder given in hot water, sweetened, will give immediate relief. It is a powerfinl correction of the bilc, alone, or with the bitter root, or may be compounded with either or all of the articles under this Number, to restore the digestive powers.

\section{Number Five.}

Syrup for the Dysentery, to string then the STOMACH AND BOWELS, AND RESTORE WEAL PATIENTS,

The artielcs are the bark of Poplar, Bayberry, Peachmeats, or meats of Cherry-stones, sugar, and brandy.

\section{PEACH MEATS.}

They are of great value to strengthen the stomach and bowels, and restore the digestion. Matle into a cordial, with other articles, hereafter described, they cffectuilly restore the tone of the stomach after long sickness, and restorc weak pitients particillarly in dysentery. An infusion of the leaves will remove colic.

\section{CHERRY STONES.}

These may be used insteal of Peach ments. An infusion with the cherrics, pounded with the stones, sweetcnel, and a litile brandy, promotes digestion, and al good appetite. 


\section{Jumber Siz.}

Rhetratic Drops, TO REMOVE PAIN, PRFVENT MORTIFICATION, AND PROMOTE NATURAL IEAT.

\section{GUM MIYRRI.}

See page 190. Mr. S. Thomson had a lane ancle, and was told by an old man to apply the Tineture of Myrrh. It was squirted into the wound, which caused a temporary smarting. It was also taken inwardly, and it effected a cure. In eases of bad wounds and old sores, it affords great relief, and is a cure for worms. Its power is increased by using spirit, and a little Cayennc, for internal administration. If slightly boiled, it prevents the fumes from rising to the hearl, which otherwise would be injurious to the hysterical. It is a firstrate remedy for rheumatism.

\section{SPIRIT OF TURPENTINE.}

For external application. A portion of it should be added to the Rlieumatic Drops, when usecl for the iteh, or other bad humours. It slould be used catutiously. See pago 278.

\section{GUM CAMPIIOR.}

For barl sprains, it may bo added to tho Rhenmatic Drops, with great al vantage.

The best Tincture of Camphor is tho third Dilution, usel by the IIomsopathists. For a close, they recomment one drop in water, or on loat sugar, to be repeated crery five or ten minutes, if neel he. It is curative of Clocleti in the lirst stage, colls, diarrlueas, epilepsy, faintines, poisoning by opinm, mac. Allopathists oreter from 20 to 60 tirops. An over-elose of Cimplior una be relieved by strong Colfec. Sce pare 6,o. 


\section{THE BOTANIC FAMILY PHYSICIAN.}

\section{NERVE POWDER.-UMBח.}

American Valcrian, or Ladies' Slipper, sometimes called Umbil, or Male and Female Nervine.

Mr. S. Thomson says, this powder is the best nervine known; I have made use of it, and have always found it to produce the most benefieial results, in all eases of nervous affeetion, and in hysterieal symptoms; in faet, it would be diffeult to get along with my pretiee in many enses without this important artiele. It is perfeetly harmless, and may be used in all eases with safety : it is better than opium, whieh is generally given in enses of spasmodie affeetion, and whieh only deadens the feelings and relieves pain only by destroying sensibility, without doing any good. Valerian has been supposed by the doetor's to be of a nareotie nature; but this is a mistake. They have drawn this eonelusion, from its tendeney to promote sleep; but this is owing to its quieting the nerves and leaving the patient at ease. When nature requires sleep to reeover the natural tone of the system, half a tea-spoonful may be given in hot water, sweetened, and the dose repented if neeessary ; or the same quantity may be mixed with a dose of either of the other numbers when given, and put into the injections; where there are nervous symptoms, it should never be dispensed vith.

\section{COMMON IIERBS.}

I eall them eommon, beeause the preeding Artieles were for a long time uneommon in America and especially in England; and beeanse they are not so powerful as Lobelia, Cayenne, \&e. Yet they are very efficneious in many complaints, of a warming nature, and eapable of arresting disease. Some of them have already been deseribed, and referenee is made to eaeh deseription.

\section{SPEARMINT.}

Described, page 180. It tends to stay romiting. If an overdose of Lohelia should produce excessive vomiting, a strong infusion of Spearmint will stop it, aud ease the stumael. 328 


\section{PEPPERMINT.}

See page 179. It promotes perspiration, and overpowers a eold, if drank just before going to bed. The essenec, or oil in warm water relieves pains in the stomacl and bowels.

\section{PENNYROYAL.}

See page 207. It is of great value in medicine. An infusion may be used in all cases of siekness; it warms and cleanses the stomach ; if drank frecly, it produces perspiration, and removes obstructions. It will throw off eolds and slight attacks of disense, and prevent sickness. In children, it removes wind and pain in the bowels. In going through a eourse of medicine, an infusion of it may be drank, and it will eause the medicine to have a pleasant operation.

\section{SUMMER SAVOURY.}

Page 245. An infusion is good for colds, and may be taken with benefit in siekness. The oil of the herb will euro tooth-aehe.

\section{HOREHOUND.}

Page 139. The Horehound Candy is very useful for coughs, especially in old people and the asthmatieal.

\section{ELECAMPANE.}

Its virtues are described, page 99.

\section{MAY-WEED.}

A hot infusion of this herl drank when going to bed, is good for a cold, and in slight attacks of fever, if used frecly, and a hot brick put to the fect, will, in most cases, effect a curc. 


\section{WORMIVOOD.}

Descrihed rage 288. The green herb pounded and tinetured in spirit, is exeellent for bruises and sprains.

\section{TANSY}

Deseribed page 265. The green leaves pounded and applied will relieve sprains and brisises, and allay the swelling.

\section{CAMOMUE.}

Deseribed page 59. An infusion is good for bowel eomplaints, and externally applich, will relieve sprrains, bruises, and swellings, and remove eallosities, eorns, see. and restore sunken kidneys.

\section{BITTER-SWEET.}

Sce page 193. It is a good external appliention. The bark of the root with eammomile and Wormwool, make an ointment of great value, very effieacious for a bruise, sprain, swelling, corns, and eallosity.

\section{MULLEN.}

Page 186. The butuised leaves lednee swellings, and restore contrated sinews. Apply them warm. It is an important artiele in the strengthening plaster hereafter describer.

\section{BURDOCK.}

Fully deseribed page 54. The leaves aro good applied to the feet in case of fever, to kicep them moist and promote perspiration.

\section{STUNTE-CABBAGE.}

The root should be pounted or nromul to $\mathbb{n}$ powder. This powder may be taken in tea, swechned or made into a syrup, 330 
or a tea spoonful may be mixcd with honey, and taken in the morning, or at night wben going to bed. It is good for asthma, courh, dificulty of breatling, and all disorders of the lungrs, and with other artieles, makes one of tho best preparations for those complaints I have cver found.

\section{WAKE-ROBN.}

See page 87. This root is cxtremely pungent and stimnlating and is often given for eholic and pain in the bowcls, and to cxpel wind. I have mostly made use of it for coughs and disorders of the lungs, for which I have found it a very nseful article, and it forms part of my composition for coughs. The root should be dried and reduced to powder, and may be mixed with honey or in syrup.

\section{TIIOROUGIIVORT.}

This herb is well known in the country, and is marle use of by the people in tea for many complaints. It is of a warming nature, and is good for conghs and other complaints of the lungs. It is used in my compound prepared for coughs.

\section{FEATHERFEIV}

Fully deseribed page 69.

\section{CIIVERS.}

$\Lambda$ strong infusion is good for urinary obstructions. Sec parge 73.

\section{BLACK BIRCH BARK.}

Page 41. An infusion of the bark cures complaints in the bowels, cepecially dysentery. Made iuto a Symu witl Peas:lmeats, or Clerry-stone-meats, it restores Heses who hawe been debilitated witl the dyscritery, \&oe, and strengthens the stomach anc promotes cligrestion. 


\section{EVAN ROOT.}

This is ealled by some people ehoeolate root, on aeeount of its resembling that article in taste, and is made use of by some as a eommon drink instead of tea or eoffee. It is good tor eanker, and may be used in No. 3, as a substitute for other artieles. It grows eommon in this eountry and is too well known to need deseribing.

\section{SLIPPERY ELM BARK.}

The inner bark of this tree is of much value, and may be used to advantage in many ways. There are two kinds of the slippery elm; one, the bark is rather hard and tongh, nud the other is very brittle ; the latter is the best for medieal use. The bark should be peeled, the ross shaved off, then ground to a fine powder. If used internally put a tea-spoonful of this powder into a tea-eup with as mneh sugar, mix them well together, then add a little eold water to it and stir it till it forms a jelly thick enough to be enten with a spoon. A tea-spoonful may be taken at a time, and is an excellent medicine to heal soreness in the throat, stomaeh and borrels eansed by eanker ; or more hot water may be put to it and made into a drink, and freely taken for the same purpose. I have made mueh use of this bark for poultices, and have in all cases found it a most excellent article for that pupose. Hixed with pounded eracker and ginger, it makes the best poultiee I hnve ever folmd; for burns, sealds, felons, old sores, \&c., it is the best thing I have met with to allay the inflammation, ease the pain, and heal them in a short time.

\section{BALSAM FIR.}

This balsam is obtained from a tree well known in many parts of this country; it is taken from small blisters which form in the bark. It is of a very healing natmre, and is good to remove internal soreness. It forms an important artiele in my healing salve. When takien it mily be dropped on loaf suingr.

\section{2}




\section{TIIE BOTANIC FAMILY PHYSICIAN.}

\section{GINSENG.}

An American plant. It is a nervine, and useful in all enses of nervous affection alone, or mixed with other articles. From half to a tea-spoonful may be given for a dose, in hot water sweetened.

\section{SNAKE-ROOT.}

Page 25l. It is of a hot nature; it is used in measles, and other eruptions, to keep the disorder out, which it does effeetually by its warming qualities, which determine the disease to the surfaee. No. 2, and the Composition Powders have the same effect. An infusion of the root promotes perspiration, removes pain in the stomach and bowels, and expels wind. 'The roots powdered may be mixed with Ginseng or Umbil, for all nervous eomplaints.

\section{MUSTARD.}

Fully deseribed page 187. It is frequently used for rheumatism, internally, and externally. Nos. 2 and 6 are superior for this purpose.

\section{HORSE-RADISH.}

Page 140, The leaves are sometimes applied to remove external pains; but they are apt to blister.

\section{BALM OF GILEAD.}

This tree is a speeies of the poplar and possesses some medieinal virtues. It resembles the black poplar, having similar tags; but the butls and leaves are larger. The buts bruised and tinetured in spirit, prorluce an effect something like the tineture of myrrh; and are good taken inwardly, as a restorative, and for bathing sores. The hark scraped liom the twigs and steeperl in hot water, is a good corrective of the bike, and will operate both as an emetic and eathartic; it is more harsh than the other kind of poplar, but may be ased to advautage in diserse. 


\section{BUTTERNUT.}

American. It bears an oblong nut, nearly as large as an egg. The kemel contains much oil. The bark of the tree or loots, boiled down till it is thiek, may be made into pills of an emetie and cathartie nature, A syrup may be made by boiling the bark in treacle and a little spirit ; it is good for worm complaints in children. The buds and tivigs have a milder effect. White Aslı bark and Balm of Gilcad, equal parts mixed, and made into a sylup or pills, form a strong purge, but it is safe. The green shell of the nut bruised forms a good blister; when applied it should be eorered with a wet bandage, and kept moist; the blister, sluperior to that produeed by flies, will rise in three hours. The bark of the Butternut is the prineipal iugredient in Dr. Hawke's Rheumatie and Cancer pills, and also iu Chamberlain's Bilious Cordial, greatly eelebrated.

\section{BLUE AND WHITE NERVINE,}

For a vomit, it ranks next to Lobelia. It is used alone, or eombined with Thoroughwort. It prevents ferer in its first starges, and has been successfully used in enses of eonsumprion, whieh the doetors liad dechured hopeless. By infusion, or in powder.

\section{PIPSISTIY OR RHEUMATIC WEED.}

An infusion is good for eaneers, and serofulons humours, drinking it and bathing the affected parts. The roots of the Wild Lettuce, and those of the Pipsisway dricd and powdered together, are good to eure all bad humours. Take a tca-spoonful of the powder in a gliss of hot water', and bathe tho alfected parts witl it. It is good to restore neak nerves.

\section{GOLDEN ROD.}

See page 125. The oil of this herb is a good medieine; and lucpared in cssenee, it relieves leadache; to be taken, or uscd as a fomentation. 334 


\section{MEADOW FERN.-AMRRICAN.}

The hurs, pounded fine and simmered in eream, lung's lard, or fresh butter, are almost a sovereign remerly for itcl or cxternal poison, and all bad hnmour sores. When the burs cannot be had, take the bush and buds and make a strong decoetion; drink of this and wash with the same. This liquor miay be prepared in syrup, and by boiling it down may be made into ointment; the syrup shonld be taken and the ointment put on the affected parts. This ointment, or the wash, is good for salt rheum, or canker sores, and may be used freely.

\section{YELLOW DOCK.}

Page 94. The root is made into an ointment for the iteh. The roots are to be fincly bruiced and mixed with crean ; kept warm for twelve hours, and not to be scalted. Rub it on at light when going to bed. Three times using it will ctlect a cure. The forcgoing deseribed ointments, with No. 3, and Rlicumatie Drops, prepared with Spirits of Turpentine, will cure any case of this eomplaint.

\section{PRICILY ASII.}

American. The bark and berries are necd. They are very pungent, a powerful stimulant, as alsu the tops and roots. It slinild be finely powilered, steeper in hot water, and purt into wine or spirit. It malses a good bitler. It is very good for fever, ague, lethangy, cold hands and feet, and all cold eomplaints. Dose, half a glass two or three times a clay.

\section{BITTER TIIISTJA.}

American. The leaves may he stecperl in lint water, and flank, or they may lue reclureol to powiler, and taken in treacle () warm waler, of in winc or splitit. It is an cxcellent and

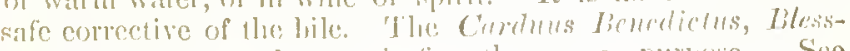

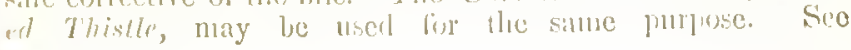
$1:$; 269 . 


\section{THE BOTANIC FAIILY PIISICLAN.}

\section{ARCIIANGEL.}

Seo page 22. In Amcrica, there are two kinds growing near each other; they elosely resemble, but are very different in taste. One is very bitter, and the other has no bitter taste, but is very rough and of a balsamie taste. They may be used together in a tea or syrup, and answer two important purposes; the rough removes the eanker, and the bitter is a corrective of the bile. By adding No. 2, the compound contains the three great prineiples of the healing art, viz., hot, rough, and bitter.

\section{DIRECTIONS FOR PREPARING AND USING THE VEGETABLE MEDICINE.}

\section{NUMBER ONE.-EMETIC HERB.}

It is prepared and used in three different ways, viz. :-

1. The powdered leaves and pods. This is the common form of using it ; and from half to a tea-spoonful may be taken in warm water swectened; put into either of the other numbers when taken to eleanse the stomach, overpower the eold, and promote a free perspiration.

2. A tineture made from the green herb in spirit. This is used to counteraet the effect of poison internally or externally used; and for asthma and other complaints of the lungs. For a dose, take a tea-spoonful adding about the same quantity of No. 2, in half a tea-cupful of warm water sweetened; and, in eases of nervous affection, add half a tea-spoonful of nervo powder. For the external eflects of poison, take the above dose, and bathe the parts affeeted with the tineture, repeating it till eured.

3. The seeds redueed to a fine powder and mixed with Nos. 2 and 6 . This is for the most violent attacks of spasms and other complaints, sueh as lock-jaw, hychophobia, fits, hrowned persons, and all eases of suspended anmation, where the rital spark is nearly extinet. For a dose, give a tea-sproonful, and 336 
repeat it till relief is obtained; then follow with $\Omega$ ten of No. 3 for canker.

For ehildren the dose must be regulated aceording to their age. If very young, steep a dose of the powrler in lialf a teacupful of water, or tea of lispberry leaves, and give a ter-spoonful at a time of the tea, strained thromgh a fine cloth and sweetcned, repeating the dose every ten minutes, till it operates; aud give pennyroyal, or some otlier herb tea for dituls.

\section{NUMBER TIVO.-C $A$ YENNE.}

This is a medicine of great value in the practice, and may be safely used in all cases of discase, to raise and retain the vital heat of the system, cause a free perspiration and kecp the determining powers to the surfice. The only preparation is to have it redueed to a fine powder. For a dose, take fiom half to a tea-spoonful in hot water, or a tea of No. 3, swectencel; or the same quantity may be mixed with a dose of either of the other numbers when taken. The dose sliould be repenterl every ten or fifteen minutes till the desired object is effected, and continued ocensionally until health is restored. When this number is given, the patient shonld be kept warm, by sitting near the fire covered with a blanket, or in a warm bed.

\section{NUMBER THREE-FOR CANKER.}

Take bayberry root hark, white pond lity root, and fluc inner bark of the hemlock, equal parts of cach, pounderl and well mixed together ; steep one onnee of tle powele in a pint of boiling water and give for a dose, a common wine-glasslull sweetened.

If the aljove cannot he had, take as a sulsstitute sumach, (lark, leaves or herlies, red laspherry or witchl hazet leaves,

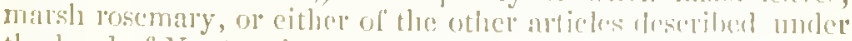
the liearl of No. 3; they ate all gool tot canher, ancl maly be used toretlier or sepatrite.

When the violence of the disense rerpuines a ronsere of merticiles, stecp one ounce of the above nembinged poweler, No. 3, in 
a pint of boiling watel, strain off a wine glass full while hot, and add a tea-spounful of No. 2, and the same quantity of sugar : when cool cnough to take, add a tca-spoonful of No. l, and half that quantity of nerve powder. Let this dose be given three times at intervals of fiftcen mimutes; and let the same compound be given by injection; and if the case requires it, again repeat it. If mortification is apprehended, a tea-spoonful of No, 6, may be added to each dose aud to the injeetions.

After the patients have recovered sufficicntly from the opelation of the medicine, which is usually in two or three Lours, plaee them over the steam as directed in page 21.

This operation is sufficient for one time, and must be repeated each day, or every other day, as the eircumstances of the ease may require, till the disorder is remored. Three times will generally be sufficient, and sometimes onee or twiee will answer the purpose; but in bad ehronie enses it may be neccssary to continue to earry them through a regular eourse two or three times a week, for a comsiderable length of time.

Great eare must be taken to keep up an internal heat, so as to produee perspiration, after they have been through the operation, by giving oeeasionally No. 2, or the composition powder ; for if this is not attended to, the patient may have a relapse, in which ease it will be very diflicult to laisc it again, as they will fall as much below a natmoal heat, as they liave been raised above it by artifieial means.

During the operation, give milk porridge, ol glnel well scasoned with a little Cayenne in it ; and after it is ovel, they mily eat any lind of nomrishing food that the appetite may crive.

A tea-eupful of the tea of No. 3, should be taken nicht and morning to prevent a rclapse of the discase, and during the dily drink frequently of a tea made of poplar bark; nnd, if eostive, use the bitter loot.

As soon as the disoleder is lemoved, use bitters, (No. 4.) to correct the bile and restore digestion; and half a wine arlassfull of the syrnp, (No 5,) taken two or lluee times a lay, will strengthen the sionach, and assist in regralating the digestive jowers.

338 


\section{THE IBOTANIC FAMILY PHYSICIAN.}

The foregoing direetions are ealeulated for the more violent attacks of direase, and such as have become settled; but those of a less violent nature must be treater aceording to cireumstances. In the first stage of $\Omega$ disense, it may be most generally thrown off by a dose of the emetie leerb, with No. 2, to raise a fiee perspiration, followerl by a tea of No. 3, to remove the eanker, and the bitters, or a ter of popla bark, to regrulate the digestion. For a sudden cold, take a dose of the composition powder on going to bed, and put a hot stone wrapped in wet eloths at the fect, which will, in most eases, remove the complaint ; but if these applieations do not answer the purpose, the patient should be earried through a regular course as soon as possible. Steaming is safe, and will always do good, and the injeetions must not be neglected, particularly where the bowels are disordered. In consumption and old lingering eomplaints, give the eomposition powder two or threc days before going through a regular eourse.

\section{NUMBER FOUR.-BITTERS.}

Take the bitter herb, or balmony, bayberry and poplar bark, equal parts, pulverized, one ounee of the powder to a piut of hot water, and half a pint of spirit. For a duse take half a wine glassful. For hot bitters add a tea-spoonful of No. 2.

This preparation is ealculated to eorreet the bile and erento an appetite, by restoriug the digestive powers; and may be freely used, both ns a restorative and to prevent disease.

When the above articles cannot be had, either of those that have been before deseribed under No. 4, which are all good for the same purpose, may be used as a substitute.

\section{NUMBER FIVE.-SYRUP.}

Take poplar bark and bark of the renot of bayberry, one pornd each, and hoil then in two gallons of water, stresiin off and arld seven pomels of goorl sugar; then scald and skin it, null and half a peund of pesch meats, or the same quantity of elnerry stone incats, pounded fine. When cool, atdd a gallon of grood 
brandy, and keep it in bottles for use. Take half a glassful two or three times a clay.

Any other quantity may be prepared by observing the same proportion of the different anticles.

This syrup is very good to strengthen the stomaeh and bowels, and restore weak patients, and is partieularly useful in the dysentery, which generally leaves the stomach and bowels sore. In a relax, or the first stages of dysentery, by using a tea of No. 3 , freely, and givimg this sylup, it will generally eure it, and will also prevent those exposed from taking the disease.

\section{NUMBER SIX,-RIIEUMLATC DROPS.}

Take one gallon of good fonrth brandy, or any kind of high wines, one pound of gum myrrh, pounded fine, one onnee of No. 2, and put them into a stone jug and boil it a few minutes in a kettle of water, leaving the jug unstopped. When setiled bottle it for use. It may be prepalred without boiling, by letting it stand in the jug for five or six days, shaking it well every day, when it will be fit for use.

These drops are to remove pain and prevent moltifieation; to be taken or applied externally, or to be put into the injeetions. One or two tea-spoonfuls of these drops may be given alone, or the same quantity may be put into a dose of eithel of the medieines before mentioned; and may be also used to bathe with, in all eases of extelnal swellings or pains. It is an exeellent remedy for rlueumatisn, by taking a dose, and bathing the part affeeted with it. In the headache, by taking a swallow, bathing the head, and snufling a little np the nose, it will remore the pain. It is good for bruises, splains, swelled joints, and old sores, as it will allay the inflummation, bring down the swelling, ease pain, and produce a tendency to heal; in fact, there is hardly a complaint in which this useful medicine ennot be used to advantage. It is the best preventive against nortifieation of anything I have ever fonnd.

For bathing, in rhemuatisu, itch, ol other hmmours, or in any swelling or external pitin, ald one qualer part of spirit of turpentine: and for sproms and bruises, a little grtun camplor silily be added.

$3+0$ 


\section{NERVE POWDER.}

This is the Ameriean valerian or umbil, and the preparation has been sufficiently described, (see page 328 ). This powder is a valuable and safe medieine, and may be used in all eases without danger; and where there are nervous symptoms, it must never be dispensed with. For a dose take half a tea-spoonful in hot water swectencd; or the same quantity should be put into a close of either of the other medicines, and also into the injections in all nervous eases.

\section{COMPOSITION, OR VEGETABLE POWDER.}

Take two pounds of the bayberry root bark, one pound of the inner bark of hemlock, one pound of ginger, two ounees of enyenne, two ounces of eloves, all pounded fine, sifted through a finc sieve, and well mixed together. For a dose take a terspoonful of this powcler, with an equal quantity of sugar, and put it to half a tea-eupful of boiling water ; to be taken as soon as sufficiently cool, the patient being in bed or by the fire, eovered with a blanket.

This composition is caleulated for the first stages, and in less violent attacks of disease. It is a medieine of much ralue, and may be safely used in all complaints of male or female, and for children. It is good for relax, dysentery, pain in the stomach and bowels, and to remove all obstructions eaused by cold, or loss of inward heat. By taking a dose on going to bed, and putting a hot stone to the feet, wrapped in wet eloths, it will cure a bad cold, and will generally throw off discase in its first stages, if repented two or three times. If the symptoms are violent, with mueh pain, addl to eael dose a tea-spoonful of No. 6, and half a tea-spoonfinl of No. 1, and in nervous symp-toms ald half a ten-spoonl'ul of nerve powiler; at the same time give an injection of the same. If these slould not answer the purpose, the patient must be carried througl a regular eourse of the medicine, as has been before deseribed. 


\section{COUGH POWDERS.}

Take foul' tea-spoonfuls of skunk cabbage, two of horehound, one of wake-robin, one of No. 1, one of No. 2, oue of baybcrry bark, one of bitter root, and one of nerve powder, all made fine, and well mixed together. When taken, to be mixed with molasses. Take lalf a tca-spoonful of the powder on going to bed ; keep warm and continue taking it until relief is obtained, particularly on going to bed.

Where the cougl has been long standing, it will be the best, whilc taking this prescription, to go through a regular course of mediciue, aud repeat it if necessary.

\section{CANCER PLASTER.}

Take the heads of red clover and fill a brass kettle, and boil them in water for one hour; then take them out and fill the kettle again with fresh ones, and boil them as before in the sime liquor ; strain it off and press the heads to get out all the juice, then simmer it over a low fire, till it is about the consistency of tar, when it will be fit for use. Be carcful not to let it burn. When used it should be spread on a picee of bladder, split and made soft. It is good to cure cancers, sore lips, aud old sores.

\section{SALVE。}

Take one pound of beeswax, one do. of salt butter, one and a half (lo. of turpentine, twelve ounces of balsan fir" melt and simmer them together" ; then strain it off in to a basin, and kecp for use. It may be used to heal fresh wounds, burns, scalls, and all bad sores, after the inflammation is allayed, and wound cleansed.

\section{STRENGTHENING PLASTER.}

Take burdock leaves and unllen lenves, bruise them and put them in a kettle, with a sullicient quantity of water, and boil them well; then strain off the liquor, press or squeeze the 342 
leaves, and boil it down till about half as thick as molasses; then add three parts of rosin and of turpentine, and simmer them well together, until the water is evajornted; then pour it into cold water, and work it with the hands like shoemaker's wax; if too hard put in more turpentine, when it will be fit for use. It should be spread on soft leather and applied to the part affected; and is good to streygthen weakness in the baek, and other parts of the body.

\section{VOLATLE SALTS.}

Take erude sal ammoniac one oumee, pearl ash two ounces, and pound each by itself, mix them well together, and keep them well stopped in a bottle for tuse. Damping it with spirit or essence will increase the strength. This applicd to the nose is good for faintness and to remove pain in the head, and is much better than what is sold by apotlecaries.

\section{NERVE UINTMENT.}

Take the bark of the root of bitter sweet, two parts of wormwood and camomilc, cach equal, one part, when green, or if dry moisten them with hot water; which put into any kind of soft animal oil, and simmer them over a slow firc for twelve hours; then strain it off and add one ounce of spirit of turpentine to each pound of ointment. To be used for a bruise, sprain, callous swelling or for corns.

\section{POULTICE.}

Make a strong ten of raspberry leaves or of No. 3 ; take $\Omega$ clneker pounderl fine, and slippery clm bark pulverised, with ginger, and make a poultice ol the same. This is good for old Eores, whitlows, felons, and for barl burns, scalds, and parts liozen. A pply this ponltice, and apply it as often as cvery twelve honls, and wash with soapsuds at every rencwal ; wetting it in the interim with cold watcr, or a tea of rasplerry leaves, till it discharges; then apply the salve till a cure is alfected. 


\section{INJECTIONS OR CLYSTERS.}

This manner of administering medieine is of the greatest importanee to the siek; it will frequently give relief when all other applications fail. It is supposed that the use of them is of great antiquity ; but whetber this be true or not, the using them to relieve the sick was certainly a very valuable discorery; and no doubt thousands of lives have been saved by it. The doctors have long been in the pratice of directing injections to be given to their patients, but they seem to have no other object in administering them than to cause a movement in the bowels; therelore it was immaterial what they were mate of.

Aceording to the plan which I have adopted, there are eertain important objects aimed at in the administration of medicine to remore disense, viz., to laise the internal heat, to promote perspiration, remove the canker, guard against mortificatious, and restore the digestion. To aceomplish these objects, the medicine neecssary to remove the complaint must be applied to that part where the disease is seated ; if in the stomach only, by talking the medicine it may be removed; but if in the bowels, the same eompound must be administered by injection. Whatever is good to cure disense if taken into the stomach, is likewise good for the same purpose if given by injection, as the grand objeet is to wam the bowels and remove the eanker. In all eases of dysentery, eholic, piles, and other eomplaints, where the bowels are badly affected, injeetions should never be dispensed with. 'They are perfeetly safe in all cases, and better that they be used ten times when not needed, than onee neglected when they are. In many violent cases, particularly where there is clanger of mortification, patients maty be reliered by admintistering medicine in this way, when there wonld be no chamee in any other. I do, therelore most serionsly advise that these considerations be always borne in mind; and that this important way of giving relief be never negleeted where there is any chance for it to do good. In many eomplaints peeuliar to females, they are of the greatest importanee in giving relief, when properly attended to ; for which purpose it is only necessary to repeat what has been before stated ; let the remedy 344 
be applied with judgment and diseretion, to that part where the disease is seated.

The common preparation for an injection or elyster, is to take a tea-eupful of strong tea made of No. 3, strain it off when hot, add half a tea-spoonful of No. 2, and a tea-spoonful of No. 6 ; when cool enougl to give, add a tea-spoonful of No. 1, and the same quantity of nerve powder. Let it be given with a Iarge syringe made for that purpose, or when this eannot be had, a bladder and pipe may be used. They must be repented as oeeasion may require till relicf is obtained.

Many other artieles may be used to advantage in the injections; a tea of witch hazel and red raspberry leaves, either or both together, are very good in many cases. For eanker a tea of either of the articles deseribed under the Inead of No. 3, will answer a good purpose. When the eanker is removed, the bowels will be left sore, in which ease give injeetions of witeh hazel or raspberry tea, with slippery elm bark. When injeetions are used to move the bowels only, No. 1, should be left out. - It is always safe to add the nerve powder, and if there are nervous symptons, it must never be omitted.

\section{STOCK OF MEDICINE FOR A FAMILY.}

l oz. of the emetic herb.

2 ozs. of eayenne.

$\frac{x}{2}$ Ih. baylorry root bark, in powder.

1 Ib. of poplar bark.

1 pint of the rhcumatic drops.

This stoek will be sufficient for a family for one year, with such articles as they can casily procure themselves when wanted and will enable them to cure any disease, which a fomily of eommon si\%e may he afflieterl with during that time. The expense will he small, aul much better than to employ a doctor, and have lis extravarant bill to pay. 


\section{GENERAL DIRECTIONS IN CURING OR PREVENT- LNG DISEASE.}

1. Be eareful to always keep the determining powers to the surfaee, by keeping the inward heat above the outward, or the fountain abore the stream, and all will be safe.

2. It mnst be recolleeted that heat is life, and eold death; that fever is a friend, and eold an enemy; it is therefore necessary to aid the friend and oppose the enemy, in order to restore
liealth.

3. That the eonstruetion and organization of the human frame is, in all men, essentially the same, being formed of the four elements. Earth and water eonstitute the solids of the body, whieh is made aetive by fire and air. Heat, in a peenliar manner, gives life and motion to the whole; and when entirely overpowered, from whatever eause, by the other elements, death
ensues.

4. A perfeet state of health arises from a due balanee or temperature of the elements; and when it is by any means destroyed, the body is more or less disordered. When this is the ease, there is always a diminution of heat, or an inerease of the power of eold, whieh is its opposite.

5. All disorders are eansed by obstruetive perspiration, whieh may be prodneed by a variety of means; that medieine, therefore, must be administered, that is best ealeulated to remove obstruetions, and promote perspiration.

6. The food taken into the stomaeh, and being well digested nomrishes the system and kceps up that heat on whieh life depends; but by eonstantly taking food into the stomach, which is sometimes not suitable for nourishment, it beeomes foul, so that the food is not well digested; this eauses the body to loso its hent, aad disease follows.

7. Canker is eaused by cold, and there is always more or less of it in all eases of disense; contimne to make use of such articles as are ealenlated to remore it, as long as there is any
appearanee of disorder. 346

8. When tho disease is removed, make free use of those 
things that arc good to restorc the digestive powers, not forgetting to kecp up the inward heat by giving occasionally No. 2.

9. Jiceping always in mind, that an ounce of preventive is bettel than a pound of curc ; and give medicine on the first appcarance of disorder, before it beconues seated ; for it may then be easily thrown off, and mueh sickness and expense prevented.

10. In cases of fever, increase the intcrnal heat by giving hot medicine, so as to overpower the cold, when the natural heat will return inwardly, and the cold will pervade the whole surface of the body, as the heat has done before; this is what is called the turn of the fevcr.

11. If No. 1 should sicken and not pukc, there may be two causes for it, viz., the coldness or the acidity of the stomach.For the first give No. 2 more frecly, and for the latter, dissolvo a piece of pearlash about the size of a large pen, in a wine glass of water, and let them take it, which will counteraet the acidity. If this fail, make use of the stenm, which will open the porcs, extract the cold, and set the medicine into operation.

12. In giving medicine to children, give about onc half, a little more or less, according to their age, of the quantity direeted for a grown person. Bc particular to offer them drink often, especially young children, who cannot ask for it.

13. Dysentery is caused by canker in the bowels, for which make frec usc of the tea of No. 3 with No. 2, and grive the samo by injection, in the first of discase, and afterwards give tho syrup, (No. 5,) to strengthen the stomach and bowels, and restore the digestive powers.

14. The piles are canker below the reach of medicine given in the usual way, and must be cured by using a wash of No. 3, mado strong, and by giving injections of the same, with No. 2. What are called bearing down jains in women, is fron the same cause, and must be relieved by injections made of witeh hazel, or red raspberry tca, steeped stmong, with No. 2, strained. If this does not give relief, go through a regular courso of melicinc. 
15. Women in a state of pregnancy ought to be carried through a regular course of medicine, especially when near the time of delivery. When in travail, give raspberry lcaf tea, with a tea-spoonful of the composition powder, or No. 2, and keep them in a perspiration. After delivery keep up the internal heat, by giving the eomposition powder, or No. 2.
This will prevent after-pains. If there should be symptoms of
fever, carry then the fever, carry them through a regular eourse of medieine, which will guard against all alarming complaints peculiar in such
eases.

16. In all cases of a buln, scald, or being frozen, wrap the part in cloth wet with cold water, often wetting them with the same to prevent them becoming dry, and be carefinl to give hot medieine such as No. 2, or the eomposition powder, to keep up the inward heat. Pursue this plan for twelve hours, and then, if the skin is off, apply the poultice or salve. If there should be convulsions or fever, a regular course of the medicine must,
without fail, be attended to.

17. When a scald is over the whole or greater part of the body, apply eotton eloth of several thieknesses to the whole body, wet with a tea of raspberry lcaves, frequently wetting thicm with the same to prevent its beeming dry, and give then the hot medicine. When the seald is under the stoeking, or any other tight garment, let it lemain on, adding more cotton eloth, and wet the whole with cold water as often as the smart
of the burn returns.

18. If the skin is off, or in ease of an old burn, to gnard against eanker, apply a poultice of cracker and slippery elm bark made with a tea of raspbcrry lcaves, washing it with soap suds, when the poultice is changed, and then with the same ten. When any part is frozen, the same method must be taken as with a burn.

19. For a fresh wound, cut, or bruise, wash immedintcly with cold water, and bind up with cloths wet with the same; keep a hot stone at the feet, and take medicine to raisc a gentle perspiration; continue this till the inflammation is allay cul, and the wound perfeetly cleansed, then alply the ponltiee or salve till healed. The air must be kept from all wounds or sores, as it will cause pain, and prevent them from haling. 348 
20. In spotted or deadly attacks, such as spotted or yellow ferer, fits, drowned persons, eroup, \&e., the lieat and aetivity of the patient is so muel diminished, that the common administration will not give relief, the determining power to the surface being so small, through the loss of internal heat, that it will not give the medicine operation, as its effects are resisted and eounterbalaneed by the pressure of the external air. To counteract this pressure, keep the room, by aid of a good fire, about as warm as summer lieat; and more fully to rarify and lighten the air, and aid the operation of the medieine, make a free use of the steam bath, and keep the patient shielded by a blanket, at the same time give Nos. 1 and 2. This course should be unremittingly persevered in till the patient is relieved. Keep always in mind to give the patient fresh air when steaming, and while going throngl a course of medicine, by making a quick fire of shavings, or very light wood, and opening a door or window at the same time; as this will immediately ehange the foul air in the room, by driving it ont, and supplying its place with fresh air fiom the surrounding atmosphere, This mode is essential in all disorders, both in hot and eold weather. Steaming is not essential in hot weather, exeept when groing through a course of medieine; after whieln a shower bath is good in the molning, as it lets down the outward heat, and gives power to the inward.

21. If the glands are dry, so that. there is no moisture in the mouth, or if the patient is much pressed for breath, give a strong tea of No. 2, sweetened, and repeat it till the mouth becomes moist. No. 3 should be used while the moutl is dry, without adding a large portion of No, 2.

22. Be eareful not to have the outwarl heat too high, by too many cloths or too much fire; for if this be the case, it will eanse a balanee of the ontward and inward heat, and will prerent the mediene from operating, by stoplung the cireulation; and the patient will he rery much distressen. - When this liap)frens, throw cold water on the fitee and stomach, and give more loot merlicine, whichl will let down the ontward heat, and raise the inwart.

23. If the patient is restless, wet the lieal and body with 349 
coll water, and if there are convulsions or spasms, give the nerve powder with No. 2. Injections must also be used.

24. Never make use of physie in eases where there is eanker inside, for it will draw the determining powcrs inward and increase the disease. I have seen so many bad effects from giving physic, that I have disapproved of the use of it altogether, but if any is given, after the operation, be eareful to keep up the inward heat, so as to cause a free perspiration.

25. Avoid all minerals used as medieine, sueh as mereury, arsenie, antimony, calomel, preparations of eopper or lead; and also nitre, and opium. They are all deadly poisons, and
enemies to health.

26. Beware of bleeding and blisters, as they ean never do any good, and may be produetive of mueh harm, they are contrary to nature, and strengthen the power of the enemy to health. Seatons and issnes slould be avoided, as they only tend to waste away the strength of the patient, without doing any good; it is a much better way to remove the cause by a proper administration of medieine, whieh will be more eertain
and safe in its effects.

27. Be careful not to make use of saltpetre in any way whatever; it is the greatest cold of any thing that can be taken into the stomach, and was never intended for any other purpose than to destroy life. It is a very bal practice to put it on meat, for it destroys all the juices, which is the nourishing part and leaves the flesh hard and difieult to digest.

28. Never cat meat that is tainted or in any way injured, as it will engender disease; for one ounee in the stomieh is worse than the effuvia fiom a whole carease. Lat salt provisions in hot wenther, and fiesh in eold.

29. Be careful about drinking cold water in rery hot weather, as it will tend to let down the inward heat so suddenly is to give full power to the cold. If this should happen, its fital effects may be prevented by giving the hot medicine to rase the inward leat above the outwart. Be enreful also not to cool surldenly, after being very watm in consequence of uneommon cxercisu. 350 
30. Remember tlat regularity in dict, is very important to preserve health; and that if more food is taken into the stomach than is well digested, it clogs the system and causes discase. This is very important to those who have weak constitutions.

31. Ardent spirit is a slow poison; it is taken into the stomach to stimulate, but the effect is soon over, and much use of it destroys the tone of the stomach, injures the digestive powel's, and causes discase. It is therefore much better, when the feclings lequire any thing of the kind to make use of stinsulating medicine, such as No. 2 and 6 , for these will answer a fir better purpose.

By a strict observance of the forcgoing dircetions, you may save much pain and expense, and cnjoy good health, and long life which is the camest wish of the writer.

\section{DESCRIPTION OF SEVERAL DISEASES, WITH DIIECTIONS FOR THEIR CURE.}

BY M. ROBINSON, M. D.

\section{FELONS.}

A felon always comes on a joint, and is often carsed by some strain or bruise, which makes a leak in the joint or muscle, and the sooner it has vent the better. If it comes on the inside of the hand, and is brought to a hear by poultieing, it will often break through the back of the hand belore it can get through the thick skin on the inside. The best way to give it vent is to bum a piece of spunk* the size of lialf a pea, on the place affected. If you think the flesh is dead down to the matter, yon may stick the point of a needle into the dead skin and raise it up, and cut ont a piece nnder the needle sufficient to let out the matter; then apply ponltice or salve; if painful, wrap it in eloths of severnl thicknesses, wet with cold water, and re-

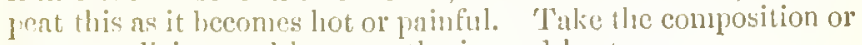
warm merlicine, and keep up the inward heat.

If the sore has been sereral days coming, and appears nearly

* Iiqtier wuod, or louchwood. 
ripe, applying a picee of nuslicked lime to it, and wet the eloth with eold water, till the lime is slacked; and repeat this till the skin looks of a purple eolonr ; then open it as before direeted. This method is safer and quiekel in causing a ellre, than laying it open with a knife, as is the practice of some doctors. Cutting the live flesh, forms a leak, and often spoils the joint; but by searing by either of the above modes, it seeures and prevents the leak, and makes a speedy eure.

\section{FREEZES AND BURNS.}

These two disorders are one and the same thing, and require the same treatment. Take a eloth wet with eold water, and wrap several thicknesses round the part, to be wet as often as the pain inereases. Give warm medieine inside. If the scald is dangerous, earry them through a regular course of medieine, as though they had a fever, or any other aeute disorder; keep the eloth or poultice on to seeure it from the air, from 12 to 14 hours, till the soreness or pain is entirely gone. - If the skin is off, a poultice of wheat bread, wet with any of the articles composing No. 3, keeping it wet with the tea till the sore disehages, then wash with soap suds; when dressed wash with the ten of No. 3 and eontinue the poultiec or salve mutil a eure is effected.

A freeeze is a direet cold, and a burn is an attractive cold; for as mueh as the heat opens the pores more than 11sual, the eold follows and eloses them as mueh more than they were before the operation of the heat-this stops the perspiration from going through the surface, and the watcr collects under the grain of the skin, which is ealled blistering : the water applied on the outside opens the pores and lets the water ont by perspiration, and the grain allueres to the skin-the pain censes and the eure is completed.

\section{CURE OF A SCALD.}

The patient was I y years of age, and was tilking from the fire a kettle of boiling ciler, which he tipper, and poured it boiling hot into a large bed of live embers, which eorered his 352 


\section{TIIE BOTANIC FAMILY PIIYSICIAN.}

feet with this hot mass ; he was obliged to hold on till the kettle was set on the floor, and then jumped into a pail of cold water, and stood there till his father procured some eloths, in which he immediately wrapped his feet; his farlher attended to pouring on water to keep the eloths filled. This keeps the air firom the surface, and eases the pain ; fol as the water wastes and lets the air to the burn, the pain will inerease. By pursuing this course for about two hours, the boy fell asleep. Water was poured on the eloths but two or three times during the rest of the night, and in the morning preparation was made to dress the wound, when to the surprise of all present, no blister had risen, nor a partiele of skin broken. IIe put on his stockings and shoes as usual, and went about his work perfeetly well.

\section{CASE OF A BOY WIO IVAS BADJY SCALDED.}

A lady took from the fire a tea-kettle filled with boiling water, when her little son, abont six years old, turned the eontents on both his feet, and falling, one hand went into the teakettle; both feet and one hand were very bally sealded. I happened to be present, and immediately tore up eloth suffieicnt to do up each part, wetting them with coll water. He was put to bed and I gave him some warm medieine, put a warm stone at his feet, and wet the eloths as often as he complained of pain. In about two hours he fell asleep, after whieh two or three times wetting the eloths, kept him easy through the night. In the morning, on taking off the eloths, there was ro appearanee of blisters, nor any skin broken, and he put on lits stockings and shoes, and appeared as well as he was before the aecident. It was the opinion of the family, the night hefore, that the boy would not he able to go to seliool for a fortnight; lut on finding him well the next molning, they were lardly able to beliove their senses, or that the child had been sealled.

\section{FURTIIER RENARIES ON BURNS.}

Burns are the most casily curerl, if rimhtly mannged, of any wounds I ever attended; and are most iliflicult and dangerons 
when not understood, and wrongly treated. IIow often have we seen these sores continue all the winter, and could not be healed? as also, burns by blısters made with Spanish flies, which amount to the same thing.-By not heing treated in a proper mannel in season, the canker gets in and eats out the flesh, after which, what is called proud flesh, fills up the sore. The doctor applies his sugar of lead, vitriol, red preeipitate, to eat out the dead flesh ; this effeets the cords and draws them ont of shape, and often makes a sore that they cannot cure, which terminates in a mortifying canker sore. Thereforc immedintely attend to the cankel, which always awaits snch cases, and where the skin is off, in cases of burns or blisters, apply a poultice of crneker, or elm bark wet with a ten of No. 3. until the canker is gone. Sometimes add ginger, keeping the ponltice wet with cold water; when the sore diseharges, apply salve until a eure is eflccted.

Observe the evil effeets of blistering. I knew a case where a doctor drew a blister on a child's breast up to the neck, for stuffing at the Iungs. It lingered with this seald near its vitals about a week; I was then called to visit the child and found it to be dying. The mother asked me what I thought was the matter with it. I took off the dressing and showed her tho mortified flesh over the blister, and told her that was the disorder; she seemed much surprised, and I then asked her if tho child had been scalded, and had mortified in the same manner, whether she would have had any doubt of its being the canse of her child's death! She said she would not. I gave her my opinion that it was exactly a similar case, and that the child's death was caused as mueh by the blister, an it would have heen by a seald. The ehild died before moming. I had declinal doing any thing for it, as I was satisfied I could do no good; it I had mado tho attempt, it would have been said that I killed it.

I have seen many cases where I was perfectly satisfied tlat the patient died in consequence of blisters, not only on the stomach, but on the hear. In many cases where a blister was drawn on the hend, as it begnon to draw, their senses were gone, and they died ravilur or strupifict. MLore than half the cases where the heal was shancd and blistered that have conc wilhiu $\therefore 51$ 
my knowledge, have proved futal. I can sec no reason why a scald on the head or the boty, done designedly, should have a tendency to cffect a curc, when persons arc sick, and the same thing happening to them by aceident, when well, should destroy their hcalth or carse their death. If a person should have his heal or stomach so badly scaldecl, as to take off the skin, we should consider him in a most clangerous condition; but nothing is said about it when it is resignedly done. I shall leave it to the reader to reconcile, if he can, this inconsistency, -I have known most dangerous stranguries causcd by blistcrs; ancl those who applicd them dicl not know the cause, and many have applied to me for relicf.

\section{MORTIFICATION OF TIIE LIMBS.}

I was called on to go on board a ressel to sce a young man, who had a block fall from the mast head on his foot weighing 13: liss, which brtuised all his toes to pices, exeept the little one. The accident happened on Friday, and I did not sce him till the Tueslay following, during which time he neither ate nor slept. Ifis nerves were much affected, and he had sjasms and convulsions through the whole system. I took off the dressing from the foot, and found it black, and the sincll vely ollonsive. The captain of the vessel sppenerl to be very anxious ahout him, and asked me if I coulil help his font-I told him [ must try to save his life, for his whole bolly was as much disorrered as his foot. He represted me to do what I thonght liest. I put a poultice of meal on his foot, and wet the cloths with colrl water to alliy the leat; then gave him menlicine the

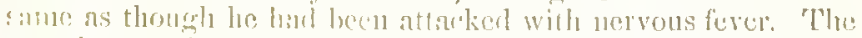

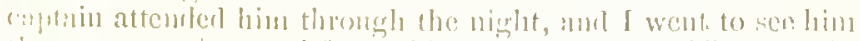

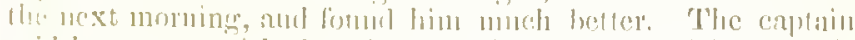
sait he was astonished at the opelation of the neclicine, for his vomiting and sweating harl carried off all the pain in his boty and loot, and hat also reconciler the nerves.

I unboumd his foot and fommd that the black and yellow

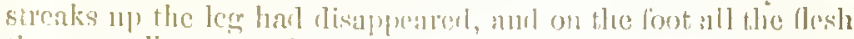
that was alive scemed to receive fiesh s11]port from the bouly; 
and the living and dead flesh appenred as though two eolours were painted by the side of each other. I then made a ley of pearl ash and warm water, and soaked his foot in it, which calleced a slimy glaze over his foot; this took away all the offensive smell. I then washed it with vinegar to lill the alkati, and keep it from irritating the skin. The acid cleared of all the sliny matter, so that it wiped elean. I then cut off the grent toe at the midale joint, and the two next at the upper joint, and set the next which was broken. I cut out the dead flesh, to stop in part the putrefaction. I then put on another poultice, and ordered it to be kept wet with cold water, and a wam stone wapped in a wet eloth, to be put to his feet to keep a stcam, giving lim wam medicine inside to keep up the inward heat; and by wetting the foot with cold water, it kept the determining power to the surface, thus raising the fountain and lowering the stream. By this treatment it is as impossible for mortifiention to go fiom the limbs to the body, as it roukl be for the log that floats over the dan to go back into the pond, when the fountain is kept full. The next day I dressed his foot and found that the dead flesh had digested very much ; I again sorked it in the ley, and next washed in vinegar as before, which was of great service in allaving the bad smell. I then caused him to be carried through a regular course of medicine, which completely restored him to bodily health; his alpretite was good, and all pain and soreness abated, so that he trook food regularly, and lost no sleep afterwarls, till he got entirely well which was in abont four weeks. The captain was a vely good nurse, and was faithfil in attenlance on the yonng man till he got well; and expressed the highest gratituile for my attention and suecess ; and as a proof of his coutidence he very handsumely remunelated me.

\section{OLD CANKER SORLS ON TIE LEGS.}

When I was a young man, I was much troubled through the winter, for many yeatrs, with sores on my legs. At the come mencement of cold weather, if I hrole the prain on ny slin, it would become a bad sore, and contime through the winter; the canker would get into it and eat into the bone, and some356 
times spread under the grrain like a burn, and feel the same, luing extremely sore, with stings and twinges like a eancer. These soles were so tronblesome, that it lead me to invent a cure. Finding the canse to he eanker, I took some of the articles composing No. 3, steeped strong, and washed the parts affecter with it; if there was a bad smell, I first washed the sore with strong soap suds, taking oft all the loose skin, which was blistered with cankery hmmour, and then washed with a tea of No. 3, to destroy the canker and harden the sole ; sometimes wetting it with drops. My present mode of treatment is as fullows: If the inflammation rums ligh, and the sore spreads fast, I put into it a pinch of finc No. 2, then put on a poultice of white bread and ginger, wet with the above tea, wrapping it up with screral thielienesses of cloth, and wetting it with eold water as often as it beeomes so dry as to be painful, being careful to exclute the air for twenty-four hours. In this time it gencrally discharges ripe matter, and the infammation and canker abate. When next dressed, the sore should be first washed with soap sulls as before, then with the tea. If the soreness is gone, you may apply the healing salve, with the wet cloth. On groing to bed, be carefinl to exchude the cold air, by occasionally putting a hot stone wrapped in wet cloths, to the feet, so as to keep up the steam. If the sore is painful, wet it with enld water. Give the medieine to keep up the inward heat, such as composition of hot bitters, and when these do not answer the purpose, go through a conise of medicine, and repeat as ocension may refuire. 'This method, if petsevered in, I seldom knew to fail of suceess.

I was called to attend a case of this lind not long since, where the inflammation and pain were very great, aurl fust sprearling under the grain of the skin. There list been applied an $\mathrm{elm}$ and rringer ponltice, made with a tea of No. 3. I took off the chessing and applicel a pinch of $\mathrm{N}^{\mathrm{N}} \mathrm{.} 2$, to the sorc, atter which I laid on the same poultice, putting on a cloth which I kept wet with cold waler till the next morning, when on hess-

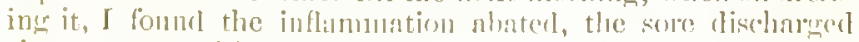
rife matter, and by two clressings nuove of the same, the cillo was completed. 


\section{CASE FROM THE BITE OF A RAT SUPPOSED}

TO BE MIAD.

Not long since I was sent for to attend a man who had been bitten on one of his elbows by a rat, snpposed to be mal. The wound healed in a few days, then tmoned purple round it, as thongh the blood had settied and tmmed black, until he was blind. He was sick at the stomach, and had a high fever. I ealried him throngh a conlse of medicine, but with little advantage. The swelling and dark colour progressed most rapidly, till his face became ery black. These appearances led me to suspect that the madness of the rat was caused by eating ratsbane, and this poison was communicated to the man by the bite, as he appeared the same as a person I had once secn who had been killed by taking that poison. I then washed his face with a strong tea of Nos. 1 and 2, and gave the same inwardly with No, 3, carried him throngh another conse of medicine, kecping a eloth on his face wet with the tea, as lefore, to keep out the air, when under the operation of the medieine, to sweat his face and thow the poison ont. I kept him in a sweat for several days, oceasionally with his face secured from the air, which method lial the desired eflect, by bringing the poison out. By continually keeping up the perspiration, the surelling abated, but whenever this was not attended to, so as to keep the determining powers to the surface the spasms would increase to such a degree that his life was frequently despaired of. He was carefully attended in this manner abont one month before I eonld determine in my own mind whether the disease or nature would gain the victory; after which he bermn gradually to l'cgain his health, and in about six months lie appeared to be clear of poison. The man was sixty years of age; and the accilent happened in the fill of the year, which rendered it more difficult to eonquer this colel and deally fuison, than it woulel have been in warm weather.

\section{BAD WOUND IN THE EYE CURED.}

A man entting turf, and accidentally had a pitchfork stnck into one of his cyes, by a person who wa pitehing the turf 358 


\section{THE BOTANIC FAMILT PIISICIAN.}

near him. It passed by the eye ball and stuck fast in the skuli, so that it was with eonsiderable exertion that he eould draw it out. The eye swelled and elosed up immediately, and the people were nuch frightened, and sent for me; but I eonld not go. I gave direetion to the man who eame lor me, to return and carry him through a eourse of medicine as soon as possible, keeping several thicknesscs of cloth wet with cold water, on his eye, and not to open it for twelve hours; and to keep him in a perspiration the whole time. This was faitlufully attended to, and on opening the wound after the above time, the swolling was all gone, the eye was open, and a large quantity of blood was in the wet cloth, which had been drawn from the eye. They continued to wet the eloth, and gave him warm medieine inside, keeping him in a gentle perspiration for the ncxt twentyfonr hours, which eleared the eye of all the blood, restored the sight, and amended his health, so that he was well in about a wcek, to the astonishment of all who saw him.

\section{CANCER SORES.}

The eause of this sore is very little understood. In all sores of an eating nature there is more or less canker, aeeording to their violence. $A$ eaneer is the highest degree of eanker, being the most powerful efteet of cold, and conscquently the greatest degree of inflammation, therefore the remedies ought to be those of a warming nature, as the grcatest preventive against canker. Whenever a violent inflammation is discovered, it is supposed that heat causes the difficulty; bnt the fact is, it is only an evidence of war between heat and cold, for there is no inflammation where there is perfect health, because heat then hears complete rule; and no disease can take place until the cold makes an attack on the body, whieh eauses an nmatural heat to oppose an unnatural eold. Whenerer the cold talies possession the inflammation shows itself, by stopping the circulation; the effect is, swclling, inflaned callous, arising from some leak, canserl by the natural enure beiner stopperl. If it suppurites and dischares it is called uleer, bile, and the like, and the canker groes off with the pustriction. If the leak is so low as to gret callous as fast as it discliarges, it becomes a hard, dead lump 
of flesh, and not having circulation enough to support it, begins to rot; here the cauker shows its heating nature, being seated in the dead flesh, and eating on the live flesh, which is intermixed with it, causes pain and distress, in proportion as the body is filled with coldness and canker; if this is sufficient to lieep the power above the natmral circulation, the patient will contiune in this distressed situation, being eaten alive, until worn out with the pain, death comes as a friend to relieve him. This is the natmoal termination of this dreadlul malady, which is far better than to combine with it the common form of practice in using arsenic, which only helps to eat up and distress
the patient.

In order to give a more correct idea of the dangerous effect of making use of arsenic in cancers, I shall make a short extract from Thacher"s Dispensatory, on the subject. "Arsenic has long been known to be the basis of the celebrated cancer powder. It has been sprinkled in substance on the ulcer, but this mode of using it is exccssively painful and extremcly dangerous, fatal effects having been produced fiom its absorption."' This fact I have known in several instances, where Davidson's ngents, and others, have undertaken to draw out caucers, when the patients wonld absorb enough of this poison, which seating on the lungs, caused them to die of consumption in the comse of one year. My wish in exposing such nostrums, is to benefit those who may be ignolant of the imposition ; for it may be relicd on as trith, that there is more or less poison in all those burning plasters used to cure cancers. I would advise all to beware of them. It would be much better to risk the eancer than the cancer quack.

The principal object aimed at is to take out the bunch, and in doing that by the above method, a worse evil is inoculated, which is more fatal than the cancer. The tmmonr is a mixtmre of live and dead flesh, anr is often under a live skin; if it he necessary to make an incision through the live skin, in order to dissolve the dead flesh, the best way is to burn a piece of spunk* on the place, and repeat it till the flesh is dead enongh to suppurate. The smart will be but two or three minutes, and not so painful as the arsenic for the same time, which lasts for

* Rotten wood, or touchirood. 


\section{TIXE BOTANXC FAMILY PIYYSICIAN.}

twelve hours. Where the tumonr is small, the eaneer balsam will be found sufficient, by repeating the plaster for two or three weeks to take ont the dead flesh and remove the canker; after this is done, apply a ginger and clm poultice wet with a tea of No. 3. If the system appeals to be generally affected with the eancer humor, carry them throngh a eommon conrse of medicine, and repeat the same while attending the sore.

I had a cancer on my foot about the size of an Indian eorn, which had tronbled me twiee, by aeute darting pains and trvinges. I cured it by applying a plaster of the caneer balsam, repeating it twice at each time. When there is dead flesh under the skin, it is best to burn the spunk first, and then apply the ponltice or balsam; it is also recommended to give medicine to eradicate the canker from the system, both before and atter the operation on the sore.

Three caneers on the breast have come under my eare, that I could not eure. One of them was as large as a half-peck measure, and grew fast to the breast bone. I earried the woman through a course of medicine several times. and applied a poultice of butternut shueks to dissolve the dead flesh, and continned this eourse for some months, until the bunch had more than half dissolved, and had grown off the bone, so that it was quite loose, and I was in hopes to have eflected a eure; but she was taken with a fever' in my absence, and died. 'The other two I conld relieve, and keep them free from pain, making tlem comfortable as long as they liver; but nature was too far exhausted to eomplete a eure. I have had under my eare other cases of eanecrs on the breast and other parts of the body, whieh I had no diffienlty in ening in the manner beforo stated.

I shall eonelnde the subjeet by a few general remarks, viz. : Guard thoroughly against cankel and eoldness-attend to the canker by a eourse of medicine, and repeat it-use the ginger poultice if the inflammation is great, putting some No. 2 on the law sore, then apply the ponltice, kecping it wet with cold water-not forgetting the composition and No. 2 insicle at the same time. Let all poisonous drugs, buming plasters, and caustics alone-nttend faithfully to the directions here grivenhononr your own judgment-keep your moncy-and bicl defimence to doctor's. 


\section{PILES,-HOW CURED.}

I was called to attend an elderly man who had been eonfined to the house, and muel of the time to his bed, for seren weeks, with the piles. Seven doetors attended him before I was sent for, and lie eontinued to grow worse. The doetors had operated on one side, and said they must on the other"; it was their opinion, as well as his, that he was in a decline. 'The side that they had operated upon was mueh worse to enve than the other. I carried him through a regular eourse of medieine twice in three days, when he was able to go ont of doors. 'The injeetion eomposed of No. 3 steeped, and a small quantity of No. 2, was used; warm tallow was applied sereral times in a day, sometimes washing externally with the same tea. He had been dieted very low; I restored his digestive powers, and he reeovered his appetite; his sores healed, his general liealth mended to such a degrce that he was no more eonfined with that complaint. A little tallow used when going to bed prevents piles and ehafes in young and old. Remember this. For ehafes Folders Earti and water is a never-failing remedy.

\section{SORE HEADS IN CHILDREN,-SCALD HEADS.}

This sore often eomes after haring the itch; it is eontagious, being eaused by ennker and putrefaetion. The most effectual way to eure this disense is to carly them through a eonse of medieine several times, as the ease may require, previons to whieh, the head must be oiled and eovered witl eabhage leaves, or draw a bladder over the head to kecp out the eold air. The liead should be eovered so as to make it swent as milch as possible, in order to dissolve the harl seabs. A fter laying all night the smell will be offensive; Wash the hear in soap snds, when elean, wash it also with a tea of No. 3, after whieh, wasl with a tea of No. 1. Sonetimes anoint it with the rhemmatic drops and nerve ointment-let it eome to the air hy degrees. Be enreful to rund the stomaeh, by giving composition, wam bitters, \&e. The ointment, drops, and No. 1, in powler or juiee, may be oceasionally used togetler or separate. Contime to wash will soap suds, and then No. 3, occasionally, until a eure is effected. 362 


\section{TIIE BOTANIC FAMILY PIXSICIAN.}

\section{SORE BREASTS.}

Some women suffer much from this complaint, which is caused by cold, occasioning obstructions in the glands of the breast When they are swelled, bathe with the rheumatic drops, or pepper vinegar ; if this does not remove the swelling, and it should be necessary to bring it to a head, apply a poultice of lily root made thick with ginger, or slippery ch bark; at the same time give the composition powder, or No. 2, to keep up the inward heat. It the woman is sick, carry her throngh a regular coursc of medicine, which will remove the complaint and restore health in a short time. I have cured a great many who wcre very bar, by pursning the above plan, and never met with the slightest difficulty. I attended a woman who hal both breasts badly swelled. She was sitting by the window with it up, and could harlly get her breath; she conld not bear to have any fire in the room, complaining that it made her faint. I told her tlat if I conld not make her bear heat, I could do her no good. I gave her some No. 2, to raise the inward heat, and caused a good fire to be marte in the room. The inward lieat, gaincd as fast as the ontward, and in one hour she conld bear as warm a fire as I could. I earried her through three regular conrses of medicine in five rlays, and at the same time applied the lily joultice, which brought them to a hear without pain; and she was soon well.

\section{TO STOP BLEEDING.}

Internal blecding is from the stomach and lungs, and is caused by canker, or soreness of the stomach ; it often tikes place very suddenly, and crontes much alarm. The patient sometimes trembles with fright, and often las fits of the arrue, which is caused by the colit increasing in proportion to the loses of bloot. In the first place shickl them fiom the air with a blanket by the fire, and rive the lottest medicine yon have: if nothing lotter can he harl, erive hot water or any kind of tea ; and get a perspiration as soon as possible; then apply the stenm bath ; giving ginger tea, or No. 2, if yon have it, if not, black pepper. $\Lambda \mathrm{s}$ soon as there is an erguilibrim in the circulation, there will be no more pressure of the blood to the stomacli or lumrs, than to 


\section{THE BOTANIC FAMILY PHYSICIAN.}

the extremities, and the blceding will cease. It has been my plactice in cases of this kind, to give some of the lheumatic drops, shield them from the air with a blanket placed by the fire, then give a dose of composition powders, and No. 2, and if this does not answer the purpose, give a dose of No. 1, which, with the steam, I never knew to fail of stopping the blood; and by giving medieine to remove the canker and to restore the digestive powers, I have always becn able to cffect a eurc. The same application will answer for other weakening and alatming complaints in women.

External bleeding, eaused by wounds in the limbs, may be stopped by plaeing the wound higher than the body. One of my sons eut his leg very badly; I placed him on the floor and took his foot in my lap; as soon as the wound was higher than the body the bleeding eeased. I then poured on cold water till the wound was white, then put in a few drops of No. 6. took two or three stitelnes to bring the wound together, dressed it with salve, and it soon got well with very little soreness. Another case of a little girl who ent off the main artery of the midcle finger, and it bled very fast. I put my thumb abore the wound and stopped the blood, then poured on cold water with my other hand, and washed the wound well, then plaeed her hand above her head, which prevented it from bleeding, till I could get ready to dress the wound. It bled no more, and soon got well.

\section{RUPTURE.}

This diffieulty is caused by a hurt or strain, whieh makes a breacl in the tongh film or meinbrane that supports the bowcls in their place, ant the intestines come dum in the carity between this membrane and the skin ; being sometimes very painfinl, and difheult to get back ; and have to be kept from coming down by a truss. When the bowels come down and remain any length of time, they become swelled, and are very paintil, causing great distress and danger, and sonetimes have proved fatal, as they eamot be grot up aginin till the swelling is remored, This may be cficeted by a conlice of medicine without danger.

$\Lambda$ gentleman was tronhled with ruptule, his bowels eamo down, swelled and were very painlinl, a duetur was sent for 


\section{TIE BOTANIC FAMILY PIIYICIAN.}

from Por smonth, who applied a bag of snow, whieh drove the pain to the stomach, and eaused puking. The swelling increased, and became very had. The case now becoming desperate, and the fimily being alarmed, I was seut for, and on henring the circumstanees, sent some medicine, and gave direetions to sweat him as soon as possible. My dircetions were faithfully attemled to, and as soon as he beeame warm, the nerves slacked, the swelling abated, and all the appenranee of mortification disappealed, the bowels went back, and in twelve hours he was restored from a dangerous situation, to almost his usual state of health. In this case may be scen the difference between the artificial doetor and nature's physieian; whieh is the same as between fire and snow.

\section{AGUE IN THE FACE.}

This is eaused by eold in the glands of the mouth, which keeps back the saliva till it causes swelling and soreness; the eanker becomes prevalent at the same time. which eauses severe pain in the face and throat. The sooner a culc is attempted the better : to effect this take a dose of the ten of No. 3 , with a teaspoonful of No. 6 in it, for the eanker; then tic a small quantity of No. 2 in a fine picee of eloth, wet with No. 6, and put it in between the teeth and cheek, on the same side where the pain is ; sit by the fire eovered with a blanket, and breathe the warm air from the fire; this will prick the glands and eause the saliva to flow very freely, whieh will take out the soreness, and relieve the pain. The face may be batherl at the same time with No. 6. If the ease is of long standing, so that the system is affected, and if this does not lemove the complaint, give a dose of No. l. If it is cansed by decayerl teeth, fill the hollow with cotton worl, wet witl the oil of summer savoury, or spirits of turpentine, whieh will dearten the nerre, and stop its aching. This is gnorl in all cases of teeth-ache, and will generally effect a elle without extracting.

\section{TO RELAX TIIE MUSCIES IN SET'TING A BONE.}

This may he done by balhing the part with warm water, and is nuch bettor than the method that is generally practiserl, of 
extending the museles by the strength of several persons, which weakens the part so much, that the bones are liable to get out of place again; besicles the opjeration causes severe pain to the patient and mueh trouble to the operator, which is all obviated by my methol. In cases where a joint is put out, or a bone broken, give a dose of No. 2, or the composition powder, with lualt a tea-spoonful of nerve powder, which will promote a perspiration, prevent fainting, and quiet the nerves; then wrap the part in cloths wet with water as hot as it can be borne, and pour on wam water for a slort time, when the museles will beeome relaxed, so that the bones may be put in their place
with little trouble.

I was onee ealled to a woman who had put her clbow out of joint by a fall firom her horse. It was badly out, being twisted about one quarter of the way ronnd. I ordered some watcr to be made hot inmmediately, stripped her arm, and as soon as the water was hot, put a towel in a large tin pan, and poured on the water till well wet; as soon as cool enongh, wrapped it ronnd her arm, and poured on the water from the pitcher, as hot as she could bear it, for about 15 minutes. I then took off the towel and directed one person to take hold of the arm above the elbow, and another below to steady it ; and then placed my fingers against the end of the bone on the upper side, and $m y$ thumb against that on the upper side, and by a gentle pressme eaeh way, set the joint without pain or force on the muscles, to the astonishment of all present, who calculaterl that it would requine the strength of several men. I then wrapped it witl the same torrel, which had become cold; this brought the museles to their proper tone, and kept the joint firm in its plare ; I put her arm in sling and sle wallied home ilsat night altont

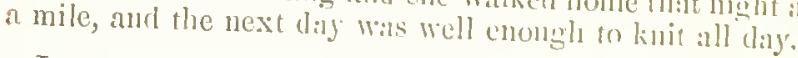

In care a shonlifer is ont of joint, I relax the museles in the same minner, and put the armo orer my slomblere and lift it up, which lias always put the joint in its place, withont an! danger, and very little prain to the patient ; and then by applying cold water, the muscles will become blaced, so that there will be no danger of its getring ont atrinil. I know of a case whele a man had his hip turnol ont, and screral doctors had exhansted theip skill in valin to set it, when one of my argents 366 
being present undertook it by my plan of treatment, and after he liad relaxed the museles sufficiently, and put his knee agaiust the lip joint, turned the lerg out and erowled the joint iuto its place, without any dilliculty.

\section{MEASLES.}

This disense is very common, especially among childien, and is often attended with bad consequenees, when not properly treated. It is a high state of canker and putrefaction; and if the determining power is kept to the surface, it will make its appearance outside, and go off itsclf ; but if cold overpowers the inward heat, so as to tnom the determining power inward, the discase will not make its appenrance, and the patient will become much distressed, frequently producing fatal consequences, if some powerful stimulant is not administered to bring the disoreler out. To give plyysic in eases of the kind is dangerons, as it strengthens the power of cold, and kceps the canker and putrefaction inside, which sometimes seats upon the lungs and causes consumption; or turns to the stomach and bowels, when they die suddenly, as has been the ease with hundreds, for a few years past. I have attended a great many eases of the measles in the course of my practice, and never lost one, and never have known of any that have died of this disorder, who were attended by any of iny agents.-When the symptoms make their apjearnec, give a luse ol the composition poweler, or of No. 2; then give tlee tea ol No. 3, to guaml against eauler, and add some No. 2, to overpower the coll; and when the second rlose is criven, add No, 1, to clear the stomach and promote perspiration; as snoll as this talkes place, the disorler will slow itself ontsile. Isy continuing to keep the determining nower to the surfice, nature will talke its restnliar course, and the "lisease will go ofl without injuring thes ecmstitution. If the bowels appear to be disorelerecl, give an injection; aud be careful to kecp the patient wallur,

$X$ onee had a case of a youngr woman who hard the measles; she lingered with the symptomis four or five days, then heentno

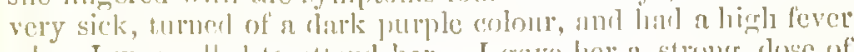
when I was callecl to attenl her. I gave here a stroner dose of 367 
No. 3 , steeped, and put in it a tea-spoonful of the third preparation of No. 1, which caused such a violent struggle that I lad to hold her in bed; but it was soon orer, for in about ten minutes she vomited, and a perspiration took place, which was fullowed by the measles eoming out, so that she was completely covered with the eruption. She was soon well and about
her work.

\section{SMALL POX.}

This disease is the highest state of canker and putrefaction which the human body is eapable of receiving, and is the most eontagious, being taken in with the breath, or communicated by inoculation, in which case it is not so violent and dangerous as when taken in the natural way. The distressing and often fatal consequences that have happened in eases of small pox are more owing to the manner in which it has been treated, than to the discase. The fashionable mode of treatment in this disease, has been to give physic, and reduce the strength, by starving the patients and kceping them cold. This is contrary to common sense, as it wealicns the friend and strengtlens the enemy; and the same cause would produce similar effects in any other disorder. All that is necessary is to assist nature to drive ont the canker and putrefaction, which is the eause of the disease, by kecping the detcmining powers to the surface, in which ease there will be no danger. The same manner of treatment should be used in this complaint as has been directed for the measles. The eankcr rash, and all kints of disease that a person is not liable to have but once, such as ehicken pox, \&c., are from the same causc, and must bo treated in a similar manner

\section{COUGII.}

The gencral opinion is, that congh is an cneny to health, and onght to be treiterl as such ; bit this idea I hold to be altogether an error, for it is the eflect. and not the cause of dis:ease. W'len the lungs are diseased, there with he a collection of matter which must be thrown ofl, and the coungh is like the 368 
pump of a ship, which discharges the water and prevents her from sinking, so also the congl throws off what collcets on the lungs, which if suffered to remain there woukl soon putrify and cause death. It is a common saying, that $I$ have a burl cough, and ean get nothing to stop it, and the doetor often says if $I$ could stop your cough, I should have hopes of a eure, but this is as unreasonable as it would be to stop the pumps of a ship, which would eause her to sink the sooner. Ask a sailor what he would do, and he would say keep the pump going till you ean stop the leak, and when that is stopped the pump will become useless, as there will be nothing to throw off. Such medicine should be given as will promote the cough till the cause ean be removed, which is cold and canker on the lungs; after this is done, there will be no more cough. If a cough is cansed by a sudden cold, it may be removed by taking the composition powder on going to bed, with a hot stone wrapped in wet cloths to produce a perspiration, and at the same time taking the congh powder, which will make the paticnt raisc casy, and also help to remore the eause. When the cough lias become scated, and the lungs are diseased, they must be carried through a regular course of the medicine, repeating the same as occasion may require, till a eure is effected, at the same time giving the cough powder, especially on going to bed.

Whooping-cough must be treated in the same manner-eon tinue to give the powders till cured.

\section{JAUNDICE.}

Much has been said about the bile, or gall, being an enemy in case of sickness; but this is a mistake, for it is a friend, and should be trented as such. It is the main-spring to life, and the regulator of health, as without it, the food could not be digested. When people have what is caller the jaundice, it is tho prevailing opinion tlat they lave too much hilc, and it is said they are bilious; this is a mistaken notion, for there is no sucll thing as there being too much gall-it would be more correct to say there was not cnough. The difliculty is caused by the stomach being cold and foul, so that the foor is not properly digested, and the bile not being appropriated to its natural niso, 


\section{THE BOTANIC FAMILY PHYSICIAN.}

is diffused through the pores of the skin, which beeomes of $\mathrm{a}$ yellow eolour. The symptoms are, want of appetite, eostiveness, faintness, and the patient will feel dull and sleepy ; tlese are evidences of bad dirgestion and loss of inward heat. The only way to effeet a eure is to promote perspiration, eleanse the stomach, and restore the digestive powcrs, whieh will eause the bile to be used for the purpose nature designed it.

Nature has eontrived that each part of the body should perform its proper duty in maintaining health, and if there were no obstruction there would never be disease. The gall-bladder grows on the liver, and is plaeed between that and the stomach, so that when the latter is filled with food, the bile is discharged into the stomaeh to digest it. The bile never ereates disorder, for it is perfeetly innoecnt, being nature's fricnd; and those appcaranees ealled bilious, show the effeet of discase, and not the eausc. 'The gall is a very bittel' substanec, and it is the praetiec of the doetor's to order bitter medicine to cme the jaundiee, and this seems to be the universal opinion, which is colreet, but it eertainly contradicts the notion that there is too mmeh bile, for if there is too much, why give medicine to make more? I have attended many eases of this kind, and never had any diffienlty in cffeeting a eure. My metlod is to give No. 2, or the eomposition powder, to raise the inward heat, and $N_{0}$. , to eleanse the stomach and promote perspiration, then give the bitters, (or No. 4,) to regulate the bile and restore the digestive system is mueh disoldered, they must be earried tbrough a regnlar eonrse of the medieinc, and repeat as oceasion may require, at the same time give the bitters two or three times a day, till the appetite is good and the digestion restored. Any of the articles deseribed under the head of No. 4, are grood, and may be freely used for all bilious eomplaiuts.

\section{WORMS.}

A great deal is said alonit worms eausing sickness, and there is seacely a disease that childeen are aflicted witl but what is attributed to worms. The doetors talk abont worm complaints, worm fevers, worm cholies, \&e., and give medicines to
$3 \pi 0$ 


\section{TIIE BOTANIC FAMILY PIYSICIAY.}

destroy the worms, and, by so doing, they frequently destroy their patients. There was never a greater absurlity thon their practiec, and the universal opinion about woms causing rlisease.

The fact is, they are created and exist in the stomach and bowels for a usefinl purpose, and are firiendly to health, instend of being an enemy ; they are bred and supported by the cold phlegin that collects in the stomach and bowels. This is their element, and the more there is of it, the more there will be of the worms. They who are in health are never troubled with worms, because they are then quict, and cxist in their natural element. Every one has more or less of them and the reason why children are more troulbled with what is called worm conplaints is because they are more sulject to be disordered in their stomach and bowcls, than grown persons. When clildren are sick and their breath smells bald, it is said they have worms, and everything is laid to them, but this is owing to discase caused by canker, for there is nothing in the mature of worns that ean affect the breath. In eases of this kind, the only thing necessary is to cleanse the stonach, by getting rit of the colel phlegm, and restoring the digestive power's, when there will be no difieulty with the worns.

The common practice of the doctors is to give calomel and other noisons to kill the wornes. This must apnear to any one who examines the sulyject to be very wrong as well as rlangerous, for the worms cannot be killed by it, without poisoning the whole contents of the stomach. I onee knew a ense of a child, who, after cating a brealkfist of breal and milk, was taken sick; a doetor wils sent for, who satid it was caused by morms, and gave ealoncl to destroy them, which caused fits. The child vounited and threw up its brealifast. $\Lambda$ dog that hatjpener to be in the room, ate what the child threw up; lic was soon taken sick and blied-the clilel grot well. 'The fin:tuntate accilent of the chilil fluowing off its stomeh what it laal taken, probably saved its life, fror if there was poison enongry

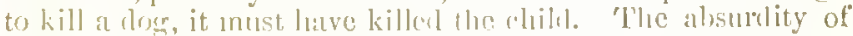
such practice is like the story relaterl by l)r. Writuklin, of a man

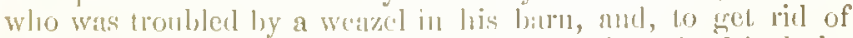

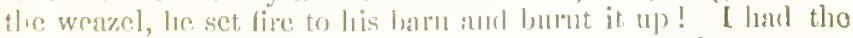
following relition fron the dockor who alteruded the cise : - 
Threc childien had what he called worm fever, and he mudertook to kill the worms. One of them died, and he requested liberty to open it to see what would destroy worms, in order to know how to cure the others, but the parents would not consent. The second died, and the parents consented to have it opened; but, after searching the stomach and bowels, to theip surprise no worms could be found. The third soon after dicd. The fact was, their death was caused by cankcr on the stomach and bowels, and the medicine increased the difficulty by drawing the determining powcrs inward, which aided the coll to promote the canker. Where children dic by such treatment, the blime is all laid to the worms, and the doctor eseapes censure. I have had a great deal of cxuerience in what are called worm complaints, and, after having become acquainted with the real cause have had no difficulty in curing all that I have undertaken. I began with my own children. One of them was troubled with what was supposed to be worms; I employed a doctor, who gave pink root, and then physic to carry it off together with the worms. It would shortly after have another tmon, which would be worse. Ire went on in this way, and the worms liept increasing, till I bccame satisfied he was working on the effect and neglecting the cause, when I dismissed him and undertook the cure myself. I first gave the warmest medicine I then knew of, to clear off the cold phlegm, and gave bitter medicine, such as poplar bark, wormwood, tansy, and physic made of twigs of butternut, to cleanse the stomach and correct the bile. By pursuing this plan, the chitd soon got well. and was no more troubled with worms. A child in the neighbourhood where I lived, about six years old, was taken sick in the morning, and the doctor was sent for, who gave medicine for worms ; soon after it had fits, and continued in convulsions during tho day, and at night died. I was satisfied that its death was hastened, if not caused by what was griven. When tle stomach is discased, or when poison is taken into it, the worms try to fleo from the danger, which causes distress, and tley sometimes get into knots, and stop the passige into the stomich.

My practice has been, in cases of worru complaints, to give the composition powders or No. 2, to wam the stonuch; a tea of No. 3, to remove the canker, and the bitters of either of the articles described under No, 4, to correct the bile. It they 372 


\section{THE BOTANIC FAMLY PIXSICIAN.}

are bad earry them through a eourse of the medieine, and give the bitters. When there are nervous symptoms, give the nurve powder. Injeetions shonld also fiequently be given. The butternut syrup is very good. If there slould be danger of mortifieation, make use of No. 6 , both in the medieine given, and in the injeetions.

The tape worm is from the same eanse as other wolms, and may be cured in the same manner. They are, when single, about half an ineh long, and one-tlired as wide; they join together and appear like tape, and olten eome away in long pieces of several yards. I was onee troubled with them, and used to be faint and had no appetite; I emred myself by taking butternut physie, which brought away several yards at a time; and by taking the hitter medicine to eorreet the bile, was never troubled with them again.

I have often heard about people having a greely worm; but this is a mistaken notion, for there never was any sueh thing. The diffienlty is, the stomaeh is eold and disordered, so that food is not properly digested, but passes off without nourishing the system, and this ereates an unnatural appetite. Remove the eause by warming the stomaeh and eorreeting the digestive powers, and there will be no further diffieulty. I was ealled on to see a young woman, who it was supposed had a greedy worm. It was thought to be very large, and wonld frequently get into her throat and eloke her almost stopping lier breath. Her mother told me that the day before, one of the neighbours was in and told a story about a person having a monster in their stomach, which was taken in by drinking at a brook; this terrible aecount so frightened her daughter that the worm rose into her throat and eloked her so that she had fits. I took the girl home with me and gave her a dose of hot bitters, with some of the nerve powder that night ; the next morning I earried her through a eourse of the medieine as well as $I$ lnew at the time, whieh eleared the stomach and bowels, and strengthcned the nervous system. I told her there was no worm that troubled her, and she lial frith in what I snid. I gruve her merlicine to eorrect the bile and restore the digestion and sho goon got well, leeing no more troubled about the worm. The clifficulty was eaused by a disorderect stomnch and want of digestion, which prorlucerl spasms in the stomach and throat. 


\section{CONSUMPTION.}

This complaint is genelally caused by some acute disorder not being lemoved, and the paticnt being l'un down by the fashionable proetice, until nature makes a compromise with disease, and the honse becomes divided against itself: There is a constant warfare kept up betwecn the inward heat and cold, the flesh wastes away in consequence of not diresting the food, the eanker becomes seated on the stomach and bowels, and then takes hold of the lungs. When they get into this situation, it is called a seated consumption, and is pronouned by the doctors to be incurable. I liave hal a great many eases of this kind, and have, in all of them, where there was life enough left to build upon, been able to effect a cure by my srstem of practice. The most important thing is to raise the inward heat and get a perspiration, elcar the system of canker, restore the digestive powers, so that food will nomish the body and keep up that heat on which life depends. This must be done by a regular course of medicine, as has been directed in all violent attacks of discase, and persevered in till the canse is removed.

This complaint is called by the doctors a hectic forer becanse they arc subject to cold chills and hot flashes on the surface; but this is an crror, for there is no fever abont it; and this is the greatest diffienlty-if there were, it would have a erisis, and nature wonld be able to drive ont the colel and effect a cure, The only difienlty is to laise a ferer, which must be done by such melicine as will raise and hold an inward heat till nature has the complete eommand. When such patients are very weak and low, they will hare what is eniled cold sweats. The cause of this is not minderstood; the water that colleets on the skin does not come through the pores, but is attraeted from the air in the loom, which is wamer that the boly, and condenses on the surface; the same may be seen on the ontsice of a mug or tumbler in a lot day, when filled with cold water, which is from the same cunse. It is of more importunce to attencl to the preventing this complaint, than 10 eure it. If people would make nse of those means whieh I have recommended, and cure themselres of dikenkes in its filst stages and avoid all poisonons drugs, there wonld never be a case of con$8 m$ mition, or any other chronic disorder. 


\section{FITS.}

These are produced by the same cause that other eomplaints are ; that is, eold and obstruetions, and may be cured by a reggular eourse of medicine, which overpower's the cold, promotes perspiration, and restores the rligestive powers. Poison, or any thing clse which gives the eold power over the inward hent, will cause fits, because the natural tone of the museular power is destroyed, which produce violent spasms in the whole systcm. So mueh has already been said on this sulject that it is unnceessary to say more, to give a correet idea of the manner of eure.

\section{ST. ANTHONY'S FIRE, OR ERYSLPLLAS, NETTLE SPRING, OR SUREEIT.}

These are all eansed by overheating the systcm, and eooling too suddenly, which leaves the pores obstrueted, and tben by taking more eold, will bring on a warfare between cold and heat, when they break out, and iteb, and smart, as if stung by an inseet. When the heat gets a little the ascendancy, so as to produce perpsiration, it will disappear till they get another cold. The only way to effect a eure is to give the lot medicine, and steam, till they are brought to the same state of licat as that which first eaused the disease, and then cool by degrees. This I have proved in several instances, and never had any diffieulty in entirely removing the eause in this way. Mako nse of a ten of No. 3, for canker, and the bitters to corret the bile, and a little nerve powder to quict the nerves, and they will soon bo restored to perfeet health.

\section{STRANGURY OR GRAVEL.}

This disorder is often eansed by hard labour and exposure to the coll in the early part of life, and when they frow old, their heat diminishes, the bile becomes thick, and a sediment collects on the bladlder, which obstructs the passages; the glands through whieh the urine passes are clorgged and beeomo diseased, 


\section{THE BOTANIC FAMILY PIIYSICIAN.}

so that there is difficulty in roiding the water, which causes great pain. It is seldom that there is a cure in such cases, but relief may be obtained by a course of the medicine, and making free use of the poplar bark tea. A tea of the hemlock bonghs is very good; and also I have known great relief from using the wild lettuce and pipsisway, the tops and roots bruised and steeped in hot water: Many articles that are good to promote the
urine may be used to advantage.

\section{DROPSY.}

There are two kinds of this eomplaint; one is eaused by losing the inward heat so as to stop the natural perspiration, whieh causes the water that is usually thrown off in this way to collect in the body and limbs. This may be cured by raising the internal heat and causing a profuse perspiration, when the water will pass off in the natural way ; then make use of such medieine as will remove canker and restore the digestive power's when the food being digested, will keep up the natural heat of the body, and also the perspiration. The other kind is caused by cold and obstruction ; but instead of the water collecting and remaining in the body and limbs, a leak forms in the glands and lets it into the trunk of the body, where there is no vent to let it off. This cannot be cured without tapping, and is very seldom completely cured. I have never known but two who were in this situation to be perfectly restored. One was a girl whom I attended. I tapped her aud took away seventeeu pounds of water, and then swathed her up close, and gave medicine to keep a perspilation; she did not fill again and was completely cured. The other was a man-he had been tapped twice. I carried him through a course of medicine several times and gavo the juniper ashes with molasses and gin, which carried off largo quantities of water, and entirely removed the disorder. I have cured a number who had the first mentioned complaint, by the common course of medicine; one woman was cured by taking the wild lettuce, bruised and steeped in hot water. Dropsy is referred to in several parts of this book, and particularly under the IIcrbal departinent. Refer to the Index. 376 


\section{BILIOUS COLIC.}

The name of this eomplaint is erroneous, for bilious means the bile, and no one ever heard of a bilc cholie, or pain caused by gall, as it is a firiend to health, and never eauses discase or dcath. This pain is caused by a disordcred stomach, and want of digestion ; the stomacl is filled with canker, which gets into the narrow passage from the stomaeh, when the action of the bowels cease ; after the pain subsicles, thosc parts wherc it was are very sore. To eure it raise the inward heat by giving the hot medicine; remove the eanker with No. 3 , and giving the bitters to correct the bile, and repeat it till a eure is effecter. If the ease is bad, carry them through a eourse of medicine, and often give injeetions.

\section{PLEURISY.}

This distressing complaint is caused by eold or want of inward heat. I never had any diffieulty in euring it by my eommon practiee. The only remedy made use of by the doctors is to bleed; this only increases the discase by reducing the strength of the patient, withont removing the eause. I was once callcd to a soldier who had a violent pain in his side; the doctor that attended him had bled him five times, without removing the pain, which made him so weak that it was with difficulty he eould be held up in the bed. I relieved him in onc hour by a eommon eourse of medieine, and bathing his side with the rheumatie drops. It took three wceks to get up his strength whieh might have been done in three days if le lad not been bled. I was ealled to another case of the kind, of a soldier at the same place. He had been bled, and a large blister put on his side to remove the pain, which caused a strangury and lie was in great distress. I deelined doing any thing for him without the ennsent of the commanding officer, who was not present. 'The soldier' begged of me to tell him what would do for the latter eomplaint, as he eould not live so. I told him to takc off the blister, which was immediately donc, and it gave lim instant relief. Tyy enrrying them throurly a course of medicine, as has been directed for other violent attacks, will cure all cises 


\section{TIE BOTANIC FAMILT PHYSICIAN.}

of this complaint without danger ; and is much better than blecding or blisters, which inercases the diffienlty.

\section{RELAX.}

This eomplaint is eansed by indigestion, or loss of the powers of the gall; which beeomes thick in eonsequence of cold, or loss of inward heat, when the stomacl will be sonr. The best remedy is to give No. 2, which will thin the gall; eleansc the stomaeh with No. 1, and give the bitters to eorrect the digestion. $A$ dose ot eomposition powders with a ten-spoonful of No. 6 in it, will in most cases effect a cure. The bayberry and poplar bark are good, and also many other articles that have been deseribed as good to restore the digestive powers.

\section{DYSENTERY.}

This is a distressing eompląint, and very eommon, especially among ehildren; although much has becn said on the subject, yet its importance will justify some fnrther dircetions. It is cansed by eold, which gets the ascendaney over the inward heat so as to draw all the determining powers inward; the stomach is disordered, the digestive powcrs are lost, and the bowels beeome eoated with canker ; the food is not digested so as to aftord any nomishment or heat to the system, and all the juices flow invard and pass off by the eommon passage. The eanker makes the bowels vely sole, and when any thing passes them it canses excrneiating pain. The best plan of treatment is to earry the patient throngh a regnlar conrsc of medicine, and repeat it, if oeeasion requiles, every day till relief is obtained. Duling the operation give ehieken broth, and after the disease is ehecked, give oceasionally a little brandy and loaf sugar burned together, and a strong tea of poplar bark. Give the syrup, (No. 5,) two or three times a day, mintil entircly recovered; the bitters (No. 4,) may be given night and norning to restore the digestion. Care must be taken to keep up the inward heat, in the interim, by giving oecasionally No. 2, in a tea of No. 3, sweetened. Steaning is very important in this complaint, and injections must often be aldministered.

378 


\section{RHEUMATISM.}

This complaint is caused by cold obstructing the natural circulation, which causes pain and swclling. It often affects the joints so that they grow out of shape. A cure is easily effected if timely and properly atteneled to, which must be done by sueh medieine as will eause perspiration and remove obstruetions. In common eases taking the rhenmatic drops, and bathing the parts affected with the same, will remove the eomplaint. When the ease is bad, earry them through a course of the medicine, and bathe with the drops, repeating it as oceasion may require till cured. At the same time give a tea of poplar bark or hemlock boughs ; and nany other articles which have becn cleseribed as good for this complaint, may also be made use of to ad. vantage.

The gout is from the same cause, and the stomach being greatly disordererl and very sour, produces a burning sensation. I have eured several cases by the common course of medicine, and giving the bitters to restore the digestive powers.

\section{SORE LIPS.}

They are enmmon in very hot or cold weather, when there is nearly a balance of power of ontward and inward cold, which prodinees canker. To eure it, take a strong dose of tea No. 3, witle a tea-spoonful of No. 2 in it, when going to berl, and wash them with the sane, then wipe them dry to take ofl the matler collected; then wet them with tea, and put on as innelı ginger as will stick; repeat the same two or three times, till the evat is sufficient to keep out the air ; when this comes off" repeat the sane process ayrain, until the soreness is gone; then wash agrnin with tea and wipe them dry, and apply warm tallow till a cure is completed.

\section{SORT EYES.}

This is gemprally eansed by being exposed to sudden clianges of heat and ecoll, which profluce canker, null where this is, there will be inflammation. There are many things good for 
this eomplaint, but the best that I have found, is white pond lily root, marsh rosemary, witch hazel, and red raspberry leaves; make a strong tea with all or either, and add one third as mueh of No. 6, with a little of No. 2; bathe the eyes several times in a day ; every morning put your fice in cold water, open and shut the eyes till well washed, repeat this till a eure is effected. At the same time take the tea to elear the system of eanker.

\section{HEAD-ACIIE.}

This pain proeeeds from a foul stomach, the bile loses its power, the food elogs, by not being digested, and the effeet is felt in the head, whieh is the fountain of sense. Sometimes there is siekness at the stomach. In sueh a ease it is ealled the siek head-ache; and when they vomit the head is relieved. This proves that the eause is in the stomach. It must be eured by eleansing the stomaeh, and restoring the digestive powers. A dose of eomposition powders, sitting by the fire, wrapped in a blanket, will generally give relief; but if it should not, take a dose of No. 1, in a tea of No, 3, and take the bitters to correet the bile; No. 2 should also be taken to warm the stomaeh, and if it be sour take the pearlash water. It is very fashionable with the doetor's to tell about dropsy in the head, but in this I have no belief; for there is no disease in the head but what proeeeds from the stomaeh, except from external injury. If they understood the real eanse, and wonld give the proper melicine to remove it, there would be no diffienlty in the head; but when a ehild is sick they give ealomel and other poisons, which inereases the disease, and if they die it is laid to the dropsy in the head, and this is satisfaetory, beeause the doetor say's so.

\section{CORNS.}

These eome on the joints of the toes and are very tronblesome. They may be eured by soaking the foot in warm water till the eorn is soft, shave it thin, talie a strip of bladder or skin of suet, eight or ten inches long, and half an ineh wide, rub it till soft: then supple it well in rattlesnake's oil, or the nervo 380 
ointment, wral] it round the toe and keep it on till worn out; if this does not eure, repeat the same till the corn is removed. I hare seltom known this to fail of effecting a cure.

\section{VENEREAL.}

The disease that is called by this name, is more eommon in scaports than the country, because there is more promiscuous and illicit intcreourse of the sexes than in other places. It is a high state of cankcr and putrefaction, which takes hold of the glands of those parts that are first affected with it, and, if not cheeked, the whole system will become diseased by the venercal taint. It is more common among sca-faring men, because of thcir being long absent at sca, and on eoming on shorc, thcy give free scope to their passions, without being very scrupulous about the manner of the indulgence. It originates probably with those common women who have eonnexion with many different men, and going beyond the impulse of naturc, this impure conncxion causes uncleanncss, which produces the disease; and when seated, is contagious.

The reason why this disease causes so much fright and alarm is owing to two eases: the fitst is the disgrace that is attached to dishonesty in getting it, and the other is the manner in which it has generally been treated, in griving mereury to cure itthe remedy becomes worse than the disease. That this disorder cannot be curer by any other means is altogether an crror, for I have eured a number of cases by very simple means. The first synutom felt is a scrleling sensation of pain when voiding the urine; and within twenty-form hours after this is experieneerl, it may he cured by applying cold water and making nse of the rlicnmatic drops ; if there be much soreness, make 11 se of a ter of No. 3, with the drops in it, which must ho taken as well as applierl to the parts. If the clisense has been of loner standiug, and the whole system las become afliceterl, they must be carrich through a couse of meticine. Where there has been merenry marle nse of, and there is all the attenrlant conseruences of such treatment, it is much more dillicult to cffect a eurc, anch is also (lone by a full comse of merlieine, and repeatimg it a number of times: raising the licat by 


\section{THE BOTANIC FAMLY PHYSICIAN.}

steam each time, as high as they ean bear, to throw out the mereury and remove the eanker, at the same time applying the poultiee, then give the bitters to correet the bile.

I had the ease of a woman who was brought to me on a bed filteen miles. She was in a very putrid state, and as bad as she could be, with all the conseqnenees that are eaused by being filled with mereury. Different doctors had attended her for eleven months, and she had been eonstantly getting worse. She had been kept ignorant of her state till a few days before brought to me, on aecount of her husband. I carried her through five eourses of medicine in two weeks, and applied a poultiee of white bread and ginger, made with a tea of No. 3. This completely broke up the disorder, and by giving medieine to colreet the bile and restore digestion, she was eured, and returned home in three weeks after eoming to me. By taking things to restore her strength, she has enjoyed good bentth evel since, Anothel woman was eured in the same manner, who had been in this way fol six years, and umable to do any business. I attended her three weeks, when she was restored to liealth, and returned home. In less than a year aftel she had two children at a birth, and has enjoyed good health to this day.

This disease may be produced by other means than what have been deseribed. It may be taken in with the breath by being much exposed in attendingr on those who are in a very putrid stage of the eomplaint : or may be communieated to parts where the skin is broken, and in many other ways; when they will have many of the symptoms the same as when taken in the common way. Children will sometimes be allieted with the venereal taint, whose parents have had the disense. A disence similar in appearanee, with much the same symptoms, may bo bronght on by overdoing nut being exposed to the colt. I unce had a ease of a young murried matu, who by straining himself from loading mill-logs and being exposed to wet and cold, eansed a wenkness in the back and loins, and he had what is called a gleet, and an inflammation, with all the symptoms common in the venereal. His wile hecane aftected in the samo manner, and they continned in this siturtion three montls, when I was called to attend them, and by making nse of such thiness as I then had a knowledge of to stringthen the loins and remoro 382 
tbe canker, I was able to eure both in a short time. The man had all the symptoms that ap?ear in the renereal, cxcept hard buneles in the groin, ealled buboes. These I an satisfied are caused by mereury ; for I never knew any to have them except they had taken mereury, Syringing with mereury and sugat of learl, dries the glands anel eontracts the passagre, and stops the discharge, when the putrid matter insteal of goingr off, collects in the groin and forms hard tumors, whieh remain a long time and have to be brought to a licid to let off the putrid nutter. Bunches of a similar kind often come on different parts of the body, cilused by mereury.

\section{$\Lambda$ COURSE OF MEDICINE.}

In all eases regulate the ruantity of the doses, and the times of administration according to the coustitution and strength of the patient. In ease of an attack of fever, if the month be dry, give eayenne in warm water sweetened, with nerve powder and a little bitter root, nntil the mouth and throat become moist, and the patient continues to spit fiecly. In the mean time have some strong eanker tea prepared from the best articles you have, (hayberry alone, is the best in this case,) and give the patient freely of this, together with the cayenue, nerve powder, and a little litter root, frequently wetting the face, lands and feet, with eold water, until the fever turns, or, in oller words, mutil you raise the internal, and let down the externil heat (roise the fonntain and lower the stream) sulficient to prorluce a matural

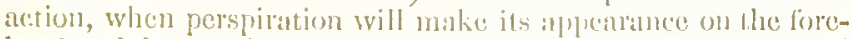

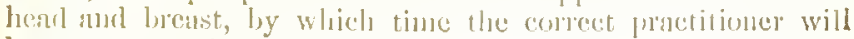
latve stones and water lot, and other things in readefiess for alplying the stean.

If the patient should have vomiterl so ss to have fhrown up the merlirine eriven, the doses should be repented milil the stomach retains a suflicient quantity to cuble the patient to bear the steam, when he shoula be divesterl of all his elothing, except the shirt, and placerl over the stean us has been before di- 
rected, and the steaming continued as long, and raised as high as it can be borne, always bearing in mind, that the higber the heat can be raised in the system, the more free and thorough will be the operation of the medicine. The patient then must be put to bed, with a stone that has been partially cooled in steaming, at the fect, and the emetic immediately given. If the heat has been suffieiently raised, and the stomach now contains plenty of cayenue, the emetic may be given in the canker tea alone; but if from any eause the steaming shall not have been thoroughly performed, or if the eayenne shall have been thrown from the stomaeh, there should be eayenne added with the emetic. Continue giving the emetic until the stomach is thoroughly cleansed; three doses will be gencrally sufficient. If the process has been conducted to the best advantage, the patient will, soon after the commencement of the romiting begin to run down, that is, he will grow pale and weak, and eontinue to sink, as it were, until he has not strength to move, or even speak; his breathing may vary from short and soft, to long and loud, and from the most free and easy to the most laborious jerking, in short, every symptom and appearance that can well be imagined, calculated to alarm and terrify those who are unacquainted with the true cause and effect; yet the experienced practitioner beholds those scencs with pleasure, because he knows this to be a certain presage of the recorery of the patient, and his heart swells with gratitude to the persecuted and much injured Dr. Thomson, who alone is entitled to the credit of discovering and furnishing the means of gaining so easy a victory.

Somctimes, instead of the symptoms above described, the patient will appear to be much distressed, will tumble in every direction, and talk in the most incoherent mannel, eren raving to insanity-these extraordinary symptoms, howerer, seldom appear, unless in desperate and deadly attacks, or in eases of long standing, where the system has bceome very mucl obstructed, and the vital heat and action nearly overcome. Tho most desperate case of the kind which we ever witnessed was of about fifty hours' continuance ; language is totally inadequnto to deserihe this sccne. 'The patient, a little girl, recovered from that time, and is now in the enjoyment of health. 


\section{TIIE BOTANIC FAMILY PHYSICIAN.}

We have known some instances where practitioners, who were unacquainted with the full operation of the medicine, liave becomc alarmed, when, as a matter of course, consternation would seize the mind of the relatives and friends of the patient, and a medical doctor wonld be sent for, and by the time he arrived, the medicine given would have completel its operation, and the patient being on the tmin, would soon revire, and furding himself perfectly relieved, is casily persuaded to believe that the steam Doctor had administered the fatal close, but that the god of Health, the medical Doctor, had arived just in time to save his life. The practice has suffered much in this way.

We have probably dwelt much louger tpon this part of our subject than may be deemed necessary by some, yet the imporanee which we attach to a knowlectge of the wonderful operation and elfect of the emetic herb, inust be onr apology, if, indecd any is required. Dr. Thomson, has said cnough to quict the fears of any one, were it not that the force of early prejudice renders it necessary t? 1 at we should have " line upon line, and jrecept npon precept."

We will now tum to our patient, whom we will suppose to have recorered strength sufficicnt to converse, when a dose of bitters should be administered, and some gruel, or other light food given; then if he wish, he should be pelmitted to sleep until he naturally awakes. The hent (and consequently strength,) will continue to gain, and by giving a few duses more of the bitter, with eaycune, (not forgetting the food) the perspriration will soon hegiin to flow, and the patient will soon be impratient to change his wet, and now nncomfortable siluation for the sterm bath. If the doctor has performed his part thus firr, lie will now have every thing in readiness for the second steming, and will set his paticnt over the steam as lefore, and arain raise the lieat as liegh as possible, when the shint shouk he talken off, the lianket heke loose aroum the patient, and two or thee quarts of colit water poured quickly over liun, so as to sprend ane much as possible on every part of the horly and liunls, then immediately wire dry, and as a clcan shirt is put on, lot the b)ankets be dopped, mul the patient get inumediately into hed,

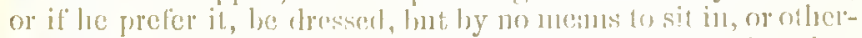

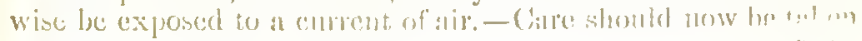


to administer the bitters and eayenne freely ; the former to eor reet the bile and strengthen the digestion, in order that food, the natural fuel, may keep up the heat, until a sufficient quantity of food should be taken and digested, to render the enyenne no longer neeessary for that purpose. If the disorder returns, repeat the eourse as above direeted.

Remaris, - The above is for a ease of fever, and may answer as a general text for a course of medieine in all eases, yet the ingenions praetitioner will, in many instanees, at onee see the propriety of numerous variations from, and additions to, the minutia as here laid down, yet, the leading objeets to be arrived at, are in all eases the same.

In eases of long standing, partientarly in eonsumption, where the digestive powers have been deranged for a considerable length of time, and the system eonsequently filled with morbid matter, it is indispensably necessary to have some good broth, beef tea, or other like food, giving it as soon as the emetie eommences operating, in order that the glands may be supplied with nourishment, as fast as the morbid matter with whieh they are eharged shall be removed by the medieine.

By this means the strength of the patient may be materially increased with every eonlse of medieine.

Care should be taken in selecting stone, to get those of a coarse, open grain. Iimestone, or those containing coal or sulphur, must never be used, as they give out 110 steam, but, cause the patient to sieken and finint.

N. B.-Give as mueh eold water as the patient wishes, at all times.

\section{POETICAL DIRECTIONS.}

First steep the eoflee, number Three, With number 'I'wo, then nse it fiee; 'To clear the cold, and raise the hent, Now place a hot stone at the feet. 
The inward warmth now of repeat, And cliange the stone when lost its heat; The fountrin 'bove the stream keep clear, And perspiration will appear.

Then take the emetic number One, Until its duty is well clone ;

The stomach eleansed, and head made free, From filth and pain both equally.

Then lie a while in sweet repose; Then wash all o'er and change your elothes; A grain to bed both elean and white, And slecp in comfort all the night.

Now take your bitters by the way, Two, three, or more times in a dlay; Your appetite, if it be grood, May be appeased by wholesome food.

Physic I would by no means ehoose, To have you first or last to use, I')r if you take it much in eourse, It will disorder reinforec.

Should the disorter reinforec, Then follow up the former conrse; The second time I think will do; The third to fail, I seldom knew.

'Th' Emetic, number One's desienned $\Lambda$ gen'ral med'cine for mankind, () f every country, eline or place, Wide as the circle of our race.

In every ease, and state and stage, Whatever mialstly may racre ; For male or fermile, youmg or old, Nor can its value haif tre told. 


\section{THE BOTANIC FAMILY PHYSICIAN.}

To use this med'cine do not eense, Till you are free from your disease; For Nature's friend this sure will be, When you are taken sick at sea.

If amy one shonld be much brois'd, Where bleeding frequently is used, A lively sweat upon that day, Will start the blood a better way.

Let names of all disorder's be Like to the limbs join'd on a tree; Work on the root, and that sublue, Then all the limbs will bow to you.

So as the body is the tree, The limbs are eholie, pleurisy, Worms and glavel, gout and stone, Remove the cause, and they are gone.

My system's founded on this tinth Man's Air and Water, Fire and Earth, And death is cold, and life is heat, These tempered well, your health's eomplete.

\section{LLEE $\triangle N D$ MOTION. \\ ALTERED FROM DR. TIOMSON.}

Clearly to mulerstand the laws of life and motion, the radical prineiples of animalization, is of infunite moment, Without some adequate eonception of these, the natme of disease cannot be correctly mulerstrod, so is to prescribe a lational, safe, and certain remely for the remural of disease in the humath sjstem.

Through many long and tedions scasums, these suljeets had revolved, in my mind, before I conle? form a conect opinion. I witnessed many distresses in the fanily of nlau; my heart 388 
was pierced with many sorrows, until my mind was established in those simple truths that have laid the fondation of ny practice, that has been so snceesstul in subsequent years.

Persecntion raged against me-all the presses in the colntry were closed against nue - priests, doetor's, lawyer's and legislators, were combined against me-ex post facto laws were put in operation - prosecution commenced - false witnesses arosebigotry, prejudice and superstition, waved their magic wand, but all in vain-truth has prevailed. 'The darkness of the ancient philosophers is passing away, and those simple truths, which are the genuine philosophy of life, and the fruits of the labours of my life begin to prosper beyond my former expectations.

Among those physicians ealled regular, I have found many who appeared to be as ignorant of the laws of life and motion, and how the functional powers of life are kept in operation, as though they themselves had never possessed an animal body.

My text is recorded in the month of everything that breathes. "Bresturig" is my text. Some have treated on respiration, but if they have not understood their subject, they might as well have been silent. Breathing is a demonstration of the existenee of animal life. The principle of life has been taught to be suri:R-natural; leave ont the suPER, and say the eanse of life and motion is NATURAL, perfeetly and entirely natural, and we will concele to the trutl of the assertion. 'The cause of breathing, or of animal life and motion, where tlere is 110 animal life, we slatl carefully cxamine. Steum machincry is propelled by stean, which is a species or kind of breathing ; these possess not the eapacity for animalization.

In animal or human bodies, the constitnent or component parts are csseutially the same in man or least. $\Lambda$ nimal bodies are composed of eartl sull water'; these constitnte the substances, flimensions, shal]e, amel the size of lowlies, \&e. and grive or constitute soliclity, in what are idenominated sounds. These elements leing constituted of various, still more simple elementiuy prineiples, which may be subliviled agrain and argin, does not militate more agninst on posidirm, than the infunte divisilitity of 11 molbers by decinal aritlunctic destroys the unity of numlers. 
Fire and AIr are properly the fluids that pervade and fill and actuate the living animal; their operation is life - the elcmentary principle of life which keep the animal machine in motion. Where heat is extinct the animal is dead. Heat and AIR combined, are so modified in the living, moving animal, as to constitute the living state, and justify the asscrtion that cold and inaction is a state of death, or rather death itself; and a specific degree of heat and motion so combined and modified, is the essential principle of life in the living animal, yea, rather
life itself.

Waving all the minutia of ehemical divisions and subdivisions, in simplyfying elementary combinations that constitute BODIES dead or living, the four great original elements of AIR, EARTII, FIRE, and WATER, contain and comprise all the moro simple elements of which they may be respectively composed. A specifie association, due proportion, mixture or combination of these four great elements, in an organic animal body, constitutes the living state, and prolongs life; an improper disproportion, combination, and modification destroys life.

To illustrate the nature and cause of respiration, or brcathing of the living animal, we will refer to the operation of fire and water: Put a skillet of cold water orer the fire; in a few minutes examine it by immersing your hand therein, you will perceive the first warmth of the water is on the top or upper surface; the coldest water is at the bottom of the skillet, nearest to the fire ; the reason is, as soon as it becomes warm, it becomes rarified and lighter, and rises; just in proportion as it grows warm it beeomes aetive, until it is all in a fluttering, fluctuating state of ebulition, and wastes by steam, sweat or breath, perspiring or respiring, until it will evaporate. This shows that heat rarifies and lightens water.

The subjeet may be further illustrated by reference to the effect of heat on the atmospheric air. You bnild your honse in the open atmosphere-the honse is filled with air" within - tho air within is a counterbalmee, or resistenee to the weight or power of the surrounding air withont; the balance within and without is equal in coldness and inaction, rescubling a state of death. To produce action, motion, or breath, kindle a fire in the house, the doors and windows being elosed in the usual manner,
$\mathbf{9 9 0}$ 
in a few minutes every door and window begins to hum and sound the march of air. The air within becomes rarified and lighter than the air without; the air without presses in at erery erevice to restore or form an equilibriun with the air within; the hotter and stronger the fire, the stronger will be the current of breath, or force of breathing air-as the heat diminishes the noise and breathing eurent of air will decline in forec of operation, and the noise and motion will cease when the licat becomes cxtinct, and the equilibrium is restored.

The effects of heat rarifying and lightening the water and air, and occasioning a breathing motion, resemble and illustrate in some good degree, the breathing, sweating, and functional motions of the animal machine. The constituent, or component parts of men's bodies, give organic shape and size, and form, and functional structure or organization to the mitchine. The peculiar mixture, composition, proportion, and modification of these clements, constitute its aptutude or adaptition to the animalizing influence of fire, lightening air, and exciting lreathing motion, and all the concatenations of motion, connected with this original or primary action, all cvincing that heat is an essential principle of life; and cold, or an cxtinction of heat, is death.

$\Lambda$ still-born ehild was resuscitated by placing the placentia or after birth on live embers, still connected with the child by the umbilical cord or navel string, and as the after birth began to heat, and had gained walenth sufficient to begin to fill and dilate the navel cord with warmth and moisture, it was stripped towards the body of the ehild, and through this medium a sufficient degree of warnth was conveyed 10 the body, the lungs expanded, and life was restored. This may serve in some measuro to illustrate and confirm our idcas of life and motion.

In every thing that breathes, the breathing is from the same general catuse. 'T'he principle of life and motion is ratlically the same in all animated bodics. Withont heat thele is no breathing; but when heat is continually generated or evolvel in a confined room, excepting at one arenue, as in the lungs, there must be breathing, or what is the sanic, an inlıaling of cold air, and an exhaling of a gascous vapour from them. 391 
Fvely animated hody has its proportion of ealoric or heating frinciple, suited to its size, allapted to its nature, proportioned to that degree of living power requisite to keep up the operation of all the aninal funetions, essential to the perpetmating of the peculiar specific form and mode of being in such
animal.

The heat of animal firc, or that degree and condition of it that constitutes the living state of animalized existence, is maintained and continued by a suitable supply of appropriate fuel, or materials naturally adapted to that end or use ; these are, food and medicines. These hamonize with cach other' in their salutary effect, or natural influence on animal bodies. Food and medieine originate from the same munificent hand, grow in the same field, and are adapted to the same end or design, viz., to supply finel to the fire of life, to sustain and nourish the animal macbine, by warming, dilating, filling the vasenlar system, maintaining the action, and supplying the wasting power's of the living state. Micdicine removes disease, not only by lemoving obstructions, but by lestoring and lepairing the waste and decay of nature.

On these supplies onr life depends, viz., the continuance of that state of wamth and action which constitute the living state. When food is masticated and taken into the stomacli, the proeess of digestion commences. By the warmth and action of the organs of digestion, and the gastric juices, the food is decomposed or consuned, like fincl consmining in a fire. The breatl and perspirable vapour are the smolse arising fiom this fire. The foenl matter of dejections are as the aslies or earthly substance remitining after the consmmption of fuel.

To understand the eanse and natme of lite and death, or of wamtl and motion, of cold and innction, it is necessury to advert to general principles, and the matogies of manceThere is one general callse of the natmal sensations of hanger, and one gencrin method to relieve that want, or satisfy and relieve that sensation. Suitable food relieves liunger wilen laken into the sifomach.

In perfect aecond:nee with this, there is but me immeriate cause of diseatse-lowever varied the remote canke may he, the immediate canse of the sensation of discase is unitumly 392 
and invariably the same, differing only in degrec, and ineidental diversity of symptoms, occasioned by local injuries, organic lesion, or functional derangement, dependent on these or whatever might predispose to a discased state. As there is one general cause of the sensation of liunger, to be relicved by one general method, viz. by food; and this food may consist of sundry articles adapted to the same general end, so there is one general, or immediate cause of the sensation of discase, to be relieved or remored upon one general principle, thongl a variety of articles may be used. But as a few simple artieles of diet are better suited to mantain a licalthy state of body than an cpicurean variety, so disease is more readily and certainly removed by a few sinule remedies, that are best adapted to the human eonstitution.

That medicme which will most readily and safely open obstructions, promote perspiration, and restorc a salutary operntion of the digestive nower's, by cxciting and maintaining a due derree of heat and action through the system, is best snited to every state or form of discase, and nutst be nniversally applicable to a discased state of the human system. Thus, the jower or faculty of breathing is a capacity or condition to be acted on with cffect, rather than any inherent power or faculty of acting. Hest rarifying aul lightening air, excites respiration-rarifying and lightening water, cxcites perspiration. Rarifying and liglitening air and water, the vapour of brenthing and sweat are produced and thrown off:

By heating water in the stomach, wo lighten the air in, and cxpand the lungs - the weight of the cool, condensed and weighticr cxtermal air, presses out the liglit and rarificd air ; these cireumstances of the living state of the animal boly, ocrasion the alternate contractions and dilations of the lungs, that constitute the action of brealling, indispensable to the living state.

By heating water in the stomarle, and air in the lings, we put the stram enrine into operation. Tlus operation of the animal machinc strongry resumbles the nuchanial operations of the steam engine. Some of the findamental primeiples of action are the same. To inspiratirm, cool fresh ail is inhaled; in respiration, the rarificd lighlitencel air and vaprour are oxhalerl, 


\section{THE BOTANIC FAMILY PHTSICIAN.}

or thrown off, out of, or from the steam pipe. This action, by which steam is expended, the whole machincry of the living animal is kept in operation-the great fountain pump of the heart is kept in play, and pumps the blood through the lungs and arteries to the extremities, decp in the flesh and near the bones, which is returned in the veins. 'The warmth and action commencing at the fountain, are propagated through the system to the rcmotest extremities. So long as the firc keeps up that state, and degrec of warmth essential to the living state of the animal body, or, to speak figuratively, so long as the fire is kept good in the boiler, to leep the engine at work, so long the pump will go.

Our regular meals supply regular fiel to keep up animal heat, as the regular tending a fire with wood or coal, will keep it burning. Drink supplies the boiler with water, which creates the steam; condensed water is diseharged through its natural channel. On these principles of the philosophy of lifo we may expect a regular well formed inachine to continue its operation until worn out, or broken by indiseretion and bad management of the engineer.

If the machinc be entrusted to the management of an ignorant, incompetent engineer, who has no eorrect conceptions of the principles of life and motion, and is negligent in the discharge of his duty, your steam boat if I may so speak, will begin to fail in its speed, for lack of fucl to keep up the fire and wat 1 . to supply the steam, or the engincer may conclude the cholcra affects the machine, and will cast ice into the boiler to cool it down, or tap the boiler as a preventive, or remedy, and draw off the hot water-his boat begins to sink rapidly down the stream. This is often done by the lancet. It you would keep your steam boat's steam breatle motions going on, keep up a supply of water in the boiler, and a supply of fuel to kecp it sufficiently warm; lanise the steam, and the actions of lifi will proceed regularly.

Concerning the doctrine of vital principle diffuscd through the whole organic structure of the animal maclune, inducing an elementary mote of nuion or specific union of the component elements, difiering in nature from all chemical nnion and affinitics, and from all the laws of physical union with which 394 


\section{THE BOTANIC FAMIY PHYSICMN.}

We are acquainted, - this subject has employed the minds and pens of many talented writers, who have east but little valuablo light on the intricate theme.

When we are askel what constitutes a living fibre, we might as well ask what constitutes any other property of living matter. What constitutes that in which tlıe life of a leaf or stem of a living tree consists? "What can we reason, but from what we know?" Every living thing has something peeuliar to the nature or life with which it is endowed in the living state, whether vegetable or animal-but a living animal has heat and motion; without this animal heat and motion, the animal becomes dead-without a due proportion of heat inward and outward, or outward and inward, there is no animal motion, no animal life. We know not of any vital prineiple, except a capacity to be brought into that peeuliar mode, state and degree of warmth and action, constituting animalization, or the sensitive living state of animal bodies.

Warmth and action do not constitute animal life, in unorganised matter-they do not constitute animal life without an organised animal structure, to which heat gives the impulse applied to and connected witl the animal strueture, caloric or the prineipal of heat rarifying and lightening air, exeites action, which eireumstance of being, constitutes animalization, or the living state.

Warmth and action do not constirute animal life, only as applied to, conneeted with, and exereised in an organized animal body, possessing a capacity inherent in its nature to be put in operation, in which state or eondition of being, seusation, pereeption, and conscionsness of iventity, or individual existenee, are gradually developed; but these circumstances of life are not like itself-there may be animal life, viz. breatl and motion, in an animal body where these functional powers are totally deranged or utterly extinct. Fire and stcam are necessary to propel a stram boat, but notwitlstanding the capacity or adaptation of the mechanical strncture to lie propelled, the liont will not go until the fite is kindled and the steam raised to put it in motion.

The animal borly is the machine so construeted, so morlifierl, cndowed with such a capacity lor life, call it vital principle, or 
what yon please, that heat ravifiying and lightening air, stimnlating and expanding the lungs, puts the machinery in motion, and pumps the tide of life through all its erimson channels. This combination of eireumstances constitutes the living state of the living animal: for where these eireumstances do not exist, there is no animal life-the animal form is dead.

Suppose a man in all the vigom of life falls into the water and sinks; in a few minutes lie is taken ont apparently dead, the warnth and motions of life, if not extinet, are at a low cbb -as soon as you can kindle up the decayed spark, and restore inward heat by medicine, friction, or any appropriate means, if the eapacity for the action of life is not utterly extinet, an energy is given to the system, the air in lis lungs becoming warm, rarifies and expands, and heaves them into action - the machinery begins to move-the wheels of life no longer wallow in back water-the proper state and proportion of heat invard and outward is recovered-nature rises to its wonted strength and vigour.

All that is requisite in sueh a ease is, to supply fuel to raise the latent spark of the fire of life. The same holds good in a collapsed state of clisease, whether it appears in a cholera form, or whatever shape it may wear. 'The vaseular system loses its wonted tone-the whole system is sinking-the power of life is unable to distend and expand the lungs-the heart and arteries no longer propel their contents by mantaining the requisite action. The spark of life is becoming extinet-the water that should breathe, exhale and perspire away, becomes congestively condensed, and extinguishes the spark of living file. The coolness and weight of the internal air is too mueh for the small degree of heat remaining in the lmigs, heart, Se. ; the power of life, or rather the power of eapacity to live, to keep the powers of animal life in their warm, and noving, or living state, becomes measmably extinet. For lack of heat, the air in the lungs is not rarificel and lightened, so as to give the necessary action, \&c.

In this eise shield the sufferers from surounding cold air, by wrapping in a blanket, and placing warm in bed, and gradually lnising a steam around him; aduinister sradually, frequenty and jerseveringly, the warming medicines, and gire injec396 
tions, whiel all aequainted with my system will readily understand-proeecd until you ean gain a sufficient degree of inward heat to expand freely, to rouse the sinking, fuinting, I might say, drowning patient, to a proper degree of warmtl and action ;? when they have had a proper course, they will sweat ficely; and when they erave food, give them enough to keep up the steam; the pump of lite will begin to work freely, and the patient to rejoice in the warmth and aetion arising from the resuscitated powers of departing life.

Mueh has been said abont drawing in the breath; but the faet is, you cannot keep the breathing air out so long as there is a clue degree, or natural proportion of heat in the lungs ; neither ean you prevent the motion of the pump-like action of your heart in its systole and diastole. But when the heart deeays, or state of living warmth deelines, the luugs begin to labour like a wheel wading slowly in back water. 'I he pump has not power to roll the blood aloug the arterial cinals-the pulsc falters-the extrcmities grow cold-the blood that maintained the warmth, by its aetive eirculation, recedcs fiom the extremities - therc is not heat enough at the fountain or hoiler to keep up the stcam, and continue the living action-blood settles in the vcins, not being supplicd and propelled by pulsation in the arteries - the fire becones cxtinet-the pump 110 longer plays at the fountain ; the man clies *** for waut of breath, fol want of capncity to brcathe, or becatse the inward heat is redueed below the living point. 'The proper and natural proportion and modification of the inward and outward heat, as they exist in the living animal, beeome deranged, destroycd, and life is extinet. The disense is as contagious as though the man had been *** hanged or drowncl ! !

'The regular faculty are requested to inquile whether the depleting antiphlogistie practice, tlat lias hecil nopular, and notoriously mortal in its results, has not been the cause of producing mueh disense, ancl many of the most fital jesults that have attented on what has been called scallet fever, yellow fever, eold plagne, and now clolera. 'Thus "tho bicatle of life" is inhaled or breathed into man; and by licat rarifying air, breathing commenees, and min thus beconies, and is thus sustnined, a living animal.

In eonclusion, the cause of vegetalle and animal life is the 
same, viz., one eommon principle prorluees similar effects; nutritive life in animals and vegetables bear a striking resemblanee to each other-vegrables, like animals, are eonstituted ol' formed of the four' great eardinal elements-all vegetable life is under the eontrol, influenee and operation of similar prineiples, as that of an animal. Without earth, water, fire and air, nothing like vegetation eould exist. The wintel season is a state of death to vegetation; just in proportion to the loss of heat is the degree of the surspension of life, we mean a loss of heat in that peeuliar modifiention or elementary combination thereof, that eonstitutes the living state of a vegetable; this is a degree of death, or a degree of the suspension of vegetable life. In many iustanecs the suspension is total.

In cold eountries, after the winter has passed away, and the spring leturns, suspended vegetation, and suspended animation, are again restored; the torpid reptile again inhales the breath of life. Heat in this ease is not only an agent of restoration to life and vigour, but is so adapted to the eondition of the being on whieh its influenee is exerted, as to eonstitute a living plinciple. So, on the other hand, eold is not only an approximntion to death, but that degree of eold which is ineonsistent with, and contrary to the living state, is death itself.

Ileat does not aet alone and independent of its fraternal elements, but in hamony and aeeordance with the whole family. But without their elder brother, there is no life in the material universe. The elements would rest in everlasting silenee and inaetivity, if destitute of this generative prineiple of life and motion.

Abstraet the element of fire from all the other elements ; stillness and silenee would be universal - the life of all that breathes and moves would be swallowed up in the stillness of etermal deatl. Earth and sea would be and remain a solid, umoring and immovable mass-the fluid air would be eonsolidated, wonld be a blank!

$\Lambda \Pi$.

$\Lambda \mathrm{ir}$, an invisible clastic Aluid, of which thero are sereral kinds, varying fiom one another as numel in their properties as
398 
the grosser fluids, oil, water, and mereury, differ from one nnother. The term air, when used without any addition, is now restricted to mean eommon air, or the air of the atmosphere; other clastic fluids being ealled geses, when cold does not condense them; and rapours when it does. Thus we have hydrogen gas, or inflammable air, permanent at all temperatures; and the vapour of water, or steam, which is condensed by cotcl. We shall now mention some particulars respecting atmospherical or common air. The rescarches of modern ehemistry have determined, that the atmosplere is not a uniform fluid, but a mixtnre of two principal clastic fluids, with a few others in very minute proportions, and holding in solution a varying quantity of watery vapour. The composition of one hundred parts of atmospherical air, fieed from all adventitious mixture, is seventy-nine parts of gas ealled azote, or nitrogen ; and twenty-one parts of another gas ealled oxygen gas. Atmospherical air is indispensably necessary for the breathing of animals; and, though inflammable bodics will burn in some other gases, yet as these gases are rare, exeept when artificially produced, air may also be considered as the great supporter of combustion. When, by various methods familiar to chemists, the oxygenous portion of the atmosplucre is separated from the azotic, it is found that an animal dics, and a burning body is extingnished; we hence conelucle that it is only the oxygenous part of the atmosplicre that is fit for the purposes of respiration and combustion. $\Lambda \mathrm{ir}$ is, by these proecsses, continually becoming more and more unfit for the use of breathing; henee the danger of continuing long in a small room without changing the air, or admitting a fresh portion of oxygen.

Change of AIR in apurtments necessary.-Independently of its chemical propiertics, air that has been long unchanged, and in which one or more human bodies have heen confinerl, is possesserl of qualities highly dangetous and eren destructive, as we see in many instances in jails, ships, and other confined apartments. ITence tle necessity of free ventilation in houses of every deseription; of daily admitting a thorongh current of air into slecping roums, and infleerl, info cvery roon of a louse. From the negrlect of this ventilation, arise the langerous and malirmant fevers in the confinel and ill-ventilated dwellings in the eloses, alleys, and courts of lange towns. Since nttention 399 


\section{TIIE BOTANIC FAMILY PIISICIAN,}

has been ealled to this cireumstanee, how seldom do we hear of the ship or the jail fevers! Though the fever, which was formerly so fatal in ships and jails, is still lamentably prevalent somewliere or other, and though we still lien of towns or traets of territory being visited with its depopulating seourge, it is not in ships and jails that it is suspected to talie its rise, bnt in the abodes of slotliful and squalid poverty, where no judieious and direeting mind enforees the necessity of ventilation and eleanliness. Even in the apartment where a patient is in bed, the fear of his catehiug cold should not prevent us from oeensioually changing the air of it, by opening the doors and windows for a few minutes at a time, taking care not to expose the sick person to the emrrent of air, but closing the curtains and using sueh other preeautions as eommon sense will readily suggest.

Air, considered with referenee to the cause, the cure, or the mitigation of diseases.- Hany circumstanees eonneeted with air, whieh chemistry is unable to traee or explain, are mueh to be attended to in a medieal point of view. 'The bad air from marsly grounds produces ague; and fevers are generated by the malignant effluvia from animal bodies; and the air seens to carry the infection of other diseases, as small-pox, measles, hooping cough, searlet-ferel, \&e. The air of eertain plaees is supposed, justly, to have an influenee in giving a tendeney to ecrtain diseases, or to bring them on direetly. The eroup is frequent in eold, dansp situations, exposed to the east wind, or nenr the sca. The sea air is unfarourable in eertain states of eonsumption, or in affeetions of the breast, which would probably cnd in that disease. "The mild, equable ail of the conntry, is unloaded with the endless variety of matters mixing with the air of large towns, is finvourable to recorery from many ailments, as indigestion, dropsy, jaundiec, breast complaints, asthmas, and the wasting disenses of eliluien, as also to that feeble state of constitution which has not reecired any appropriate name. It is remalrable that some persons in asthma are not better in air, which we should llink the purest.Chunge of air, eren to a worse, lias been of selvice in loopingcongh ; but it is useless to attempt this, at an enrly period of the disease, as it is hardly possible by any means to prevent it from running on a considerable time. In genernl, it is hardly worli while to try a change of air till it las contimed 400 


\section{TIIE BOTANIC FAMILY PHYSICIAN,}

distinetly at least a month or six wecks. $\Lambda$ grood deal of the $1 n-$ fluenec of the air on the skin and lungs must depend on its degree of moisture or dryness. When there is much watery vapour in the air, it is less able to receive more, and the perspirable matter from the skin not being earried off, we shall appear to perspire more, though in reality the perspirntion is less. In like manner, the watery vapour which is continually thrown off by the lungs is not carried away fast cnough by a heavy, moist atmosphere ; and in eertain diseases of the lungs, in colds, consumptions, asthmas, \&c., some patients, according to the quantity of watery vapour, or muens, exhaled from the lungs, will be benefited either by a dry air, or the contrary. It is wrong, therefore, to lay down any general rule about a particular spot or climate, as its good or bad effeets will vary according to the state of the disease in oach particular patient.

\section{CLOTHING.}

The choice and regulation of elothing is of great importance both to health and comfort. It will rendily be supposed that the physician does not meddle as to its form and decoration, but that his instructions are chicfly confined to what is worn next the skin; and that he will forbid all sueh artieles of dress as are likely to prove injurious by pressing on tender parts, and altering their structure, or imporling functions. In this variable and unecrtain elimate of ours, woollen garments are by far the best kind of elothing. They enable the body to resist the effects of the frequent changes of the weather ; being what the ehemists eall bad eonductors of lient, they both prevent the natural warmth of the body from eseaping, and the extermal heat from reaching it, and thus prescrve it in a stendy temperature. When sweatiug oceurs spontaneonsly, or is induced by artificial means, flannel does not take up the moisture in a fluid form, but lather as a vapour, and thus the colchess of the fluid is not perceiverl. Flannel is sometines deloblitating by the perspirattion it exrites too constantly ; or, it is imitatimer by its rouglness on some tenker skius. It repuires, in the lims case, either to be worl of a very thin textme, of to be exchanged for cotton; and, in the sccond casc, it must be discontinued, and 
linen must be used. Flannel, which is worn next the skin, should bo frequently ehanged; it should be washed in water not very warm, which prevents its beeoming too thiel- Cotton has all the good properties of flannel, though in an inferior degree.

Chamois is used next the skin by many people, as uniting the advantages of both the former materials. Linen forms imner elothing of great eomfort to the strong and healthy, ehanged, it renews the to eleanliness; and if it be frequently

silk should not be worn next the skin, as it has no affinity for water, and the sweat not being absorbed is apt to fret tbe body, and to eause a slivering whien it cools. It should be worn above flamnel or linen. Fur is necessary in very eold climates, but it is apt to harbonr inseets; and it is one of the most powerful retainers of eontagion.

In our elimate mucl eaution is required in ehanging of dress. The winter clothes should be worn till sumner is unquestionably arrived. A few days of sunshine in April or May should not tempt us to lay asicie our warm clothing. It is of the greatest importanee to health, to keep the extremeties dry and warm; and in those who are subject to gout, to any eomplaint of the head or ehest, or bowels, partieular attention should be paid to the feet. The shoes should be carefully lept from admitting moisture; the stockings should be warm, and frequently ehanged. The feet should be washed often, and not in very hot water. If we proeed to the more cxterior part of our elothing, we shall find that the prineipal thing to be attended to is to prevent undue pressure on any part by ligntures, bandages, garters, or stays. The blood-vessels are liable to be eompressed, or the abdomen aud ehest, with the important organs eontained in them, to be hindered in the free excreises of their functions. In the regulation of the female dress, mueh is sacrificed to fashion and appear:ance. But the plyysician onght to be leard when he warns the deliente young lidy of the danger of cold, eonsumption, and sore throat, from the insuflicient covering of the neck, the breast, and the amns; and when ho points ont the danger of stay's and tight lacing, to induee disurder's of tho liver and other visceral of the abdumen, or to 4.02 
eause headaches and spitting of blood, by lindering the due performanee of the eireulation.

\section{EXERCISE.}

The necessity of exercise to the health and eomfort of the animal body is demonstrated by the instinetive resire for it whieh appears both in man and in tle lower animals; as also by the pernieious and lamentable consequences of sedentary babits, and a life of indolence. Even fiom the moment of birth some excreise is neecssaly, and this is supplicd to the infant by the washing and dressing to which it is subjeeted; and its vigrorous erying, when we are sure it is not from the feeling of pain, is to be regarded as a salutary mode of dilating its chest, and of putting many museles into aetion. In the progress of its days, the dandling of the nurse, and then its own exertions, suceceded by the active play of the schoolboy, conduce, by the motion given to the limbs, to the digestion of the food, the cirenlation of the fluids, and to tlie growth and health of the body; while the bad effects of the want of excrcise are scen in the ill health of the imprudent student, the plodding merchant, and the indolent and luxurious man of wealth. As cxcreise is of the most essential use in prescrving the health, so it is a very important agent in the eure of discase. The disorders of digestion receive most decided bencfit from exereise. The feeblo eonstitution which serofula attacks, is invigornted by exereise, and enabled to resist that very prevailing malady. Even hereditary gout may be mitigated or kept off, if the subject of it has fortitude to resist the blandishments of luxury aliu indolenee.

The modes of exercise are varions, and, in the ease of disease, a chnice is necessary. That exercise is the best which employs the erreatest number of muscles, and as the most useful oljects are, hy the kindurss of L'rovirlence, the most ensily attainerl, so walling, which is the lest of all cxorelses, is in the prower of all. Walling, in a degree proportioned to tho strength of those who employ it, is usefial in the cure of varions discuses, as of throse of the stomateb, in gront, and some otluers; but there ane other connlants in which it is unsile, as in in- 
flammatory affections, and in those where there is a tendeney of blood to the lungs. It is, therefore, a hazardous plan to drive away a eold by walking it off, instances have bcen known where violent inflammation of the lungs has been brought on by such an attempt. All the more violent exercises, as fencing, dancing, running, wrestling, and the like, are to be aroided in diseases of exeitement; and in those of debility, exereise is to be preseribed at first with great eaution, and to be taken very gradually; and thus by prudence and perseverance, very feeble persons have beeome able to take exereise of the most active kind. When a paticnt, for whom exereise is good, is unable to take it by his own exertions, we must direct some mode of exercise, as riding on horseback, or in a earriage, sailing, or' springing on an elastic board. Riding on horsebaek has been mueh eelebrated in eonsumptive diseases; and, provided it be taken in fine weather, and before the disease has made mueh progress, it will assist the other means of attempting to arrest its progress ; but we must not expeet from it the great and signal benefit whieh Sydenham ascribed to it. Sailing, also, has been mueh famed as a remedy in eonsumption, and though it has failed in numberless instanees, it is worth a trial. The sea air appears to be beneficial, and the siekness and vomiting wbieh neeompany a voyage, have the effect of improving, in many eases, the action of the stomach and bowels, in removing tumours, and stopping discharges of blood. Riding is to be aroided in disenses of the kidneys, as it is apt to occasion much pain, and a diseharge of blood. Rirling in a carriage is an exereise of bedy and mind, well adapted for a variety of chronie ailments, stomach eomplaints, and low spirits. The excreise is good, and the ehange of scene prevents the patient from brooding over his real or fancied maladies. Exercise shonld gonerally be taken in the best and purest air, and a moderate degree of eold, provided it be not attended with moisture, alds to the strengthening effeets of exercise, In some cases of discase neither excrcise nor gestation is in the paticnt's power, and we must substitute for them rubbing with the flcsh bush, or with the hand. Such treatment is somctimes nccessary in rhenmatism, sprains, tumours, white swellings, and dropsical limbs. 


\section{TIIE BOTANIC FAMILY PIIYSICIAN.}

\section{SLEEP.}

That state in which the powers of sense and volntary motion are suspended, in order to recruit the powers of the system, exhausted by the continued actions which thcy cxert. All animals generally sleep in the night, when the silence and dnrkness remove the ordinary impressions on the senses; and the continuance of sleep varies much aecording to the age, constitution, habit, and other circumstanees of the individual. New-born children sleep a great deal, and thus their nutrition in the very early periods of life is favoured, while the parent in her weakened state is not fatigned. It is impossible to specify a period for the durntion of sleep, which shall be adnpted to all constitutions; but in an adult healthy person, from six to eight hours may be reckoned suffieient. Too much sleep blunts the faculties, and disposes to listlessness and inactivity of mind and body; it also gives rise to flabby, corpulent, and unwieldy habits. A disturbed and unsound sleep arises from a variety of causes; from the presence of feverish and other discases, from disordered bowels, from too great fulness of stomach witl ment or drink. Slcep is also prevented by uneasiness of mind, by a certain degree of cold ; by light, noise, and other impressions on the senses; and in sonie persons by the use of green tea, or of coffec. To bring on sleep is often an essential object in several diseases. The medicines which have this power are called nareotic, and are of primary importance in the practice of physic. Of these, the most grenerally usefill are opium and its various preparations, henbane, and hemluek.

\section{EXTERNAL APPLICATIONS.}

Hest. $-\Lambda$ certain degree of external heat is necessary to pro mote the vital manifestations of att warm blooded animals. It is freruently employed as a remedial arent extematly, Tho Hot Air Jiath, at a temperature of from $100^{\circ}$ to $130^{\prime \prime}$ Wahr. is a powcrful stimulant, and principally vahuable when the bloos has receder from the superficial parts of the borly, and tho internal organs congesterl; as in some cases of fever, in splasmorlic cholera, in drowning, in chronic rhcumatism, and stillness of the juints. 


\section{TIIE BOTANIC FAMLY PIISICIAN.}

Botrues filled with hot water, are applied to the fect, to excite the cireulation and angment the animal heat in diseases attended with eold extremeties, for which purpose nothing is better than eommon wine bottles, filled with boiling water and wrapped round several times with flannel to prevent them from burning the patient. Hot bricks may be used in a simitar manner. 'The same arre applied to the stomaeh to relieve spasmodie pain. Hot sand, inelosed in a bag, may be employed for simi-
lar purposes.

Cold BAtII.--The eold bath, thongh popularly estecmed one of the most innocent remedies yet discovered, is not however to be adopted indiscriminately. On the contrary, it is liable to do eonsiderable mischief in all eases of disensed viscera, and ought not to be used during custiveness. As a general bracer of the system to persons of a relaxed fibre, espeeially females, it generally proves highly benefieial, and in most enses, when not earried to exeess, is a great means of promoting a good state of health. When benefieial, a glow of heat sueeceds the bathing ; if ehilness and headaclie are the result, it should immediately be abandoned, as being evidently pernicions. Cold water is a powerful tonie, but, like all other valuable things, may be abused. Sea water, in general, is preferable to fresh, though when not attainable, the latter is a valuable substitute not to be despised.

Нот Batri-By which is muderstood any degree of hent between 93 and 96 degrees. It has a peenliar tenteney to bring on a state of repose, to remove local irritation, promotes personal eleantiness, and is execllent to ehildren affected with eonvulsions and diseases of the skin. It restores suppressed perspiration, relieves gouty, rhemmatie, and heetie patients, and is useful in eomplaints of the kidneys and liver. It is also especially useful in swellings of the legs, and in obstruetions peeuliar
to females.

The Suower BAtr is very similar in its efleets. In insanity it is used with the greatest henefit, to allay mental cxcitencent. When the patient appears overcome it should be discontinned, and renewed when the violent symptoms recur. After fonr or five spplieations of this kind, the patient becomes entirely subdned, when he shonld be taken ont of the bath, rapidly dricel,
406 
warmly eovered up, and put into bed. Calmness and sleep generally follow, with many days of tranquillity and ease. 'The daily use of the shower bath is very benefieial.

TEPrd Bata - A bath at about 90 degrees. It is often useful in fevers and in discases of the skin, is quite sufficient to produce a salutary reaction, with a degree of perspirability on the surface of the skin. It is useful in gout, rhenmatism, headaches, colis, \&e.

THE VAPour Batr is employed in the same way as hot air, but it is more soothing and sudorifie. It softens and rom laxes the skin, produeing eopious perspiration. It may likewise be employed during the eold stage of intermittent fever, cholera, dropsy in old debilitated persons, liver eomplaints, rhenmatism, gout, slight colds from eheeked perspiration, and ehronic skin discases aceompanicd with a dry state of the eutaneous surface. It is of great value in producing a relaxed state of the skin, and profuse perspiration.

Tire Inmalation of tile Vapour of Hot Water proves highly serviceable as a soothing remedy in irritation or inflainmation of the membrane lining the throat, or bronchial tubes and tonsils.

Warm Fontentatrons and Poultices are employed to ro lieve inflammation, pain, tension, and spasms.

WARM WATER has been highly extolled as an application to bums and sealds, especially those on young ehildren. Tho water must be applied with flannels, repeaterlly changed, but at the same time preventing as much as possible tle exposure of the burnt surface to the air. In every case it soothes and mitigates the pain, and lessens the infammation and constitutional disturbanec that usually follows injuries of this kind.

Cold $\Lambda$ FFUSION is often recommenter for use, when it is desirable to make a powerful and suclden inipression on the system. In inflammatory affections of the hrain (even of young children), in violent delirium, in poisoning by opium or prussic acid, or in torpor from the fumes of burning charconl, it may be used most advantageotisly. In hysteria, epilepsy, or lockjaw, it is often serviecable in rliminishing the duration of tho fit, and in relieving the deatly sleep that follows. 'T'he inolo 407 


\section{TIE BOTANIC FAMILY PHYSICIAN.}

in which eold affusion is effected, is as follows:-Water is poured on the head (inelined over a pan or tub), from a piteher beld a height of two or three feet. If the person be in bed, the heal shonld be placed over the side of it. In ehildren, it is sufficient to squeeze a large sponge, filled with eold water, at some height from the head. The time that it should be continued varies from one to two or three minutes, afterwards the body should be earefully wiped dry, wrapped up warm, and plaeed in bed.

TePID AFFusion is frequently employed, and by some regarded as a safer, though less powerful means than eold. Sponging the body with tepicl water in searlet fever is very benefieial; in eontinued fever, it diminishes the frequeney of the pulse and of respiration, and eauses a tendeney to sleep.

Cold is frequently used as a remedial agent. CoLd AIr, in fevers, is both grateful and efficacions. In the admission of fresh and cold air to patients affeeted by febrile disorders, eonsists one of the most important features of the improved methods of treating fevers.

The Cold BATr is employed with the view of obtaining the plunge or slioek, and the reaction or glow after it. In general the immersion being only temporary, renetion quiekly takes place, and a sensation of warmth is soon felt: the eirenlation of the skin is speedily re-established, a glow ensues, perspiration eomes on, and the body is invigorated.

In weakly persons, however, this reaetion may not follow, or only imperfeetly, and on such the cold bath will be fonnd to net injuriously. As a general rule, it should only be used when there is a sufficient degree of tone and vigonr in the system to eause a reaction. Even with the strong, long immersion renders the pulse small, and nltinately imperceptible. the respiration diffieult and irregular, a feeling of laugour succeeds, the joints beeome rigid and infexible, pain in the head, drowsincs, and eramps are expericncel, the temperature of the body falls rapidly, and faintness, followed by death, may ensuc. The treatment of such a state, must be ilie same as in

Drownixg. - Keep the lieal raised, dry the borly and rub with hot eloths, let one person press on the chest with his flat hands and another also with his flat hands, shove the belly $11 \mathrm{p}$
408 
to the ehest, then suddenly take away their hands, and in this way, by performing the action of resjiration, endeavour to restore breathing. A hot bath is also of great vahue Have several assistants to rub the body with their hands. Clear tho mueus from the mouth, hold the nose, and then suck out the foul air with a tube, and blow in fresh air, as represented in the cut. Place hot bricks and bottles of lot water in the armpits, between the thighs, and at the feet, keeping up the friction the whole time; irritate the nostrils with a feather, or hartshorn, and administer a elyster of warm tnrpentine. If possible, apply eleetricity. When swallowing ean be performed, give weak warm wine, or spirit and water, and soon afterwards a mustard emetie. After restoration, purge or give sucl medicines as seem to be required. Persons have been recovered who have been under water twenty-five minutes. 'Twelve hours' exertion may result in restoring a person to socicty. Blceding is often required during the progress of rccovery, partieularly when the respiration is laborious, the brain oppressed, and when delirium or wandering, the frequent attendant on restored animation, is present.

Cold Lotions. - Water and spirit lotions are employed to generate eold by evaporation, and thereby to relicve local imitation and inflammation. They should be applicd by a single layer of thin linen, and not made to confine the part. Cold lotions are applied to the head in brain fever in severe bruises, fractures, disloeations, and erysipelous inflammation.

ICE is sometimes employed to stop long eontinued bleedings from the nose and other parts. In eases of madness, inflammation of the brain, and in fever, where there is great cxcitement of the brain, with a hot dry skin, it is often noed witl the grentest benefit. Iee is alsu taken internally in the latter stages of typhus fever.

\section{FOOD.}

There is a period in the life of man in which the organs of digestion ale weak, and yet, at the same time, there is a necessity for much nourishment. 'Tlis period is infancy ; for sis at this time the body increases fast, nuch nourishuent is recunired 
to help and forward the growth; milk being naturally provided and therefore probably adapted to it, we may suppose it to be a food of casy digestion and considerable nourishment. Examining then the properties of milk, will give us some insight into the nature of food in general.

Milk is not a simple substance; it is a mixture of threc; namely, coagulable mattcr, cxpressed oil, and sugar: Congulable matter is that which will unitc, and become solid, leaving the rest thinner and more fluid, viz. the curd; and expressed oil is such as can be procured from any substance by pressing, as oil of almonds, olives, and the like : by cxplessed oil in milk, we understand the cream.

The most simple food, then, docs not appear to be the casiest of digestion ; if it were, we should have cxpected that milk would have consisted of onc substance only.

That coagulable matter is capable of affording considerable nourishment, may be gathered from our experiencing that animal mucilagc nourishes the most; mucilage being that substanec which lias sufficiant moisture to kecp it together: as, for, cxamplc,-sound, good ment.

This coagulable matter in milk is fluid indect when taken, but there is a juice peculiar to the stomach, very difierent from an acid, that render's it solid. We find the stomnch of a calf, though clcar of every thing that is acid, to lave this property. An infusion of a few grains of the iuner coat will coagulate or curdle scveral quarts of milk.

Dr. Cullen says, this coagulating or eurdling of milk in the human stomach, is mole owing to a weak acid in the stomach, of healthy persons, the relicts of vegetable food ; but in different stomachs it has a different cflect, giving a scuse of weight and licaviness. Dr. Mosley says this scnse of weight may be removed by mixing milk with sugar; but I liave tried it and found no such cficet, probably because I did not add cnough sugar, which to me is impleasant. When young, I ate much milk and found no weight; now I am old, I fiud this weight ; thereforc refiain from inilk.

Milk new drawn is hest and most wholesome for treakly persons and infants. Mrilk is of a costive nature and boiling it renders it more so, and as boiled nilk is less neescent in the 410 
stomach, it is better for the robust and vigorous, partieularly as it is in this state more cooling. As sugar prevents the spontaneous separation of the several parts of milk in the stomach, it is proper to give sugar along with it to convalesecnts.

Cuesse. - Witl respect to checse, for we shall not have a better opportunity to mention it, it has in general, a costive quality; but it differs, in proportion to the quantity of oil in the congulable part. The more rieh and oily parts there are in checse, the more nutritive it is and soluble; that is, the readier it will digest; the leaner the eheese, the more difficult it digests. Cheese is liable to become rank and putrid; we must then consider it as having all the effects of animal food when advanced to putuefaction; at this time it ccases to be nutritive, and can only be considered as an assistant to digestion. Cheese, indeed, as food, is only fit for the laborious and robust.

Butrer. $-\Lambda$ quantity of pure eream eaten is undoubtedly unwholesome; being, fiom its dispositions to get acid and rancid, very diffieult of digestion; but, in the form of butter, it may be used with advantage. It is a strong nutriment, fit to necompany our vegetable diet, especially sueh vegetables as are naturally dry of themselves; in this case, it gives them the properties of rich, oily substances.-But, to retru'n,

It appears then that mille, and, of eourse, all other food, must become solid in the stomach, and, after that, undergo a fresh change, that is, be redissolved, for digestion; for which julpose, it must remain some time there, befere it be passed off.

Now, that the expressed oil, which is the eream, helps digestion, is evident fion milk's not rligesting so well when it has been skimmed, the eurd being hareler; for the eream ant the sugar, being mixel with the eurd, separate the diflerent parts of it more firom one another, so that, the natural fluid of tho stomach will penetrate the easier, ancl formentation gro on bettel.* $\Lambda$ nd as to slerar, it being from its nature more apt to ferment, will of eourse facilitate digestion.

That expressed oil aflords much nomrishment, we find from

- If new milk be too rich or henvy for a child's stomach, let it bo diluted or mixed with ryter; it showld never bo skimmed. 
men and animals being able to live a long time upon nuts, almonds, \&c., sueh containing a quantity of this oil. But, expressed oil alone produces sense of weight in the stomach, owing to a relaxation it brings on, preventing the stomach's contracting and expelling its load; and, if talien in quantities, it will bring on sickness.

That sugar also affords great nourishment, is evident from arimals thriving on the shoots of young plants, which contain a great deal of sugar ; and from some negroes living wholly on the sugar-eane. But sugar alone is viscid, and by adhering to the sides of the stomach, will stimulate it, disorder the system, and, if diluted with any watery fluid, wonld be so thin as not to be retained in the stomaeh long enough for digestion; but mixed with the eoagulable part of the milk, it is sufficiently retained. Either of these substances alone then, viz. congulable matter, expressed oil or sugar, would be hard of digestion; but blended, as in milk, they are easy of digestion.

Immediately after child-birth, when the milk begins to flow in the mother's breasts, it contrins a larger quantity of sugar and water, for there is always a small quantity of water in proportion to the coagulable matter. Some months after chillbirth the coagulable matter increases, and the sngar proportionably diminishes. For as the infant-stomnch is weak, the solid part of the milk is at first less, so that a looser mass is formed, much easier to be dissolved. As the child grows stronger, its stomach can bear more of this congulate matter, and digests it, if it be firmer. This points out that a young child, one of $a$ month old, will not thrive, in general, on breast milk eight or nime months old.

We also learn from this, that weak stomachs require food of easy digestion; strong stomachs, food of harder digestion. Thus, chicken, \&e., will nourish people most recovering from siekness; and bacon, \&c. will best recruit a laboner.

For breakfast, milk is the most proper food, provided it agree with the stomach and bowcls. If it give a scnse of weight and disagrees, as sngar soon ferments and faeilitates digcstion, Dr. Mosley, as I lave salid, lecommends to those who feel weight and fulness after milk, to use a good quantity of sugar with it, which will correct this inconrenience.

412 
Milk is equally flt at every period of life, being, in general, easy of digestion, and ocensioning less heat to the system than any other animal or vegetable food, producing less feculent matter, and not offending the stomach, unless it form into too firm a coanlation, which occasions the fulness and weight $\mathbf{I}$ have mentioned. In such eases, if it be not correeted by sugar, it should be avoided.

Boiled milk has been found, by experienee, more costive than raw. When milk is boiled, a considerable quantity of air is detached, evident from the froth on the surface; and air is tle chicf instrument of fermentatiou in bodies; of course, after boiling, it is not so apt to turn sour in the stomnch. We find that boiling it will keep it sweet some days; for these reasons it is proper for the robust and vigorous, but not so proper for weak stomachs.

'The bad effects of millk, I eonceive, says Dr. Cullen, to be in the eream; the quarter part of which is not pure vil, the rest congulable and saline parts. In the form of butter, the oil is much more pure and more nutritious, taken with vegetables, particularly such as are lenst furinaccous.

Milk when new drawn fiom the eow does not so easily separate into parts as when it has been some time exposed to the air, and, of conrse, it is more nutritious. A mixture of sugar will prevent this spontancons separation, therefore gives it the arlvantage of new drawn milk. Convalescents therefore should mix it with sugar, as I have before observed.

Whey carrics with it a great part of all the ingredients of milk, thongh it may not scem so, and is mole nourishment than the milk itself. Farmers fatten pigs solely upon whey.

\section{VEGETABIE FOOD.}

Taste and smell generally direct our chice in vegetables, and it may be sairl, witl very few exerptions, that those esculents which are most agrecable to the taste and smell are uost salutary, and vice versa. But as the tiste and sucll in ecrtain constitutions are often depraved and vitiated, we had hest galy, that those which sit gasiest on the stomach are most wholesonte. 


\section{THE BOTANIC FAMILY PHYSICIAN.}

Vegetables tend to reduce plethoric and full habits; abate heat, and are, of course, very proper for corjulent people, and those troubled with fererish heats and distensions of the blood
vessels.

That vegetables correct putrescency, is evident from their culing what is ealled the sca-senrvy, brouglit on by living on flesh meat, which, without a mixture of vegetable food, is apt to continue long enough in the stomach to putrefy.

Vegetables are particularly proper in hot climates, being less stiunlunt; and though less nutritive, and have been aceounted flatulent, they are more cooling than animal food: but as flatuleney is seldom experienced by persons in a healtly state, it muy reasonably be imputed rather to the weakness of the stomach and bowels than to the regetables themselves.

The vegetable substauces capable of nourishing are as follow:

1. Farinaceous matter or flour. This is generilly contained in grain; but sometines we find it in the stems of plants, and sometimes in their roots, muel of it in potatoes.

2. Vegetable mucilage; as for example, gum-arabic, Se. "That this is capable of noulishing, is evident from whole carnvans living on it, for a long time, when they can procure no other food.

3. Sugar.

4. Expressed oils. And

5. Native vegetable acid; or the jnice of sour fruits, which tends to take off the putrescency of animal food; that is, to prevent ineat from corrupting ol putref'yiug, whilst it continues in the stomnel.

For animal food, without a mixtme of veretable, is apt to continue too long on the stomach, before it ferments. In this ease, it will sometines begin to put efy before it is passed oft, which putrefaction getting into the blook, will often bring on al putiefaction of all the fluicis of the borly. This is a complete sen-scurvy, which, if not timely remedied, always teminates dreadfully. Salting provisions nuakes them havele of digestion; and thougl it prevents uncat from corrupting soon ont of the bouly; yet, as the silt seldom, if erer, penetrates sufficiently 414 
into the substance of the meat, so as totally to sccure it against putrefaction, when in the body; if it be not immediately maclo to terment, by the acklition of vergetable food, or some regetable arid thromin in with it, it will be apt to putrefy before it digests, and contaminate the whole system. Henee we see, how liable mariners are, ou a voyge where there is a sealcity of vegetables, to be afflicted with the seurvy, and how soon they get ricl of that disorder, when they once gret on shore again, to tho free use of herlos and roots.

Now, those five regetable substances, we have mentioned, go naturally through fermentation, and are converted into blood.

With respeet to the fibres, the solid part of vegetables, we find them frequently pass throngh the body, without being altered. As for example, peas and the skins of gooseberries, enrrants, sc. Now, as the texture of the strongest tendons of animal food is constantly destroyed in their passage through tlic body, while sueh parts of vegetable fool shall be evacuated as they are taken in, it is a question whether these last are digesterl; if any of them arc, it must be such only as are young and tender.

In the East, they eat rice ; in England, wheat; in Germany, rye; in some parts, oats and barley; and in Afirica, Indian wheat. This is the grain commonly used for food, and it appears to be well arlapted to digestion.

liec has of late years been introduced into this country as a cheap food. Whole nations in the enst snbsist wholly on rice and othor vegetibles, get live long and are licalihy. 'The universal opinion that rice is an astringent is founded in error. It is renerally preseriber, and juliciously, as a dict in lax labits aurl debility of the digestive orgaus, beennse it produees less disturlance to the stomach and bowels in digestion than any other fork ; yet it is lighly nutritious, and more ensily rligested than brearl, sclilom oceasions acility or flatulency, and pebhaps is the nusst wholesone grain nserl by man.

Fotriuaceons matter is, in its nature, soliul, enpable of being disolved in water, and forming a jelly. If, helore we dissolvo it in water, we cappose it to lueat, it coamulates or hecomes solid, thas if we bake it, we convert it into hreal ; after which, it will not so readily dissolve. but bread dissolved by long boil- 


\section{THE BOTANIC FAMILY PIIYSICLAN,}

ing, is less viseid than a solution of flour wonld be ; and consequently inore wholesome. Were flour nsed, with water, raw, it would be so viscid as to clog and cloy the stomach; we therefore prepare it, to take off this viscidity.

Flonr is not apt to undergo that fermentation in the stomach so as sufficiently to correct the putrescency of animal food; we therefore ferment it first ; that is, we make it into bread. Anotler reason for eonverting it into bread, is that, in fermentation extrication of air takes place, which leaves a number of holes, making the bread spongy; by which means, when eaten, it soaks up the flutid of the stomael and facilitates digestion.

In order to eoagulate the flour, that is, make it into bread, and give it a whiteness, which is the nature of all coagulants to do, bakers sometimes mix it with a quantity of alum, which if not so great as to give the bread a taste, can do no harm to arlults; but a small quantity will do much mischief to infants. Panada, therefore, for children, should by no menns be made of bread in which any alım has been mixed. It is for this reason physicians preseribe biscuit-powder.

Sometimes bakers use whites of eggs, and sometimes spirits of wine, to coagnlate the flour, as in French bread; the first is innocent, and the last evaporates during the baking; and can produce no ill effect. For if bread be not perfectly congulated, and well baked, it will sometimes ferment a second time in the stomach, particularly if it continue long, as in weak stomachs, and turn sour : but baking it a second time will totally prevent this. Thus, rinsks and tonsted bread are often preseribed for disordered stomaclis, as being least linble to do mischief; for the least extrication of air in weak stomachs is injurious.

But farinaceous seeds and roots are not sufficicnt to correct the putrescency of meat; we therefore make use of verctables, that were not originally designed for foul, ummely, pot-herbs. Of these,

The one sort are calbages, eniliflowers, brocoli, and all the varieties of unis class of plints. 'l'hey natmally contain al stiunulating oil, and a bitter astringent juice, so as not to be fit for use; hit we find this only in wilu cabbages, \&e. l3y cultivation, this oil and bitter juice are destroyed, and such as grow in 416 
our gardens consist of little more than mucilnge and sugne; and, of coulse, are fit f'or food.

The methor taken to destroy these noxious juices, is, to mrow the plants in the dark, or, with as little ar as prosible; this is done by planting them in a rieh soil, and thus making them so luxuriant, that the leaves shall cmbrace one another ; by which means the body of the plant grows in the dark, and with little or no air. Hence the inner leares beeomes white, and are free from those hurtful juices. The outer leaves may lje caten, but the inner ones are most wholesome. So young plents are more wholesome than old ones, as whatever of these juices they contain, they are not near so rank.

A nother kind of plants we use, is parsley, fennel, thyme, mint, sage, \&e., and sonie others of the sane linil. These contain at stimulating oil that would be injurious to the constitution, if caten in any quantity ; and, on that accomnt, are only necel as condiments with a seasoning to other foods. Celery is of the same kind ; but, by corthingit up, and thus making it grow in the dark, and with little or no air, we destroy its noxions oil. IVid eclery, if eaten, will blister the month.

The several species of onious, garlie, shalots, Sc. are of another elass; we cannot destroy the oil in these, but by boiling.

Lettnec, endive, dandelion, \&e. contains much opium, and when wild are very bitter and dispose to slcep, comseruently are unfit for food; but by cultivating them in rich soils, and corrcring them from light and air, by tying them up, we render tlucm wholesome.

Spinage, beets and other plants of that kint whell will, contain also a bitter oil, so as not to be catable ; but, by calcivation in rieh soils they lose this oil.

In the aame mamner asparagns contains oil so stimulating, that if eaten wilel, it womlif blister the tomgute; but, lyy culliviting it in rich groumr, and malkingr use only of the joung shoots, we avoid this inconvenience.

None of these plants alnue afford much nomrishument; wo use them to eorect the putreserucy of aninal foot, and fiattit:ularly in the smmmer, ns not stimulatimen.

'They are ajet to ferment, and turn sour in a weak stomnel, $A \mathrm{~A}$ 417 
and in fermenting, will let loose the air contained in them, become flutulent and occasion wind: when persous find this, they shonld retiain fiom eating them, till the stomach grows stronger; for, by continuing to take down such things as disagrce with them, they not only disorder themselves for the present, but will, in time, so injure their digestive organs, as to be hereafter attended with dreadful consequences.

Pcas, beans, kidney-benns, \&c. are more flatulent or windy still; especially, when eaten unlipe, they are very windy : such persons therefore with whom they disagree, should by no means cat them.

IVith respect to csculent roots ; these contain mucilage, sugar, and farinaceous matter, that is, flour. The last two afford much nourishment, but the mueilage does little else than forward fermentation. The more mucilaginous and watcry these roots are, the more apt they are to ferment and eorrect the putrescency of animal food, and eonsequently the fitter to be eaten in warm weather. But the more sugar aud flour they coutain, the more they nourish.

Turnips, radishes, onions, \&cc. are equally as liable to ferment and correct putrescency, as the herbs springing from these roots ; and as they contain a greater quantity of sugar thau their respective herbs they are more nutritive.

Carrots, parsnips, artichokes, Jcrusalem artichokes, bectroots, \&e. contain much sugar and furinuccous nutter, but very little mucilage. These are wholesome, nutritive, and easy of digestion.

'The sugar adds much to the nutritive quality of the farinaceous matter in all these substances.

Potatoes, yams, cartli-nuts, \&c. contain flour almost alone, with very little sugar, but more water than we find in furinaceous sects. Howerer the farinaceons matter is the same in hoth, and is coanulahle by heat. Wre boil them and roast them, to destroy their viscidity.

Potatoes are more casily digested thon broal, and very rarely disagree with the most delicate stomaleh; but they afliord less nomrishnent than eillor lice or bread ; which procecels chiefly from the large quantity of water contained in their substance; 1is 
get many of tic Irish, a strong, healthly people, live wholly on potatues and milk.

Potatoes, articlokes, asparagus, often agree with weals stomachs, when cabbige, carrots, onions, \&c. will not.

It is not yet deteminel whether mushronms are animals or vegetables. They have all the properties of aumal food, and must be cousidered as such.

\section{FRUITS.}

A proper use of fruits greatly contributes to the preservation of health. Ripe fruit extinguishes thirst, moderates leat, and opens the body.

Acils, particularly the native, vegetahle ones, moderately user in diet, are grateful to the stomach, assist the appetite, promote digestion, cool the borly and correct a tordency to putrefaction; bnt the too frec usc of them will disorder both the stomaeh and the bowels.

Fruits contain sugar, native vegetahle acir, and mucilage; and their skius contain more or less an astringent juice ; but so little of it, as not to render them wnwholesonic. Niy, it is rather of service, as it Gtimulates the stomach, causes it to contract strongly, and thus jrevents the fruit becoming acid and flatulent. The surgar, acil and nucilage are capnble of fermenting and being converted into blool. As surar aflorels more nourishment than any other sulsstunce, such firtits as are sweetest are the most wholesome, viz. figs, mrajes, \&e.

Surgal is even more nutritive than flour, but it is selulom thorongrily diegested ; beiner so very soluble, it passes of lirom

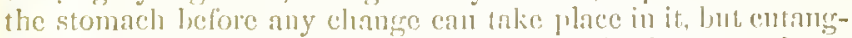
lerl in the cells of finit, it is retained lomere in the stomanch, so as to yiell some nomrishment. So argiul, it is not alpt to lerment in the stomach alone, but mixel with the mucilinge of firtits, fermentation rendily takes place. liesiles, the acid of fruits helps to correct the purerescuey of animal food.

'The more diluted surer is, the more apt it is to ferment. Ilence, watery or uncilagincus truits, with litte sugar, as 
gooseberries, eurrants, eherrics, \&e., affurl but little nonrishment, but then they teud nore to correet the putresceney.

Such as eontain more snceur and less water and mueilage, are not so apt to ferment, eonsequently are not so proper to correet putreseeney; but then they are more nutritive than sueh as contain more mucilage and water, and less sugar. They afford so mueh nourishment, that in many conntries they are used as food: thus figs, dates, \&e, in Portugal, are eaten as eommon food.

By evaporating the water from fruits, that is by drying them, we lessen their disposition to ferment, eonsequently, we make them less fatulent and more nutritive, if eaten moderately.

The fermentation of some fruits in the stomach, has, by letting loose the air, sonctimes so distended it, as to prove fatal; but we may correet this by adding sugar to them, or spices. However, snch as find they disagree with them, if they ralue their health, should refrain from eating then.

Fruits eontaining a great quantity of native regetable aeid, afturd so little nourishment, (as lemons, oranges, Sce) that we seldom use them, but as a power acting on the stomich, to correet the bad properties of other food; as will be shown hereafter.

Sour fruits, eaten in antumn, have been acensed of bringing on riolent continued purgings, but withont any reason. Inded, some sour fruits will act as purgatives, and the purging shall eontinue; but this must be owing to the state of the body, predisposed to purge; for we find, that when fruit purges a body, not predisposed to purge, no purging continnes when the fruit is evacuated. In hot summers, when there is great plenty of frnit, dysenteries or eontinued pingings are ant to be general; but this is owing to the heat of the weather ; for persons will be aftlicted with dysentery, who cat 110 fruit. In short, in such disorders they eounteract ; and those who cat no fruit, are more apt to purge, than such as do. Niy, if linge quantities of fruit should purge, it will not prove dangerous ; it will act no further than as a dose of physic.

Lord ehtancellor Bacon, one of the best writers on the preservation of health, condemus the nse of encumbers and nelons. 
Ire says they are cold and bad, and that a French pliysician, who hat great practice fiom suel persons as ate much of them, huilt a comutry-sent, and wrote over it in gold letters, in French, the English of which is, "Cold enemmbers built this hall, and crude-nusk-melons furrished it."

\section{ANIMAL FOOD.}

Let us first consider the difference betreen animal and vegetable food. Now, as we said before, fermentation which takes place in food, within the stomach, is different from that which takes place out of it. If the stomach then be weak, so as not to bring on the fermentation which is natural to it, fhe fermentation that would take place out of the stomach. will take place in it, and bring on certain discascs. Thus the misehiefs of animal food putrefying, are greater and more dangerous than such as arise from undigested vergetable fool ; as this turns sour only.

A nother difference is this. Vegetable food, during digestion, stimulates less. When the stomach is distended with food, the whole system, during digestion, is more or less stimulated ; but more so with animal food than with regetable. Now the more our system is stimulated, the quicker is the cirenlation, and the more feverish we become.

As animal food fills the vessels fuller, and with denser bloorl, than vegetable, it naturally increases our muscular strengtlı: but then it lonrls the brain, (every part being fuller of bloort in proportion) and oceasions heaviness and stul)ol"; whereas, vegetable fort, forn not loading the system with bloorl, rather diminishes musenlar strength, but enililes the mind to act with greater force. Veretable forsl, therefore, is fitter to give elear-

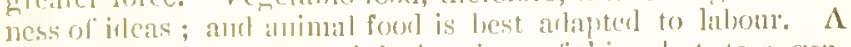
physiogl demonstration might lie reiven of this ; Int, to a gen-

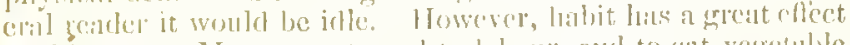

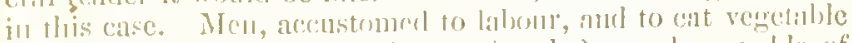

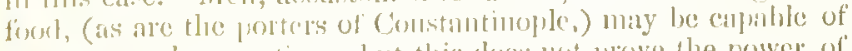
freat musculall exertion; hut this dues mot prove the power of veretable food over animil, So a horse led on grass, and licpt 
in exereise, will be better able to work, than one fed on hay and eorn for twelve months togetlicr, withont exereise: but neitler is this any proot.

That food which eontains the greatest proportion of liquid creates the greatest evacuation by stoul; but it must be recolleeted at the same time, that though liquids liave the above good quality, and promote seeretion, yet, the sooner food is evaeuated the less nutritive it beconles of course, those who use least drink are most nourished.

The more vegetable food a person eats, the less drink he requires; and that drink should be pure water; the substanee with which water is impregnated is of little eonsequenee: but those who eat mueh auimal food may require fermented liculurs; but it must be remembered, that, though fermented licjuors eontain an acid proper to correet putresecney, they also contain an aleolol, which, though it stimulates, is hurtful to the stomaeh.

The chief nourishment drawn from food, as I Inave observed, is the oil it contains; and there is more oil in animal food than in vegetable. A proof of this is evident, there being more eorpulent persous in England, where animal food is eaten in larger quantites, than in any other nation of twice the population in the world.

In time of digestion, perspiration is stopped, and more so when we have caten mueh regetable food; but in general, vegetable food is more perspiralule than animal. Nature, in the strueture of the body, has desigued man to live on both kinds of food, and reason should teach him which to eloose and when.

Dr. Cullen has aeenlately eonsidered this subject, and says, that the more a man labonls with his boly, the more animal food he shonld eat, and the more he labours witl his mind, the more vegetable. Ton much animal lood eaten produces dulness, laziness, and yawning.

Dr. Cullen's doetrine on animal food is as follows :-Though it wives strength, it is hazardous to the system, as it produces plethola and all its eonsequences; and by its stimulating power's, sooner wears ont the systen ; and if we take cxercise sufficiont to render this diet sulntary, such an aeeumulation is 
made of putrescent fluids, as in after life to lay a foundation of the most inveterate elronic distempers. It is therefore a question whether we should desire this high degree of bodily strength, with all its inconvenicnees and dangers. Certainly, those who lead a sedentiny life, slould aroid an excess of animal food. In hysteric and hypochondriac constitutions animal food is absolutely neecsary; but it should be used with as much vegetable food as is found requisite : and when a cure is performel, this diet may be changed. If this luxurious age could be persuaded, eontinues the Doetor, this discase might be removed, witl muel less danger, by exercise, fresh air, and avoiding warm chambers, venery, and late hou's.

Sueh persons slrould ent a great deal of bread, the safest of all vegetalle food. Vegetable food is not only necessary to scemre health, but long life. In infancy and in youth we should be confined to it mostly, in manhood and deeay of life, use animal food, and near the end regetable again.

Variety of fnol, adds Dr. Cullen, scems to me neessaly, and liquicl and solid foor should temper each other; the only danger of raricty is eating too much.

Animal fond, though scemingly of greater eohesion, is readice dissolverl in the stomach than veretables; not quicker, bnt more effectually or entirely: hut though some vegutables never dissolve, yet their jnices are more quickly extracted than those of animal food, and pass soonel off'; for solubility lloes wot depend so much on firmness of texture as on viscillity of the juices. Thus the younger the animal, the less soluble it is ; veal than beef; lamb than mutton, \&ec. Youmer fooul lecing more viscid than oll.

IImainess, as it is ealled, in the stomach, is schlom felt from veretables, cxecpt eaten with tongh pastry, or the mure viscid sulstallces.

Vegrtalis food continues louger in the stomarl than animal, snd grves little stimulus; and hie system is affecterl in proporfion to the extent of this stimulite, which is incomparably grester liom the animal viseid, oily foorl, than from the vergetaisle, firmer, and more aqueous. 


\section{TIIE BOTANIC FAMILY PIIYSICIAN.}

D1: Cullen says, where neither putrefaction nor aeidity has geme a great lengtli.in the stomach, animal fool keeps the body mure regular and less costive than veretable food; and thus, thrue who ane costive fiom regetable food, having recourse to minual, are, in this respect better.

The Hinloos, we are told, who live wholly on vegetable food, camnot work so long as Eurojeans; they mar, as the porters of Cunstuntinuple, have muscular strength, bnt they soon tire.

The chict of the fluids in the hody is oil. Now, as animal food is cariel convelted and Innger letained in the sistem, and as it eontains a greater proportion of oil, it will afford more nonrishment than vegetable, and repair best the waste of the solid tibles.

Next, as to pereeptibility, of which I shall give some explanation hereafter, Sanctorious, to whom we are indebted for this knowlelge, says, mutton is the most perspirable of all foods, and that veretables rather check perspiration. - This is owing to less stimnlus in veretables, so that persons who live on vegetables lave not theic perspiration so suddenly exeited. In time of digrestion, as before observed, perspilanion is stopped from whiterer food we eat-much more from eooling regetables.

Next, as to the quantity of these mixed fooks, animal and vegrable, of which most is best to be eaten. It is an aphorism of - Fanetorins, that weight gives strength. Men, in some measule, are able to work in proportion to their food. The English haboni more than the Dutch, and wherever men are expused to har:l libour, their food shonld be animal: but animal food, though it gives strength, loads; hence it is only proper for bodily labour. and entirely impropel for mental exercise; for whorver wonld keps his mind acute and penetrating, should cat rallere more veretable foul than animal. The boily is even opluesed by animal foul ; a full meal always produces heaviness, duhness, and intartivity.

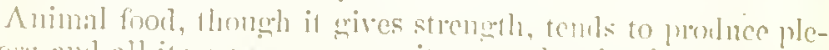

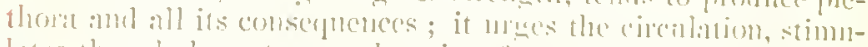
lates the whole system, and excites ferele b hat promotes pers-

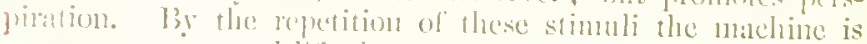

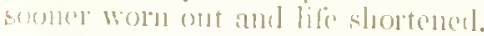

Vergetalble diet has this atrautage over animal, that it whets 4.2 
the appetite, and we ean hardly snffer from a full menl of it. Upon the whole, it must be coneluded, that a larger proportion of regetable fiorl is uscfinl and more wholesome to the generality of mamkind.

There is no error in this eountry more dangerous or more eommon, salys Dr. Cullon, than the nergleet of bread; it may well be ealled, "the staff of lile." It is the safest vegetable and the best corrector of animal foor ; and in a lypochondriac state, a large proportion of it will obriate its bad consceptenees. The French, by their great use of breat, aroid this state, and therefore it should be partieulurly eaten by the English, who are so voracious of animal food.

Buchan arlvises families, where they have convenienee, to make thejr own breat, and mix it with a little rye, for bakẹr's bread is often foumet muwlolesome.

Spiees, as einnamon, cloves, nutmegs, maee, pimento, Se, which are the produce of watmer elinates, and mustard, anise, caraway, corianter, and the sweet herbs of our own eountry, stimnlate the stomach, promote its digestive powers, remove spasms arising from flatulency of fool, sud are antiseptie, molerating the putrid tendeney of our food in the intestines. They onchlo only, says Cullen, to he nsed in the comtries where they grow; they are introdueed here unfitly, an any antiseptie vintue they latve, would be overcome by their stimulant properties.

J'hcre are ecrtain acrid or hot plants, as eresses, horecralish,

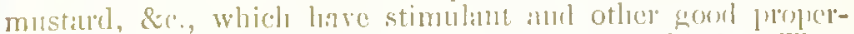
ties. Garlic, shalots, \&e, are of the same linel. 'T'luey are dimetic and diaphoretic, that is, they promote mine and swert.

The next thing to be considered, is, a maxim generally laid

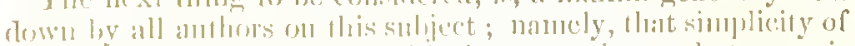

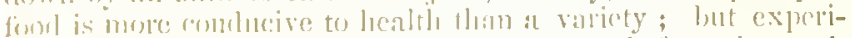

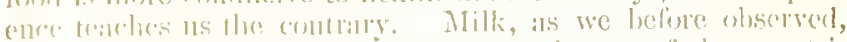

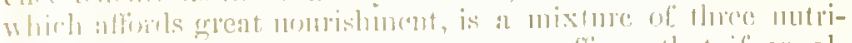

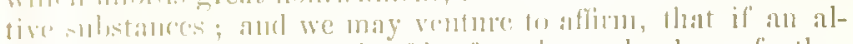

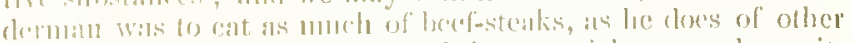

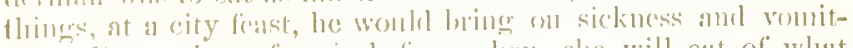
ing. I'ut varicty of granin before a hen, she will eat of what 
she likes best hut, before the day is ont, she will ent of the other. Instinct leads her to this, as most conducive to her health. The only danger in variety is cating too much; if we can resolve against this, varicty will not do harm, if of casy digestion.

Almost all food contains oil, and the stomach can bettcr bear a varicty of this oil, tlian a quantity of one particnlar sort. Besides, animal and vegetable food correct the ill qualitics of onc another. Animal food colrects the fiatulency of regetable; and vegetable food, the putresecncy of animal. But, a mixture of such foods as will disaryce, viz. acids with milk, fish and milk is improper ; acids or fish coagnlating milk too firmly for easy digestion; but there is no rulc without an excoption.

Food may be very wholesome and nutritive in itsclf, ret when combined with other nutritive food, may be very injurious. Certain drinks may occasion what we have caten to do harm. They may occasion fermentation in the stomach, or harden what wo have caten, and render it indigestible.

We shall now proceed to the properties of the different kinds of animal food. There are two snisstances in meat capable of nourishing; mucilage and cxpressed oil.

Animal mucilages differ much from one another ; bnt considered as food, they do not. The only difference of consesequence is, as far as depends upon thcir textul'c. When the fibres of an animal are lare, they are not casily dissolved; of coursc, they are diffeult of digestion. Beef is, on this account, more difficult of digestion than mutton; the fibres of the one being larece than those of the other. On the same lninciple, when food is coagulated firmly, it is also dificult of digcsilon. The firmer the compulum, that is, the less fluid it contains, the more difficult it will he of digestion. Animal tood, whose fibres have lut little fluid between lliem, thit is, dry incat. is more indigestible than moist. 'Ilus, lean animals are harder of digestion than fat ones; and the lean pillt of fin meat is easier of digestion than the lean pant of lean meat. By the same way of reasuning, ment roasted or boiled a great deal is not so digestible as when roasted or boiled hut little; for when the fluids are expelled by heat, the fibies nplroach closer to 426 
each other, and, when in the stomach, will not admit the juice of the stomach so readily to penetrate it; consequently, fermentation will lot take place so soon. This also is the opinion of 1) r. Cadogan, who lecommends most persons, particularly weak persons, to calt their meat very little clunc.

The readier animal food dissolves in water, the more digestible it is. A flommler boiled in an equal quantity of water, is sooner dissolved than mutton; therefore, flounders are casier of digestion than mutton; the juice of the stomach being litle else than warm water, helped by fermentation. But fish, thongh readily soluble in water, has a property in it that renders it indigestible, which is a certain glariness or viscidity ; but, when the stomach is strong enough to digest it, it is easier of dicrestion than cither flesh or fowl.

Meat apt in its natme to putrefy is sooner digested than such as is not. Pigcon will putrefy sooner than dluck: of course, pigeon is easicr of digrestion than duck. Now, as the fluids in animal food tend to hasten putrefaction, by depriving it of those fluids, by long boiling or roasting, we render it harder of digestion. By boiliug meat till it be free from gravy, we can lieep it from corrupting for six months. $\Lambda$ further proof that meat much dresserl is less wholesome than such as is little dressed. Such meats, however, as putrefy the somest, are injurions to weak stomachs, as this putrescency stimulates during the time of cligestion.

It is with a vicw of rendering meat casicr of digestion, that we keep it some time after it is killerl, befure we eat it, but the bnere we kecp it the less nutritive it is, losing its juices by drying. As soon as meat is killed, it begins to putrely; and putrefaction is the most cffectual breaker-rlown of mimal substance, and a great assistant to solution, which is the immealiate forerunner of digrestion. Sut the lengrth of time ment ourlat to be kept, should lie proportioned to its tendency to putrefy, nurl the hoat of the woratlice. It is eaten, for example, much sooner in summer than in winter. Sct it be olserved, at the same time, that though rendererl easier of digestion, it is not so nomlishing, as it loses some of its juicess ; and if any way tninted, it is still the worse.

That the property in which meats differ most is their visendity or glariness. Such as are viscial, atlicie to the sirles of the 


\section{THE BOTANIC FAMILY PIISICIAN.}

stomach, and stimulate much. In quadrupeds, young animals have this property, such as veal, pig, fawn, and lamb; but in a smaller degree. Young birds liave the same bad property, and all fish in a great degrec ; particularly shcll-fish, which, on this account, has often proved poisonous and fatal to many. When these have proved fatal, it has been aseribed to the copper vessel in which they were dressed; but a little observation would show the contrary. When persons lose their lives by the ill effeets of copper, sickness, voniting, and purging, take place : but when poisoned by shell-lish, the head swells, the
bleast is oppressed, and stupor is the consequence.

Animal food dissolved in water, forms a gelatinous solution or jelly, which is of a viscid natnre, and, in some degrec, produces the same effect as riseid foods. It stimulates, bnt does not yicld much nourishment. At the same time, it is difficult of digestion, and of comrse impropel to be taken by diseased or weak stomachs, Jellics, though long preseribed to strengthcu the system after a ferer, have lately been found prejudicial, and the use of them is therefore exploded.

Essential oils, inherent in some animal food, render it difticult of digestion. The essential oils of vegetahles are often agreeable to the stomacl, and stimulate it so as to formar digestion; but those of animal food, though agrecable to the taste, are injurious. Pork, geese, ducks, salmon, Sc., contain much of this oil, and are of consse high-flavomed. They may be agrecable to the taste of those who have strong stomaclis, but, if caten in too great quantitics, or if the stonnch be too weak, they will disagree with it, and have the same effect with viscidity; that is, they will stimulate the systen, and sometimes bing on a fever: Animal tood, then, that is viscid, which contains much essential oil, or will not realily dissolve, is apt to remain too long in the stoniach, and do lammi. But that which ivill condily putrefy and dissolve, is retained but a slort time in the stomach ; and is of course casily digested : for digcstion depending on the contraction of the stoninch, if the stomach he so disordererl as to lose any of its contractile porrers, cither by the oil or riscidity of the food, the food will be retained too long in it.

We seldom use animal food without some preparation. 428 


\section{THE BOTANIC FAMILY PIIYICIAN.}

These preparations are cither exposing it to such heat as will cougulate the solicls and fluids, or, after such congulation, dissolving it in water. By coagulating any animal solid, we take off that viseidity which almost all have when raw, and the stomach eonsequently bears it much better. Thus we ean digest twice the quantity of oysters roasted, that we ean raw.

In coagulating animal substanees by licat, we often expose them to a great fire, as in roasting; which eoagulates the outer parts, forming a erust, as it were, round the inward fluids, and retaining them. This gires them an empyreumutic oil, oflensive to the smell. In boiling, we avoid this empyreumatic oil, but then we take out the essential oil. In fiying, we retain both oils, so that firied meat is more difficult of digestion than either roasted or boiled.

In baking, (particularly in baker's ovens, which contain variety of things,) whatever is evaporated from meats, \&e. baked, is thrown down on them again by reverberation from the top of the oven, and gives them a very peeuliar and unpleasant taste.

Dr. Crullen makes some judicious observations on our modes of cookery. The design of dressing meat, he says, is to render it soluble in the stomach for the purposes of digestion. Young animals are more soluble than old, but they are more viseid, and apt to eling to the euats of the stomach and do injury, unless eaten with sour sauces. It is for this reason lemon-juice is eaten with veal, mint-sauee with lanib, vinegar with lolster, \&e. Viscicl fool is not so realily passed from the stomach. Persons are often more oppressed with a full meal of veal than of beef.

By looiling of meat we extract the juices from hetween the fibres, make the texture of that meat firmer and less soluble in the stomach and nunch more rearly to putrefy. 'Those who throw away the broth of boilerl meat, aet very improperly. It is a fluid, not nnpleasant to drink, and when drunk with on fourl, increases its solubility.

linasting of meat retains those jubes which boiling extracts, hut the less mat is roasted the nurres soluble it is ; raw 1ureats are still more soluble: it is on this principle that lor. Cialogan so warmily recommended meals very little rousted or 


\section{TIIE BOTANIC FAMLY PIIYSICIAN.}

boiled; but, at thr same time, the less dressed they are, the more they are apt to putrefy in thc intestines, an evil the other way.

Clicken, partrilges, veal, \&e., are more wholesome when ted when boiled.

All quadrupeds that feed on vegetables are used, somewhere or other, for food; sueh as the ox, the sheep, the deer, the goat, the hog, the hare, se.

Bircls also are made use of for food, exeept birds of prey, and all fish also have been eaten, and all shell-fish which have suffieient museular flesh to render them worth eating.

Those birds that are not very putreseent in their nature, and are most free from essential oil, are the ensiest of digestion. As for example, moor-game, poultry, partridges, pheasants, \&e., and of quadrupeds, the deer', the sheep, the ox, Ee. The older animuls of this class are easier of digestion than the younger ones. Mutton, for instanee, is easier of digestion than lamb; beef than veal; venison than fawn; and that on aceount of the viscidity of the flesh of young animals. Fish is more diffienlt of digestion than flesh, especially in weak stomaehs. And of fish, those that have least flavour, that is, sueh as have least essential oil in then, are white, and have some degree of firmness, will digest mnch sooner thin sneh as are of stronger flavour. Flounders, whitings, Ee., are easier of digestion than samon, soles, \&e.

But still, quadrupeds afford more nonrishment than either birds or fish ; and those animals of stronger flavom, viz., pork, geese, duek, salmon, $\mathcal{E}$ e., aftord more nourishment, and are fitter for sueh as labour or take a grent leal of exereise, than auinals of the same elass, that are easier of digestion.

An equal quantity of liquid fool is found to be more heary than the same quantity of solid food; bread and flesh are light, wine and brotls more herly: a cup of wine is of greater weight than a picce of bread of thrice the bulk of the wine.

If a man feel himself lighter than in fuct he is, it is an argument of a most henlthful constitution.

430 


\section{TIIL BOTANIC FAMILY PHYSICLAN.}

\section{NUTRITION IN GRAIN AND FLESH.}

Vugetables contain a large portion of starch or surgar. which surstunes do not adt to the nomishment of the boly, but are enturaced in the purposes of respiration, and maintain the animal heat. Thes are rely necessary to the hody.

Chemists agree that the substanees of vegetaloles add to the organism, and are eonverted into the tissues of the borly; are posscssed of azotised, nitrogenised or nutritious prineiples; these are tibrin, albumen, and easein, and are denominated protein eompounds. If we take wheat flour and knead it under water, the starch separates from it, and the gluten remains in the hand, which is insoluble in water. Albumen is eongrulable by hent, and is, by this means, readily separated from the juices of many vegetalbles; as cauliflower, asparagus, or turnips, and is likewise abundant in curtain sceds, as nuts or almonds. Cascin is soluble in water; it does not eorgulate with heat, but enrls witl acicls; it abounds in peas and beans. Vegetable albumen and fibrin in the animal are found to be the sanie, and althontr grain contains muel starch, yet the large quantity of altuminous matter is what renclers it nutritions. "The following table is griven by Dr. R. D. Thomson, in his "Experimental IRcsearches on the Food of Animals," Se.

\begin{tabular}{|c|c|c|c|c|c|c|}
\hline \multicolumn{3}{|c|}{$\begin{array}{l}\text { Albuminous, or Nutritive } \\
\text { Natter, per Cent. }\end{array}$} & \multicolumn{4}{|c|}{$\begin{array}{l}\text { Albuminous, or Nutritive } \\
\text { Mlatier, per C'ent. }\end{array}$} \\
\hline Bean meal & - & $25 \cdot 36$ & IIay & - & . & $9 \cdot 71$ \\
\hline rl meal & • & $23 \cdot 66$ & Mialt & & " & $8 \cdot 71$ \\
\hline oatmeal & • & & Kiec (Last & t India) & . & $8 \cdot 37$ \\
\hline lina. & • & 12 & Siluo & & & $3 \cdot 33$ \\
\hline arlian flour & - & 11 . & Itili Sea & $\Lambda v$ & $-1.00 t$ & $3 \cdot 21$ \\
\hline ley . & - & 11 . & ioc:i & 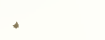 & - & 3 \\
\hline$\cdot$ & & & Putitoes & & , & \\
\hline (.x flour & & $11 \cdot 80$ & alisli I & [uruips & . & \\
\hline
\end{tabular}

\section{E. Lothian flour $9 \cdot 74$ to $11 \cdot 55$}

IrTert. - The flone of wheat grown in the south of Britain

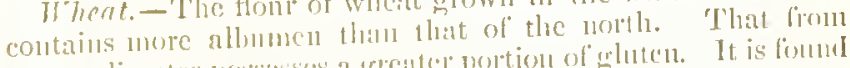

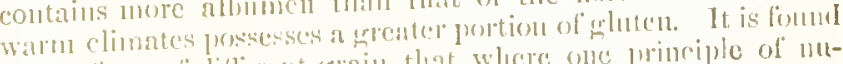

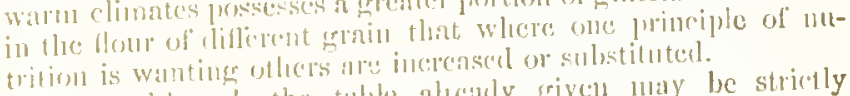

Now, altwouth the table aleady given masy be strictly 431 
correct in a chemical point of view, there are other concirterations that mankind must take into accomt, in lespect to themselves, before being satisfied with the apparent result; and that is, as to the digcstibility of the articles, and their assimilation and conversion into animal organism.

On the nutritive propertics of animal food Professor Brande writes :-"When the muscular parts of animals are washed repeatedly in cold water, the fibrinous matter which remains consists chicfly of albumen; and is in its chemical properties, analogons to the clot of blood. Muscle also yiclds a portion of gelatine; and the flesh of beef aud some other animals atfords a peculiar substance, of an aromatic flavour, called by Thenard osmazone. Albumen and gelatine constitute the lcating nutritive ingredients in the different kinds of flesh used as food, and it is curious that their relative proportions are not very dissimilar in quadlupeds, birds, and fishes, as shown in the following table. The water was detemined by evaporation in a closecovered vessel, or at a temperature below 212.

\begin{tabular}{|c|c|c|c|c|c|c|c|c|c|c|}
\hline $\begin{array}{l}100 \text { Parts } \\
\text { Nuscie } 0\end{array}$ & & & & Water. & & $\begin{array}{l}\text { Albumes } \\
\text { or Fibrin }\end{array}$ & & Gelatine. & & tive 1 \\
\hline Mutton & & - & - & . 71 & - & - 22 & . & . 7 & . & \\
\hline Chicke & & - & - & 73 & - & 20 & - & 7 & • & - \\
\hline Bcef & - & - & - & 74 & - & 20 & - & 6 & - & - \\
\hline Veal & - & - & - & 75 & - & 19 & - & 6 & - & - \\
\hline Pork & - & - & - & 76 & - & 19 & - & 5 & - & - \\
\hline Cod & & - & - & 79 & - & 14 & - & 7 & - & $\cdot$ \\
\hline $\begin{array}{l}\text { Sole } \\
\text { Halddoc }\end{array}$ & i. & - & - & 79 & - & 15 & - & 6 & - & - \\
\hline & & • & - & 82 & - & 13 & & & & \\
\hline
\end{tabular}

On looking at this table, we see it stated that chicken contains more nutritive matter than beef, and veal more than pork; yet we know fiom experience such a result does not tilke place in our own persons. $\Lambda$ nd, again, on comparing the former with the latter table, we are aware that we shonld derive more nomishment fiom real or pork than linsecel-meal; licnce, as we beforc observed, mucl depends on the suitability to the digestive olgans, and the tacility with which it combines with the anlmal olganisation.

I'rofessol Jolmston has proved that bread perfoctly white is not so nutritions as when mixed with the pollarel or inner bran; 432 


\section{THE BOTANIC FAMILY PHYSICIAN.}

that this bran is richer in fatty matter, and nitrogenised principles than the grain itself. It contains more phosphate of lime, and is therefore more efficient in supplying the materials for building up the solid portions of the body. Brown breal should therefore be adopted, not merely on a principle of economy, but also as providing more of these ingredients, which are deficient in the better kind of flour.

It has been eorrectly aseertained that

112 lbs. of Wheat flour yield 154 lbs. of bread.

$\begin{array}{llll}\text { Do. } & \text { Oatmeal }, & 336 & \text { do. } \\ \text { Do. Rice } & 450 & \text { do. } \\ \text { Do. Maize } & 560 & \text { do. } \\ \text { Do. Indian Meal ", } & \mathbf{4 5 0} & \text { do. }\end{array}$

But it is not to be supposed for one moment, that beeause Indian meal, by absorbing more water than wheat flour does, which mercly causes it to swell into a greater bulk, that it contains more nutrition. Yet this property may serve as a recommendation to its use, by cnabling us to obtain an equal weight of bread with a less consumption of flour, making up the deficiency by eating more of other and cheaper lind of vegetables.

\section{UINTS IN EMERGENCIES.}

Pecoter of Persons apparentey Drowned or Dead.

Recommended by the Royal Humane Society.

CAUTIONS.-1. Lose no time. 2. A void all rough usage. 3. Never hold the borly up by the feet. 4. Nor roll the bolly on casks. 5. Nor rub the horly with salt and spirits. 6. Nor inject tobaceo smoke, or infusion of tobatco.

Restorateve meins, if apparentey Drowned.

Sencl quickly for medical assistance; but do not delity the following means :-

1. Convey the borly CAREFU, filpported in a raised condition, to the nesurest honse.

II. Surip the body, and rub it, rlyy; then wralp it in loot blankets, and place it in a wirm bed in a warm chamber. 
III. Wipe and cleanse the mouth and nostrlls.

IV. In order to restore the natural warmth of the body :

1. Move a heated covered warming pan over the back and spine.

2. Put bladders, or bottles of hot water, or licated bricks, to the pit of the stomneh, the armpits, between the thighs, and to the soles of the feet.

3. Foment the body with hot flannels; but, if possible,

4. Immerse the body in a warm bath as hot as the hand can bear without pain ; as this is preferable to the other meaus for r'cstoring warmith.

5. Rnb the body briskly with the hand; do not, howerer, suspend the use of the other means at the same time.

V. In order to restore brenthing, introduce the pipe of a common bellows, (where the apparatus of the Society is not at hand) into one nostril, carefully closing the other and the month ; at the same time drawing downwards, and pnshing gently backwards, the upper part of the wind pipc, to allow a free admission of air ; blow the bellows gently, in order to inflate the lungs, till the breast be a little raised : the mouth and nostrils shonld then be sct free, and a moderate pressure made with the hand upon the chest. Repeat this process till life appears.

VI. Eleetricity to be employed early by a medical assistant.

VII. Inject into the stomach, by means of an elastic tube and syringe, half a pint of warm brandy, or wine and water.

VIU. $\Lambda$ pply sal-volatile or hartslion to the nostrils.

\section{If apparentily dead from Apoplext.}

The patient should be placed in a cool air, and the clothes loosened, particnIarly abont the neck and breast. Blceding must be early employed by a medical assistant : the quantity regunlated by the state of the pinlse. Cloths soaked in cold water, spirits, or vinegar and water, shonld be lscpt applied to the head, which should be instantly shaved. All stimulants shonld be aroided. In crses of conp-tc-solicl, or strokes of the sun, the same means to be used as in apoplexy.

\section{IF APPARENTLY DEAI) FROM INTENSE COLD.}

Rub the body with ice, snow, or cold water.-Restore warmtl by slow denreces ; mul, after some time, if necessary, employ the 434 
means recommended for the npparently drowned. In thicse accidents, it is mGHLY DANGEROUS to apply heat too carly.

\section{IF APPARENTLY DEAD From HaNGiNG.}

In addition to the means recommended for the apparently drowned, BLEEDING should carly be cmployed by a Medical Assistant.

\section{If APPARENTLy DEAD FROM Noxious VATOURs, LigmTNing, \&C.}

1. Remove the body into a cool fiesh air.

2. Dash cold water on the neck, face, and breast frequently.

3. If the body be cold, apply warmth, as recominended for the apparently" clrowned.

4. Usc the means recommended for inflating the lungs in Direction V.

5. Let Electricity (particularly in accilents from lightning) be carly employed by a Medical $\Lambda$ ssistant.

To Purify tue Air.-Powdered nitre and oil of vitriol, six drachms each. Mix, by ackling one drachm of vitriol at a time. The ressel must be placed on some hot substance, and the mixture stirred with a glass rod. Place in difierent parts of the room.

To prevent Infection from TypHes Fragr.-Powdererl nitre six drachms, sulpluric aeid six drachms. Adul one drachm of the acid at a time. I'lace the vessel on some liot sulstance, and stir with a glass rod or tobaceo pipe ; this to be placed in the sick room.

\section{ANTIDOTES TO POISON.}

The treatment of cases of poisoning must, of courso, vary witle the nature of the poison, the quantity atken, and the peculiarities of the indivirlunl. In almost, all eases, coplons vouniting shonll be excited ats soon as possible hy tickling tho throat, and by cubetics, such especially as sulplute of rinc, or ijecrenanlat with emetic tartar ; the former, lowever in tengrain doses discolved in n little wall'm water, and repented every ten or fiftecn minutes till it fiecly operates, is gencually most 
effectual. The use of the stomach-pump should also be resorted to. The vomiting should be kept up, and the stomich washed out with bland albuminous or mucilaginous fluids, such as milk, barley-water, flour and water, or thin pastc, etc.; sometimes sugar and water.

The following is a short summary of the antidotes which may be resorted to, in reference to particular poisons. They should, of course, be administered as speedily as possible.

Emetic in cases of Porson.-Two table-spoonfuls of marle mustard in a pint of wurm water ; if taken immcdiately, this is a certain remedy, instantly producing violent vomiting. Administer large draughts of warm milts or water, mixed with oil, melted butter, or lard.

1. Arsenic.-Lime water, chalk and watcr, and the hydrated sesqui-oxide of iron, have cach been strongly recommicnded; the last is decidedly the bcst.

2. For Mineral Acids, or Acetic and Oxalic Acid.-For this form of poison, give quickly large dranghts of chalk, whiting, magnesia, soap and watcr, about as thick as cream ; followed by albuminous diluents, such as milk, and whitc of egg mixed with water. Or, if thesc cannot be procured at once, warm watcr; and promote vomiting by tickling the throat.

3. Alkalies, Sorla, Potash, Ammonia, ctc.-Vinegar, or any mild acid and water, or cven very dilutc mineral acids, such as water acidulated by them; olive oil, almond oil.

4. Corrosive sublimate.-IVhite of $\mathrm{cgg}$ and water; milk and eream ; dccoction of einchona; infusion of galls.

5. Sulphate of Copper, and other poisons.-Sugar and water; white of cgrg and witter.

6. Antimonial, poisons.-TVarm milk, gluel, or barleywatel : infusion of galls; decoction of cincliona.

7. Nitrate of Silver.-Copions draughts of warm salt and water.

8. Sulphate of Zinc.-Solution of carbonate of soda in water, with milk, and nucilngiuous or fariunceous liquids. 


\section{TIIE BOTANIC FAMILY PHYSICIAN.}

9. Acetate of Lead.-Emeties, solution of sulphate of soda in water; milk, white of $\mathrm{cgg}$ and water.

10. Opium and its preparations.-Einetics, strong coffee : dashing cold water upon the face and breast; preventing torpor by forced cxercise.

11. Prussic dcid.-Ammoniaenl stimulants cautiously applied to the nose; ammonia, or sal-volatile in repeated small doses of solution of ehlorine in water ; small doses of chloride of lime in water.

12. Strychnia and vegetable alkaloids.-Infusion of gall nuts; decoetion of cinchona; emetics.

\section{IF APPARENTLY DEAD FROM INTOXICATION.}

Lay the body on a bed, with the head raised: remove the neekcloth, and loosen the clothes. Obtain instantly medical assistance, as the treatment must be regulated by the state of the patient; but in the mean time apply cloths soaked in cold water to the head, and bottles of hot water, or hot brieks, to the ealves of the legs and to the fcet.

\section{General Observations.}

On restoration to life, a teaspoonful of warm water, should he given; and then, if the power of swallowing be returned, small quantitics of warm wine, or weak brandy and water, warm; the patient should be kcpt in bed, and a disposition to slecp cneouragcd, except in cases of apoplexy, intoxication, and coup-rlesolicl. Great care is requisite to mantain the restored vital actions, and at the same time to prevent unduc excitement. 'The treatment rccommended by the Socicty, is to be persevered in for three or four hours. It is an croncous opinion that $\mathrm{per}^{-}$ sons are irrceoverablc because life does not soon makc its appearance; and it is absurd to suppose tlat a body must not $\mathrm{bc}$ merldled with or removed witlont the permission of a Coroner.

\section{ReMarKable instances OF GUSPENDED ANIMATION.}

At the annual Mecting of the Bristol IIumane Society, the Society's silver medal was presented to I) r. Fairbrother, of Clifton, for his exertions in recovering a boy who liad heen under the water in the floating harbour a quarter of an lowr; 


\section{THE BOTANIC FAMHY PIYEICIAN.}

and another quarter of an hour liad elapsed before the Doctor eould operate ipon the body. The most remarkable feature in this case is the new mode by whieh Dr. Fairbrother suececded in his lautable ohject; nanicly, by closing the mouth with his finger, sucking off the fonl air from the lungs through the nostrils, and pronoting respiration by pressing on the abdominal nutuscles on the siles. The usual mothod is to inflate the lungs, but it is very sclulom that persons arc reeovered by this method if they have bcen under water more than a few minutes.

J. W., a seaman belonging to a packet-ship from New York to Havre, fell ovel the side into the doek, where the water was from 12 to 16 fect deep. Some stragglers saw the accident, and gave the alarin. Two men, who had not pereeived it, jumped in at hazard, but were unsuccessful in finding him, owing to his having sunk in the mud. A grappling iron was obtained, and the man hauled up. He was carried to the guard-house, nearly fronting the vessel, and from thence he was conveyed to the Stranger's Hospital, a distance of half a mile. On his been brouglit in, fourteen minutes after the submersion occured, as stated by Dr. Douglass, Physician to the Hospital, he was immediately stripped and laid on a bed. It was then ten minutes past three P. M. There was not the slightest appearance of animation. Whilst water was being heated, and hags of hot salt got ready, D1: Douglass says, "I desired 4 of the men to commence rubbing the body with dry flannel cloths. These men were relicved every half-hour by 4 of their ship mates, and constant friction was thus kept up. Bags of hot sand, placed round the body, and lavements of hot water, to which were ardded spirits of turpentine and tincture of assafoetida, formed the whole treatment. I was frequently on the point of abandoning all hope; but I saw, or thought I saw, slight convulsive twitchings in the right interior eyelid and around the mouth. This animated me. Tlic relajs worked on wcll; and at a quarter after eleven at night we joreeired respiration, eight hours and a half from the time of immersion. Before twelve o'elock he swallowed a tea-spoonfinl of warm brandy and watcr. It required for some time great care to keep up the feeble spark that animated the firunc; but it was two days before intelligence was restored. Within twenty-four hours, re-aetion set in so violently, I was obliged to order four 438 
leeches for eneh temple, and to take six ounces of blood from the arm. It was well blood was abstracted so cautionsly, for the pulse suddenly fell, and beerme almost imperceptible, the respriration becoming greatly hurricd; stimulants were instantly had rescourse to. Typhoid symptoms supervened, which we had to combat for six weeks; however, he was discharged cured from the hospital."

\section{NOTES ON NURSING THE SICK.}

No one has done more to elevate nursing to what it really should be-a social scicnee - than Miss Nightingale, whose efforts are gradually bearing fruit in hospitals and infirmaties all over the kingdom. Her experienec has been embotied in an earuest and interesting pamphlet, entitled "Notes on Nursing," a real and practical hand-book for the houschold, from which we extract the following useful hints :-

There are not a few popular opinions, in regard to which it is useful at times to ask a question or two. For example, it is commonly thought that children must have what ate commonly called "children's epidemies," "current contagions," \&c. ; in other words, that they are born to bave measles, hoopingcough, perhaps even searlet fever, just as they are born to eut theil teeth, if they live. Now, do tell us why a child must have measles-and it must take them-and it is safer that it should. But why must other children have measles? And if they have, why must yours have them too? If you believed in and observed the laws for preserving the healili of houses which inculcate elennliness, ventilation, white-wasting, and other means, and which, by the way, are laws, as implicitly as you belicve in the popular opinion, for it is notling more than an opinion, that your childien must have elildreu's cpidemies, don't you think that upon the whole your child would be moro likely to eseape altogether?

Is it not living in a continnal mistnke to look npon discases, as we now do, as scparnte entities, which must exist, like cats dirty and a elean condition, and just as mucl under own control; or ruther as the reactions of kiudly natu" 


\section{THE BOTANIC FAMLY PIIYSICIAN.}

the conditions in whieh we have placed ourselves? I was bronght up both by scientific men and ignorant women, distinetly to believe that small-pox, for instanee, was a thing of whieh there was once a first specimen in the workl, which went on propagating itself, in a perpetual chain of descent. Since tben I have seen with my eyes and smelt with my nose small-pox growing up in fir'st speeimens, either in elose rooms or in overerowded wards where it eorld not by any possibility have been "eaught," but must have begun. Nay, morc, I have seen diseases begin, grow up, and pass into one another. I have scen, for instanee, with a little overcrowding, eontimued fever grow up; and with a little more, typhoid ferer, and with a little more, typhus, and all in the sane ward or but. Would it not be far better, truer, and more practical, if we looked upon disense in this light? For diseases, as all experienee shows, are adjeetives,
not noun substantives.

A few words upon bedsteads and bedding; and prineipally as regards patients who are entirely, or almost entirely, eonfined to bed. Feverishness is generally supposed to be a symptom of fever-in nine cases ont of ten it is a symptom of beding. How ean it be otherwise? Look at the ordinaly bed in which a patient lies. If $I$ were looking out for an example in order to show what not to do, I should take tbe specimen of an ordinary bed in a private house; a wooden bedstead, two or even three mattrasses pilcd up to above the height of a table; a valance attached to the frame-rothing but a miraele could cver thoroughly dry or air sueh a bed and bedding. The patient must inevitably alternate between cold and damp after his bed is made, and warm damp before, both saturated with organic matter, and tbis from the time the mattrasses are put under him till the time they are pieked to pieces, if this is ever done. A nurse will be careful even to fidgetiness abont airing the elean sheets from the damp. Airing the dirty shcets from noxious damp will never occul to her. Besides this the most dangerous cfluvia we know of are from the exereta of the sick -these are placed, at least temporarily, where they must throw their effuvia into the undersic of the bed, and the space under the bed is never aired, it cannot be with onl arangements. My heart always sinks within me when I henl the gool housewife, of every cliss, say, "I assure you the bed has been well slept 440 
in," and I ean only hope it is not true. What! is the bed already saturated with soincbody clse's damp? IIns it not had a singlc chance to be aived? No, not one. "It has been slept in every night."

When I see a paticnt in a room nine or ten feet high, with his head, when he is sitting up in bed, actually within two or three feet of the ceiling, I ask myself, is this expressly planned to produce that peculiarly distressing feeling common to the sick-namely, as if the walls and cciling were closing in upon them, and they becoming sandwiches between floor and ceiling, which imagination is not, indeed, here so far from the truth. If, over and above this, the window stops short of the eeiling, then the patient's head may literally be raised above the stratum of fresh air, even when the window is open. Can human perversity any farther go in unmaking the proeess of restoration which God has made? I need scarcely say the old foulpost bed with eurtains is utterly inadmissible, whether for sick or well.

Never use anything but light Witney blankets as bed eovering for the sick. The heavy cotton impervious counterpane is bad, for the very reason that it kecps in the emanations from the sick person, while the blanket allows them to pass through. Weak paticnts are invariably distressed by a great weight of berl-clothes, which often prevents them getting any sound sleep whatever. Every weak paticnt, be his illness whatever it may, suffers morc or less from difficulty in breatling. 'To take the weight of the body off the chest, which is hardly up to its work as it is, ought therefore, to be the oljject of the nurse in arranging his pillows.

Another extraordinary fallacy is the dread of night air. What air can we breathe at nirglit but night air ? The choice is between pure night air from withont and foul night ail from within. Fully one hall" of all the discasc we suffer from is oecasioner by people slceping with their windows shut. An open window most nights in the year ean hurt no one. I could better understant in towns slunting the windows during llic lay than rluring the night, for the sake of the sick. 'J'he ahsenre of smoke, the quict, all teurl to making night the best lime for ai:ing the paticnt. Often the niglit air is the best and purest 
in the twenty-fonl hours. Always air your room, then, from the outsicle air if possible.

\section{SARRACENIA PURPUREA.}

A New Remedy for tile Syall Pox.-The Sarracenia Purpurea, or Iudian cup, a native plant of Nora Scotin, the specific used by the Indians against the small pox, bids fair to realise the expeetations entertained by medieal men of its effcaey. In a letter addressed to the American Medical Times, Dr. Fredcrie W. Morris, president physieian of the Halifax Visiting Dispensary, states that this Sarracenia, a papareraceous plant, will eure small pox in all its forms within twelve hour's after the patient has taken the deeoetion. "Howercr" alarming and numerous the ertiptions," he says, "or conflnent and frightful hin " may be, the peeulial action of the medicine is sueh that very seldom is a sear left to tell the story of the disease. If either vaeeine or variolous matter is washed with the infusion of the Sarracenia, they are deprived of their contagious properties. So mild is the medieine to the tastc that it may be mixed with tea and coffee, and given to connoisseurs in these beverages to drink without being aware of the admixture. The medicine las been sueeessfully tried in the hospitals of Nova Seotia, and its use will be eontinued."'-Galignani.

"We are now faronred with the following partieulars respeeting this valuable plant. The Surracenia Purpurea, or Indian cup, a native plant of Nova Scotia, fomd in swamps and moss bogs, has the wouderful reputation among the MieMac Indians of euring Small Pox; and of being as great a specific in this disense as quinine for ague. It is supposed to aet by nentralizing the virus in the blood, rendering it incert and liarmless; and that this is its action nay be gathered from the fact that if cither vaeeine or variolons matter be washed with the Infusion of the Sarraeenia, it is deprived of its eontilgious [roperty. Morcover the eruption, eren if confluent, on its disappearance, lcaves no trace belind. The root of the plant is the part employed. The dose, when reduced to powder, is about a dessert-spoonful, simmered in a pint of water down to lialf a pint; this is usulilly diviiled into two doses, to be taken during the day. Sugar should not be used with it." 


\section{MEDICAL RECEIPTS}

\section{BOTANICAL, ALLOPATHIC, \& HONIEOPATHIC.}

Acetous Cataplasar, on Poultice. - This is made with vineugr and bian cnly, or with the addition of oatmeal, or breal crumbs. It is a simple poultice, but very useful for sprains and bruises. As it becomes dry, it should be moistened with vinegar.

Air:-Country superior to Town Air.- "If you examine," says M. Pouchet, " the bodies of animals, who live in our towns, and in our houses, you will be astonished at the enormous quantity of starch contained in their respiratory organs. In birds you will find it even in the middle of their bones. Partieles of soot, filaments of the different kinds of textures of which our clothes are made, are also found there in great abundance. But the further the animal lives from a town, the more scarce become these bodics. In aninals and bircls living in the midst of forests, you will scarcely find auy at all of them; in their case the respiratory apparatus is, on the contrary, filled with a large quantity of vergetable debris, chlorophylla, \&re. I have found in the lungs of man the samo atmospheric corpuseles as in animals. I found two persons who died in one of our IIospitsls - a man and a woman-and whose lungs I inspeeted, a notable quantity of feeula, normal, or after panification, particles of silien, and fragments of glass; fragments of pairuted woorl of a lscautiful red eolour; debris of clotles, and a lavve of a microscopic arachnis still alive."

Aperiket, Infants'. Take of rhubab, five grains ; magnesia, three grains ; white sugral, a seruple ; manna, five gl'ains ; mix. Dose, varying from a piece half the si\%e of a sweet-pea to a piece the size of an ordinary pea. Magnesia is a useful remedy in acidity of the stomach and bowets, particularly of clifldren, and proves to them a suitable and efficient purgative, when combinerl, as above, with Rhubab. It may be mixed with a listle $A$ niseed Water, which will tend to explel wind, a common ailment of Infints.

Aperignts, Srring, for CHILdren.-Nothing is better than:-1. Brimstone and treacle; to ench teacupilul of this, 
when mixed, add a tea-spoonful of cleam of tartar. As this sometimes produces sickness, the following may be used.-2. Take of tartrate of soda one drachm and a half, powdered jalap and porvdered rhubarb, each fifteen grains; ginger, two grains: mix. Dose for a child above five years, one small tca-spoonful; above ten years, a large tea-spoonful; above fifteen, half the whole, or two tca-spoonfuls; and for a person above twenty, three tea-spoonfuls, or the whole, as may be required by the habit of the person. This medicine may be dissolved in warm water, common or mint tea. This powder can be kept for use in a wide-mouthed bottle, and be in readiness for any emergeney that may occur.

Aperient, Tonic.-Take of Epsom salts one ounce, diluted sulphuric acid one drachm, infusion of quassia chips, half an imperial pint, compound tincture of rlubarb two drachms, Half a wine-glassful for a dose - to be taken twice a day.

Ascarides, or Seat-worms to Destroy.-A tea-spoonful of flowers of sulphur, in a wine-glassful of Gin, or Brandy, in a morning fasting. The addition of a small quantity of Aloes will render it more effectual.

Astima.-Take of the Milk of Gum Ammonia, six ounces ; syrup of squills, four ounces and a half; mix. A spoonful to bc taken when relicf is required. It greatly relieves by copious expcetoration.

Balsam, Friar's. - The old monks knew what was good. This balsam was used by them. Gum Benzoin, $3 \frac{1}{2}$ ounces;

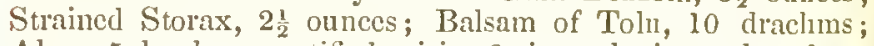
Aloes, 5 drachms, rectified spirits, 2 pints; let it stand 14 days, shaking well occasionally; and always before using. It is very useful in confirmed Astlima, catarlis, and consumption, witl a lauguid circulation. Dose, half a drachm in mucilage, or dropped on limp sugar. Applied to wounds, it stimulates gently, and nicely heals them.

Barley Water.-Callefully clean two table-spoonfuls of pearl barley, put it info a (puart jug, adding a very little salt, and Immp sugar to taste. Fill up witl boiling water, and keep stirring for ten minutes. Cover, and let cool. It will be fit 444 
for use in ten or twelve hours. Finely shred lemon peel, or a little calf's feet jelly, greatly improves it.

Bite of a MAD Dog.-Wash well with a strong decoction of tobaceo, and then bind wetted tobaceo on the wound.— $\mathrm{Or}$, take a pound of salt, dissolve in a quart of water. Squeeze, bathe, and wash the wound with this liquid for one or two hours; then bind some salt upon it for ten or twelve hours.

Bitters, or A Tonic.-Take Gentian root two onnees, dried o: ange peel two ounces and a half, cochincal, in powder, half a drachm, proof spirit or brandy, two pounds; let them stand ten or twelve days, and decant off what is elcar for use.

Black Draugim.-Take of senna leaves six drachms, bruised ginger half a drachm, sliced liquoriec-root four drachms, boiling water half an imperial pint. Keep this standing on the hob, or near the fire for three hours, then strain, and after allowing it to grow cold, add of sal volatile one drachm and a half, of tincture of senna and of tincture of cardamoms, each half an ounce. (This mixture will keep a long time in a cool place.) Dose - a wine-glassful for an adult; two table-spoonfuls for young persons above fifteen years of age. It is not a suitable medicine for children.

Breati, Fotid.-Many persons suffer from fotid breath, without this being attributable to the presence of bad teeth, or the want of attention to the mouth, the gums and mueus membrane being also quite healthy. The smell may procecd from the lungs or the stomach, but in nine eases out of ten it originates in the stomach, and the following is then a simple and prompt remedy :- Thice hours after a meal take a large teaspoonfil of a solution of six parts of chlornte of potasli in 120 parts of surgared water, and at the same time rinse out the mouth well with the same solution.

Burve ant Scatros, See Sranigir Frues. - If the elothes

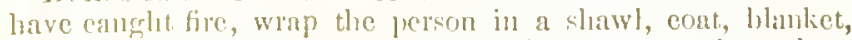
\&ce. very tightly, to extingrish the flames; or when these are not at hard, roll the person on the flone. Then gently disengage the chothes from around the burned surface. If any fratt of the dress slonled stick to the hurierl part, do not renove them, but eut the clothes firm around that part. 
The treatment for burns is applicable to sealds. If the injury is merely superficial, saturate a picec of cotton wool, or walling, \&c. with Tincture of Spanish Flies, largely diluted witl water, and apply it over the burned or sealded part, and cover it with folded cotton or linen. \&c. to exclude the atmospherie air. Saturate with the liniment as the eloth dries. If the wound is deep, nse the Amica Lotion, (Sec plant Lcopard's Bane,) instead of Cantharis. When the burning pain ceases, apply simple cerate spread on a linen rag, and cover well $n$ p. During this process three drops of Arnica Liniment, should be taken every quarter of an hour, to compose the excited nervous system. Liniments are better than Lotions, as they contain sonp dissolved in spirits of wine, both curative of burns, \&c. To be obtained from any Homœopathie
Chemists.

When the afore-mentioned liniments are not at hand, Cotton Wool, or a Linen rag may be well satnrated in oil and soap lather, and applied. In scalding of the mouth, soap liniment, may be advantageously used, which is made by dissolving soap
in spirits.

"A most primitive, yct very effectual remedy in the treatment of burns and sealds is cow-dung; and from its being so rich in phosphorus, it must exert a specific, and a mechavical action to cure injuries resulting from fire."

Some persons will object to the treatment of burns and sealds by Spanish Fly Liniment. But of late years has come into practice the use of irritating substances in preference to the injurious method of treatment with iec, cold water, and other refrigerants. The treatment now recommended is not the old treatment by contraries; but that "likes slould be treated witl likes."

Bunns ani SCatuns. $-\Lambda$ few raw potatocs are to be pecled, and finely beaten in a mortar; add a diachm or 1 wo of laudannm; apply to the affected parts, like a poultice. It is very eflicneious in the cure of burns or scalds, ancl otler inftancd parts.

Cinarcont Memelne. - This is extensively used in Mexico, and in miny parts of Sonth Awerien, where few dlugs are pro-

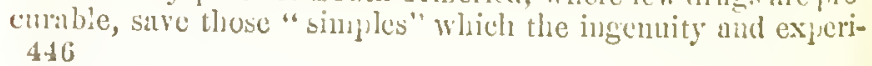




\section{MIEDICAL RECEIPTS.}

ence of the Indian Herbalists have devised. Freshly-burnt Charconl, reduced to powder and given in water, is in great repute. Within a few hours of taking, it remores offensive odours from intestinal and renal discharges, and purifies the breath, also offensive cxhalations from the feet, any part of the body, either given in water, or in the form of pills, made up in wheat flout, or gum mucilage. It removes those local pains about the right sloulder which are usually attributed to obstructions of the liver, and this within forty-eight hours. As an antiacid, cither alone, or combined with rhubarb, and carbouate of soda, it speedily and permanently remores heartburn. Charcoal is a powcrful antiscptic, removing, or checking decay, and must be very valuable in the incipient stages of cousumption.

Chilbratss. - To cure chill,lains, simply bathe the parts affected in the liquor in which potatoes have been boiled, at as high a temperature as ean be borne. On the first appearance of this ailment, indieated by inflammation and irritation, this bath affords almost immediate relief. In the more advaneed stages, repetition prevents breaking out, followed by a certain cure; and an occasional adoption will operate against a return.

COLD, $A$, now To cure. - The following plan is very effectual in euring most colrls, but not all :- Let a man cat nothing for two days, provided he is not eonfined to bed, because by taking no carbon into the system by food, and by consuming the surplus which eaused his disease, by breatl he soon earries off his rlisense by removing the eausc. This will be found mole effectual if he arlds copious water draughts to protiacted fasting. By the time a person has fasted one day and niglit, he will cxperisuce a fiecrlom from disense, and a clearness of inind, in a clelightful contrast with nental stupor, aud physical pain calnserl by colles. Jlow infinitely better is this notlod of bleakijug up colls than hy uncolicines.

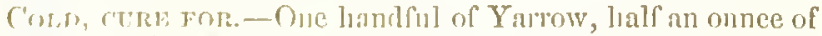

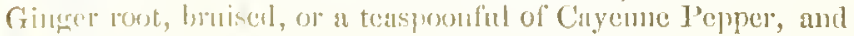
alusut thre pints of water. Broil to one pint. $\Lambda$ cld a littlo sugar if' you like. 'T'ake a goorl dose at bed-time, and your cold will loc cured by the next nuolung; if not, repeat the dose. 


\section{MEDICAL RECEIPTS.}

Cold, to Aroid Catcinng.-Aecustom yourself to the use of sponging with cold water every morning on first getting out of bed. It shonld be followed with a good deal of rubbing with a wet towel. It has considerable effeet in giving tone to the skin, and maintaining a proper aetion in it. and thus proves a safegnard to the injurious influenee of eold and sudden ehange of temperature. Sir Astley Cooper said, "The methods by which I have preserved my own health are-temperanee, early rising, and sponging the body every morning with eold water, immediately after getting ont of bed; a praetiee which I have adopted for thirty years without ever eatehing eold."

Coltsfoot Wine to make eqdal to Sherrt.-Take twenty pounds of Coltsfoot, and twenty- $t$ wo quarts of cold water, let it stand three days, drain the eoltsfoot well from the liquor through a sieve; put three and a half pounds of brown sugar, three lemons, three sweet and one bitter orange to each gallon of liquor, then put the whole in a tub, with a few spoonfuls of yeast; let it work two or three days, stirring it frequently; drain through a sieve again, and put into a barrel; when done fermentiug, add half an ounee of isinglass, bung the barrel well up, let it stand six months, then add a bottle of braudy, and bottle it.

Consumption, UseFUl DRINK For.-Coltsfoot, two ounees; Horehound, one ounee, and the same of Rue. Boil in three quarts of water down to two quarts. Strain, and to the liquor, add of figs and sugar, of eneh four ounees, and boil fifteen minutes. Take a wine-glassful three or four times a day.

Corns, A Positrve Cure for. - The strongest aectie aeid, applied night and morning with a eamel's hair brush. In ono week the corn will disappear-soft or hard eorns.

Corpulencr.-Mr. Alfred William Moore, sent the following communieation to the Mcclical I'imes:- "Fat is a neeessary ingredient of the body. Nature, however, is sometimes too liboral in its supply ; it then beeomes burdensome, and subjeets the objeets of its prodigality to much ridieule. The discovery of a eertain renedy, under these eireumstances, nnay prove a boon. The following experiment, or systematie plau of treatment, adopted by myself, who an eonstitutionally fint, 448 
will elcarly slow that abstaining flom bread and fermented liquors will remedy this inconvenience in an inercdible manner : - Weighing $15 \frac{1}{2}$ stone, I redueed myself in three months to $12 \frac{1}{2}$ stone, by strictly adhcring to the following plan of dieting mysclf: - Breakfast carly, consisting of $20 z$. of biscuit, I egg, two cups of tea or coffec; then firsted till five; my dinncr consisting of anımal food, \&c., but no bread; lilicwise aroiding bread at my tea or supper.

Codgh. - Two table-spoonfuls of Linseed, four onnecs of Liquorice root, or Spanish Juice, four ounees of Elccanprane root, water thrce quarts; boil down to three pints. Dose, a winc-glassful four or five times a day.

Covgrr.-Powder of tragaeanth, onc drachm ; syrup of white poppies, two drachms; laudanum, forty drops; water, four ounecs. Sliake the powder in the water till it is dissolved, then add the otlers. Dose :- $\boldsymbol{\Lambda}$ teaspoonful three times a day.

Cough - Astmantrc. - Take two good handfuls of Coltsfoot leaves, onc ounce of Garlie, and two quarts of water. Boil down to thice pints. Strain, and to the liquor add eiglit ounces of sugar, hoil gently for ten minutes. Talic half a cuyful occasionally.

Cough, Consumption, \&e. Cure for.-The following is 凡 most valuablc recipc: - Of Sanctuary, Horchound, I3arberry Bark, two pennyworth of cach; and of $\Lambda$ grimony, Rasplerry Lcaves, Clevers, and Ground Ivy, one penlyy wortl ; Extract of Liquorice, 4 oz.; and half a tea-spoonfinl of Cayenne pepper. Gently simmer in two gallons of water for lialf an hour.

Cougrt, Cure for Dry.-Talic of powdered gum-arabic, half an onnce; liquorice juice, half an ounce. Jissolve tlee gum first in warm water ; squecze in the juice of a lemon; then arkl of paregonie, too drachuns; of syrup of squills, one draclum. Cork all in a loottle, and shake well. 'l'ake one tcisjuounlul when the congh is troublesone.

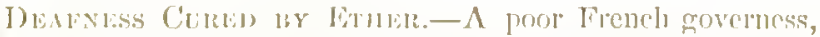

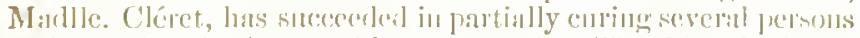
allicter with deafiness allul loss of speech. 'T'le lirench $\Lambda$ millcury have awarded the Montlyon l'rize for the discovery, which 
was accidental, and has been proved perfectly innocnous. The method consists in introducing sulphuric ether into the anral concuit, in doses of four to cight drops a day fol about twenty days, when the application is suspencled for a short time, and agrain recommeneed. Since the publication of this fact numerons applications from persons suffering from deafness have been received by physicians, and a certain mumber of cases have been unade public. A gunner's mate, aged 51, hat been attacked six months before with acute rhematism, which at length became chronic and complicated, with deafness in the left ear, and difficulty of hearing in the right one. There was frequent singing in both curs, but no otorihoen; and the deafness used to increase and diminish with the rhemmatic pains. At tho first, a few drops of ether were instilled into both his cris, when he immediatcly experienced a fecling of expansion within, accompanied by a slight pain, and from that moment he could distinguish sonuds less confusedly. On the following morning he declared he could hear with his right ear quite as well as before his illness; the instillation was thercfore only repeated in the left ear, and on the fourth day he declared himself quite cured. Another case, similar to this, is reported by Dr. Berlemont, of Joncourt ; and Dr. Coursier, of Honnecourt, ammounces that he has been treating six patients, between five and fifteen years of age, for some time with ether, to their manifest adrantage. In one of these cases, however, the application was productive of much local pain.

Diarrifea. - Blackberry Cordil.-To one quart of blackbery juice add onc ponnd of white sugar, one tablesponful of eloves, one of allspice, one of cimmimon, and one of nutmeg. Boil all together fifieen minutes; achl a wineglises of whisky, brandy, or rum. Bottle while hot, cork tight ant seal. This is almost a specific in cliarhan, One rlose, which is a wincrglassful for an adult-hall that (puantity for a chihl-will often cure diarrhas. It cam be taken three or four tines a tay il the case is severe.

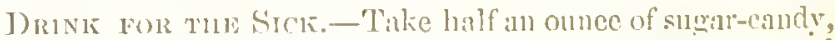

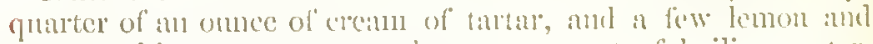

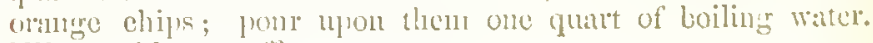
Wher coli pour off 
MEDICAL RECEIP'TS.

Tres, Goon For TuE.-To give brilliancy to the eyes, shut them early at nichlt, and open them early in the morning; let the mind be constantly intent on the acquisition of benevolent fcelings. This will scarcely crer fail to impart to the eycs an intelligent and amiable expression.

Ere-Lid, Remoning foreign Bodies from reneatis THE.-M. Renard, in the ease of small moveab?c lorlies which become entangled bencath the npper cyclid, recommends the following simple procedure, which will often dispense with all others. Take holel of the upper eyclicl near its angles with the index finger and thumb of cach hand, draw it gently forwards and as low down as possible orer the lower eyelid, and retain it in this position for about a minute, taking carce to prevent the tears from flowing out. When, at the end of this time, you allow the eyclid to resume its place, a flood of tears washes out the foreign body, which will be found adhering to, or near to, the lower cyclid.

Ere Podutice.-Stir two drachms of powdered alum in the whites of two ecress till a coagulum be formed. Place it between a piece of soft linen rag, and apply it. Very applicable for infamed eyes attended with a purulent discharge, and for chilblains.

Fyi-water. - Inalf a pint of the best brandy, two pints of spring water, and sugar of lead, one ounec; mix. 'This is a good eyc-water.

ETE-WATER $\Lambda_{N}$ EXCELLent. - Take six onnecs of Rectified Spirits of Winc, lissolve in it one Iraclim of Camphor, then atsl two small liandfuls of drich Eller Flower's infuse twenty-four hours. Bathe the forchearl, over your eyes, and cach temple, several times a day; meantime, dijp a solt lag in stale small beer, new milk warm, and bathe eacls eye a few times gently noming and crening. If it is a watery lumnour,

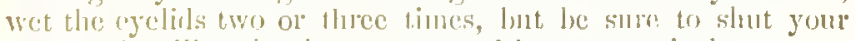
eyes, or it will make them smant and burn excessively.

It is also a goord remerly for the 'Tuothache, or swelled face, bruises, \&e., used as a rubeliscient.

Fragrant Odour, to Diffuse $\lambda_{0}-\Lambda$ few drops of nil of 
sandal wood dropped on a hot shovel, will diffuse a most agreeable balsamic perfume throughout the room.

Gravel or Stonk-Take one ounee of the spirits of sweet nitre, two dinchms of liquid laudaum, and half an onnee of the oil of juniper. Take a tea-spoonfinl in a eup of linseed tea sweetened with honey. 'This has performed wonders.

Gravel, Exceldent For tile.-Take of Dandelion and Marsh Mallows roots, of each two ounces, Agrimony a small handfil, to three quarts of water ; boil to two quarts. Dosea wineglassful every three or four hours.

Hard and Swelled Breasts. - An exeellent remedy is made of Camomile Flowers, and bruised Marshmallow roots, each one ounee; boil in one quart of water down to one pint. Foment with the liquor, as hot as ean be borne; and then place the flowers and roots in a eloth, and apply as a eataplasm or poultice.

HEAD ACrE.-One seruple tmbith mineral, half a draehm of powdered ginger, one seruple of powdered nutmeg, three diops of the oil of rosemary, all mixed, and snuffed up tho nose.

HeAD-ACIE. - Talie a small handful of Centaury, and as much Feverfew, and one ounee of Camomile Flowers, to two quarts of water; boil to one quart; then add while lot lialf an ounee of rhubarb, and stir well. Dose - a wine glassful tluce times a day.

Hoofing Covgir.-Dissolve a seruple of salt of tartar in a quarter of a pint of water ; add to it ten grains of cochincal; sweeten it witl sugar. Give to an infant a lourtl piut of a tablespoonful four times a diy ; two years old, lialf a spoonful, fiom foul years a table-spoonful.

Hoonng Colan. Talie flower of Benjanim, and strained opium, of each two dracluns, camplate, two scruples, essential oil of aniseeds, lualf a drachun, rectiticd spirit of wine, one puntet, fom onnces of powdered liquorice, and foul ounees of loney : then digest and strain oft the elixir. Or,

Take of the musk juleps, six ounees, paregorie elixir, half 452 


\section{MEDICAL RECEIPTS.}

an ounce, volntile tincturc of valerian, one drachm, mix them, and take two spoonfuls three or four times every day.

Hydropiopia. - Immediately wash the bitten part with clcal water ; then take good tobacco, (leaf tobacco, if possilile ; if not, strong manufactured cut tobacco) and make a banklare for the place, changing it three or four times a day for a week. This effectually absorbs cvery thing poisonous.

Indigestion, - Take of Gentian and Culnmba roots (bruised) and Camomile Flowers, of each one ounce, to three quarts of water; boil to three pints. Dose-two or three teacupfuls a day.

JaUndice, Yeltow.-Burdock root, one ounce, Agrimony one ounce, water, two quarts ; boil down to three pints. Dose, a wine-glassful two or three times a day.

JeLLY FOR TIIE Sick. - Mix one ounce each of rice, peall barley, sago, and hartshorm shavings, in thrce pints of water. boil till reduced to one, and straili. When required for use, dissolve in milk, winc, or broth.

Liniment, Volatile. - Spirit of hartshoin, one onnce; olive oil, one ounce and a half. Shake them well in a bottle. If a drachm or two of laudanum be added, it will make it moro efficacious. Rub the affected part with it, apply aftelvards a rag saturated with it. It removes pains and swellings.

Iotion Valuable-Camphor, five drachms, cut it into small pieces, and dissolve in half a pint of spirits of wine in a closely corked bottle; when fully dissolved, add half a pint, or more, of oxgall, which can be bought of any butcher, and aliout fifty or sixty drops of laudanum. Shake it well, and hottle for use.-This has been a patent medicine, and is very eflicacious in the enre of fresh wounds, euts, bruises, swellings, sores, aud inflamed and pained parts. It ought to be kept in every houso ready for need, as a Domestic Embrocation.

Marigolns. - Theil virtues lave been lost sight of. Tho juice, or a strong decoction, with (or willont) a very small portion of spunts of wine, is a rave application for healing lacerations, bruises, cuts, botl pain mol blecding being innediately 4is's 
arrested. By its usc in severe wounds Erysipelas is prevented. It scluon leaves a eleatrix, or mark, behind it. It has a tendeney to eontraet the mouths of the small arteries, when direct'y ent across, and where they have been slit longitudinally. 'T! e Tincture may be purchised of the Homoopathie Chemists; and largely diluted with water, it is a first-rate remedy.

MEasles. - This disease prevails extensively iu eities during the winter season, and will ustally eure itself, if only proteeted against advel'se influenees. The older persons are, the less likcly they are to reeover perfeetly from this ailment, for it very oft leaves some life-long malady behind it. The most hopeless forms of eonsumptive disease are often the result of ill-eondueted ol badly-managed measles. In nine cases out of ten, not a partiele of the mediciue is needed. Onr first adriee is, always, and under all eireumstanees, send at onee for an cxperieneed physieian. Meanwhile, keep the patient in a eool, dry, and well-aired room, with moderate eovering, in a position where there will be no exposure to dranghts of air. The thermometer should range at abont 65 degrees where the bed stands, whieh should lje moderatcly hard, of husk, straw, or eurled hair. Gratify the instinet for eold water and lemonade. It is safest to keep the bed for several days after the rash has begun to dic away. The diet should be light, and of an opening and cooling eharacter. The main objeet of this artiele is to warn persons that the greatest danger is after the disappearanec of the measles. We would advise that for threc weeks after the putient is well cnough to leave his bed, he should not go out of the house, nor stand or sit for a single minnte near an open window or door, nor wash any part of the person in eold water or warm, but to wipe the faee and lands with a wam damp cloth. For a good part of this time the appetite should not be wholly gratified; the patient should cat slowly of licht nutritious food. In one easc, a little eliild, alnost cntirely well of the mcasles, got to playing witl its hands in eold vater; it gradually dwindled away and dicd. All exereise shonld be moderate, in order to prevent eooling off too quiekly aftelwards, and to be in danger of exposure to dranglits of air, which by eovering the surfice canses chronic dinmoca if it falls on the bowels, deafiness for life if it falls on the car, or inemable consumption il it fills on the lungs. 


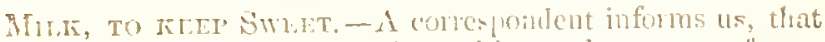
he lias practised a peculia method with much sucess of prescrving milk sweet in the pans. It simply consists in phacing a piece of new hammered iron, or three twelre-peuny nails, in each tin pan, then pouring the warm milk on them. He belicves that electrieity has something to do with producing the result. He liad tried many experiments Jefore he hit on this "one, whieh he found to preserve the milk sweet for a longer time than other plans tried by him.

Ointanext, Cimblain.- Two ounees of lard, half an ounce of turpentine, and a quarter of an ounce of eamphor, melted together.

Onatment for Broken Citilblains or Chapped Hands, \&o. Sweet oil, one pint ; Venice turpentine, thrce onnees; logs' lard. half a pound; bees' wax, three onnces. Pnt all into a pipkin over a slow fire, and stir it with a wooden spoon till the bees' wax is melted, and the ingredients simmer. It must be spread very thin on soft rag, or (for chilps or elacks) rubbed on the hands when you go to bed.

Onsment, Spermacetr-Take Spermaeti, one onnce; white wax, two drachms; olive oil, three ounees. Melt orer a slow fire; when cool it is fit for use. It is good for healing blisters, exeoriations, and abrisions ol the skin.

Pans IN The IIfad and Face. - Take half a pint of rose water, two tea-spoonfuls of white vincrar, and furm a Iotion. Apply it to the affected part three times a day. It requires fresli linen and lotion cacl application; this will, in two or thlee days, gradnally take the pain away.

PAINS IS TIE JoINTs. - Makic a poultice of the young leaves of liag-wort, and put on as hot as ean be bone.

Truts For a BAD Comgri. - Compound ipeencuanha powder, half a drachin; fresh dried scyulls, ten grains; sulphate of : immoniscum, ten grains; sulplate of quiuine, six gratins; trearite, sufficient quantity to make a mass. Divide into twelve pills ; one to be taken night and morning.

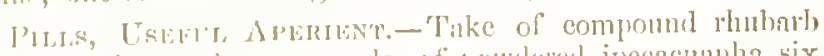

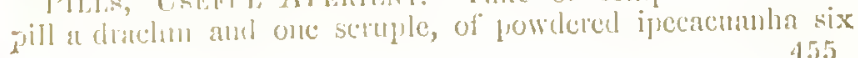


grains, and of extract of hyoscyamus one scruple. Mix and beat into a mass, and divicle into twenty-four pills. Takc one, or two, or, if of a very costive habit, three at bed time. For persons requiring a more powerful purge, the same formula, with ten grains of compound cxtract of colneynth, will form a good purgative pill. 'The mass receiving this ardition must be divided into thirty, instcad of twenty-four pills.

\section{RIIEUMATISM AND ITS REMEDIES.}

To those who dwell in damp districts, or damp houses, and arc hence subject to rheumatism, coughs, colds, \&c., the free usc of lemom juice (when strained and where it does not disagree with the stomach) is a most cffectual preventive as well as a remedy ! I have found the regular use of a winc-glassful or two a day so to strengthen a very delicatc constitution, liable to colds on the slightest occasions, that it in a slort time defied not only damp, but every inclemency, and all exposure.

Rheumatism, Cure for.-A Correspondent of the Medical Circular rouches for the relief he has cxperienced in the liberal usc of lime (fresh lemon) juice, whilst labouring under the paroxysms of rhcumatism. By repeated indulgence in the above simple acid, for the space of three days, avoiding all stimulating liquids, the most confirmed rheumatism will, he says, relax, and the tone of the muscular and nerrous system will be restored to its usual character. The fact was first cs. tablished by the circumstance of the Jews being as a general body, scarcely cver affected with the above disease, and this partieular exemption from the malady under consideration, as aftecting the disciples of the Hcbrew persuasion, was, and has becn, attributed to the very liee indnlgence which the above people cxercise in their dictary consumption of lemon-juice.

When lemon juiee disagrees, cither of the two following formulæ may be substituted :- $\mathbf{k}-$ Lemon juice (strained or filtered) and treacle, equal parts ; powdered sugar candy, q. s.; mix intimately - a table spoonful tliree or four times a day.

SEcond Rrcipe.-R.-Powdered rhubarb, 2 draclms ; acetate of potash, l ounce; guniacum, l drachun; sulpliur, 2 onuces; 1 nutmeg, gratted fery fine ; treacle, 16 ontuces. 
Mix-take two tcaspoonfuls night and morning.

The seat of rhemnatism is in the muscles-electro galvanism must be used; it is generally the best plan to begin with currents of the weakcst power, and gradually to increase their strength so long as the application causes no pain. Dumb bells should be used above all, every day; they sliould never excecd in weight one pound for ladies and four for men. Silk is the best monconductor of cold $w c$ have, and it is affirmed that those of the fair sex who wear tight fitting slceves to their silk dresses are not so subject to rhcunatism; males should wcar thick silk sleeves to all thcir waistcoats ; they can bc easily takcn off, and tacked or sewn on to another vest; besides the above precautions, flanncl must be worn summer and winter by day, "but never by night," ncxt the skin : at night a small flanncl spencer or jacket should be worn over the night di'css.

Tailors and millincrs have much to answer for in introducing such modern inventions as the wille slccves, and in like manner "the apology of a bonnet," this last the causc of tic doloreux, rhcumatism, \&c.

Embrocation for rlicunatism:- R.-Olive oil, 2 ounces ; water of ammonia, 2 drachms ; oil of rosemary, 10 drops; oil of cloves, 5 drops. Mix and keep tightly corked.

Rinedmatism.-Takc a large handful of Buckbcan, four ounces of Whitc Mustard Secds, and onc of Lignum Vita, or Wood of Life, to two quarts of watce; boil to three pints. Duse-three tea-cupfuls a day. Use also the following Liniment. Take of Sal Volatile threc ounecs; oil, onc ounce, Camphor, quarter of an onnec, Laudanum onc onnce. liub the part affected with this liniment threc times a day.

Rneumatic Pains.-Take opodcldoe, one ounce; tincturo of cantharides, thrce draclıms; spirits of sal anmoniac, threo drachms; rectificd oil of amber, thrce drachms. 'This forms a liniment, wherewith frecucntly to mb the painful part. Wrap up in finc, soft flanncl, and kccp warm.

RIIJUMATIC PAINS AND ACIIES IN TIIE BONES AND JOINTS, A REMUDY FOR.-'Take firiar's balsam and tiucture of mylth of cach one ounce, spirits ol turpentine two onnees, and grool 
old strong ale diegs three onnces; mix all of them weil together, and bathe the afticted part with the same.

Salve, Famer. - Talie the root of yellow doek and dandelion, equal parts ; add a good proportion of eelandine and plairtain. Extract the juices by pressing or steeping. Strain carefilly and simmer the liquid with swcet eream, or fresh lutter and mutton tallow, or you may take sweet oil and mutton tallow. Simmer together until no appearanee of the liquid remains. Before it is quite eold, put it into boxes as you may desire. This is one of the most soothing and healing preirarations for burns, sealds, euts, and sores of every description that can be produced.

SALVE FOR ALL wounds. - Take one pound of hog's lard, three ommees of white lead, three ounees of red lead, three ounces of bees' wax, two ounees of black rosin, and four ounces of common turpentine; all these ingredients must be put together in a pan, and boil three quarters of an hour; the turpentine to be put in just before it is done enough, and give it a gentle boil afterwards. This is an exeellent eure for burns, sores, ur uleers, as it first draws, then leals afterward; it is excellent tor all wounds.

Scratcines, Hints apodt.-Tlifling as seratehes often seem, they ought never to be negleeted, but should be eovered and proteeted, and kept elean and dry, until they liave eompletely incaled. If there is the least appcalanee of inflammation, no time should he lost in applying a large bicad-and-water poultiee, or hot fammels repentedly applied, or even lecehes in good numbers may be put on at some distance fiom each other.

Scure in tire Incad.-This is a simple and eftectual remedy. Into a pint of water drop a lump of fresh quick-lime, the size of a walnut; let it stand all uight, then poun the water oft" elcar from sediment or deposit, ald a quarter of a pint of the best vinegar, and wasl the heal with the mixture, wetting only the roots of the hair. It is perfectly hamless.

Scurvy.-Dandelion loots, and fickl Daisies, of early two onnees, in three quartis of water, boil to two qualts. 'Tikle a toat-cuplut nigle and norning. 


\section{MEDICAL RECEIPTS.}

Scchry ix the Guns. - Make strong sage tea and discolve therein a little alum, dip a cloth therein and rub your gums with the same. If you wish to make your tecth white, nix a little burnt alum with six spoonluls of honcy, and two spoonfuls of the juice of eclandine, and rub your teeth with the same.

Small-pox, Prevention or Pitting in.-MIr. Startim, the senior surgeon to the Gurney Hospital for Diseases of the Skin, has communicated to the Medical Times a vely important plan, which he has adopted during the last fourteen years, for preventing pitting in small-pox, and which, he states, has always proved successful. The plan consists in applying the acetum canthar$i d i s$ or any vesiceating fluid, by menns of a camel-hair brush, to the apex of each spot $\mathrm{l}^{*}$ pustule of the disease, on all the exposed surfaces of the body, until blistering is evideneed by the whiteness of the slin in the parts suljeeted to the application, when the fluid producing it is to be washed off with water or thin arrowroot gruel. The pain attending the application of the vesiceating fluid is very slight and transient.

Sore Turoat, Cure for a.-Pour a pint of boiling water upon twenty-five or thilty leaves of common sage; let the infusion stand for balf an houl. Add vinegar sutficient to make it moderately acid, and honcy according to the taste. 'This combination of the astringent and the emollient principle seldom fails to produee the desired effect. The infusion must. be used as a frargte several times a day. It has this advantige over many garerles-it is pleasant to the taste, and maly be swallowed occasionally, not only without danger, but with advantage.

Spanisir Futes; (Greek, Cantharis;)-Tracture or.Take of Spanish Flies, redueed to a fine powvler, 2 ounces; spirt of wine, one pint; infuse for two or three days, and then strain. It is an acirl stimulant for external use. It will prevent the formation of l,listers in cases of burns or sealds, anm chilblains are eured hy a weak solution of the l'incture. In burns or scalles it is very injportant to protect the iujured sulfirec from the air, for which purpose cotfon wool, or eotton of close texture, is the lost. lt is very cflicacious tor chuted skin, and for frost-bitus esyecially. 
Tea and Coffee, Substitute ror.-Substitute for Tca as follows :-Take a small handful of Agrimony, one handful of Blackberry lcaves, and a few Raspberry leaves, and a very sinall quantity of Balm or Mint, according to taste; put it into a jug that will hold three pints, then pour on boiling hot water, let it stand alout five minutes, then sweeten to palate; for a ehange, you may use $\Lambda$ vens in the same way and mauner as Agrimony.

Substitute for Coffce. Take six or eight pounds of Dandelion roots, cut off the tops, then wash the carth from them. After which, hang them uj to dry ; when dried take one of the roots and grate it like Ginger. Grate alout a teaspoonful and a laalf, put it in a pot that will hold a pint and a half. Let it stand for five minutes, then use it.

Teetr, Cements for Stopping tire.-M. Vagner recommends the following : $-\Lambda$ drachm of gutta perclia, softened by hot water, is to be worked up with catechu powder and tamuic acid, of each half a drachm, and with a drop of essential oil. For use, a morsel is to be softened over the flame of a spirit lamp, introduced while warm into the cavity of the tooth, and adapted properly. The mass becomes hardened, and even after several montlis exhibits no traces of decomposition. M. Ponton states that we may also obtain an excellont eement by dissolving one part of mastic in two of collodion. IIaving well dried out the carity, a small ball of cotton soaked in some drops of the solution is to be introduced. It soon solidifies, and will remain in situ, seeming also to exert an infuence on the further progress of the caries.

Tobacco, Britisn Herb.-The prineipal ingredient in this compound is dried coltsfoot leaves, to which a smatler portion of thyme, wood botony, eye-briglit, rosemary, and yarrow are added.

Tumours, Cure of.-Dr. Simpson, of Edinburgh, has been experimenting on the removal of tumon's by a method novel in this country. IIc introduces a hollow actupuncture needle, or very fine trocar, into their tissue, and injects in a few drops of some irritant liquid, such as a solution of chloride of zinc, perehloride of irun, or creusote. 'The eliect has been to destroy 460 
the vitality of the tumours so trenter, and they have been separated by a proeess of enucleation. We have seen a somewhat similar plan adopted in Paris by M. Maisonnenve. He had slender stylets, made of a paste eomposed of flour, water, and ehloride of zine. These are baked. A puneture is made in the tumour, the eaustie stylet is inserted, broken off', and left. We saw several malignant tumours treated in this manner, and some eases in which a healthy granulating surface was left, after the separation of tumours which had been destroyed in this manner.

Vinegar, Aromatic.-Dissolve one ounce of eamphor in a pound of the strongest acetic acid (vinegar), and add one ounee each of the oils of lemon, cloves, and lavender.

WArts.-The juice of Marigolds frequently applied is effectual in removing warts.

Wintuows.-A lady who had been troubled some time with a whitlow on her finger, grives a simple remedy, from which she experieneed great relief, and which enabled her to obtain sleep after many restless nights. It is, to eut a hole in a lemon, and wear it on the finger like a thimble-the whitlow being eneased in the fruit.

Wind in the Stomacri. - Take a large handful of Feverfew, and Cummin seeds and Ginger, one ounce of each, to three quarts of water; boil to three pints. Dose-three or four wine-glassfuls a day.

Wind in the Stomacir.-Take oil of Juniper, tineture of myrrh, lavencler water, sweet nitre, equal quantity of each : shake them in a lottle. Dose:-One terspoonlul in a eup of colll water. The above is a dose lior an alult.

Worst Lozrsices. - Jalnp, quarter of an nunce; powdered rhularb, ruarter of an ounee; gramboge, two drachums ; syrup of bear's-foot, sufficient to make it into paste ; then nakle it into ordinary sized lozengres. Dose:- For a cluid three years o'd, half a lozenge ; six years, one lozenge ; and so on, necording to years. 


\section{INDEX OF DISEASES}

WHICII TIE PLANTS IN THIS FERRAL ARE ADAPTED TO RELIEVE AND TO CURE.

Amortion, Page 175.

Alsscess, 60, 107,109 .

AGUE, 16, 17, 26, 28, 31, $38,40,43,48,51,70,72$, $106,121,122,127,132$, $143,158,163,172,185$, $206,215,220,222,242$, $253,254,257,262,275$, 288, 335.

ANTISEPTIC, $51,155$.

A perieNt, 90, 156, 168, 228. ArOPLEXY, 87, 157.

$\Lambda$ PPETITE, to improve, 67,69 , $86,126,153,180,197,227$, $256,288,325$.

Asciditr, 132, 169.

Asconides, See Horms.

Asthin, 28, 50, 57, 69, 75,

$78,115,120,132,141,159$,

$161,173,190,238,2+8$, $271,272,273,281,316$, 331 .

Astima, spasmodie, 119.

BALUNEse, 101, 120.

Billous Aflections, 18, 31 , $46,94,110,135,166,228$, $268,289,325,326,333$, 335,336 .

Bitu of Mall Dog, 52, 273.

Br.ACK Exl: 254 .

BrAnDER, Disenses of, 34,47 , so, $105,212,286$.

462
BLeeding at the Lungs, 72, 83.

BLEEDING at the mouth, 116 , 135, 150, 163, $186,210$.

Bleeding, inward, 152.

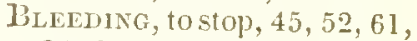
$84,86,149,163,180,183$, $252,262,279,286$.

Buister, to raise, 87, 119.

Blisters, 36, $265,334$.

BLood, to purify, $16,46,47$, $69,84,94,107,117,166$, $19 \mathrm{I}, 243,244,255,25 \mathrm{~s}$, $271,283$.

BLooD, congenled, 29, 83 , $10 \%, 108,262$.

Bloody Fuux, See Dysentery.

BolLs, 34, 164, 197, 256, 285. Boxies broken, $79,100,137$. Bowers, Inflammation of, $171,266$.

Bowles, Lax, 15, 47, 180 , 223, 228, 322 .

Bowels, obstricted, 24, 29.

Bomists, to strengthen, 149.

Blisi, Aflections of, 36, 58, 84,122,

Brisate, hurts in the, 37,69 .

limeast, pains in, $80, s 6$.

BLLAsTs, sore, 112.

bisдtit, fatid, 258. 
Brmenrmx, hifienty of, 56 , $88,106,140,166,179$.

Ii:oxcuits, 78, 198, 260.

BELISES, 19, 24, 3t, 3i, 43, $45,55,69,91,105,125$, $164,171,173,205,250$, $254,272,287,297,330$.

S('12. 13, 1 1 17, 18.36, 101, $109,132,136,152,159$, $186,197,211,213,324$.

Cixiler, 16, 110, 135, 154, $191,198,262,3 \pm 2$.

Chrier. 36, 59, 74, 92, 108, $151,251,021322,332,337$.

Cirmuxere, 248.

Citirith, 39, 144, 146, 150, $171,223$.

CIIAPPED ILANDS, 297.

C!llot, Diseases off, 172, 190. Culst, inflannation, paius, $29,87,88,106,144,171$. Cinimlins, $80,149,188$, 285,297 .

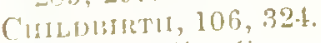

Ci1lorosis, Sice Green Sickness.

Cukisrs, $198,327$.

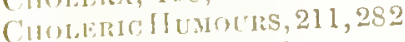

CACILCTIC, 51, 81, 31.

(i)1, :39, 64, 109, 291, 328. (4)1,Ic, 16, 21, 22, 26, 58, 62, $67,76,83,106,111,129$, $130,13.5,1+8,157,179$, $181,190,2(12,201,23.5$, $2+1,215,27$.

(ल)काना10, 77, 87, 170, 184,219

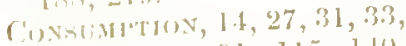
(3), 41, 51, 91, 115, 1.11, $180,190,213,232,263$.
Congungtive Sweats, 234. Convulsions, 38, 82, 122 , $125,133,232,235,271$. Corss, $143,1+7,286$.

Covail Pills, 137.

Codgis, 16, 21, 28, 33, 38, $40,46,51,58,64,70,72$, $76,78,98,100,104,107$, $109,120,122,129,132$, $135,140,144,159,164$, $170,185,190,197,203$, $204,205,207,213,220$, $225,231,233,218,279$,

Cran1", 16, 19, 58, 121, 122, $125,172,187,268$.

Cuts, 3s, 39, 150, 173, 253, 255, 287, 297, 298.

Dimitr, $226,264$.

1) LAFNiss, 22, $119,130,171$. Deliriua 'Tremens, 5t, 198. DENTRIFICE, 95, $148,190$. Disistis, Sue Incontinenco of Urine, 15, 16, 43, 154 .

DinisileA, $15,20,29,6 \%$, $72,76,95,97,111,113$, $119,145,149,161,163$, $173,180,187,213,21 \%$, $221,226,253,275,293$.

DigLSTION, to promote, 326 . 1) Istiasis Contagions, 21, 274. I)ISINIECTANT, 76, 124, 233. DIU15Y, 14, 16, 18, 25, 26, $27,31,33,38,41,47,40$, $51,52,51,60,67,81,86$, $92,99,110,111,112,114$, $11 ! 122,132,133,1+1$, $111,146,156,157,15 \%$, 1 (i), 169, 170, 172, 173, $185,188,201,206,212$, $210,261,261,270,289$.

4633 
Dropsical Swellings, 114.

Dropsy in the Chest, 114.

Dysicntery, or Bloody Flux, $13,16,19,29,30,31,64$, $75,76,83,84,89,107,111$, $112,114,116,125,141$, $145,146,148,149,150$, $161,173,195,201,226$, $233,253,254,256,260$, $274,286,291$.

Drspepsia, See Indigestion.

EAR-ACHE, 34, 74, 88, 144, $176,195,217,284$.

EAR, rumnings in, 205.

Ears, Worms in , 38, 112, 122. EMLNagogue, 134.

EMETIC, 91, 129, 137, 141, $145,161,188,204$.

EPILEPSY, 50, 115, 120, 149, $152,159,182,288$.

Eruption, 17, 92, 94, 112 , $118,174,194,248$.

Erysipelas, 18, 98, 126, 132, $135,143,149,171,216$, $219,220,253,287$.

Excoriations of the bladder, \&e., 141.

ExpeCtORANT, 90, 98, 132, 145, 146, 161, 169, 215, $231,246,260,279,287$, 296.

EYE, Blood-shot, 144.

EYE, Spectis in, 135, 138.

Erles, Humours, 32, 35, 36, 108.

Eres, Inflammation of, 21, $45,46,52,66,70,72,87$, $98,99,110,113,157,162$, $169,176,266,269,275$, $285,286,297$.

464
Eyes, Dimness, 22, 38, 57, $73,88,97,102,117,122$, $176,212,213,246,279$. FACE, Spots and blemishes on, $37,62,86,89,144,158$, 231, 246, 248, 254, 263, 286.

Faintings, $96,101,153,154$, $184,327$.

Falling Sickness, 19,38 , $104,107,122,133,170$, $208,217,219,238$.

Eeet, Galled, Sore, \&e., 17. FELON, 24, 34, 277.

Fevers, 29, 31, 47, 76, 93, $123,138,158,174,211$, $326,330,334$.

Fevers, Drinks in, 32, 101. Fevers, intermittent, Sco Ague, 46, 59, 67, 70, 154, $196,213,222,289,296$.

Fever, Heetie, 14, 145, 190, 234.

Fever, Malignant, 221, 264. Fistula, 53, 61, 130, 196, 223, 225, 261.

Finatulenct, 22, 32, 33, 43, $59,69,74,90,94,9 \mathrm{~S}, 100$, $103,123,153,163,179$, $180,209$.

FleAs, 17, 24, 111.

Fluxes, $18,23,42,44,55,56$, $70,72,89,92,108,125$, $152,158,175,182,221$. Fricklies, 49, 52, 93, 97, $10 \mathrm{~s}, 15 \mathrm{~s}, 165,246,269$, 285.

Gir., obstricted, 96, 103, $130,135,164$. 


\section{DISEASES CURED BY HERBS.}

Gangrene, $31,49,53,54,79$, $92,150,198,252,265,283$. Govorrhasa, $34,56,64,77$, S0, 149,173 .

Gout, 19, 23, 38, 50, 51, 52, $58,60,76,83,85,88,101$, $112,123,125,127,130$, $133,155,157,173,174$, $187,195,207,210,221$, 255, 277, 288, 289.

Goutty Pains, 136, 149, 183. GrAVEL, 18, 25, 46, 50, 54, $57,67,69,74,78,80,84$, $98,103,109,118,121,125$, $126,136,137,166,170$, $179,192,196,202,221$, $233,240,256,258,263$.

Green Sickness, 67, 153, $172,190$.

Griping Pains, 30, 125, 130 , $163,185,270$.

Gumbolls, 107.

Guss, Scurvy in, 148, 235, 322.

Guss, Spongy and blecding, 32, 64, 191, sore, 266.

IIAlR, Growth of, 154, 257, 291.

IEAD, Defluxions, 89, 125, $142,147,150,223$.

IFADACIE, 36, 38, 54, 62, $72,81,98,104,106,112$, $122,129,143,147,154$, $157,180,183,203,206$, $207,213,219,222,233$, $235,250,28 \mathrm{I}, 283,322,334$.

Ifan, I'ains in, 272

IfEAD, Obstructions of, 26, 49,321 .

Illados, Sore, 106.
Meartburi, 62, 159.

Hedrt, Disease of, 174, 286. Heart, Eulargement of the, 14.

Heart, Palpitation of, 184. HEArT, Undue action, 27, 96. HICCUP, 60.

Hirs, Pains of the, 85, 127, 223, 279.

HoARsENESS, 19, 57, 61, 67, $72,98,107,112,140,141$, $144,153,159,171,190$, $204,238$.

IGamorrinaEs, 42, 111, 114. Hooping Cougit, 39, 100 . $135,146,178,273,294$. Humours of the Breast, 16. Hurts, Inward, 93.

Hurts, 56, 79 .

HYDROPIOBIA, 48, 71, 160 , $180,273,336$.

Irpocirondria, See Melancholy.

Hysterics, 33, 49, 64, 119 , $152,186,208,221,232$, $235,280$.

Iмгоsтпumes, $25,32,70,94$, $112,138,151,171,180$, $182,191,223,237,248$, $256,277,282$.

INDIGESTION, $17,20,22,31$, $36,59,61,63,92,119,123$, $190,228,268,289$.

INFECTION, 55, 197.

INFLAMMATIONS, or inflamed parts, I7, 18, 59, 68, 70, $83,112,132,156,183,188$, $217,218,219,256,257$.

INSAN1TY, I14, 272.

INTOXICATION, 147. 
Irritatiox in Bowels, Lungs, \&c., 136, 170, 198, 239.

IтCH, 18, 19, 31, 32, 36, 46, $47,66,93,94,97,100,111$, $125,133,139,152,153$, $154,170,207,256$.

JAUNDICE, $15,16,18,20,24$, $27,31,33,38,46,47,56$, $58,60,66,72,81,98,101$, $102,110,117,118,121$, $128,130,135,137,139$, $141,146,153,160,163$, $165,185,190,194,201$, $202,203,204,230,233$, $238,240,242,254,256$, $259,260,263,269,275$, $281,289,291,293,295$.

JoInt-ACIIEs, 127, 190, 210, $238,259,283$.

KIDNEYS, 13, 20, 50, 61, 74, $96,148,150,160,175,212$, $216,225,238,265,291$. King's Evil, or Selofula, 14, 102,121 .

IINEe, Enlargement of, 243.

Knots and Kernels in the flesh, $75,92,166,186,277$.

LEPROSY, 21, 107, 118.

Letinarg Y, 86, 104, 203, 238. LICE, 18, 173, 236, 265.

Liver, Ohstrtetions, 17, 18, $22,26,33,38,47,53,55$, $66,70,81,91,96,102,103$, $110,138,139,140,153$, $163,169,196,202,207$, $212,226,227,233,249$, $254,281,287,291,295$.

Liver, Influmed, $30,31,89$, $91,101,131,149,220,242$, $26 ; 3$.
LIVER, Affections of, 16, 37, $38,40,128,160,269$.

Liver, to Strengthen, 94.

LnCK-J A w, 317, 336.

LowNESS of Spirits, 20, 35, $46,57,122,153,228,258$.

LOMBAGO, 14, 50.

LUNGS, 13, 17, 21, 40, 69, $78,107,114,164,232,281$. LUNGs, Ulecrated, 182, 190, 201.

Mania, 49, 137, 167.

Measles, $19,60,168,317,333$ Melancilol $y, 23,55,96$, $122,270,283,289$.

Menses, Profuse, 20, 43, 47, $70,72,83,89,97,106,108$, $132,150,163,182,183$, $233,238,266,279,284$, $285,291,293$.

Menses, Obstructed, 21, 23, $25,33,34,38,40,43,4 \%$, $56,59,69,71,81,103$, $121,147,181,189,194$, $201,207,258,283,295$.

Menstruation, Painful, 131. Mick, to div up, 217.

Milik, to incrense, 46, 103.

Montifications, 79.

Moutr, Sore, or Ulcerated, $31,41,46,54,59.78,126$, $130,171,266,283$.

Nausea, 34, 103, 199.

Navit, Swelling of, 112, 220 . Neck, Stiti, 2:1.

Nervous 1)isorder's, 2s, 29, $38,82,136,153,170,181$, $184,193,208,221,233$, $271,278,280,251,292$, $236,328,333,334,341$. 


\section{DISEASES CLRED BY IIERBS.}

Netratgia, 14, 139.

Nigiturare, 18:.

Nipples, Chappet, 64, 112.

Nose, Bleching at, 20, 23, $38,108,1$ I $6,135,150,163$, $185,186,191,192,210$.

Orisity, or Fatness, 26, 103, 192.

Oyer-Purging, 112.

Pains, 16, 18, 19, 21, 26, 90, $154,197,205,243$.

Palsy, 38, 135, 157, 226, 262. Paralisis, 50, 82, 87, 88, 9 I , 122, I27, 141, 192, 296.

Persirifation, to Promote, $26,30$.

Punegh, 26, 38, 56, 67, 81, $86,106,140,144,259.277$.

Pincomatic hahits, $123,14 \mathrm{I}$. I'fitinsis, See Consumption. PIIES, 40, 47, 65, 66, 70, 80, $108,119,132,142,149$, $151,175,186,205,209$, $210,213,234,262,266$, $275,276,282,291,324$.

Primles, 93, $118,317$.

I'Litrisy, 21, 133, 163, 248, 252, 282.

Porson, 42, 103, 121, 124, $169,221,235,262,274$, $277,283,327$.

Polsowols Bite, 252.

Jor,ypus, 8.9, 97, 215.

J'Rotadestis of the $\Lambda$ mins, 195. l'timonary Complaints, 125, 135.

PIISE, to abate, 114.

Princturti, 19.

I'URat, the Ilend, 21.
Purgn, 17, 27, 40, 41, 48, $80,86,99,110,112,129$, $147,189,220,249,251$. Pustules, 91.

Putrefaction, 121.

Quissy, 46, 89, 144, 162, 163, 201, 209, 252, 284.

Rictum, 20.

Rueumatic Distillations, 33. Rineujatism, 14, 22, 50, 52. $54,60,86,88,110,128$, $130,135,141,116,155$, $167,173,174,178,193$, 226, 238, 295, 296, 297, $323,327,333,335,349$.

Riciets, $105,271$.

Ringworns, 31, 66, 92, 245. Rrxgworsi, 46, 119, 139, 214, $256,285$.

Ruptuke, 40, 42, 79, 86, 100 , $121,125,152,236,254272$, Scats, $18,27,31,35,85,94$, $104,118,152,170,171$, $180,214$.

Soditis, 152, $160,197,213$. Scanlet Fever, 114, 193, 238.

Scars, 125.

Sciatica, 22. 23, 84, 85, 91, 92 , I I 2, $127,133$. I 49,186 , $190,206,210,211,217$, $262,273$.

Scrofuta, or Ting's Tivil, 14, $23,32,50,51,59,65,78$, $107,115,135,167,178$, $22 ?, 243$.

Scrofilous sores, 149,152 , $171,245,275,287$.

Scurr, 286. 
Scurvy, 31, 41, 47, 51, 54, $66,70,74,84,85,95,100$, $101,107,117,141,153$, $155,171,172,214,230$, $231,243,244,249,288$.

Secretions, to promote, 17 , 194.

Silortwess of Breath, 21, 30, $33,35,38,57,58,78,98$, $100,103,144,148,164$, $171,190,203,204,205$, $214,220,248,279$,

Sickness, 54, 288.

Side, pains and stitches in the, $29,32,58,71,80,100$, $121,122,147,203,237$.

Sight, Loss of, 296.

Sinews, shrinking of, 38,83 , $100,248,285$.

Srin, Discases of, 16, 51, 85, $93,95,100,211,243,255$. Slemi', to promote, 60,91 , $139,156,197,204,218$.

Shall Pox, 19, $31,60,119$, $168,317$.

Sores, 22, 23, 48, 50, 61, 63, $67,81,92,95,110,112$, $113,117,125,142,162$, $166,176,182,197,227$, $235,250,262,266,327,333$.

Sr'ASMS, 39, 193, 198, 271, $280,317$.

Speecir, loss of, 88.

Spitting of Blood, 16, 23, $29,38,44,46,54,76,79$, $94,97,100,145,164,183$, $188,191,195,214,238$, $253,262,285$.
Spleen, Hardness of, 17, 18, $23,33,102,104,122,270$, $273,274,283,295$.

SpleEN, discases of, 85, 91 , $96,125,128,138,165,168$.

Sprains, 55, 91, 330.

Stings of Wasps, \&c., 33, $171,212$.

St. Anthonx's Frre. Sce Erysipelas.

Stomiach, Foul, 175.

STomacir, to strengthen, 29, $67,72,81,98,121,148$, $154,169,182,188,212$, $227,233,256,257,259$, $269,281,284,290$.

STomach, pains in the, 62, 200.

STONE, 25, 26, 33, 34, 38, 41, $42,61,63,68,71,78,86$, $96,121,125,128,139,148$, $150,152,153,170,171$, $185,202,225,244,247$, $259,261,277$.

Strakgurr, 22, 37, 75, 150, $166,170,217,231,247$, $259,265,278,323$.

Strptr, (Stopper of Bleeding.) $20,38,41,45,72$, $141,149,173$.

Sunmulix, 89, 97, 158.

Swallowixg, Diticult, 178. Swedt, to promote, 255, 283, $293,295,329,333,337$.

Swlllixgs, $17,23,24,32$, $34,59,70,73,91,108$, $138,139,143,151,160$, $169,171,237,243,273$, $277,282,330$.

SwooNixgs, 46. 
Throat, sore, 16, 31, 61, 90, $99,101,107,126,130,138$, $149,154,186,192,196$, $201,332$.

Tenesues, 89.

TEETI, to fisten, 18, 100, 126.

TeEtil, wash for, 18.

Testicles, swelled, 149, 190.

Tetands, 198.

TetTers, 285.

Tooth-ACIE, 18, 22, 24, 36, $38,74,139,153,154,170$, $187,191,205,206,275$, $291,328$.

Tumours, 23, 50, 73, 93, 115 , $135,158,168,171,176$, $178,193,213,241,277$.

Trroat, swelling in, 24, 30, 93.

Throat, ulcerated, 223.

Tic-Dolorea Ux, 209.

TMMPANY, 278.

Trpilus Fever, 31, 59, 60, $119,134,198,221,296$.

Utcers, 16, 18, 22, 23, 24, $32,35,37,45,56,69,70$, $86,101,108,122,128,133$, $139,149,154,160,162$, $176,197,207,213,225$, $235,241,262,275,285$. ULCERs in the kidneys, 72 , $89,212,286$.

ULCERS of lungs, 79 .

URINARY Or'ms, 14, 19, 68, $129,212,220,281,323$.

URINe, Incontinenee of, 15 , $16,92,165,291$.

Urine, Ploorly, 16, 38, 70, $79,220,253$.
URINe, Obstruction of, 17,22, $33,45,54,63,100,119,122$, $147,153,157,163,166$, $169,170,177,185,203$, $215,246,254,255,256$, $257,275,276,278,294$. Urine, Sealding, 109.

UTERINe, Obstructions, 163. UTERINe, homorthages, 234, 296.

UTERUS, 20.

Urula, diseased, 149, 191, $195,206,238$.

Venomous Bites, 18.

Veins, rupture of, 75 .

VenterfaL, 244.

VERTIGO, 19.

VoICE, loss of, 153, 157, 190. Vomiting, 34, 40, 112,142 , $152,154,180,182,183$, $237,262,328$.

VULNERARY or healing, 15, $19,25,84,125,239,242$, $245,250,254,261,262$. WARTs, 106, 217, 269, 277, $286,298,317$.

Wens, 30, 186, 269, 277.

WIIEEZING，144，164，192, $215,258$.

Wintss, 20, 23, 43, 44, 72, $98,143,149,160,183,196$. WintLow, 191, 297.

Wind. S'ec also Flatulency, $62,63,93,137,148,176$, $179,187,201,205,259$, $273,290,333$.

WOMm, rlsorders of, 23. Woms, filling down, 38. Woress, Tupe, 16, 104, 105, $151,215,283$. 
DEFINITION OF TERMS.

Worms, remedy for, 17,18 , $24,33,43,52,57,67,77$, $81,82,89,93,113,120$, $121,122,133,139,140$, $144,147,150,172,197$, $204,213,220,237,257$, $266,269,275,278,283$, 288, 327, 334.

Worms, $A$ seurides, or Seatworms, 20, 97, 120, 235, $266,289$.

Wounds, fresh and green, $15,16.19,38,39,41,42$, $45,53,55,67,73,74,80$, $83,86,89,91,93,97,104$, $115,116,140,144,152$, $158,163,171,172,175$, $182,183,186,196,197$, $201,205,211,213,223$, $241,246,248,250,253$, $266,275,277,279,281$, $284,285,286,297,298$.

\section{DEFINITION OF TERMS.}

Amaurosis-Loss of sight proceding from parnlysis of the optic nerve. Anodyne.-Medicines which assuage pain. Anthelmintics.-Medieines which expel worms. Antispasmodic.-Mcdicines which abatc or remove spasms. Antiseptic.-Medicines which prevent putrefiction. Antidote.-Medicines opposed to any discase. Astringent.-Remedies which act by eontrneting the animal fibres, and rendering the solids denser and firmer.

Cachexia, Cachectic. - $\mathrm{A}$ bad habit of the body - an unhealthy statc of system resulting from want of nutrition, bad air, \&c. Carminatives. - Remedies which allay pains, and expel flatulency, or wind.

Calaplasm.-A ponltice.

Catarrh.-Inflammation of the mucons membrane of the nostrils, or bronehial passages, \&c.

Cathartics.-Laxative, purgative, or drastic medicines which open the bowcls.

Cephatics. - Renedies for disenses of the head.

Chorosis. - The green sickness.

Chronic.-Discases of long standing.

Cicatrix.-A sear or mark left by a wound,

Cullygrium.-A wash for the eyc.

Constipation,-Habitual confinement of the bowcls.

Demulcents:-Medicines which have softening and sootling properties. 470 


\section{DEFINITION OF TERMS.}

Deobstruent. - Medicines which remove obstruetions from any part of the boly.

Diaphoretic.-Medicines which incrcase the natural cxhalations of the skin, or perspiration.

Discutient. - Mclicines which disperse the morbid matter of tumours, \&c.

Dinretic.-Mcdicines which incrense the urinary discharge. Emetic.-Medicines which cause romiting.

Emmenagogue.-Medicines to promote the monthly discharge. Emolient.-Medicines which relax and soften the animal fibre. Empiric.-Formerly, an experimenter in medieine; but now

a ventler of nostrums-a quack.

Enema.-A clystcr, lavement. or injection.

Expectorants.-Medicines which promotc a discharge of mucous or other matters from the trachoea and its branches. Febrifuge.-A medicinal agent used for the reduction of fever. Flatrlence.- IVind in the intestines.

Gangrene.-The first stage of mortification.

Hamoptysis. - A flow of blood from any part of the body.

Homorrhage. A flow of blood from any part of the body.

Hydrophobia.-Canine or dog madncss.

Hydrops.-Dropsies.

Lethargy.-Profound and continuous slecp.

Leucorrhoa.-The Whites.

Nansea.-Sickness at the stomach; loathing.

Phthisis. - A discase produced by tubcrelcs on the lungs, called Consumption.

Styptic.-Medicines which stop bleeding.

Sudorifics. - Medicines which promote perspiration or sweating. Suppuration.- The formation of matter in alosecsses \&e.

Tonesmus.-Powerful and frequent straining at the rectum, to procurc stonl, cnding in discharge of mucous only.

Tetanus. - Contraction of the museles of volumtary motion, in which a part or the whole of the body becomes rigid.

Tetters.-Skin cluptions, consisting of clusters of vesicles seated upon inflaned patehes of ir'tegular size and form.

Vulnerary. - llerbs, unclicines, \&e. which have the power to

heal woumds.

Whitlow. - An inflammation at the end of a finger or thumb, paindul, havingra as tendency to suppurate. 


\section{GENERAL INDEX.}

Acacia Tree PAgE.

A eanthus $\quad \cdots \quad$.. 13

Aconite

Adder's Tongue

Agrimony

do. Water

Ague in the faee

Air.

Air, Change of

Air, its influence on disease

400

Aleost

Alder Tree do.

Alehoof

Alisander

Alkanet

All-heal

Almonds

Aloe

Amaranthus

Anemone

Angelica

do. Cordial

Animal Food ..

Aniseeds

Antidotes to Poison

Arehangel, red and white,

and yellow

22,336

Arnien

Arraeh, Wild and Stinls.

ing

do. Garden

Arsemart

Artieholio

Arım

472

.. 23

.. 24

.. 24

. 25
.. 13

.. 14

.. 14

. 15

.. 16

. 365

.. 398

. 399

Ash

Ashweed

Asparagus

Assafoetida

Avens ..

Avens, Tincture of

Balm

Balm of Gilead

Balmony

Balsam Fir

Balsam, Friar's

Balsam Herb

Barberry

Bark

Barlss

Barley

Barrenwort

Bayberry

Bay-tree

Bazil, Garden or Sreet 34

Beans

.. 34

Beans, French

Bear's Breech ..

Beeeh Tree

Bee Nettlo

Beets

Behen, White ..

Behen, Red ..

.. 35

.. 13

.. 35

. 22

.. 36

. 292

. 292

Benzoin, or Gum Benjamin39

Betony, Water do. Wood

Bilberries

Bilfoil

.. 36

.. 37

Bilious Colic ..

Bindweenl

. 39

.. 40

.. 377

Bird's Foot 
GENERAL INDEX.

Bishop's Weed

$\begin{array}{llr}\text { Bistort } & 42 \\ \text { Bite of a Rat Cured } & \text {. } & 358\end{array}$

Bitters

Bitter-root

Bitter Sweet ...

Bitter Thistle ..

Blaek Bireh Bark

Blaekberry-bush

Bleeding, to stop

Blites

Blood Wort $\because$

Bloody Flux ..

Blue Blow

Blue Bottle

Bone, Setting a

Borage

Bowels, to seour the

Box-tree

Bramble

Brank Ursine ..

Breasts, Sore ..

Brooklime

..

. . 339

325,330

.. 193

. 335

.. 331

. 46

. 363

.. 43

.. 44

.. 378

.. 45

.. 44

. 365

.. 45

.. 321

.. 46

.. 46

.. 13

.. 363
Broom, and Broom-rape 47

Bruisewort .. . . 255

Bryony $\quad \ldots \quad \ldots 48$ do. Blaek $\quad$.. 49

Buckbean $\quad \ldots \quad \ldots 50$

Buck's Horn Plantain 51

Buck thorn $\quad . \quad \ldots 52$

Buglo

Bugloss

Bull's-foot

Brill Wort

Burdoek

Burnet

Burns, to curo

.. $\quad . .53$

.. $\quad \ldots 45$

‥ $\quad$.. 77

$\begin{array}{lll}\ldots & \ldots & 43\end{array}$

. $\quad \dot{54}, 390$

. $\quad \ldots 55$

.. 352

Jurns, finther remarks on 35,53

Bur-reed

55

Buteher's Broom
Butter

Butter-Bur

PAGE.

Butter flowers, or Butter-

cups .. $\quad$.. $\quad$.. 87

Butternut $\quad$. $\quad$.. 334

Butterwort .. . . 241

Cabbages and Coleworts 57

Calamint $\quad \ldots \quad \ldots 58$

Caltrops, Water $\quad$. 58

Camomile $\quad$. $\quad 59,330$

Camphor $\quad$. $\quad 60,327$

Campion, Wild $\quad$.. 60

Caneer Plaster _. 342

Caneer Sores .. $\quad$.. 359

Candle Berry . . . 322

Candy-tuft $\quad \ldots \quad$.. 85

Cauker .. $\quad \ldots . \quad \ldots 337$

Canker, to remove .. 321

Capsicums $\quad$.. 61,319

Cardamom $\quad \ldots \quad \ldots 62$

Carraway $\quad \ldots \quad \ldots 62$

Carrots, Wild .. $\quad$.. 63

Cascarilla $\quad \ldots \quad \ldots 76$

Caserwort $\quad \ldots \quad$.. 252

Castor Oil $\quad \ldots \quad$.. 63

$\begin{array}{llll}\text { Catechu } & \ldots & \ldots & 64\end{array}$

Catmint $\quad$.. $\quad$.. 64

Cat's foot $\quad$. $\quad$.. 129

Cayenne Pepper $\quad 319,337$

Celandine, Great $\quad$. 65 do Littlo $\quad . \quad 65$

Centaury $\quad \ldots \quad \ldots 66$

Cheso $\quad$.. $\quad$.. 411

Cherries, Wiuter $\quad$.. 68

Cherry Stones .. $\quad$.. 326

Cherry-treo $\quad \ldots \quad \ldots 67$

Chervil .. $\quad \ldots \quad$.. 69

Chervil Sweet .. $\quad$.. 68

Chestuut Treo .. $\quad$.. 69

Chestuuts Earth _. 70

473 
GENERAL INDEX.

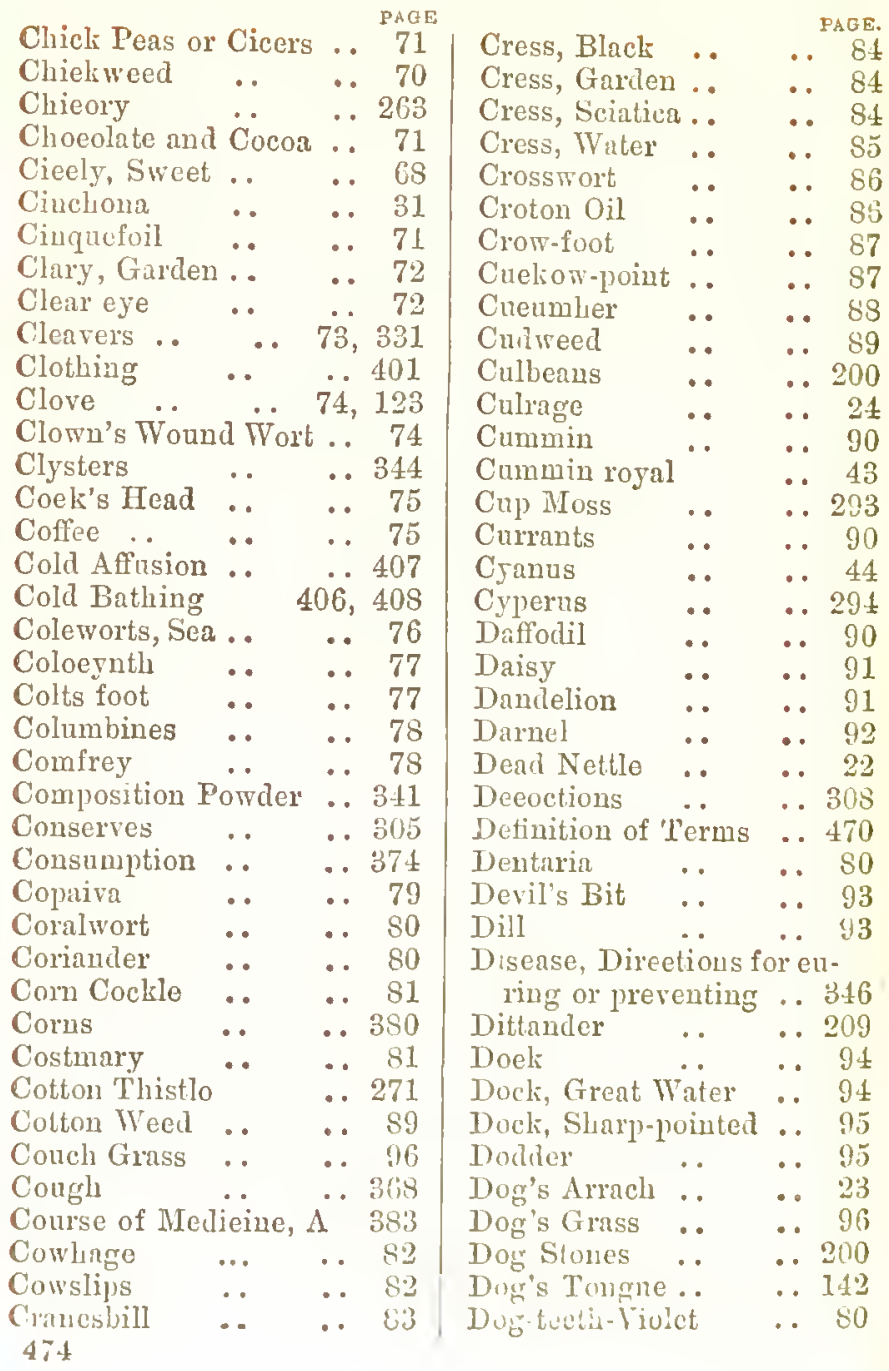


GENERALINDEX.

PAGE.

\begin{tabular}{|c|c|c|c|c|c|}
\hline Dragons & & . 97 & Fleabane & .. & .. 111 \\
\hline Dragon's Blood & & $\begin{array}{l}\text {. } 97 \\
\end{array}$ & Fleawort & . & .. 111 \\
\hline ropsy, Treatm & ment of & of $\quad 376$ & Flower-de-luee. & e.. & .. 112 \\
\hline ropwort & $\cdots$ & . 97 & Flower Gentle. & .. & . 20 \\
\hline Drowning & . & . 408 & Flowers of Her & rerbs & .. 29 \\
\hline Duekweed & . & .. 98 & Fluellen & .. & \\
\hline warf Cotton. & .. & .. $\$ 9$ & Flux-Weed & .. & $\ldots$ \\
\hline r's Weed. & . & .. 287 & Foal's-foot & . & .. \\
\hline entery & & . 378 & Fonl-stones & . & .. \\
\hline ibow, out of $j$ & joint & .. 366 & Food & $\cdots$ & $\cdots$ \\
\hline Dwarf & . & .. 99 & Foxglove & .. & - \\
\hline Tree & .. & $\ldots 98$ & es, to eure & ro & . \\
\hline mpano & . & 99,329 & Bit & .. & . \\
\hline ries & - & .. 304 & & . & . \\
\hline $\operatorname{lm}$ & $\therefore$ & .. 100 & tory & -. & -. \\
\hline Emergeneies, I & Hints i & in 433 & & -. & - \\
\hline ic Herb & .. & .. 336 & $\mathrm{Ga}$ & .. & .. \\
\hline & . & .. 1 & $\mathrm{Ga}_{\mathrm{a}}$ & - & . \\
\hline & .. & ... 101 & an & .. & .. \\
\hline rysipelas & . & .. 375 & Gentian, Foreig & ign & . \\
\hline thiopian Cum & $\operatorname{mmin} \mathrm{S}$ & Seed 43 & Germander & & .. \\
\hline & & .. 403 & Gill-go-by-grou & und & .. \\
\hline oal Applic & ications & $13 . .405$ & Gilliflowers & .. & $\cdots$ \\
\hline d woun & nd in & ured 358 & Gil & .. & 23 \\
\hline right & $\cdots$ & .. 102 & Ginseng & $\ldots$ & .. \\
\hline Cure of & & .. 351 & Glarlwin, Stink & king & $\cdots$ \\
\hline few & .. & 106,331 & wort & .. & .. \\
\hline ort & .. & .. & s Arraeh. & .. & -. \\
\hline & .. & .. 1 & stones & .. & .. \\
\hline 1, Hog's & $\ldots$ & .. 1 & wort & -. & .. \\
\hline Female & .. & .. 1 & cilps & -. & \\
\hline Male & .. & .. 1 & Golden Rod & $\cdots$ & 125 \\
\hline n, Water & -. & .. 1 & Gold of I'lensut & & . \\
\hline ig Tree & .. & ... 106 & Goosubery-Bus & $\mathrm{sh}$ & . \\
\hline ig Wort & -. & .. 107 & Goose-sliaro, o & or Goc & pose- \\
\hline 3 & $\ldots$ & .. 375 & & & \\
\hline lag, Yellow IV & Vater & .. 108 & tis of Irrac & diso & 62,1 \\
\hline 7. & .. & .. 1118 & rel & .. & . 3 \\
\hline in & & .. 10 & nwell & . & \\
\hline lax Weed & .. & .. 11 & Ground Ash & . & \\
\hline
\end{tabular}


GENERAL INDEX.

PAGE.

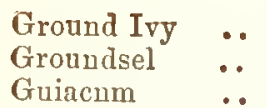

.. 129

.. 129

.. 130

. 259

.. 295

.. 131

.. 129

.. 132

.. 132

.. 362

. 380

. 133

.. 277

Heliotrope

Hemlock

Hemp

Henbane

Herb Bennet

Herb William ..

Herb Carpenter

Herb Twopence

Hints in Emergencies

Hollyhock

Holly

Honeysuckle

Honewort

Hop

Horehound

Horsc-Raddish

Horsetail

Horse Parsley ..

Horse-hoof

Hot Bath

Hound's Tongue

Housclcck

Hurt-sickle

Hyssop, Hedgo

Hyssop

Iceland Moss . .

Inlalation of Vapour \&c. 407

Injections

476 from .. .. .. 437 Ipecacuauha $\quad$. $\quad \ldots 145$ Ivy $\quad \ldots \quad \ldots 146$ Jack-by-the-hedge $\quad$. 129 Jalap . $\quad$. $\quad \ldots 147$ Jaundice Treatment of 369 Jesuit's Bark . . . . 31 Juices . . . . $\quad$. 300 Juleps .. $\quad \ldots \quad \ldots 307$

Jum $\quad \ldots \quad \ldots \quad \ldots 92$

Juniper Bush .. $\quad$.. 147

Kidneywort .. $\quad$.. 148 Kino $\quad$.. .. 149

King's Knob .. $\quad$.. 87

Knot-grass _. $\quad$.. 150

Kousso $\quad$.. $\quad \ldots 151$

Ladies Bed-Straw _. 151

Ladies Mantlo $\quad \therefore 152$

Ladies-Smock _. 153

Lavender $\quad$. $\quad \ldots 153$

Lead Wort .. .. 151

Lcaves of Herbs _. 299

Legs, sores on the .. 356

Lemon $\quad \ldots \quad \ldots 154$

Lentil $\quad$.. $\quad \ldots 155$

Leopard's Bane .. 295

Lettuce, Garden $\quad$.. 156

Lettnce, Wild .. $\quad$.. 156

Life and MIotion _. 388

Lily of the Talley $\quad$. 157

Lily, Water . . $\quad \ldots 157$

Lily, Whito .. $\quad$. 158

Lime Tree . . . . 159

Limbs, Mortification of 355

Liquorice $\quad$. $\quad$. 159

Liverwort $\quad$. $\quad \ldots 160$

Liverwort, Ash-coloured 160

Lobclia

Logwood
.. 161,315

.. 161 
GENERAL INDEX.

PAGE.

Loosestrife, Purplo _. 161

Loosestrife, Willow-Herb 162

Lovage

Lungwort

Nadder

Maiden Hair, Golden .. 165

Maiden Hair, White .. 165

Mallow, Common _. 166

Mallow, Vervain

Mandrake

Manna

Marigolds

Narjoram, Sweet

Marjoram, Wild

Marshmallows

Marsh Rosemary

Wasterwort -.

Matico

May Weed

Meadow Trefoil

Meadow Saffron

Meadow Sweet

Meadow Fern ..

Measles

Medce Fitch ..

Merilar

Medical Reccipts

Mellilot

Nercury, Dog ...

Mercury, English

Mezereon

Mirldle Confound

Middle Comfrey

Milk

Mint, Horse :

Mint, Peppermint

Nint, Spearmint

Nint, Watcr ..

Misletoe

Monk's-hood ..

.. 167

..170
.. 166

.. 168

168,298

. 168

.. 169

.. 323

.. 172

..173

.. 329

.. 138

.. 173

.. 174

.. 335

.. 367

.. 75

.. 175

.. 443

.. 175

.. 176

. 177

.. 178

.. 53

$\therefore 53$

.. 410

. 179

. 179

. 180

. 181

.. 181

.. 14
PAGE.

Moneywort $\quad \ldots \quad \ldots 183$

Moonwort $\quad \ldots \quad \ldots 182$

Mortification of the Limbs355

Moss, Ground .. .. 183

Moss, Tree $\quad$.. $\quad \ldots 183$

Motherwort $\quad$. $\quad \ldots 23$

Mother of Thyme .. 184

Mountain Mint _.. 58

In Louse-Ear $\quad$. $\quad \ldots 184$

Mugwort $\quad$. . $\quad$.. 185

Mn]berry Tree $\quad$. 186

Mullein $\quad$. 186,330

Mustard $\quad$. $\quad$.. 187

Mustard, Treacle _. 189

Mustard, Hedge . 189

Nuscles, to relax .. 365

$\begin{array}{lll}\text { Myrrh } & \text {.. } & 190,327\end{array}$

Nailwort $\quad$.. $\quad$.. 191

Nerve Powder _. 328

Nervine .. .. 334

Nervo Ointment $\quad$. 343

Nettle $\quad$.. $\quad$.. 191

Nightshade, Deadly .. 192

Nightshade, Woody .. 193

Nightshade, Common.. 194

Nutrition in Grain and

$\begin{array}{lll}\text { Flesh } & \ldots & \ldots 431\end{array}$

Nursing the Sick $\quad \ldots 439$

Nutmegs $\quad$.. $\quad \ldots 195$

Oak $\quad \ldots \quad \ldots 195$

Oats . . .

Oils $\quad \ldots \quad \ldots \quad \ldots 303$

Ointments $\quad$. $\quad \ldots 305$

One-Berry $\quad \ldots \quad \ldots 276$

Ono Bliado . . .. 196

Onions .. $\quad \ldots \quad \ldots 197$

Opium .. .. .. 197

Ornngo . $\quad \ldots \quad \ldots 199$

Orchis .. .. .. 200

Orpino .. .. .. 200

477 
G ENERAL INDEX.

PAGE.

Parsley.. .. . . 201

Parsley Piert .. _.. 201

Parsley Macedonian .. 202

Parsuip, Wild ..

Parsuip, Cow ..

Pareira Brava ..

Park Leaves ..

Peach Meats ..

Peach Tree

Pear Tree

Pellitory of the Wall

Pellitory of Spain

Pennyroyal

Peony ..

Pepper ..

Pepperwort

Peppermint

Pepper, Red

Pepner, Black.

Perriwinlile

Pills

Piles, how cnred

Pimpernel

Pink, Inclian

Pipsisway

Piss-a-bed

Plantain

Pleurisy ..

Poison, Antidotes to

Polypody of tho Oak

Pomegranate ..

Poplar Tree

Poplar Bark

Poppy ..

Poultices

Poultice

Preserves

Primroses

Privet ..

Prickly Ash 478
. 202

.. 203

.. 212

.. 278

. 326

.. 204

. 204

.. 205

. 206

207, 329

.. 207

.. 208

.. 209

179, 329

.. 321

.. 321

.. 210

.. 307

. 362

.. 211

. 212

. 334

. 91

. 213

.. 377

. 435

. 214

.. 215

.. 216

.. 325

. 217

.. 306

. 343

. 302

. 219

. 219

335
Prinnes ..

Purslane

Quassia .

Quince Tree

Quinine

Radish ..

Ragwort

Ramp ..

Ranunculns

Raspberry

Raspberry leaves

Rattle Grass

Red Fitching ..

Red-rot

Relax ..

Rest Harrow

Rhatany Root

Rhenmatism

Rheumatic Weed

Rleumatic Drops

Rhododendron...

Rhubarb, Bastard

Rlunbarb, Foreign

Rhubarb, MIonk's

Rice

Rock Cress

Rocliet ..

Roots

Rosa Solis

Rosemary

Roses ..

Rue, Garden

Rue, Meadow

Rupture Wort ..

Rupture

Rve

Suffron

Sigre

Sngro

Salvo
RAGE.

219

220

220

221

. 222

222

223

87

. 223

. 224

. 324

.. 221

.. 75

. 232

. 378

- 225

.. 226

.. 379

. 334

.. 310

.. 226

. 227

.. 227

. 229

.. 230

. 230

.. 231

. 300

. 232

.. 232

.. 233

.. 234

.. 236

.. 236

.. 364

.. 237

.. 237

. 238

. 239

.. 312 
GENERAL INDEX.

Samplire

Sanicle

Sapentary, Dragonwort

Saracen's Coufound .. 241

Sarracenia Purp.rea .. 442

Sarsaparilla $\quad$. $\quad \ldots 242$

Sassnfras

Siluce Alone

Savine

Savory

Saxifrage, Burnet

Saxifrage, White

Scabious

Scald, a cure of

Scald Heads ..

Scalds, to cure..

Scammony ..

Scurvy-Grass ..

Sea Holly ..

Secrls ..

Segrum

Self-heal

Senna

Septfoil

Serpentaria

Serpeut's Tongue

Service Treo ..

Shepherd's Purse

Shonlder out of joint . . 36,6

Shower Bath ..

Sicklewort ..

Skunls Cabbago

s'leep. .

Slippery Elm .

Siloe Bush

Simnllage

Simall Pox, New Remedy for

Simnll Pox

Suake Root
.. 243

.. 244

.. 245

. . 245

.. 246

.. 247

.. 247

.. 353

.. 362

.. 352

.. 248

.. 249

.. 101

.. 300

. 223

.. 250

.. 250

.. 271

.. 251

.. 14

. 252

. 252

.. 406

. 53

.. 330

. 405

. 332

.. 253

. 253

.. 36,8

251,933
.. 442
Snakeweed

Solomon's Seal

Sopervort ..

Sore Breasts ..

Sorc Eyes ...

Sorc Heads in children 362

Sore Lips

Sorrel

Sorrel, Wood ..

Southeru Wood

Sow Thistle ..

Spearmint

Speedwell

Spignel

Spikennrd

Splcenwort

Squatw Weed ..

Squill

St. John's Wort

St. Peler's Wort

Staggerwort ..

Stanmerwort ..

Strmeliwort ..

Star Thistlo ..

Stavesncre ..

Stearning ..

Stomnch, to clcanse

Stonc-Crop

Stramoninm

Strangury

Strengthening Plaster

Succory

Sugar ..

Sumnch

Summer Snvory

Suspended Animation

Siweet Flng

Sivine's Cross ..

Syrupis . .

Sigrup ..
PAGE.

42

.. 254

.. 255

.. 363

.. 379

. 379

.. 255

.. 256

.. 257

.. 257

180,328

.. 258

.. 258

.. 298

. 259

.. 324

.. 259

.. 261

.. 210

.. 223

. 223

.. 87

.. 260

.. 261

.. 309

. 321

.. 262

. 271

. 375

342

.. 263

.. 412

. 323

. 329

.. 437

.. 201

.. 293

.. 301

.. 339

473 
GENERAL INDEX.

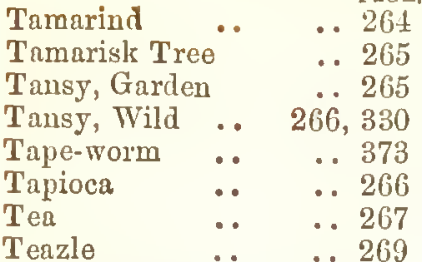

Temperaments of Herbs 6

Tepid Affusion $\quad$.. 408

Thistle, Blessed $\quad$.. 269

Thistle, Melancholy .. 269

Thistlc, Our Lady's .. 270

Thistle, Woollen

Thorn Apple . .

Thorough-Wort

Thorougli Wax

Throat-wort ..

Through-Leaf ..

Thyme

Toad Flax

Tobacco

Tooth-wort

Tooth-violet

Tormentil

Trefoil

Troches

True-Love

.. 271

.. 271

.. 331

. 272

.. 107

. 272

. . 272

.. 110

.. 273

. 80

. 80

.. 274

.. 276

. 306

Turnhoofs

.. 276

Turnsole

Tutsan

Twa-blade

Valerian

Vanilla

Vapour Bath :.

Vegetable Food

Velvet Flower...

-. 276

.. 129

.. 277

.. 278

.. 40

.. 279

. 280

.. 407

.. 413

Venercal

.. 20

.. 381

Vervain

Vine

Violet

Viper's Bugloss

Volatile Salts ..

Wake-Robin

Wall-Flower

Walnut Tree

Warm water, as an application

Wart Cress

Water Nuts

Water Pepper ..

Water Pimpernel

Water Plantain

Water Trefoil ..

Wheat

Whin

White Pond Lily

Whitlow-Grass

Willaw

Winter Green ..

Witch Hazel ..

Woad

Wold, or Weld. .

.. 407

Wolf's Bane ..

.. 293

.. 58

. 24

.. 47

. 284

.. 50

.. 285

.. 118

. 322

.. 191

.. 285

.. 286

.. 323

.. 286

.. 287

Woodbine $\quad . . \quad \ldots 138$

Worms, Treatment for 370

Worm Seed .. .. 287

Wormwood .. 288, 330

Wormwood, Common .. 288

Wormwood, Sen _. 289

Wormwood, Roman .. 290

Wortle Berries _. 39

Wray _. . . 92

Jarrow .. $\quad \ldots \quad \ldots 291$

Yellow Dock .. .. 335 
$i_{32}-i, 2 y$ 



$$
\begin{aligned}
& \text { Dr A A } \\
& \text { का }
\end{aligned}
$$

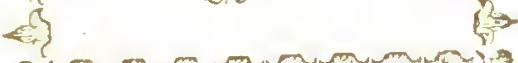

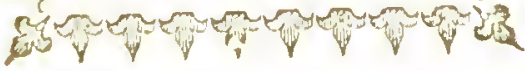


SOME TIGHT

GUT PARS 
